\title{
EDITED AND
}

TRANSLATED BY WENDY MICHALLAT

\begin{tabular}{l|l}
320 rue St & The Diary of \\
Jacques & Madeleine Blaess
\end{tabular}




\title{
320 rue St Jacques: The Diary of Madeleine Blaess
}

\author{
Wendy Michallat
}

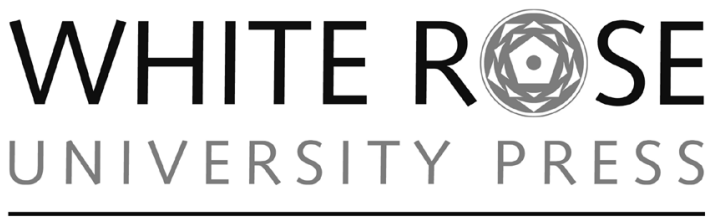

Universities of Leeds, Sheffield \& York 
Published by

White Rose University Press

(Universities of Leeds, Sheffield and York)

University of York,

Heslington, York, UK, YO10 5DD

https://universitypress.whiterose.ac.uk

320 rue St Jacques: the diary of Madeleine Blaess

Translation (c) Wendy Michallat 2018

This translation has been prepared with the support and permission of the owner of the copyright, the University of Sheffield.

First published 2018

Front Cover: Portrait of Madeleine Blaess (C) Andy Brown (CC BY-NC 4.0) Back Cover: Madeleine Blaess graduating from the University of Leeds, 1939 (C) Andy Brown (CC BY-NC 4.0); Portrait of Wendy Michallat (c) Wendy Michallat (CC BY-NC 4.0).

Cover designed by Tom Grady, WRUP.

ISBN (Paperback): 978-1-912482-12-2

ISBN (PDF): 978-1-912482-13-9

ISBN (EPUB): 978-1-912482-14-6

ISBN (MOBI): 978-1-912482-15-3

DOI (volume): https://doi.org/10.22599/Blaess

Reuse statement: Apart from exceptions, where specific copyright statements are given, this work is licensed under the Creative Commons Attribution Non-Commercial 4.0 International License (CC BY-NC 4.0). To view a copy of this license, visit https://creativecommons.org/licenses/by-nc/4.0/ or send a letter to Creative Commons, PO Box 1866, Mountain View, California, 94042, USA. This license allows for copying any part of the work for personal and non-commercial use, providing author attribution is clearly stated.

Example citation: Michallat, W. 2018. 320 rue St Jacques: the diary of Madeleine Blaess. York: White Rose University Press. DOI: https://doi.org/10.22599/Blaess CC BY-NC 4.0, https://creativecommons.org/licenses/by-nc/4.0/

To access this work freely online via the White Rose University Press website, please scan this QR code or visit https://doi.org/10.22599/Blaess.

\section{口过回




\section{Contents}

Acknowledgements $\quad \mathrm{v}$

General Introduction ix

About the Manuscript $\quad$ xv

Introduction 1940

$\begin{array}{ll}1940 & 7\end{array}$

Introduction $1941+29$

194133

Introduction $1942 \quad 87$

$1942 \quad 93$

Introduction $1943 \quad 169$

$1943 \quad 173$

Introduction $1944 \quad 287$

$1944 \quad 291$

References 377

Principal Personalities 381

$\begin{array}{ll}\text { Places } & 387\end{array}$ 



\section{Acknowledgements}

This translation has been prepared with the support and permission of the owner of the copyright, the University of Sheffield. The author and publisher are very grateful to the University of Sheffield for its support of the project.

Many thanks to Jacky Hodgson and James Parsons for providing digital copies of the manuscript, which greatly facilitated the work of translation.

Madeleine's godson, Phil Morris, and Pat, his wife, both sadly passed away while this translation was in preparation. Both Phil and Pat were very excited and enthusiastic about the project and their daughter Helen Bartlett has continued to support it in the same vein. The translator and the University of Sheffield are grateful to Helen for agreeing to donate wartime photographs of Madeleine to the Madeleine Blaess Collection at Sheffield.

Dr Robin Adamson of the University of Western Australia was also a great source of support and encouragement. She was researching the Occupation diary of Christine Morrow, an Australian friend of Madeleine's in Paris. Sadly, Robin also passed away in 2015 before this translation could be published.

Many thanks to Delphine Biechler for permission to reproduce the photographs she kindly took for me from Madeleine's room on the 8th floor of the rue St Jacques and to Anne and Patrick Doppler, Delphine's neighbours, who 
put us all in touch. Thanks are due to Errol Nadeau and his brothers, sons of Madeleine's friend Ruth Camp for telling me more about their mother and her later life and to Marie-France Leroy, Madeleine's great niece, and her husband, who were both so welcoming to me when I visited them in Le Mans. I am also grateful to Robert Pickford, Madeleine's friend and solicitor for all the help and advice and information about Madeleine he gave me in the early stages of the project.

Thanks are due also to Kate Petherbridge and Tom Grady of the White Rose University Press, who have been a pleasure to work with, and to Michael Fake who set the ball rolling in the early days of the Press.

Finally, many thanks to family, friends and colleagues who have been enduringly positive and encouraging about the project. Thanks to my Mother and Father, Shirley and Colin Michallat and to my sister and brothers, Claire, Mark and Clive. Thank you to Dr Roger Baines, Dr Timothy Baycroft, Professor Máire Cross, Dr Lindsey Dodd, Professor Alison Fell, Professor Nicholas Hewitt, Pat Marshall, Tracey Ralph, Pat Roddis, Amy Ryall, Dr Audrey Small, Professor David Walker and Professor Jan Windebank. 


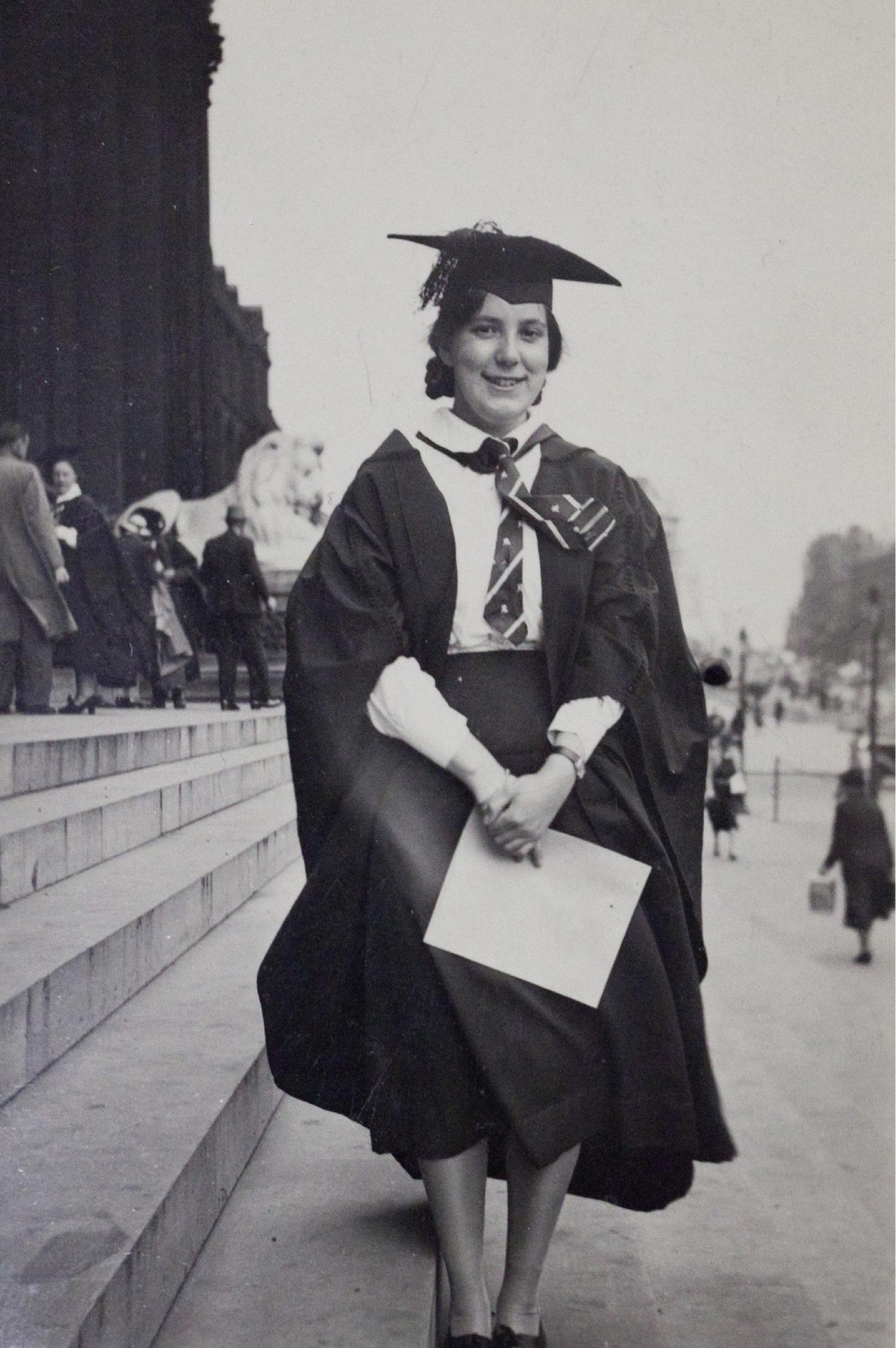





\section{General Introduction}

\section{0 rue St Jacques: The Diary of Madeleine Blaess}

In July 1939, Madeleine Blaess graduated with a first-class degree in French from the University of Leeds. The future was bright and exciting. She had been awarded a university bursary to begin doctoral research at the Sorbonne in Paris and take a step closer to her dream of becoming an academic. Two months later, in September 1939, France and Britain declared war on Germany. Uncertain whether still to go to France, Madeleine took advice and finally made the decision to leave for Paris a month later than planned, in November 1939. Her decision to go did not appear to have been a difficult one to make. There was a generalised confidence that the allies would be able to easily contain and repel a German attack in the unlikely event of it happening. Indeed, her account in letters sent to her parents of her passage from Folkestone to Calais and her subsequent rail journey to Paris describe a country going about its everyday business with a minimum of disruption. This generalised calm and ordinariness - other than regular air-raid alerts and bomb shelters being dug in the street - endured until the late spring of 1940.

Page vii: Madeleine Blaess graduating from the University of Leeds, 1939. Copyright Andy Brown, licensed under CC BY-NC 4.0. Used with permission from Helen Bartlett. 
Yet, even then, when the British Expeditionary Force was stranded on the beaches of Dunkirk and traumatised Belgian refugees were arriving in Paris, the atmosphere was one of unease, not panic. At the same time, students in Paris, particularly the British and Australian expatriates, began to drift away from Paris towards the ports, much to the annoyance of professors at the Sorbonne. In a final letter to her parents on June 1st Madeleine spoke casually of her imminent departure like a summer holiday, wondering whether to take her winter clothes with her in case she was unable to return to Paris in the autumn. Madeleine did not catch the boat train to Folkestone in early June as she had planned. ${ }^{1}$ The German advance cut off her escape route to the ports and she fled the capital together with thousands of other panicked civilians in a blind and largely purposeless flight to southern France. The little that is known about Madeleine's final days in Paris comes not from anything she herself wrote, but from the letters of an Australian student friend Dorothy Clarke who had managed to get on a boat to Britain in May. Clarke wrote to Madeleine's parents in August 1940 to tell them that their daughter had been calm and organised and busily preparing for her departure when she had last seen her. Indeed, Clarke claimed that Madeleine had been preoccupied with buying souvenirs of Paris for her family back in Britain. ${ }^{2}$

Madeleine returned to Paris in July 1940 and found temporary accommodation in an apartment on the rue Rollin vacated by a British expatriate friend of the publisher and bookseller Sylvia Beach and which she shared with Canadian postgraduate student Ruth Camp. It was here, on the evening of October 1st 1940, sat in lamplight and wrapped up warmly in a dressing gown that she completed the first entry of the diary she would keep diligently for the next four years.

The diary written by Madeleine Blaess in Paris during the Nazi Occupation of France is an extraordinary document. Were it not for the fact that Madeleine had a French birth certificate, she would have been arrested and interned, like many of her British, Commonwealth and American friends, by the occupying authorities. Instead, she remained at liberty to record everyday life roving occupied territory as, effectively, a civilian enemy of both Germany and France's collaborationist Vichy state. Not only is the diary unique for this reason, but its

${ }^{1}$ For more on Madeleine's experience of the Phoney War and life in Paris in the months before the German invasion, see the 2012 journal article by Wendy Michallat, Mon cher Papa, ma chère Maman: The drôle de guerre of Madeleine Blaess, Essays in French Literature and Culture 49: 135-153. Madeleine's Phoney War letters are held in the Madeleine Blaess archive at the University of Sheffield.

${ }^{2}$ Correspondence between Dorothy Clarke and Madeleine's parents is held in the Madeleine Blaess archive at the University of Sheffield. Full reference is in the bibliography. 
documentary style means that there is a richness about the data she gathers into diary entries which are diligently completed and rarely missed from the first day of October 1940 to the final entry made on 17 September 1944, a month after the Liberation of Paris.

When Madeleine began the diary she imagined it as a letter to her parents to replace the long letters she used to write them the previous year but which she could no longer send to Britain. The first page of the diary is thus set out like a letter with her address in the top right hand corner and a first line 'Dear Daddy and Mummy'. Although the letter format does not endure and the direct interpellation of her parents as readers becomes less frequent as the months pass, the chatty evocation of the minutiae of her daily life which had characterised her letters home continues to dominate the diary content. The use of the diary as a letter replacement goes some way to explaining the descriptive content of it. Madeleine intended the diary to be a log of activities and news, which her parents would be able to catch up on when she finally returned home and she could give them it to read. However, the epistolary style does not explain her documentalist approach entirely. Madeleine does not meander through her diary pondering philosophical questions or analysing her feelings, unlike many of her peers who also kept diaries because it was fashionable amongst the educated elite to do so. She declared that she wanted to write about people and 'things' instead. It was the sort of tenacious 'reporter' style of diary writing positively and popularly encouraged through the British press by the Mass Observation Project in 1930s Britain, as well as being a style redolent of Pepys, whose famous turns of phrase 'and so to bed' - Madeleine occasionally cites when signing off a diary entry. Joe Moran's description of the British inter-war diary and the inspiration for its descriptive style bears similarities with Madeleine's diary. The Mass Observation Project - a survey of everyday life in Britain carried out in the 1930 s - advertised for typical and simple diary entries describing the facts of the lived everyday of ordinary working-class people. This documentary style also found an echo in a new wave of women's fiction in which the domestic everyday of ordinary women was elevated to the forefront of narratives. Lives formerly regarded as trivial were now foregrounded for a generation of post-war and post-first-wave feminist women readers to critically evaluate (Moran, 2015: 138-162).

A diary which simply tells what happened every day would once have held little worth for historians for whom diaries - even those containing substantive historical data - were of dubious worth as historical sources. Little by little over recent years, however, diaries have been rehabilitated through the turn towards 'grassroots upwards' historiography, which valorises life-writing as a source of important data with which to challenge or to elaborate upon what is known of a historical period. There is an increasing number of so-called 'Occupation diaries' in circulation as the war generation passes on its memories to surviving relatives who want to publish these testimonies or otherwise make them 
public. ${ }^{3}$ There is an enduring enthusiasm for testimonies where an 'extraordinary' personal story contributes to the drama of a known historical moment. There were plenty of 'moments of drama' in Paris between 1940 and 1944 and plenty of narratives of valour and self-sacrifice for high ideals in the face of despotism. But what to make of a diary like Madeleine's diary, which explicitly declares before the first year of the Occupation is out that it is preferable not to talk about 'political matters'? If the reader comes to this diary with an expectation that it will evoke the wartime Paris of the newsreels, the Paris of feature films and of tales of Resistance derring-do, then they may be disappointed. Whilst there is indeed some of all that, particularly in the months after the Normandy landings in June 1944, Madeleine mostly describes what it was like to live through the real-life grind of the everyday, for which the Occupation was, for many, a remote backdrop. That is not to say that the Occupation is not in evidence. It is. But it is articulated largely through the deprivation, physical discomfort and psychological strain it causes than through reflections on the political situation of accounts of heroic acts of resistance to Nazi repression. Madeleine's diary is unique because her account describes the Occupation as lived through the routine and banality of everyday life. It is a precious de-dramatisation of the Occupation because it shows how the Occupation was swept up into lives which maintained a focus on ambitions and priorities which had nothing to do with patriotic defiance, resistance nor moral obligation.

Most every entry tells us something about the impact of the historical event of the Occupation on the lives of individuals. The value of these entries, frequent and detailed for the most part, is incalculable for the research data they provide. The day-to-day struggle to find enough to eat and to cope with the freezing cold in winter with a very limited fuel allowance is the well-documented experience of most Parisians during the Occupation. Madeleine's diary articulates these facts in a narrative where coping strategies and ruses, periods of respite and abundance became the very fabric of a new life to which people adapted. Lack of food and comfort forced people to readjust their daily priorities and shaped most every social interaction they made; social interactions could still be fun but they were invariably accompanied by Machiavellian motives connected with the acquisition of foodstuffs through exchange and barter.

The attention to everyday minutiae is a constant of Madeleine's diary style. Only occasionally does she deviate from the logging of 'things' and happenings to more contemplative entries, deviations which are usually relatively brief. Nevertheless, through her forensic inventory of everyday existence under Occupation, Madeleine sketches a record of what life was like for the first generation of women students to enjoy tertiary education in large numbers in

3 Two recent edited collections in which life-writing is used to cast new light on the period of the Occupation are a useful reference here. See Michallat and Dodd (2017) and Dodd and Lees (2018). 
France. The diary is woven through university life from the outset. She begins it at the rentrée to tie in with the resumption of courses at the Sorbonne and over the course of the four years of occupation, the diary gives insight into how the Sorbonne managed practical disruption, political interference and how students, female students in particular, adapted to challenging circumstances of the Occupation in order to continue their studies. It is apparent at numerous points in the diary that Madeleine was aware of the fight she faced to realise her career ambitions as a woman.

Madeleine's status as a student brought her into contact with a fascinating cultural milieu and, also, into direct contact with the anti-Semitic brutality of the Vichy and German authorities. She worked briefly at Shakespeare \& Co, a bookshop and lending library owned by Sylvia Beach, publisher of James Joyce's Ulysses and a figure of some importance and influence in the Paris literary scene of the inter-war. It was through Beach that Madeleine met Hélène Berr and Françoise Bernheim, Jewish students who were also studying at the Sorbonne. We only see traces in the diary of Madeleine's encounter with the horror of anti-Semitic persecution through these two close friends, both of whom were arrested, deported and murdered in the camps.

The military circumstances of the Occupation are not always in the background in the diary. There is considerably more engagement with the conflict from the summer of 1943 onwards when Allied readiness for an assault on the European mainland is common knowledge and liberation becomes a tangible hope for the first time. By 1944, the military conflict is much more prominent and entries centre on bombing raids, the response of civilians and the German military to the Normandy Landings of June 6 and the weeks running up to the Liberation of Paris in August 1944. The Liberation itself is a remarkable record provided for by a confluence of the documentary style predominant elsewhere in the diary and her recognition, for the first time, of the historical importance of the events unfolding. Madeleine's account of the Liberation stands out from other testimonial accounts of Liberation because, in keeping with the style of the rest of the diary, the dense detail and regularity of the entries meant that the minutiae and the fabric of the everyday was maintained in addition to her eye-witness account of fighting.

The Blaess diary is certainly an engaging and important historical record. It is also an example of how life-writing can be employed as a coping mechanism. The diary helps her to imagine and enact discourse with the parents she can no longer see, thereby helping her manage loneliness and isolation. And, by noting down challenges and difficulties and the successful strategies employed to overcome them, she uses the diary as a source of reassurance and support there to be read back over when needed. It is broadly accepted that diarists can keep journals to try to maintain or restore psychological health in times of stress or crisis. Even the genesis of a diary, the reason why it comes into being, has been interpreted, most notably by Philippe LeJeune, as a saving recourse, a catharsis, a means to maintain self-control whilst living a crisis. When the 
crisis ends so too, invariably, does the diary. ${ }^{4}$ To an extent Madeleine's diary fits with this model. The meticulous note-keeping format maintained throughout enables her to impose order not just on the things happening in her life but on thoughts, feelings and sensations promoted by depression and anxiety which may have otherwise overwhelmed her. Lists are one way of doing this, and Madeleine's daily diary entries do, on occasion, read like lists. She notes the people she has seen, the books she has read, the people she has taught and, on occasion, synthesises this everyday data into lists. She does this with every new rationing quota announcement which she sets out food item by food item.

The value of the diary as a living history which makes a contribution to our understanding of the period of Occupation is clear. The density of the detail logged over a period of four years makes it a unique historical record. But it holds many more intriguing and enlightening narratives in respect of gender, the evolution of tertiary education for women, the purpose and place of life-writing in wartime and its use as a panacea for psychological distress. These are just a few of the areas of interest I have identified over the course of several years researching the diary. There are inevitably many more possibilities for interpretation in the many thousands of words with which Madeleine unselfconsciously records everyday life.

${ }^{4}$ Philippe Lejeune, 'How Do Diaries End?', Biography, 24, 99-113. 


\section{About the Manuscript}

Madeleine writes her diary in the imperfect French of an experienced yet non-native speaker. The register is everyday and informal and regularly interspersed with English words and idioms. Only on one occasion do we see a substantial passage in English, when she reminisces about her childhood and the land and seascapes of Yorkshire. In parts, the detail is sparing, the sentences short and sometimes abbreviated into telegraphic note form. At other times, the passages are lengthy and the writing style is literary, florid and reflective. The layout of the diary evolves over the course of the Occupation. The first page of the manuscript is set out like the letters she had sent home to her parents between November 1939 and June 1940 during her first year of study in Paris. She explains that the diary will serve as a replacement for letters she can no longer send. The letter format quickly gives way to a conventional journal format whereby dates are diligently and uniformly listed down the left-hand margin and the diary entry is written across the page from left to right. Although the epistolary layout does not endure and the presence of interlocutors is less obviously written into the diary text as the months go by, there is, nonetheless, always an intermittent dialogue in which the other party would seem to be Madeleine's mother.

Madeleine's longhand is neat and uniform. For the most part, it is miniscule and for that reason it can be difficult, at times, to decipher. In the final weeks of the Occupation - also the final weeks of the diary - this tiny script unfolded into an untidy scrawl which presented new deciphering challenges. In a diary 
which offers psychological succour during the Occupation, one can intuit much from the uniformity and discipline - of lack thereof - of Madeleine's diary entries. From the translator's point of view, it has meant that the occasional omission for reasons of illegibility has been unavoidable. There are more of these omissions towards the end of the manuscript as Madeleine's pen nib, which she was unable to replace, was worn and damaged and her handwriting less clear. For the most part, though, the diary has been translated in its entirety. High-resolution photographs of the manuscript have been an enormous help in the examining of indistinct letters and puzzling out of the meaning of stubborn passages. Where there has been doubt over a word, a gap with a footnote where appropriate has been inserted.

As I read and translated through almost four years of entries producing 123,000 words of English text, Madeleine seemed very alive, her voice always vivacious and vibrant as she described, with little self-consciousness or censorious discernment, the minutiae and fabric of her everyday life in wartime Paris. On occasion, she felt so present that finishing the work for the day felt sad and poignant. Looking up, it felt like she had just slipped away. It is my hope that these translated words retain the zest and vivacity of Madeleine's voice and enable her story to find its place in the narrative of that extraordinary period in French history. 


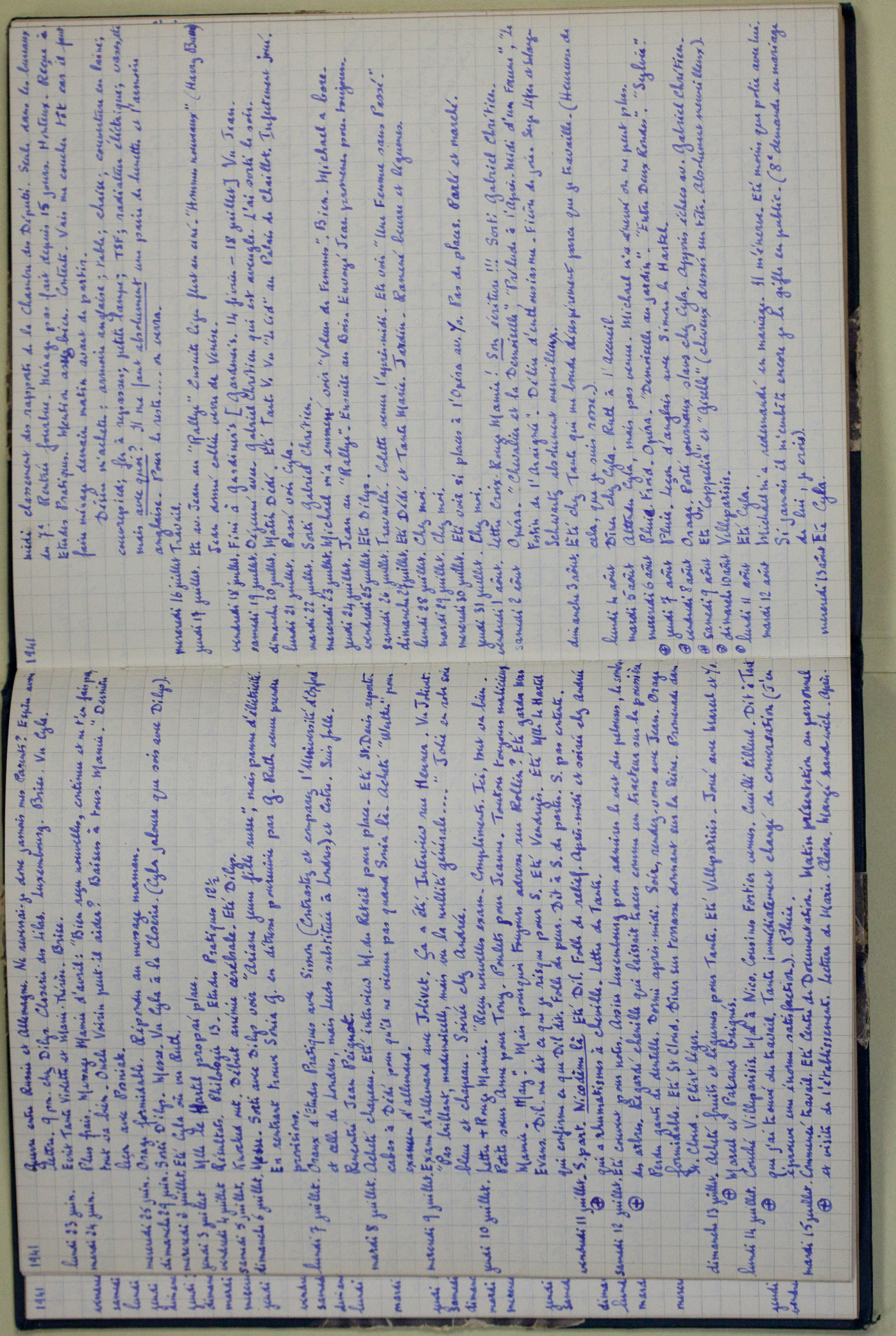





\section{Introduction 1940}

\section{First Months: October to December}

By the time Madeleine began writing her diary in October 1940, Paris had been under German occupation for four months. October 1st, was, she wrote, an appropriate time to start writing it because it marked the return to work after the long summer break. It was the rentrée for workers, for schoolchildren, students and their teachers and lecturers. October 1940 also signalled the rentrée and the return to daily routine for the hundreds of thousands of French people and Parisians who had joined the exode - the panicked flight to the south of the country in the face of the German onslaught the previous May. Madeleine had been among those who fled the capital. By July she had returned and by the autumn she was preparing - with some excitement - for what she hoped would be a resumption of scholarly routine and reinstatement of the scholarly purpose for which she had come to Paris in 1939. The occupying authorities wanted a rapid return to routine and normality so as to shore up support for the armistice and for the new system of government - unique in Europe - which saw the French state enter into formal and peaceable cooperation with the enemy occupier to govern the country. The French republic had been dissolved and replaced by an ostensibly independent sovereign state governing a free, unoccupied zone in the south of the country. Based in the spa town of Vichy, the political apparatus conceived in connivance and collaboration with the Nazis was led by First World War veteran and war hero Philippe Pétain. Newspapers and newsreels focussed on persuading the population of the sense, wisdom and desirability of the policy of collaboration. For the most part, civilians went with it. A resumption of normal life, of familiar routines and work patterns under a trusted leader, was welcomed by many after months on the road and seemed preferable to more death and destruction; in that regard especially, there was a readiness to listen to the cautioning of Great War hero Pétain. There was no Resistance movement to speak of in these early months of occupation. The first

Page xvii: Journal opening. Copyright Andy Brown, licensed under CC BY-NC 4.0. 
Resistance bulletins had been produced sporadically in the autumn of 1940, but armed resistance was negligible and uncoordinated and would remain so until networks formed around greater numbers of recruits by the end of 1942 and the beginning of 1943. Charles de Gaulle's defiant BBC broadcast from London made on 18 June 1940 had been heard by very few amid the chaos and upheaval of the exode. There was little, in the first months of occupation, to divert the focus away from getting on with life the best one could. ${ }^{5}$

The first weeks of the diary show the keenness and urgency of Madeleine and of her student entourage to reintegrate with their scholarly routines and the difficulties they faced in doing so. Madeleine's diary entries are dominated by anxiety about the lack of money and by tales of fellow students forced to abandon their studies and return home to support their families. Madeleine gives precious insight into the range of practical difficulties she had to overcome and, also, the nature of the support and saving recourse she was able to call upon. Accommodation was problematic in the early months. No longer in receipt of her grant and without access to funds in her blocked bank account, Madeleine could not afford to stay at the boarding house, Les Marronniers. She had taken lodgings at her aunt's in the suburbs, but she moved from there into an apartment belonging to a British expatriate, a 'Miss Longhurst', who had fled south to the free zone. When Ruth Camp, the Canadian friend with whom she shared the apartment, was arrested and interned in December 1940, she was forced to move from there too and decided to find herself a 'bohemian' flat of her own, which she could ill afford. Despite financial uncertainties, which had convinced her to register for an English degree in addition to the doctorate to guarantee employability as a secondary school teacher, she was intent on living a life as an independent woman scholar within the intellectual community of women she had been a part of since the Phoney War. One of the most influential figures in this milieu was the bookseller, publisher and literary muse Sylvia Beach, whose bookshop and lending library Shakespeare \& Co was a meeting place and intellectual forum for young, mainly female, Paris students. Beach became an increasingly important figure in Madeleine's life later in the Occupation (see 1942 and 1943), but already, in the first months, she was helping Madeleine with food, money and lodgings. It had been through Beach that Madeleine had found her temporary address at 4 rue Rollin, and Beach paid the gas and electricity bills when Madeleine had to move out, helping her through the first months in her new apartment with loans of money.

The arrest of Ruth Camp in December 1940 had a significant bearing on how Madeleine engaged with the military occupation. Ruth's arrest so alarmed her

5 There are a number of useful general histories of the Occupation which provide insightful and engaging overviews of the public response to Occupation in the early months in both Paris and the provinces. See especially Diamond (1999), Jackson (2001), Laborie (1990 \& 2001) and Vinen (2007). 
that she wrote that she thought it prudent from then on to make no mention of what she described as 'political matters'. Until this point, she had seemed relatively comfortable in relating the defiance of the Sorbonne and had not shied away from describing in detail what she had seen and heard of the student-led protest against Vichy at Étoile on Armistice Day, which had resulted in violence, mass arrests of students and the temporary closure of the Sorbonne. However, so fearful was she that she might be vulnerable to arrest herself, she avoided overt references to the war until the summer of 1943, by which time there was a generalised confidence among the French public that the arrival of the allies and a long-awaited liberation was not far away. The first months of Madeleine's diary are an intriguing glimpse of a life accommodating change fraught with challenges and difficulties. The entries tell us about how the shortages of food and fuel were already a problem in the autumn and winter of 1940 but not yet dominating everyday life. In the early months, Madeleine was more concerned about how the war and Occupation might disrupt her studies. She was positive and cheerful, chattily relating news of the first rationing measures and the first experience of winter cold without heating with an almost juvenile excitement. She wrote of the improvised dishes she concocted with make-do ingredients or ersatz replacements. She described with amusement the many layers of clothing she had to wear to keep warm in bed at night and about the changes in daily routine - going to bed early and rising late - enforced by the bitter cold. Four years later, there was no such jocularity. Four years of struggle to survive the daily misery of cold and malnutrition did not make for levity. It is nonetheless interesting that the first months of Occupation, before the impact of shortages began to be felt, were lived for the most part with no great evidence of distress or trauma. Madeleine, like those students around her at the Sorbonne, was primarily concerned with getting her life back on track.

In these first months, more than at any time in the diary, Madeleine gives an insight into how the Sorbonne encountered and adjusted to the new regime in its first academic year under occupation. Already, in letters written in the autumn of 1939 and the spring of 1940, Madeleine had painted a picture of recalcitrance and defiance among the Sorbonne's lecturing staff, who were, for the most part, septuagenarian veterans of the Great War who were 'holding the fort' in the absence of younger colleagues conscripted to the front. The over-confident and bellicose attitude of these academics in May and June 1940 and their determination that students should stay to finish their year of study may have been partly responsible for Madeleine's lack of urgency to leave the capital in June (Michallat, 2012: 135-153). There were signs that the same attitudes had carried through to the autumn of 1940 in Madeleine's descriptions of defiant and moving speeches made by Joseph Vendryès, the Dean of the Arts Faculty. Indeed, the Vichy authorities assumed that students and staff had connived over the student protests at Etoile on 11 November 1940. The rector Roussy was sacked and Vendryès was suspended from his post on several occasions over the course of the war. There was nothing for Madeleine to 
report in respect of organised student resistance in 1940, even though students were already secretly organising into a network and producing the newspaper Defense de la France in the basement of the Sorbonne. The student cohort for 1940/41 was significantly depleted. Men of university age were also of military age and had been conscripted, and many were now being held as prisoners in Germany. In his traditional address at the start of the academic year, Joseph Vendryès stated that of the 5000 students who had registered for courses at the Sorbonne in 1940, women were in the majority and would, he declared, be at the forefront of driving the Sorbonne forward with their 'courage, tenacity and intellectual verve. Even though women went to the Sorbonne in numbers in 1939, Madeleine's diary talks of a number of them dropping out or being forced to return to the provinces or the colonies. In the absence of fathers and brothers, young women were under greater pressure to support the home and family through domestic and workplace labour. This pressure, compounded by the spiralling cost of living, which made independent living and full-time study impossibly expensive for many, persuaded many women to abandon their studies. ${ }^{6}$

The autumn and winter of 1940 are not especially difficult to live through for Madeleine. Although there are shortages of certain food items and disruption to the study routine at the Sorbonne, she lives relatively comfortably, unmolested by the authorities. Nonetheless, she is tense, anxious and frightened and the arrest of Ruth gives insight into the vulnerability and fear she feels as a British student in an enemy state.

${ }^{6}$ See Michallat 2017 article on the student diary of Madeleine Blaess in Essays in French Literature \& Culture for more on student life at the Sorbonne in the early months of the Occupation. 
Madcline Blacess

320, un St Jaequen,

Paris. $v^{c}$

\section{JOURNAL.}





\title{
1940
}

\author{
4, rue Rollin, \\ Paris $5^{\mathrm{e}}$ \\ 1 October 1940
}

My dear Daddy and Mummy,

I am writing this for you because I can no longer send you letters. What I am writing here is a replacement. The first of October, the date classes begin again, is a suitable date to start but I have been wanting to do this for a long time because it is a way to feel closer to you. Alas, you know what I am like; I put off everything until tomorrow - and when I was living with Aunt I couldn't write down what was in my head. I am sure that you wouldn't have minded me moving out of Aunt's - I can study better here and I am free. I worry that I hurt her by leaving; she is so good and kind, but she does not seem to understand that I need to get up early and study late without getting overtired; that it was too far away, that the métro was expensive; that I couldn't study and do the housework, washing, mending, shopping; nor study whilst knowing that everything would have to be tidied away into a drawer at a moment's notice. But especially - and this is the major reason - I didn't want to have her keeping me. She would have never wanted me to work, she is too generous in that respect and, if at 22 I have to depend on others for my food, social life and even my work, then life is just not worth living. I'd just be a parasite then. Here, I depend on no one other than myself. I am going to give lessons to groups of students at the Institut d'Anglais - I will tell you the full story later, and I hope to give private lessons. I have decided to start an English degree to have a French qualification in case the war lasts a long time. To think that Cohen advised me to do just that last year but I didn't want to know then. Mind you, I would have been doing a 'licence libre' which would not have allowed me to teach, while this one is for teaching. Talking of which, I need to apply to $\underline{\mathrm{Mr} \text { the Minister of National }}$ Education (ooh!) for a certificate attesting that my qualifications equate to the

Page 5: Journal title page. Copyright Andy Brown, licensed under CC BY-NC 4.0. 
baccalaureate with proof that you have spent longer than five years at home and, as I haven't, I will have to declare as such 'on my honour.' Tut! Tut! Tomorrow (always tomorrow) I will buy the official document to do this.

At the moment, I am trying to study hard because I will have to 'undergo' ${ }^{8}$ an exam on the $18^{\text {th }}$ of November. I have seven authors and the history of English literature to do. I'll have to hurry up with it but at the same time, I don't feel in much of a rush. Perhaps this is because classes haven't started yet - they start, I think (at least the English lessons start), on the $7^{\text {th }}$ of October. In addition to those, I'll have French, Latin - and later German (because I chose German for Études pratiques). I am happy, so happy at the idea of starting my studies once again, but I will have to buy a lot of books which is a nuisance because there is not a lot of money around (I've got 400 and some francs left. I gave Aunt 1400 francs while I was living there (three months) and when I left her she gave me back 500 (which means that I gave her 900 francs for three months - and I did the shopping, the housework, stood in queues, did the washing, the ironing, the mending. I don't feel I owe her anything in that respect even though I could never repay all her kindness and her willingness to take me in). With all these outgoings - I am trying, without much success it has to be said, to put some money aside - and my registration fees at the Sorbonne, I'll only have left what I told you. And on top of that I will have to find 110 francs for the library . . . .56 by next week, all my French and Latin books and most of my English books. And I will have to eat and if possible buy some coal. Life isn't so great when one looks in ones purse. This fight for existence will do me good. I've had it easy thanks to you both going without, Daddy and Mummy; "let the weakest go to the wall", 9 and if I take after you, I will survive. Anyway, don't worry too much (if I was writing you a real letter I would never tell you such things) a little hunger and cold will not do me too much harm - even with money one can get cold and hungry in winter, - God help those who are suffering- and I can ask Vendryès for some university support if things get really tough. I know that this wouldn't be much but it would be better than nothing, - and if I have nothing I will go to the soup kitchen with a milk can for a bit of coloured water and a stick of bread (probably 350 grams worth with a ration ticket). Anyway, we're not there yet! And unless the Germans invade the whole of France and Miss Longhurst comes back then I have lodgings - beautiful lodgings with three rooms, kitchen, porch, bathroom and toilet shared with Ruth Camp, a Canadian

7 This may refer to the Blaess family property in Nancy. Madeleine moved to Britain as an infant.

8 'Subir un examen' can mean simply to take an exam but Madeleine puts 'subir' in quotes possibly to highlight the sense it also has of struggle or hardship.

9 'Let the weakest go to the wall' written in English in the manuscript. 


\subsection{0 in the evening}

Sat under the lamp in the lounge, wrapped up warmly in my dressing gown, here I am taking up my conversation with you again. Ruth is sat on the other side of the lamp and she's reading 'The Man with the Horn'. It must be funny, because she 'chuckles' (what is the word for this in French?), now and again. I am writing. I wrote to Aunt and Godfather. I also meant to write to Voirin but given that I am writing on my lap I reckon that my writing might suffer so I will put it off until tomorrow (as usual). If I am honest, I really don't know what to write to Voirin.

The lounge is OK - a little scruffy but comfortable. The armchairs are lovely. At the moment, the loveliest thing is the scent of the roses that Godfather gave me at Villeparisis on Sunday. There is also a gladioli opening up. It's flame-orange. In my room and in Ruth's room there are Michaelmas daisies that I picked in Vert Galant woods. I have lots and lots to tell you - three months of news to give you but I will do that bit by bit because now I have to work. I have decided to work 8 hours a day but because this morning I did my washing and this afternoon I went to see about the courses at the Sorbonne and bought a book etc I only did two hours. Jacqueline dropped in too - Jacqueline is sweet - sweet and twenty ${ }^{10}$ - I met her at Dilys's. She was studying for a degree in Biology but because of the war she has had to stop in order to do temporary supply teaching (that's all she is allowed to do because she only has the baccalaureate). She is waiting to be called up for that. Her father is a prisoner - in Poland they think; he is cold. It is sad, so sad for these poor prisoners. Thankfully, all the men from our family came back safe and sound. My uncle at Château moved in to old M. Cassés place. In the rubble in the cellar he found a few small things of value otherwise he would have been completely destitute. At his age, it's tough. Well, anyway, I wanted to stop but I am still writing. But this bit is the last; I am working. It has only taken me a quarter of an hour to write this. I am getting faster. Goodnight. You are so much in my thoughts. I hope that my thinking of you is of comfort to you so far away. I am sure that your thoughts are keeping my spirits up here. One thing is really worrying me. Have you received any news from me?

\section{October Tuesday}

It is raining. It's cold and I haven't been working. The time just runs away and I have to go out with Jacqueline in an hour. The cost of living is more than our grant. I am annoyed with myself and with everyone else.

I wrote to Voirin.

10 'Sweet and twenty' written in English in the manuscript. 
Jacqueline came to get me for the Quaker meeting. We had tea and biscuits. There were a lot of old English men and women and Madame Cazamian was there with them. ${ }^{11}$ I spent time talking to an old man who wants to get back to the Free Zone and from there, get to England!!! After tea there was a music concert. It was freezing. I picked up a letter there from 'my' prisoner. I have one, you know. Not last Saturday but the Saturday before I got up at 6 am and with Ruth, Miss Prenter and Jacqueline, took the metro to the Croix de Berny and went from there on foot to Fresnes prison. It was raining. Ruth, Jacqueline and I had been given three names - Lambeth, Lucas and Yanni. Ruth took Yanni, Jacqueline Lucas. We each of us brought something along - me, a cake. We had to queue in the rain for two hours to get through the German security. Then we were interviewed before being allowed to see them. In a long corridor, there was a rope lengthways and a line of dazed looking men trying to see who was coming to see them. Then a little group on its own. Our men were there! But, woe! Instead of Englishmen, Yanni is Greek, Lucas Syrian and Lambeth from Bermuda. I am very disappointed. I don't like Lambeth that much and don't really know what to say to him. But he is completely on his own. He promised to write to me and I gave the Quaker Centre address. I have the letter here. It's written in flowery English. He's asking for slippers, underwear, chocolate, sugar, a bar of soap, cigarettes, etc, etc! Oh dear! I have no money, or nearly no money. He'd be better off with another godmother. I will see what I can do but not having any money means that all I can really give is me and my time. Let's hope that it sorts itself out.

We are cooking bran - Ruth's idea for making porridge. I'm doubtful about the nutritional value of it, but we can but try it. I am going to darn some stockings.

\section{October, Thursday}

A cold day but a beautiful evening. I'm writing a few words in a hurry just to describe the colour of the sky. I spent the whole day studying curled up on the couch and round about 7.30 I put on the bedside lamp because it was getting dark. Suddenly, I looked at the window, it was completely green, a green light,

${ }^{11}$ Madame Cazamian was President of the Association des Femmes Françaises Diplômées (AFFDU) (French Association of University Women Graduates). In her chapter in When the War Was Over: War and Peace in Europe, 1940-1956 (edited by Claire Duchen and Irene Bandhauer-Schoffmann), Sylvie Chaperon mentions that the Quakers helped to fund the work of the AFDU who helped women academics across Europe to hide or flee from the Nazis. See also Rémy Cazals' excellent monograph about the work of the AFDU and Marie-Louise Puech during the Occupation: Rémy Cazals (2004) Lettres de réfugiées. Le réseau de Borieblanque. Des étrangères dans la France de Vichy (Paris: Tallandier). 
like looking through coloured cellophane. It was almost supernatural. Jacqueline came as she does nearly every day. Yolande came, to see what I was up to probably. I think that Aunt is furious with me. She is still objecting about my getting wood from Villeparisis. It annoys me a bit. I think that I am old enough to know what I want to do.

The courses at the Sorbonne started on Tuesday. I didn't go. I start on Monday. Yesterday, I registered at the Institut d'anglais, but the students who were there said that the teachers were not around because of the examinations. I saw Jacqueline there; she has decided to do an English degree. Afterwards, we went to Dilys's as we do every Thursday; Ruth and Mock were there; Mock is from the States; he came to France to study, he joined the ambulance corps and spent three months in Finland. Back then, he had a beautiful beard and looked really rather fine. Now, he has shaved it off and does not look quite as fine. We spoke about getting hold of supplies, about babies, about courses about pretty much everything I think.

This evening Ruth is happy. She has found some wheat and we're going to have porridge tomorrow. The bran was horrid we're not animals at the end of the day. Since yesterday, we've been having to hand in our bread tickets at the canteen. We're having to find substitutes for meat. I don't think that we will have enough to eat this winter. But, that's some way off (there is very little heating). I am tired, I am going to go to bed. This morning I wanted to get up at 7 to go to the class on Diderot but I was so warm in my bed that I stayed there in a delicious torpor until 8.30. I'm making the most of the last week.

\section{Thursday 14 November}

No, I haven't forgotten you, you are always in my thoughts, but I have been studying for my exam which officially is supposed to take place on the 18th of November but which will not take place on that date - unless there are unexpected developments. The weather is so beautiful. The sun is warm, I have the window wide open, - I should study - if you knew how hard I have been studying, - until two o'clock in the morning, getting myself up for seven, because I need to fit into six weeks what it has taken the others a year and sometimes two years to do. Anyway, as you know, this kind of game suits me.

Anyway, I am writing to you before my exam as I promised I would to tell you that the Sorbonne is shut. No courses, nothing, no library either - St Geneviève is closed and I don't know whether the $\mathrm{BN}^{12}$ is open (even if it is, I don't think that they would let me in because I am a student). It is because of the 11 November. The Sorbonne and the Latin Quarter were as calm as could be,

12 Bibliothèque nationale, more commonly known as the $\mathrm{BN}$, is France's national library. During the Occupation, the buildings at 58 rue de Richelieu were the library's principal site. 
but at 15.30, it seems that there was fighting at Etoile. ${ }^{13}$ What went on, I don't know but outlandish rumours are going round; I know one should not trust rumours. People died and were injured and some were locked up - there's no doubt about that. What is also certain is that yesterday, Wednesday, after normal classes on the Tuesday, the Sorbonne was shut. Ruth told me. She had gone there for her French teacher training course as normal at 8.30 am and came back around 10 all pale. I didn't want to believe what I was hearing when she told me the news. I was doing a translation in fact, which I finished and I was all ears. The riot police were everywhere waiting for demonstrations to break out, all soaked and looking sorry for themselves in their vans and under the café awnings while it hailed. What a blow for everyone. All the students have got to go home to their parents - wouldn't that be great! I'd love it! - students from the provinces have to go home immediately and everyone has to sign at police headquarters every day!!!! I went to register yesterday and was welcomed with open arms by the police who I know well, because I go there every day with Ruth just to have a walk. So, we are going to go there arm in arm every day. I was wondering what Yolande was going to do. You wouldn't know of course, but she has registered at the Sorbonne. She went on and on about it because I was there. It's for free German lessons supposedly, but between me and you, it's costing her a pretty penny. Anyway!!!

She was to have gone on holiday to Orgeval ${ }^{14}$ but because she has registered, she also has to go and sign every day . . . . whose fault is that?? I went to see Aunt at the bank yesterday, causing quite a stir because I was the first student they had seen since the demonstration. She doesn't know what will happen. I do hope that Yolande will be able to go on holiday, because she is really tired, the poor thing - Coming back, I wanted to drop in at the Sorbonne. The police were closing it off, there were cordons across rue Victor Cousin and Place de la Sorbonne. They made me do a major detour to get home.

Vendryès read the declaration of the German authorities at 2 oclock - he was reading it on the hour every hour - and begged us to be calm and sensible. We applauded and cheered him and he wept. All the campus security staff removed their hats in respect. I do so admire this man. He is so good and so fine. He ran into me in the corridor and straight away he said "Will you be alright, will you be alright." He is worried that I will have problems because you are at home; ${ }^{15}$ but I don't think so. He told me that he is going to do all he can to ensure that nothing happens to me. He is so nice to me. And one thing that I will never forget is that it was him who was the first to give me your news.

${ }^{13}$ The 'trouble' at L'Etoile was a student-led demonstration - the first in occupied France - against the Vichy regime and the Germans. It took place on 11 November 1940 and was brutally suppressed.

${ }^{14}$ Orgeval is a small town in the Yvelines region of France, north west of Paris.

15 At home in York, England. 
One Saturday morning - I was washing my things - the concierge brought me "an urgent letter", "good news from your mother" - I went nearly mad with joy - I cried with joy, with relief and then I went to her office to find out more. We wrote the reply together and I hope that you got it - it was sent by telegraph on the $18^{\text {th }}$ of October. Since then I have received the cards you sent in September to which I will reply over the next fortnight - and I am going to send the first reply today. What a joy it is to have heard from you. It was the best day of my life, I think, the happiest and the saddest. I wanted to yell it from the top of the Panthéon; ${ }^{16}$ but I had to be careful not to appear too happy because poor Ruth hasn't heard from her grandmother since February, I don't think- it doesn't seem to occur to her that something bad could happen one clear night ....

(I really have to try to write legibly, because my dissertation was criticised for the handwriting, so, I'll have to be careful, especially when it comes to the exam).

2 p.m. I have just been to sign in. What a lovely day it is; I am going to work at the open window all afternoon. Roussy, ${ }^{17}$ the Rector, has been removed from his post! We presented a petition in his defence. I signed my name legibly. The little Creole chap at the canteen was very worked up. He came out with one or two things ...... The closure is bad for the life and future of so many students. I can always fall back on my thesis but how many are throwing away their time and money - Ruth, for example and the dentistry student from Alger where there is no Dentistry faculty.

The sky which was blue just a short time ago is now full of grey and black clouds. The wind is sending blue, white and russet smoke over the roofs. There is a light mist which is blocking out everything other than the closest houses The church which the Cité universitaire students go to is just a grey silhouette against the moving grey sky. Before, I could see the gold and red of a tree in the courtyard opposite. Now I have to stare hard to see anything at all - the few yellow leaves that remain look as if they are hanging in the air. It is getting colder and colder. I shut the window and work.

\section{Friday 15 November}

It was fine yesterday from first thing nearly. Jacqueline Eichhorn and her friend Jacqueline arrived in a state about the closure of the Sorbonne. Yesterday

16 The Panthéon was originally a church and is now a mausoleum where the remains of some of France's illustrious public, political and military figures are interred.

17 Gustave Roussy, a neurologist and cancer specialist was Rector of the Sorbonne at the outbreak of war in 1940. He was sacked by the Vichy authorities after the student protests at Etoile on Armistice Day 1940. 
Jacqueline went to the Commissariat, and she says that they threatened to send her to a concentration camp for not having come on the first day. I think that she is exaggerating. Cyla ${ }^{18}$ went too - she has to sign even though she is Russian. I thought that only French citizens had to. In the evening Ruth went to Cyla's for a jab. Her thyroid gland is not functioning as it should. And, there was a beautiful full moon, we went to look at Notre Dame and approached it from the back. It was magnificent, this black and white symphony, and the plane trees, which were even blacker, framing it. It was cold. The Seine seemed hardly to be flowing. Then we went to stand under the main entrance but not excitedly - when it was Halloween, it felt like there were witches, magic around and even though I had promised myself I would work, I had to go out. Ruth was at the American Club. I was right under the entrance of Notre-Dame and watched the black mass that seemed set to crush me, the wind that swept the Valkyries through the sky, the clouds raced and the wind lashed me and the dead leaves hit me with sharp cracking sounds. A car went by and its headlight made all the saints jump from the night to bless me. It was dark but I had the impression that it was light. I had sung and shouted into the wind. Then I walked on the dark riverbanks to the Tuileries. I went round the carousel and I went home via the rue Bonaparte, St Sulpice, and the Panthéon. I was booming inside like a church filled with the reverberations of the organ. At Panthéon, I could hardly walk another step, I was so tired. Ruth wanted to relive it all with me, but yesterday wasn't right. Ok, it was fine weather but there's not the same mystery with a full moon. N.D. was pretty but it didn't amaze me, like it had on Halloween, or when I had seen it from the same place as yesterday evening in the springtime when the stone had seemed flesh-tinted and the soft blue sky, greens to make you wild with joy. And, well, I think that Ruth gets excited enough for two - and anyway, she doesn't admire the same things as I do. A plane tree, a black silhouette heavy with black bell flowers set against the moon was as beautiful as the cathedral itself but when I told her this, she pulled a face. Each to his own. One thing I want to know - the silhouette of a saint - or of the Virgin Mary? - against the moon.

On the way back we heard the German anti-aircraft barrage.

\section{Monday 18 November}

Today I should have taken an exam. Oh dear! When will I take it? The weather is cold and grey.

${ }^{18}$ Cyla Babicka was a medical student at the beginning of the Occupation and later qualified as a doctor. She was a Russian Jew and had to go into hiding later in the war. According to a brief post-war memoir written by Ruth Camp, she was active in the armed Resistance. She survived the war and worked as a psychologist in France. 
On Friday evening I went to see Aunt. Yolande doesn't have to sign at the Commissariat anymore because she is in the Civil Service. I am very happy for her. So, she has to be at Orgeval now, staying at Mme Fastier's. What a good woman that woman is. I admire her and I'd like to be like her despite her miserable life.

On Saturday I went to the Red Cross to send you a reply. I hope that you'll get it soon. Twenty five words doesn't allow a lot of space for news.

The BN is open, I am happy, I'll be able to do my thesis - in the morning I'll work on the English degree, do the housework and the darning, etc. Lunch at the canteen; BN; sort out notes, have dinner, knitting, reading or darning that's what I hope I will be able to do - even though this morning hasn't been the best of starts. I gave a dictation to Ruth and I wasted a huge amount of time messing with my hair. Ruth has been going on at me to wear my hair up. I don't like this style for loads of reasons but I promised that I would do it for a week.

On Saturday evening, we decided to go to watch Carmen on the cheap. I was meant to be getting the tickets but they were only allowing one ticket per person. I had arranged to meet Ruth at quarter to six in the foyer and I waited for her outside so that I could nab her before going straight in to get the tickets. She arrived by the side door sometime after six. So, we missed one another and after a bit we left. We wondered whether we might go to the cinema but in the end we went home and ate sweets miserably.

On Sunday, we went to see "Les Noces de Jeannette" at the Théâtre National Populaire, Palais de Chaillot. There was a ballet too by Janine Solane, ${ }^{19}$ but I didn't think much to it and I was a little disappointed with "Les Noces de Jeannette". Jean was too much of a caricature but Jeannette was sweet. The person sat next to me struck up a conversation. A farmer, a super chap - he disapproves of students but he was nice all the same. I'm going to stir myself to join the Folklore group. I really can't be bothered doing much at all. My feet are too cold.

P.S. Yesterday I ate Bird's Nest soup. It was a delicious, a little like "Turtle soup". 20

\section{Thursday 21 Nov}

St Denis to see Abbé Moulin and take a package to him

19 Janine Solane (1912-2006) was a dancer and choreographer and teacher. She created the style danse classique naturelle. A biography about her life and work was published in 2011: Zaïna Folco (2011) Parcours artistique d'une danseuse, chorégraphe, pedagogue, 1912-2006. Paris: Editions L'Harmattan.

20 "Turtle Soup" written in English. 


\section{Friday 22 Nov}

Went to the BN.

\section{Sunday 24 Nov}

Went to Orgeval

\section{Monday 25 Nov}

Went to Ursulines ${ }^{21}$ to see "Le Puritain"

\section{Tuesday 26 Nov}

Opéra-Comique ${ }^{22}$ to see "Carmen".

\section{Thursday 28 Nov}

Bought a present for Yolande (plate and a hand-painted cake knife). Went to Aunt's.

\section{Friday 29 Nov}

Went to St Denis to take a package.

\section{Saturday 30 Nov}

Yolande's birthday. Went to the Deux-Magots ${ }^{23}$ with Miss Brigham. Spent the evening listening to records with Miss Beach ${ }^{24}$ Cyla and Ruth were there. Went to Red Cross to send you some news.

${ }^{21}$ This is likely to be the avant-garde cinema Studio des Ursulines set up in 1925 by actors Armand Tallier and Laurence Myrga.

${ }^{22}$ The Opéra-Comique is an opera company founded in Paris in 1715. The theatre is located at 1 place Boieldieu in the city's second arrondissement.

${ }^{23}$ Les Deux Magots is a café in the St Germain-des-prés district of Paris famous for its association with literary figures of the inter-war period in particular.

${ }^{24}$ This is the first mention in the diary of American publisher and bookseller Sylvia Beach, owner of Shakespeare \& Co, the English language bookshop and lending library on rue de l'Odéon, Paris. Madeleine had met Beach in February 1940, four months before the German invasion. 


\section{Sunday 1 December}

\section{Villeparisis. ${ }^{25}$}

It has been a while since I wrote to you but I am at the BN every day. I have just come back from Villeparisis, I've had a bath and I am in bed. I meant to write to you but my writing is so bad so I am going to do some knitting instead. But I will write tomorrow without fail.

\section{Tuesday 3 December}

"Manon". Opéra-comique with Yolande.

\section{Thursday 5 Dec}

Ruth is taken away.

\section{Friday 6 Dec}

Went back to the flat.

\section{Saturday 7 Dec}

Queued all day. What a day! I am on the floor because the air raid warning has just sounded, but it was cancelled, if one can say that, a few minutes later; now and again there are a few sirens blaring out. I don't know now whether it's an alert or not. I prefer to be on the floor with cushions around me rather than risk getting into trouble for not observing the blackout.

Since Thursday, it's all been happening!!! On Thursday at 8.30, two policemen told us that we had to leave - two hours to get out. They took Ruth God knows where - because she is a British citizen. ${ }^{26} \mathrm{I}$ came back here. I am only using the bedroom - I hope that they are going to let me stay here. The Germans can seal up the other two rooms if they want so long as they are kind enough to leave me this room, the kitchen and the toilet, - and the bathroom, even though they can seal that up as well if they like. (More sirens in the distance. I'd like to know whether there is still an alert - I don't think that there is.)

Today, I queued from 9.30 to midday and from 2.30 in the afternoon through to 7 for horse meat for Aunt. That really is the last time in my life that I'll be

${ }^{25}$ Villeparisis is a small town in the north-eastern suburbs of Paris.

${ }_{26}$ British and Commonwealth citizens were rounded up and interned on December 5th 1940. Madeleine had French papers because she had been born in France even though she had been brought up and educated in York, England. She was not, therefore, arrested. 
queuing for her, - she sent me a jolly letter yesterday evening - it is clear that her feet aren't freezing off, pains in the legs and back from having had to wait without moving in the cold. At midday I was practically crying because I hadn't managed to get anything. The events of the last few days have shaken me up a little. Sylvia B wants me to leave the apartment and go to the hostel ${ }^{27}$ but it is too expensive - 530 francs a month. I would like to stay here on my own or find a little room just for me.

Sirens again. We had them at 10.05, 10.10, 10.20, 10.25, 10.35 and now 10.40. Yesterday there was a pretty white, green and red fireworks display. They say that Orly was targeted.

Dad is going to be pleased. I bought him some stamps. I can't write anymore. My back hurts too much.

\section{Sunday 8 December}

Aunt. 'Bach en Correctionelle'28 and 'Janosik le rebelle'29

\section{Monday 9 Dec}

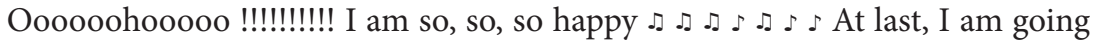
to have a room of my own. I am singing all that in Opera style ... I am going to leave here and go to a room of MY OWN!!! Oh Heck, ${ }^{30}$ I am so happy. It will be great fun - with my suitcase for a chair probably. Tomorrow I am going to look for rooms with Cyla. At last, a little place just for me. It will cost me loads at the start but I don't care. I will have to furnish the whole thing, but it will look lovely. I will probably die of cold at the beginning but I don't care. Sylvia wants me to go to the Hostel but 530 francs a month is too expensive and there is no heating and I won't get food thrown in for that price. I am so thrilled at the thought of having something of my own that I can't write nor work, nor go to bed. I take after you for wanting the things I want and for having my own home - and it will be a little bolt-hole for later - Gosh, this is life, this is really what it is all about - I will have beautiful curtains - red geraniums on the window sill, a bird, - or fish even? Maybe I could have the one Mlle Brigham had, if I asked for it nicely at the boarding house where she must have left it - I am going to have a fruit bowl, a piece by Hauchecorne ${ }^{31}$, - I'll be able to have a silk painting, beautiful books - all bit by bit, when I have the money. I have never

27 The Foyer international des étudiantes, 93 Boulevard St Michel. Many international students from the Sorbonne lived at the Foyer which was run by Sarah Watson (1885-1959) American expatriate and close friend of Sylvia Beach.

${ }^{28} 1940$ French film directed by Henry Wulschleger.

291936 Czech film directed by Martin Friĉ.

30 'Oh Heck' written in English.

${ }^{31}$ Gaston Hauchecorne (1880-1945). French artist and sculptor. 
felt as much joy since hearing from you - and before that, since when I was getting ready to return home to you. I'm squeaking with delight! I feel like I am going to burst from the inside, my head is full of music and singing - I will be able to have a violin - I am going to ask Jeanne for the TSF ${ }^{32}$ again, I am going, I am going, I am going - oh Lord, what am I not going to do?

This morning, I had lunch with Miss Clisbe. She is very nice. Cyla came to eat this evening. We ate anchovies, salted cucumbers, soup and drank tea with rum and vodka. Since Thursday, the studies have gone to pot. Soon, I'll be able to give it a good go ... study hard to make up the time. It's not a problem, I'll just not take any holiday at Christmas, that's all. But Christmas, I hope to be able to spend at home. ${ }^{33}$

\section{Tuesday 10 Dec}

'La Vie de Bohème'. 2 first acts, didn't understand a word. Last 2 were fabulous.

\section{Wednesday 11 Dec}

Looked for an apartment.

\section{Thursday 12 Dec}

\section{Looked for a room}

I have it at last!! It's all signed. It is mine. Not a room, mind, but a real apartment - bedroom, kitchen, WC with a wash basin!! And a rubbish chute, my dear!! Just next door to Chez Dilys, 320 rue St Jacques. I am on the 8th floor with a fabulous view over the Val-de-Grâce and the whole south east of Paris. I'll have the sun all morning and I'll have heating in January and February (how about that?) Oh, I am so happy.

Yesterday Cyla and I went round most of the 'quartier' and saw two rooms without being that impressed. This morning I trailed around the area and ended up right outside a room. It had loads of things wrong with it but my God I really liked it.

First of all, the bad points :

1. Ground floor

2. Facing onto the courtyard.

32 TSF (Transmission sans fil) was a radio receiver. TSF literally means 'wireless' but this refers to the nature of the transmission of the sound that came out of it. It was a valve radio run off mains electricity.

${ }^{33}$ Home was 49 Rosedale Avenue, Acomb, near York, England.

Page 20: Diagram of apartment taken from journal. Copyright Andy Brown, licensed under CC BY-NC 4.0. 
3. No sun.

4. No running water.

5. W.C. on the 1st floor.

But it was big and had an "atmosphere" that one could have cut with a knife. It had two bedrooms, a fireplace, two windows and cupboards on each side of the fireplace and it was bohemian, it really was. Because I liked it despite the things wrong, I dropped Cyla a note asking her whether she would come with me to rue de l'Ancienne-Comédie to see it, then I dropped in at Dilys. On the way past, I saw the advert and I went in - saw it, liked it lots. Mrs Evans ${ }^{34}$ really wanted me to take it because she's worried. Went to Sylvia's who said "why don't you go to the hostel?" But she came to see it - I wanted a bedroom. She was very enthusiastic about it. 'But you really have got to take the apartment!! So, that's that. I saw the agent and everything is signed. 2500 francs a month. I can manage that but it will be tough at the beginning; 300 francs deposit and 200 francs to pay before the 15th of January, then 825 francs as soon as possible after that. And there is no furniture. I'll ask Voirin to send me another 1000 francs, and I'll give English lessons. I am so, so happy. I want to do some sketches.

${ }^{34}$ Dilys's mother 'Bessie' Evans. Bessie lived with Dilys, Dilys's husband, George, and baby Gaël, in the building next door to Madeleine, 322 rue St Jacques.

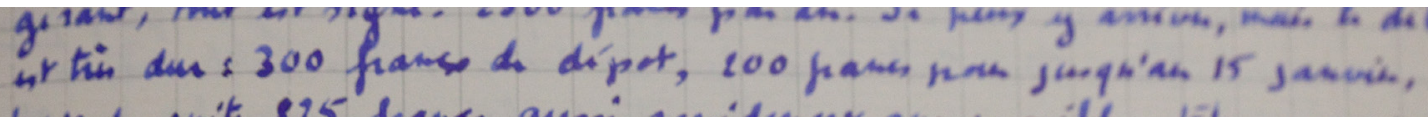

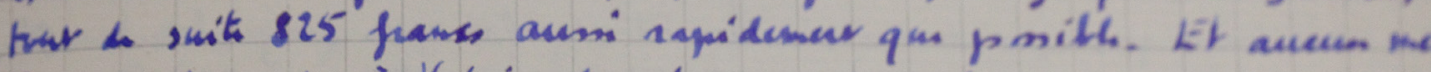

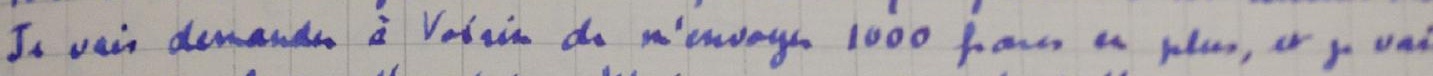

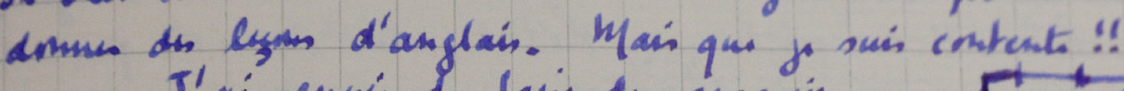
J'aí envis de pasit des evoquis.

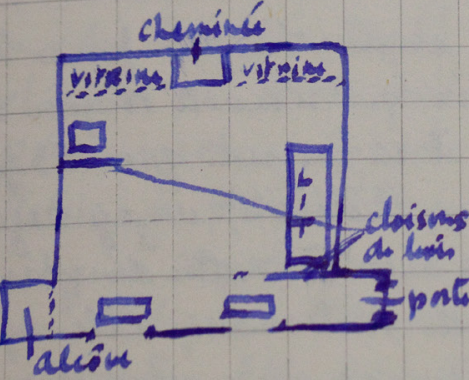

Chambu quimis plu.

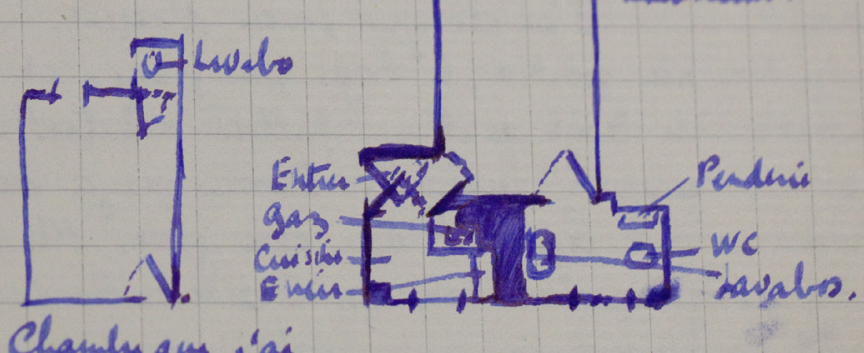
Chanduring ini failli mendus. Appostemort.

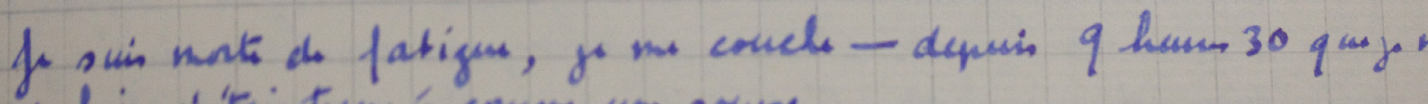

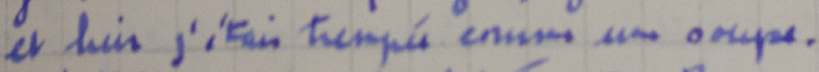
Eto' Villipasisis. Conch Tants. Beaucoup do nigh. 
[Plans of rooms and flat]

Room I liked Room I nearly rented Apartment

I am dead on my feet, I'm going to bed - since 9.30 I've been walking around and I am like a drowned rat.

\section{Sunday 15 Dec}

Went to Villeparisis. Stayed over at Aunt's. Loads of snow.

\section{Monday 16 Dec}

Went to town in the afternoon with Yolande. Went to see the apartment. Ate at Aunt's. Slept over at Aunt's.

\section{Tuesday 17 Dec}

Electricity. Ste Yolande. Roger (Blot) 41 ans

\section{Wednesday 18 Dec}

Gas

\section{Thurs 19 Dec}

Went to the shops. American embassy. Gaël Perrine le Colleter born 9.45-10.00 pm.

\section{Friday 20 Dec}

The Sorbonne has reopened. I don't have to sign at the Commissariat anymore!!!!! Went to see Cyla. I understand why people drink: when it's cold, when there's not much to eat and a lot of work to do, alcohol is warming. I'll only turn to it as a last resort, when I am frozen stiff. I have no heating, thank goodness it is not too cold. Worked until 4 am on Saturday.

\section{Saturday 21 Dec}

It's cold. Queued for Aunt. Confession. 


\section{Sunday 22 Dec}

Mrs Evans is ill. Mass at St Jacques du haut (or is that de Bas?) [Note copied from 4 avril, = St Jacques du Haut-Pas ${ }^{35}$. Aunt. "Feu de Paille". Note from Jacqueline.

\section{Monday 23 Dec}

Xmas shopping and "home shopping". ${ }^{36}$ Frozen stiff.

It seems as if I am neglecting you - I'm not at all. I am thinking about you constantly, especially because of Christmas. On Christmas day I am going to go to Orgeval to escape all the terribly sad memories. I want to laugh loud that day, to be in a noisy hurly-burly so as not to have to think about Mummy all alone in front of the fire with Mamour curled up on her cushions. And then there's Daddy, bringing mince pies home in his pocket. Oh Hell. I'd give my life, 10 years of my life to be with you. What are you going to do for Christmas? My Canadian prisoner has just been ordained. He has promised to say a prayer for my exam. Oh God, let the prayer be for my parents. Sometimes I can think about you without getting upset, but most of the time, my throat goes all tight with emotion and my eyes go misty all of a sudden.

It is cold, so cold. I still have nothing to make a fire and as a result have to get myself into bed around 10 and in the morning I can't, just can't get myself up before 8.30. Jack Frost draws beautiful pictures on the kitchen windows but not on the bedroom ones, it isn't warm enough there. At home, - my real home, rue St Jacques, the whole window was covered with ice ferns. When will I be able to go there? There is no gas, no electricity either. As soon as it is installed I will go, despite the discomfort.

I've got big money worries. I borrowed 1,000 francs off Miss SB. ${ }^{37}$ It has all gone, the rent hasn't been paid and Voirin still hasn't sent me anything! All these Christmas presents to buy!! And I only have 153 francs 30 to survive until when? On top of that, presents, electricity, the trip to Orgeval, - things look gloomy.

Cyla is a great kid. She is going to put up some shelves. Oh dear, pity I'm not as handy as her. Tomorrow she is operating - I mustn't forget to ask her how it all went.

Today, I got paid the 90 francs for three lectures. I wasn't pleased about getting the money. I was much more pleased to get my bursary, money that

\footnotetext{
${ }^{35}$ Small church at 252 rue St Jacques. At the Liberation, Madeleine writes of enemy snipers holed up in the bell tower.

${ }^{36}$ 'Xmas shopping' and 'home shopping' written in English in the manuscript.

${ }^{37}$ Sylvia Beach.
} 
I really have earned through the sweat of my brow. It's strange how little I care about money - except when I have debts as I do at the moment. I have amazing plans for my place. As soon as I am solvent, I will save terribly hard to furnish it.

First of all, I'll need a settee - 900 francs. then a "cabinet" to put in the kitchen - 250 francs. Mirror and glass splash-backs for the bathroom - 100 francs. Pillowcases 66 francs (for two). Pretty curtains ?? francs, wardrobe, table, chair, electric heater, TSF, etc etc, etc. I'll need money for it all. I'm going to scrimp and save and also put some aside for the thesis. My feet are so cold. I am going to write a Happy Christmas greeting to Godfather, Granny, and send it with some cheese ration tokens - 200 grams for their Christmas. New Year's Day will be better - maybe I will have a little money.

There is no butter, no meat, no onions, no fish, no soap, no milk. We have to queue up for carrots, for everything except lettuce and dates. No chocolate at all. Fortunately, we are well fed at the canteen. ${ }^{38}$ I don't have to worry about lunch as a result. In the evening I eat sautéed potatoes because I have some rancid butter. When I have more of them, I will eat them boiled. I have never liked confectionary much and I used to hate cream especially on cakes. Now, I dream about nothing but. When I look at cakes on Friday, Saturday, Sunday (the only days they are allowed) my mouth starts to water. Tastes change?? I really must write to Godfather and Granny this evening. Och! Second thoughts, I might as well go to bed, I no longer have any feeling in my feet. Tomorrow I will write by writing Christmas cards, whilst waiting for Cyla, or in the morning. This evening I will knit a little in bed - perhaps and then bye-byes. I've been wanting to have a proper wash and when it comes to it, I can't face it because it is just so cold - and my dressing gown is at rue St Jacques. I was stupid to take it there first.

I told you that the exam was the 13th of January. I am so cold that I don't care. Is that a good or a bad thing? I just don't know.

For Christmas - I would like - a doll. It's daft, but I want one. When I have the money I will buy myself one. I haven't seen one I like. They are all made out of celluloid or last year's shop-soiled stock. I'd like a little baby made out of rubber. Aunt is going to give me a Hauchecorne. Normally, I'd be thrilled. But just now, I would have preferred a coffee grinder. Bah ! I bet I will be pleased to have the little Chinese terracotta lady - I haven't yet dared say to Aunt that I am moving. Good God. She'll go mad. It might be better not to upset her before Christmas and New Year. Then I will tell her and I will disappear until after the exams. It'll take her until Easter to recover. She makes me lie to her; I hate that but it is her fault. She has her own ideas and she won't listen to anything else. -

${ }^{38}$ This is possibly the Foyer international des étudiantes on the Boulevard St Michel. 
I know that you wouldn't be too happy that I took this room, you would have preferred me to lodge with a family - but it is too dear - and anyway, we can use it as a little bolt-hole in Paris. If the war lasts a long time, which I hope it doesn't, I am going to be very pleased to have somewhere I regard as my home perched up on the eighth floor. Ooh, this cold! I am going to go to bed, my nose is threatening to freeze, the chilblains on my feet are burning. I am not going to knit. I am going to bury myself in the bed wiggling my toes and shivering, shivering until sleep overcomes me - probably two minutes after turning the light off. I don't suffer from insomnia fortunately, - not like poor Mrs Evans. She does suffer...

ps: Mustn't forget to go to see Jacqueline tomorrow. What a busy day!!!

\section{Tuesday 24 Dec}

The moon is a silver crescent. It was russet earlier. A little snow fell and it'll snow again. I couldn't get myself up for $7 \mathrm{am}$. It was too cold. Now I am going to hurry myself along to get to work. Bought some shelving with Cyla at the market at the Hôtel de Ville. Moved. Saw Miss Beach. Stayed talking with her and Cyla. Cyla came to mine. Took presents.

\section{Wednesday 25 Dec}

Christmas. Orgeval. Mass. Danced. Slept over at Aunt's.

\section{Thursday 26 Dec}

Moved. Couldn't get into the rue Rollin apartment. The key didn't turn. Cyla helped. Went to sort out electricity.

\section{Friday 27 Dec}

Moved. Water leak from above at rue Rollin. Gas. Went to Jacqueline's. I am dead tired and I have a very bad cold. I want to move in properly today but can't. I don't have electricity yet. I am too tired to write. I should write to Voirin but I keep putting it off until the next day. I've borrowed another 300 frs. I am crippled with debt!!! If only Voirin could send me some money. If I get nothing tomorrow I'll write. Let's hope that there is something.

\section{Saturday 28 Dec}

Slept at 320 rue St Jacques 


\section{Sunday 29 Dec}

Went to Aunt's. "Ils étaient neuf célibataires" ${ }^{39}$ Wrote to Voirin.

\section{Monday 30 Dec}

Sorted and tidied. "Samson et Dalila". ${ }^{40}$ Miss Beach got a letter from Ruth. ${ }^{41}$

\section{Tuesday 31 Dec}

Queued for potatoes. Marcel came.

${ }^{39}$ A 1939 film comedy directed by Sacha Guitry, starring Guitry, Max Dearly and Elvire Popesco.

${ }^{40}$ In all probability the Opera by Camille Saint-Saëns.

${ }^{41}$ Ruth Camp wrote to Sylvia Beach from Vittel internment camp on several occasions. The letters can be consulted in the Sylvia Beach archive at the University of Princeton. 



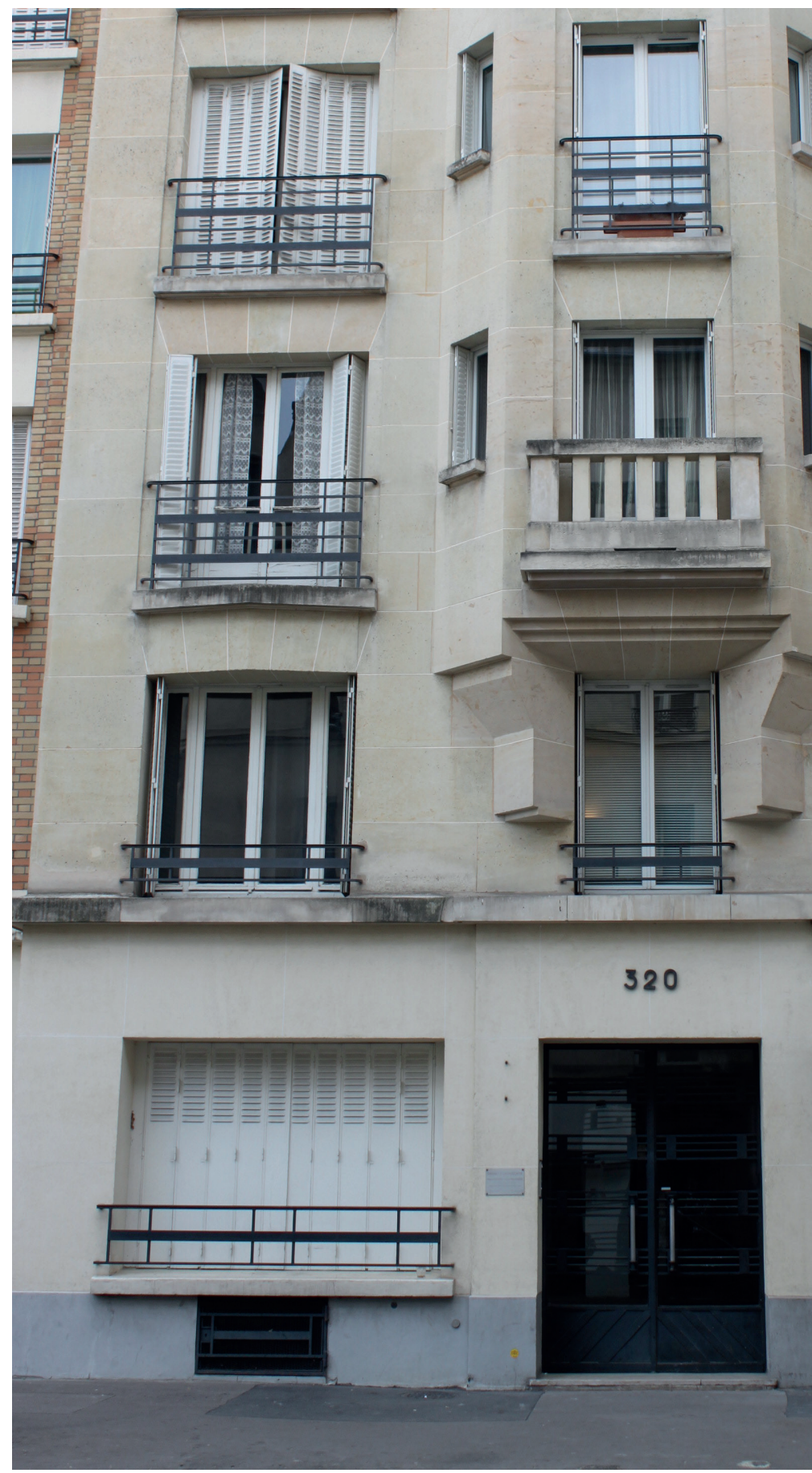

320 rue St Jacques from the street (present day). Copyright Jack Charnley, licensed under CC BY-NC 4.0. 



\section{Introduction 1941}

\section{Hardening Conditions}

The second year of Nazi Occupation is marked by a severe deterioration in living conditions, an intensification of repression and an increasingly demoralised populace. The winter is exceptionally bitter, the rationing is increasingly severe, the first major round-ups of Jews take place in the 10th district of Paris and prisoners, irrespective of their crime, are now hostages and are shot in retribution for Resistance activities. Closures of cafés and restaurants were becoming more frequent, as were early curfews. There was growing scepticism that the project of collaboration vaunted by the Vichy government was really a necessary interim. The Introduction to this section examines Madeleine's engagement with deteriorating conditions in both a practical and psychological sense. Her struggle with the cold and with hunger are thoroughly documented, as are the strategies she employs to cope with both. Despite her cautiousness about noting down too much about 'political matters' she notes down Resistance attacks and the nature of the Occupier's punishment of the population in response. There is a clear sense of growing alarm and anxiety about increasingly regular shootings and conspicuous threats in ubiquitous posters plastered over the walls of Paris. The final months of 1940 had not been especially onerous for Madeleine. She had felt sufficiently confident about her income to rent her own studio flat at 320 rue St Jacques and had been thrilled to move there on December 27th. However, the excitement about a new-found independence did not survive long into the New Year when living conditions began to rapidly deteriorate. Madeleine began to feel the impact of the first food and fuel penury in January 1941 and her diary entries betrayed an increasingly fragile morale.

Daily life became a harsh struggle to bear the bitter cold with no means of heating and very often with little to eat. In letters written towards the end of 1941 and which were intercepted by the Vichy authorities Antoine Lefébure describes a population for whom little other than getting food and keeping warm mattered (Lefébure, 1993: 93). The lack of heating was compounded by the lack of warm clothes which, like food, were rationed. Only certain categories of workers qualified for outdoor wear. Everyone else had to manage with the coats and shoes they already had. Queuing for food was a necessary daily chore. It was often the only way of having a chance to obtain food, even 
though there was no certainty that there would be any food left to have once one arrived at the head of the queue. Hanna Diamond writes that queuing was a responsibility which women tended to have to shoulder. They often had to spend several hours before work queuing up. It was tiring and stressful, as was trying to manage the household budget to pay for goods, which were often extremely expensive. (Diamond, 1999: 53-54). Of course, Parisians had to find ways to cope with food, fuel and clothes shortages, and they did so with some vim and creativity. Lefébure describes how his letter writers substituted cuts of meat with all manner of alternatives and imitations, although even the giblets and beef dripping ran out eventually and they had to go back to the ubiquitously available and much maligned rutabaga swede (Lefébure, 1993: 94). People were also resourceful in respect of clothing. Again, the chore largely fell to women who commandeered all manner of scrap material and textiles to make, alter or to repair clothes. 'Dresses and trousers were lengthened by adding of scraps of material. Curtains, tablecloths, everything possible was mobilized to be made into some item of clothing [ . . ]' (Diamond, 1999: 62-63). There were strategies to get hold of food as well. Queuing was unavoidable for most, but those who worked were able to develop practices of sharing and exchange through the workplace. The Black Market flourished and those who could afford it used it, and many travelled to the countryside where farmers were only too pleased to have a clientele because of the difficulties of taking their wares to Paris to sell (Diamond, 1999: 54-57). However, the strategies could only often only palliate hardships which got progressively worse as the Occupation wore on. All manner of ruses were being used to find enough to eat, but the challenge was a formidable one. By 1941 there wasn't even any shoe leather to mend worn-out shoes. Only wooden soles or clogs were available (Diamond, 1999: 65).

Madeleine deploys all of this ingenuity and resourcefulness in her diary to manage an experience which resembles very closely indeed that described by Diamond and Léfebure. Food substitutes are experimented with - bran instead of oats for porridge, acorns instead of cocoa beans for coffee to name a few, but all too often rutabaga swede is the default menu item. The Black Market is expensive and a rare treat, but Madeleine uses it when she has no choice. She makes clothes out of curtains and seemingly spends hours darning and repairing garments which, one would suppose, might ordinarily have been thrown out. She also makes use of 'supply' networks at the Bibliothèque nationale where she works part-time, at the Sorbonne, the lending library and bookshop Shakespeare \& Co and at home in the building where she rents her flat.

The general view of commentators that practical difficulties dominated the lives of Parisians rather than the political and military situation is to a great extent borne out by Madeleine's diary. The weather and the availability of food become determiners of mood and morale and an obsession as Madeleine and Parisians struggled with the cold and as rationing became more severe and food became increasingly scarce and unaffordable. Madeleine's diary shows the extent to which her daily life had to revolve around lack. The difficulty of coping 
with the cold impacted on the routines and the rhythm of both day and night. Not only was the cold of winter miserable to endure, but the shortage of fuel often meant no light to read or to eat by and candles were almost impossible to find. She had to go to bed at nightfall wearing layers of ill-assorted garments, hats, blankets and stoles in order to keep warm. Sometimes, she was so desperate for warmth that she used the entire month's ration of electricity in a single night. On occasion she did not attend classes because the cold was such that she couldn't bear to get out of bed. Getting around Paris was fraught with difficulty. Fuel shortages meant public transport cuts and overcrowded underground and suburban trains. She often had to walk long distances across the city in the dark and the wet in wooden-soled shoes (there was no leather to be had, either).

The everyday struggle to survive the many hardships exacted a psychological toll on Parisians. Madeleine's diary gives us insight into the impact that the everyday grind had on the mental health of herself and others. Mental illness during the Occupation has been little written about, yet the first references to it appear in 1941 in Madeleine's diary, and her psychological fragility is echoed in other diaries and letters of the period. Pierre Laborie notes the fragility of fatigued French civilians in letters intercepted by the Vichy authorities. The struggle to negotiate material difficulties, financial hardship, separation from loved ones was wearing people down in both body and mind. By 1943, he writes that the atmosphere is 'heavy and anxious' and that people are 'disappointed, disillusioned, apathetic at the end of their tether and wanting peace at any price' (Laborie, 1990: 292-7). As early as the Phoney War, the fragile mental health of civilians in wartime had been identified. Gregory Thomas refers to the December 1939 meeting of the Société medico-psychologique where it was reported that cases of 'mania and melancholy' had increased over the period (Thomas, 2009: 74-75). By 1941, anxiety and depression, exacerbated in Madeleine's case by homesickness and loneliness, became a regular feature in her diary. Incidences of depression and bouts of anxiety were regularly noted down from 1941 onwards. ${ }^{42}$ In respect of physical health, malnutrition had brought about a public health crisis which imperilled people of all ages. Madeleine constantly yearned for the countryside and for her home and family in the UK - all the more so because prolonged mental and physical debilitation in Paris were causing people to die from conditions which were generally benign and treatable. The city was becoming a grim and unhealthy and dangerous environment where easily transmitted colds and 'flu could be lethal to a malnourished population. Tuberculosis was also rife in Paris because of poor public health. This scourge was still a major threat in the 1940s because the BCG antibiotic drug treatment was not yet widely available. Madeleine lived in constant fear

${ }^{42}$ Madeleine's struggle with mental health is examined at length in Michallat's 2017 article, 'Mental Distress under Occupation: The Journal of Madeleine Blaess', French Cultural Studies 28 (2): 173-185. 
of contracting it, which was understandable given that her cousin Yolande and Georges, the husband of Madeleine's best friend Dilys, both had it. George was so severely afflicted that he was dispatched to a sanatorium early on in the war. ${ }^{43}$

This association of the urban with disease, death and deprivation causes Madeleine to turn her writing away from the bleakness of urban life and decor to lush and vibrant representations of the natural environment and countryside. Her entry for March 21941 is typical of this displacement. Objecting to Dilys's view that her consumptive husband Georges should remain in Paris, she ruefully notes, 'mind you, the air in Paris is hardly doctor's orders even without buses. Madeleine then abandons grim descriptions of rationing for joyful evocations of a recent trip to the countryside. 'What a delight to be in the countryside once again. I lose contact with it living in the City which really upsets me. This year, for the first time in my life I did not "feel" Springtime.' The vitality of Madeleine's description of the countryside with which she ends her entry in March 2nd contrasts with the privation and disease that begin it: 'The fields are full of celandine, of speedwell, of chickweed. The juniper is going to flower. There are primroses everywhere. There are daffodils showing. What a sunny day with a mild breeze. ${ }^{34}$ It lifts Madeleine's spirits and inspires her to contemplate the future. 'Everyone was out in the fields turning the soil; the earth of France is so rich and so beautiful. I want to finish my degree this year (23 years old) and take my doctorate the year after (24 years old). Then, I will get married and stay in the countryside. I have had enough of Paris. If the war isn't over by then and if I have work I will try to live in the countryside anyway. Oh dear! ${ }^{45}$

The climate, the weather, the seasons and the natural environment feature regularly in Madeleine's diary. Spring, especially, prompts vivid and joyful descriptions of the returning lushness of the trees and flowers in her favourite urban parks and gardens. Pastoral references, and particularly those related to the return of life in the Spring months, were subsumed into political rhetoric on both the side of the Resistance and the Vichy authorities with their irreconcilable common notion that spring represented national renewal and rejuvenation. Although Madeleine did not intend to convey a political message, it was certainly the case that there was an intensity - a collective rapture - about a season which marked the end of cold, dark winters.

For all this, though, 1941 is one of the most challenging and difficult years of the Occupation for Madeleine. She experiences severe material deprivation for the first time and begins a struggle with her mental health. At the same time, it is during 1941 that she begins to garner the experience and forge the resourcefulness which enable her to get through the subsequent years.

\footnotetext{
${ }^{43}$ See Jackson (2001), Vinen (2006) and Laborie (1990) and (2001) for general overview of the hardships of living conditions during the Occupation.

${ }^{44}$ March 21941.

${ }^{45}$ Ibid.
} 


\section{1}

\section{Wednesday 1 January}

Went to Villeparisis. Snow!!

\section{Thursday 2 January}

Here I am alone at last and here I am IN MY OWN HOME!!!!!

I have been humming that since Saturday and since Saturday I've been wanting to write to you but it is virtually impossible because I haven't any electricity and only two candles. So, I go to bed early in the evening and in the morning I get up at day break. But what can I do!

The day before yesterday it poured down, Marcel came 'to help'. He was cold and so he put on my slippers, my dressing gown and his hat. He looked very handsome I can tell you. Yesterday, snow fell all day at Villeparisis and it was as deep as anything. Today, I have three millimetres, no, I am exaggerating, one millimetre at least of ice on the inside of the window panes! I am cold but I prefer to freeze and be in my own place. At around 5 oclock I am going to go to Mrs Evans and stay for as long as I dare - it's just to keep warm and to be able to see. I would like to write more, much more but I have some notes to copy up for the exam. I've stained the floorboards walnut.

Brilliant!! Brilliant!! Voirin has just sent me two thousand francs. I'm saved!! No more potatoes in their jackets and bread for lunch and dinner and nothing else. Hooray!! ${ }^{46}$

I've paid back Sylvia Beach her 1000 francs. Bought sausages. How extravagant!

46 'Hooray' written in English. 


\section{Friday 3 January}

Sorbonne started up again. Electricity installed

\section{Saturday 4 January}

Victor Hugo was a liar when he said that he thought the Val-de-Grâce was horrible. Had he never seen the fabulous tints in the stone at sunrise and at sunset? Saw Gaël. A beautiful baby but with a few spots. Dilys is as skinny as anything. I really must study. All I want to do is housework. Isn't that strange. True though. I'm going to settle down to work anyway. It is snowing again.

\section{Sunday 5 January}

Have had a bad bout of depression since yesterday evening. Yesterday evening I was crying whilst I was eating. It was good to cry, tears falling into the soup or onto the jacket potatoes. Still felt terrible this morning and tonight. I can't get myself up before 10 in the morning, it is too cold. Then there's mass, queuing for carrots, lunch. I wrote New Year cards all afternoon when I have plenty of other things I'd be better off doing. But, I don't think that I have forgotten anyone. I should have gone to Cyla's yesterday but feeling too depressed I was worried about not being fun - and I think that she is attached to me because I don't ask her for free consultations and I am genuinely interested in her and in her work. Once, she never used to speak about the hospital, now she is more willing to tell me about the operations that have taken place - the day before yesterday there were two amputations and a stomach ulcer - there are lots of ulcers around at the moment. I would have liked to be a doctor. It is too late now, I am too old to be starting at $22 \frac{1}{2}$. If I can get my degree here and my doctorate then I will be happy - and if I qualify to teach in a French university ...!!!! But, I don't want that because that will mean that the war will have lasted all that time. I want to get my degree this year, but everything is conspiring against me. Roll on the exam so I can soon be 'settling down ${ }^{37}$ to a normal routine. I keep having doubts all the time over the 'wisdom" ${ }^{48}$ of taking on this apartment. I think that my big cold must have been the flu and that's why I am so depressed at the moment. It's ages since I've had such a long and acute period of depression and each time it is after illness or exhaustion. But fifteen months not seeing you seven and a half months without any news. It is far too long. Do you remember how I couldn't bring myself to eat sugar? Now I can eat pure honey off the spoon without finding it too sweet!! I shouldn't open this pot. I should keep it for later because 'they' have told us that we will be eating what animals eat by

\footnotetext{
47 'settling down' written in English.

48 'wisdom' written in English.
} 
March. It is starting to go that way. Ration cards for potatoes, rice, pulses, sugar, coffee, pasta, bread (even cakes), meat, butter (if one manages to find any), cheese, shoes. The only vegetable not included is swede and cauliflowers which are astronomically priced. Huge queues for carrots. The rue St Jacques is better for food than the Rue Mouffetard that everyone goes on about. I got some cold meat at lunchtime and I saw some cheese and some yoghurt that I'll buy when I have the money. I need to put the letters in envelopes and get studying - finally. God knows what I am going to do to keep warm. Yesterday evening I wrapped myself in a woollen blanket over my dressing gown with my pinny on my head to keep my head warm and even then I wasn't warm - because Georges hasn't yet fitted the socket in the ceiling so I've only got one socket so when I want light I can't have heat. I have the little fire bowl thing but it doesn't put out much heat. My feet are blocks of ice.

\section{Monday 6 January}

11 o'clock in the evening and - miracle, I haven't gone to bed - and that despite getting myself in bed at 8.30 pm nearly crying because of the cold. No, I still have no heat - I only have a scrap of a woollen from Madame Fastier on my head, two woollen jumpers, my dressing gown. I wrapped myself up in Dilys's big woollen bed cover and the eiderdown. I can make it through to about 2 oclock in the morning like that but I will have to get up at 7 am tomorrow.

This morning - disgrace! I had my seminar paper to give at 9 am and I didn't get out of bed. It was too cold. It is snowing again now though so the temperature won't be so bad.

I had a letter from Voirin, full of moaning of course. I will reply tomorrow. I'll know better what to say once I have slept on it. There are sheets etc that Dad left. But how can I get them sent over?

Despite the dreadful expense I am going to start to have meals again at the student hostel. I need to eat well at least once a day. This morning, I felt dizzy and sick. I ate well at lunchtime and this evening too with the result that I am alert, happy and warm. I need to feel OK in order to study, to work and to deal with my money worries. Voirin says that he thinks that we'll have to leave Nancy. How awful but let's hope not - let's not go expecting that to happen.

Dropped by at Dilys's place. Gaël is pretty. "Auntie Madeleine" already loves this tiny little thing. She smiles but this afternoon she was crying, the poor thing. She has a very strong body but hardly any hips at all. She probably won't be able to have children.

I am making loads of plans for doing up my room which, in the main, consists in putting in as many shelves as I can (I can but dream) to put everything on. I'd like to have enough space for a beautiful big wardrobe, but alas, no way, the room is too small. I really need a single bed - this one takes up nearly all of the room and only leaves a little passage on the one side and in front of the window. I would like a bureau with drawers - it is so handy for tidying things 
away and it wouldn't take up much more space than this table - I'd do better carrying on this dreaming in bed. I am practically falling asleep on the page.

\section{Wednesday 8 January}

Just dropping you a line to find some relief from Leroy's "The Knight Sir Thomas Browne", because my mind is beginning to wander. Yesterday I had class - I bought cod liver oil. I'm a good girl aren't I? But, God, how I hate it.

All the classes are disrupted because of the cold - the 9 and 10 o'clock classes will take place at lunchtime and the 11 o'clock classes at $1 \mathrm{pm}$. Can you imagine? What a mess up! We'd prefer to be cold and have classes at normal times than all this. Tomorrow I go without a break from midday to 5 o'clock!! So, I am going to have to have breakfast and lunch at $11 \mathrm{am}$. What a life! I'm doing my stomach no good at all already through not eating much let alone not eating regularly. I've bought some bread tickets for the refectory. I went today and I ate more in a single meal than I normally eat in an entire day. I'm going to do my best to go there as much as I can because with one good meal a day one can make do with whatever otherwise. Yesterday George came to fit the electricity socket - I am so happy to be able to study in the warm sat on the bed baking hot against the radiator. There is nothing worse than being cold. I would rather be warm and hungry than cold and not hungry. I know all about that. I feel a little happier today.

Got a letter from Zéau. Those kind folk are still upset that I couldn't get back home to you. They have been the first to reply to my New Year letters. Truth be told, I am not expecting any other replies, because I know how bad people are at writing. ... Pierre and Félix are POWs. Pierre is a woodcutter in Germany, Félix is working on a farm in France. Thank God that they are not in the camps!! $\mathrm{M}$ and Mme Zéau, Yvonne and their two children, Laurence and the two little ones manage how they can at Lardy. I hope that M. Zéau will lend me his violin!!

I must write to Voirin. It is a letter I don't want to write because I need to ask for money up front. Counting the 60 francs for lessons I have just had, I have 88 francs to last me until when? And I owe 300 francs. I need to find some work. Given the disruption of classes the tutorships are not being offered - so that means bye bye to 60 francs a week!! This time I am really "up against it" 49 And what's more Miss B is talking about leaving for America. Mock is leaving and will take your address with him. Today it was sunny and tonight the wind is getting up which makes me happy. I start to think about flowers, about the pet bird I will get.

49 "up against it" written in English. 


\section{Thursday 9 January}

You'd never think that the days are getting longer - at 9 o'clock it is completely dark as if snow is on the way.

At 11 o'clock, we had a March sky. Pink and grey clouds racing over the soft blue. I had a hell of a battle getting off a layer of ice from the window to let the light and air through.

Wrote to Voirin. Praise the Lord! What a chore it is to have to ask for money. Twenty to midday - I really ought to get off to my lessons. I've eaten lots to enable me to 'last' until 6.

What a beautiful day, sunny. My bedroom is South South East facing and so I have the sun all morning until 12 noon, quarter past (so two hours, two and a quarter hours Europe time) and when the sun takes longer to move round I reckon that I will have it in the kitchen in the evening. Never in the bathroom because of the chimney that blocks it.

I heard an owl. Is it the one from the Luxembourg Gardens? Memories of the Captain. ${ }^{50}$

\section{Friday 10 January}

Wonderfully sunny. Leant against my open window for a quarter of an hour enjoying the scenery and the Val-de-Grâce.

Card from Colette Brand - they are clearly delighted that I wrote to them. Letter from Madame Faure. So Madeleine Carroll's ${ }^{51}$ sister has been killed in a bombing. My only memory of her was of an overweight girl wearing too much make-up and who made a show of herself, with Gilberte, on the train to Whipsnade.

Change of date for the exams . . . . but there won't be any exams. Vendryès announced it this morning.

He gave us some pamphlets that he had written. I was so proud. There is a 'new' young married man who seems really nice. We - and M. Lebel - are going to run the library together. Long conversation with M. Lebel about names of

50 The owl reminds Madeleine of living in the Pension Les Marronniers opposite the Luxembourg gardens and of a naval captain she knew as the 'Commandant', who had rooms there.

${ }^{51}$ Madeleine Carroll was a Hollywood actress born in West Bromwich, England. She is particularly famous for roles in several Hitchcock movies. She was half-French, had studied French at University and tutored French in Hove, East Sussex, whilst training to be an actress. Her sister Marguerite was killed in a bombing raid in London on October 7 1940. It is unclear where Madeleine met Marguerite, but it may have been through her sister's tutoring. See: https://www.madeleinecarroll.com/biography/ 
rivers. [...]. The Don, the Danube, the Dneiper - connection with the Danaïdes Denmark and the Danaï (Greeks) as seafaring people. Very interesting it was. Oh I so love studying. I do want to get married but I would rather be a spinster than give up my studies. I must organise my days well because I'll need to do degree, Anglo-Saxon, thesis, Welsh, the Celtic library and housework. I also need to earn a living giving lessons etc. The only way is to get myself up earlier. 9 o'clock isn't early enough but given that it is even colder and darker (they say that the days are getting shorter!!!). When the days get longer that will be better because then I will get up at daybreak provided I go to bed at $10 \mathrm{pm}$. That will save on electricity. I wonder whether the winter meridian is the same as the summer meridian because it seems that the sun lasts longer in my bedroom than I thought it would. 2 hours 25 minutes already!! I have to run to class. It's funny - I write lots on days when there isn't much happening but on days when there is lots to say I say nothing. December 5th is one example. It is true that it is better to keep quiet about political events. God, I write badly! A few writing lessons wouldn't do me any harm. Mind you, writing on my knees doesn't help!

\section{Sunday 12 January}

Yesterday Dilys was really poorly. She has an abscess on her breast and had an injection that caused such a reaction that I was asked to stay and look after her. - I stayed until half past seven. But, what a day!! Because of all the changes to the timetable no one knew whether the lesson would take place at $11 \mathrm{am}$, midday or at one in the afternoon. They took place at one but I was there at each of the times. Then, between times I was running around for milk for Dilys. The lessons lasted until three oclock then I went to eat lunch at Dily's place potatoes, chicken, honey.

Today I got up late at around 9 oclock and I missed mass. Bought a puff pastry to take to Dédés. Trying to decide whether or not to buy tobacco for Dédé as well as for Grandad. The thing is, I only have 14 francs to last me eleven days and with the cost of getting there, tobacco etc I'd only be left with 8 francs.

I feel so down. I cried this morning. I so want to see you after having dreamt of you all night. I nearly burst into tears in the street so I bought myself a mimosa to console me. I know it's terribly extravagant but I am so low. It's the lack of food and news and being so far away from you.

Went to St Denis. They couldn't have been nicer to me. I stayed to dinner even though I didn't want to - they don't skimp on food there I can tell you. René is still away. He went to Brest and was there when it was bombed so heavily. He is a handsome young man and Colette is pretty. It's like living in the eaves at their place. I know that they would have never invited me if they hadn't known I had my own place because they sense and get upset by Aunt's contemptuous attitude. I think all this snobbery is stupid. Their home is full of colour; quite bohemian and I really like bohemian buildings. That's what I don't like about this room, a/ It has no character $\mathrm{b} /$ there is not enough wall to put the bedstead against. 
Grandfather has been very ill. He says that when they sounded his chest they didn't find a heartbeat. That doesn't surprise me (apologies for the cattiness, ${ }^{52}$ but he is a stranger to me. He is a very intelligent chap but so, so arrogant. He claimed that the Larousse was wrong - he forgets that at his age his memory might not be able to recall such and such a principle in Physics). Dédé is in better health. He made a little electric stove which he gave to me as a present. The intensity of the love Aunt Marie bathes him in, brings out all her qualities in him. He is a handsome lad now and he has practically stopped trembling.

The Germans at St Denis are not as well disciplined as those in Paris. I can see why Dédé and Aunt Marie wanted to go with me to the station on the way back. Worked on notes until Monday at $4 \mathrm{am}$.

\section{Monday 13 January}

Depressed. 3 francs 90 left in my pocket. Mlle Martin didn't come for her lesson. Cyla came. Went for dinner at her place. She's a great kid. She lifted my depression. Chatted for two hours about my thesis to the young man with whom I am going to do the cataloguing of the Celtic collection. James Joyce died on Saturday (11th) at Geneva. What a blow for Miss Beach. I am becoming so very parisienne (nosey parker). I stayed for half an hour in the cold watching the fire brigade take down enormous icicles coming off a leaking gutter. Went to see Vendryès. What a fine chap. He offered me money. I didn't turn my nose up at it. I will have it on Monday.

\section{Friday 17 January}

Voirin sent 1000 francs.

\section{Saturday 18 January}

Joined Madame Monnier's ${ }^{53}$ library.

52 'cattiness' written in English.

53 Adrienne Monnier (1892-1955) was Sylvia Beach's life partner. She, like Beach, was also a bookseller and ran La Maison des amis des livres opposite Beach's Shakespeare \& Co at 7 rue de l'Odéon in the 6th arrondissement. When Beach's bookshop closed in 1941, much of Beach's stock was transferred to Monnier's bookshop and it continued to be loaned out. There are inventories of the stock transferred from Beach to Monnier in the Maurice Saillet archives held in the Carlton Lake Collection at the Harry Ransom Humanities Research Center, Texas, United States. 


\section{Monday 20 January}

Dédé came to put up some shelves.

\section{Thursday 22 January}

First lesson at the Vignet's (got paid)

\section{Sunday 26 January}

Went to Villeparisis.

\section{Thursday 30 January}

Lesson with Vignet. Got a card from Mother Ambroise.

\section{Sunday 2 February}

Went to a Chinese restaurant with Yolande. Then the cinema 'L'Héritier de mon désir'. Had dinner at Aunt's. Started with a cold.

\section{Tuesday 4 February}

As sick as a dog.

\section{Wednesday 5 February}

Cyla came over. Snowed.

\section{Thursday 6 February}

English literature exam. "The Power of the Imagination in Coleridge". $8.30 \mathrm{am}-$ $1.30 \mathrm{pm}$. Didn't have lunch. Lesson with Vignet. Went to the Red Cross. Snowed.

\section{Friday 7 February}

Went to see Berthe at Hôpital Necker. Snowed.

\section{Saturday 8 February}

Went to see Berthe at Hôpital Necker. Snowed. Colette came to dinner and to sleep over. Went to see 'Angèle'54 at the cinema.

54 Angèle (1934) was a comedy film directed by Marcel Pagnol starring the actor Fernandel. 


\section{Sunday 9 February}

Went to Dédés for the day. Went to see 'L'Intrigante'.

\section{Monday 10 February}

Met Andrée (the nurse who lives at number 3). I already know Madeleine (number 4). Their water is frozen up. They are coming to mine for it.

\section{Tuesday 11 February}

We can only have 150 grams of butter a month and 30 grams of margarine. 100 grams of cooking oil. Allowed through to the oral exam.

\section{Thursday 13 February}

Went to Gardiner's. ${ }^{55}$ Asked for a job. Interview with a Scotsman. Got the job. 14 February will be the first lesson.

\section{Saturday 15 February}

Went to Dilys's.

\section{Sunday 16 February}

Studied at home.

\section{Tuesday 18 February}

Oral. Cazamian ${ }^{56}$ was sweet. Delattre ${ }^{57}$ was dreadful. Passed.

\section{Wednesday 19 February}

Visited St Séverin and St Julien le Pauvre (Orthodox Greek rite) with Paulette Trois-Gros. Hail. Received letter from Aunt with a letter from Dorothy Clarke enclosed.

${ }^{55}$ Gardiners was a private language school. Madeleine tutored English there.

${ }^{56}$ Louis Cazamian (1877-1965) was a professor of English literature at the Sorbonne.

${ }^{57}$ Floris Delattre (1880-1950) was a professor of English Civilisation at the Sorbonne, a poet and a writer. 


\section{Thursday 20 February}

Lesson with Vignet (5 to pay for). Red Cross. Went to Lloyds Bank but my account is frozen.

\section{Saturday 22 February}

Michael took me to the cinema. "If you love me". He bought cakes and chocolate. I can't stand him. Godfather's birthday.

\section{Sunday 23 February}

Went to Villeparisis.

\section{Monday 24 February}

Snow. Did washing.

\section{Tuesday 25 February}

Read "Sido" by Colette. ${ }^{58}$ Very good. It reminds me of mum. Read "Enchanter's Nightshade" ${ }^{59}$. Bought full cream milk (half a litre).

\section{Wednesday 26 February}

Did washing. Sunshine. Michael confessed his love to me and asked me to marry him. I laughed in his face. He 'will wait for me'. Tut, tut. An eternal and undying love, etc etc. Wants me to allow him to love me at least. To have pity, etc etc. I think Michael is a complete idiot. I will have to draw up a timetable to make sure that I don't waste time. Went to see Babicka. ${ }^{60}$ What a great girl.

\section{Thursday 27 February}

Mlle Vignet wasn't there so couldn't give the lesson. Went to hairdressers.

\footnotetext{
58 Sidonie-Gabrielle Colette (1873-1954) was French novelist. Sido, based on her childhood and reminiscences about her mother was published in 1929.

${ }^{59}$ Ann Bridge's novel Enchanter's Nightshade was published in 1937.

${ }^{60}$ Cyla Babicka.
} 


\section{Friday 28 February}

Michael declared his love for me once again and asked again for my hand in marriage. What an imbecile. Vendryès was very kind. He wants to look after me. Was paid 68 francs by the Ecole Gardiner today. That will have to do me the week. Read "Claudine à l'école" (Colette). I didn't like it. Read "The First Wife \& Other Stories" (Pearl Buck). Good.

\section{Saturday 1 March}

Did the housework. Letter from Odette and from Granny. Saw Jacqueline Eichhorn. Went to Confession. Went to the baptism reception for Andrée - prior to which I did a tour of all the dairy shops to get some milk for his cream and his Béchamel sauce.

Menu: Excellent soup (green bits in it and cheese)

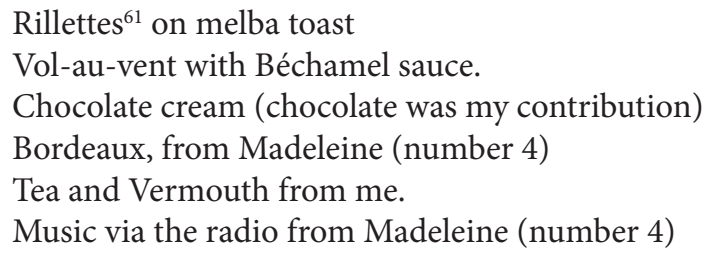

We had some laughs and good conversation. Went to bed at $1 \mathrm{am}$.

\section{Sunday 2 March}

Made a casserole (not bad, I like cooking and should find the time to make little dishes because if I do so at the moment it is at the expense of the housework). Met Dilys. She was in tears. She has just got over the 'flu. Georges has TB!! The left lung is badly affected and nothing can be done about that but they hope to be able to save the right one by draining it. She is really upset. It is very sad. She's upset about money too but he will be paid for 5 months so she can stop worrying about that. She'd like to move to a little house that is for rent on the rue du Val-de-Grâce. She thinks that once Georges is there he won't need to go to the sanatorium nor to the countryside - mind you, the air in Paris is hardly doctor's orders even without buses. I'm so sad for Georges.

Mass.

I've been silly. Bought cake and cyclamen. I know it is stupid but it is the last day for cakes and given that it could be years until I see one again - it might not come to that - I thought I'd go out with a bang! It wasn't bad.

${ }^{61}$ Rillettes are a type of potted meat; a cross between paté and meat dripping. 
Will there be more restrictions. Already, we have:

Very little butter, 200 grams of cheese a month, 300 grams of bread a day (but soon to be 250 grams), 500 g of vegetables a month, 360 grams of meat a week, $1 \mathrm{~kg}$ of potatoes a month, 1 bar of soap (regulation soap) and $200 \mathrm{~g}$ soap flakes per month. No cakes or confectionary. Not allowed to buy shoes, slippers, clothes (over and under garments), cloth, woolies, bed linen, curtains etc without a voucher. Silk and rayon can be bought without a ticket.

Went to Massy-Verrières to see Paulette Trois-Gros. What a delight to be in the countryside once again. I lose contact with it living in the City which really upsets me. This year, for the first time in my life I did not "feel" Springtime. The fields are full of celandine, of speedwell, of chickweed. The juniper is going to flower. There are primroses everywhere. There are daffodils showing. What a sunny day with a mild breeze. Everyone was out in the fields turning the soil; the earth of France is so rich and so beautiful. I want to finish my degree this year (23 years old) and take my doctorate the year after ( 24 years old). Then, I will get married and stay in the countryside. I have had enough of Paris. If the war isn't over by then and if I have work I will try to live in the countryside anyway. Oh dear! $!^{62}$ Went for a walk down the Avenue des Cambacérès and through the park and the woods behind. If I had money I would buy myself something at Verrières - some land or a house. It is an area which I like enormously. The Trois-Gros are very nice. She speaks slowly and softly. He loves taking photographs.

9 chickens hatched today, Brought back a bunch of primroses. Going to go to bed because tomorrow - Oh for resolutions - I am going to get up early etc.

The brook that passes under the viaduct next to the field where the 'Man with the Old Horse' worked is the Bièvre which flows from the Seine!

My primroses are in a mustard pot. I daren't take them out of the kitchen. They look so pretty against the white tiling with the green edge - I am going to open the windows for them so that they don't suffocate during the night. My cyclamen isn't going to last. It was madness buying it. A bud showed a petal tomorrow it will be in full flower. I would have been better buying a hyacinth. Michael is an ass. He wants to give me money, a coat, buy me a house in the country and all sorts but the imbecile can't even manage to buy me a bunch of violets. Here's hoping that his love sickness abates so as not to have him hanging around me with his teary fried fish eyes begging for me to give him an afternoon - a few hours - and to have pity on him. Poo!

If I only knew if the war is going to last for a long time or not - I would be able to settle down. But I will not stay here. As soon as I get regular work I will move out for something bigger and in the countryside if poss. I am building my house in my head.

62 'Oh dear' written in English. 
It is over with Michael. Thank God!63

\section{March St Colette ${ }^{64}$}

But sent nothing because I have no money. ${ }^{65}$

\section{Friday 7 March}

Got news via the Red Cross from Mum!

\section{Thursday 13 March}

Went to Aunt's to see Berthe. Slept over.

\section{Sunday 16 March}

Went to Villeparisis. Went to St Julien-le-Pauvre for the Greek orthodox service. Colette slept over Saturday night.

\section{Tuesday 18 March}

Jacqueline Martin's last lesson with me. She is leaving clandestinely to get back with the one she loves - if she can't marry him then she is going to go to Algeria to be a doctor in the colonies. She will be 21 next month. I could never leave like her.

Saw Madeleine Lavelle's study room on the 8th floor with a balcony. It is exactly what I would have preferred instead of this place. If this big push results in nothing on either side then I will be looking for a place I like where I can settle because it will mean that the war is going to drag on - unless I manage to get home. For now, I have to work - I am 26 hours behind on my schedule so I won't be going to the hospital tomorrow. I will go Tuesday so I can have the whole day with my head down if I have to.

Georges has TB. Yolande has found out that she has it too. She was a bridesmaid at Roche's son's wedding. The white velvet dress suited her but was one for the day after a wedding. It wasn't the right outfit.

63 'Thank God' written in English.

${ }^{64}$ Saints day. Madeleine sent presents to friends and relatives on their saint's day. Colette was a cousin.

${ }^{65}$ Opposite this reference in the margin, Madeleine has added in brackets: '(Don't forget. [ ... ] Quarteron, to write to Granny, also'. The 'also' refers to St Colette day, 6th March. 
PS: Must write to Roche to give permission to take trees down.

Note. Write more often. I can't get back the time that passes by but I will be happy to recall later what I am feeling now.

goggling voiceless o's beautiful phrase, really expressive and the only thing that was good about "Tobit Transplanted" - other than - but she wasn't that good - the cold little Russian woman - she is like me. Like there is some of me in Philip Quarles in "Point Counterpoint" (Alduous Huxley). ${ }^{66} \mathrm{I}$ am too much of a loner. I am afraid of people.

Cyla is a great girl - helped me to put the mirror up; I could have done it on my own but she didn't think I could - going to have dinner over at her place tomorrow - great - super friend. Her and Margaret - but so different from each other. I must see Dilys, only I neither have the time or the desire to. It is fine and warm. I can hardly believe it. Jacqueline $\mathrm{M}$ - will she be happy? It's mad to leave like that; she has enough money for 10 months (10,000 francs?). I should have told her to stay but what would I have said? She would not have listened. I do so hope that she will be happy.

Better not show this book to my parents, perhaps I could to Mum if she wants to see it - if I had a room with a balcony I could have an animal or something. I've always wanted one. Perhaps that'll come. If there's no result in June I will look for something like that - easy if I have work. But, Lord - I so want to be back there. I am losing contact, I so want to get back. If only I hadn't destroyed Mum's letters; but during the exode $e^{67}$ it was impossible to keep them, especially with Aunt Violette who would have read them. Unexpected reconciliation. She must feel better.

I've had enough of working and enough of the family. Dédé is pestering me nice enough but I don't want to get tangled up with family. I don't like Colette just turning up to stay the night. It'll be easier when I've just got a sofa bed. It's not good for a kid to spend the night away from home like that. She sees too many films, bad for her but she is spoiled. When she is around I can't even do the cooking or anything else for that matter.

I am restless like a caged animal. Ooh, I am sleepy. 8 hours sleep. 8 hours work. It doesn't work out. ${ }^{68}$ Sleep, no fun and little work. I don't stop and I don't have a minute to myself. Should read less. Lightheaded. Sleep.

\footnotetext{
${ }^{66}$ Aldous Huxley misspelt in the manuscript.

67 The exode was the panicked flight of Parisians from Paris towards the south of the country in June 1940.

68 'Doesn't work out' written in English.
} 


\section{Wednesday 19 March}

Did my 8 hours of work.... marvellous. But I didn't go to Tenon for my eye - I really need to summon up some courage. Swapped book at Sylvia's. No news about Ruth. They have been punished, apparently. I really need to write to her. Had dinner at Cyla's - great girl but I get the feeling that she wants to know what I am prepared to do ${ }^{69}-$ it's annoying. I won't go there as often. Does race depend on ancestry - Damn, not French. Not good. Can't do anything about it. The Celts always built on hills, Romans in the valleys - I have always wanted a house on the top of a hill but now I do not know what I want.

Beautiful sunny day and warm too but there is a haze over Paris. Loads of planes prowling around in the night. One had its lights on red; a searchlight. When I was coming back midnight was ringing out from the churches. I should be careful because one of these nights I am going to get myself picked up by a patrol. I'd hardly been home when I heard vehicles go by. Luckily I was no longer in the street.

NB: Go tomorrow - or rather this morning to look up ${ }^{70}$ J. Chamberlain in the Encyclopedia Britannica. Perhaps also go to the Institut Britannique. Start to return Miss Longhurst's ${ }^{71}$ things.

\section{Thursday 20 March}

Middle of Lent - and I hadn't even noticed. At Neuilly a few chestnut trees are starting to come into leaf. Plum trees are flowering. Red Cross.

\section{Friday 21 March}

Returned things to Miss Longhurst - except 2 sheets and one pillow case and a counterpane which are at the laundry.

\section{Saturday 22 March}

Went to see the Semaille ${ }^{72}$ family. Did nothing.

\section{Sunday 23 March}

Mass. Went to St Denis. Saw the bedroom in the new apartment. Did nothing. Chatted to Madeleine and Andrée.

69 This may be a reference to Resistance activity.

70 'to look up' written in English in the diary.

${ }^{71}$ Miss Longhurst owned the flat at the rue Rollin which Madeleine shared with Ruth Camp in the autumn of 1940.

${ }^{72}$ Family of Jean Semaille, who Madeleine was seeing at the time. 


\section{Monday 24 March}

Wrote to Godfather and to Granny. Sent off permission for Roche to do some work on the land. Notice on the door of a tenant on the 7th floor: 'Knock very loudly and be very patient'.

\section{Wednesday 26 March}

Went to see Cyla. Returned double bed. The bed from next door.

\section{Thursday 27 March}

Went to see about another bed because Voirin can no longer send money.

\section{Sunday 30 March}

Went to Villeparisis. Wedding René Roche.

\section{Monday 31 March}

Snow.

\section{Thursday 3 April}

Get together at mine with Andrée and Madeleine. Singing.

\section{Friday 4 April}

Letter from Mum - took 5 months to get here.

\section{Saturday 5 April}

Holidays

\section{Sunday 6 April}

Went to Aunt's. Saw the 'Folle Etudiante" (Jenny Jugo) ${ }^{73}$

I am losing track of dates, I should write them as I go along.

${ }^{73}$ This was a German-produced film which was first shown in France in January 1941. 


\section{Wednesday 9 April}

Went to Cyla's. Wrote to Mum.

\section{Friday 11 April}

Aunt Violette's birthday

\section{Saturday 12 April}

Did shopping for Easter. Train ride to St Germain. 4 and a quarter hours on the footboard. Went through Poissy. The trees were pretty, all pink and white. Orgeval not in bloom. Went up to the Mill. Had dinner. Lost 100 francs.

\section{Sunday 13 April}

Easter day. Got up early. Had lunch at Mrs Fastier's. Pretty little cats. Went up to the Mill. Sang and danced. Took photos and had dinner.

\section{Monday 14 April}

Got up late. Little orphans came. Yolande announced that Jacques is going to get married in June (what a blow for her and Aunt). Announced also that she has something going on with Captain Magnier (she wants there to be more like). Moaned on to Madame Fastier just like she did to me when I was little. She has not changed and I admire her. Went up to the Mill. Got the train back. The lilies are starting to bud. Carpets of anemones. Feel all at sea in this milieu. Nasty carrying on and no shared interests. Would have preferred to go on solitary walks in the woods. Madame Fastier is a lovely woman. Slept over at Aunt's.

\section{Tuesday 15 April}

Paid for [ . . . ]. Gone up. Warm. Brilliant sunshine. Making the bed cover into a bed sheet. I must do 8 hours work a day. If I don't, then it is simply because I am lazy. Found some cress for 2 francs. Found the 50 francs that I was looking for three weeks ago. I hope that I'll find the 100 francs.

\section{Wednesday 16 April}

Sewed the sheet. Went to Gardiner's. Went to Cyla's. 


\section{Thursday 17 April}

Sewed the sheet. Went to Monsieur Posniak's to give English lesson. He claims that he is Russian. Dull and uninteresting decor imitating luxury. His face isn't pitted by smallpox like I first thought but covered with red blemishes. On the way back from Posniak saw Michael and walked some of the way with him. I can't stand him.

\section{Friday 18 April}

Sewed the sheet. Gardiner's. Paid for the week. Thank God.

\section{Saturday 19 April}

Saw Dilys and Jacqueline. Was invited by Madeleine Lavelle to meet her niece. Not going, too shy. ${ }^{74}$ Finished sheet. Went to Cyla's. Motus, 'Curlylocks' and Zorchka were there. Went to confession.

\section{Sunday 20 April}

Communion. Mass. Villeparisis. Had lunch at Roche's. We were sat at the table from midday until 7 oclock in the evening. Phew! He's a little man who made us laugh. Small, funny face. Professionally "comic". ${ }^{75} \mathrm{He}$ must have an inferiority complex. Monsieur Roche "in his cups". Fantastic scenery. Apple trees, Pear trees, peaches, crab apple trees all in flower. Aunt gave me 3 eggs and 50 francs as an Easter present for me to buy a stole with. Aunt gave me a message from Mum from the English Red Cross and St John. It had been sent at the beginning of March. The message said: Quin, Aunt Margaret, friends, us, Gyp, well. Hoping Malzey can give helping hand. Is Yo with you? Keep smiling. Mummy. ${ }^{76}$

\section{Monday 21 April}

Courses started again. Worked for 6 hours. Gardiner's.

\section{Tuesday 22 April}

Lesson with André and Mme Chevalier. Posniak. Warm. My foot hurts. Took shoes for repair. Worked 4 and a half hours. Went to Sonia's to eat chicken.

\footnotetext{
74 'too shy' written in English.

75 'Professionally "comic" written in English.

${ }^{76}$ The entire message was written in English and transcribed by Madeleine.
} 
There was Sonia, Rudi, Irma (painter), her sister, her brother, Gisèle, Guta, Laschmann, Lola, me. Lola is pretty, full of beans and 'joie de vivre'. talked about bullfighting with enthusiasm and passion. Not at all "self-conscious".77 Pretty black hair with a pretty shell comb in the shape of scallop behind her ear. Sang some boleros. Michael at midday. Pah!

\section{Wednesday 23 April}

Wrote to Voirin, Marie-Thérèse, Madame Déchlette, Dédé. Queued for 11/2 hours for 3 eggs. Did some intensive reading. Sonia suggested that I make some cut backs to get me through the summer because, so it seems, there will not be any tuition to be had. I hope that I'll still have Gardiner's, Andrée and Posniak; but it would be good if I could put 2000 francs to one side just in case I have nothing for four months - and what about October's rent? Oh so what. Sufficient unto the day is the evil thereof ${ }^{78}$ and I may well get some lessons. Now I have to go for an outing with Dilys which I couldn't care less about. Went to the shops. Dilys is such a bore to go out with. Gardiner's.

\section{Thursday 24 April}

Went to Tenon for my eye. Dunkovitch is a great fellow. But Roche is better. The hospital has a sinister appearance. It reminds me of the 'Grand Guignol'. Inside, it is quick and efficient. ${ }^{79}$ The boss, Bollach, makes the diagnosis. He's a great fellow. He looks like the Captain. I always have a bit of a weakness for men who look like the Captain. Sty painful swelling. Cocaine drops in the eye. Took off sty. Cauterised. Steeled myself for the worst which didn't come. Injections - more cauterising. Not too bad but I played it up. Shaking like a leaf not from the pain but from getting so worked up. Got bandaging over the eye. Sinister. Makes me think of Captain Hook and of the boss of the café in "J'attendrais". It feels strange only having one eye; I have the feeling that I am walking like a crab. $3 / 4$ of the world no longer exists to me; I am tripping around. I go off to the side when I try to pick up things. Pitying expressions, worried expressions on every friend's face; first of all it was funny now it is just annoying. I am having a lie down for 2 hours. Had a lesson with Posniak (suitably impressed). ${ }^{80}$

77 'self-conscious' written in English.

${ }^{78}$ In French, Madeleine writes: à chaque jour suffit sa peine’. It is a citation from the Christian bible, Book of Matthew.

79 'quick and efficient' written in English.

80 'suitably impressed' written in English. 


\section{Friday 25 April}

Woke up early to prepare Welsh. Put patch back on. Welsh etc. SB gives me new address for English. Too many compliments. Detestable. Ruth getting out soon? Deep down I'm not pleased because of Cyla which is unfair and bad of me. Rationally I hope that Ruth gets out quickly. The problem is my affection for Cyla - it shouldn't make me jealous. Cyla probably considers me just like another friend and does not share the deep attachment that I have for her. It's stupid. I dare not go to her place without having been expressly invited otherwise I would be there every evening. Gardiner's.

\section{Saturday 26 April}

Went to the Hospital Tenon without a dressing. Ointment. Sick with fright on the métro. Very calm at the hospital. I'll have to have an operation on 7 May - I've been written in on the big board. The boss is probably going to do it. On the way back I was accosted by a German in plain clothes who could speak only German. "The way to the Gare de L'Est?” Like a mug, I was obliging ... ended up with an invite for coffee. "Nein, danke schön". When I go out, I'm thinking that I'm quite nice looking. Went to the shops in the afternoon to buy scarf with the 50 francs from Aunt. Letter to Voirin. I am sure he is doing me out of money. Should I get all the linen sent over? Went to bed early at $10 \mathrm{pm}$.

\section{Sunday 27 April}

Queued for an hour for 90 grams of mutton chops. Cold. Letter arrived asking for English lessons. Did SB or F recommend me? Great. Cold. Didn't go to mass.

\section{Wednesday 7 May}

Operated on for the second time at Tenon. Awful. Bled non-stop because the thermometer had dipped. The operation was pretty brutal. Ruth Camp came back from the camp.

\section{Thursday 8 May}

Went back to Tenon. I'll have to wear glasses all the time.

\section{Friday 9 May}

Found out about Ruth's return. Too worked up to be able to write. Typed thesis for Rudi for the 20th May. 


\section{Saturday 10 May}

Gave a lesson to Miss Le Hartel. Colette came over. This child just does what she likes. Went to see "La Tour de Nesle". ${ }^{81}$ Got rid of her the next day so that I could ...

\section{Sunday 11 May}

... type. Phoned her mother who didn't know that Colette had spent the night at mine!

\section{Monday 12 May}

Typed, lessons, typed, Gardiner's. Typed from Monday at 11.15 at night through to Tuesday 13 March...

\section{Tuesday 13 May}

... five o'clock in the afternoon without stopping other than 4 times for half an hour in order to eat. Went to Posniak's. Came back. Typed for an hour to finish it up. Thank God. ${ }^{82}$ I am absolutely shattered. Rudi came over. We discussed domestic politics. ${ }^{83}$

\section{Saturday 17 May}

Ruth came to see me. Took me to a semi-vegetarian restaurant. She had a terrible time. But she is not bitter as Dilys led me to believe. I think that Dilys only likes her friends for their usefulness to her. I'm all mixed up with my dates - no, perhaps I'm not (today is the 2nd June and I have not touched my diary since 27 April) ${ }^{84}$

\section{Saturday 24 May}

Went to get shoes with Sonia.

${ }^{81}$ The play written by Alexandre Dumas.

82 'Thank God' written in English.

${ }^{83}$ Given that Rudi and Sonia are, we learn later, actively being sought by the Germans, it may mean Resistance activity. Madeleine has a number of contacts in the Resistance. Some of them like Hélène Barland and Georges Auclair are key figures but she never explicitly links them to Resistance activities.

${ }^{84}$ This discrepancy between the date in the diary and the date Madeleine says she is writing might suggest that she is writing up notes into neat here. 


\section{Sunday 25 May}

Went to Villeparisis. Rain. Played little horses. ${ }^{85}$ Maurice Roche only made a brief appearance because he had asked Yolande to marry him and had been turned down. I am wondering when Jacques Lefebvre is getting married and whether Yolande and Aunt will be invited. What a blow for Aunt Violette. Brought back white lilac and lilies.

\section{Monday 26 May}

Went to see Dilys. Wanted to stay 3 minutes just to find out about her mother who has been really ill - ended up staying 3 hours. Gaël is adorable. Georges is in Brives. He may not be able to work again. I am dead tired after the thesis typing.

\section{Tuesday 27 May}

Posniak. Lesson.

\section{Wednesday 28 May}

Lesson with Delavigne. I refuse to have the lessons in twos to split the cost. Miza.

\section{Thursday 29 May}

Lesson with Posniak. Went to the Red Cross. Lesson with Simone le Hartel.

\section{Friday 30 May}

Nothing special.

\section{Saturday 31 May}

Starting to wake up. Lesson with Delavigne.

\section{Sunday 1 June}

Pentecost. This is the second Sunday running that I haven't been to Mass. The shame of it. Spent 32 francs on a cake. 12 francs for tobacco. Gave Colette

${ }^{85}$ A French board game similar to Ludo. 
9 francs $=52$ francs. ${ }^{86}$ That's a lot for a single day. Went to St Denis. Grandfather is feeling his years - walking with a stick. What a mad house!! Dédé and Marie were nice but the kids are spoilt and at that difficult age. Went to the garden. Dédé is loving setting about it. Spoke with an anti-English plane mechanic chap. Nice looking. His ideas are shared by a good majority. The rest of the population is fiercely pro-A, ${ }^{87}$ because they don't like the $\mathrm{G} .{ }^{88} \mathrm{I}$ fear for my folks given the success of the parachutists in Crete. ${ }^{89}$ Colette supposedly went to the cinema but came back sunburnt. Aunt was furious. Colette confided in me that she had been boating on Lac Enghien ${ }^{90}$ with a girlfriend and the brother and friend of the girlfriend. Wants me to cover for her by saying that she went to the cinema. Good Lord, at 14 years old!! I don't approve but it is not my place to preach at her. Aunt Marie wants her to take up an apprenticeship to be a sales assistant. Colette wants to come to see me. May the good Lord spare me from her visits! Dédés nickname - the fruitcake. How awful. I thought that all that was done with. I put on my beautiful blue silk dress. Felt good.

\section{Monday 2 June}

Monday of Pentecost. Washed my hair. Not as warm as yesterday but it is drying well nonetheless. Exams on the 16th and 20th of June. When are the Orals? I'm going to have to swot up.

\section{Saturday 7 June}

Sing-song ${ }^{91}$ over at Dilys's.

\section{Sunday 8 June}

Aunts. Saw "Cora Terry". ${ }^{22}$ Good. Also parachutists in Crete. Hell!93

${ }^{86}$ A rare adding-up error.

87 Allies.

${ }^{88}$ Germans.

89 The German invasion of Crete between 20th May and 1 June 1941 was principally an airborne operation involving the parachuting in of troops. Madeleine fears that the same strategy may be repeated in England.

${ }^{90}$ Lake and beauty spot in the northern suburbs of Paris.

91 'Sing-song' written in English.

${ }^{92}$ German film 'Kora Terry' released in November 1940 directed by Georg Jacoby.

93 This sentence - 'Also parachutists in Crete. Hell!' - is one of the rare sentences written in English in the diary. 


\section{Sunday 15 June}

Villeparisis. Saw Deschamps. Note from Marie-Thérèse.

\section{Monday 16 June}

7.30-11.30 Philology (translation)..$^{94}$ Foul. ${ }^{95}$ Hot.

\section{Thursday 19 June}

Dying in the heat. Not a single vegetable left in Paris.

\section{Friday 20 June}

7.30-11.30. Etudes Pratiques (translation into French) ${ }^{96}$ Foul.

\section{Saturday 21 June}

The heat is killing me. Nudity at home. Confession. Went to Dilys's place. Went to the Closerie des Lilas ${ }^{97}$ with the 2 Jacquelines, Dilys and Gaël.

\section{Sunday 22 June}

Mass. No vegetables. Nudity. Went to See Dilys and Anka (me the proof-reader). War between Russia and Germany. Will I never see my parents again then? I hope to get a letter. 9 pm was at Dilys's. Closerie des Lilas Luxembourg. Breeze. Saw Cyla.

\section{Monday 23 June}

Wrote to Aunt Violette and Marie-Thérèse. Breeze.

\section{Tuesday 24 June}

Cooler. Message from Mummy written in April: 'Was glad to get your news. Carry on the way you are and don't worry. Everything is fine. Can Uncle Voirin help? Love to all. Mummy". Last lesson with Posniak.

${ }^{94}$ In the manuscript this is 'thème' which means translation into the foreign language. It is not clear which foreign language this is.

${ }^{95}$ The word 'foul' written in English here and in the entry of 20 June.

${ }^{96}$ In the manuscript this is 'version' - translation into the mother tongue. Here this would be French.

${ }^{97}$ Café-bar situated at 171 Boulevard du Montparnasse. La Closerie des lilas was a popular meeting place for writers and artists. 


\section{Wednesday 25 June}

Huge storm. Replied to Mum's message.

\section{Sunday 29 June}

Went out with Dilys. Mass. Saw Cyla at the Closerie (Cyla jealous that I was with Dilys).

\section{Wednesday 2 July}

Went to Cyla’s. Ruth was there.

\section{Thursday 3 July}

Mlle Le Hartel told me about a job.

\section{Friday 4 July}

Results. Philology 13. Etudes Pratiques 121/2.

\section{Saturday 5 July}

Knocked out. ${ }^{98}$ Starting with a migraine. Went to see Dilys.

\section{Sunday 6 July}

Mass. Went out with Dilys to see "Ariane jeune fille russe" power cut. I got home to find Sonia G in a state pursued by G. ${ }^{100}$ Ruth came to get food supplies.

\section{Monday 7 July}

Orals for 'Etudes pratiques' with Simon (Compare and contrast the universities of Oxford and London, but I've substituted Leeds for London). Am mad. Met Jean Peignot.

98 'Knocked out' written in English.

${ }^{99}$ Ariane jeune fille russe (1931) was a French-German film production starring French film actress Gaby Morlay (1893-1964).

${ }^{100} \mathrm{G}$ means Germans here - possibly Gestapo. 


\section{Tuesday 8 July}

Bought a hat. Went for an interview with Monsieur du Retail. ${ }^{101}$ Went to St Denis to take back the shopping bags to Dédé so that he doesn't come when Sonia is here. Bought "Werther" for the German exam.

\section{Wednesday 9 July}

German exam with Jolivet. It was OK. Interview rue Henner. Saw Jolivet. "Not brilliant mademoiselle but given the general uselessness ...." Looking pretty in blue silk dress and hat. Had soirée at Andrée's.

\section{Thursday 10 July}

Letter via the Red Cross from Mummy. "Received the news about the exam. Well done. Here, everything is fine. Tony now has a little sister called Anne. Chickens for Jeanne. Toutou is still being wicked. Mummy. [ ... ] "But why was it addressed to rue Rollin? Went to look after Mrs Evans. Dil. told me the risks I am taking for $S$. Went to Vendryès. Went to Mlle Le Hartel who says that same as Dil. I am beside myself with fright. I told S to go. S. was not happy.

\section{Friday 11 July}

S. leaves. Nicodème ${ }^{102}$ has arrived. Went to Dil's. I am so relieved. Spent the afternoon and the evening at Andrée's who has rheumatic pain in her ankles. Got a letter from Aunt.

\section{Saturday 12 July}

Went to the convent for notes. Sat in the Luxembourg Gardens to admire the green of the lawns and deep greens of the trees. Watched a snail leaving a trail like a tractor in the dust. Lost lace gloves. Slept in the afternoon. Met up with Jean in the evening. Amazing storm. Went to St Cloud. Had dinner on the terrace looking out over the Seine. Walked around St Cloud. Flirted a bit.

101 This was an interview with Armand Boutellier du Retail (1882-1943), curator and director of the Centre de Documentation at the Bibliothèque nationale $(\mathrm{BN})$ where Madeleine was applying for work. See the bibliographic entry on the BN's catalogue: http://data.bnf.fr/12329432/armand_boutillier_du_retail/

102 Nicodème is a code word Madeleine uses for menstruation. Nicodemus was the first disciple of Jesus and is a Roman Catholic saint but Madeleine's use of the name may owe more to the evolution in meaning of the name to mean someone (or something) idiotic, facile or imbecilic. 


\section{Sunday 13 July}

Bought flowers and vegetables for Aunt. Went to Villeparisis. Played with Marcel and Yolande. Marcel and Pataud went for a swim.

\section{Monday 14 July}

Slept over at Villeparisis. Poorly because of Nico. ${ }^{103}$ The Fortier cousins came over. Picked some lime blossom. Told Aunt that I had found work. Aunt immediately changed the conversation (I was extremely satisfied by that). Rained.

\section{Tuesday 15 July}

Started work. Went to the Centre de Documentation. ${ }^{104}$ In the morning I was introduced to the staff and shown around the building. Read "Marie-Claire". Ate sandwich. In the afternoon I had to file reports from the Chambre des Députés. I was on my own in the offices in the 7th arrondissement. Got back home exhausted. The housework hasn't been done now for two weeks. What a disgrace. Got through the Etudes Pratiques. Got a merit. Happy. I'm going to go to bed early so that I can get up early to do the housework before going out.

I'd like to buy myself: an art deco wardrobe; table; chair; wool blanket; quilt; an iron; little lamp; radio; electric radiator; vases, etc but what with? I really must get a pair of glasses and the art deco wardrobe. As for the rest... well, we'll see.

\section{Wednesday 16 July}

Work.

\section{Thursday 17 July}

Went with Jean to "Rallye". Then went to the cinema. Slightly flirty again. "Hommes nouveaux"105 (Harry Bu..). Jean gave me a necklace made out of Venetian glass.

${ }^{103}$ Nicodème. See note above.

${ }^{104}$ Centre de documentation at the Bibliothèque nationale. Madeleine begins part-time work here on July 15th 1941.

105 Les Hommes nouveaux (1936) was a French film directed by Marcel L'Herbier, It starred Harry Baur. Baur was arrested and imprisoned during the Occupation and died shortly after his release in 1943. Madeleine refers to Baur's imprisonment and death in her entry of April 12th 1943. 


\section{Friday 18 July}

Finished at Gardiner's [Gardiner's 14 February-18 July]. Saw Jean.

\section{Saturday 19 July}

Had lunch with Gabriel Chrétien who is blind. Took him out in the evening.

\section{Sunday 20 July}

Spent the morning with Dédé. Went with Aunt V. to see "Le Cid" at the Palais de Chaillot. Appallingly acted.

\section{Monday 21 July}

Went to see Cyla.

\section{Tuesday 22 July}

Took Gabriel Chrétien out.

\section{Wednesday 23 July}

Michael took me to see "Voleur de Femmes". Good. Michael a bore. ${ }^{106}$

\section{Thursday 24 July}

Went with Jean to the "Rallye". We then went to the Bois. Gave Jean the boot forever.

\section{Friday 25 July}

Went to Dilys's

\section{Saturday 26 July}

Worked. Colette came in the afternoon. Went to see "Une Femme sans passé"

\section{Sunday 27 July}

Went to see Dédé and Aunt Marie. Garden. Brought back butter and vegetables.

106 'Michael a bore' written in English. 


\section{Monday 28 July}

Spent at home.

\section{Tuesday 29 July}

Spent at home.

\section{Wednesday 30 July}

Went to see whether there were any seats for the opera with Yolande. There weren't any. Walked and talked.

\section{Thursday 31 July}

Spent today at home.

\section{Friday 1 August}

Letter from the Red Cross from Mum! Her writing!!! Took out Gabriel Chrétien.

\section{Saturday 2 August}

Opera. "Chevalier et la Demoiselle", "Prélude à l'Après-Midi d'un Faune", "Le Festin de l'Araignée". Bowled over by it! Serge Lifar ${ }^{107}$ and Solange Schwartz ${ }^{108}$ were absolutely fantastic.

\section{Sunday 3 August}

Went to Aunt's who is in a terrible sulk with me because I am working. (Good, I am happy about that. What a cow I am).

\section{Monday 4 August}

Had dinner at Cyla's. Ruth opened the door.

107 Serge Lifar (1905-1986) was a French ballet dancer and choreographer.

108 Solange Schwartz (1910-2000) was a French star of the opera and ballet. She performed in several of choreographer Serge Lifar's creations during the Occupation. 


\section{Tuesday 5 August}

Waited for Cyla but she didn't come. Michael is annoying me to the point where I can't stand it anymore.

\section{Wednesday 6 August}

Rain. Cold. Opera. "Demoiselle au jardin". "Entre Deux Rondes" "Sylvie”.

\section{+ Thursday 7 August ${ }^{109}$}

Rain. English lesson with Simone Le Hartel?

\section{+Friday 8 August}

Storm. Took Slav newspapers to Cyla's. Learnt how to play chess with Gabriel Chrétien.

\section{+ Saturday 9 August}

Went "Coppélia" and "Giselle" (hair all up. Absolutely wonderful)

\section{+Sunday 10 August}

Villeparisis.

\section{+ Monday 11 August}

Went to see Cyla.

\section{Tuesday 12 August}

Michael asked me to marry him again. He annoys me. Was less than polite with him. If ever he annoys me like that again I shall slap him in public (8th marriage proposal from him I think)

\section{Wednesday 12 August}

Went to Cyla's.

109 The + sign against the date of the entry possibly refers to menstruation (Nicodème). 


\section{Thursday 13 August}

Left for Orgeval.

\section{Friday 15 August}

Mass at Orgeval

\section{Saturday 16 August}

Orgeval. Went with Madame Fastier to the market. Altered the mauve work blouse given to me by Madame Kerjean. Grandson of Mme X . . (Baronne de Bel-Air) mistreated by her. Yolande protected the kid (Doudou) same name as the horrible novel. I burst into tears.

\section{Sunday 17 August}

Orgeval. Came back to Paris. St Germain-Pereire-St G. en Laye in a car (in the afternoon Germans at Mme F's)

\section{Monday 18 August}

I am 23. Work. Found a letter from Soeur Ghislaine ${ }^{110}$ about the exercise book.

\section{Tuesday 19 August}

I am officially 23. Revised for exams.

\section{Wednesday 20 August}

Went to Cyla's. Ruth has moved in. Card from Jean Peignot.

110 This is a reference to Soeur Ghislaine, a Roman Catholic nun in the Paris order of Notre Dame de Sion, 61 bis rue Notre-Dame des Champs, in the 6th arrondissement of Paris. From the early years of the war, the nuns were active in helping Jewish children escape arrest and deportation. Madeleine Conte wrote a history of the Order's activities during the Occupation. Madeleine Conte (2001) Sauvetages et Baptêmes: Les religieuses de NotreDame de Sion face à la persécution des Juifs en France (1940-1944). Paris: Editions L'Harmattan. 


\section{Thursday 21 August}

Work. Tired out. Birthday card from Aunt. Depressed.

\section{Friday 22 August}

Work. Went to Chrétien's to play chess. Dad's birthday.

\section{Saturday 23 August}

Spoke to Madeleine Bloch. Spent the entire day shopping. Bought an electric iron. Went to Cyla's.

\section{Sunday 24 August}

Went to Villeparisis. Picked blackberries. Aunt and Yolande gave me a reading lamp.

\section{Monday 25th August}

Tired. Did washing. Returned the book to Soeur Ghislaine. Wrote to Dad through the Red Cross. I really should note down what I am thinking from day to day. I never remember. I had already forgotten how Ruth liked to control things by making her "helpful suggestions". ${ }^{111}$ At that time, then, I was too polite to put her in her place but Cyla tells her straight. "She needs to be trained" says Cyla and how I agree with that! Ruth's main quality is that she is clean ${ }^{*}{ }^{112} \mathrm{Her}$ bedroom would never be a mess like mine is. But she has everything she needs to tidy stuff away and I haven't. I will have to make a serious effort to buy what I need and keep everything neat. Ruth: clean, generous, good hearted and full of enthusiasm and does not think about sex ${ }^{* * 113}$ can't conceive of the notion that anyone thinks differently to her, she loves pills, injections and vitamins. I can't imagine that her living with Cyla will work. Cyla has a bossy side which has surprised me. But what Slav charm. Yolande and Aunt strongly disapprove of her being my friend - the room is entirely in shadow other than the pool of light cast from the table lamp. There are daisies in the broken stoneware pot and two divine smelling roses. The geranium is on the chair. I am on the half-made bed. I can hear the muffled sound of Madeleine Fortan's radio - Oh! I would love to have a radio!!!

111 'helpful suggestions' written in English.

112 Adds alongside in the margins: ${ }^{*}$ clean - physically but not morally (note made 28 May 1943).

${ }^{113}$ Adds alongside: ${ }^{*}$ Good God (!!) That is all she thinks about (note made 28 May 1943). 
No vegetables in Paris. Our movements have been restricted. Germans have been killed. Trains have been blown up. For a week now there's been poster after poster. ... a million reward to anyone ready to denounce those blowing up the tracks. ... two men have been shot .... . white posters, red posters. ... the Communist Party has been dissolved. ... warning to the population. .... prisoners are to be considered hostages. .... posters - posters.

Found a tract in the Bois de Boulogne yesterday but I didn't keep it. The English promise not to touch our colonies. Saturday at Orgeval, Achères ${ }^{114}$ station bombed.

$10 \mathrm{pm}$ !! The plane is doing its rounds to check on the blackout. I can set my watch by it. We need ration tickets for everything! On Saturday I went to look just to look mind - for curtains etc. If I want curtains without tickets then I'd have to buy tulle and I'm not keen on that. Thicker netting is 1 to 5 ration points a metre!! Silk is 5 points a metre!! It's mad. If only I had money. But I don't want to ask for any from Voirin. I didn't reply to him and didn't get him to send the linen. I wouldn't have known where to put it. I will have to send for it before winter. I'll have to go to the flea market to see whether I can get hold of some cheap furniture. I dream of having a little house in the country ... a dream that I will finish in bed. I am tired out.

People in my office: (in my Section)

Simone Le Hartel

Masson. 20 years old. Good worker.

Bernard Olivier 19 years old. Wild. Lazy.

Nathalie Kerjean - former professional singer

Antoinette Rousselet. 20 years old. Ex-P.E teacher.

I've been looking back over the old rationing lists. Now - ha!

Bread - per day 275 grams, Fat products 600 gr, wine 1 litre per week, meat 930 grams a month. Potatoes $2 \mathrm{~kg}$ a month, sugar 1 pound a month. 1 bar of soap. Coffee 125 grams a month (60\% ersatz). Cheese 200 grams a month. Chocolate, cakes, wheat, oats, rice, pasta, pulses - nothing.

On sale without tickets: wood, ironmongery, sanitary products, tulle, lace, lamé, angora wool, pillow cases, mattresses.

Difficult but fun to imagine making a home. Can't be bothered studying. Couldn't care less about anything. I'm mentally drained.

\section{Tuesday 26 August}

Wrote to Madame Fastier.

114 Achères is a small town to the north of Paris. 


\section{Wednesday 27 August}

Paul Colette ${ }^{115}$ wounded Laval and Déat.

\section{Thursday 28 August}

Letter from Madeleine Lavelle. She's going to the Free Zone. Listened to the radio with Andrée. Masson left.

\section{Friday 29 August}

Wrote to Hélène Berr with news for Dad and Mum. ${ }^{116}$ Wrote to Madeleine Lavelle with news for Dad and Mum. Left for Orgeval. Interesting conversation with a Chinese prince at the 'Accueil de Midi'.

\section{Saturday 30 August}

Rain, rain, rain. Started socks. Roger Leclerc. What an ace!

\section{Sunday 31 August}

Quite nice weather. Going back in the evening. Went to the Mill. Learnt a skit on 'Lorsque descend le crépuscule.' Slept at Aunt's. Quilt and curtains.

\section{Monday 1 Sept}

Came back from Aunt's. Tidied up before cleaning. A very delayed letter from Sonia about writing to my parents. National insurance.

\section{Tuesday 2 Sept}

Cleaned the toilets. Went to the document store from 1-6.30. Received a note from Dilys.

${ }^{115}$ Paul Collette (1920-1995) attempted to assassinate Pierre Laval. His death sentence was commuted to a life sentence of hard labour. He was deported to German concentration camp Mauthausen in 1944 but survived the war.

116 This is the first reference to Hélène Berr in Madeleine's diary. It is unclear why Madeleine sends news for her mother and father via Hélène. It could be that Hélène is staying in the free zone and may be able to get messages out a little more easily than in the occupied zone. Or else she may have been able to avail of contacts within the engineering firm Etablissements Kuhlmann where her father, Raymond Berr, was a director. 


\section{Wednesday 3 Sept}

Dead tired. Went to Dilys's. Went out with Dilys.

\section{Thursday 4 Sept}

Went to the shops. Scrubbed with steel wool. It is so hot! Looked after Mrs Evans. Had lunch at mine: melon, veal chop, sauted potatoes, grapes, coffee (ersatz).

\section{Friday 5 Sept}

Went to the shops to buy stuff - but bought nothing. Relaxed. Tired. Tidied room. Went to see Sylvia Beach. Went to see Gabriel Chrétien but he wasn't there. Got a pneu from him when I got home.

\section{Saturday 6 Sept}

Feeling awful. Went to sort out the change of electricity meter and tariff. Slept. Went to see "Nanette" with Jenny Jugo playing Nanette. Not bad.

\section{Sunday 7 Sept}

Villeparisis. What a pain it was. Roland was there. Yolande refuses to believe that I have a job in the civil service.

\section{Monday 8 September}

Went back to work. Madame le Hartel found the original manuscript of Chambres de Commerce in the provinces dating from 1700 ?

\section{Tuesday 9 Sept}

Went to see Gabriel Chrétien.

\section{Wednesday 10 Sept}

Received news from Mum from the Red Cross: "Health is good, Do you receive our letters regularly? Whether you do or you don't, don't worry."

\section{Thursday 11 Sept}

Lesson with Simone Le Hartel. 


\section{Friday 12 Sept}

Letter from Madeleine Lavelle who quotes the telegram of 2 September from Mummy. "Health is fine, don't you worry". Card from Cyla. Letter from Mme Faure.

\section{Saturday 13 Sept}

CPDE. Contract. Went in to sort out contract. Worked a little.

\section{Sunday 14 Sept}

Worked a little. Knitted. Cold.

\section{Monday 15 Sept}

Had lunch at the Women's Hostel. Looked for Madeleine Lavelle's notes. Card from Hélène Berr giving news from Mummy.

\section{Tuesday 16 Sept}

S. Le Hartel bought me tea on the Champs-Elysées. Les "Jeunes Filles" (Monthérlant).

\section{Wednesday 17 Sept}

Went to see Cyla.

\section{Thursday 18 Sept}

German officer killed. Lesson with S. Le Hartel.

\section{Friday 19 Sept}

Paris punished. Curfew is at $9 \mathrm{pm}$. Wrote to Aunt.

\section{Saturday 20 Sept}

Paris punished. Bought electric radiator. Curfew at $9 \mathrm{pm}$.

\section{Sunday 21 Sept}

Curfew at $9 \mathrm{pm}$. 


\section{Monday 22 September}

Curfew at $9 \mathrm{pm}$.

\section{Tuesday 23 Sept}

Went to Gabriel Chrétien's but he wasn't there.

\section{Thursday 25 Sept}

Lesson S. Le Hartel.

\section{Friday 26 Sept}

Went to the première of "Vétir ceux qui sont nus" (Pirandello) at L'Atélier. ${ }^{117}$

\section{Saturday 27 Sept}

Confession. Washed hair. Letter from Aunt with a ticket for Arlésienne. Today was the première at L'Atélier. Went with Madeleine Fortan (Number 4) who is the fiancée of the cousin of André Barsacq (Head of l'Atélier). Since I have been going out so infrequently I've been getting worked up about going out. L'Atélier ${ }^{118}$ is really tiny and very plain. The walls are cream, there are crystal coat hooks fixed up between electric light bulbs. A little disappointed by the lack of grandeur; they say that it gives it an "intimate" feel, - I find it looks more provincial than anything, and out-in-the-sticks provincial at that were it not for that intangible atmosphere that can only be Paris. A small bar - the Green Room is the leafy square out front. What can be more delightful than going out into the mild air on a starry night and, by the light of the door that opens and closes as the spectators drift in and out, seeing dark perfumed silhouettes, a flash of blond hair, the sparkle of a ring picked out by the light, and all that despite the D.P? ${ }^{119}$

117 Pirandello's play, adapted by André Barsacq (1909-1973), ran for 49 performances at the Théâtre de l'Atelier in 1941. More information about the director, cast and venue can be found here:

http://www.regietheatrale.com/index/index/base_donnees/dossiers/rep. php?id=2804

118 Barsacq took over the Théâtre de l'Atelier in 1940. He premiered plays by many new dramatists including Jean Anouilh, Marcel Aymé and Françoise Sagan. See Edward Forman (2010) Historical Dictionary of French Theater. Lanham: Scarecrow Press.

119 'D.P' means 'défense passive' - the black-out. 
The première was a very informal, family affair. I had imagined that there would be cosmopolitan people, like at the premières I've seen at the cinema or read about in the newspapers. Not a bit of it! It is wartime to be fair. Most of those there were family - Annie (Mad F's fiancés cousin), her parents (her step-father Nicholas; "I don't like plays with talking in them"). There must have been journalists there but didn't see any. There was Mila (Madame Barsacq). After the play we went backstage but lost one another and Nicholas was getting impatient and so we left. I had put on my beautiful black shoes (killed my feet). For the office I'll "talk it up" a bit. I'm the only one to have been to a première and the others will be jealous much to my satisfaction. Especially Simone Le Hartel who goes on about functions at the Academy. She likes authors like Proust, Gide etc. I read Lawrence's "Phenix" and liked it - what a vibrant, alive yet unfussy writing. I served up some just criticism to S. le $\mathrm{H}$ making out that it was of my own confection: "These writers (Proust etc) have a scent of flowers under which one can make out the smell of decomposing flesh". Lawrence wrote it but how appropriate for French writers (I am thinking of Proust, Gide, Montherlant, even Flaubert) She wasn't happy. She is very nice but she wants to be a fixture in my life - another one!! Why want to be indispensable when nearly no one is except Mum and I plod along without her. Each day without her I am steadier on my feet. Nearly two years!! - What matters is showing a "grown-up"120 adult exterior and remaining a child as long as I want inside myself. What I feel inside is no one else's business and I think modern novels are horrible. It is no one's business what I feel and think. I don't want anyone's pity. As soon as they find out that I am alone in Paris they drown me in pity - why, why? I'd be more in need of their pity if I was still living at 6 rue de l'Orme but then I wouldn't get an ounce of pity. Does being "alone" frighten so many people so much?

This week coming I will go to see Cyla. It has been a fortnight since I last saw her. I mustn't go too much. If only I could see her without Ruth, but how? There too they call me "La Petite". Everywhere it's the same: Kiddy or The Kid, Le P'tiote, Babykin and now "La Petite"!! Cyla was deeply shocked that I had read the dreadful "Jeunes Filles" by Montherlant. Shed be quite happy giving me a doll to play with I think. Tomorrow I am going to have to do the housework and work as well. I haven't got much enthusiasm for my studies. Nothing, nothing, nothing - why? It isn't that I am working too much at the office. I am going to knit a little before I go to bed. The priest was really nice at Confession. There are evenings where I want to write, write but I don't do anything wanting to work instead. And this evening, I am lacking in inspiration. I am going to knit and go to bed. There are a lot of grapes around [ 3 francs 50 a pound].

\section{Sunday 28th Sept}

Mass. Knitted. Madeleine Fortan had a violent nosebleed.

120 'grown-up' written in English. 


\section{Monday 29 Sept}

Worked

\section{Tuesday 30 Sept}

Andrée Corneil came back. Brought cream, 1 egg, 1 tomato, Café crême. Went to SB's to take back "And so came Victoria" Took out "The Call of the Wild" (Jack London)

\section{Wednesday 1 October}

Worked a half shift. Nice weather. Fresh, lovely sun. The weather was like back home. The Luxembourg was autumnal. The chestnut trees, gold and green. Masses of red dahlias on the green lawns "flecked" with golden leaves. The dahlias around the ornamental lake smell of Autumn. It is cold and misty in the morning, bright later. The shifting of these two hours ${ }^{121}$ have done much to change the atmosphere. Colette Brand came over with a friend - totally uninhibited. Rummages through everything to see what there is. I didn't invite her to stay for dinner even though there was whipped cream. She was wearing a dirty blouse.

\section{Thursday 2 Oct}

Wrote to Aunt and Mme Faure. Went to get meal tickets but there weren't any tickets for potatoes and so didn't get any. Upset but stupid about it, (extra sensitive because of Nico.) Went to the Sorbonne and saw that I am late registering for the exam. I will have to write to Vendryès. Still upset later and so bought "Diderot, l'Homme et l'Oeuvre" to console me. Studied it all afternoon. Now I am restless. I don't want to do anything. Bored, fed up and have had enough of everything. Going to knit a little and go to bed even though I haven't done my 8 hours of study. I'll have a go at a Latin translation. Why do I get the writing bug in the middle of studying or at meal times and never in my free time. "Children of the Frost" (Jack London) and "Pavements at Anderby" by Winifred Holtby. ${ }^{122}$ She's the one who wrote "South Riding" - I love it because she speaks of Yorkshire, the place I know and love. It is there I will return to, there with its magnificent

121 The Germans were two hours ahead of Greenwich Mean Time in June 1940. This is the two hours Madeleine refers to and not the one hour roll forward the Germans imposed in occupied France, which became known as 'l'heure allemande'.

122 Winifred Holtby (1898-1935) was born in Rudston in East Yorkshire. She studied at Somerville College, University of Oxford, and became a journalist and novelist before her premature death at the age of 37. 
sunsets, green pastures ${ }^{123}$, grey skies - windy ridges and grey stone walls. Cold, sharp coldness but joy. Lambs wagging their tails at their mother's teat. The wind and the spray at Robin. The smell of baking, and the sight of the steps edged with white or ochre. Choosing a sheltered spot for the lilac, the lupins and the laburnum. Weeding in an old red mac and pulling up the clover meandering round and wandering after its roots and tendrils. Miss $\mathrm{M}$ like a rose in her white satin blouse. A good coal fire and the smell of toast. Leeds University. French House. The tennis courts dripping drip, drip under the splash of the wet autumnal leaves. Women's room, in the draughty bay-window, curled up in my green coat and the fur warm against my cheek and laying in tiny damps wisps on my lower lip, tickling as my breath comes and goes, as I read some magazine story. Mary Pickett, thin and gaunt, - not gaunt - but slight is too lovely for her. Her large feet splayed, specs, small plait - rather twist of hair round head. "Ah Noble, dear Noble" - I have forgotten the names of the lecturers already who was it, big brown hairy hands, grey hair, nice man? Why do names go and appearances remain? Bibby -Bibby. How could I forget? And he of the purple shirts and white, brown-spotted butterfly bows? I can't have forgotten his name after having made him tear his hair so at my Latin. And the lean sarcastic Communist, translating Plautus into American slang, now in S. Africa somewhere? Whereupon I promptly shut up this book to do a Latin unseen - and no more souvenirs - for when I get back home my vie de bohême ${ }^{124}$ will appear as sweet as honey. I shall have forgotten the scarce dinners, the tiredness, the boredom at the "bureau", the homesickness, the blankness of incipient mental breakdown to remember the sights, the thrills, the evenings with Cyla, the days alone. And now to work! Hell, isn’t my writing foul?

\section{Friday 3 Oct}

Studied.

\section{Saturday 4 Oct}

Studied - Went to see "Michel Strogoff"125

\section{Sunday 5 Oct}

Villeparisis. Took cakes with me. Huguette was there. Went up the woods.

${ }^{123}$ From 'green pastures' Madeleine writes the rest of the entry in English.

124 'Vie de bohême' written in French in an October 2nd entry otherwise written mostly in English.

${ }^{125}$ Michel Strogoff was adapted for the theatre by Jules Verne and Adolphe d'Ennery from Verne's 1876 novel of the same name. 


\section{Monday 6 Oct}

Sweet message from Cyla.

\section{Tuesday 7 Oct}

Went to Cyla's but she wasn't there. Chatted with Ruth. Brought the TSF back. Played with it until 2 am.

\section{Wednesday 8 Oct}

Played with TSF. Letter from Sister Ghislaine.

\section{Thursday 9 Oct}

Went to Cyla's, not there but waited despite Ruth. Saw Cyla. She's just had the flu. Sonia came over. Bitterly cold. Brrr!!. . . . But letters from Dad Mum. Such happiness!

\section{Friday 10 October 1941}

Letter from Fauchier de la Vigne. All property owned by French people living abroad must be declared. I think that we will lose Nancy. I will have to do everything I can to provide a home ${ }^{126}$ for my parents. I feel sad. It's just a feeling I have. I hope that it isn't true . I don't care about Nancy. ${ }^{127}$ But it matters for my parents! Such a disappointment after so many sacrifices. Hope to be able to get all the linen. Madeleine Lavelle came over - sweet. She wanted to bring news from my parents but there was nothing. She is kind. Andrée Corneille is moving. She is going to be a clinical tutor at the Salpétrière. What a shame. She is so nice.

Read "The Lonely Plough" by Constance Holme. ${ }^{128}$ Good.

Wrote Vendryès, godfather, granny, Aunt Violette, Sister Ghislaine, Dédé. Scribbled note for Voirin. Let's hope that he is not too late to get the linen. I am going to furnish this place. If we lose Nancy and if something happens back home at least I will have something to offer them here. It doesn't fill me with joy exactly - what I mean is that I am thinking about how unhappy my parents will be if they lose everything they have worked so hard for. What crimes must my

126 'home' written in English.

${ }^{127}$ Madeleine's parents owned property in Nancy in the East of France.

128 Edith Constance Holme (1880-1955). British romantic novelist and playwright. Contemporary review of the novel available online at:

http://archive.spectator.co.uk/article/18th-july-1914/24/the-lonely-ploughby-constance-holme-mills-and-boo 
grandparents have committed for my parents to have had so much to endure? All this spoils the joy of receiving letters. But it doesn't worry me. I'll quite happily fight for others, so that the other isn't hurt by the loss of what she or he has made sacrifices to acquire for me.

I must study - but I couldn't care less about what will happen. Mentally I am at cracking-point. ${ }^{129} \mathrm{I}$ will give my mind a month off after the exams. Then plough on! Forgot to say that on Wednesday I found Michael at the door. He must have been waiting for several days. He thinks that he is undefeatable and that his tenacity will overcome my aversion for him. Once again, I had to destroy his illusions - he's mentally ill.

\section{Sunday 11 Oct}

Mass. Lesson Fauchier-Delavigne.

\section{Tuesday 14 Oct 1941}

I can't be examined in Etudes Litt. Classiques because I can only register for 3 things.

\section{Thursday 16 Oct}

Saw Cazamian. Decided to do a diploma. Went for tea at Françoise Boësse’s place.

\section{Saturday 18 Oct}

Went to see about the lesson but "off". ${ }^{130}$

\section{Sunday 19 Oct}

Mass. Beautiful walk along the quais and the Île (not the Cité - but St Louis) Saw Sonia.

\section{Monday 20 Oct}

Classes started - joy!!! Mysterious telegram from a "Jannings"

\section{Tuesday 21 Oct}

Classes still. So happy. Posniak.

129 cracking-point' written in English.

130 'off' written in English. 


\section{Wednesday 22 Oct}

Classes. Telephoned "Jannings". Still none the wiser.

\section{Thursday 23 Oct}

Classes. Dilys came over with George. Letter Voirin, Wrote off for birth certificate.

\section{Friday 24 Oct}

Dilys's birthday. Bought her some roses. Posniak. Looked after Mrs Evans. 9-12 pm.

\section{Saturday 25 Oct}

Letter from Fauchier-Delavigne. Telephoned. Work between 9 am and 12 . Lesson at $2 \mathrm{pm}$. Frosty.

\section{Sunday 26 Oct}

Mass. Did washing. Ironed. Darned. Lesson at 2 pm with Delavigne. Not as cold.

\section{Monday 27 Oct}

Worked. No lecture because Pauphilet ${ }^{131}$ and Levaillant are not here. Helped Miss Beach with books from 3 to $6.30 \mathrm{pm}$. Parcel of linen sent by Voirin. Cold. Stomach ache. Ill all over. ${ }^{132}$

\section{Tuesday 28 Oct}

Copy of birth certificate. Frosty. Couldn't work. Met up with Ruth. She passed her diploma. What a surprise that is given that her French is atrocious. I hope that I am not being overly catty in supposing that either the exam was very

131 Albert Pauphilet (1884-1948) was a specialist of Medieval French. He was arrested for pro-Resistance sympathies during the Occupation. His son Bernard Pauphilet (1918-2015) was active in the Resistance network Combat. Madeleine Pauphilet (possibly Albert's wife) also taught at the Sorbonne and is mentioned in Madeleine's diary. Madeleine Pauphilet was active in the Resistance network Turma Vengeance.

132 'Ill all over' written in English. 
easy or they let her pass it because she's been in a concentration camp. I should watch out with RC. My first instinct is always to be "catty" about her but with a bit of an effort sweet and friendly. She is not the sort of person - as charming, dependable and as loyal as she is (note the effort I am making) who I would have chosen as a friend.

\section{Wednesday 29 Oct}

Feel ill. Hail - but so light and fine that you'd think it was snow. What will we get later if we're getting snow already. I'll be going to a new department in the CDBN - with the Polish fellow, document retrieval. Mlle Kerjean gave me a sweater and some knee socks. I hate charity. I haven't asked for it and if there is one thing in this world that I don't understand it is why people insist on giving out charity when one doesn't want it. Mlle Kerjean has a heart of gold. Her greatest pleasure is giving. But, Christ almighty, I wish she would choose people who don't mind charity. I do like people - so far but no further ${ }^{133}$ - I think that it would be easier to invite people over if I had two rooms. One would be for them etc and one would be for me with all the things I love in it. My home ${ }^{134}$ is my castle, very feudal, the drawbridge always up. Will I get a wage rise? Oh what I would do with a bit more money! Letter from Monique Vignet asking to start up lessons again.

\section{Thursday 30 Oct.}

Cut classes. ${ }^{135} \mathrm{Up}$ at $10 \mathrm{am}$. Feel ill.

\section{Friday 31 Oct}

Got up at $10 \mathrm{am}$. Ill.

\section{Saturday 1 Nov}

All Souls. Mass. Washed woollies.

\section{Sunday 2 Nov +}

All Souls Day. Mass. Went to the flea market, but got nothing. Hail, snow. Olivier came to tell me that there is no work tomorrow.

\footnotetext{
133 'so far but no further' written in English.

134 'My home' written in English.

135 'Cut' written in English in the manuscript.
} 


\section{Monday 3 Nov +}

Did a load of washing. Electrician came to do the socket. 100 dead in an accident at Austerlitz. ${ }^{136}$

\section{Tuesday 4 Nov +}

Work. With Monsieur Kopelojpai (?) [Korbelecky]. Nice. Interesting work. He’s a bit of a one for tidying. Snowy everywhere. Snow on the autumn leaves still on the trees. It is a strange sight. It is snowing. Bought an electric lamp. Sorted out the English and the German marking. St Charles.

\section{Wednesday $5 \mathrm{Nov}+$}

Ice and then a thaw. Saw Ruth at "Emaux et Camées" (Pommier's seminar). Was invited for tea with Dilys and Gaël. Replaced the lamp that I had broken. Saw Cyla. Great. Message from André Corneil. Wrote to Voirin. Guy Fawkes.

At the Ciceron lecture: Tiberonius did not want to take part in the invasion of Britain with César because he did not know how to swim!!

Spent more money than I thought I would. If only Voirin would take the hint and send some. Lessons are also needed.

\section{Thursday 6 Nov}

Stayed in bed. Lesson with Monique. Went to Salpétrière with Andrée Corneil. Beautiful spacious and warm room. Had dinner. The midwifery assistants were very nice.

\section{Friday 7 Nov}

Went to the Commissariat for identity card. Vendryès's course started again. Bachellery invited me to lunch. Decided to drop the diploma and concentrate solely on the doctorate if I can.

On the way back from Posniak's I was stopped for not having my pocket torch covered over. I have to fetch it on Monday from the Mairie in the 6th arrondissement and pay a fine of 15 francs. I don't think that I have enough money to get me to the end of the week.

136 On November 2nd, an empty goods train hit a packed passenger train heading into Austerlitz station from Orléans. Twenty passengers died and 100 were injured. Le Figaro, 6 November 1941, via Wikipedia. 


\section{Saturday 8 Nov}

Office. Did washing and ironing. Tired and starving. Ate nearly a half pound of bread and butter. What an extravagance - but I was so hungry. There are no vegetables other than a few turnips. Queue for carrots. What I brought back will have to last the week. I can't see it. It'll be OK if I don't have to pay the Sorbonne straight away - otherwise I will have to borrow money. If only it would occur to Voirin to send me some or if I could get myself another lesson. If that happened I wouldn't get any black marks. Got a parcel from Mme Kerjean containing torn stockings and a warm cardigan. Wrote to Aunt, Mme Kerjean.

\section{Sunday 9 Nov}

Mass. Worked. Darned.

\section{Monday 10 Nov}

Went to get the torch from the Mairie in the 6th. Went to meet someone about lessons.

\section{Tuesday 11 Nov}

Minute's silence. Lesson with Posniak. Saw Ruth.

\section{Wednesday 12 Nov}

Received linen from Voirin. Started lessons on Racine. Welsh. Breton.

\section{Thursday 13 Nov}

Lesson with Monique. Saw Dilys.

\section{Friday 14 Nov}

Letter from Hélène Berr with news of Charles and Gaby. Saw Dilys. Welsh. Lesson with Posniak.

\section{Saturday 15 Nov}

Letter from Aunt Violette. Saw Dilys rue R. ${ }^{137}$

137 'rue R' is possibly rue Richelieu in the 2nd arrondissement, then the main site of the Bibliothèque nationale where Madeleine worked part-time in the Centre de Documentation. 


\section{Sunday 16 Nov}

Villeparisis. Took a cake. Rain. Played little horses. Brought back sorrel.

\section{Monday 17 Nov}

Tidied up. Darned.

\section{Tuesday 18 Nov}

Letter from Sister Marie Ghislaine about lesson. Housework. Lesson with Posniak.

\section{Wednesday 19 Nov}

Office. Welsh. Breton. Rue R. Dilys gave a lesson in my bedroom. Went over to Dilys. Found out that she has had her radio taken off her and she is no longer allowed to phone nor to go out after the blackout nor use any transport other than métro or bus.

\section{Thursday 20 Nov}

Slept in until $10 \mathrm{am}$. So tired. Wrote to Voirin, Hélène Berr. Cold. Saw Françoise Boësse. Monique. Concierge's son went into her bedroom. Hungry, hungry, hungry. Worked until $12 \mathrm{pm}$.

\section{Friday 21 Nov}

Vendryès didn't give his class. Spoke with Mme Desjardins (?) [Desportes] who is doing a diploma on Celtic Ethnology; married with a little girl 21/2 years old. Paid registration. Rain. Work. Office. Windows of a rive gauche bookshop blown out. Lesson with Posniak.

\section{Saturday 22 Nov}

Pneu from Aunt saying not going to the countryside. Groceries. Office. Swot. ${ }^{138}$ Rue R. St Cécile

\section{Sunday 23 Nov}

Swot. Rain.

138 'Swot' written in English throughout the manuscript. 


\section{Monday 24 Nov}

Office. Swot. Went to ND de Sion but didn't see Sister Jeanne Ghislaine. Returned notes to Françoise Boësse.

\section{Tuesday 25 Nov}

St Catherine but didn't see any Catherinettes. Office. Swotted. Lesson from Posniak who asked me to 'catalogue' his library. Madeleine Fortan came over. Stayed very late.

\section{Wednesday 26 Nov}

Office. Welsh. Breton. Rue R. Swot. Pneu from Monique inviting me for lunch. Swotted. Went to bed at midnight.

\section{Thursday 27 Nov}

Got up at $4 \mathrm{am}$. Swotted until 9 am. Exam. Delattre $11 \mathrm{am}$. Pons $12.30 \mathrm{am}$. Pons knows Jean. Pneu to Monique declining offer of lunch. Monique. Saw Madeleine Lavelle. The restaurants in St Michel are shut in the evening for 10 days. ${ }^{139}$ Dilys came over 8-12 pm. Heart affairs. ${ }^{140}$ Went to SB's. ${ }^{141}$ "Have his Carcase" (D.L. Sayers) and "Uncanny Stories" (May Sinclair). ${ }^{142}$ Letter from Voirin.

\section{Friday 28 Nov}

Read until 4 am. Slept until 9 am. Welsh. Office. Met Paulette T and invited her for tea on Tuesday. Wrote to Aunt and sent a card to Yolande. Lesson with Posniak but only for half an hour - so I owe him an hour. Passed the exam.

\section{Saturday 29 Nov}

Card to André. Office but didn't work, listened to Monsieur Korbelecki. Very keen on being clean and tidy. Ran to get Yo's book. Rue R. Chat ${ }^{143}$ with Jacqueline P. ... (?) (No 5) who spent the evening at my place. Nice, young.

139 The authorities regularly imposed curfews and/or shut restaurants and cafés to punish citizens for Resistance attacks.

140 'heart affairs' written in English in the manuscript.

141 'SB' is Sylvia Beach.

${ }_{142}$ Novels borrowed from Shakespeare \& Co.

${ }_{143}$ 'Chat' written in English in the manuscript. 
Talks passionately about love. Attack at Montmartre. 2 Germans killed in a brothel. Curfew after 6 pm in the XVIII.

\section{Sunday 30 Nov}

Villeparisis. St André. Yolande is 23. Gave her the "Vie de Jesus" by Renan which she had asked for. Marcel left at $4 \mathrm{pm}$ because of the curfew. We had a fright because the Gare du Nord is in the 18th but the way was clear between the Gare du Nord and the Gare de l'Est. Aunt was charming. Brought back apples. Godfather had a fall, huge lump on his forehead.

\section{Monday 1 December}

Office. Was pulled up because late. Ran in after Mlle Guillaume who has a beautiful apartment. Housework. Dil came to pass on a lesson to me. - and also because she can't go out after the blackout. ${ }^{144}$ Talks and smokes. I listen. Went shopping but fed up because everything is so dear. No cloth to make underwear - nothing at all. No furniture in Scots pine - a table was 190 francs a year ago and now going for 345 francs for the same size. Want a doll. Am going to buy myself a goldfish. Hoarfrost.

\section{Tuesday 2 Dec}

Office. Babysat Gaël. Did the cleaning. Put on the blue jumper given to me by Mlle Kerjean. Tea for Paulette Trois-Gros (walk in Luxembourg before) and Ruth. Had buttered rusks and the biscuits from Dil. Ruth brought crêpes. It was nice. Lesson with Posniak. 3 pm. Hoarfrost still there in the shade in Luxembourg Gardens. Cold.

\section{Wednesday 3 Dec}

Winter. Fog. Morning $-7^{\circ}$. $1 \mathrm{pm}$ ( 11 am in the sun) $0^{\circ}$ in full sun on the Boul' Mich. Office. Welsh and Breton in an overheated room. Rue R. 10th and 13th arrondissements have to stay indoors? Madeleine F. came over. Darned.

\section{Thursday 4 Dec}

Ice on the inside of the kitchen window panes. Dil passed on Mlle Koch for a lesson. Stayed in bed until $10 \mathrm{am}$. Saw Dil. Georges was there. Second pneumo. Got

${ }^{144}$ As a British citizen, Dilys Evans was subject to restrictions of movement. She was subject to a curfew and was not allowed to own a bike. Had she not been married to a Frenchman, she would have been interned. 
tickets for René Desprès. Had to run. Took back "Le Feu et la Forêt" (unread). Took out "Un cirque en Voyage" (Paul Eippner) Eiper). Returned pillowcases to Françoise Bernheim with flowers. Took out "Murder Must Advertise" (Dorothy L. Sayers) and "A Century of Detective Stories". Quite high-brow, must relax though. ${ }^{145}$ Saw Dil again. Only the 10th arrondissement is affected because of the German medical officer killed between 2-3 Dec. If those who did it are not found before $10 \mathrm{Dec}-$ reprisals. Will make sure I have enough in to eat before the 10th because you never know. Cold. Monique paid. Saw Lake Boulogne for the first time. Pretty with sharp pointy pine trees and mist and ducks. Dead leaves everywhere with, in parts, the lighter yellows of leaves which have come down recently.

\section{Friday 5 Dec}

Welsh. Lunch. Office. Walked to Posniak's. It took $3 / 4$ of an hour. Lesson. 6th arrondissement lock-down? No.

\section{Saturday 6 Dec}

Office. Waited for Deschamps. He didn't show. Rue R. 6 arrondissement lock-down? No. But Luxembourg shut and all the roads around Odéon are shut off. Goering is at the Sénat.

\section{Sunday 7 Dec}

Went to Aunt's. Roger brought some blue fabric. Aunt and Yo. gave presents: teapot, cream jug, lamp-shade. Went to see "La Folle Imposture" ${ }^{146}$ Daft. Fellow in the métro said that tomorrow the curfew is from $6 \mathrm{pm}$.

\section{Monday 8 Dec}

Curfew 6 pm. Until when? Another officer killed. Office. Did washing. Got a cold. 6 pm. Looked down onto road. Sudden silence. Two fellows arguing with a revolver out. German patrol (3) then nothing. Number 4 and number 5 at the window with me. Pneu from Mourgeon and Posniak.

\section{Tuesday 9 Dec}

As ill as Hell. ${ }^{147}$ Office. 2 pm . In bed. Slept on and off until

145 'Quite high-brow, must relax' written in English in the manuscript.

${ }^{146}$ La Folle imposture (1937) was a German comedy film directed by Wolfgang Liebeneiner.

147 'As ill as Hell' written in English in the manuscript. 


\section{Wednesday 10 Dec}

7 am. Better. Office. Saw the Vigots. Will only have a single one hour lesson on Saturday. Letter from Jacqueline. Pneu from Deschamps. Went to Miss Beach's. Took out "Prince Charlie" (C. McKenzie) and Wells "The Invisible Man". Welsh. Saw Dil. Had tea with Dil. Climbed over rails ${ }^{148}$ into the courtyard. Read. Ironed. Korbelecky spent night at the station. Rumours: boulangeries closed for two days. Blockage ${ }^{149} 3$ days. [grandfather Louis fell and has broken 3 ribs]

\section{Thurs 11 Dec}

Mlle Koch. Monique. America in the war. Mourgeon.

\section{Friday 12 Dec}

Welsh. Office. Pneu from Posniak. Françoise B’s father arrested. ${ }^{150}$

\section{Saturday 13 Dec}

Office. Posniak. Rue R. Saw Dil. Slept over at Dil's. Shakespeare \& Co has shut down. Pneu from Dédé. Bought presents for Yolande. Roger.

\section{Sunday 14 Dec}

Went to Aunt's. Saw "Narcisse". Stupid but funny. Curfew lifted.

\section{Monday 15 Dec}

Office. Went to St Denis. Grandfather is very ill. Dying. Doc came. Let Aunt V. know. Lesson with Mourgeon. Went back to St Denis. Had dinner at Aunt Marie's.

\section{Tuesday 16th Dec}

Office. Went back to St Denis with Aunt V. and Yolande. Shops.

148 'climbed over rails' written in English.

149 'Blockage' written in English in the manuscript. It may refer to an interruption of food supplies.

150 This is likely to be Françoise Bernheim's father, André Bernheim. André Bernheim survived the war. 


\section{Wednesday 17 Dec}

St. Yolande. Roger's 42nd birthday. No office. Welsh. Bachellery invited me, Dil and Gaël for tea. Rue R. Cyla.

\section{Thursday 18 Dec}

No Monique. Shops. Went to St Denis with Aunt V and Yo. Mlle Koch.

\section{Friday 19 Dec}

Gaël Lecolleter is 1 today. Welsh. Office. 11 am. Grandfather Louis died. Went to St Denis at $6 \mathrm{pm}$ because I had a feeling. Saw Grandfather L. Stayed for dinner. Funeral arrangements (2500 francs)

\section{Saturday 20 Dec}

No office. Waited for Deschamps but didn't come. Rue R. Cyla.

\section{Sunday 21 Dec}

Lunch at Aunt V's. St Denis. Dinner at Aunt V's.

\section{Monday 22 Dec}

Dressed in black (stockings Jacqueline: coat, gloves Dil; hat Aunt) Office. Had lunch with Aunt. Burial at $2.30 \mathrm{pm}$. Mourgeon. Read til 5 am.

\section{Tuesday 23 Dec}

No office. Ill. shopping.

\section{Wednesday 24 Dec}

Office. Shopping. Handing out of presents. Got a flannel glove from Mrs Evans. Cup from Dilys. Sweets from SB. Went to Dil's - and Cyla's (but she wasn't there). Discussed 'social conditions' with Curlylocks. Went out with Ruth. Rue $\mathrm{R}$ but Myriam Vigot has got mumps.

\section{Thursday 25 Dec}

Christmas at Villeparisis 


\section{Friday 26 Dec 1941}

Mlle Koch. Mlle Koch gave me a superb scarf. Monique. Went to Dilys's.

\section{Saturday 27 Dec}

Telegram from Bachellery inviting Dil, Gaël and me for lunch. Dil back out. ${ }^{151}$ Send telegram to Bachellery. Cold. Ice. Mme Louvel rented violin.

\section{Sunday 28 Dec}

Went to Versailles. Lunch. Tea. Dinner with M. Mme Bachellery. Visited Parc Versailles, small and large Trianons. Sweet. ${ }^{152}$ Cold. Icy. Ornamental ponds frozen.

\section{Monday 29 Dec}

Went to office to get paid. New Year's gift from the Maréchal - 500 francs!! Mourgeon.

\section{Tuesday 30 Dec}

Rested. Darned.

\section{Wednesday 31 December}

Washed. Rue R. Last day of the year. Sorted out old letters - so felt depressed. I hope that Hogmanay 1942 is spent at home with Dad and Mum!! What a New Year's Eve with no heating, sat alone in the middle of old letters, old memories. Another year has passed by - ruined. Everything is ruined. So far from Mummy. And what about my thesis?

Grand resolutions for 1942:

Wash the linen as I go along - don't let it build up

At least 2 hours of violin practice per week

At least 5 hours thesis a week

Reply to letters straight away

Don't read too much.

151 'back out' written in English in the manuscript.

152 'Sweet' written in English in the manuscript. 



\section{Introduction 1942}

\section{An ongoing struggle with no respite}

In 1942, a fatigued and anxious public was facing a third year of Occupation. The difficulties with which the population had struggled in 1941 continued, but the hardship was all the more brutal and challenging because there was still no visible prospect of it coming to an end. As in 1941, malnutrition and the illness and disease it abetted were rife. Anxiety about finding enough food to eat to stay alive and to stave off serious illness was constant, and, for many, there was the perpetual fear that loved ones from whom they were separated were in harm's way in POW camps or factories in Germany. The Occupation had forced people into compromises and put them under additional pressure in every aspect of their lives. Women were very much on the front line. Many women had to continue to care for elderly and for children and, at the same time, be the family breadwinner in the absence of fathers, husbands and brothers. The period was stagnant and lived very much in the present. Plans to study and to pursue a career often had to be put on hold. The possibility of marrying and starting a family was a remote aspiration for many. The future was determined by circumstances of war which were unpredictable and uncontrollable.

Madeleine's 1942 entries continued broadly in the vein of those of the previous year. Her record still shows that most Parisians were preoccupied with getting through their lives from day-to-day. We get an insight into the extent to which the hardships of the Occupation were forcing Madeleine to forsake her scholarly ambitions. At the outset of the Occupation, Madeleine had been determined to keep studying, but the rising cost of living and the loss of her grant (the bursary had been frozen in 1940) meant that she had to juggle part-time work at the national library, private English lessons, babysitting and caring for elderly invalids. Her doctoral thesis was now less important than securing a degree in English, which would qualify her to teach in French schools in case she was stranded in France indefinitely. There is a very clear sense of how financial pressures on Madeleine preoccupied her and diverted her energies away from her studies. Living alone, she was entirely responsible for her own upkeep and welfare.

The winter of 1942 was harsh and rationing was increasingly stringent. The theme of food - the lack of it and trying to obtain it - becomes even more 
preoccupying for Madeleine. She regularly itemised new rationing restrictions which, on the one hand, may have been a practical 'aide-mémoire' noted down in the same way as she noted down times of appointments, anniversaries and birthdays. But the lists also demonstrate concern, worry, incredulity and anger and betray brittle morale. Food entries also show how the shortages brought people together in new convivial communities based around the pooling of food and sharing of 'work' associated with food, like queuing for it and cooking. Madeleine shared food and the responsibility for cooking it with co-tenants on the top floor of 320 rue St Jacques. Queuing for food which had become a time-consuming burden was also shared between several people. Food shortages also gave rise to innovative systems of exchange. Madeleine would regularly trade private English language tuition for items of food, swap cigarette and wine ration tickets for food tickets and exchange sardines sent to her in Red Cross parcels from Portugal for more varied foodstuffs. People also shared space (and sometimes beds) to economise on heating and lighting and cooking fuel. Thus, a feature of urban living during the Occupation was the transformation of private, personal space into public, shared space which enforced a surrender of privacy. These reformulations were not without tension. Communal living was not to everyone's taste and not all social interaction was positive. Perceptions of unfairness in dealings over food provoked conflict between people discernible in outpourings of anger from Madeleine. Certain personal relationships appeared to be largely transactional; formed simply as a means acquire food but the approach amounted to a collective coping strategy which made even the most desperate weeks of penury liveable.

American publisher Sylvia Beach owned the bookshop and lending-library Shakespeare \& Co in the rue de l'Odéon in Paris. She was famous for having published James Joyce's Ulyssees in 1922 and for the literary community of French and American intellectuals and novelists which grew up around the shop in the inter-war: Joyce, Hemingway, Gide and Simone de Beauvoir were only some of the many illustrious patrons who had made its enviable reputation. ${ }^{153}$ Sylvia Beach had close social links to the student community of the Sorbonne during the Occupation. Although academic attention has largely focussed on Beach's links with the inter-war Paris literati, there is much of interest in the links she had with Paris students and with the female contingent of that community in particular. Madeleine's connection with Sylvia Beach and Shakespeare \& Co was central to her life in Paris and increasingly so, it would appear, from 1942, when references to an intellectual community of women friends she meets through Shakespeare \& Co, book-readings and theatre outings become more frequent. Madeleine was the recipient of moral and financial

${ }^{153}$ These writers were members of the Shakespeare \& Co lending library. Their borrower cards are held in the Sylvia Beach archive at the University of Princeton. 
support from Beach and, judging by the record of the contemporary American and British fiction she borrowed from Beach's bookshop, the recipient of a significant degree of intellectual guidance too.

Shakespeare \& Co was one business of a number of 'scholarly' businesses owned by expatriate American and British women which drew on the University of Paris for their clientele. Mary Niles Maack describes the transatlantic entrepreneurs who set up these businesses as 'bookwomen' who had made Paris their home in the first decades of the twentieth century. Clara Longworth de Chambrun, an American countess and Shakespearean scholar with a doctorate from the Sorbonne ran the American Library. Miss Sarah Watson, who ran the Foyer internationale des Etudiantes and Sylvia Beach who herself had been a student at the Sorbonne were also amongst their number (Maack, 2005). In wartime Paris, it is interesting that networks offering moral and practical support to women students were presided over by British and American women. These kinds of pastoral and intellectual structures were apparent in the early days of women's university education in Britain and the States. In her DPhil 'Claiming an Education: The Transatlantic Performance and Circulation of Intellectual Identities in College Women's Writing, 1870-1900' Jill Lamberton discusses the importance of extra-curricular support offered to these early women students through all-women study, debating and social groups. They were an important source of affirmation in a male-dominated environment where women's presence was not universally encouraged or welcomed.

Madeleine first began to make entries about the books she was borrowing from Sylvia Beach's bookshop and lending library Shakespeare \& Co in 1941. The volume of entries which, on occasion, show her to have read as many as three novels in a single day, support a generally held view that reading was one of the most popular leisure activities during the Occupation. Reading was cheap. Books could be borrowed from libraries and privately owned bookshops like Sylvia Beach's Shakespeare \& Co and Adrienne Monnier's La Maison des amis du livre and, here at least, reading was economically democratic because affordable student subscriptions were available. It was a distraction which could be enjoyed in the relative comfort of one's own home. In other diaries written during the Occupation, those of Jean Guéhenno, Hélène Berr and Geneviève Gennari, books and reading offered psychological respite. They were a distraction from the day-to-day, read sometimes to inspire hope and bolster dissent. Books were censored but censorship proved ineffective in practice. The 'Liste Otto' - a list of banned books drawn up by self-censoring French publishers under pressure from the German authorities - came into force very early in the Occupation in 1940, but Madeleine did not appear to have any difficulty obtaining what she wanted to read. During 1942 she reads voraciously, including banned English titles in both the original and in translation, as well as French writers from the 1920s and 1930s. From the borrower records obtained from Shakespeare \& Co, there is a sense that her reading choices are aligned to the challenges and dilemmas facing young educated women wanting 
careers and financial independence but feeling pressurised to get married and raise children. Writers of the so-called British 'middlebrow' like Rosamond Lehmann, Winifred Holtby and Dorothy L. Sayers, whose novels dealt with conflicts between desire and 'duty' were particularly popular with Madeleine as she contemplated her future.

By 1942, Madeleine began to refer to anti-Semitic repression in relation to Hélène Berr and Françoise Bernheim, young Jewish students who were two of her closest friends. Madeleine had met Bernheim through Sylvia Beach. Like Madeleine, Bernheim had worked part-time in the shop. She had met Berr either through Bernheim and the bookshop or at the Sorbonne where Madeleine had taught as an English language assistant on the undergraduate English degree Berr was taking. Contact between Madeleine and Berr became very frequent when Berr's father was arrested and were especially frequent over the summer of 1942 when the yellow star edict came into force and in the days before and after the Vel d'Hiv round up in July 1942. In 1942, the diary entries about Berr were brimming with love and support and are admiring and sympathetic. When Berr achieved excellent summer examination results Madeleine wrote that Hélène was the cleverest girl she knew and the only people she liked in her life were Freemasons and Jews. It is clear that Madeleine supported Berr. Sometimes Madeleine's entries were cautious, using only initials to denote her Jewish friends - more a feature of later diary entries when both women were in hiding and Madeleine knew where they were. The two women corresponded almost daily while Berr's father was in prison. After his release Madeleine was invited to meet the family at the Berrs' apartment. When, the same night, she disclosed that she was knitting yellow socks and gloves, it is clear that she was doing what many gentile French citizens did by way of a show of support. She was knitting yellow coloured accoutrements to show solidarity with her friends forced to wear the yellow star. Although Hélène talked, in her diary, of feeling isolated and alone as she faced persecution, Madeleine's support of her Jewish friends mirrored the attitude of fellow students and staff at the Sorbonne. Although largely ineffective, there was antagonism about Vichy's anti-Semitic policies within the staff and student body. In 1941 and 1942 there were clashes over the imposition of anti-Semitic programme led by Henri Labroue and disquiet about the introduction of a quota system for Jewish students which limited numbers to $3 \%$ of the student population. In his article 'Léchec du cours antisémite d'Henri Labroue à la Sorbonne (1942-1944)' Claude Singer described how it took time for there to be a stirring of opposition to the persecution of Jewish students and teaching staff but that by the end of 1941 and the spring of 1942, public disquiet over the treatment of Jewish people had grown (Singer, 1993: 3-9). Madeleine was involved in Resistance activities. She had close contact with Resistance leader Georges Auclair and Hélène Barland, administrator in Vichy's Service des monuments historiques, who was 
responsible for counterfeiting documents in the Resistance network Turma Vengeance. ${ }^{154}$ Although there is no firm evidence that Madeleine was involved in protecting Jewish people in Paris, Hélène Berr and Françoise Bernheim certainly did help Jewish children to find safe sanctuary under cover of L'Union générale des israélites de France (UGIF), ${ }^{155}$ where both women worked. By 1942, there is more evidence that Madeleine was becoming a more active opponent of the regime, even if that activity was contained within allusive references in dispersed diary fragments. Even in 1942, Madeleine did not waver from the vow she made in December 1940, namely to keep silent about 'political matters'.

${ }^{154}$ Marc Chantran, Turma Vengeance : Réseau de renseignement - évasion action de la Résistance http://chantran.vengeance.free.fr/ [accessed 4 January 2011].

${ }^{155}$ L'Union générale des israélites de France (UGIF) was set up at the request of the Vichy authorities. 



\section{2}

\section{Thursday 1 January}

Went to Villeparisis. Godfather, Granny, Mme Elizabeth (Deschamps), M. Deschamps and Gérard D, Roger, Aunt V, Yolande, Marcel, me were at lunch. Same for dinner. Played Ludo and Old Maid. ${ }^{156}$ Misty. Aunt has the 'flu.

\section{Friday 2 Jan}

Mlle Koch. Monique didn't come. Ironed. Cut out hood. Sent card to Dédé (and family), Huguette, Simone Pelletier, Zinzer, Paulette Trois-Gros. ${ }^{157}$ Went for dinner at Dil's but had another dinner back here. Read until 1 am (Embury Heath by Stella Gibbons). ${ }^{158}$ Card from Dédé and family.

\section{Saturday 3 Jan}

Bought and took cyclamen to Simone Le Hartel. Card to Vendryès. Waited on Jacques Deschamps for the radio. Fine weather. The sun is rising earlier. Jacques Deschamps came. The radio valve isn't working. Went along with him to the Capoulade ${ }^{159}$ to have a coffee. Rue R. Took back "Mythe et Dieux des Germains" Took out "Les Sociétés Secrètes de Mystères" (O.E.Briem). Very good. Confession. Card from Simone Le Pelletier.

${ }^{156}$ A card game.

157 When Madeleine lists names in this way they are people to whom she has written letters or pneus.

158 Stella Dorothea Gibbons (1902-1989) was a British novelist. Embury Heath was published in 1935. See Rachel Cooke's Guardian piece for more about her life and career:

https://www.theguardian.com/books/2011/aug/07/stella-gibbons-westwoodstarlight-vintage

159 A café on the Boulevard Saint-Michel. 


\section{Sunday 4 Jan}

Mass. Spent the day at Aunt's. J. Deschamps came over. Cafés, restaurants, theatres, picture houses etc shut at $5 \mathrm{pm}$ because of the two bomb attacks (1 German hotel and 1 German bookshop destroyed). Got a new valve for the radio. (I owe Aunt $60 \mathrm{fr}$ for the valve and 430 for the fabric)

\section{Monday 5 Jan}

Went back to the office. Started to have lunch at the hostel again. Started back at the Sorbonne. Waited for Sonia but nothing.

\section{Tuesday 6 Jan}

New "collaborator" for Korbelecky but I don't think that he likes her. Visit from Paulette Trois-Gros. I will have to learn Welsh, but I have eaten too much!!!!!!! (and in times like these!! - but I am eating much better than last year, - and boy, ${ }^{160}$ do I not feel the benefit?). Abbé Falcon speaking on the radio about Breton in schools. Darned.

\section{Wednesday 7 Jan}

Office. Welsh. Rue R.

\section{Thursday 8 Jan}

Mlle Koch paid. No Monique. Colette's birthday. Took nail scissors but no one was home.

\section{Friday 9 Jan}

Welsh. Office.

\section{Saturday 10 Jan}

Office. Darned. Rue R.

\section{Sunday 11 Jan}

Went to Aunt's. She was very catty. "Fille d'Eve". If I don't bring anything, she's catty!! I owe her 500 frs for the fabric and the radio.

\footnotetext{
160 'boy' written in English in the manuscript.
} 


\section{Monday 12 Jan}

Office. Shopping for Korbelecky. Pauphilet. Lesson Mourgeon.

\section{Tuesday 13 Jan}

Office. Darned. Letter and money order Godfather, Granny for tree. Snow.

\section{Wednesday 14 Jan}

Office. Welsh. No rue R. Waited for Jacques Deschamps but he didn't come.

\section{Thursday 15 Jan}

Mlle Koch. Monique paid. Gave eggs, onions, carrots. Rent (reduced because of lack of heating)

\section{Friday 16 Jan}

Welsh. Office. Darned. Got the 150 fr from the money order for the tree.

\section{Saturday 17 Jan}

Office. Darned. Went rue R. but no lesson because they were doing diphtheria vaccinations.

\section{Sunday 18 Jan}

Went to Aunt's. Paid back 100 fr. I still owe her 400 frs. "Face au Destin" Jacques Deschamps there. Was miserable the entire day. Brought cake so there wasn't too much cattiness. ${ }^{161}$

\section{Monday 19 Jan}

Office. Pauphilet. No A. Chenier. Mourgeon.

\section{Tuesday 20 Jan}

Office. Welsh. Rue R. Read "Grey Owl. Récit de la cabane abandonnée” "Ambassadeur des Bêtes". "Un homme et ses bêtes".162

161 'cattiness' written in English.

162 "Grey Owl" was the assumed name of Archibald Belaney (1888-1938), British-born author and conservationist. 


\section{Wednesday 21 Jan}

Office. Welsh. Rute R. Paulette Trois-Gros came over. Snow. Cold. Wrote to Godfather and to Granny. ${ }^{163}$

\section{Thursday 22 Jan}

Mlle Koch. Monique. Snow. Cold. Dil. came. Cold $-9^{\circ}$ at midday!!

\section{Friday 23 Jan}

Welsh. Office. Dil. borrowed my bedroom. ${ }^{164}$ Wrote to Voisin. Andrée Corneil. Hot water.

\section{Saturday 24 Jan}

Office. Did washing. Bought stamps. Thaw. Rue R but didn't get paid. Darned. Pneu from Paulette Trois-Gros about not coming tomorrow. Hooray. ${ }^{165}$

\section{Sunday 25 Jan}

What a beautiful day. Window wide open. Sun. Ate Miss Longhurst's pickled prawns. Wondering if I'll get food poisoning. Not very confident about pickles. We'll see if I get ill. cf. ate bad stuffed olives 13 months ago but fine - no aftermath. ${ }^{166}$

\section{Monday 26 Jan}

Took shoes to be repaired. Put red shoes on. Beautiful. Lots of compliments but my foot hurts!! Took watch back to have glass repaired which has broken again. Office. Pauphilet. A Chénier. Mourgeon. Wrote to Mme Faure. Corbeil. Zéau.

${ }^{163}$ Entries 20th and 21st January have arrows against them in the diary margin to show that their content has been muddled. Madeleine made a correction to the entry of 21 st January, crossing out text and inserting it in the entry of 20th January.

${ }^{164}$ Dilys may have been in involved in Resistance activities. Madeleine may have been lending the room to shelter someone hiding from the authorities.

165 'Hooray' written in English.

166 'no aftermath' written in English in the manuscript. 
Mme Fastier, Uncle at Chateau, Godmother Berthe. Took out “L'Homme à la Bêche" (H. Pourrat). ${ }^{167}$

\section{Tuesday 27 Jan}

Office but holiday because the windows are having draught excluder fitted. Shopping (dates 125 gr, pulses 125 gr). My feet are hurting terribly. Saw Paulette Trois-Gros. Improvised mittens because so cold. Pneu fom André Corneil telling me about a trip out to get vegetables.

\section{Wednesday 28 Jan}

The ice is terrible!!! Got carpeted by Kobelecky because I did not stay on Tuesday. Mme Maréchal brought vegetables. $5^{\circ}$ doing the cataloguing. ${ }^{168}$ The inspector was due to come round but I slipped off for lunch. Went to the Enfants assistés for parcel. Topinambours ${ }^{169}$, carrots, pumpkin!!! (on Tuesday only had pasta to eat - there's nothing to buy anywhere. Bought chicory roots and cooked them with some stock but too bitter. There are no vegetables to be had anywhere. The bread shop is shut. There's no flour. I have porridge for breakfast). Welsh. Breton. Rue R but only Micheline was there. Myriam is ill. My feet hurt a lot. I?

\section{Thursday 29 Jan}

+ Got up late. Mlle Koch. Fine weather. Monique. Red Cross. Ironed. Wrote to Aunt V. Can't get my finances straight. Got the watch back and it wasn't working. Put it on and it works. Took back "L'Homme à la Bêche" annoying. Full of big theories but with nothing to back them up. Visionary without the evidence. Playing the prophet in his toga - but wrong about the facts. Didn't finish reading it. Took out "L'Empire des Serpents" F.G. Carnochan and H.C. Adamson. It's about snake hunters in Africa. Interesting.

167 Henri Pourrat (1887-1959). French writer focussing on rural life in the Auvergne. For more about the writer and his status as an 'official Vichy author' read online: Christian Faure, "Vent de Mars d'Henri Pourrat, Prix Goncourt 1941, ou la consécration d'une ouvre littéraire par le Régime de Vichy", Bulletin du Centre d'Histoire économique et sociale de la région lyonnaise, Lyon, $\mathrm{n}^{\circ} 1,1982$, p. 5-25.

${ }_{168}$ Unclear. Looks like $5^{\circ}$ which might explain why Madeleine slips away early.

169 Otherwise known as Jerusalem artichoke, a root vegetable. 


\section{Friday 30 Jan}

Welsh. Office. Reminded by Ruth about the lesson with Appel. Had dinner at Dilys's with my pasta. Disgusted. ${ }^{170}$

\section{Saturday 31 Jan}

Office. Interviewed Appel. Rue R. Went to Cyla’s

\section{Sunday 1 Feb}

Went to Massy-Verrières. Snow. "Epiphany" "Chapeau Chinois" "Gringoire". Very so-so.

\section{Monday 2 Feb}

Pauphilet. Levaillant. Mourgeon. Snow. Parcel from Corbeil +100 frs

\section{Tuesday 3 Feb}

Office. Monique. Letter from Corbeil

\section{Wednesday 4 Feb}

Office. Welsh. Rue R. Food poisoning from a fish bake. Very ill. ${ }^{171}$

\section{Thursday 5 Feb}

Mlle Koch. Office. Letter from Voirin. Kamska. Letter from Aunt.

\section{Friday 6 Feb}

Office. Welsh

\section{Saturday 7 Feb}

Office. Appel. Snow. Cold. No rue R (sick of this ${ }^{172}$ ). Saw Cyla. Wrote to Corbeil. Went to see Cyla. Letter from Corbeil. No food in Paris.

\footnotetext{
170 'Disgusted' written in English.

171 'ill' written in English.

172 'sick of this' written in English.
} 


\section{Sunday 8 Feb}

Went to see Aunt V. "President Kruger" Huh! Paid Aunt back. No food in Paris.

\section{Monday 9 Feb}

Wrote to Corbeil. Pauphilet. Levaillant. Mourgeon. No food in Paris.

\section{Tuesday 10 Feb}

Office. Monique. No food in Paris.

\section{Wednesday 11 Feb}

Office. Welsh. Sonia came to get the sheets etc. Rue R. No food in Paris.

\section{Thursday 12 Feb}

Mlle Koch. Office. Kamska. Rise in salary ${ }^{173}$ No food in Paris.

\section{Friday 13 Feb}

Vendryès ill. Office. Ruth came to sleep over. Huh! No food in Paris.

\section{Saturday 14 Feb}

Red Cross parents Nov. ${ }^{174}$ Appel. No rue R. Dédé came. Office. First food deliveries of the week.

\section{Sunday 15 Feb}

"Le Bourgeois gentilhomme" with Mlle Koch. Went to Café "La Source" Darned bedsheets until $4 \mathrm{am}$.

\section{Monday 16 Feb}

Red Cross parents 15 Nov. Letter Jeanne Semaille. Mourgeon. Cold. Snow. Dil came. Pauphilet.

\footnotetext{
173 'Rise in salary' written in English.

174 Presumably a letter sent by Madeleine's parents via the Red Cross the previous November. Sometimes mail took months to get through.
} 


\section{Tuesday 17 Feb}

Got a cold. Rue R. (1 hour) Snow. No Monique.

\section{Wednesday 18 Feb}

Office. Welsh. No rue R. Queued for one hour for a kilo of beetroot. Filled out forms for rue de Pressbourg. ${ }^{175}$ Granny's birthday.

\section{Thursday 19 Feb}

Mlle Koch. Office. No Kamska. Wrote to Aunt Violette.

\section{Friday 20 Feb}

Vendryès ill. Office. I need to have a vaccination. Mme Faure came to the office. Met up with her afterwards and had a drink at Etoile. Was invited to her place on the 6th March. Bought [...].

\section{Saturday 21 Feb}

Office. Bought wooden shoes ${ }^{176}$ from Manon. Appel. Rue R. Had vaccination at $2 \mathrm{pm}$.

\section{Sunday 22 Feb}

Godfather's birthday. Icy. Went to Aunt's. Ran from cinema to cinema without getting to see anything. Bored stiff. ${ }^{177}$ I'll go to Aunt's as little as I possibly can in future.

\section{Monday 23 Feb}

Snow. Got up late. Pauphilet. Took back "Grandeur et Décadence des Romains" (Montesquieu). Got out "Le Vin Blanc de la Villette" (Jules Romains). Populist but alive. ${ }^{178}$ Letter from $\mathrm{HB}^{179}$ with a letter from my parents dated 28 January.

\footnotetext{
175 rue de Presbourg.

176 When shoe leather ran out, Parisians were forced to wear shoes with wooden soles.

177 'Bored stiff' written in English and underlined.

178 'alive' written in English.

179 HB is Hélène Berr.
} 


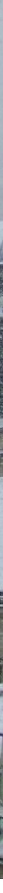

View from 320 rue St Jacques in winter. Copyright Delphine Biechler, licensed under CC BY-NC 4.0.

Had some hot chocolate with Jacqueline Piatier (room 5). ${ }^{180}$ Cold. Darned. [Monsieur Blum dead - note made 25.7.43]

\section{Tuesday 24 Feb}

Office. Monique. Thick snow. Kamska. Depressed. I want my mummy. ${ }^{181}$

\section{Wednesday 25 Feb}

Office. Korbelecky told me that his fiancée had died. Surprised that he had one. Breton. Welsh (there was only Raude and me. Bachellery was disappointed at the low turnout - well it was snowing!) Went to rue R. but the children were not there. Gave the sheets and packing blanket back to Sonia.

180 Room 5 in 320 rue St Jacques.

181 'I want my mummy' written in English. 


\section{Thursday 26 Feb}

Mlle Koch. Snow. Office. Mme (Jacqueline) Maréchal didn't come to the office because sore leg after the vaccination. Mine is like a mosquito bite. Kamska. Wrote to Voirin, Aunt, HB, Godfather, Granny. Got some extra pasta. Just as well because for over a week there has been nothing for sale in Paris. No deliveries. Eating pasta every evening (luckily I had stocked up). A third winter!! Woe. Everything is relative. One day last week: By jove, hot. Went out without a coat, so mild, Spring is here etc etc. $1 \mathrm{pm}$. Still thrilled about the mild weather, winter is over etc. Looked at the thermometer on the Boul'Mich. $-\underline{2}^{\circ} ! ! !$. Granny's birthday. Having bother getting paid at the office.

Bread 275 gr per day. Fat 450 gr per month including 100 oil and 75 marg. Cheese 50 gr a week. Pasta 250 gr a month. Pulse 250 gr a month. Sugar 500 gr per month. Potatoes none. Fresh meat 180 gr per week. Cold meat 90 gr a week. Coffee etc 250 gr a month or 60 gr of tea. Milk, eggs, vegetables etc nothing for the moment. Gas $15 \mathrm{~m}$. cube per month. Electricity $60 \mathrm{kw}$ per month.

\section{Friday 27 Feb}

Vendryès ill. Picked up the patterns - 68 fr a pair!! I'd thought they'd be 24 frs and had ordered two pairs. Only took the one. Office. Mme Maréchal came back. Icy.

\section{Saturday 28 Feb}

Office. Mme Maréchal's last day. Gave her some messages for Dad and Mum. Didn't work much. Korbelecky was all over Mme M. with compliments. Tided the kitchen a little. Appel. Rue R. Took out "Claude" Geneviève Fauconnier. ${ }^{182}$ Great. Marvellous. She thinks like I do. She likes the same things pretty much. Calling frogs "touics" is just lovely. Note to self. Buy it as well as "Sido" (Colette) ${ }^{183}$

\section{Sunday 1 March +}

Went for a stroll. Lovely sun. The snow is melting. Stood leaning against the window, writing. Noises from outside come together with the silence of my bedroom and the pulse of my two alarm clocks, and die. There's the low distant

${ }^{182}$ Geneviève Fauconnier (1886-1969). French writer who won the Prix Fémina for Claude in 1933. See:

http://data.bnf.fr/12147677/genevieve_fauconnier/

183 Sido (1930) is a collection of autobiographical stories by the French novelist Colette (1873-1954):

http://data.bnf.fr/12199028/colette_sido/ 
growl of a barge on the Seine. There's piano playing coming from the building next door. There's the rhythmic grating of a spade clearing the snow. And underneath, there is the soft hum of Paris. Only on evenings of early curfew, before the German patrols, does the humming stop only to start up again little by little. I need to get some more stockings. Those I bought off Mme Fortan are absolutely hopeless - completely crisped up by the dye. I've had them on three times and the net is breaking everywhere. Had hot water so had a "bath".

\section{Monday 2 March}

Sent a pneu to Sonia telling her not to come. Lesson Mlle Rouquette, Pauphilet (2) Levaillant. Mourgeon. The two little girls there are awful. The oldest one doesn't want to learn anything. Mme M. was whining about food. Each time I go, I notice how much the days are getting longer astonishingly quickly. At the beginning, they were pitch black and freezing, then greyish, more lately we've had low sunsets over the snow and today the sun is higher than the Arc de Triomphe. Sonia had been over and left a note. Listened to "Antony et Cléopatra" until midnight. Liked it.

\section{Tuesday 3 March}

Moignard registered me for the Contribuables directes ${ }^{184}$ for the 3000 and some that I got in '41. How nice of him as if I can't think of anything better to do with my money. Letter from Voirin. He seems a little anxious, worried. Sent me 2,000. I expected half of that. I'll put it in the Caisse d'Epargne ${ }^{185}$ because I would like to put at least 6,000 to one side even though money isn't worth anything. I'll be all too pleased to have it if I fall on hard times (anyway, need it to pay Voirin back). Office. Decossin and Uzal report to me. I didn't manage too well telling them to do one thing and then another instead but I didn't know what was what and as Korbelecky says, "tomorrow is another day". Met up with Sonia who is dead set on giving me German lessons. I'm put off. ${ }^{186}$ I don't want to be around her at all. Housework. Beautiful day. Warm sun. Sat on the window ledge for $1 / 2$ an hour.

Read "Claude" in one go. Wasn't blown away by it as I was when dipping in and out of it but I still like it a lot. It isn't obvious that a 40 year old woman wrote it. It is so fresh. - anyway, we stay children all our lives inside. We change on the outside. There is a right way to age. - ie: don't do what one wants to do in public at 30, 40 or even at 20 things that younger people delight in doing.

\footnotetext{
${ }^{184}$ Income tax.

${ }^{185}$ National savings bank set up in the early 19th century to encourage saving among the working classes.

186 'put off' written in English.
} 
Avoid looking ridiculous. Wanting to dance and jump around when one is the size of an elephant is not wrong but just don't do it in public because it looks bad. Ageing gracefully means distinguishing between the interior and exterior and acting in public according to what the exterior expects. Only young people can truly be themselves. Neither frivolity nor seriousness looks out of place in a child. If the exterior is attractive one can be oneself for far longer.

Monique. Hungry. Rue R (1 hour). Mlle Piatier gave me some jam. Finished "Claude". Should have been working but feel too restless. Spring is unsettling me. Very hungry and restless. There's nothing on the radio I like. I'd like to sink into a deep sleep.

\section{$9.45 \mathrm{pm}$}

Was typing up the notes for Welsh with the radio at full blast. The building shook several times. Heard it on the radio. It was like a thunderclap. Went to the window. Planes, flak. Was overjoyed. The caretaker (Mrs Berger), Jacques (her son), a tenant and Miss Fortan and me were flying from window to window to see as much as possible. Smoke trails from flares especially round the Eiffel Tower, South West Paris and five good ones just in front of here. Everybody went to the windows. Planes silhouetted against the clouds. The moon half blotted out. Suddenly just above the Panthéon, 2 light beams and tracer bullets (blue, yellow, red, white), A few bombs maybe? By quarter past eleven things quieten down. Pretty tired. Had a piece of bread and jam (who cares about the bread ration, will try and get more tickets) and finished typing up notes. There were a few more blasts and by quarter to midnight everything was calm. The noise is incredible because it echoes from one hill to another through Paris. Headache now, tired. And so to bed. ${ }^{187}$

\section{Wednesday 4 March}

They say that the air raid alert started at 9.15. It rained all night. At 1.20 in the afternoon the sirens started up. Real or just joking? The road empties in the blink of an eye. Everybody just runs - it's for real then. I took off my coat and shoes. If it is still the same at quarter to two I'll go off to my Welsh class. Got 2,000 francs (two thousand) off Voirin. Shock and horror at the office this morning. M and Mme Somazzi stayed over at friends last night. When they got back in the morning their house was destroyed and their mother dead under the rubble. This was at Boulogne-Billancourt obviously!!! Renault got hit. After the first moments of panic the street has got back to normal. I'm off to class now then.

Cinemas, theatres etc closed today and restaurants shut from 8 pm because the German sentry killed on the rue de Tanger on Sunday 1 March is being buried.

187 'And so to bed' written in English. 
Left for lessons. Was turned back on the rue Soufflot and police insisted that we got to the shelters. But I got back on the Boul'Mich by the rue de l'Abbé de l'Epée which is accessible to pedestrians but not vehicles. Alert over at $2.25 \mathrm{pm}$. Bachellery was late. Lebel and l'abbé Fal'cun even later. Raude and Mme Desportes were there. Went to the rue Mouffetard for food shopping. There were only shallots ( $3 \mathrm{fr}$ ) and cartons of cress ( $7 \mathrm{fr} 50$ !! 14 months ago they were dear at 1 fr 50 but slightly better because they were 10 fr 50 , so I couldn't afford them). Letter from Aunt. Returned "Claude". Got out "Les étangs de la Double" (Geneviève Fauconnier) and read it instead of working. I don't like it as much as I liked "Claude" because it is more novel-like, less about the countryside. But it is good all the same. Wrote to Aunt Violette. Dilys came over.

\section{Thursday 5 March}

$1 \mathrm{~kg}$ carrots. Bought mimosa and violets. Mlle Koch. Office. Mlle Loiret is on work experience. She's nice. I'm now deputy head of the office. Well, well!! Kamska. Made myself up! Everyone thinks that I look pretty with it. I don't. Don't have any envelopes so couldn't send letter to Aunt. Can't find any anywhere. Quite cold.

\section{Friday 6 March}

Lesson with Vendryès. Office. Mlle Loiret came and then left and won't be coming back. Had tea and dinner with Mme Faure. Torrential rain this evening. St Colette.

\section{Saturday 7 March}

Day of national mourning (burial of the Boulogne-Billancourt victims). No office. Got up late. Went to the market but there was nothing. No lunch. St Louis 12.30-1.30 pm. Lesson Kamska. Bought some coquilles St Jacques. ${ }^{188}$ Ate them on the go. Pneu from Aunt who is going to Orgeval. Wanted to buy "Mabinogion" gloves but couldn't. Appel. Rue R. Little Christine Vigot was born at 2 am. Cyla.

\section{Sunday 8 March}

Read late. In the afternoon went to Dilys's and babysat Gaël while Dilys and George went out. Had tea with them and then went to see "Madame

${ }^{188}$ Scallop dish generally made with mushrooms and white wine but can also include other vegetables. 
Sans-Gêne"189 at the Odéon cinema. Read "Grand Meaulnes" (Alain Fournier) and "Turn on the Heat". Went to bed at 2 am.

\section{Monday 9 March}

Got up late. Lesson Pauphilet. Levaillant. Mourgeon. Letter from Mummy. Hooray!! Saw Hélène Berr. Wrote to Aunt. Voirin. Nice day.

\section{Tuesday 10 March}

Office. Registered at the Sorbonne. Monique didn't come. Ruth.

\section{Wednesday 11 March}

Office. Welsh. Read “Malaisée” (Henri Fauconnier). Good.

\section{Thursday 12 March}

Mlle Koch. Office. Kamska. Overtime ${ }^{190}$ at the office. Alert 3-4.30. Went down the shelter because was at the office.

\section{Friday 13 March}

Welsh. Office. Read “Images d'Alain Fournier” (Isabelle Fournier). Not bad.

\section{Saturday 14 March}

Office. Went to the Louvre for cover work but nothing. Bought cactus. Weather fine. Rue R. They'd brought the Vigot baby in. No Appel. Bought gloves and lipstick. Droz bookshop. ${ }^{191}$ Bought "Les Origines du Roman" (Wilmotte). Red Cross, mummy. "Everyone is fine, good news from Nils who hopes that you will go to see his father. Best wishes for the New Year from everyone. Hugs and kisses. Went to Dilys's.

\section{Sunday 15 March}

Kamska. Villeparisis. Lovely day. Hot.

1891925 American silent film starring Gloria Swanson: http://www.silentera.com/PSFL/data/M/MadameSansGene1925.html

190 'Overtime' is written in English in the manuscript.

191 The Librairie Droz, a bookshop and independent publishing house, was founded by Eugénie Droz, a Swiss academic and writer, in 1924. 


\section{Monday 16 March}

Lesson with Rouquette, Pauphilet, Mourgeon. Had some fish. Ruth maketh me sick. ${ }^{192}$ Hungry.

\section{Tuesday 17 March}

Office. Monique. Rue R. $1 \mathrm{~kg}$ of potatoes. At last!! And dates too! Chatted with Madeleine F. Hungry.

\section{Wednesday 18 March}

Office. Welsh. Queued for 2 hours for $1 \mathrm{~kg}$ of carrots. Spotted Cyla. Hungry.

\section{Thursday 19 March}

Mlle Koch, who invited me to Sunday lunch. Office. No Kamska. Hungry. Wrote to Aunt. Letter from Godmother Berthe. Hungry. No sugar. Tired out. ${ }^{193}$

\section{Friday 20 March}

Welsh. Office. Queue for Carrots. Letter from Appel.

\section{Saturday 21 March}

Spring. No Appel. Office. Mourgeon. Bought girdle, bra and a clip. Cyla. Scene between Ruth and Cyla. "Autant emporte le vent" (Margaret Mitchell). ${ }^{194}$ Picked up artichokes from the BN.

\section{Sunday 22 March}

Lunch with Mme and Mlle Koch. Nice change. Ate too much. Went to see "Marius" (Panthéon) and had an ice cream. Read 8.30 pm-9 am.

\section{Monday 23 March}

Went to bed at 9.15 am and got up at midday. Lesson with Pauphilet. Mourgeon. I was asked 4 times for bread tickets (for nothing in return, no meat tickets, no money, no nothing). Feel savage. ${ }^{195}$

\footnotetext{
192 'Maketh me sick' written in English in the manuscript.

193 'Tired out' written in English.

${ }^{194}$ Gone with the Wind (1936) written by American novelist Margaret Mitchell (1900-1949).

195 'Feel savage' written in English in the manuscript.
} 


\section{Tuesday 24 March}

Office. Tired out. Spotted Kamska. "Jettais une petite fille" (Irène Français). ${ }^{196}$

\section{Wednesday 25 March}

Office. Letter from Aunt saying that Berthe is at the hospital Antoine [...]. Lesson. Went to see about going to the ballet at Opéra but it was full. "Valses de Vienne" full. Missed the cinema showing of "Nous les gosses". ${ }^{197} \mathrm{Had}$ a fascinating air raid alert instead. Was pushed back to the Odéon on the Boul'Mich. Was in a shelter on the rue Monsieur le Prince until 12.30. Got back home at $1 \mathrm{am}$. Saw the DCA ${ }^{198}$ in the sky. "Chair de ma chair" (American author).

\section{Thursday 26 March}

Mlle Koch. She gave me a little shawl. Office. Kamska. Went back to see "Nous les Gosses". Another alert but managed to get home. Warm night. Dil came round with a letter in Welsh. "Retour de l'enfant prodigue" (A.Gide).

\section{Friday 27 March}

Welsh. Office. Went to the BN. Got paid. Holiday. Came back on foot. Bought a window box for flowers. Knocked-out. ${ }^{199}$ Went to bed early. "Claudine à Paris" (Colette).

\section{Saturday 28 March}

Got up late. Went to the clinic to see Berthe who has had a breast removed. Was just coming round from the ether. Not a nice sight. Aunt and Yo were there. Appel. Rue R. Kamska. Cyla. Alert. A man was killed in a car at Petit Luxembourg. Tracer bullets are pretty. The chestnut trees are starting to show their leaves.

\section{Sunday 29 March}

Mass. Rameaux. Went to the clinic to see Berthe. Mme Paolotté was there, Berthe's sister in law and nephew. Beer and petits fours with Mme P etc. Berthe

\footnotetext{
${ }^{196}$ Published in 1941.

${ }^{197}$ Nous les gosses was a film directed by Louis Daquin released in 1941. The screenplay was written by Daquin and Marcel Aymé.

${ }^{198}$ DCA is anti-aircraft 'flak. DCA is the French acronym for 'défense contre les aéronefs'.

199 'Knocked-out' written in English in the manuscript.
} 
cheerful and with it. Juniper flowering. Hawthorn is all green. Tired out. ${ }^{200}$ Washed hair. "Les Romanesques" (Jacques Chardonne). ${ }^{201}$ A cloudy and warm day.

\section{Monday 30 March}

Tired out. Got up late. Had a big wash. Spring is tiring me out something rotten. 44 hours behind at work but I'm taking a few days holiday because I am too tired. I feel heavy all over. Went to the clinic to see Berthe. Got my soap (300 gr for two months including $200 \mathrm{gr}$ in bars), my cauliflower ( $1 / 2$ a pound for March), my kg of artichoke. Went to get food ration cards. 20 gr less fat. For bread, it may be that the 350 gr tickets are worthless- meaning that we are only going to be getting 250 gr of bread a day. Appel.

The little yellow juniper bells are weighing down the branches. On the Place Denfert-R there are primulas in flower but no roses. Nearly all the chestnut tree buds have flowered. The avenues are lit up by them. The little flowers of the [...] are set in little bunches against the blue, white - and especially grey - motion of the sky. My hyacinth has opened. It is a beautiful blue-mauve colour but doesn't have much of a scent yet. The crocus have come to nothing. As soon as the hyacinth is finished I'll smash that horrid vase it's in.

\section{Tuesday 31 March}

Sent a message to the Red Cross. Got up late. KO. Went to the Office. Got paid. Bought some soil and some flowers for the window box. Went to Kamska but didn't have a lesson because he was ill. Dinner at Dilys's. Saw Sylvia. Got a photo of Gaël.

\section{Wednesday 1 April}

Got up late. Went to see Berthe at clinic. Brought back the soil I needed. Planted flowers. Did the washing.

\section{Thursday 2 April}

Mlle Koch. 1 pm-7 pm. Went out to the shops with Dilys. Tired out. Drank fizzy wine at Rohan and got slightly "tipsy". 3-4.45 am there was an alert. Poissy (the Mat-Ford factory) bombed. Did ironing. 11 pm-1 am. Alert. Maundy Thursday.

200 'Tired out' in this and the next entry of the 30th March written in English.

201 Jacques Chardonne (1884-1968). French novelist. 


\section{Friday 3 April}

Good Friday. Went to see Berthe at clinic. Invitation Mme Faure for next Friday. Scrubbed floorboards and filled the grooves between.

\section{Saturday 4 April}

Confession. Went to see Berthe at the clinic. Saw Aunt. Yo. Came back on foot with them to Denfert. The plum is flowering (at the bottom). Lesson with Appel (1 hour 1/2) Got paid $150 \mathrm{fr}$ (March and 1 lesson in April). Went to a Milk Bar (Patrick's) for an ice-cream. ${ }^{202}$ Bought an egg for Gaël, sweets, macaroons for Godfather. Listened to the "Damnation de Faust". ${ }^{203}$ Very good. Good singers. Understood it all even the 'chanson de la puce'.

\section{Sunday 5 April}

Easter. Communion. Villeparisis with Aunt, Roger. Godfather's nephew - Jean. Went to the cinema "Narcisse" (already seen it but laughed as much). Yo railed violently against going to confession. So it's Godfather and Granny who had been pushing for a marriage between Yo and Maurice Roche which Yo rejected. Maurice will be getting married in a few days. Went to the "Bois" St Denis. Not a tree left. A lot of anemone. There were violets along the side of the canal smelling good - and the first cowslips. Little white rabbits. Very few trees in blossom. Slept over at Villeparisis (in the morning, had taken an egg to Gaël).

\section{Monday 6 April}

3-5 am. Alert heard at Villeparisis. Saw flowers. Goodrich-Colombes got it. Did some digging. Weeded round the strawberry bushes. Granny gave me 4 eggs.

\section{Tuesday 7 April}

Wrote to Mme Faure. Went to see Berthe at the clinic. Saw her nephew (so flirtatious, goodness me) Went to the BN. Ruth Camp came, because she had come yesterday but I wasn't in. She's up to something, but what? Nothing at the market. Lettuce.

202 'Milk bar' and 'ice cream' in English.

${ }^{203}$ Opera/Cantata written in 1846 by Hector Berlioz. In all likelihood, Madeleine was listening to the performance of the Grand Orchestre de RadioParis conducted by Jean Fournet. 


\section{Wednesday 8 April}

Finished the boards. Went to see Berthe at the clinic. BN. Alert 10.30-12 pm. Nothing.

\section{Thursday 9 April}

Mlle Koch. M (Alexandre). Chabert came to offer me some work. $2 \mathrm{pm}$. Went to collect the translation - I have to look up each word at the moment but it'll probably get easier in a bit. Radishes, cauliflowers, leeks! The image of the proper student - science treatise under one arm, basket full of vegetables, radishes in the other. Head full of dreams. Walked through the Luxembourg gardens. Horse chestnuts ${ }^{204}$ are all flowering. Constantly daydreaming about a little white-washed farm with just a few animals, sunshine, a well. Going to work - so there! ( $\underline{\text { Crinex }}$, for 10 days, finish $18[\ldots]){ }^{205}$

\section{Friday 10 April}

Typed translation. Tea and dinner with Mme Faure. BN. Ruth Camp came over.

\section{Saturday 11 April}

Typed translation and delivered it. Went to Cyla's. Went to the clinic to see Godmother Berthe.

\section{Sunday 12 April}

Mass. Quasimodo. "Marie-Stuart" with Hélène Koch. Had an ice-cream at "The Source"206 Luxembourg with her and her friend. Wore wooden shoes. Aunt Violette's birthday.

\section{Monday 13 April}

Lessons started again at the Sorbonne. Typed translation. Rouquette. Pauphilet.

\section{Tuesday 14 April}

Typed translation. Letter from Monique Vignet (mumps). Letter from Granny. Kamska. Went to the clinic to see Berthe. "La Chatte" (Colette) ${ }^{207}$. Not bad.

\footnotetext{
204 'Horse chestnuts' written in English in the manuscript.

205 Bracketed phrase truncated and abbreviated. Difficult to decipher.

206 Café on the Boulevard St Michel in the 6th arrondissement of Paris.

207 Novella published in 1933.
} 


\section{Wednesday 15 April}

Rent. Office. Bachellery. Typed translation and took it. The young man was sweet. “Trente Arpents" (Ringuet ) ${ }^{208}$. So-so.

\section{Thursday 16 April}

Mlle Koch. Vendryès arrested at 6 am!! Office. Korbelecky came. Typed translation. Dilys came. "Nos Mitrailleuses nont pas tiré"209 (?). Barrage balloons around Paris. Alert $12 \mathrm{pm}-1$ am.

\section{Friday 17 April}

Waited in vain for Vendryès. Found out about his arrest. Read "Desert de Gobi" (P. Benoît). ${ }^{210}$ Very so-so. Office. I? Typed translation. Delivered translation.

\section{Saturday 18 April}

Went to office but not open. Met M and Mme Zéau. Chestnut trees starting to blossom!! Already!! Went to clinic to see Godmother Berthe. Saw Aunt and Yolande. Germans requisitioning cars at Denfert. Appel. Saw Dilys. Had dinner at Cyla's.

\section{Sunday 19 April}

Mass. Bought grape sugar. There's loads of leeks (asparagus are a little dear, 12 and 15 frs a pound). Wrote to Mummy. Feeling good about myself.

\section{Monday 20 April}

Typed translation. Went to the clinic to see Godmother Berthe. Pauphilet. Tired.

${ }^{208}$ Novel published in Quebec 1938.

209 Novel by Jean-Marie Aimot published in 1941. Interestingly, it was based on the French defeat in 1940. He was a collaborationist and a member of Jacques Doriot's Parti Populaire français.

${ }^{210}$ Novel by Pierre Benoit (1886-1962) published in 1941. Benoit was a prolific writer known, according to his biographer Gérard de Cortanze, for novels with erotic undertones framed in exotic contexts. For more on Benoit, see Cortanze's Pierre Benoit (2012) Le romancier paradoxal (Paris: Albin Michel). 


\section{Tuesday 21 April}

Office. Seminar paper. Thought that it was Montesquieu but it wasn't. Monique. Kamska.

\section{Wednesday 22 April}

Office. Welsh etc. Vendryès released. Typed translation.

\section{Thursday 23 April}

Mlle Koch. Office. Bought a little teapot. Godmother left the clinic. Typed the translation. Chestnut trees in flower. Card from Mme Faure on holiday at La Charité. Lilac in flower.

\section{Friday 24 April}

Welsh with Vendryès who looks well. Lost weight. Office. Bought a ticket for the national lottery $\left(\mathrm{N}^{\circ} 33,247\right)$. Delivered the translation. Kamska.

\section{Saturday 25 April}

Office. Got the money off the lottery ticket. Bought another with the money I got back. Went to the clinic but Berthe had gone home. Appel gone home. Letter from Berthe. Pneu from Aunt telling me to buy some dog biscuits for Pataud. ${ }^{211}$ Had to go out again despite my feet killing me. Bought some iris for my garden. The chestnut trees are all out now. All the zinc counters are being replaced with wooden ones. Flappée dead. Cyla.

\section{Sunday 26 April}

Mass. Villeparisis. Hoed strawberry bushes. Lots of lilac everywhere. Brought back big bunches of white and mauve lilac. Sunny.

\section{Monday 27 April}

Rouquette. Pauphilet. Went to Dilys's. She has a swollen neck. Rue R. Fine weather. Torrential rain in the evening. Met Mlle Péchegut who has a poorly

${ }^{211}$ Aunt Violette's dog. Less than a month later, on May 17th, Madeleine writes that Pataud has been put down - probably because there was not enough food to feed him. 
arm. She told me about a cashier job. I wonder whether anything might come of that? Had the egg allowed by the rations (my 3 rd since October). [...]

\section{Tuesday 28 April}

Office. Very windy. "L'Empreinte du Dieu"212 with Mme Fortan.

\section{Wednesday 29 April}

Wrote to Hélène Berr. Office. Welsh. Very windy. York bombed. Invited Jacqueline Piatier and Madeleine Fortan for tea. Housework.

\section{Thursday 30 April}

Wrote to the Red Cross. Mlle Koch (gave me Lily of the Valley). Georges is back. Took lilies to Dilys but she wasn't there (she'd gone to fetch Georges). Nice weather. Windy. 0.10-1.45 am alert. Big fire over Courbevoie (?) way. Gosh, tracer bullets are so very pretty. Difficult to believe that such a pretty fireworks display is sowing death. "La Vie et ses Secrets"213 (Edmond Rostand)

\section{Friday 1 May}

Welsh. Office. Took the lilies to Cyla then stayed too late. "Discours de Bêtes"214 (Colette).

\section{Saturday 2 May}

National Work day today. Stayed in bed. Had lunch at the "Patte d'Oie" with Dilys and Georges. Went to Appel's but wasn't there. Letter from Jean Soulier. Jacqueline Piatier came over at $7.20 \mathrm{pm}$ and talked without stopping once until 10 to midnight. I'd had more than enough. I still gave her a rum and lemon tea whilst wanting to strangle her. Cold. Put the radiator on.

\section{Sunday 3 May}

Mass. Kamska. Went to the flea market but there was nothing. Worked a little. Went to bed early. Beautiful day. Police and militia everywhere in the streets.

2121941 French film directed by Léonide Moguy based on the Goncourt winning 1936 novel by Maxence Van der Meersch.

${ }^{213}$ The attribution of this work to Rostand may be an error as he does not appear to have published anything with this title.

214 This should be Dialogues des bêtes, published in 1930. 


\section{Monday 4 May}

Bought gloves, wooden shoes, Latin dictionary, Lawson and Truffeau. Pauphilet. Went to Hôtel de Ville to see Jean Soulier. I am in huge pain with my foot. Went to rue R but no one there. Fine. "Propos sur le Bonheur" (Alain)

\section{Tuesday 5 May}

Office. Mme Tiffernau started work. I don't like her. She is too indiscreet, her wrists are too fat. Summer is here. Beautiful day. Swotted for exam the whole afternoon. Anxious. Worked until $1 \mathrm{am}$. Alert 11.55 (Crinex $^{215}$ - to the 14th of May inclusive)

\section{Wednesday 6 May}

${ }^{216}$ but the all-clear sirens just went on and on and then started up again. This carry on lasted a good half an hour. Got up early. For a while I have been waking up automatically at $6 \frac{1}{2}$. Office. I don't like Mme T. She is too indiscreet. She rather skilfully grilled the Pedron girl about me. Full of compliments. Feel terribly lazy. Felt as if I was going to fall fast asleep in Breton. What can I do about it? . . . didn't sleep. Went to Appel and phoned. Lesson on Saturday $14 \mathrm{~h} 30$. Got oranges (4). Worked. Tired out. It is warm. For my 'Aucassin et Nicolette' essay: - "in May when the nights are long, serene and silent", - or "warm, silent and serene?" Phew. Hurry now. Off to beddy-byes.

\section{Thursday 7 May}

Mlle Koch. Letter to Hélène Berr. Office. Bought a navy blue jacket. Saw Dilys. Went to Kamska's but not there. Very hot day. Saw Michael. What a bore. Bought blue iris and splendid tulips "Coq de bruyère" bright red with gold edges. Money is going like water. Today 100 frs just like that. Tired out.

\section{Friday 8 May}

Welsh. Office. Rue R. "Jean-Christophe” (1 Vol. "L'Aube")

${ }^{215}$ Crinen or Crinex. A translation commission perhaps?

216 The entry seems to run over from the 5th of May. 


\section{Saturday 9 May}

No office because on holiday. Ill. Sicky. ${ }^{217}$ Appel (paid for April) 11/2 hours. Dad, Mum OK. Bought "Water Babies" for Cyla. "Mariages" (Ch. Plisnier) ${ }^{218}$. Was on the ticket office at Schola Cantorum. ${ }^{219} 14$ people!! - Saw Dilys. Went to see Cyla. Sweet. Row between Cyla and Ruth - about cigarettes. Ate couscous.

\section{Sunday 10 May}

St Jeanne d'Arc. Mass. Pneu from Aunt. Met in Paris. Late. Yolande sulking but still in time for the theatre. Weather bright. We were going to see extracts from various Jeanne d'Arcs at the Palais de Chaillot but it was banned at the last minute. ${ }^{220}$ Saw "Mademoiselle de la Seiglière"221 (Sandeau). Funny. Weather is good. Rue de Rivoli, Tuileries, métro Tuileries shut to the public. Yo sweet. Aunt too. Skirt and 6 eggs. Went to see Aimée. She has a few grey hairs. Victor was there. Very thin. The little girl is fabulous but spoilt. Storm. Ill. (bought cakes for Aunt but ate them).

\section{Monday 11 May}

Prisoners of the Germans at the Val-de-Grâce. Pauphilet. Tired and ill. ${ }^{222}$ Dil came. Wants my bedroom for Wednesday morning. KO. Dog-tired, ill, sicky. ${ }^{223}$ Saw Hélène Berr and Madeleine Lavelle. "Létui de nacre"224 (A. France).

217 'Ill. Sicky' and 'row' later in the entry written in English.

${ }^{218}$ Charles Plisnier (1896-1952) was a Belgian writer and Goncourt winner. A disillusioned Communist, he became a Catholic and established a reputation for novels challenging bourgeois family values. See: https://www.britannica.com/biography/Charles-Plisnier

219 The Schola Cantorium is a private music conservatory founded in 1896, which is still housed on Madeleine's street at 269 rue St Jacques. See: http://schola-cantorum.com/index.php/fr/histoire

${ }^{220}$ Interestingly, Gabriel Jacobs mentions this May 10th performance on page 78 of his chapter 'The Role of Joan of Arc on the Stage of Occupied Paris' in Michael Balfour (2001) Theatre and War: Performance in extremis (Oxford: Berghahn) but does not say that it did not go ahead.

${ }^{221}$ This would be André Antoine's 1921 film of the 1847 novel by Jules Sandeau. See entry in http://www.imdb.com

222 'Tired and ill' written in English.

223 'KO. Dog-tired, ill, sicky' written in English.

${ }^{224}$ A collection of short stories by Anatole France (1844-1924). The 1923 edition is accessible via France's national library digital collections: http://gallica.bnf.fr/ark:/12148/bpt6k229517w 


\section{Tuesday 12 May}

Office. Monique. Rain (I?) Really poorly. Ruth came 8.15 pm. 8.30-11.15 pm. Comforted Ruth. Ruth slept here.

\section{Wednesday 13 May}

Office. Breton. Welsh Bachellery. Rue R. "Berlioz” (Guy de Pourtalès) 225

\section{Thursday 14 May}

Ascension Day. Mass. Mlle Koch didn't come. Ill. Letter from Soulier about a seminar at Ivry but doesn't put the place or the time! Ruth came and took me for lunch to an English restaurant opposite St Julian le Pauvre. Came back with her to study here. What a pain. Dil came and we went to the Closerie des Lilas. Kamska. Ill.

\section{Friday 15 May}

Welsh. Sick as a dog. Nausea [. . .] etc, etc. office. Went by the Hôtel de Ville to find out the time of the seminar. Got back KO. Wanted to go to bed because had an awful migraine but Ruth came over to have another cry. "I feel so humble; I kneel before the eternal Mother in you [sic]. And then blubs. I am too ill to kick her out and I let her carry on crying in my arms. Kisses, more kisses. After an hour of that she finally left. I don't want her here again. It is definitely unhealthy. ${ }^{226} \mathrm{Had}$ an aspirin in a bowl of lemon tea. Temperature all through the night. Cyla no longer goes to the hospital. Mme Scarpazza is dead.

\section{Saturday 16 May}

Office. Doctor Bossin-Legros about Nico. ${ }^{227}$ I have the organs of a little girl!! If I don't look after myself - no children. Damn!! The madwoman in the attic is out. Prepared to do anything even have an illegitimate child by a lover. But this morning (Sunday) after a good night I decided that it'd all be OK with injections etc and if I will it to be so. But I didn't think it was as serious as

${ }^{225}$ For more about Swiss novelist Guy de Pourtalès (1881-1941) see the archive entry at the University of Lausanne:

https://www.unil.ch/crlr/fr/home/menuinst/fonds-darchives/guy-depourtales-1881-1941.html

and the website of the Foundation Guy Pourtalès:

https://guydepourtales.ch/

226 'Definitely unhealthy' written in English.

227 Nico short for Nicodème, which is how Madeleine refers to her menstrual cycle. 
that. Like a little girl!!! I'll reach puberty after I'm married. How lovely! But back to the diary. Was leaving for the docs and the lift comes back up with Ruth. "You're off somewhere?", "Aha" "Where?" "Doctor's" "Let me stay in your room this afternoon" (and what a look!!) "No you can't" "Why not?" "It is in a mess" "Oh I don't mind" "No, I don't want you to. It's an unimaginable mess" "Ah, I see" (another look!! She sees what exactly?). She tags along with me to Denfert-Rochereau, telling me about her knickers which are slipping down and then, because I am monosyllabic, wants to know why I am going to the doctor. "Women's problems" "But what? Don't you want to talk to me about them?". "Sweetheart" (shades of Quin who would call us sweetheart when she was furious with us) "Why? You can't cure me" "Oh, but ... describe your symptoms to me" (that look is back). "I don't have any - that's the problem" (the look is well and truly back) "I see." And then she's off talking about her own experiences etc. Why have I just written all that which reads like a page of Colette minus the style? I don't normally note down anything in this diary now because of nosy parkers. (Phew!!228 the thought of Ruth in my bedroom and this book hanging around!! Argh! 7.45. I need to get myself up. Need to finish quickly. Went to Ivry. The countryside is like Yorkshire near Wakefield with the road sloping down etc and stone walls and the rain coming down. Was on the ticket desk for "les Mystères de Paris" (by Eugène Sue) by Renaud. ${ }^{229}$ Helped by a nice chap. Dropped by Dilys's. Late evening she came by here, drank tea and chatted. She is sweet. ${ }^{230}$ Goodnight.

\section{Sunday 17 May}

Woke up at 6 am. Superb weather. Did Latin translation and wrote diary, did everything in bed which explains the writing. Mass. Missed the train for Villeparisis but met Aunt in tears in the station because Mme Scarpazza is dead. She is really upset about that. Now, she is really worried about Yolande's health. I talked about myself and shouldn't have done. I needed some reassurance and some kindness but AV told me that the doctors didn't know what they were talking about and whilst she didn't say that I was an idiot in so many words, it was clear by her tone. Oh, she was too upset about Mme Scarpazza and was worried about Yolande. No one else is allowed to be ill. Yolande and Roger arrived on Saturday evening at Villeparisis. Yo looked awful, ashen with circles round her eyes. Godfather was very, very thin. In a fortnight he has just wasted away. He hasn't enough to eat. He's used to having lots. Pataud has been put down. I don't know when. It's probably best. He was starving to death. Studied (well, I made out that I was reading). Yo was having hot flushes etc. It's not

228 'Phew!!' written in English in the manuscript.

${ }^{229}$ Possibly a theatre adaptation of Eugène Sue's 1842 novel.

230 'nice' and 'sweet' written in English in this entry. 
nice, obviously and obviously when she's with the family she can behave how she likes but I really felt like slapping her. I said my piece - she wasn't unpleasant but she thinks that I am stupid. Only Granny could relate to me properly. The atmosphere over there is depressing. Perhaps I am hyper-sensitive but I didn't feel good. It's daft. I really should know that I am not allowed to be ill nor to come over more than twice without bringing anything. When I bring something they are nice. They make me take something away - eggs, a skirt etc. If I come empty-handed - Good God, I'm in the way like a piece of furniture. Anyway, I can't complain. I left Aunt (what would my life had been like if I had stayed with her). But when I think that the girls on my landing are kinder to me than they are there (with the exception of Godfather and Godmother), well!! It's funny. Lots of whispering going on between them all about next weekend with Yo and it's "Shush, here's Madeleine" when I come in from the garden. I've got good hearing. Yolande is off to the Opéra-Comique on Saturday and then probably on to Orgeval afterwards. So what? I can go out without asking their permission. But what a load of creeping about and when I think that for 3 months they've been coming out with the same old "No one is hiding anything. Everyone knows everything". I could see it then and I see it now!! The Sunday before, Aunt had been so nice. I had thought that it would last - but moods don't last. I'm a slow learner. What other grievances do I have while I'm moaning on and lancing the boil? Well, it does help saying it and writing it down. I must be twice as careful to make sure that this book doesn't fall into the wrong hands. What a waste of effort it is not saying anything for months on end just so that if there is an accident nothing comes out. Oh well. Never mind!!

Usually, I find it funny when I hear "Life is so hard, coming back after work, having to get food in, housework too. And Yo hasn't enough to eat. She's only got her rations you know!!! No meat. We save it up for Sunday" (not quite true). They are forgetting to mention the monthly parcel and the Black Market. They are forgetting ... but it doesn't matter to them that I am on my own too in respect of finding food and that I too have only got my card. Oh well anyway. Yo pulled out of her exam. Too tired (I've got nothing to do though of course).

\section{Monday 18 May}

Had a big revelation!!! Of course, why didn't I think of it before!! Last Sunday Yolande asked me how much I was earning. I told her the truth (I didn't say anything about my pay rise). Crikey me, from $460 \mathrm{fr}$ to $1,273 \mathrm{fr}$ is a big leap!! Yo told me that she was getting 1,600 frs which is probably around 1,450 frs. She must have said all this to Aunt which explains absolutely everything. Ah Nanère, you reckon you're a psychologist and that's the one thing you forget!! There'll also be a question mark over inheritance if I don't have kids. But, steady on. I'm not yet infertile and I will do my best not to be. But if I am, I will adopt kids.

I love this apartment - the same me who couldn't stand it before. When I came home wounded and depressed yesterday evening it was like bathing in 
joy and optimism as soon as soon as I opened the door. It is time to get up. It is 9 o'clock. Beautiful sunshine (and rotten writing - yes, indeed. I'm lying on my back and this book is heavy to hold). They treat Godfather and Roger in the same off-hand way they treat me. I wonder if that hurts them at times. Granny started a lace crochet for a blanket for me. It is very pretty and she is kind.

PS: What a misery guts I am! Everyone has problems. Granny with Riri who is now just a labourer and who can't wear the uniform after having been kicked out of the fire service. There's Aunt with Yo who she can't marry off etc. Hey get up!!231 Mlle Rouquette. Went to Hôtel de Ville to take the ticket receipts. What a beautiful day. Ruth - what a letter she's sent me!! Is she mad? Female homosexual? Or does she just want to make herself appear interesting? Bought flowers for Mme Scarpazza and took them to Aimée who is not at all devastated, horrified nor helpless as Aunt had led me to believe. Pauphilet. I am avoiding Ruth. Went to the Société des gens de Lettres to get paid. Went to Dilys to get her advice about Ruth's letter. She thinks it's funny - luckily!! I fear I lack a sense of humour. Appel (1 $1 \frac{1 / 2}{2}$ hours) Kamska. Bought a pound of cherries. What an oppressive heat! Going to write to Ruth and send her back her letter.

\section{Tuesday 19 May}

Dilys came early. Office. Wrote to Ruth and posted letter at $9 \mathrm{am}$. Noticed that although $\mathrm{R}$ had put Friday evening as the date, posted it after having seen me on the Saturday which proves that she hasn't an ounce of spontaneity about her. There a new "collaborator" in the office. Cleaned from top to bottom. Monique. Injections still not arrived. 57 (fifty seven) francs for rubber soles for wooden shoes. Christ almighty. Bought another pound of cherries - and I realise that I have not enough money to last me until the end of the month. I bought a heavenly rose - the red is so dark that it looks black in certain lights. I really must get myself a crystal vase for the roses. Went to Dilys's to babysit her kid from $7.30-10.15 \mathrm{pm}$. Found out that Rudi and Sonia have been arrested. I have no energy for working. Got a message from mummy via the Red Cross: "In excellent health. Nils, family his five colleagues send best wishes, received news from Hélène, Madeleine. Daddy is still collecting stamps. Try to send more news. More news!! Ye Gods. ${ }^{232}$ How? I can see myself writing: "Pretty poorly because Nicodème doesn't come" or "Very tired but I am looking after myself". God, mummy would imagine me dead or at best on my death bed surrounded by a bunch of doctors. Or else I could write: "I bought a new pair of glasses" - then they would think it was some sort of new code at the German Red Cross. I'll

231 'Hey get up' written in English in the manuscript.

232 'Ye Gods' written in English in the manuscript. 
sleep on it. I'll wake up with fresh ideas. Ruth came over when I was out and put a message under the door: "Came over to catch up" I have been avoiding her for two days and I have been expecting her to turn up. Did she get the letter? Tomorrow I will not be able to avoid her I fear. I am hungry. Shall I go to bed or shall I eat something? I daren't touch my 100 grams of bread for tomorrow, nor the rice. I've got nothing. I think I'll nibble a carrot.

\section{Wednesday 20 May}

Office. Welsh with Bachellery. Mme Desportes brought me a little bit of full cream milk. Ruth. Gale and violent rainstorm. My cacti are going to flower!! Can't get over it. Got news from Mummy sent in March. "The lack of news doesn't mean that there is anything to worry about. We are all fine and everything is good generally. Well done on the exam. When will you finish? Much love from us and the gang." 233

\section{Thursday 21 May}

Cleaned from top to bottom. Mlle Koch. Wrote to Godfather, Granny. Showers.

\section{Friday 22 May}

Welsh. Office. Appel (1 hour)

\section{Saturday 23 May}

Office. Ticket desk at 10 Rue de Lancry for 14.30 (because Soulier told me so) but the performance was on at $17 \mathrm{~h}$. Note from Cyla saying that she had gone camping. Ruth came. Made a bit of a scene but I didn't play along.

\section{Sunday 24 May}

Pentecost. Mass. Villeparisis. Saw “Gueule d'Amour” with Jean Gabin. Rubbish.

\section{Monday 25 May}

Went to Kamska's. Not there. Studied

${ }^{233}$ Written in the margin opposite the entry of 20th May: 'No, the cactus isn't flowering. It's just new branches. 4-6-42.' 


\section{Tuesday 26 May}

Did some mending. Dylis ${ }^{234}$ came to get me up. Françoise Boësse brought 3 eggs and stayed 3 hours. Cyla came to do the injection. Went to Dilys who made strawberry tarts. Got a pneu from Auclair. Letter from Mme Fauchier-Delavigne.

\section{Wednesday 27 May}

Office. Saw Cyla in the street. Went to rue R but not there. Period. Completely infertile. All I want to do is sleep. Feel sick. ${ }^{235}$ My head is swimming. I can't work. I can't study.

\section{Thursday 28 May}

Koch. Cold. Office. 6-7 pm went with George Auclair to "La Source". He wants to know what I am made of. Much good may it do him!! Got tomatoes. Went to Cyla's for injection.

\section{Friday 29 May}

Welsh. Ill. Office. "La Mort" by Maeterlinck. Appel (1 hour) Went to the jardin des Gobelins . Pretty. Full of trees.

\section{Saturday 30 May}

1.15-3.45 am. Alert (but sounded at $2.30 \mathrm{am}$ ). Thought that it was a storm. Office. Telephoned rue Las Cases - not there. Tifferneau took me for lunch and tried to get me drunk. Very sleepy. Went to do the tickets at Trocadéro but didn't stay long. No vegetables or fruit anywhere. Saw Cyla in the evening. Did my own injection. Cyla, Zeila, Sonia sang in Russian. Lovely.

\section{Sunday 31 May}

Mother's Day. Bought flowers and cake. Villeparisis. Rain. Ill. Went to "Marie Stuart". Yo gives me the impression that she's taking stimulants the way she laughs, shouts and races round. She has a nice "swing" figure. She needs a husband I think. Aunt was nice.

\footnotetext{
234 'Dylis' is a misspelling of Dilys.
}

235 'Feel sick' written in English. 


\section{Monday 1 June}

Start of month abundance - butter, bread, cheese. Fine and warm. Ill. ${ }^{236}$ Can't study. KO. Appel ( 1 h 30). Out of the blue at $19 \mathrm{~h}$ felt a sense of well-being, felt joyful. Went to Cyla's. Did my own injection. Cyla was revolted but calmed down soon after. Ruth called me to unburden her heart etc. Since Cyla rejected her she needs a pole to wrap herself around. I call her the 'creeper' but it's not wrong. I picture her as a green snake with loads of red mottling (her tail is attached somewhere but I can't see it) and the head lifts and falls and tries to come after me (tree trunk lathered in oil). What a strange recurring vision to have when I think of her. It's like thinking of Ravel's 'Bolero' every time I think of Simone Noëlle - when I used to see her way back when or even when she was there and I didn't know she was. The exams are the 17 th or the 18 th. I feel happy. I think that Ruth wanted caresses but I laughed it off and was whizzing around like a Catherine wheel and so it was impossible to create a romantic atmosphere. She hates that she can't just shack up with someone - what's her problem if that's what she wants?

\section{Tuesday 2 June}

Office. Monique (who brought me 4 eggs, some potatoes and onions) Studied Balzac (Ernst-Robert Curtius). ${ }^{237} \mathrm{Had}$ an uneasy feeling that Ruth was going to come. I am determined not to let her intrude upon me here at home. Hot.

\section{Wednesday 3 June}

Hot. Office. Met Ruth who wants me to ask Cyla if Cyla will invite her to go on holiday with her. I said that I would ask her to avoid a scene in the street but it is up to Cyla what she does. My thoughts are blooming furiously [. . .]. I'll have a pretty bouquet by this evening to put in front of Mummy's photo. Hot. Met Dilys. Welsh. All the cats are on their backs in the sun, striking adorable poses. Graceful and sweet, their arms in the air like children sleeping soundly in the heat. Went to Cyla's for the last injection of this course. I'll go back next Wednesday. Zeila and Cyla very depressed at first but later perked up. There was a row between Zeila, Cyla and Ruth about margarine. Ruth got me to go to her place afterwards. Me, me, me!!! She tried the big seduction scene and had washed in scented soap, put on a very low cut dress, the reading lamp was very low, I was in bright light and she was a blurry silhouette in the shadows. After a few whimpers, she came to kneel down in front of me and played around

\footnotetext{
236 'Ill' written in English in the manuscript.

${ }^{237}$ Ernst-Robert Curtius (1886-1956) was a German literary critic and philologist.
} 
with her dress, letting it slip over her shoulders as low as she decently could, watching me intently like a cat. I found all this carry-on hilarious. It was like being in the presence of a fat squashy maggot. Certainly as repulsive. She got going with her carry-on and trembling with desire squeezed my feet between her hands and then quickly adopted a praying pose - and then we got the prayer. I laughed in her face. Even she could see that I didn't like it: "Your face is so tight. What are you thinking of?"238 She went on about wanting to know what I was thinking. All my "love interests" have done the same when things are going off the boil. They are insistent that I tell them what I am thinking just like her or rather she does like them. She behaves like a man in love. She's a funny girl. She is as materialist as it is possible to be and then makes out that she is an idealist. What she needs is a man. I left in the end. "Ah, kiss me, kiss me" I pecked her on both cheeks. 239 "No, no more than that". Annoyed, wanting to see how far she would push me to tell her some home-truths "You want me to do the great rough lover?" ${ }^{40}$ I caught hold of her roughly and planted a kiss near her ear and then I set her straight again. She put her hands on my shoulders and kissed my cheek with a drowning cat expression on her face. Should I have gathered my skirts and fled saying "Fine, if you want to be a homosexual but count me out". Don't know. I make as if I don't notice. She'll never get anything from me. I won't be able to show this book to anyone else I don't think. But things fade so quickly. What about all those quirky personalities at the Pension. ${ }^{241}$ I didn't set them down and they become indistinct so quickly. Ruth wants to leave for Zone libre $e^{242}$ and to her great disappointment I am encouraging her. Studied until 1.30 am but didn't get to sleep until around $3.45 \mathrm{am}$. There was a quarter moon, orange and not bright. Got up at $3 \mathrm{am}$ and put on the radio but could only find Russian (or Polish or Slav). Took off a blanket. Slept well. Rue R.

\section{Thursday 4 June}

It is going to be really, really, really warm. Bunches of ideas for my "garden". Mlle Koch brought brooch and biscuits. Office.

238 'Your face is so tight. What are you thinking of?' written in English in the manuscript.

239 'kiss me, kiss me' and 'pecked' written in English in the manuscript.

240 'home-truths' and 'You want me to do the great rough lover?' written in English in the manuscript.

241 This is a reference to Madeleine's co-lodgers at Les Marronniers boarding house, where she lived during the Phoney War, November 1939 to June 1940.

${ }^{242}$ The Free 'unoccupied' zone in southern France governed - ostensibly - by the French Vichy authorities. 


\section{Friday 5 June}

Welsh. Office. Appel (1 1/2 hours). Hot.

\section{Saturday 6 June}

Office. Kamska. Did the tickets Bd. Barbès. Went to Hélène Koch's to meet her brother. Ruth came but I wasn't here. Hooray. Hot.

\section{Sunday 7 June}

Went to Aunt's. She lent me photos. Took a walk with Yo in the new park and at the Buttes Chaumont. Ruth came but I wasn't here. The Jews have got to wear a yellow star. ${ }^{243}$ Jacques had a little boy a few days ago.

\section{Monday 8 June}

Studied. Washed hair. Appel (11/2 hours)

\section{Tuesday 9 June}

+ Office. The weather is fresher. Monique.

\section{Wednesday 10 June}

Cold. Insides all mashed up; hacking cough. Not an unpleasant feeling!!! Welsh. Rue R. Cyla. Injection. Office.

\section{Thursday 11 June}

In the bread that we get at the hostel there is everything one might wish for bran, straw, sawdust, worms. The bread at my bakers is just about edible. Kamska. Office.

\section{Friday 12 June}

Office. Appel (1 $1 \frac{1}{2}$ hours). Last lesson.

\section{Saturday 13 June}

Office. Pneu from Mme Faure. Talk at avenue Ed. Vaillant, Pantin. Storm. Went to Mme Faure's. News from Mummy. "Darling, don't worry yourself. Everything

${ }^{243}$ From Sunday 7th June 1942 the German authorities decreed that Jews had to wear the Yellow Star in France. 
is fine. Everyone is in good health. Dad is doing his gardening as usual and he sorts out his stamps for relaxation. There are two apple trees behind the house. The little courtyard is just the same. Topsy has a three day old son. I had my teeth seen to. I'll be having to have false teeth one of these days. Aunt Germaine, Gilberte and everyone are in good health. All of us send you all our love. Mummy." Went to Dilys's place. Mrs Evans's birthday.

\section{Sunday 14 June}

Went to Villeparisis. Ate strawberries and raspberries until I could eat no more. Every time I go there I swear that I will never go back but I do. Everything Aunt says is designed to hurt but deep down and despite everything I do love her. In the end, though, I have decided to go "live my life" - family or no family. Brought back beautiful roses. Ruth came over but I was not in.

\section{Monday 15 June}

Library was not open. Pity. Swotted here.

\section{Tuesday 16 June}

Swotted. Talk ${ }^{244}$ with Adrienne Monnier ${ }^{245}$ about modern poetry. Not much said but as I left I felt that I could rule the world.

\section{Wednesday 17 June}

Swotted. ${ }^{246}$ Knitted. 1.30-6 pm. Classical literature, French composition. "To what extent is it true to say that the doctrine 'art for art's sake' is already discernible in the 'Bucoliques" by Chénier?” I think that I did alright but the plan was "wonkey" 247 and repetitive. Writing awful. It was funny but I had a feeling that the subject would come up and so went in with a few ideas. Hope I don't fail it. Hélène Berr got a commendation for her diploma. She is the most intelligent girl I know. For the Latin unseen translation they were allowed dictionaries! And what next?? A fair copy?? I can't get over it! I'll set off tomorrow with

\footnotetext{
244 'Talk' written in English in the manuscript.

245 Adrienne Monnier was a bookseller and publisher and proprietor of the bookshop and lending library La Maison des amis des livres. She was also Sylvia Beach's life partner, which may have been how Madeleine made her acquaintance.

246 'Swot' written in Engish.

247 'Wonkey' (sic) written in English.
} 
my big fat Gaffiot ${ }^{248}$ under my arm. Why is it that the only good souls around me are Quakers or Jews? Tired out after the exam. 9-11. Went for a walk. Ruth came but I was out.

\section{Thursday 18 June}

8-12 am. Did Latin translation. A real Chinese puzzle. I think that it went $\mathrm{OK}$ in the end. Saw Madeleine Lavelle. Tired out. Bought "Cent phrases pour éventails" (Claudel) 249 "Enfantines (Valery Larbaud) ${ }^{250}$, "Le Piéton de Paris" (Léon-Paul Fargue). ${ }^{251}$ Read "Les Haïkaï de Kikakou!” All delightful. Flappie. Went to Dil's. She has a new maid, Françoise. Went to Elizabeth's. Superb studio flat. She is a designer. Had dinner with Dilys. Dilys came over to mine.

\section{Friday 19 June}

Mlle Koch. Brought me some flowers. Did the housework. Aching all over and KO. Office. Went to Cyla's. Read "La Fille du Capitaine Pipe"252 and "Les Chakras".

\section{Saturday 20 June}

Office. Weather was fine. Tired out. Ruth came over. Danced between 9-11 pm. She wanted to be the weeping willow again but I didn't encourage it. She is after me.

\section{Sunday 21 June}

Tired out. Went to the market and got two artichokes. Money just goes like its nothing. I should spend $200 \mathrm{fr}$ a week. I've spent 400. Expenditure I haven't bargained for is fatal for the budget. What am I going to do this summer? Did some embroidery. Finished the handkerchief. Deep depression. ${ }^{253}$ Cried and then felt happy. Started the ankle socks again.

\footnotetext{
${ }^{248}$ Gaffiot is a Latin-French dictionary first published in 1934.

249 Poetry collection by Paul Claudel (1868-1955) published in 1942.

250 Valery Larbaud (1881-1957). Enfantines Published in 1918.

${ }^{251}$ Léon-Paul Fargue (1876-1947). For more on Fargue and Le Piéton de Paris see:

http://republique-des-lettres.com/fargue-pieton-9782824903057.php

${ }^{252}$ Written by Simone Saint-Clair and Juliette Lermina-Flandre La Fille $d u$ capitaine Pipe was published in 1941.

253 'Deep depression' written in English.
} 


\section{Monday 22 June}

Office. The blue [...] dress went down a storm. Why? Didn't get any cigarettes. Wrote off for extract from birth certificate. Mme Faure. H. Berr. Dropped a note to Cyla. Got up. Ironed. Did the washing at $3 \mathrm{pm}$ and by $7.30 \mathrm{pm}$ everything had been ironed. Bought some stamps for Dad - got some for 140 frs!! (and I ask myself where the money goes?). Typed [...]. Welsh. Wept. ${ }^{254}$ But then was happy afterwards and for the rest of the day. Is it a sign of getting right? Of the nerves getting back to normal? Or is it a bad sign? I think that it's no more than a sign of extreme fatigue. Fine and warm since yesterday. There is no food to be had. Potatoes with tickets only. That is all I am living on. Got some milky substance and some cheese without tickets last weekend thankfully!!

\section{Tuesday 23 June}

Office. Last lesson with Monique. Took cigarettes over to Cyla's Wrote to Aunt.

\section{Wednesday 24 June}

Office. Welsh. Last lesson at Rue R. Letter from Mme Faure, Hélène B.

\section{Thursday 25 June}

Mlle Koch. Cyla came. Went to Boissin-Legros' place. Chic! I feel better. Got some medicine. Went to Mme Faure's. Wrote to Hélène B.

\section{Friday 26 June}

Went to the Welfare Bureau. Office. Went to Cyla's for an injection. Read "Crime en Australie". Ruth tried to bewitch me again and wanted me to stay the night. Christ almighty! How awful!! Refused point blank. Went to Dilys's but only her mother was there.

\section{Saturday 27 June}

Office. Letter from Aunt telling me that Granny had an operation for a strangulated hernia on Tuesday. Poor woman. She has been through such a lot in life! Confession. Slept most of the afternoon. Hope that the storm gets on and happens. I've felt on edge all day. The nap calmed me down a bit. Had to queue for an hour to get some peaches. Horribly tense. Ate at least a pound of peaches on the way back. I feel agitated, angry. I don't want to work. I don't want to do anything. What is in the air?

254 'Wept' written in English. 


\section{Sunday 28 June}

Mass. Sick as a dog. Stomach ache. Thumping migraine. And I am as anxious as all Hell. Read "L'Eternel mari" by Dostoïevski. Was on the ticket kiosk at Boul. Barbès and went to the talk on "Folk-lore de L'T̂le de France" Nice. Wrote Aunt Violette and went to Cyla's. Wanted to get back quickly because was feeling ill and weary but Cyla made me stay, made me sing, brightened me up. She sang.

\section{Monday 29 June}

Office. Ill. Waves of pain coming from the stomach. Telephoned Aunt. Granny has got over the operation well. Finished the washing. Cyla gave me an injection. Went to the Atelier to see "Sylvie et le Fantôme"255 with Mad. Fortan. I've not laughed as much since "Pygmalion". Didn't have dinner. Mass. St Pierre and St Paul.

\section{Tuesday 30 June}

Fine. Ill. Argued with Stella Tifferneau. Have got to go back in to get pay. Read "Fin de Chérie" (Colette). Had an ice cream with Stella T at Weber's. So expensive!! Both tiny. Too dear. Won't be doing that again. Went to Cyla's for injection. Very offended that I couldn't stay to have dinner because I had a lesson with M. Koch. She didn't believe me. Didn't have dinner. Lesson with Mme Koch. Had a fruit juice with her at "La Source". Sick as a dog. Mme Desportes came but I didn't open the door to her.

\section{Wednesday 1 July}

Office. Ill. Hot. Went to Cyla's and she said that it is my appendix and that I shouldn't wait until I have a third attack of appendicitis. Went to Mme Desportes. She was very nice. Went to Dilys's who sorted me an appointment with her doctor - woe! Big storm. 1 yoghurt and 1 cracker for dinner. Tasted like ash. Went to bed early. Took an aspirin.

\section{Thursday 2 July}

Mme Koch. It's warm and close. I feel slightly better but weak and heavy; feel like I've been at death's door. Slept. Went to Hélène Berr's. Huge storm. Read "Nez de Cuir"256 (? ). ${ }^{257}$

${ }^{255}$ Play produced by André Barsacq at his theatre l' Atelier in Paris.

${ }^{256}$ By Jean de la Varende. Published in 1936.

${ }^{257}$ Gap and question mark in the manuscript. 


\section{Friday 3 July}

Office. Ruth got her exam. The results were not up. Slept until midday and feel better, Dilys came read "La Vagabonde" (Colette) ${ }^{258}$ and "Le Noeud de Vipères"259 (Mauriac).

\section{Saturday 4 July}

Office but left early. Telephoned Aunt. Letter from Aunt. A Mlle Blaise passed. Me? Not me? Not me. I've failed. Strange but I am fine about it. Very relaxed and cheerful. I should be unhappy but I am not. Am happy. Why? Saw Ruth who is all confident about her oral exam. She gave me some little cakes and then said, rather condescendingly, that she would come to see me when I am at Cyla's. But got to Cyla's and Cyla was irritated and Ruth didn't come. Brilliant. Cyla is fed up - her bike was stolen last Wednesday, etc. Went to Dr Cusin's with Dilys. He diagnosed appendicitis too. I'll have to have an operation. Wants me to go to the clinic. Read "Nous avons fait un beau voyage" (Francis de Croisset). ${ }^{260}$

\section{Sunday 5 July}

Got up at $5.30 \mathrm{am}$. Waited for Françoise who didn't show. Went to Denfert and found her there. Couldn't go by bus. Had to take métro and bus. What joy to see the countryside again. Great big fields of corn, green flecked with gold and solitary trees, dark green and standing deep in the corn. ${ }^{261}$ Roses and clematis everywhere. It's such a delight to see cows again - I nearly jumped up onto my seat in the bus, pointing at them with my finger, yelling "Look, cows". Baby. Villages, big farms like towns in MA surrounded by high walls. At Bligny I saw Georges. So much for my plans to go walking in the countryside!! Georges latched on to me and wouldn't let go. It is the first visit he has had for a year. Dilys doesn't go any more. Death stalks this Sanatorium. It is horrible. It is pretty though. There are the woods, the coastal pines with their red trunks against dark green, there's the pond. It's even worse as far as the women go; these young misses with their parasols and their fixed smiles like in adverts! Terrible!! Had lunch at Brice [Brüsse? (Brüce)] Came back from the Bligny sanatorium. Dying in the heat. Went to Dilys to take her a letter, $\mathrm{M}$ and Mme Bachellery were there and they couldn't believe that I hadn't passed my exam. Georges wrote complimentary things about me; Dilys visibly narked. Stayed to dinner. The wounded

\footnotetext{
258 Sidonie-Gabrielle Colette (1873-1954). Published in 1910.

259 François Mauriac (1885-1970). Published in 1932.

${ }^{260}$ Francis de Croisset (1937-1937). French-born playwright. For a digital copy, see: http://gallica.bnf.fr/ark:/12148/bpt6k5452390d.r=.langFR

261 'in the corn' written in English.
} 
returned having waved the white flag. Ruth didn't pass her exam. Read "Féerie Cinghalaise" (Francis de Croisset). ${ }^{262}$

\section{Monday 6 July}

Office. Failed Latin with a 6, French with a 7. Declared my identity card lost. Telephoned Aunt - who spoke to me like I was an idiot because of appendicitis.

\section{Tuesday 7 July}

Office. Slept. Mlle Koch. Went to "La Source". Read "Le Film de ma Vie"263 (Lefèbvre).

\section{Wednesday 8 July}

Office. Read "Un Rude Hiver"264 (Raymond Queneau). Made myself something to eat. Welsh. Knitted. Dil called over for me to go out with her. Went to Sylvia's and then to Dr Duheim's to get some glasses. He has a beautiful black spaniel, Mayou, "Prince of Darkness". ${ }^{265}$ Dr D is a radiographer and yachtman. ${ }^{266}$ Handsome old man. Beautiful apartment. Had Kirsch and petits fours. Mrs Evans ill. Dilys is so eminently selfish. She knew that I hadn't had dinner - oh you poor darling, oh you poor dear $-{ }^{267}$ but she didn't invite me back for dinner or shorten her walk, Her mother is very ill. Oh, you poor dear, but she goes on about her [.. . $]^{268}$ without a second thought. And what about Georges? He hasn't had a visit now for a year is it? She also boot licks the rich and steps over the poor. Knows that I haven't got any money at the moment but is being very sweet because she wants something no doubt. But what friend, what human being is perfect? She's my friend, even with all these faults.

\section{Thursday 9 July}

Mlle Koch. Did my washing watched by a soldier at the Val-de-Grâce opposite. They must find it tedious watching what their neighbours are doing opposite.

${ }^{262}$ Published by Hachette in 1935. See full scan of the work in French national library digital collections: http://gallica.bnf.fr/ark:/12148/bpt6k58126108

${ }^{263}$ Written by René Lefèvre. Published in 1940.

264 Novel published in 1939.

265 'Prince of Darkness' written in English.

266 'yachtman' written in English.

267 'ill', 'selfish', 'oh you poor darling, oh you poor dear' written in English.

${ }^{268}$ Looks like 'verres' (glasses) in manuscript but that would seem incongruous. 
Write to Aunt and to the Tax Office. I am trying my very best to make sure that I don't spend more than I have in the bank. Went to the Red Cross and sent: "Got the message from Paul. Congratulations to Topsy. Granny had a successful operation for a hernia. Everyone here is well. Look after yourselves. Kisses! Went to see Vendryès about the meal. Read "Le Mystère de la Charité de Jeanne d'Arc" (Péguy) Welsh. Went to Cyla's. Ruth was annoying me and to get rid of her I said "Oh, everyone knows that you love Cyla" - ! A huge storm is brewing.

\section{Friday 10 July}

Washed. Ironed. Office. Dilys cancelled going to the Bachellerys. Went to the Police about the identity card. Saw Michael who said to me "So you see, I'm doing what you wanted and not seeing you". I said "That's just fine. Carry on like that and it'll be perfect”. Letter from Hélène. Letter Mme Faure.

\section{Saturday 11 July}

Office. Knitted. Welsh. Read "Chéri"269(Colette) and "The Man who had Everything” (Louis Bromfield). ${ }^{270}$

\section{Sunday 12 July}

Mass. Welsh. Knitted. Wrote half a story. News from Mummy written 1/6/42: "We are all fine still. We had 8 days off and made the most of them. Uncle Tom did a few repairs at Aunt Marguerite's who has been a little poorly but don't worry. She is much better but like all of us isn't getting any younger. Francis is going to get married in a couple of months to a school friend from the same year group. Doggywoggy has a little playmate; a little black cat with a white patch called Niki. Jeanne is their nanny. Kisses to everyone."

\section{Monday 13 July}

Office. Physical exercise. "Goodness gracious" as Korbelecky would say. Sumptuous meal at mine - fish, peas and potatoes. Read "Houtekiet" (Gérard Walschap). ${ }^{271}$ Welsh.

${ }^{269}$ Published in 1920, a novel about a romantic relationship between an older woman and a younger man. Colette was one of Madeleine's favourite novelists.

270 The Man who Had Everything was published in 1935. Brief biographical details about Louis Bromfield (1896-1956) can be found at http://www.ohiohistorycentral.org/index.php?title=Louis_Bromfield\&rec $=52$

${ }^{271}$ Gerard Walschap (1898-1989) was a Belgian writer. Houtekiet was published in 1939. The most fulsome biographical information about him 


\section{Tuesday 14 July}

Pneu to Mme Koch. Did physical exercise. Went to Versailles to the Bachellerys with Dilys. Dilys and B did a lot of talking. Went to the Parc de Versailles. Saw and smelt the orange blossom for the first time ever. Came back. Had dinner at Dilys's. Got a note from Mlle Jorges.

\section{Wednesday 15 July}

Office. Telephoned Aunt. Typed story. Mlle Jorges came. Physical exercise.

\section{Thursday 16 July}

Wrote to Hélène Berr. Mlle Jorges and Mlle Koch. Went to the BN. Russian and Polish Jews 27,000-40,000 according to rumours. Where have they been taken? ${ }^{272}$ Went to Ruth's and to Dilys's. Wrote to Mme Faure and Mummy. "Katherine Mansfield and Me" (H. Middleton-Murray). ${ }^{273}$ Depressed. Physical exercise.

\section{Friday 17 July}

Physical exercise. Mme Jorges. BN. Office. Horribly depressed. Ill. Read "The Road" by Warwick Deeping ${ }^{274}$ and "J'ai tué un homme" (Maurice Rostand). ${ }^{275}$

appears to be contained within a Wikipedia entry at:

https://en.wikipedia.org/wiki/Gerard_Walschap

272 This is a reference to the infamous Vel d'Hiv round-up of Jews in Paris over the 16 th and 17th of July 1942. More about the Vel d'Hiv round-up can be found on the website of Yad Vashem, The World Holocaust Remembrance Center: http://www.yadvashem.org/yv/en/holocaust/france/vel_dhiv_roundup.asp

273 Either an edition of the letters exchanged between Katherine Mansfield (1888-1923) and lover John Middleton-Murray (1889-1957) or an edition of Mansfield's diary. For more on the life of Murray, see:

http://spartacus-educational.com/Jmurry.htm

${ }^{274}$ George Warwick Deeping (1877-1950) was an English writer. See Mary Grover's entry in The Literary Encyclopedia for more information on his life and career: Mary Grover 'Warwick Deeping. The Literary Encyclopedia. [https://www.litencyc.com/php/speople.php?rec=true\&UID=1199]

275 Maurice Rostand (1891-1968) was a French novelist and the son of poet and dramatist Edmond Rostand (1868-1918). The title of his novel appears to be incorrect in Madeleine's entry. Rather, it should be L'Homme que jai tué. The novel was published in 1921. 


\section{Saturday 18 July}

Office. BN. Went to confession. Nothing to say but just wanted to hear the sound of a human voice. Sick, ill tired, ${ }^{276}$ terribly depressed. "Roi des Montagnes" (About). ${ }^{277}$ Pneu from Aunt telling me not to come tomorrow.

\section{Sunday 19 July}

Mass. Sick and tired. Am no longer able to tell myself stories. The only story: getting home. Terribly lonesome. Worked on thesis all afternoon. Feel better, happier.

\section{Monday 20 July}

St Marguerite Wrote to Aunt, Granny. BN. Saw Ruth when I went to buy the meal tickets. She feels important and tries to hurt me. She is completely sadistic. With a gleeful, sadistic look she tries to discern evidence of pain. I hope that she is happy because I am not remotely suffering. Remark from Ruth: "The young girl who collects the tickets must have such sharp hearing to have discerned my English accent. So sharp". Good heavens!! You'd have to be deaf not to hear it!! No Mme Koch. "Fin de Chéri" (Colette).

\section{Tuesday 21 July}

Office. BN. Saw Ruth at St Louis. She is trying to hurt me. What on earth is the matter with her? I said that I would like to go to see Cyla before Saturday and she pulled a "gleeful sadist" face. Maybe she thinks that she has found the weakness in my armour. She hasn't yet. "Message actuel de l'Inde" (Les Cahiers du Sud). ${ }^{278}$ Wrote Dr Cuzin, Bachellery, Mlle Jorges.

\section{Wednesday 22 July}

St Madeleine. Gave Madeleine Fortan some roses. Office. BN.

\section{Thursday 23 July}

BN. Letter from Mlle Piatier. Saw Ruth. Went to the Grande Madeleine. Cyla. Cyla was difficult. She thinks I look ill. Mlle Koch. Then I went with her to "La

276 'Sick, ill tired' written in English.

277 Published 1897.

${ }^{278}$ Les Cahiers $d u$ Sud was a French literary journal founded in 1925 by Jean Ballard. For more on the history of the journal see Alain Paire's 2004 history of the journal, Chronique des Cahiers du sud, 1914-1966 (Paris: IMEC). 
Source" to meet her fiancé. He is ugly and speaks French very badly. Mlle Koch fell out with her mother a month ago now.

\section{Friday 24 July}

Mlle Jorges. Got a card from Aunt. Office. Tired out ${ }^{279}$ because I was up at 6.30 am because I couldn't sleep. Took back "Messages actuels de l'Inde" without getting past the Introduction because I was too tired to take anything in. "La Naissance du Jour" (Colette). ${ }^{280}$ Gosh. Like me, she needs to be suffering to write. I also understand why she writes about the things she does. It's to get them out of her system ${ }^{281}$ so that they don't haunt her - like with Ruth. Sido, Colette's mother says something very true. "We can only be happy by wanting and not by having".

This evening there was a gorgeous sky - turning from blue to a faded green silk with long plumes of liquid gold spreading out in a fan shape towards the West; "ruffled" plumes. ${ }^{282}$ The swallows chirping way up high. The church bells ringing out softly. The sun's red glow is reflected onto a single window in the Val-de Grâce. The moon, which is almost full, is high in the sky. Read by moonlight alone, leaning up against the window until $10.45 \mathrm{pm}$. Couldn't sleep.

\section{Saturday 25 July}

Woke up at $6 \mathrm{am}$. Went back to sleep. Was determined to. Too tired to get into this bad habit. Woke up at 7 am with a headache. Well done. Didn't do exercises. Too stiff. Office. Went to Dilys's. Bought sweets. Stepfather. Did the washing 3-8 pm. Cyla came. Knitted. The heat is heavy and overpowering.

\section{Sunday 26 July}

Mass. Went for a walk around Luxembourg. Villeparisis. Aunt very sweet. Brought back first apples of the season. Cherries. Beetroot, peaches, roses and daisies.

\section{Monday 27 July}

Got up at $6.30 \mathrm{am}$. Did the ironing. Physical exercise. Office. Ironed. Darned. Mlle Koch brought two beautiful roses, 1 red dahlia, some daisies. Wrote to Mlle Piatier. Very windy. "aventures quotidiennes" (Colette)

\footnotetext{
279 'Tired out' written in English.

${ }^{280}$ Published in 1928.

281 'It's to get them out of her system' written in English.

282 'ruffled' written in English.
} 


\section{Tuesday 28 July}

Office. "Mme Colette" (Gonzague Truc). ${ }^{283}$ Did washing. Slept.

\section{Wednesday 29 July}

Office. "Mes apprentissages" (Colette). I'm getting a real thing about Colette. She's really great this woman. What a lot she has been through. Cyla came over with Zeila. Went to Cyla's. Saw Sylvia. Brought back bottles, clothes hangers etc. I’ve only got 40 c left!! Saw SS again. Read "Mystérieux No1".

\section{Thursday 30 July}

Neither Mlle Koch nor Mlles Jorges came!! Office. Darned. Went to Dilys's. Gaël is lovely. [...]. And she really loves me. She gives me hugs. Did the washing. "Les Vrilles de la Vigne" - Colette.

\section{Friday 31 July}

Mlle Jorges came. Went to Dilys. Tided everything away. Put things in a suitcase. Saw Ruth - things are not going well between her and Cyla. Went with Cyla to the atelier. ${ }^{284}$ Goodbye meal with her and "Curlylocks". She kissed me before leaving. Oh! It hurts so much that she is leaving. Said goodbye to Mad. Fortan.

\section{Saturday 1 August}

Took the train from Luxembourg at $7.50 \mathrm{am}$. St Rémy at 8.40. Waited for the bus until 10.45!!! Brawl to get onto the bus for Fonteney-sous. Got off at Briis and went on foot to Mulleron. $2 \mathrm{~km}$ ? Pretty views. They were cutting the corn by hand. Only saw two women reapers. It's pretty hilly in patches. ${ }^{285}$ Wooded hills. Pretty butterflies, yellows, blues, reds. Emperor butterflies, those dark velvety ones with the black streaks? It is hot but not overly. Was not expected for lunch but had some. Black pudding, beef stew, jam, bread, wine, coffee, eau-de-vie. Rested in bedroom. Note to self: Remember to thank Ruth for the sweets. Went for a walk. Lay under the trees. Hot. Pretty view. Blackberries. Went to the woods. Two planes collided mid-air and fell out of the sky.

${ }^{283}$ Gonzague Truc (1877-1972) was a French literary critic.

284 Théâtre de l'atelier.

285 'patches' written in English. 


\section{Sunday 2 August}

Mass at Petit Fontainebleau. Saw Georges. Slept. [. . .]. Saw Georges. Ate blackberries in the valley.

\section{Monday 3 August}

Wrote to Aunt. Zinger. Stole plums.

\section{Tuesday 4 August}

Went for a walk. Saw Georges. Went down the valley.

\section{Wednesday 5 August}

Went to Janvry. Pouring down here. Then went to La Vallée picking up what I could on the way.

\section{Thursday 6 August}

Did some gleaning. ${ }^{286}$ Went to see Georges.

\section{Friday 7 August}

Did some gleaning. Knitted. Very tired. Wrote to Godfather and Granny. Mlle Péchegut

\section{Saturday 8 August}

Went to Fontenay-les. Briis. Saw a marriage. Went to Briis-sous-Forges. Bought a book from Evelyne.

\section{Sunday 9 August}

Switched rooms. Beautiful room over the hills. Mass at Fontenay. Went to see Georges. Read "la Fille du Puisatier" ( $)^{287}$ Jacqueline Haubre and her mother came.

286 This means picking over fields for any vegetables left behind after the crops have been harvested.

287 Brackets blank in manuscript. Written by Marcel Pagnol (1895-1974) and published in 1941. The film of the book, produced and directed by Pagnol, came out the year before in 1940 . 


\section{Monday 10 August}

Chantecoq. Went gleaning

\section{Tuesday 11 August}

Went fishing.

\section{Wednesday 12 August}

Chantecoq. Lost myself in the Charmeuse woods in the afternoon. Lovely butterflies!!

\section{Thursday 13 August}

The Guillemots have gone. Went to the Sanatorium to see Georges and Dilys and Gaël. Went to Janvry, Chantecoq, virtually as far as Gometz-la-Ville, La Brosse, Janvry. Saw a crashed plane. Tired out. $14 \mathrm{~km}$ in one afternoon.

\section{Friday 14 August}

Tired out. Knitted. Played 'Submarines'. Mother and Father nursemaids came. Ill all night. Madeleine Fortan’s birthday.

\section{Saturday 15 August}

Mass at Fontenay. Quite poorly. Knitted. Cloudy day.

\section{Sunday 16 August}

Mass at Janvry. Back to Paris. Very hot and close. Got the keys from Dilys and saw Sylvia. Letter from Mme Desportes - dated 29 July!! Gas leak. Didn't see Georges at the Sana. At Janvry the sky is "matonne" (moutonné), ${ }^{288}$ la chouette "gueule"289; one gets a "coquin"290 ( un amoureux); "je suis été"; 291 "On se "goberge"292

${ }^{288}$ Sky full of little white clouds like sheep. It is interpreted as a sign of rain to come.

289 Une chouette can mean a little owl. Here its seems to also be a variation on 'gueule' which can be a slang term for face used at Janvry.

${ }^{290}$ Could mean rascal or rogue here.

${ }^{291}$ Incorrect conjugation of être in perfect tense. Not clear what Madeleine is getting at here. Possibly she is mocking improper usage or alluding to language play engaged in with friends at Janvry.

292 Pamper oneself. 


\section{Monday 17 August}

Toilets are leaking. Flood! Got a valve for the gas. Did the housework. Went to the office to borrow 500 francs. Returned the money to Dilys who is being very cold with me. She is only nice to me when she needs me or sense that I have some money. Am going to gently drop her. Wrote to Mme Desportes. Paris is airless. Unpacked bags.

\section{Tuesday 18 August}

I am 24 years old. I feel younger now than I did a year ago - or even two years ago. Wrote to Gillemot, Viala, Godfather and Granny. Got lunch book. Bought flowers from the barrow. 8 frs wasted because they are withered. Washing. Darned. Very hot. A little canary came to see me - cheeky like a sparrow. He sings prettily.

\section{Wednesday 19 August}

Started exercising again. Tidied all the food together and put the box under the radio. I have a spare chair. Spent an hour at Mlle Péchegut's. When I got back I noticed that I didn't have my food card. Did I lose it or did Viala not give me it back? It really is worrying me more than I want to admit. Read "Jules de Corneillan" (Colette) whilst eating tomatoes, apples and sugar. Unhappy and bored to tears. Ironed. Heavy. There's probably going to be a storm. I can't find "La Terre qui meurt" by René Bazin anywhere. I am bored - bored, bored - and I am too hot. I sweat making the slightest movement. My toilet isn't repaired yet. I don't feel as if I can do any housework. Everything is such an effort. If only it would break with a storm. Dil came to hear the news. Raid - or landings? At Dieppe. Nine hours later, they left. Dilys came to talk to me about Georges. I acted not bothered and she felt reassured. She probably needs me at the moment because she's offering to do favours and paying me compliments about everything. Huge storm. Lots of sheet lightning. ${ }^{293}$ It looks strange - right in the middle of the storm, rain, flashes, thunder and the moon there shining away. Silvery reflections coming off the wet roofs and the bright fringes of clouds containing the storm itself. Feel in a better mood.

293 'sheet lightning' written in English in the manuscript. 


\section{Thursday 20 August}

Wrote to Aunt. Went to the market, Tomatoes Can't make pickles because I only have ground salt and I need powdered salt. Darned.

\section{Friday 21 August}

Tidied papers. Letter to Granny, Aunt. Got a young persons' work prospectus for Germany. There was a message from the Red Cross but it wasn't for me. Wrote to Mme Faure and Voirin "Duo" (Colette). Cleaned the toilet and the kitchen. Tired out. Looked for the food card at Dilys's. Knitted.

\section{Saturday 22 August}

Dad's birthday. Finished tidying the kitchen. Got a letter from Hélène Berr. Saw Ruth twice. Message from mummy "Darling. Everything is still fine here. Thoughts are with everyone and especially with you. Don't you worry about us. Everything is fine. Aunt Marguerite is ageing a bit; she acts old. Aunt Cardines's brother died. The rest of the family is well. I went to the school and they all want to be remembered fondly to you. Gérald and Agnès died following accidents. Loving thoughts and kisses to everyone. Cuddles from Toutou. I forgot to tell you that the lilac has flowered this year" 20/7/42. Pneu from Aunt telling me not to come tomorrow. Good. Confession and cross-examination from the priest. I didn't like it at all. Bought one cauliflower. Two tickets for green beans ( $1 \mathrm{~kg}$ in total), radishes. I've got tickets for $\underline{340}$ grams of meat. I have never seen as much. Misty and cold. "L'Envers du Music-Hall" (Colette).

\section{Sunday 23 August}

Mass. Communion. Knitted. Fine. "Le Toutonnier" (Colette)

\section{Monday 24 August}

Mass. Communion. Washing. Ruth came over. Went to the cemetery at St Denis. Had a shock when I saw the grave. It looks impoverished and poorly maintained. Decision made. I should come every month. That is more than I do. Resolved to come and maintain it. Mummy would like that. The return journey was never-ending. Y had put out some evil smelling gypsophila and dahlias. Went to the BN. Did the ironing.

\section{Tuesday 25 August}

Card from Cyla. Letter from Hélène Koch. Got food card. Helped Ruth send off the chests. BN. Ruth came and then got me to go to her place to get the table 
and then decided that no - she just wanted me to talk to her, etc. Resolved to see her as little as possible. St Louis. Mass. C. "Contes" by Maupassant. ${ }^{294}$ Duke of Kent killed in a plane crash. ${ }^{295}$

\section{Wednesday 26 August}

Mass. C. Washed hair. Beautiful hot day. Moved the table out with Ruth. BN. Got card from Mme Faure. Queue for tomatoes. "Salute to Adventurers" (J. Buchan). ${ }^{296}$

\section{Thursday 27 August}

Mass. C. Blessing. Miss Beach came while I was darning sheets. 9.10-10.30. She is sweet. Had lunch at 10.30 am but wasn't hungry!! Telephoned office. We won't be paid before Saturday, unfortunately! BN. Went on foot to Mme Faure's because am completely broke. Waited from 5.30 until 6.30 then left inviting them to call round on Saturday.

\section{Friday 28 August}

Mass. C. Did curtains. It takes ages. Madeleine Fortan came back Gave me 1 tomato, 2 carrots, 1 clove of garlic, parsley and tarragon. Talked until 3 am. Warm. Close. Chatted with Mlle Péchegut.

\section{Saturday 29 August}

Can't do my exercises. I feel too stiff. Went to the office. Made up all the time I owed. Got things ready for Mme Faure. Bought some honey. Put the curtains up in the bedroom. Didn't want them at first because I thought that black curtains would be more original. But once they were up was happy. They look pretty and cheerful. Bought pink and white coloured carnations. Nobody came. Something probably came up. Got some news from Mummy dated 27 July. "Darling. Thank you for your news of the 19th. We are fine and we are happy to

294 Short stories by Guy De Maupassant (1850-1893). It is unclear which collection Madeleine is reading.

295 Prince George, Duke of Kent (1902-1942) died in a plane crash in Scotland while on active military duty. Speculation and conspiracy theories continue to surround the cause of the crash.

${ }^{296}$ Published in 1915. See more on the novel and on John Buchan (1875-1940) at The John Buchan Society:

http://www.johnbuchansociety.co.uk/books/49.htm 
know that you are well. We've been on holiday and we spent a day amid white violets, Doggywoggy is here too. The weather was super. Condolences about M. Semaille and we are so sorry about Yolande. I expect that Violette is no longer as happy but what happened was not unexpected. Time will heal everything. I have a primula too. Mine is mauve. We are both in good health and I've got my rambling legs back. I am planning to go on some long walks. Did you pass your exam? And have you been able to find a little time to play the violin? Magui has had news from Aunt Cardénas. She's living out of town and is happy. The chicks are now hens and are starting to lay. I kept a little kitten. She's all black with a white patch on her front. We're calling her Niki. The other Niki is in a farm. He's doing all the work. Love to Granny. Very sorry about Joseph. Pass on my thanks to all our friends". I'm as pleased as punch to have had some news but I felt depressed by it too.

\section{Sunday 30 August}

Mass. C. Put curtains up in the toilet and in the kitchen. They look very sweet and especially so in the kitchen; a countryside or seaside feel to them. Went out at a quarter to midnight to inspect my black-out. Complete and perfect darkness for my bedroom. The same for the toilet. The kitchen is a little bright but it looks out onto a wall 1 metre away and so it doesn't matter. Very pleased with myself. Very windy.

\section{Monday 1 September}

Office. Talked for a while with Denise Pedon. Glimpsed Stella Tiffernan who has made good use of the holiday period to get in with Korbelecky and to oust me from favour. She's now in charge of the mail!! Denise and I have been demoted to the basement. I couldn't give a damn so long as I get paid. What about a pay rise? Rain. BN. Tired out. Saw Jacqueline-who-is-married-youknow. Went to Mme Faure's - lovely, just lovely. Found out that Aunt and I are finished. ([. . . ] am very happy but a little sad too. It's been something of a fixture). She looked as if she knew everything. Yo must have been telling her all sorts about me. Mme Faure as much as said it: “They don't know you at all, and especially not in that milieu”. I egged her on a bit by saying “They think I am feckless". She agrees, of course she does. I had always suspected it to be the case since Orgeval when they said I was too fat because I "stayed too long in bed and didn't do anything" (God knows. At that time I was hardly ever in bed) and they kept making barbed comments about my 'lover' - wherever he was! Yolande is very good at everything and I have always admired her for that. But, the poor thing. What a life she has there.

"Because the road of my life is a road paved with misery" - Ha and her joviality is false, nervous energy. I dropped into the conversation with Mme Faure "I think she might be on drugs when she's as jolly as that" and Mme Faure said: 
"Yes, her eyes are so shiny and so empty". Yolande is a proper little snake. She got me kicked out and I take off my hat to her. It is strange not to feel in the slightest bit saddened by it. Quite the opposite apart than the slight discomfort of breaking an old routine. I have to write to Stepfather and Granny but I am tired out and my eyes are closing. I'll write tomorrow. Granny is very like Yolande but she seems to love me. Is that the case or is it just scheming? Hush, infant, go to beddy-byes. ${ }^{297}$ Your feet are burning up, you can't keep your eyes open. Go wash and then sleepy-byes because tomorrow it's up at 7.15 for exercises. If you hurry along you'll just get to bed by quarter to midnight. So, hurry along. Letter from Jean Soulié about doing the ticket kiosk.

\section{Wednesday 2 Sept}

Whilst doing my exercises this morning I broke the jug in the shape of a Breton woman's head given to me by Yolande. Is it symbolic? I broke the other jug and the teapot - and look now? Especially with the row. Office. Stella Tifferneau was charming. Wrote to Soulié. ${ }^{298}$ Granny. Stepfather. Aunt. BN. Saw Jacqueline Viaux. Saw Mme Maréchal who has had diphtheria. Bought tomatoes, plums, grapes. Queued up with Gaël who was lovely but so utterly spoilt. Unravelled a bit of Mlle Péchegut's jersey. Tired out.

\section{Thursday 3 September}

Got up late. Wrote to Cyla. I won't go to the BN because I haven't the time if I go to the market to try to find some onions [...]. Went to market and bought a blue chrysanthemum which I have just planted. I can feel Autumn on the way. The nights are already that bit colder and the leaves are thinning out on the trees. The chestnut trees are turning rust brown. There are conkers on the ground. The plane trees take on the pale spring tints of trees which are green-gold or red in full leaf. There is a freshness to the air. Terribly hungry. Yesterday I ate half a cabbage, three tomatoes, lettuce, one pound of plums and nearly a kilo of grapes. This morning I finished off the grapes and had lunch $(100 \mathrm{~g}$ of bread and butter) and now, $10 \mathrm{am}$, I am dying of hunger. Ate three crackers and a sugar cube. Is that a good sign? The return of my periods? Office. Stella Tiffernan informed me that I would be put in a concentration camp because of my parents. What next? Saw the young waiter from Louis-Le-Grand. He's got a crush. He thought that Michael was my lover - I made sure he got his facts straight and left him in no doubt with some choice details. And this because we've had lunch together. And if I have dinner with Miss Péchegut I suppose that this

297 'Hush, infant, go to beddy-byes' written in English in the manuscript.

298 Jean Soulier is now spelt Jean Soulié. 
means that I am a lesbian? It seems as if one really has to be a lone wolf ${ }^{299}$ to avoid being said to be this or that. For dinner I had 3 tomatoes, bread, Cancoillotte, grapes, buttered crackers and sugar. Mlle Koch. Very hungry. Sleepy. Tired out. Hungry.

\section{Friday 4 September}

Darned. Had lunch at mine. Ruth came by. Went to the Red Cross. Went by Ruth's (who wasn't there) to pick up some shoes (1 pair) from Cyla.

\section{Saturday 5 September}

Office. Mlle Péchegut came over. Letter from Hélène. Aunt, Mme Desportes. Typed up notes.

\section{Sunday 6 September}

Mass. C. Tired. Migraine. Was on the ticket kiosk for the Festival Chabrier. Jean Soulié was there. Orchestra was a little uncoordinated at first but improved towards the end. Indisposed?

\section{Monday 7 September}

Indisposed. ${ }^{300}$ So happy but terrible pain. Office. Typed notes. Mlle Koch - went off with my shoes because her own are too painful to walk in. Police inspector came to the office about a stolen brass door knob (someone wanted a free litre of wine). Adrienne Monnier's is open again. "Les Plus belles histoires de la peur" ${ }^{301}$ So-So. Spent 50 frs today on nothing out of the ordinary - métro etc. I did spend 25 frs on fruit - but for Berthe who is ill again. The poor thing. Congestion of the lungs. I really must rein in my spending though. Aches and pains, legs feel heavy, appendicitis etc but above all hungry, hungry, HUNGRY. It's only $10.30 \mathrm{pm}$ but I am very tired. I'm off to bed. It's been a chilly day. Autumn is well on its way. Wrote to Aunt, Hélène.

\footnotetext{
299 'lone wolf' written in English in the manuscript.

300 'Indisposed' or just the letters 'I' or ' + I' mean menstruation. Madeleine suffered badly with period pain throughout the Occupation.

${ }^{301}$ Collection of short stories published in 1942 and edited by André Lorde. Contributors included Colette, Pierre Mac Orlan and Jean de la Hire. More on the collection can be read at:

https://www.babelio.com/livres/Andre-de-Lorde-Les-plus-belles-histoiresde-peur/514690
} 


\section{Tuesday 8 September}

+ I. Read "La terre qui Meurt" (René Bazin). ${ }^{302}$ I liked it. "Péguy présenté aux jeunes" (P. Péguy). ${ }^{303}$ Went to see Berthe. The poor love is very low. She has a number of tumours in the lung. She wants to die. She is suffering. She was ill on the 17 August. It seems to me that Aunt would have known when she wrote to me because she wrote to me on the 19th or later. Then I think well maybe she didn't know - oh well! BN. Lovely warm day. Was complimented three times on my looks and my youthfulness. 1: They were betting as to whether I was 19 or 20. 2: Godmother couldn't take her eyes off me finding me very "attractive". 3: Madeleine Fortan confirmed it, saying "You're becoming so beautiful. It's amazing". Also, all the German troops going by on patrol looked at me and I got the feeling that I was 'easy on the eye. ${ }^{304} \mathrm{I}$ inspected myself in the mirror and I don't think that I am beautiful. There are days when I look better. Am I becoming coquettish? Perhaps it's my age? Letter from Voirin. Severine has a little baby Colette two months ago. I didn't know that she was married but maybe she's done what her mother did. Her parents seem to be resigned to it; a beautiful baby can make everything alright - especially here. It wouldn't work back home. M. Duret is much more personable at the office.

\section{Wednesday 9 September}

+ I. Office. BN. Bought some sweetcorn. Went to Necker. Godmother is very poorly. She is delirious and she's in and out of consciousness. Poor love. And she really is suffering. Awful! It seems that I'll get the gold chain bracelet and a ring with a red stone. Mummy will get a silver goblet and a silver napkin ring and Aunt and Yo will get the rest of the jewellery. I will also be getting (apparently) some pans and some crockery. She's not yet dead and everything is being divided up. Poor love. She really makes me sad. Saw Aunt at the hospital. Things aren't good between Yo and Mme Fastier, as I expected. Marcellette's little maid has died. She was so cheerful, so lively! Everyone is dying around me. That's life! - or rather death. Bought some damsons. I'm going over my budget

302 Bazin's novel about peasant life in the Vendée at the turn of the century was published in 1898.

303 Péguy présenté aux jeunes was published in 1941. 'A clear and edifying little study of the evolution of P's religious and patriotic though by P's second son' Richard A. Brooks, Douglas W. Alden (1980) A Critical Bibliography of French Literature Vol 6 (3) (Syracuse: Syracuse University Press), p. 932. The entry is a transcript of a review which appeared in Cahiers de l'Amitié Charles Péguy 2:69, 1948.

304 'easy on the eye' written in English. 
because I am buying fruit but I might as well eat! (there's a philosophy). Had lunch (a good one) with Stella Tifferneau. Paid for it with two kisses.

\section{Thursday 10 Sept}

+. Office. Went to Necker. Godmother won't last the night. Her hands are ice cold. Her forehead is dripping sweat and her right hand and arm are very, very swollen, mottled. Her breathing is hoarse. Her eyes are either closed or rolled back. Her breath is fetid. I can't understand what she says. At first she did not recognise me. Then there was a spark of recognition. "Yo is going to come" "Ah" (indifferent). "Godmother, I really have to go now" "Go, go" (impatience). The only thing she said that made any sense was "You don't understand anything I am telling you". I think that I saw her for the last time today. I'm praying to God that I might just die quickly or slip away in my sleep to not have this long awfulness. Telephoned Aunt. To buck me up, I went mad - fruit and cakes. I'm not upset as such but touching her frozen hand and kissing her on that cold face bathed in sweat, her being all stiff and that foul-smelling breath made me feel nauseous. I wanted to go to the BN but came back here. "la Vie de Beethoven" (Romain Rolland). ${ }^{305}$ Today, the fourth day, ${ }^{306}$ I didn't expect to be ill. I took some aspirin with my coffee. Legs are so very heavy. I think that I would have been in pain. Spotted Ruth at St Louis which proves that Gabrielle has left. What a pain that is. I must watch out. She'll be over here soon. I don't want any of that carry on at mine.

\section{Friday 11 Sept}

Mlle Koch. Godmother Berthe died at 3.30 am. Came back with Yo on the métro from Odéon. We were speaking as if we were merely acquaintances - no intimacy. I have more meaningful conversations with my friends. Went to see "Escadron Blanc". ${ }^{307}$ Good. Read "Marie Chapdelaine" (Louis Hémon). ${ }^{308}$ Hot and suffocating today. Starting with a depression?

${ }^{305}$ Romain Rolland (1866-1944). His study of Beethoven was published in 1903. More on Rolland, humanist, philosopher, essayist and playwright can be found at the Association in his name:

http://www.association-romainrolland.org/

${ }^{306}$ Fourth day of her period.

${ }^{307}$ Italian film which came out in 1941. It was directed by Augusto Genina. See:

http://www.allocine.fr/

3081913 novel written by Louis Hémon (1880-1913). Full text available at Project Gutenberg:

http://www.archive.org/stream/mariachapdelaine04383gut/mrcpd10.txt 


\section{Saturday 12 Sept}

Office. Korbelecky sent a "crude" card to both me and Mlle Pedron. Disgusted. Headache. Very depressed. "Suomi" (?) Bought a big cabbage.

\section{Sunday 13 Sept}

Buried Godmother today (same day 11 years ago she was burying her mother). Divided up the jewellery. Aunt was kind. On the door at the Festival Chabrier. Knitted. Storm.

\section{Monday 14 Sept}

Office. Heat intense and so slept in the afternoon. Heavy. Terrible storm. Waves of water against the the kitchen window. It was like being on the open sea. Mlle Koch and a card from Cyla. Letter from Colette. Mme Piatier came back. "Visite aux américaines" (J. Romains) ${ }^{309}$

\section{Tuesday 15 Sept}

Office. "Prisons et Paradis" (Colette). I really do like to read Colette. It is not so much what she says but how she says it. Real charm. Revised for the exam which means that I snacked continually. I put away nearly a kilo of apples and 3 cubes of sugar. If only I had chewing-gum or a cigarette!! Studying didn't make me do that before. Mlle Cécile Péchegut is going to the Free Zone tomorrow. I feel really pleased wearing the ring and the chain bracelet. I feel very, very pleased actually. It feels strange. I hardly ever wear jewellery. I really want to put perfume on. More and more strange it is. Rain. Autumn is on the way. Enormous grey drapes veil the horizon. When I was doing the cooking today, there was the first steam on the tiles.

\section{Wednesday 16 Sept}

Office. Stella Tifferneau was sacked. Letter from Mme Faure who is coming Sunday. "Montesquieu! (Lawson). Did the washing. Ironed the curtains for the wardrobe and for the toilet. Put the table in the kitchen. Mme Maréchal is 24 years old.

309 Published in 1936 by Flammarion, Visite aux américaines recounts Romain's fascination with America together with his travels across the country in the form of articles he wrote for the French journal L'Intransigeant. See Dominique Viart (1996) Jules Romain et les Ecritures de la simultanéité (Presses Univ. Septentrion), p. 284. 


\section{Thursday 17 Sept}

Office. Studied. Put away the laundry etc. Very nice letter from Aunt. Mlle Koch brought some flowers. Ate some pomegranate.

\section{Friday 18 Sept}

Waited for Hélène who didn't turn up. Knitted. Ate figs. Pneu to Mme Faure. Denise Pedon is 20.

\section{Saturday 19 September}

Office. Wrote to Cyla. Warm sun. The cost of living is rocketing. It is terrifying. It costs 150 francs a week to buy the absolute minimum. With a bit of fruit it costs 200 francs. It is just ridiculous. We've been punished. Apparently, they tried to blow up the Rex, the cinema for the German troops. Sanctions: 116 communists have been shot, there have been lots of deportations. All going-out places have been shut today and tomorrow. Tomorrow the curfew is from three in the afternoon. ${ }^{310}$ Great, won't have to visit Aunt! But I am losing out on $50 \mathrm{fr}$ for the concerts. Oh well, never mind. Went to Mme Paolettés to meet up with Aunt, Yo, and Berthe's nephew and daughter-in-law. The mother and the nephew were utterly stupid about everything. Aunt was furious and she had a right to be. Well! It was a wasted afternoon. As I left I invited Aunt and Yo over. Aunt really wanted to come but then after a sideways glance at Yo to know what to say, she decided no. Yo doesn't forgive me for leading the life that she would so like to lead.

\section{Sunday 20 September}

Mass. A beautiful sunny day but so windy!! I decided to take in my cacti and my geranium now the nights are colder and the dew is heavier. There isn't much difference between the inside and the outside because I always have the windows open. It might only be 1 or 2 degrees difference but that is a lot for a plant. Went on a weevil killing hunt. It takes ages and is boring but at least it is done. Curfew at three oclock. Nothing happened. A window got smashed a little before but I couldn't see anything. A police truck passed by and stopped off to tell the little cobbler to shut his door. Before that a policeman and a member

${ }^{310}$ Forty-six hostages were shot in reprisal for this attack at Mont Valérian, Paris. According to Jacques Delarue, the Germans ordered that $125 \mathrm{Com}-$ munist and Jewish hostages be shot, but because 88 men had been executed the previous month not enough could be found. See: Jacques Delarue (2008), The Gestapo: History of Horror (Barnsley: Frontline Books), p.246. 
of the Garde mobile went by telling us all to get inside. But there's not been a single German patrol. They couldn't care less about us. When there's a curfew they should be coming down the street on motorbikes revolvers in hand, hammering the tarmac with their boots or something so as to scare us all! But alas! In the beginning they were around and we were getting our money's worth but now!! - It is fair to say that this little corner of the rue St Jacques - village St Jacques one could call it - is as calm and as quiet as anything. Time to knit! I swore that I wouldn't do any studying today on a Sunday. There's a scent of autumn in the air but the trees at the Val-de-Grâce are still green. Shut the windows. It's summer but an English summer. The sky is too wan and the sun is too white to be the kind of summer we get here.

\section{Monday 21 Sept}

Rain. Lunch with Ruth at St Louis. She annoys me. Mlle Kamska came back. Boësse. Studied. It really is cold. Mlle Koch came over.

\section{Tuesday 22 Sept}

Office. Did the washing. Went to get the lunch tickets but the staff store is only open mornings. Went to Françoise Boësse's but she wasn't there. All these little gardens around the buildings are so pretty. Took in the cactus and the geranium. I won't even put them outside during the day. Bad memories of what has happened before in spring. Dilys came over because - complete coincidence she wanted to borrow something. This time it's knitting books. Can't she just go buy some? Went to see her room. It's OK. It appears big but it is lacking in taste. She moans that it is difficult to get doing things when Georges is there. I should say! 5 in 2 rooms!! It'd drive me mad. But, well, if it suits them like that. . Jacqueline Piatier locked out of her room. Lent her blanket, towels etc. Raining and cold. Wrote to Hélène.

\section{Wednesday 23 Sept}

Office. Studied but was falling asleep over my book so did some ironing. Jacqueline $\mathrm{P}$ gave me back my cup. She is awfully talkative. 1 and a half hours without stopping. I was going mad by the end because I wanted to go out and get food in. Got some sausage with 3 tickets - carrots, tomatoes. Made myself a nice little meal. Ruth came to give me back the book and to borrow my typewriter. I wasn't keen but refusing would have caused a scene. She wanted to type in my room but only when I wasn't there. What's got into her? I refused point blank of course. That's the second time that she has tried to get into my room when I haven't been here. I don't want that. She tried to get me to feel sympathy for her by talking about the news she got about her grandmother a year ago; news that a friend had not got right. She obviously does not remember that she 
said exactly the same thing in the same words just after Cyla left. She was not banking on me having a good memory. I didn't shower her with sympathy and asked her, as I did the last time, why she had not made use of the Red Cross. I don't know whether it was at that point that she remembered that she had already told me about it. I carried on with what I was doing the whole time that she was there without looking at her once. She tried her ingenious best to find things that would make me get up, leave what I was doing but I went back to it straight away. When she could see that it wasn't working she left with the machine. Straight afterwards it started to pour down. Let's hope that my machine didn't get wet. I've finished my jumper apart from the collar. It is a total success. It suits me very well. If I get the collar right it'll be perfect. I am very pleased with myself.

\section{Thursday 24 Sept}

Wrote to Mme Faure, Mme Desportes. Letter from Hélène. The wind broke one of the stems on my red snapdragons. It's right at the back end of flowering. It's autumn. I only have 24 frs to last me until the end of the month. How annoying. But I will get there maybe. Studied "Montesquieu" (Albert Sorel). ${ }^{311}$ Dilys came. Sylvia was arrested this morning along with all the other Americans. She's at the Jardin d'Acclimatation. Will she go to Vittel or to Compiègne? ${ }^{312}$ Mme Koch didn't come.

\section{Friday 25 Sept}

Office. Studied. Rain. Cold. Wrote to Hélène, Aunt. Letter from Mme Faure.

\section{Saturday 26 Sept}

Office. Studied. Rain. Cold. Scrubbed the floor with wire wool. Got my monthly ration of carrots (one pound) ${ }^{313}$ so that made three (3) big carrots. I was told about 3 arrests in the quartier. They are arresting so many Communists round here. Depressed, bored, listless, no go about me.

${ }^{311}$ First published 1887. The full text of the first edition is available via the Bibliothèque nationale's digital collections: http://gallica.bnf.fr/ark:/12148/bpt6k295180

312 Sylvia Beach was interned at Vittel in France. She was later released. The precise circumstances around her release are unclear, although it is likely that influential contacts played some role.

${ }^{313}$ In the French Madeleine stresses that livre has a feminine gender [une livre]. 


\section{Sunday 27 Sept}

Kamska. Cold rained. Housework. M. and Mme Faure came over. Brought superb dahlias. But I sense some disappointment. Then I understood. They were expecting something more bohemian, a garret with sloping ceiling, books on the floor, socks on the furniture etc. That is exactly why I keep my home very clean. They've seen too many "bohemian rooms" at the Pictures. I hate that. I like things to be clean and beautiful. I like to surround myself with nice things even though I have no money. Ruth came to borrow the typewriter again. Even in the apartment, one can see one's breath.

\section{Monday 28 Sept}

Office. Korbelecky returned. Huge drama because he is investigating Mme Tiffernau. I am ice cold with him because of the card he sent. He told me that Mme $\mathrm{T}$ had had an extremely bad influence on me. I couldn't believe it. I asked him to explain and he told me that I was too young. Me: "Nevertheless I seem to have been able to stave off evil influence". K: "I hope that you stave it off all your life". He smiled an enigmatic smile and disappeared. I've been round and round in circles in my head. I can't find an answer. Real $1^{\text {st }}$ of November type weather. Cold so had myself a cup of tea at 5.30 with crackers and a bunch of grapes. It was mad but I've only got a few bits of chard for this evening. I'm going to be hungry. Went to the Town Hall in the 6th for some lamp fuel for Cécile Péchegut. There wasn't any. Luxembourg turning rust-coloured. The palm trees are still there. Beautiful dahlias, almost no lawns left, beans instead. Did washing. Rain and more rain. Mlle Koch didn't come. Ruth brought the typewriter back when she knew I had a lesson so she could see what my pupil looked like. Sent her packing. She has sewn the button on the cover back on.

\section{Tuesday 29 September}

Office. Kort very cold. Wanted to thaw out without knowing how to without losing all dignity. Rained without stopping. Went for tea to Hélène's. Met her sister, her father, her mother. Her father is very nice. She has a superb violin - and a beautiful Chinese quilt. Finished second pair of yellow socks and started yellow gloves. ${ }^{314}$ In the night I woke crying with cold put on a nightshirt and some wool socks, closed the window and woke up as warm as toast. Got a pneu from Colette.

314 To show solidarity with Jewish citizens forced to wear the Yellow Star as an anti-Semitic means of identification, some brave gentiles wore yellow items of clothing. Here Madeleine pointedly refers to the yellow socks and yellow gloves which she is knitting. Her visit to the Berr family comes shortly after Hélène Berr's father Raymond has been released from Drancy internment camp. 


\section{Wednesday 30 Sept}

Slept very well. Telephoned Dick Ivanoff. Very amusing. So that we could recognise one another I said that I had plaits braided round my head and he told me that he would be wearing a beige overcoat. He has a beautiful voice (my dear!!). ${ }^{315}$ Rain. Going to iron. What happened to the time when I used to start my washing at $15 \mathrm{~h}$ and finish ironing it by 19.30 ? It takes nearly two whole days for it to dry now. I'll go to the office this afternoon to get paid. I'll do my 3 hours there. Aunt sent me a card of Versailles. Office. Very tired. Kamska. Went to Colette's. Rain. Letter from Mlle Koch.

\section{Thursday 1 Oct}

Office. Start of the month abundance: butter, bread and sugar. Very depressed. Went to the "Carnet de Bal" (very, very good but not the sort of thing to cheer one up). Lesson with Dick Ivanoff. Got a note from Monique with some money and some pears. Cold. Letter from Jean Soulié.

\section{Friday 2 Oct}

Office. Police were called to the Centre to throw out a bloke who called Mme Roche-Bernard a "monster" and M. de Retail "Sewer breath". Went to Dyl's for news about Sylvia. Wrote to Cyla, Monique, Mlle Koch. Studied. (I?)

\section{Saturday 3 Oct}

Hôtel-de-Ville. Soulié not there. Ill. Went to Souliés but no reply. Went to "Symphonie Fantastique" Jean-Louis Barrault acts very well.

\section{Sunday 4 Oct}

Villeparisis. Aunt was lovely. Yo is unhappy. She can't get over Jacques. There are no longer any trees along the canal. There was a woman called Gilberte there with her husband and her son Michel. All 3 unpleasant. Granny gave me some lace trim and Aunt gave me 6 plates (for my birthday).

\section{Monday 5 Oct}

Office. Mlle Koch. Ate some disgusting sardines which have given me an upset stomach. Went to Souliés. Stayed for an hour. He is very nice. Saw Jacqueline.

315 'my dear' in English in the text. 


\section{Tuesday 6 Oct}

Office. Ill. Visit from Mlle Bruaud to arrange lessons. Dick. Kamska. Message from Mummy: "Sweetheart, got your June message and Germaine has had a letter from Lulu. Nils is sorry that you've received nothing from his family but hopes that one day you will. Niki has almost grown into a beautiful cat. I have to put her out if I want to work in peace. He sleeps in the armchair. Toutou sleeps on the sofa. We make do with the chairs. Germaine is coming here on holiday for a fortnight. She is managing in the face of adversity. Raoul left her! That was a year ago now. . infidelity. Don't say anything to her sister if she doesn't know. Môme's parents send their very best. Môme hasn't changed and is still where she was. We got some good news about Marguerite. She came back home six months ago and plans to start back working a bit soon. She and all of the family are thinking about you. Her brother got married. I hope that you are all well and that you are less tired. I would be pleased to meet your friends one day soon. Love and thank you from the bottom of my heart to everyone".

\section{Wednesday 7 Oct}

Office.

\section{Thursday 8 Oct}

Mlle Bruaud. Mlle Koch didn't come. Went to Hôtel de Ville to see Soulié who gave me the flyers. Letter from Mme Desportes.

\section{Friday 9 Oct}

Handed out the flyers around the Musée Historique, rue de Sévigné. Looked for some lining. Found some in front of Notre-Dame. Chabert. Kamska. Pneu Jean Soulié.

\section{Saturday 10 Oct}

Office. On the desk at the Bibliothèque Historique, rue de Sévigné. Went to "Charles Gounod" (Delacour) ${ }^{316}$ with Jean Brémaud. Had dinner with him. Hôtel de Ville. Soulié wasn't there.

${ }^{316}$ Possibly a minor play about French composer Charles Gounod (1818-1893). 


\section{Sunday 11 Oct}

Had lunch with Jean Brémaud. "inconnus dans la Maison" starring Raimu. ${ }^{317}$ Had dinner with Jean Brémaud. Jacqueline Piatier left.

\section{Monday 12 Oct}

Office. Mlle Bruaud. No Mlle Koch. Françoise Boësse came to visit.

\section{Tuesday 13 Oct}

Office. Jean B. telephoned. Had lunch at S.B's Went to Châtillon, Bagneux with JB. Splendid weather. Dick. Kamska. Dinner JB, pneu from Mlle Koch. Unhappy.

\section{Wednesday 14 Oct}

Office. Jean telephoned twice. Had lunch with Jean. Went to get flyers with Jean. Went to "Celestine" but there was no performance because Marcelle Génait who was in the lead role was ill. ${ }^{318}$ Fagged out. ${ }^{319}$ Chatted to Madeleine Fortan until $2 \mathrm{am}$. Jacqueline has still not come back. Letter from Mme Koch. Soulié.

\section{Thursday 15 Oct}

Wrote to Aunt, Mme Koch. Office. Went to Hôtel-de-Ville to see Soulié. Dropped in at Jean's. Mlle Koch. Ruth came by apparently and Jacqueline did too I think. Studied.

\section{Friday 16 Oct}

Queued with Jean for sweets and biscuits. Had lunch with Jean. Put posters up at Montmartre. Dick. Kamska. Ruth came over. Mlle Bruant.

3171942 film directed by Henri Decoin and starring actor Raimu (1883-1946), whose real name was Jules-Auguste Muraire.

${ }^{318}$ Pierre Laville wrote an abridged French version of Roja's 1490 text, and it was performed for the first time at the Comédie française in 1942. The mise-en-scène was by Jean Darcante. Agnès Pierron (1977), Maréchal, sa carrière lyonnaise (1960-1975). (Lausanne: L'Age d'homme), p.109.

319 'Fagged out' written in English. 


\section{Saturday 17 Oct}

Office. Lunched with Jean and some friends from Bourges. Went to St Denis "Guignol à Paris". Had dinner with Jean. Opéra-Comique. "Mon Oncle Benjamin." Daft. 320

\section{Sunday 18 Oct}

Went to Chantilly. Drizzly. In the afternoon went to see the Table Ronde, Ory-la-Ville, Les Etangs, Chateau de la Reine Blanche. Back to Paris.

\section{Monday 19 Oct}

Office. Got a note from Jacqueline E. Telephoned Jacqueline E. Message from Mummy. "Condolences to Aimée. Thinking of you on your birthday and of Aunt and the family. Germaine is staying with us for a fortnight's holiday. Everyone is fine. Hugs and kisses. Mummy. 17 August 1942." Letter from Aunt. Mme Piatier. Jacqueline is in hospital. Mlle Koch.

\section{Tuesday 20 Oct}

Office. Errand for Mrs Evans. Had dinner with Jean. "La Celestine". Very good, but crude (dearie me, not for innocent young girls). Letter from Jean. Wrote to Aunt.

\section{Wednesday 21 Oct}

Office. Kamska.

\section{Thursday 22 Oct}

C. office. Mlle Koch. Dick. Went to the Hôtel-de-Ville. Alert. Jean came to dinner. Dilys came.

\section{Friday 23 Oct}

Had lunch with Jean. Mlle Bruaud. Chabert. Kamska. Met up with Paulette Trois-Gros. Got card from Cyla. Bought earrings for Dylis. ${ }^{321}$ Alert.

320 'Daft' written in English.

${ }^{321}$ Dilys misspelt here and in entry of 24th October. 


\section{Saturday 24 Oct}

Office. Had lunch with Jean. His friends came over. Talk at the Hôtel de Sévigné. Rain. Had dinner with Jean. Beautiful moonlight. Dylis's birthday.

\section{Sunday 25 Oct}

Went to Villeparisis. Cold. Yo is very poorly (very serious anaemia).

\section{Monday 26 Oct}

Office. Had lunch with Jean. Broke up with him. I feel very sad and a bit all over the place. Went to Hôtel de Ville. What a void in my life. I'm in terrible pain. Mlle Koch. Dilys and Georges. Wrote to Jean but won't ever send the letter. Raining.

\section{Tuesday 27 Oct}

Office. Knitted. Kamska. Dick. Nothing from Jean. Raining.

\section{Wednesday 28 Oct}

Office. Still nothing from Jean. Went to the Gens des Lettres. Met up with Jean. "Au Pays du Soleil" (variety show). ${ }^{322}$ Stupid. Very music-hall - bad music-hall. ${ }^{323}$ Raining.

\section{Thursday 29 Oct}

+ Office. Sent a pneu to Jean. No Mlle Koch. Jean came for dinner. Raining. I.

\section{Friday 30 Oct}

+ Queued at Jacquin. No sweets. Had lunch with Jean. Went to the office in the afternoon. Dick. Kamska. Raining. Got soaked through to the skin. Letter from Jean Soulié. Chatted with Madeleine Fortan. I.

\section{Saturday 31 Oct}

+ Got up late. Had lunch with Jean. Went to pick up the ticket stubs. Soulié wasn't there. Talk at Hôtel de Sévigné. Turned down by the Ecoles. Raining.

322 An 'Operette marseillaise'. See: https://www.operette-theatremusical.fr/2015/07/04/au-pays-du-soleil/

323 'Bad music-hall' written in English. 
Dinner with Jean. "Promesse à l'Inconnue" (Colisée). ${ }^{324}$ Letter from Mme Faure. I. "Retraite Sentimentale" (Colette).

\section{Sunday 1 Nov}

+ All Saints Day. Got up late. Had dinner with Aunt. Didn't go to grandfather's grave because I had bad Nico. Yo came back with me and stayed until $19 \mathrm{~h}$.

\section{Monday 2 Nov}

+ Had lunch with Jean. Kamska, No Mlle Koch. Raining.

\section{Tuesday 3 Nov}

C. 7.30-12.30 Exam. Essay in French "It is said that "Phèdre" marked the pinnacle of Racinian genius. What is your view?" 2-6 pm. Latin translation. Jean was supposed to come to meet me but was at the studios for "Goupil aux mains rouges" so went for dinner at his place. We had a long talk. Missed the last métro. Raining. Wrote to Mme Faure, Aunt.

\section{Wednesday 4 Nov}

St Charles. Raining. Office. 2 new staff members. - Gilberte X.__? [Frey], Mme Giselle X__ [du Mesnil] and Jacques Dupuis (very nice). I have to work 30 hours a week (damn it). Did washing. Jean came 4-7 pm. Cold. Went to bed at 8.30. Ruth came at $9 \mathrm{pm}$. I don't think that I will see her again for a while. Thank God.

\section{Thursday 5 Nov}

Office. Covered books. Wrote to Jean, Aunt, Cyla, Mme [..?...]. Raining. Went to Dick's but there was someone there and so I came home even though I am sure that today was his lesson. Never mind. I'll go tomorrow and pretend to be surprised.

\section{Friday 6 Nov}

Office. Ironed. Hôtel de Ville. Dick. Kamska.

3241942 French feature film directed by André Berthomieu. For more information see the film entry at:

http://www.unifrance.org/film/6225/promesse-a-1-inconnue 


\section{Saturday 7 Nov}

C. Office but sent home because there was no heating. Talk at the Hôtel de Sévigné. Went to Jean's. Heavy rain. Very cold.

\section{Sunday 8 Nov}

C. Lunch at Jean's Went to Joinville. Dinner with Jean. Weather fine. The Americans have landed in Africa. ${ }^{325}$

\section{Monday 9 Nov}

Washed hair. Weather fine. Very cold. Dilys came. "Invitation à la Valse" (Rosamond Lehmann) ${ }^{326}$ "Chambre d'Hôtel" (Colette)

\section{Tuesday 10 Nov}

Cold. Fine weather. Office. Letter from Mlle Bruaud. Jean came. Dick. Kamska.

\section{Wednesday 11 Nov}

Office. Bachellery "A l'ombre de l'Usine" (?). Had dinner with Jean.

\section{Thursday 12 Nov}

C. Office. Jean came for dinner.

\section{Friday 13 Nov}

Vendryès. Office.

\section{Saturday 14 Nov}

C. Office. Lunch at Jean's. Dinner at Jean's.

325 Operation Torch, the Allied invasion of North Africa, began on 8 November 1942.

326 Rosamond Lehmann (1901-1990) was an English novelist. Her 1932 novel Invitation to the Waltz was one of a number of so-called 'middlebrow' novels by British women writers read by Madeleine during the Occupation. Many of these novels featured women central characters torn between societal convention and new opportunities for social and career mobility after the political successes of first-wave feminism in the first two decades of the Twentieth century. See Nicola Humble's 2001 monograph The Feminine Middlebrow Novel 1920s to 1950s: Class, Domesticity and Bohemianism. 


\section{Sunday 15 Nov}

Villeparisis.

\section{Monday 16 Nov}

Office. Lunch with Jean. "Une Note de Musique” (Rosamond Lehmann). Made me feel depressed.

\section{Tuesday 17 Nov}

Office. Dick. Kamska.

\section{Wednesday 18 Nov}

Office. Bachellery. Hôtel de Ville. Had lunch with Jean. Had dinner with Mme Faure. Chicken, chips. Ill. Went to Jean's to get some pills for my digestion. Alert 8.30-9 pm. Got some news from Mummy. "20 Oct. Darling. I hope that Granny has recovered well from her operation. Germaine spent 3 weeks with us and is doing well. I am pleased that you had some news from Paul. We haven't yet had any news from Cyla. We will be glad of it when it does arrive. Here all is well. Health is good. Jeanne also has a little cat. She calls it Fluff. The mice are no longer having a free run. I was given some new plants for the rockery and did I tell you that there are 2 apple trees in the garden behind the house? Since Germaine's stay I have been getting used to my dentures. Kisses. Be well. Mummy".

\section{Thursday 19 Nov}

C. Office all day. Had dinner with Jean. "Dernier Atout" ${ }^{327}$ Missed the last métro.

\section{Friday 20 Nov}

Vendryès. Office. No Dick.

\section{Saturday 21 Nov}

C. Office. Lunch with Jean. Dinner with Jean.

${ }^{327}$ A 1942 film thriller by Jacques Becker. 


\section{Sunday 22 Nov}

C. Showers. Lunch with Jean. Went to the Jardin des Plantes. ${ }^{328}$ Very cold. Dinner with Jean. Alert 9-10 pm.

\section{Monday 23 Nov}

Office. Lunch with Jean.

\section{Tuesday 24 Nov}

Office. Lunch with Jean. Dick (paid). Kamska.

\section{Wednesday 25 Nov}

C. Office. Chabert. Bachellery. Jean came to dinner. Jean Soulié telephoned.

\section{Thursday 26 Nov}

C. Office all day. Hôtel de Ville. Met Jean. Dined with Jean.

\section{Friday 27 Nov}

Vendryès. Mme Péchegut bought me a coffee and cake. Office. Dick.

\section{Saturday 28 Nov}

C. Office. Had lunch with Jean. Distributed posters. Bought "le Grand Meaulnes" 329 for Yo's birthday. Met up with Dilys. [...] nobody from the camp. Pneu to and from Aunt. Had dinner with Jean. He wants me to become his mistress. $\underline{\mathrm{NO}}$

\section{Sunday 29 Nov}

Missed the 10.25 train. Took the midday one. Villeparisis. "Alerte aux Blancs" (Stupid).

${ }^{328}$ Le Jardin des Plantes is a botanical garden of exotic plants in the 5th arrondissement of Paris.

329 Written by Alain Fournier (1886-1914). Fournier was killed in action in September 1914. 


\section{Monday 30 Nov}

St André. Yolande is 24 years old. Office. Jacques Dupuis is leaving. Had lunch with Jean (very distant) Handed out posters. Had hot water. Washed. Less cold. Pauphilet. Chabert. Rue St Jacques [...].

\section{Tuesday 1 Dec}

Office. Kort was ill. Michael spoke to me at midday (he said that he loved me). Did the washing. I'm at a dead end with Jean. Do I love him? Do I not love him? Saw Françoise Boësse. Dick. Darned. I've had enough. My head is spinning with all these thoughts. Not very cold. Saw some little dolls - was going to buy myself one but they were 100 frs each!! They'd be $1 / \%$ back home. No, no, no.

\section{Wednesday 2 Dec}

C. Office. Bachellery. Hôtel de Ville. Went to Jean's but wasn't there so waited $1 / 4$ hour. Had dinner with Jean (a slice of roast pork).

\section{Thursday 3 Dec}

Office all day. Tea with Dilys. Food supplies are better this winter than last because there are still some carrots, turnips (with tickets) and without tickets there's lettuce, beetroot. Jean told me that he was disappointed in my journal because I only talk about trivia. That's right because I am wary of prying eyes like his for example. Got card from Cyla. Dilys came to listen to the TSF.

\section{Friday 4 Dec}

+ Queued for biscuits at Samaritaine with Jean. Office (was late and got a dressing down from Korbelecky. Ironed. Dinner with Jean at Le Pajolec and La Saugette. Nice. Jean missed his connection. I

\section{Saturday 5 Dec}

+ Office. Lunch with Jean. Tea with Mme Desportes. Dinner with Jean. I

\section{Sunday 6 Dec}

+ Lesson with Dick. Read "Undine" (Fouqué). ${ }^{330}$ Read "Amour en Amérique" (?) Darned. Dilys came over to listen to the radio. Great Sunday. Had a good rest. Quiet. I

${ }^{330}$ Fairytale by Friedrich de la Motte Fouqué (1777-1843) published in 1811. 


\section{Monday 7 Dec}

+ Office. Lunch with Jean. Lesson Pauphilet. Françoise Boësse came for a cup of tea (returned books) Went to Chabert's but he wasn't there because he was called up on Saturday with the other Rumanians. Ruth came over. Pneu from Hélène Koch. Wrote to Aunt, Cyla, Hélène Berr, Hélène Koch. No money to buy Christmas presents but I have to. What will I do? I

\section{Tuesday 8 Dec}

Office. Slight stomach ache. Had lunch with Jean. Argued with him. I stop him from doing anything and that makes him really angry. How many days has this been going on for now? He is secure in his certainty that the next time he asks me to be his mistress I will agree and all the while I am preparing never to see him again. I no longer love him. And I feel that deep down. It has lasted two months. The longest relationship I've had. I had one in ' 40 - I no longer remember his name even, Michel perhaps or Marcel? He came out with "You're married it seems!" First I'd heard of it but I said "yes I am" just to get rid of him. It worked. Thank God for that. Where does this nonsense come from? Françoise told me yesterday that I was English and that my father was an engineer. What next!! I'm looking forward to the sequel. I'll probably end up with kids. That'll get people talking given that I live alone. Funny how people think that one can't live without physical love. I mustn't be normal. Thought back over my boyfriends. It's awful. I can't remember their names: -

Friday ? Dec 1937: Peter Simpson 25. 1st kiss July 1938: 1st date with ?? (35 yr old Bulgarian)

March 1940: Michael? Marcel? Maurice? 26 years old. Artist [looked through the archives - he was called Marcel Legros]

July 1941: Jean Peignot 35 (?)

October/December 1942 Jean Brémaud 36.

Huge unrequited love for Kachinsky - Spring 1938

A bit of flirting with Roger August 1940

Was kissed on the train by a Greek on 1 April 1938

Michael falling in love with me, winter 1940-41

The soap ration has been cut by half - what a pain. Bought Néméton, the Druid studies review. Quite strange it is. Darned. I'm hungry. It isn't very cold. Jean came but I wasn't here. Lesson with Dick. Alert 7.10-8.15 pm. One more around midnight but didn't hear it because I was asleep.

\section{Wednesday 9 Dec}

Cold. Office. Kort was in a good mood (about time!) Chabert hasn't been called up. Bachellery. Renewed my readership membership at Adrienne Monnier's 
Saw Dilys who was not happy to see me. Had dinner at Jean's. Went to "La Corrida" at the Théâtre Charles de Rochefort with Charles de Rochefort and Mary Grant. Only the woman acted well. Cold. "Ondine" (Giraudoux). ${ }^{331}$

\section{Thursday 10 Dec}

In the office all day. "Poussière" (Rosamond Lehmann) ${ }^{332}$ Lesson with Gilberte Frey. Chabert. Letter to Hélène Koch. Mme Faure. Wrote H. Koch, Jean. Less cold. Saw a quarter moon and a shooting star. Restless, happy but pale and drawn. I need 3 days of absolute rest. Studied Welsh.

\section{Friday 11 Dec}

Got up at $9 \mathrm{am}$. The sun looked as if it was on fire and then it went grey. Vendryès 10-12.15. Office. Finished "Poussière". It made me depressed. Met Mlle Bruand. Dick. Nothing to eat. Made pancakes but with no eggs or milk. I make them better than Jean does. Bought a box of chocolates for 130 frs (in 1938 the same box was 13 frs) At the office, Kort and Duret were flirting with me. Am I attractive then? To be completely honest I can't see anyone want to love me. I am fearful of living life to the full. I like to feel safe. Let's hope that I find a good husband who can give me children, a beautiful house a beautiful garden. I really do miss a garden. Oh I wish I could go back!!!

\section{Saturday 12 Dec}

C. Office. Pneu from Mme Faure. Lunch with Jean. "Siegfried et le Limousin" (Giraudoux). Dinner with Jean. Folies Bergères.

\section{Sunday 13 Dec}

Split with Jean. Cried for two hours about him. Came home and went to bed. Read "Crime du [...] Chamois" (Wells) Slept. Read Giraudoux. Only had noodles to eat. Spent 40 frs on sweets and cake to console me! Dilys came to listen to the news.

\section{Monday 14 Dec}

Office. Pauphilet. Lesson Mlle Koch. Glberte. Chabert. "Si le Grain ne meure" (Gide). ${ }^{333}$ I think Jean was play acting yesterday and I took him seriously. He

${ }^{331}$ Giraudoux's play Ondine was based on Fouqués Undine, which Madeleine had read the previous week.

${ }_{332}$ Dusty Answer was first published in 1927.

${ }^{333}$ Si le Grain ne meurt was a 1924 autobiography by French writer André Gide (1869-1971). Madeleine misspells the title in her entry. 
must be very annoyed. That charitable thought has comforted me a lot. Saw Hélène Berr, Françoise Boësse, Madeleine Lavelle. Terribly hungry. Bought $475 \mathrm{~g}$ of honey for $105 \mathrm{fr}$. Thinking about the winter.

\section{Tuesday 15 Dec}

Office. Darned. Lesson with Dick (got paid). Ate mussels.

\section{Wednesday 16 Dec}

Office. Welsh. Breton. Bachellery 2-4. Saw Paulette Trois-Gros. "L'Heure des Adieux" (German film, so-so) ${ }^{334}$ with Giselle de Mesnil. Had dinner with her. Wrote to Aunt.

\section{Thursday 17 Dec}

St Yolande. Office all day. Kort in a bad mood. Typed from the book I borrowed off Bachellery until $1.30 \mathrm{am}$. Letter from Hélène Berr.

\section{Friday 18 Dec}

Irish, Welsh Vendryès. Office. Lesson with Dick. Typed book. I've been so much happier and lively since I've stopped seeing Jean. I see now that subconsciously I didn't like him. Raining. Mild.

\section{Saturday $19 \mathrm{Dec}$}

Office. Did the tickets rue de Sévigné. Saw Dilys on the rue St Jacques. Went to Confession. Had tea with Françoise Boësse (she gave me potatoes and tickets for potatoes). "Katrina" (Sally Salminen), 335 "Derrière les Barbelés" (Louis Walter). ${ }^{336}$ Letter from Aunt.

${ }^{334}$ A 1941 German film directed by Helmut Käutner. For more information on plot and cast see:

http://www.telerama.fr/cinema/films/l-heure-des-adieux,447575.php

${ }^{335} 1936$ novel by Finnish author Sally Salminen (1906-1976).

${ }^{336} 1942$ account of the author's captivity as a POW between 1940 and 1941. Read more about Louis Walter and his testimony at the website and database EGO 39-45, Écrits de Guerre et d'Occupation hosted at: http://www.ego.1939-1945.crhq.cnrs.fr/recherche/detail_ouv.php?id_ ouvrage $=198$ 


\section{Sunday 20 Dec}

Sun. Mass. Put my hair up. Bought some holly and decorated Mum's picture with it. Alert between 12 and $12.50 \mathrm{am}$. Worked. Ill. Mad. Fortan came to talk.

\section{Monday 21 Dec}

Office. Ill (Gastroenteritis?). Wrote to Hélène Berr. Lesson with Dick. Letter Mme Koch stopping lessons with Hélène. Letter Mme Yvonne Disner. "la Couronne" (Sigrid Undset) ${ }^{337}$ Worked. Cold.

\section{Tuesday 22 Dec}

Office. Giselle warned me that Chantal said that Kort wants to sack me. I don't believe her. "La Maison près du Cimetière" (Morgin De-Kean). Not bad. Torrential rain. Lesson with Gilberte. Cold. Worked.

\section{Wednesday 23 Dec}

Office. "La Femme" (Sigrid Undset). Welsh with Bachellery. Tea with Mme Desportes. Met a prof of Parasitology. Package from Cyla, biscuits, sweets. "Les Petites âmes" (Géraldy). Rain.

\section{Thursday 24 Dec}

Card from Chantilly. "Thoughts of you - Jean". What does he want me to do with his thoughts? Got up late. Lesson with Dick. Read. Did shopping. Took the radio over to Dilys. Stayed for dinner. Dilys gave me some powders.

\section{Friday 25 Dec}

Christmas. Villeparisis. Aimée, Huguette, M. Labine were there. Went out with Huguette. So true! For nearly 18 years she has been scared stiff of everything and lethargic. Aunt is worried that Yo has something on the lung. I don't think she has.

\section{Saturday 26 Dec}

Got up late. Card from Mme Faure. Pneu from Gisèle du Mesnil inviting me for Christmas Day eve!! Had some bacon (40 grams) Made an omelette with fat and potatoes (with my 2 eggs allowance for December). "Le Mariage de

337 Sigrid Undset (1882-1948) was a Norwegian novelist. She won the Nobel prize for literature in 1928. 
Chiffon"338 with Cécile Péchegut. Got some Oxo and some cake with her at Marcuisot. "La Mort du Cygne" with Madeleine Fortan. Very good. It was well heated there.

\section{Sunday 27 Dec}

Got up late. Mass. Read. Sorted letters etc. Read Mummy's letters again. She is so adorable, so simple, so kind - all the qualities! My sweet Mummy. Made some bread (a little hard and it didn't have any yeast but very successful!!!). I think that I would cook quite well if I had the time and the utensils. A little bowl (?) from Ruth. What can I buy her? Wrote to Cyla, Mme Faure, Yvonne Zéau. - Mad F came over to talk for 2 hours. Got the radio back. Tired. It's really good in this apartment. God, I am hungry!

\section{Monday 28 Dec}

Office. "La Croix" (3rd vol of "Christine Lavransdatter" 339 [Sigrid Undset]). Jean came. Lesson (?) Chabert. Cold.

\section{Tuesday 29 Dec}

Card from Cyla. Office all day. Had lunch with Jean. Tea with Hélène Berr. "Deirdre of the Sorrows" (John Synge). ${ }^{340}$ Snow.

\section{Wednesday 30 Dec}

Got up late. Had lunch with Jean. Got the beginning of the explanation but had to go to the office. Went to the Red Cross. Snow. Lesson with Chabert. Three of his friends came.

\section{Thursday 31 December}

Got up late. Went to Dick's but not there. Letter from Mme Faure. Pneu from Yvonne Disner with ticket. Snowing. Did the grocery shopping. It takes so

${ }^{338} 1942$ film directed by Claude Autant-Lara. This was an adaptation of an 1894 novel by French woman novelist Gyp - a.k.a. Sybille Riquetti de Mirabeau (1849-1932). There is very little information about Gyp other than that available at a French wikipedia entry: https://fr.wikipedia.org/wiki/Gyp\#Liens_externes

339 Kristin Lavransdatter. 'Christine' appears to be a misspelling.

${ }^{340}$ Irish playwright John Synge (1871-1909) published Deidre of the Sorrows in 1910. See René Agostini's article on Synge's 'problem play': http://www.persee.fr/doc/irlan_0183-973x_1988_num_13_1_2485 
long and I spend so much money!!! Draught-proofed my room. Wearing ankle socks still. Put on my straw weave shoes because the wooden soles don't grip in the snow. Went to 'The Winter Circus' with the same tigers that injured Gina Manès - real beasts. Broke up with Jean. Went to see Dilys $11.45 \mathrm{pm}$ for the New Year. Came back to mine at 12.15

Resolutions: $1 / 4$ hour of physical exercise every working day (ie: not Sunday) 1 hour of mending and darning etc, housework every day 10 hours thesis a week. 



\section{Introduction 1943}

\section{Turning points}

By 1943 the prospect of Allied victory began to look increasingly likely. Daily life in Paris was still exceedingly difficult for the most part, but morale had improved. It helped that food shortages were interspersed with short-lived periods of relative abundance. Madeleine writes almost double the number of words in 1943 than she had in the previous, bleaker years. She wrote more about her social life. Theatre, opera and classical music concerts were regularly noted down. Notes about the fiction she was reading are also plentiful. The prospect of an end to the Occupation also meant that Madeleine appeared to be less reluctant to refer to its political and military context. In 1943, we see that Madeleine's renewed hope of a return home cause her to contemplate the scholarly and career possibilities which might await her. These musings give a fascinating insight into the struggle she shared with other educated women of the 1940s to pursue her ambitions in the face of societal and cultural pressure to settle for a more traditional role as wife and mother. Madeleine's listings of her reading choices are important in this regard because many of these choices, from Marie Bashkirtseff's posthumously published diary to the novels of the first generation of post-first-wave feminism writers like Winifred Holtby, Rosamond Lehmann and Madeleine Bourdouxhe, reflected her own dilemma between an academic career and a stay-at-home existence - two divergent paths which she struggled in her diary to reconcile.

Madeleine's year began with snow, severe cold and ailments. On the 5th of January she wrote that she was 'dizzy' with hunger. The diary narrative continued to focus on getting enough food to eat and how to cook and prepare it so that it was palatable. At home, in her apartment, the cold was such that the windows were iced up on the inside of the panes and she could not sleep at night. The snow and ice and lack of adequate footwear made it difficult to get around Paris on foot which, given the limited availability of public transport, many Parisians were forced to do. However, unlike the previous two years, the winter gloom was quick to lift. The early spring, which Madeleine described with keenly observed descriptions of a variety of flora in bloom, ushered in an optimistic, brighter tone to her entries. She talked of the possibility of liberation by 
way of scattered references to the progress of the war, Charles de Gaulle's optimistic speeches and to her home country of Yorkshire to which she 'returns' by way of the pastoral evocations of Winifred Holtby. After reading South Riding, set in North Yorkshire, she wrote 'Je belong au Yorkshire'. Home, in 1943, felt closer than it had done for the whole of the previous three years.

By the summer of 1943, military setbacks for the German army in Italy and on the Eastern Front had caused French civilians to speculate - with some confidence - about the imminence of an Allied assault on mainland Europe. There was also evidence that civilian resistance was becoming more established. Certainly, the military wing of the Resistance had, by 1943, emerged as an organised force boosted by large numbers of young men avoiding compulsory work service in Germany: the 'Service du travail obligatoire' or STO (Jackson, 2001: 480). But many ordinary citizens were becoming actively involved in 'soft' resistance. Julian Jackson describes this as 'individual acts of protest like tearing down posters or scrawling graffiti' (Jackson, 2001: 476). For Madeleine, this involved giving up her bed for the night to shelter Allied airmen shot down over Paris and giving English lessons to individuals like Hélène Barland, the document counterfeiter associated with the key Resistance network Turma Vengeance.

Madeleine's brighter mood reflected the improvement in living conditions and her financial circumstances. She had regular and secure employment at France's national library, and more disposable income meant more opportunities to go out and enjoy herself. Incidences of depression and homesickness were fewer. She had got better at coping with the day-to-day grind by 1943 and, over the course of the summer, appeared to switch her attention to how she might cope with life after the Liberation. The Occupation had delayed the completion of her doctorate on which she depended for a future academic career, and a return home to her parents on whom she was still financially reliant was not an appealing prospect. The Occupation had been an ordeal but an empowering ordeal. The struggle to survive and the freedoms she had enjoyed had, she felt, made it impossible to return to the life she had shared with her parents in York before the war. By the summer of 1943, Madeleine was 26 years of age and objectives of both marriage and a career seemed to be slipping away. There are a number of ponderous and sometimes anxious passages in which she contemplates positive and negative scenarios of what life might be like back home after the war. These passages displace, for a brief time, the documentary style of the diary which had dominated the narrative from October 1940. They are prompted by speculative reverie and, on occasion, the 'unreality' of anxiety dreams relating to the future which awaits her.

Dissatisfaction about the possibility of limited opportunities back home comes through very clearly in what she was writing in August: 'A girl stays at home - well, yes, perhaps but not when she has had to earn her crust all alone for three years dictated to by necessity and with only herself to keep her going. The feelings Madeleine was expressing mirrored those of many women 
towards the end of the war. Hannah Diamond describes how women had been forced to take on greater responsibilities during the Occupation. In many cases they took on key responsibilities at home and, on occasion, in the workplace, and many were reluctant to go back to their previous lives after the personal and financial autonomy they had enjoyed (Diamond, 1999: 207). Feminism might have taken a backseat to the fight against fascism in the 1930s but it had not disappeared. Women's liberation had continued to evolve on a number of fronts during the Occupation in spite of discriminatory, revisionist legislation which excluded married women from the civil service, made abortion a capital offence and divorce more difficult to obtain. Indeed, Sylvie Chaperon specifically refers to this wartime generation of young, educated women as providing the political, intellectual energy for the revival of organised feminist protest in the 1960s and 1970s. These women, were, she wrote, women who had fought through adversity to succeed (Chaperon, 2001: 99-116). ${ }^{341}$

It is in 1943 that it becomes clear that Madeleine was selecting novels to read because they mirrored the challenges and dilemmas she faced at this particular point in her life. Over the summer she reads a number of novels by British 'middlebrow' women writers of whom Winifred Holtby and Rosamond Lehmann featured most prominently. A key recurring theme of these novels, written by university women of the inter-war in the immediate wake of first-wave feminism, was the schism between what their female protagonists wanted from life and what society wanted them to settle for. The novels examined the struggle of (mainly) middle-class women to realise their raised expectations when societal and cultural pressures to conform to traditional gender norms were still very present and persuasive. The novels are not a confident validation of a woman's right to pursue her own unfettered course oblivious of social convention and responsibility. Indeed, they present young women as conflicted and frustrated, facing choices which make them vulnerable to isolation and social stigma. A good number of these novels show that 'sex success', the term given by Nicole Humble in her study of the middlebrow novel to women's attainment of social mobility through marriage, still presents women's best chance of improving their lot in life. ${ }^{342}$

Madeleine's anxiety returns time and again to focus on the apparent choice she felt she faced between marriage and a career. Like the middlebrow heroine, she was captivated by the excitement of independent bohemian living and the 'intellectual life'. But she also shared her fear of being 'left on the shelf', of being alienated and cast out for pursuing ambitions of benefit only to herself. If anything, it would appear that the novels, which did not offer happy solutions

${ }^{341}$ Muel-Dreyfus (2001) and Miranda Pollard (1998) both give insightful accounts of the experience of women under Vichy.

${ }^{342}$ Humble (2001) makes this connection between the post-first-wave feminist generation and the inter-war middlebrow novel. 
encapsulating the career and marriage Madeleine hoped for, did not help. After she has read them, she writes 'depressed' after their titles. However, it is interesting that she battled her fears by articulating her own narratives in which she could have everything she wanted but feared she might be denied. She describes her ideal home, complete with diagram. In it, she is an academic, with an academic husband and four young children. She and her husband have study rooms and there are bedrooms and other facilities for their four children. For Madeleine it would seem that 'sex-success' went in hand-in-hand with career success. It was a very modern outlook. We see glimpses elsewhere in 1943 that Madeleine understood feminist discourse, which was still very much in circulation during the Occupation. She was very impressed by Madeleine Bourdouxhe's novel, A la recherche de Marie (1943), recognising through Marie, the novel's Sorbonne graduate heroine, Bourdouxhe's message that if women surrender to societal and cultural expectation then they surrender the possibility of freedom. 'One can polish oneself by using others but one must watch not to wear oneself away. We must not polish ourselves so that the image of the other becomes engraved in us', she writes on August 13th, 'I am getting carried away this evening but it is something I hold very dear and I will fight for that and my freedom all my life. ${ }^{343}$

In conclusion, 1943 is the year when Madeleine begins to see the possibility of an end to an existence which for her, and for most French people, had caused their lives to stagnate and had stymied their personal and professional plans. But alongside an understandable excitement and anticipation of an end to the Occupation came anxiety of what the end of the war would mean for the future. Anxiety about what lay ahead would not have been unique to Madeleine. Many people had endured familial rupture through bereavement, forced labour in Germany or imprisonment of loved ones. Reconciliation with former lives would prove emotionally and practically impossible for many.

${ }^{343}$ For more on how Madeleine contemplated her post-war future, the gender expectations to which she was subject and the place of reading in these reflections, see Michallat's 2017 article 'Writing a Scholarly Occupation: Student women diarists (1940-1944)', Essays in French Literature \& Culture. 


\section{3}

\section{Friday 1 January}

Went to Lardy's. Everyone charming. Françoise's 8th birthday.

\section{Saturday 2 Jan}

Wrote to Jean: "My dear Jean. By the looks of things we have arrived at a bit of a dead end. I can see no way out other than us finishing it. So, adieu. Madeleine. ps. I'd be grateful if you could give me back my "Merlin L'Enchanteur" and my wine allowance card." He'll have that Monday morning. I'd love to see his face. Went to Mme Faure's for $2 \mathrm{pm}$. Had ice cream at Weber's. Card from Mme Desportes inviting me over but received it too late. Pneu from Aunt. Read "Via Mala". ${ }^{344}$ Very good. Went to bed at $4 \mathrm{am}$. Confession but think that I will need to confess again. Card from Colette Brand and Paulette Trois-Gros.

\section{Sunday 3 Jan}

Mass. Went to Aunt's. Aimée and Huguette came to lunch. I hate it at Aunt's but at the moment she couldn't be nicer. Had a note from Colette.

\section{Monday 4 Jan}

Office. (Started the year off well by not doing my gym but I am tired out by all these late nights). Pauphilet. Saw Jacqueline Eichorn. Returned "Deidre of the Sorrows" to Hélène Berr. Went to pay the electricity but it was shut. Went to Mme Desportes. Went to Colette's but she wasn't there. Went to Dilys's. Bronchitis and perhaps the right lung has got something wrong with it? Diphtheria and

${ }^{344}$ A thriller by Swiss writer John Knittel (1891-1970). It was published in 1934. See the Swiss Review for more on Knittel:

http://www.revue.ch/en/editions/2015/01/detail/news/detail/News/heturned-the-world-into-a-stage-for-his-novels/

Page 174: View of Val-de-Grâce from 320 rue St Jacques in winter. Copyright Delphine Biechler, licensed under CC BY-NC 4.0. 
'flu in this district. Wrote to: Chateau, Corbeil, Troyes, Dédé, Colette Brand, Paulette Trois-Gros, Zinser, Zéau, Mlle Bruard (for money), Jeanne Semaille, Godfather, Granny, Vendryès, Jacqueline Piatier. Sent a note to Ruth Camp. It is starting to get colder. I am going to have to put on stockings and wear a wool pull-over under my make-do blazer. Thirsty, pain in the small of my back, stomach ache. Am a bit all over the place just lately - it's all the different food when I am flying all over the place as well as the irregular times. Colette brought "Merlin l'Enchanteur" (2 volumes) (Edgar Quinet). They don't look that good. The lift still doesn't work.

\section{Tuesday 5 Jan}

Snowed. Was at the office all day. Gilberte was transferred to Mlle Murray. Had lunch sat next to Michael who was very intrigued by who had managed to get me to go out with them and reiterated his profession of everlasting love. Paid the electricity. Went to the Hôtel de Ville for the posters. Lesson with Dick. Paid. Feet hurt so much because the soles are made of wood with straw uppers and the snow is so thick. Letter and card from Hélène Koch. Wrote to Mlle Koch. Am so hungry. I was forced to eat some horrible but expensive stuff at 5 pm because I am dizzy with hunger.

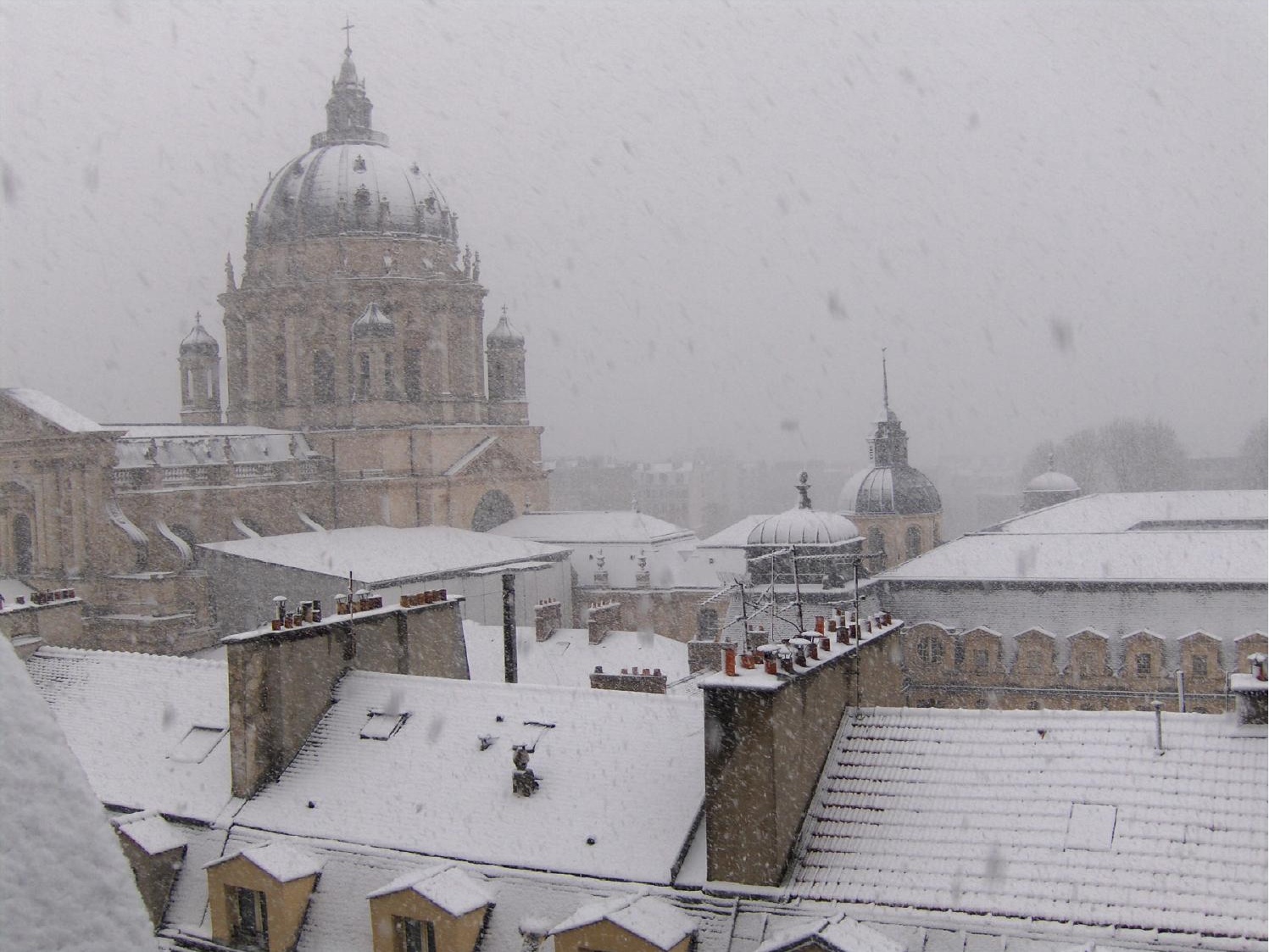




\section{Wednesday 6 Jan}

Office. Breton. Irish 2-5 pm. Tea with Mrs Desportes but a horrible friend of hers was there. "La Source" 7 pm. Hélène. Restaurant. (v.good) "Les Affaires sont les Affaires" (Ch. Vanel). ${ }^{345}$ Could have been a good film.

\section{Thursday 7 Jan}

Office all day. Lesson with Gilberte. Had flageolet beans. Jean returned book. The Pole brought his medicine book to type.

\section{Friday 8 Jan}

Welsh. Irish. Vendryès. Office. Dick. Started translation. Hot water so had a wash. $1 \mathrm{pm}-2^{\circ} \mathrm{C} \ldots$

\section{Saturday 9 Jan}

It is freezing cold. Ice on the inside of the windows. Office. Marc Chesneau visited on behalf of the City of Paris. I was introduced to the poet Paul Fort. ${ }^{346}$ Little 70 year old man very full of himself. Good paper. Not impressed by the poems. Saw Jean but slipped off before he could follow me. He sat behind me listening to the whole thing much to Mme [. . .]'s great amusement. Ate roasted beetroot. We are seeing coins in our change again. Before they gave out stamps or metro tickets. Letter from Corbeil. M. Blum died 23 February 1942!! Confession. Typed the translation. Very windy - being here is like being in a boat in open sea, everything vibrates, sings and sways in the howling wind.

\section{Sunday 10 Jan}

3 am. Pouring rain woke me up. There was a fire behind the Val-de-Grâce. This morning there were long icicles on the iron rail. Ice outside and fog. Mass. C. Villeparisis but Aunt, Yo didn't come - Granny is upset and uptight. - kind.

${ }^{345}$ Directed by Jean Dréville and starring Charles Vanel, the film was an adaptation of Mirabeau's play.

346 Paul Fort (1872-1960), 'French Poet and innovator of literary experiments, usually associated with the Symbolist movement. For more on Fort, see: https://www.britannica.com/biography/Paul-Fort 
Mme Dumont, Gérard, Jacques Deschamps, all came to eat the Epiphany cake. $M$ Lebère made a brief appearance to say that he would not be coming because his wife had come back. Maurice Roche is very ill. Stepfather and Granny are devastated. They would have so loved him to marry Yolande. Came back on the $7.10 \mathrm{pm}$ train. Here 8.50. Fog. Typed translation.

\section{Monday 11 Jan}

Office. The weather is mild as if it's April. Daffodil bulbs sprouting in the window 'garden'!!! Very happy. Typed translation. Took a few posters. Pauphilet lecture. Request for jacket rejected because only for those doing greasy, oily work. Asked for shoe and slipper tickets. Found out about the going rate for medical translations - 14 francs per 100 words of French!!! Telephoned Aunt. Typed translation until $5 \mathrm{am}$.

\section{Tuesday 12 Jan}

Slept from 5-8.30 am!! 40 minutes late to the office!! Went to see Mlle Horn and came down from 750 to 650 francs for the thesis! Went to the Maison des Lettres for interview. Will I get a job? At the very least I should get note taking and translation corrections. Lesson with Dick. Card from Cyla. Wrote to Voirin. Not tired but will go to bed early.

\section{Wednesday 13 Jan}

Office. Welsh. Bachellery - only me and Mme (Maggy) Desportes and I was late too because I had taken posters to St Louis and to Louis-le-Grand. Tea with Mme Desportes. "Jérôme $60^{\circ}$ Latitude de Nord" (Maurice Bedel) ${ }^{347}$ Bought "Sylvie et le Fantôme (Adam). ${ }^{348}$ (I?)

\section{Thursday 14 Jan}

Office all day. Kort insufferable. Went to Hôtel de Ville. Wrote to Aunt. Ruth came but I soon sent her packing. She wanted "Chut Chick" and I haven't got it.

\footnotetext{
${ }^{347}$ Maurice Bedel (1883-1954). The novel was awarded the Prix Goncourt in 1927.

348 A play by Alfred Adam (1908-1982). The play was staged at André Barsacq's théâtre de l'Atelier in Paris in 1943. For more on Barsacq's theatre under the Occupation see section on it in Limore Yagil (2015) Au nom de lart, 1933-1945: Exils, solidarities et engagements (Paris: Fayard).
} 


\section{Friday 15 Jan}

Welsh. Vendryès is sweet. Office. Kort is poison. Has installed clocking-in machines at the office to check hours spent out etc. Cinemas and theatres now not only have a day's closure a week but also no matinée showings except Saturdays, Sundays and national holidays. Gorgeous weather. Homesick. Dick. Went to Chabert's but he wasn't there.

\section{Saturday 16 Jan}

Office. "Ti-Coyo et son requin"349 (Clément Richer). Mlle Péchegut stuck to me like a leech. Told me her woes - poor thing. Came to mine despite the mess. Took the ticket money for the seminar at Mangin "Les Sciences Occultes". Sapellier and Jean were there. Jean stuck to me like a leech. I listened to the paper despite being bored and cold. Jean was not as hardy as me, left at $4.30 \mathrm{pm}$ - after Sapellier. Went to cancel wine allowance card. I'm as happy as Larry - I haven't been as happy for a long time. I feel now that I am free, free. I'd like to be in a little corner to see his face when the shopkeeper tells him the bad news!! Lesson Chabert - who gave me a bit of butter. Beautiful moon. Summons for shoes (already!!) and university medical appointment.

\section{Sunday 17 January}

Mass. C. Bought 6 oysters and after a battle of Homeric proportions, during which I had to change the knife for a penknife, I managed to open them all I'm becoming such a good housekeeper. Wanted to do a thorough tidy but unwisely started with my books so spent the whole day doing that. But I found 2 envelopes. Marvellous. I don't have any more and it is impossible to get any. Went to Madeleine Fortan's and had a delicious hot chocolate. Wanted to go to Dédés this afternoon but as he hasn't replied to my letter I didn't go. It's been a very pleasant day.

\section{Monday 18 Jan}

Office. Lesson with Pauphilet. Saw Jacqueline Eichhorn. Only got a token for slippers. Bought 1 book for degree. The others are out of print. Lesson with

${ }^{349}$ The novel was published in France in 1941. Clément Richer was from Fort-de-France in Martinique. For more on Richer, his background and the novel, see: Damiano Benvegnù (2016) 'Ti-Koyo and his Shark', humananimal brotherhood from Clément Richer to Italo Calvino and Folco Quilici Ecozon@: European journal of literature, culture and environment Vol. 7 (1) pp. 59-75. 
Gilberte Frey but only for a quarter of an hour because the library shuts at $6 \mathrm{pm}$. "Vaisseaux dans le Ciel"

\section{Tuesday 19 Jan}

Office all day. Dick. Letter from Voirin. He isn't pleased that I am still here.

\section{Wednesday 20 Jan}

Office. Bachellery. Breton. Telephoned Boissin-le-gros. Lesson with Chabert. Card from Uncle de Chateau (well, at least from Aunt Aline). Letter from Mlle Piatier. My foot really hurts.

\section{Thursday 21 Jan}

Office. Wrote Dédé a card. 2 pm visit Boissin-Legros. Upset. More injections needed. What a nuisance. I weigh around $60 \mathrm{~kg} 500.3 .30 \mathrm{pm}$. Skin allergy test 13 rue du Four. Saw Denise. 5.30 lesson with Dick. 6.45 Dr Denise Boulenger for my foot which is very swollen and sore. Rheumatism?!!! Talked with Mad. Fortan for a while. "Révolte dans la Montagne" (Meyer). Jean is a "little man" in all senses of the word.

\section{Friday 22 Jan}

Irish with Vendryès, Pneu to Aunt to tell her that I'm not going on Sunday because of my foot. Office. Lesson with Chabert. Lesson with Gilberte Frey at the PTT rue de la Boïté. Jean should find out today that he can only get a single litre of wine!!!!!! His face'll be a picture!! My foot is very painful and pain all up the leg. Worrying.

\section{Saturday 23 Jan}

Office. Mlle. Péchegut is going on a paid stint in a château on Monday. I've sorted her out some cigarettes. Went to Hôtel de Sévigné. Sapellier and Jean. Jean was a picture of despair. Listened to the seminar a bit. Jean asked: "Did you take back your wine ration?". “That's right”. He looked as if he'd been struck by lightning. My taking back my wine rations seems to have affected him more than no longer seeing me. Mlle Péchegut told me that Brémaud was swapping potatoes to get wine (despite having my card as well). That must be some loss

${ }^{350}$ Gunnarsson. Translated from the original Danish and published in France in 1942. 
for him; a greater loss than that of my love. He probably thought that I wouldn't dare do such a thing. I'm quite happy with the result - although I would have wanted to see his face in the shop. He must have had a fit and told them that it was all a lie - he must feel so stupid now. Letter from Aunt. Pneu from Dédé. $1 / 2$ hour lesson with Chabert. Got chemist stuff. Tripoli taken. Got money back on lottery ticket. Nearly bought flowers but didn't. Bought cake for 49 francs. What a disgrace!! - more than I had thought. I mustn't buy any more. Wanted to go to bed and not work or tidy as I should be doing.

\section{Sunday 24 Jan}

Went to Dédés. Aunt has lost weight. “Forte Tête” with René Dary. ${ }^{351}$

\section{Monday 25 Jan}

Office. Pauphilet ill. "My Lady Nicotine" (J Barrie). ${ }^{352}$ Lesson with Chabert.

\section{Tuesday 26 Jan}

Office. Ill. Delivered flyers. Medical examination. Lesson with Dick. Went to Delplanque's to arrange lesson. Dinner with Mlle Kerjean.

\section{Wednesday 27 Jan}

Office. Welsh. Tea with Mme Desportes. Lesson with Chabert. "L'Herbe qui tremble" (Williams).

\section{Thursday 28 Jan}

Office all day. Lesson with Gilberte. Injection. I'm putting on weight. "L'Homme au Pied Bot" Letter Mme Boussingault, Odette.

\section{Friday 29 Jan}

Welsh. Office. Lesson with Dick, Chabert.

3511942 film directed by Léon Mathot (1886-1968). See: http://www.unifrance.org/film/38024/forte-tete

${ }^{352}$ See Ian Jack's article 'Wishful Thinking' on Barrie's 1890 novel about tobacco addiction:

https://www.theguardian.com/books/2006/feb/11/featuresreviews.guardianreview13 


\section{Saturday 30 Jan}

Office. Splendid weather. Went to rue de Sévigné but no seminar. Bought flowers. Telegram Dédé. Confession. Lesson with Chabert half an hour.

\section{Sunday 31 Jan}

Mass. Went to St Denis. Grandfather's grave and "Simplet".

\section{Mon 1 Feb}

Office. Hôtel de Ville. Lesson with Delplanque, Chabert.

\section{Tues 2 Feb}

Office. Had hair cut and waved. Lesson with Dick. Made crêpes.

\section{Wed 3 Feb}

Office. Welsh. Handed out flyers. Lesson with Chabert. Letter Aunt, Mlle Pêchegut, Hélène Koch.

\section{Thursday 4 Feb}

Office all day. Lesson Gilberte Frey. Went to the Maison des Lettres. Signed up to the theatre group!!! 8.30 audition. Mimed "Le Fain" Not bad. Didn't go lesson Chabert - for possibly 20 minutes. He annoys me with these half hours all over the place.

\section{Friday 5 Feb}

Welsh. Office. Lesson with Dick. Colette came. Telephoned Aunts, Wrote to Hélène Koch.

\section{Saturday 6 Feb}

Office. Bibl. Hist. Lesson Chabert. Hairdresser. "Comédie et Proverbes" (Musset)

\section{Sunday 7 Feb}

Mass. Villeparisis, Marcel is a handsome man. 


\section{Monday 8 Feb}

Office. Lesson Pauphilet. Returned book to Mlle Appel. Lesson Delplanque, Chabert. Mme Delplanque arrested. Darned. Finished (finally) salmon pink sweater. Letter Jeanne Semaille.

\section{Tuesday 9 Feb}

Office. Was paid by the Soc. des Musicians. Went to the Red Cross. "No news. Worried. Uncle Corbeil died. Zeau. André, all friends send fond wishes. Another haircut; permanent wave; obvious improvement. Health good. Much love. Thinking of you constantly. Madeleine". Lesson Dick. Went to bed early. Wrote to Colette. Aunt. "Vieux coeur en voyage" (Hans Fallada). ${ }^{353}$ Office all day.

\section{Wednesday $10 \mathrm{Feb}$}

Office. Welsh. Bachellery. Hôtel de Ville for posters. Chabert.

\section{Thursday 11 Feb}

Office all day. André telephoned. He is going to Germany on Monday. ${ }^{354}$ Injection. Lesson Gilberte Frey. Wrote to Hélène Koch. Prepped Welsh.

\section{Friday 12 Feb}

Welsh with Vendryès. Bachellery didn't show. His wife is worse? Office. Giselle de Mesnil not there. She is leaving. Lessons Chabert, Dick. Telephoned Aunt.

\section{Saturday 13 Feb}

Office. Injection. Hôtel de Sévigné (Jean was there. "Why thank you" in response to my filthy look. Lesson Chabert. Signed up to a French language group. "Theatre" (Sacha Guitry)

${ }^{353}$ Written by German novelist Hans Fallada (1893-1947) See the site Et puis après? Actualités littérature autour de Hans Fallada for a contemporaneous 1942 review of Fallada's novel and background about the novelist:

http://etpuisapres.hautetfort.com/archive/2017/04/16/vieux-coeur-en-voyagerecension-le-journal-21-avril-1942-5933439.html

${ }^{354}$ It is unclear whether this is voluntary or obligatory work service in Germany. 


\section{Sunday 14 Feb}

Mass. St Denis with Yolande. Came back to Paris with Colette to get ham. "Les Petits Riens"355 (stupid). Dinner with Dédé. He is leaving tomorrow. Race for the train "I'll kiss you another time". How grown up he is!

\section{Monday 15 Feb}

Office. Hôtel de Ville to see Mme Boussingault - not there - heard Jean's voice talking politics (his sickly voice irritates me) so I left. Lesson Pauphilet. Lesson Delplanque, Chabert. Injection. Ruth came to borrow my typewriter - I refused. She only calls by when she needs me and so I politely showed her the door. Wrote C. Péchegut. Rain.

\section{Tues 16 Feb}

Office all day. Sent cigarettes C. Péchegut. Hôtel de Ville. C. Péchegut there. Sold cigarettes to Mme Boussingault. Jean's eyes popped out of his head when he saw the cigarettes. He wanted to take me to one side to talk but my way out was covered by Soulié. Lesson Dick. Slept badly.

\section{Wed 17 Feb}

Office. Welsh. Bachellery. They are saying students have to leave for Germany on Sunday but everything is on hold for the moment. Wrote to Aunt Violette. Injection. Lesson Chabert.

\section{Thursday 18 February}

Granny's birthday. Was at the office all day. Mme Boisin-Legros. Huge joy. I will have to get married between 25 and 30 but not later than 30 that's for sure so as not to go mad. Damn it. I know that I am attractive. Bought a mirror and a comb for Gaël. Locket for Kitty. Went to Dilys's place, made dinner for Gaël. Dil. came over later to speak to me about Françoise. Miss Beach is back from the camp. ${ }^{356}$ Kort has a limp or, at least he does when he remembers (is this to get my sympathy or to get out of going to Germany?) (either way, he's sniffing around me) Lesson Gilberte Frey. Cold. Sent a few words and a drawing for Denise.

${ }^{355} 1942$ film directed by René Leboursier starring Raimu and Fernandel. http://en.unifrance.org/movie/7608/les-petits-riens

356 Sylvia Beach was released from internment in Vittel. 


\section{Friday 19 Feb}

Welsh Vendryès. Office. Kort charming. Denise telephoned. Student of dental surgery spoke through the whole of lunch. Lesson Dick, Chabert. Chabert suggested an outing tomorrow. I accepted. Why not? Injection. Big smile. Mme Delplanque came back. "Croix du Sud".

\section{Saturday 20 Feb}

Office. Seminar rue de Sévigné. Went to Chabert's. He bought me an ice cream at Pons (yum yum). Colette came to eat. Note from Cyla.

\section{Sunday 21 Feb}

Mass. Villeparisis. Beautiful day. Walk round the pond. Last injection.

\section{Monday 22 Feb 1943}

Office. Queue for food ration card. Mlle Delplanque did not come. Lesson Chabert. The Swiss woman (Mme Laberrie) and young German officer were there. Very misty. Housework.

\section{Tuesday 23 Feb}

Office all day. Wrote to Cyla. Did washing. Lesson with Dick. Very misty.

\section{Wednesday 24 Feb}

Office. Welsh Bachellery. Spoke to M. Kermarec - lent me "20 ans de Jeunesse" (Maurice O'Sullivan). ${ }^{357}$ Tea with Marguerite Desportes. Lesson with Chabert. Pneu from rue Henner about getting paid tomorrow - have I gone back to 460 frs? That wouldn't be on - I'll leave.

\section{Thursday 25 Feb}

Office all day. Pay was still the same. Lesson Gilberte Frey. Went for dinner at Giselle de Mesnil's. Cold. Saw daffodils at the florists.

Maurice O'Sullivan. Irish writer. The novel was translated into French by Raymond Queneau in 1934. See: Etudes irlandaises for Claude Fierobe's 1998 compte rendu:

https://www.persee.fr/doc/irlan_0183-973x_1998_num_23_2_1471_ t1_0182_0000_5 


\section{Friday 26 Feb}

Welsh Vendryès. Office. So it seems that I'll have to do 32 hours a week? What next? 3 hours less than those on 2,200 - and me on 1,400? And what about my studies? I want to leave - but go where to earn money? I'd happily do 32 hours a week at home - but not in the office. Plumber came. He was wearing a bowler hat - like the ones in England. Is that a requirement of the job? Lessons Dick, Chabert. Saw a fellow in the street, pallid, shaky on his feet, hunched over, tongue swollen up and hanging out, frothy yellow saliva. The bobby was keeping his distance. Latin translation. Wrote to Aunt. Jacqueline Piatier came back. Tired.

\section{Saturday 27 Feb}

Office. Went to the Bibl. Hist. Costumes hadn't arrived. Soulié not there. Desperate telephone calls. The office boy grabbed me by the waist in the corridor!!! Since I've had my hair cut I'm being called out at in the street, something that hasn't happened to me since I was 19!! Very amused by Jean who turned up dressed up to the nines and thinking himself very chic in his black overcoat. Beside himself that I paid no attention to him. "Beau temps - pour une promenade à la campagne". He said this very slowly and intently whilst staring at me. Found out that he is a detested little sneak. Lesson Chabert. Went to Colette's for a Latin translation. She has a big bedroom with 2 windows. Same sort of home-made things (bookshelves out of planks, table etc). Fine weather but cold.

(Saw that the fire station on Bd Pont-Royal all shuttered up. Françoise B. told me that young people who did not register their names at the first census are being held there. Tuesday 9 March). ${ }^{358}$

\section{Sunday 28 Feb}

Mass. Did a bit of housework. Drank 3 glasses of wine - number 1 was bad, the other two were good - will I become a lover of drink? Fine weather. I have been hearing the first cooings of pigeons for about a week now. In my box, baby forget-me-nots are growing - there is a crocus too. Did I say that a daffodil was going to flower? I must do some mending. Tired but feel very positive. I have two lumps under my eyelids. It must be like last year. It is so splendidly sunny, not a cloud. The trees of the Val-de-Grâce are not in bud but they are a shade of brown which anticipates the rose colour of the leaves to come. The branches are white in the sun. My first fly of the year climbed up the window pane.

Rations for the month of March: per week - 90 grams of meat, per day - 275 grams of bread, per month: -310 grams of fat. 160 grams of cheese. 1 pound of sugar - 150 grams of coffee

358 Note added on 9 March. 
250 grams of pasta - 150 grams of soap (including soap for the bathroom).

Darned. Mad. Fortan came to chat. 2 ankle socks: 4 hours of repairs. I shouldn't let there be such big holes - but the socks are of such poor quality; and even though I have had them for 8 months I can't replace them because I have neither points nor money (for black market).

(the baby forget-me-nots were only weeds 25 July) ${ }^{359}$

\section{Monday 1 March}

Gymnastic exercises. Office. So, I'm having to do 32 hours!!! Shall I leave? Or go back to 2,200 - if they will have me. Saw Mlle Péchegut. So Jean is complaining that I treated him badly - like a subordinate, He is doing all he can to sully my good name. He's playing the little blackmailer! What a wretched fellow - I can understand why he is not liked. Paid the Gas. Went to the Soc. des gens de lettres to get money. Housework. Mlle Delplanque came for her lesson. She is very afraid of me. Lesson Chabert. Madeleine Fortan invited me for dinner at her friend Marcelle's. Vermouth, noodles, fried potatoes, sugar and biscuit de soldat. ${ }^{360}$ Very tired so went to bed.

\section{Tuesday 2 March}

Office all day. Didn't do any exercise because my stomach hurts. I've had pains in the stomach now for 15 days. I can cope with it. It's more a dull ache than anything. It's like I've been hit hard there but I remember nothing about it. So, we are expected to work 32 hours a week now - but neither party is insisting and we manage to get away with not doing it. I really need that degree ${ }^{361}$ if I am going to find work or if I want to earn more. Bought daffodils - they are beautiful, really divine. It'd have been nicer if they had their own leaves instead of the ferns even though they are pretty. Watered the plants. The dryness is killing them and I don't look after them enough. Worked here. Lesson with Dick. Bought $1 \mathrm{~kg}$ of rice for 250 francs. I'm mad but I'll be glad of it later. Mad. Fortan came to mine. She's going to get ill. Finished "Vingt ans de Jeunesse" (Maurice O'Sullivan). Very good. I am working in the light of the little lamp. It is a pool of light. The rest of the room is in shadow. The daffs are a transparent yellow in the light with a green tint like flowers in a dream that drift

359 A note added on 25 July.

${ }^{360}$ Also called the 'pain de guerre'. More on the biscuit and its history can be read (in French) here:

http://www.compagnons-boulangers-patissiers.com/crebesc/pain-de-geurre/

361 The degree in English Madeleine registers for in 1940 which will qualify her to teach in schools in France. Her doctoral thesis remains her priority but there was no telling, in 1940, just how long the war would last. 
downwards through a green sea. Madeleine F and Jacqueline Piater are chatting in the corridor. I won't go out. I have to get on with studying.

(A bomb was thrown at the soldiers' restaurant Bd' Mich' at around 21 hours Chabert told me $)^{362}$

\section{Wednesday 3 March}

Office. Welsh. Bachellery. Chicory. Chabert for an hour. I'll only have two hours a week from now on - a lesson down and I need the money. Never mind. Wrote to Aunt.

\section{Thursday 4 March}

Office all day. Lesson with Gilberte Frey. Letter from Mme Faure. Wrote to Mme Faure.

\section{Friday 5 March}

Welsh with Vendryès. Office. Giselle telephoned. Went to Dick's but not there.

\section{Saturday 6 March}

Office. Rue de Sévigné. Sapellier and me. "Du côté de chez Swann" by Proust. ${ }^{363}$ I am thrilled by it. It is marvellous, powerful, this evocation of the past. Such artistry. Identity checks at the concert at Ecole Normale Sup de Musique. Jean came. "What is dead is dead but that is no reason not to stay good friends", he says. Fair enough, but I don't want it to be a starting point for an attempt to win me over again. Got an insight into the thoughts of a chic well-dressed young woman, clearly from a very good background, when her papers are checked by mistake 3 times. "Ah! They really bloody annoy me!!" (!!!) Went to the concert. Very good. Loved the harp. The cellist played very well, particularly the "noisy bit". Astonishing foreshortening of her when viewed from above, like a ball, in a black velvet dress, rounded white arms bent around this large instrument. The violinist had a perfect technique but played with no feeling. Jacqueline Piatier is leaving for a while, left me some flowers to look after. Confession.

\section{Sunday 7 March}

St Thomas Aquinas. Mass. C. Beautiful day just as I like them, the air cold; wind - a retreating horizon - for the first time this year, the houses stand out

362 Written in brackets in the margin alongside the entry for 2 March.

${ }^{363}$ Marcel Proust, French novelist (1871-1922). Du côte de chez Swann was published in 1913. 
and behind them the shadow of the mountains. I should go out to enjoy the beautiful weather but my foot is very painful again after yesterday (all day in little red shoes). There are also too many people. Read Proust. Am bowled over by it. What a great style, what description, what atmosphere!! I'm going to unpick my coat so I can have it turned up. A daffodil (the only one) on my balcony has broken through its envelope of dead leaf, yellowed its green pod before its trumpet burst through. Baby forget-me-nots are coming through everywhere. I am going to instil some order amidst their sproutings. But, what flowers shall I put in? I haven't got room for everything. I'll have to make a choice. (Boutillier du Retail - director of the Centre de Documentation at the $\mathrm{BN}$ is dead).

\section{Monday 8 March}

Intended to do some thorough housework but didn't really feel up to it and because I hadn't yet finished unpicking the stitching of my coat I set about doing that. I haven't yet finished. It takes a long time to unpick it stitch by stitch particularly because it has been done by machine. Cécile P. received some bad news from home. She's got a hard life and not a lot of friends because of her off-putting manner. She has a heart of gold - but her table manners are horrendous. Françoise B. came over. Alas, she is making visits "Jacqueline style" 4 and a half hours!!!! Very nice, but she stays too long. Then the lesson with Marguerite Deplanque who didn't turn up - got a pneu from her at 6 o'clock - a bit late! Oh well! Françoise must be bored - talked about art, literature, music, war. I must go to see her. She seems to want to have me as a friend. She's always prompting meets! Lesson with Chabert. Very bawdy. Very attracted by sexual matters - the only thing he remembers about London is the prostitution. Wants my views on prostitutes etc. Good God, men here are really obsessed with sex!! Strange - on a different matter - to see his reaction to the "Pugna Thermopylae" at the Concert Colonne. His opinions very different to those of Françoise. He sees himself as very radical for liking it. I would have had to have heard it to be able to appreciate it - even though I am not an authority on music - to see what it is about. Mad. Fortan lost - or has had stolen - her beautiful suede belt in the office. She is so upset. The nights are very fresh. Woke up at 2 am shivering. Had left the window ajar, but I had more covers over me than I usually have. Round $11 \mathrm{pm}$ and $2 \mathrm{pm}$ anti-aircraft fire was pounding away. They must be going into Italy. Beautiful day, beautiful sun but cold.

\section{Tuesday 9 March}

Mardi gras. I'll have to buy myself a bit of butter to make myself some crepes (without milk, eggs, vanilla, sugar). Replanted the snapdragon - wanted to throw it out but it would have broken my heart to condemn it to die so I put it in a pot. I don't know whether it will survive. My little geranium is fighting hard for its life so many times I've thought it dead when I've left it out in the cold or taken it from 
the warm bedroom or forgotten to water it. What a lesson in vitality and fight it gives. Had a glass of wine and 50 grams of bread for my lunch - bah! When I go back to the market (because I am going to the market for the first time since August) I'll get myself a slice of bread and butter. I will have to throw out my daffodils. They are not completely withered but the scent of dying daffodil bothers me, it jumps out at me when I walk into the room or when a brisk movement stirs the air. The sparrows are chirping at the window for crumbs - but I don't have any. The mist is thick this morning and one can't see further than the trees behind the square building of the Val-de-Grâce. At the market - long queues in front of the 3 stallholders selling cauliflowers. Carrots could be had with a ticket (which I no longer have) and artichokes (which give me stomach ache). Bought 12 oysters, dandelions, thyme, bay leaves etc. No butter at Dubois. Will they have any this evening? No nice flowers. I'll make myself a stew with my last potatoes and half a carrot. If it's simmered for a while it might work? Lesson with Dick.

\section{Wednesday 10 March}

Sent money to the Ecole Universelle. What will come of that? Welsh with Bachellery. He is such a crashing bore. It's awful. Finished unpicking my coat. I only have to take it up now. Official announcement of death of Boutellier du Retail. Died Sunday. Sent carte de visite with condolences.

\section{Thursday 11 March}

Tacked coat. 1 pm lesson with Chabert with Mme Laberrie. Chabert very flustered by the presence of Mme L - did an atrocious dictation. Went to the hairdressers to have hair curled. Not very pleased. Went to Mme Faure's who said that Yolande had had congestion in her lungs but that she had not taken time off work!!!!!!!! Phew! Well that's quite something (she could make that up about a simple cold. Never believe anything she says). When I got home I typed up article [...] then prepped Welsh until 5 in the morning. Not hungry nor tired. My anxiety attacks are back. Stomach very painful like as if I had been punched - pain in the side. It must be an attack of appendicitis.

\section{Friday 12 March}

Woken up at 8 am by Jacqueline Piatier who gave me 2 eggs and told me that she has got engaged!! The doctors who looked after her must be good. Welsh with Vendryès. Went to book a place for the theatre with Mme Faure. There are only places for Wednesday left. Went by the bank to see Aunt. Her cousin Jean from Verrières has died, fell under a métro train at Massy-Verrières. "Maybe he had an attack of dizziness?' - "He takes his secret with him"!! - Shades ${ }^{364}$ of

364 'Shades' written in English in the manuscript. 
Henri Bordeaux!! Went to the Soc. des Musiciens. Lesson with Dick, Chabert. Anxiety.

\section{Saturday 13 March}

Slept in late. Went to rue de Sévigné - forced to stay until the end, because Villabella (?) Fontoblia was there. Got ready for Colette coming over, cake etc but she has the flu and so she's not coming - all that expense for nothing - and having to eat into my stocks of beans - oh well, never mind.

\section{Sunday 14 March}

Didn't go to mass because talked too long to Mad.F. Villeparisis. Everyone charming. A few anemones in the woods; a blue vetch, a few catkins. There are a few primroses in the gardens; lilac in bud.

\section{Monday 15 March}

Office. Went Hôtel de Ville to see Fontoblia for posters. Lesson with Delplanque, Chabert. Dilys came - she is going to ask me something!!! Started to study seriously. Anxiety attacks. Eaten too many beans - Gosh I'm bloated. My daffodils are opening nicely. They are still a little greenish. No more shop window displays. The antique dealers have their windows painted white with just a little opening to show a small item of furniture. It is ridiculous. Wrote to Colette and the theatre circle.

\section{Tuesday 16 March}

Office all day. Lesson with Dick. His mistress was on her way out. She's pretty, although a bit tubby.

\section{Wednesday 17 March}

Office. Handed out posters. Shattered because it was hot. Saw an adorable little pot in Dresden porcelain - a windmill, 2 houses, blue on white. Bought it. I (very pleased but tired). Hôtel de Ville. Welsh with Bachellery. "La Baie de Destin" (Byrne). ${ }^{365}$ Very good. Wolfed 3 biscuits and then rushed to the Atelier for "L'Honorable M. Pepys", with Mme Faure and one of her friends. The benches are awful in the Gods. The play was fun, had some go about it. Enjoyed myself. Dead tired.

365 Donn Byrne (1889-1928 ). Translated by Maurice Rancès and published in 1931 in France. See bibliographic entry at the Bibliothèque nationale: http://data.bnf.fr/12105697/maurice_rances/\#rdt680-12105697 


\section{Thursday 18 March}

Office all day. Lesson with Gilberte Frey. Went to Giselle de Mesnil's for potatoes. I.

\section{Friday 19 March}

Welsh with Vendryès, Office. Lesson with Dick. Wangled 1,250 g worth of bread tickets from the Centre. Very hungry. What lovely weather.

\section{Saturday 20 March}

Office. Kort furious that we were reading the newspaper. Bibl. Hist. the singer didn't turn up and I had to announce that to the audience. Not good. Confession. Dinner with Mad. Fortan and her friend Marcelle. Pneu from Aunt. Card from Jean de Dex.

\section{Sunday 21 March}

Communion. Mass. Changed the bedroom around. Very pleased because the room seems bigger. Made a bedroom area and a lounge. Darned. I.

\section{Monday 22 Mar}

Office. Posters. Hôtel de Ville. Didn’t see Fontoblia. Went to Françoise Boësse's, not there. Saw an almond tree, in full flower. The chestnut trees are bursting into blossom. One can see them opening up hour by hour. I'm not exaggerating. I will never get used to these Springs which explode like a bomb. Yesterday I listened to a speech by $\mathrm{Ch}-\mathrm{L}$. War over ' 44 or ' $45 .{ }^{366} \mathrm{Oh}$, crikey me!! Will I live to see the day? The sty in my eye has burst. 15 days now without any butter. Wrote to Aunt. Yesterday night there was a strong smell of burning wood. Me and two little girls told the concierge. Turns out that the Zazous downstairs were burning a floorboard!!

366 This may have been a speech by Charles de Gaulle made on 18 March 1943 and broadcast on Radio Londres. Madeleine was not always accurate with dates so the fact that she noted this down on 22 March does not entirely exclude the possibility that she is referring to this speech. For more information about De Gaulle's wartime broadcasts from London and the reference to the 1943 speech (p.181), see: Marie Geffray (2011) Charles de Gaulle et André Malraux, le discours et l'action (Paris: Éditions François Xavier de Guibert). 


\section{Tuesday 23 March}

Office all day. Kort was poisonous. Bought return métro tickets. Lesson with Delplanque - paid me thank goodness (I only had 10 francs left). Many compliments about the new bedroom layout. Dick wasn't there but I will count that lesson. I have had enough. "Roman du Lièvre" (Francis Jammes).

\section{Wednesday 24 March}

Mummy's birthday. Office. It rained a little. Welsh with Bachellery. He is such a yawn. Tea at Maggy Desportes's. Ketty cried a lot. Izou is adorable. I must get some expensive wine - I got some for 20 francs 10 centimes!!! I really have to work - or what will happen with the exam? Got ration card for food but not for coal because the queue was too long. I will go early Friday morning. My eyelid has gone down a lot. "Leçon d’amour dans un parc" (René Boylevsé) "Le Vieillesse d'Hélène" (J. Lemaitre) It is bad to read instead of working - I really need to get down to it. Raining heavily.

\section{Thursday 25 March}

Woke up late. Office all day. Kort was poisonous. Beautiful sunny day. This lunchtime spoke with the young woman about theses - I didn't recognise her. Absolutely tired out - so didn't work. I wanted to but my head is spinning and the words are spilling around like water in a spring. I went to bed at $10 \mathrm{pm}$ to try to come round a bit. Dark and warm night, a strong scent coming from my stocks.

\section{Friday 26 March}

Coal ration card. Welsh with Vendryès. Bought 'South Riding' (Winifred Holtby. ${ }^{367} \mathrm{I}$ am so very happy because it is a book I've wanted for such a long time. Rain. Office. Lesson with Dick. It warms my heart to see Leeds-YorkAlderman in print. Je belong au Yorkshire. ${ }^{368}$ Slightly depressed because of homesickness? ${ }^{369}$ I've had enough of eating noodles, potatoes, noodles, potatoes since October. 10.15. It's pounding away.

367 Winifred Holtby (1898-1935). Associated with British inter-war women 'middlebrow' writers. Madeleine evokes the North Yorkshire landscape of home through Holtby's novels.

368 'Je belong au Yorkshire' written in French and English in the manuscript.

369 'homesickness' written in English. 


\section{Saturday 27 March}

Office. "Litt. épique et poésie hindoue". Brémaud was there to work the projector. Mme de Mesnil came. Colette came in the evening for the translation. Not yet able to throw her out. My beans were very good. Lesson Chabert.

\section{Sunday 28 March}

Mass. C. Washed coloureds. Housework. Mended.

\section{Monday 29 March}

Office all day. Cold. Paid. Lesson with Delplanque who brought me "Le Livre de San Michele" (Axel Munthe) ${ }^{370}$ It is brilliant, brilliant, - but I read it until 2 am. [...]

\section{Tue 30 March}

Office all day. Did ironing. Bought cauliflowers. Bought books so as not to waste my ration tickets before they go out of date. Lesson with Dick.

\section{Wed 31 March}

Office all day. Rain. Wrote to the Librairie Carus because still not got the paper. Little bookshop below. Was so upset yesterday. They took all my points from one card (I had 198 francs worth!!!! - and put them with the 130 frs from the other card!). That's 300 frs that I was not planning on spending. It is going to be tight again this month. I need to be careful. The trees in the Luxembourg Garden are all green. Bachellery had a son 3 days ago. Went to Giselle's for dinner and pancakes. The pancakes stuck but the flour was made out of broad beans! Nasty letter from Aunt "We don't make a habit of going to houses where fun is all that matters"!!!! "I was going to send you a pneu but didn't have the time. You couldn't apologise but you weren't going to, maybe" (perhaps an add-on doesn't even have the courage of her convictions). Marcel had come. I am sure that she was only too pleased not to write to me. I must be the main topic of conversation between Yo and Aunt - as if they have nothing better to talk about!!

${ }^{370}$ Axel Munthe (1857-1949). Memoirs of Capri and the cultural circle in which Munthe worked and socialised. 


\section{Thursday 1 April}

Wrote to Aunt. Started writing up diary. ${ }^{371}$ Office all day. Giselle came to the office. Lesson G. Frey. During her lesson everything went black and started to swim. Ate 2 mushroom crepes without tickets and felt a lot better. Everyone thinks that I am prettier and prettier - delicate features etc etc. Nothing but flowers left. The little shopkeeper woman opposite is pushing it - one little lettuce with three leaves for 5 francs!! Ate some radishes today for the first time this year. In the office, everyone pinning little paper fishes to their neighbours' backs. A circular came round - students work 24 hours a week instead of 32 but because it's all fiddled, it only means one and a half hours less. Kort is losing his marbles - after making Bertin-Conrad take the iron minerals stuff out of the iron file he made Deirdre and me put it all back exactly how it was before!! Haven't they got anything more useful for us to do? So we started doing our own work for our studies. He was flitting around us doing nothing useful himself and didn't dare say anything.

\section{Friday 2 April}

Welsh. Vendryès. Vendryès very worried and cross. A record has been made of the names of foreigners at the Faculty. Office. Bertin-Conrad has been demoted - now he is filing etc. Went to Hôtel de Ville (saw Soulié, Fontoblia. Bought one artemisia, one begonia with the money I wangled (they hadn't marked up the commission on the tobacco). 10 minute lesson with Dick, having waited for him for 50 minutes. There won't be any seminars on Saturdays for a long time. That's rotten luck, 200 francs less!!! But one plus - Saturday afternoon free and more opportunity to see J, thank God. Mlle Péchegut is ill. I must take her some flowers - perhaps. Jacqueline Piatier must be getting ready to move out - saw the furniture being shifted. I think that her mother is with her. All the chestnut trees except one in the square in front of ND are in full leaf. What a beautiful fresh wind blowing in the sun.

\section{Saturday 3 April}

Office. When I got back Dilys came round. On verge of nervous break-down. ${ }^{372}$ Went to Dilys's straightaway and she gave me Georges' meat ration tickets and an egg. She wants me to take Gaël to Poitiers. It is a long way, but I'll go. Did Latin translation for Colette, but when I went over, I didn't breathe a word

371 'diary' written in English. This is the first hint that Madeleine may be transcribing notes made during the day into the diary 'in neat'.

372 This sentence - 'on verge of nervous breakdown' - in English in the original manuscript. 
about it other than when I gave her the book back. Lesson with Chabert - half an hour. Went to Colette's. Her mother came. Her mother is a bit deaf and a bit fussy, ${ }^{373}$ and very proud of her daughter. Colette found her mother's presence awkward in front of friends. She curled herself up ${ }^{374}$ like a tiny little girl. Another friend came. She was a rough sort. I think I'm rid of her - or perhaps C. no longer needs me to be spied on. That suits me.

\section{Sunday 4 April}

Mass. C. Splendid weather. Beautifully sunny. Housework. Wrote up diary. 2.15 air raid warning. Heavy firing. The birds are terrified. Mad. F came over. We stayed at the window for a good hour until the end of the alert. I've got a bit of a headache. What superb sun. I can make out the houses behind the forest at Vincennes which is still completely grey. Three chestnut trees are in leaf at the Val-de G. The other trees are a browny yellow; a colour which comes ahead of the green. Lots of bees are heading for my wallflower!! Going to eat a slice of bread and butter (although it's extravagant) and I'll get back to copying out the diary. I'll be a lot neater doing this. I'll do some mending this evening by lamplight. 10.45-11.30. Alert. Renault at Boulogne-Billancourt was bombed this afternoon.

\section{Monday 5 April}

Office. Cold at the office but boiling later on. Put posters up. It isn't the going back and forth that is exhausting but the going from floor to floor. Had the surprise of my life at Luxembourg. The buds on the chestnut trees are about to open out!! And only 8 days ago there was barely a dusting of green!! 4.30-4.50 air raid warning. Went to Dilys's. Jacqueline Eichhorn was there. The little girl is so well behaved and mature for her age. Wrote to Dick to cancel the lesson for tomorrow. Marguerite Delplanque arrived $3 / 4$ hour late so gave her a lesson for $1 / 4$ of an hour. Lesson with Chabert. Dilys came over about the arrangements for tomorrow. She found a pile of excuses for sending Georges and Gaël away. The truth is that she does not love them She's the sort of woman who would like to have lovers - not a home life - and to think that there are women who would love to have children, a home to be proud of (me) and who don't get married. She is tired but she only has to give up a few lessons. Smoking tobacco is the only thing that keeps her going. Did some mending. To think I'll have to be up tomorrow at 5 o'clock (3 oclock with the sun - or no sun). What heroics!!!

\footnotetext{
373 'fussy' in English in the manuscript.

${ }^{374}$ Written 'se curl up' in the manuscript.
} 


\section{Tuesday 6 April}

5 am alarm. 6.15 over to Dilys's. 7 am to the train. 7.45 am train leaves. 11.15 arrived in Poitiers. 5.10 pm leave Poitiers. 9.15 pm arrived Paris. $10 \mathrm{pm}$ at Dilys's. 11.15 back at mine. $12 \mathrm{pm}$ in bed. Wonderful day. It was raining when we left in the morning. Had Gaël on my knees the whole time but she was so lovely, not like the little horrors, boy and girl, who wouldn't sit still in the compartment and were fighting, yelling, crying and rolling around on the floor etc. It was the opposite with Gaël who was encouraged to be more sensible because everybody was enthusing about how sensible she was. Dilys was heavy hearted to see her little girl leave. Because I couldn't open the case of toys en route I produced my little toy dog - but disaster struck. Because it made her cry she woke up the real dog sat on the lap of the woman next to me. Melodrama untangling the real dog, Gaël and the toy dog. Gaël won over the Gentleman-with-the-dog. Arrived in Poitiers, no Georges but he came later after lunch. Gaël slept and when she woke she was as fresh as a daisy and thrilled by the little kittens which she called "little ducks", she so wants to see little ducks. She was just lovely when she saw her father, she bunched herself up, her arms crossed tightly and wriggled around just like a puppy - all the while stamping her feet. She is just so lovely, I don't understand why her mother wants to get her off her hands. The trees are all in bloom - huge blue bouquets everywhere. Very little pink - which is a shame, pink is so pretty. Near Orleans, the lilac is in flower. At Poitiers there was wisteria and in the cracks in the walls there were yellow wallflowers. I was thrilled to bits when we went over the Loire - the beautiful Loire - wide, shallow - sandbanks and so, so blue. I had not anticipated that I would be so moved. On the way back, saw my "first" chateau de la Loire set against the greenery, another thrill. It was such a wonder I wanted to yell out. It was only a passing glimpse but it was very clear - two octagonal towers (?) which must be so richly worked and which must have a staircase inside - (I don't know that but I would like it to be the case) At Poitiers, old churches. I didn't have a clue about the layout of the town and Georges did not help but I think that I saw the main bits. Went to the cathedral St Pierre (XI-XIII centuries) which is sunk in the earth right up to the top of the gate. There are a dozen steps to climb down to get into the cathedral which is very light (the windows have had to be taken out), spacious and cold. Then tried to go into a strange little chapel which was shut, then walked around St Jean's basilica (IV century), circular, (not Roman style, couldn't find it in the Larousse). The roof comes down to the road; a moat has been dug around it. It's funny how these things are sunk into the earth. Saw Notre-Dame la Grande (Roman style). Very pretty inside with all its frescos which are so bright and cheerful, so fresh. They've gone from the bases of the pillars, rubbed off by centuries of worshippers but so dazzling higher up and in the dome. St Michel - not that interesting other than it is like two churches stuck side by side. Got a little bit lost, not knowing the name of the hotel, but found my way after a few panicked moments. Went 
to the Salle des Pas Perdus (Palais de Justice) an old chateau belonging to the dukes of something or other I can't remember. I finally realised that I was in the great hall of a chateau - at the top end with a dais and three chimneys. Ghosts of Lancelot and Perceval. Because I was on my own I could go into the chimneys to see the sky, going from one end to the other and everything. Pretty.

Bought a pair of gloves from a young girl in regional dress who makes them. A bit expensive but never mind. Sent a card to Denise Pedon.

On the way back saw lots of different colours of earth - very white then browner. There is a beautiful cathedral at Orleans. Saw my pretty Loire again.

Brought back 2 doz eggs, 2 camembert to share between Dilys and me - she said: "Stay to dinner", I had to be persuaded but I stay. 1 egg on the plate, purée, a bit of camembert. "That makes 8 eggs for you" she says (yes, if her mother is counted in). But she makes off with the two camembert (and mine?). When I get home I see that I have only 7 (seven) eggs. She served me "my" egg at dinner "given" (?) by her. What a strange way to work it. Luckily I had bought two cheeses without tickets without fat. ${ }^{375}$ which are not bad. If I had known I would have bought more. Finished off Gaël's coffee in the flask.

\section{Wednesday 7 April}

Office. Windy enough to blow you away. Rain. Hail. Finished taking the posters. Welsh with Bachellery. His son is called William. Went to Hôtel de Ville but Fontoblia wasn't there. Went to Dick's but not there. 30 francs lost that Dilys despite her promises won't ever pay me. She didn't come this evening (she was supposedly coming to bring me some potatoes) - Oh I couldn't care less, I know what she is like - but the camembert that was whipped from under my nose upset me. Had a bit of a fright - thought the flask was broken because it makes a funny noise like sand when shaken. Mad. F says its nothing. I'm dead tired and aching all over. I had Gaël for over 7 hours!! I'm wondering whether I will have enough money to pay my rent. Tired out. Aching. Headache, cold, eyes stinging, hungry (despite hefty dinner ${ }^{376}$ ), going to bed. Tomorrow I'll be alright again.

\section{Thursday 8 April}

Office all day. Very very cold. Lesson with Gilberte Frey. Received a summons to go to the Maison des Lettres for community service in the event of Paris being bombed, one afternoon a month. Can't refuse. Worked on the stats for

${ }^{375}$ Ambiguous. 'sans tickets, sans matières grasses' may mean without the tickets used for oil/fat products or may mean cheese which does not contain fat.

376 'hefty dinner' written in English in the manuscript. 
Chabert. Wrote to Aunt. Jacqueline Piatier came to ask for details in order to find me a job as a tutor - I can't see that happening.

\section{Friday 9 April}

Welsh. Vendryès. Office. Lesson with Dick. Worked for Chabert. Saw Mlle Péchegut who is getting over bronchitis. She is in love with Brémaud. All she does is talk about him.

\section{Saturday 10 April}

Office. Brought calculations to do at the office, Finished the work for Chabert. Went to the Maison des Lettres for public service. Brilliant seminar by M Leroy (?) Was telephoned about those who were bombed out at Billancourt but was stood down by the Maison des Lettres when I went to sign up. Soulié telephoned. Didn't understand a word of what he was saying. Had to phone Mme Boussingault. Had dinner at Dilys's. Jacqueline Eichhorn was there. Dilys planning on freshening up all her old dresses. She's very impressed by what she packs into her lessons. 10.45-12 pm air raid warning. Bought a pound of sugar on the black market despite not having any money.

\section{Sunday 11 April}

Aunt's birthday. Mass C. Dreamt that mummy came. Am a bit worried because I've not had any news at all. I'll write to Nils. Made potato quenelles, one egg, half an onion. But they really did need some flour!! Amazed. Stuffed them down and fell asleep. 2.15-4 am, air raid warning. Went to rue du Conservatoire to hand out leaflets for the next concert. Soulié was in a bad mood. Brémaud was there. Mad. Fortan bored me for an hour. Saw Jean-Louis Barrault who was striding towards the concert. He had a disdainful, fed up expression. I wouldn't like to know him personally. Did the work for Chabert but because it needs very careful checking - it is maths and I am useless at it - I can only ask him for half of the time spent on it which works out at $7 \mathrm{fr} 50$ an hour. It isn't enough. I'll refuse his next batch of sums.

\section{Monday 12 April}

Tiring and disappointing day. Office - got yelled at by Kort who told me that he'd show me the door if I was late again - and I'm rarely late. Went to Hôtel de Ville for voucher. Went to rue V. Massé to get paid but didn't. Not enough time to go to the Red Cross because of the lesson. Waited for half an hour to telephone Soulié. Waited for Delplanque but didn't come - received pneu at 6 o'clock. Foot hurting. Want to cry. Upset. Lesson with Chabert. Gave me 2 eggs in part payment for the statistics. Mme Laberrie came to see Chabert. 
"Noeud de Vipères" (Fr. Mauriac). ${ }^{377}$ Had already read it but enjoyed re-reading it. Tired out. Bed: 1 am. Harry Baur was buried, cinema actor who died straight after his release from a concentration camp. ${ }^{378}$ The supply of electricity has been cut to $6 \mathrm{kw}$ a month!!! It is simply impossible, I’ve already used 3 in a week!

\section{Tuesday 13 April}

Office all day. Warm outside cold in the office. Lesson with Dick. Not with Delplanque who came but not for a lesson but because invited by Dilys to see "Les Visiteurs du Soir" 379 (v. good). Motive: so that I look after her mother when she is busy. Letter from Aunt which was as catty ${ }^{380}$ as anything. Says "well I never", that I am inviting her over for the first time - what she means is that this is the first time she has deigned to accept. Tells me that I have plenty of time for my studies and that this is more a case of me changing my tune. In other words "My dear girl, I don't believe a word you say". And what's more "It's Palm Sunday and Godly people go visit cemeteries". I didn't know. Anyway, whilst I am not particularly pious I don't speak ill of my neighbours as much as she does. Ah, well who cares!! Let her moan on!! She and Yo must be dying of jealousy. I couldn't care less. I wouldn't want to be in their place for all the tea in China. But loving Aunt as I do, this does hurt - I'm learning.

\section{Wednesday 14 April}

Office. Welsh Bachellery. Only Raude was there. Mme Desportes must have given up. I don't blame her!!! I think that I have a cold coming. Gosh, it is warm. "Extraits choisis" (Péguy). Cut the first bunch of flowers from the garden. Stocks, a daisy with daisy, violet and daffodil leaves, everything in a little blue Delft pot on the radio. It looks pretty. Tonight there's firing going off all over.

377 François Mauriac (1885-1970). French Catholic novelist. Le Noeud de vipères was published in 1932. See the website dedicated to him here: http://francois-mauriac.aquitaine.fr/flash.htm

${ }^{378}$ Harry Baur (1880-1943). For a potted biography of French actor Baur, his film career and the circumstances surrounding his death, read the entry on page 40 of Dayna Oscherwitz and MaryEllen Higgins's 2009 cinema encyclopaedia, The A to $Z$ of French Cinema (Lanham: Scarecrow Press).

${ }^{379}$ Film directed by Marcel Carné (1906-1996). See Jonathon Driskell's 2012 study of Carné, Marcel Carné, in the French film directors Manchester University Press series for more on Carnés creative activity during the Occupation.

380 'catty' written in English in the manuscript. 
Very worried. Still not had news from Dad, Mum. I can't get it out of my head that they are dead. - the Germans must have gone into the Free Zone at the end of November/December. If Mummy had realised then she'd have written straightaway - though I wouldn't have a message before end of April, beginning of May, true. So, pointless tormenting myself about it. Mme Desportes took her painting to the Salon.

\section{Thursday 15 April}

Office all day. Lesson with Gilberte Frey who'll be finishing lessons at the end of the month. I'm astonished that she has carried on for so long with them. I will have to replace her. Where can I get money from? Lesson with Chabert. He gave me some work for tomorrow. I went to bed at 3.30 am and still hadn't finished. Gave the radiator to the electrician who had come to repair Madeleine Fortan's lamp. Jacqueline Piatier came to chat, to tell me that I should go be a class tutor. It is tempting. I've had enough of the office and of Kort. I'll have to speak to Vendryès. I

\section{Friday 16 April}

Finished work for Chabert. Irish with Vendryès. The poor man is overwrought. Spoke to him. Nothing before October but thinks that it is a certainty. ${ }^{381}$ Office. Lesson with Dick. Wrote to Aunt. Telephoned Soulié who wasn't there. Very annoying because still not paid and no money - I really need to buy some shoes, my token expires tomorrow. I want to have an early night because for ages I have been going to bed early in the morning. Mended jacket. 11.05? Air raid warning. didn't hear the all clear. I

\section{Saturday 17 April}

It really was pounding away at around $4 \mathrm{am}$. It woke me up. What beautiful weather it is. A flower flowered in my garden. Going by the number and size of its leaves I thought to myself "It'll be a beautiful marigold!" Woe - the yellow floweret is the size of a press stud......

Between 4 and 5 went with Maggy Desportes to the Luxembourg. ${ }^{382}$ The weather was radiant. All the chestnut trees are in flower. The fullness of their leaves makes it seem like midsummer. It is a shame that there aren't any pink chestnut trees. I remember the one at the convent, in the corner reserved for the nuns. A pink rain

${ }^{381}$ This may be a reference to round-ups of 'foreign' students, expected after they were made to register their names. Or it may be a reference to the STO (Service du travail obligatoire), compulsory work service.

${ }^{382}$ Luxembourg Gardens. 
falling from it onto the nun, dressed in black and white, reciting the rosary below. I remember her being like a statue. Oh, if only I could sit on a lawn.

Bought slippers with token. I quite like them. Bought some lilac for 20 francs out of the 60 francs I had left. Am I always going to be this mad? It is mauve and smells divine! It's a bit parched and looks a bit sorry for itself but already, after half an hour in water, it is standing more proudly and sending out its scent into the room. Now that's a flower that makes an excellent and elegant arrangement without having to do too much with it. Letter from Mme Faure asking me for student tickets for "Pepys". What next? She says that she has news from Germaine. Will it be long before I have news from my parents? Went to speak to Jacqueline Piatier in evening.

Went to "Lissa" the milliners opposite, to have my hat brim reshaped. She was worried about how I made a living. When she found out that I got 1200 francs she said to me "You need a man to support you" (!!!) Went to the tailor to find out how much the making up of the jacket would cost - 850 frs. I don't think that I can have one that it wearable. Confession. Air raid warning in the night. I.

\section{Sunday 18th April}

Communion. Mass. Did the housework. 10.15-11.20 air raid warning. Maggy Desportes came when I was in the middle of the housework. She admired the view and the apartment. Mad.F came to wash her towels in my basin. She went to a chic marriage yesterday. Asked the youngest sister (18 years old) of the bridegroom 'What do you think of your new sister in law?' - 'She looks like a virgin' (the modern girl '43). Darned. Listened to the "Damnation of Faust", but the "Chevauchée infernale" was interrupted by the Lent sermon. Pity. I love the "Damnation" especially the "Hungarian March" "Voici des roses" and the bit before it where Méphisto calls the sylphs, "Le Roi de Thulé" and the "Chevauchée aux Enfers". Dilys came at 11 o'clock to bring eggs (6 were broken - out of how many??) but more particularly to try to get tobacco and to moan that $\mathrm{SB}^{383}$ no longer goes to see her (private suggestion not for saying out loud - perhaps SB has finally realised what Dil is (?)). Woke up twice in the night because it was pounding away so loudly. The second time, heard flak shrapnel bouncing off the roofs and crashing onto the road; but this morning there wasn't a trace although there was a lot of police. Beautiful moon after a hot and sunny day. I.

\section{Monday 19 April}

Rain. Office. Denise wants a storm "If it thunders in April, get out the water butts". She had her wish granted by this afternoon's storm. My word the rain is

383 Sylvia Beach. 
good. One can see that the flowers are happy about it, they look all perky and they have grown - something which all our watering hasn't managed to make happen. The cactus got a good soaking, their spines shining like tiny ivory pins. Had lunch at the house. Forgot that I am on the 4 th day of Nico. ${ }^{384} \mathrm{Had}$ to swallow an aspirin hurriedly but didn't go lie down. Made a hand flannel and a hand towel. Went to Chabert's but he wasn't there. Saw Dilys in the street. This morning I saw a barrage balloon going off freely into the sky. It looked like a big fish swimming way up high. The chestnut trees in the Val de G are blossoming - I saw two roses in the Luxembourg, Very happy. I have at last located the bird that sings so well. He perches on the chimney of number 326 (there isn't a 324) and, with his head towards the sun, he sings. Goodness me, doesn't everything smell wonderful when it has rained. The greens of the $\mathrm{V}$ de $\mathrm{G}^{385}$ are fantastic. Inside two blackbirds form a duo. Theirs is the last song before nightfall. There are only soft sounds. One can feel the peace of the evening drawing down over ones worries and, showing no mercy, extinguishing them all under such a pretty veil of calm. It is still too light for the houses on the horizon to become "my hills and my woods" and the real hill is encircled in mist like Fugi-Yama. ${ }^{386}$ The blackbird has found a very pretty tune; he has another go at it, switches and comes back to the first refrain. Such peace!!

My little wild stock plant is funny. Little Miss will only open up for the sun. Once evening comes, or the rain comes or even a big black cloud, quick, quick, she closes up. Even the prettiest rose would not look after its little self so carefully.

Lights come on here and there. In the workers' block, a $25^{\circ}$ turn from here on the 7th floor, a black silhouette stands out against the light. It gets colder and everything goes dark. I am going to close up, the news has come on so all the more reason. ${ }^{387}$

Today I saw the little girl (Henriette, 14 days old) who belongs to the Concierge at the Centre de Documentation at the BN. She is chubby and beautiful; mum is horribly tired. Went to bed early $(10.30 \mathrm{pm})$ in order to get up for $6 \mathrm{am}$. Can only use 6 kilowatts per month - so have to keep a close eye on the meter and use daylight as much as possible - but what a change in routine!! Denise pulled out my first grey hair!!!! I

\section{Tuesday 20 April}

Woke up at 6 am. Did some darning. Office all day - too fed up for words. It looks like we will be moving down to the main room - in that dust-caked

\footnotetext{
${ }^{384}$ Nico short for Nicodème, Madeleine's name for her menstrual cycle.

385 Val de Grâce.

386 Fujiyama.

387 This may be a reference to listening to illegal broadcasts from the BBC (Radio Londres).
} 
icebox. How awful. Maggy Desportes phoned but I couldn't understand what she was saying and so I sent her a pneu. Had lunch at the office. 1 hardboiled egg, 2 little cheeses (a ticket for each one). 100 gr of bread and butter, 2 lumps of sugar. Quality if not quantity and it kept me going until 9.30 pm when I managed to get rid of Mad. Fortan who stayed for an hour and 15 minutes making me miss the news. Lesson with Dick. Dropped by to see Maggy - her picture is being shown at the Salon. Great. Wrote to Mme Faure. Telephoned Soulié who doesn't seem too worried about paying me for my voucher. The hawthorn is in flower - it smells divine. There's a laburnum too. It is colder today though. I.

\section{Wednesday 21 April}

Office. Soulié telephoned - I'll get paid by The Musicians Union at last. Swapped a litre of wine for 2 eggs. Light but persistent rain. Went to the Musicians Union. Waited for Maggy Desportes at Luxembourg then had tea with her. Her husband is very nice. Tired. Very hungry. I've gone over my bread ration but I need to eat something. I've still had no news from Mum.

\section{Thursday 22 April}

So terribly tired, woke up at $7 \mathrm{am}$ ! Wanted to open up the thumb in the yellow glove I am knitting and so didn't manage to do gym exercises and got up at $8 \mathrm{am}$. Washed and dressed, did hair, made snack for lunch in 10 minutes. Goes without saying that breakfast went by the by. Office all day and had lunch there ( 2 hard boiled eggs, $100 \mathrm{~g}$ of bread and margarine, 2 lumps of sugar). Was poisonous with Bertin-Conrad but with good reason. He doesn't do any work. Disappears for two hours or an hour and a half - and me and Denise aren't allowed to open so much as a book (in the office at Ecorcheville, Saulet and Hartz are allowed to study as much as they like). What's more, Denise and I have to do the registering of new files. We have to manage on our own but we have to help out' Bertin-Conrad - in other words, we have to do his work for him. I moaned non-stop. Kort and Duret thought it was hilarious. I want to smash everything up. In October, I may well leave.

Took cigarettes to Dilys who gave me potatoes and sold me 4 eggs. She doesn't suspect that I am making 45 francs on her fags. She is very nice with me - she is doubtlessly going to ask me to do something.

What abundance - jam, pasta, tins of peas, pulses!! (I'm spoilt, but not all months are like this). We're getting much better supplies in this year - and I am starting to "get myself straight" - cf: Gilberte Frey's parents will send me things. Tried on my dangly earrings this afternoon and they suit me a treat! It is frightening to see now that I am pretty after having spent nearly 25 years thinking that I wasn't. If only I had some money - alas. But, no point complaining about it. I am getting by quite well despite the poor pay from the office. The lessons save the day. Tired. 


\section{Friday 23 April}

Got up late. Office in the afternoon. Good Friday. Lesson with Dick. Letter from Aunt telling me to come stay for two days. Went to see the Easter alter at St Jacques du Haut-Pas.

\section{Saturday 24 April}

Office. Letter from Marguerite Delplanque:

My dear Miss Blaess, ${ }^{388}$

I hope, Miss Madeleine, that my letter will meet you in good health.

My letter will be short because I find my words with difficulty.

It will learn to you that I am well and chiefly that I enjoy myself very much.

Can I confess to you that I did not still begin the exercises you have given to me.

All the day long I walk with my cousin Suzanne on bicycle or on foot. This day I have clean the house of my grandmother. So, this evening I am tired.

I hope that you, yourself are well.

Perhaps you will have a few moments to write to me.

I expect and hope your letter and writing I pray you to want to admit with my good wishes for Easter, the best friendships of

Marguerite

Worked.

\section{Sunday 25 April}

Easter. Mass. C. Housework. Took the radio to Dilys (couldn't hear the church bells from home this morning because of the wretched interference - I wept about it) Villeparisis with Aunt. Yo, Marcel, Aimée, Huguette. Played together. M. Labère came over with Armande and ? Zinzer. They haven't yet come to terms with the marriage of their son. "Signé illisible". ${ }^{389}$ Fun.

${ }^{388}$ The letter was written in English and reproduced in English by Madeleine in her diary.

3891942 film by Christian Chamborant. 


\section{Monday 26 April}

Marcel left early. Visit Jeanne Pelletier with Jean and Simone. Brought back lilac and iris.

\section{Tuesday 27 April}

Office all day. Waited for Dick who didn't come. Got paid anyway. Still no news from Mum. Worried, very worried. Took back the radio from Dilys. Dilys sulked.

\section{Wednesday 28 April}

Office. Lesson at $1 \mathrm{pm}$ with Dick so didn't have the time to have lunch. Scoffed a sandwich at Marcuisot. Spotted Soulié with a young woman. Went to Hôtel de Ville to see Fontoblia. Got a leek. Posters. Saw Cécile Péchegut. Collected food ration cards. Had lunch and dinner all together when I got back.

\section{Thursday 29 April}

Office all day. In the morning I helped Madame Chaillon shelve the books in the basement. Bertin-Conrad called me "pig headed”!! Last lesson with Gilberte Frey "L'Appel du Silence" ${ }^{390}$ V. good. Since then I have been in the Hoggar mountains. Wrote to Marguerite Delplanque.

\section{Friday 30 April}

Wanted to get up at 6 am - to do the washing and to distribute the posters - but alas, got up at $9.30 \mathrm{am}$. Worked. Office. Got paid. Joined the American Library. "The Axe" (Sigrid Undset) ${ }^{391}$ "The Vita Merlini" (J.J Parry). ${ }^{392}$

\section{Saturday 1 May}

Bought lily of the valley which smells very nice. Worked all day. Letter from Aunt. Still nothing from mummy. This time, very, very worried but think that

3901936 French film directed by Léon Poirier. The story of Charles de Foucauld. See: http://www.unifrance.org/film/8517/l-appel-du-silence

${ }^{391}$ Sigrid Undset (1882-1949). The Axe is one volume of a fictional tetralogy about medieval Norway.

392 John Jay Parry's translation from Latin into English of Geoffrey of Monmouth's Life of Merlin. 
there is a 'freeze' at the Red Cross. ${ }^{393}$ Perhaps she can only write after one of my messages? I need to send one, double quick.

\section{Sunday 2 May 1943}

Mass at the Val-de-Grâce. The chapel is awful - contorted, over-ornate, gilded. It echoes loudly. In a corner there is a beautiful painting. Went to Aunt's - who was charm itself. "Une femme dans la nuit" with Vivienne Romance ${ }^{394}$ - daft but VR is very beautiful. Aunt gave me 4 eggs, leeks, potatoes. Mended Yo's stockings Marcel broke a tile. Brought back my doll's set. Very pleased about that. It is prettier than I remember. There was also a doll's tea service and a doll's washroom set. What a shame that Dad took Claire ${ }^{395}$ back home. I would have had her now. The rain is terrible. The night is black - lucky that I can find my way back from the Odeon with my eyes closed because I couldn't see anything at all.

\section{Monday 3 May}

Put posters up. Got soaked to the skin. Paid the gas and the electricity. Impossible to get warm again despite tea and rum. Terribly hungry. Heard the clock of the Panthéon strike 10 o'clock. It has such a pretty sound. Conversation with Cécile Péchuget, I don't want to go out with her on Sunday in the slightest. Worked on my Irish. Mad. Fortan came over. Long conversation. Dilys came with me - to check out the lie of the land for the cigarettes. Georges and Gaël are back tomorrow. Today I had beer instead of cider at the Centre. $11.45 \mathrm{pm}-$ air raid alert?? Was asleep.

\section{Tuesday 4 May}

Gave ration cards to Jacqueline Piatier - she is getting married at Pentecost. Housework. Fixed my shifts. Since Saturday I have been wanting to get up early, and I have been waking up at 8.30-9 oclock!! Oh who cares it is the holidays. Might as well make the most of it before having to get back to the grindstone. Got a message from Chabert to give me urgent work to get done this evening. That's fine. It is silly but an unexpected ring at the doorbell and my legs give way from under me and I shake for a quarter of an hour afterwards. ${ }^{396}$ Went to Chabert at 1.30 to fetch the translation. Did some work on it. Went to bed at $3.00 \mathrm{am}$.

\footnotetext{
393 No mail getting through at the Red Cross.

3941943 film directed by Edmond Gréville. Vivienne Romance (1912-1991) was one of the most famous French actresses of the day. See: http://www.unifrance.org/film/37103/une-femme-dans-la-nuit

395 Claire is the doll, presumably.

396 A rare insight into how frightened Madeleine is that she will be arrested.
} 


\section{Wednesday 5 May}

Got up at 5 am (2 hours sleep!) Translation. Went to Bachellery's class. Horrible because Maggy Desportes left straight away to go to a preview at the Salon and so I was on my own with Bachellery. It was painful. He was sad because he no longer has any pupils. In the end an old fellow came in the evening. Translation. Cécile Péchegut came over - I made her tea. She was charmed and charming. Told me that Brémaud had been thrown out - he had asked for 3 days off like Dax had been given and just like Dax he came back smiling all over his face 10 days later. It was happening too often. Cécile Péchugut had managed to find him a job as a security guard at a museum but he snootily refused manual work. He'll do alright with his cinema, the black market and his crocodile tears which he turns on to get the sympathy of his chums. CP told me that he couldn't even make an alphabetic list nor write an address on an envelope properly. Deep down, she likes "our friend Brémaud" as she is fond of saying. But I am pleased he has lost his job; in my opinion he was stealing his pay. He'll probably end up in prison - let's say he can't help it, that he is retarded, a dimwit, or whatever. "He is romantic" says CP "and that's how to take him". Take him by the belly and by the - more like! That's a big digression for such a little man. Let's bury him. Nice weather.

Dilys made a brief appearance with Gaël, who has whooping cough, to bring me three eggs. Translation. Upset. Spoke with Mad. F then was very, very tired. I lay down fully dressed for

\section{Thursday 6 May}

an hour - woke up 3 hours later at $6 \mathrm{am}$. Typed quickly and finished just in time. Took the work over. Went round the market, bought a pansy to plant in soil and anemones for the vase. Very pretty but too tired to be wildly admiring of it. Upset when I got back because I couldn't see my cacti on the window ledge but the gutter cleaners had been by and moved them to a place of safety. Dead tired -6 hours sleep in 48 is not enough. Rain. Françoise Boësse came over. Slept 3-6 pm and from 9 pm.

\section{Friday 7 May}

Irish with Vendryès. Darned. Started to type up Merlin. Lesson with Chabert. Hail. Showers.

\section{Saturday 8 May}

Bought ticket for the National Lottery - the ticket sellers earn 2 francs per ticket. Violent rainstorm. Typed from Parry's "Vita Merlin". Went to Françoise Boësse's who gave me butter. Her two room flat is just what I need - I am totally 
jealous. Damn!! Lunches have gone up by 2 francs per meal - that will cost me 60 francs extra a month. Annoying. Letter from Cyla. Went to see "Dernier des Six" ${ }^{397}$ - queue - and no room so came back. Tunis and Bizerta taken. ${ }^{398}$

\section{Sunday 9 May}

Mass. Just as I was setting off to get the train for Villeparisis there was such an enormous downpour that I stayed here. Ate like a Queen: Onion omelette (2 eggs), Rum crêpes, tea. Feel sleepy. Worked on thesis. Started cardigan with unpicked wool because I won't have enough to make another jumper, the ersatz navy blue wool kept snapping all the time and was therefore useless. Spent a nice afternoon looking for a pattern. Result: I'll make it my way.

\section{Monday 10 May}

Office. Before leaving here I opened the window as I do usually and went to the kitchen to fetch some crumbs. A cheeky sparrow came to wait for me to come back. Bertin-Conrad is the happy grandfather of a little girl Catherine who was born yesterday. But it was pretty horrid that the parents hadn't even told him that they had gone to the clinic. He was all emotional at the thought of being a grandfather (it's the 2 nd time. What must have it been like 1st time round?) Met up with Mlle Péchegut who gave me some beans. Denise brought mushrooms. And there's me thinking I have nothing to eat. In the evening I ate the beans in a veal trotter gravy and a mushroom omelette. In the afternoon I worked for 4 hours. I did the washing (a big wash). Tired out. Strong wind - several times I was worried for my pot plants. Pneu from Fontablia.

\section{Tuesday 11 May}

Office all day. Sent another pneu to Fontablia. Went by Hôtel de Ville to collect the posters. Lesson with Delplanque and Chabert. Got a very nice letter from Aunt. Threw away the veal trotter. Horrible. I don't like that, it makes me feel sick. I thought that I had done a good job of cooking it. Ate roast beef. I dare not think about my budget. Mad. F in the mood for talking but I sent her away

\footnotetext{
3971941 French film directed by Georges Lacombe.

398 British troops captured Tunis on May 7, 1943. American troops captured Bizerte 'the last remaining port in Axis hands'. Axis forces surrendered on May 13, 1943. See the United States Holocaust Memorial Museum's entry on the North Africa campaign: https://www.ushmm.org/wlc/en/article.php?ModuleId=10007304
} 
because I wanted to have dinner before my lesson. Worried that I might have annoyed her. Cold but not raining. $10 \mathrm{pm}$. Washing nearly dry.

\section{Wednesday 12 May}

Office. Had lunch here. Put up the posters. Welsh with Bachellery. Tea with Maggy Desportes. Had dinner with Giselle du Mesnil. Saw her dog which is horribly thin. Not very cold. Got up at 6 am to do the ironing.

\section{Thursday 13 May +}

Office all day. Had lunch at the office. Finished "Vita M." by Parry. Went to the American Library. Waldren (Thoreau) ${ }^{399}$ “The Jackdaw's Nest"400 (?) 4-4.50 pm. Got caught in an air raid alert at Etoile. Walked to the Red Cross, waited in front of the door. When the alert was over I wrote a message to Mummy. "All is well here but a long absence of news from you. In good health. Marcel hopes to go to visit Charles and Gaby. André is well. Hugs to all". Waited 3/4 hour for the bus. The sun was beating down. I? The métro only started up $3 / 4$ of an hour after the all clear - huge queue and crowd. Bought my first cherries: 17.50 per pound ${ }^{401}$ (they used to be 15 and 18 francs per $100 \mathrm{~g}$. Same thing for strawberries, 19 and 20 francs per $100 \mathrm{~g}$ ). Dilys came over because of a row and she really needed to speak to Georges alone. Between 9 and 11.30 pm I went to look after Gaël and her grandmother. It was impossible to work because Mrs Evans was moaning on, doesn't get on with Georges and spoke non-stop. Did some emergency sewing until 2 am. Washed hair. Dry in quarter of an hour!! Found 50 francs in the métro.

\section{Friday 14 May}

Lesson with Vendryès who was charming. Office. Got a 100 franc bonus for the work I did clearing out. There are rumours that there won't be any holidays!!! Very hot. Telephoned Fontablia. Went to Hôtel de Ville for the posters. Beans have all gone off. Went to see Chabert but he wasn't there - he had said that maybe he wouldn't be. In a bad mood, all the more because I have to go to Aunt's at the weekend (such a nice letter that I can't refuse) Does she not

${ }^{399}$ Henry Thoreau (1817-1862 ). See Robert McCrum's appraisal of what British newspaper The Guardian describes as one of the best non-fiction books of all time:

https://www.theguardian.com/books/2017/apr/24/100-best-nonfictionbooks-walden-henry-david-thoreau

${ }^{400}$ Possibly by Gerald Bullett (1893-1958). A 'five-fold anthology' published in 1939 (various sources).

${ }^{401}$ Unclear in the manuscript. Looks like 'livre'. Madeleine alternates between metric and imperial weights. 
understand that it is the only day that I can spend at home?? Letter from Soulié about checking tickets at the concert tomorrow night. Absolutely exhausted with tiredness, by the heat, by Nico. Didn't work. Started Walden - amazing. Had to throw out my beans - they'd gone off and had to finish my meat which was starting to go mouldy.

\section{Saturday 15 May}

Office. Went to Confession. Did the tickets at "Jeunesse et Musique" rue Cardinet. J. Soulié was charming - he noticed (at last?!?!) that I had had my hair cut. The concert was good. 5-6 air raid warning. Half an hour Lesson with Chabert. Very curt pneu from Aunt.

\section{Sunday 16 May}

Villeparisis. Roger was there. Brought lots of things. I had a quarter of butter because he'd said so but Aunt was furious about it. I asked him to send me a parcel knowing that he would refuse. Aunt glared at him and he did just that. Aunt had made herself up and dressed very smartly, putting on little airs and graces. Tch tch!!

\section{Monday 17 May}

Office. Worked. Took posters. Tired out. Letter about National Insurance.

\section{Tuesday 18 May}

Office all day. Was late so there was a bit of bother. Lesson with Dick, Chabert no Delplanque.

\section{Wednesday 19 May}

Office. Finished distributing the posters. Welsh with Bachellery who was charming. $11.30 \mathrm{pm}-1$ am air raid warning.

\section{Thursday 20 May}

Office all day. Went to see Vendryès but he wasn't there. Madeleine Lavelle, Dilys and Jacqueline P visited. Wrote to Cyla. Hot. Tired. Bought "Sacra Famiglia" by Luini. Happy.

\section{Friday 21 May}

Irish with Vendryés who was charming. Had a long conversation with him. Superb paintings in his office. Office. Hot. Lesson with Dick and with Chabert. 
There is going to be a storm. I feel so heavy and tired. Unsettled. Not happy. Impossible to work. Can't concentrate.

\section{Saturday 22 May}

Office. Boiled the washing and waited for it whilst knitting but I fell asleep. Confession. Priest was fed up - and my knees hurt from being knelt down on wood. Bought strawberries. Eggs arrived. Made an omelette flambé with strawberry jam. Don't feel right. Ill. Appendicitis. Bought "Montaigne" (Villey) ( $^{402}$ and "Tristran et Iseult" (Bédier). ${ }^{403}$ Got out "Refuges" (Léon-Paul Fargue). ${ }^{404}$

\section{Sunday 23 May}

Mass. C. Dilys came over. She wants me to hire a radio. ${ }^{405}$ Finished the gloves. Lay down all day knitting and reading. "Walden" (Thoreau) full of important truths but the style is heavy going. Ill. Burning pain in the side. Dots in front of my eyes. Dizzy and have a headache. Listened to the 2 nd concert of the Beethoven cycle. Liked it a lot. Cool and dull day.

\section{Monday 24 May}

Tired. Office. Mme Maréchal is having a baby in August. Did the washing with the woollens too. Very heavy rain after strong winds. Arc of a rainbow right in front of me. All I needed to do was to jump out and go underneath it to get into the Beautiful Country. I would love a house in the country. Dilys came over to tell me that she is being lent a radio. She's got whooping cough. She wants something, but what? She hung around for a bit, paid me a few compliments and then went off.

${ }^{402}$ Pierre Villey's doctoral thesis Les Sources et l'Évolution des Essais de Montaigne submitted to the Faculté des lettres de l'Université de Paris and published by Librairie Hachette in 1908. For more details and a digital copy, see: http://gallica.bnf.fr/ark:/12148/bpt6k66607q

${ }^{403}$ Retelling of the legend by Collège de France academic Joseph Bédier (18641938). For a full scan of the Piazza edition, see: https://archive.org/stream/leromandetrista00bd\#page/n9/mode/2up

${ }^{404}$ Léon-Paul Fargue (1876-1947). Refuges was published in 1942. For more on Fargue see (in French): http://republique-des-lettres.com/fargue-9782824902708.php

${ }^{405}$ Possibly hire a radio for Dilys. As a British citizen, Dilys was not allowed to own one. 


\section{Tuesday 25 May}

Office all day. Didn't go for lunch at St Louis but ate snack in the office instead. Bibli. Américaine. ${ }^{406}$ "The Little Girl and other Stories" (Katherine Mansfield). ${ }^{407}$ She writes very well. Such youth, such freshness, such powers of evocation. Lesson with Dick, Marguerite and Chabert.

\section{Wednesday 26 May}

Office. Ironed 6 to $7.30 \mathrm{am}$. C Péchegut brought round the barter for the wine. ${ }^{408}$ Sent packaging to Frey. Requested birth certificate. Welsh with Bachellery. Hôtel de Ville. Token from Soulié. Bought potatoes which I sauteed. Glorious! - There's a change.

\section{Thursday 27 May}

Office all day. Went to Victor Massé to get my pay. "Marie-Claire" (Marguerite Audoux $)^{409}$ Bought $1 \mathrm{~kg}$ of strawberries!!! Ate the lot with yoghurt. What a greedy guts - but I rarely buy myself treats - and I had convinced myself that they cost only 8.50 per pound (and not per quarter).

\section{Friday 28 May}

Went to collect food ration book. Welsh with Vendryès. Office. Got paid. Lesson with Dick. Letter from Aunt. She is jealous that I am seeing Dilys. Dilys came round with 6 eggs. She is charming at the moment. What does she want? Hot.

\section{Saturday 29 May}

Office. Came back tired out from the Salon where I'd been to see Maggy Desportes' paintings. The Salon was pretty insipid on the whole. There were

406 The American Library was founded in 1920 and was open throughout the Occupation. See the American Library's website for more on its history: https://www.americanlibraryinparis.org/about-the-library/history-of-thelibrary.html

${ }^{407}$ Katherine Mansfield (1888-1923).

408 'échange vin' in the manuscript. Could refer to the goods Madeleine has bartered her wine rations for, or possibly, empty wine bottles for refilling (and possibly the return of a deposit).

${ }^{409}$ Marguerite Audoux (1863-1937). The novel Marie-Claire was published in 1910. 
some beautiful portraits, some splendid roses by Etchevarry, three stirring skyscapes by Pierre de Clossade ${ }^{410}$ and three beautiful canvases by Ivanoff. There was a tapestry portrait and several Richelieu motifs which Mum could have thought up and done. So many steps and such heat! Breeze and trees at Trocadéro were very pleasant. My hats aren't ready yet. For over a week there hasn't been anything in Paris and for three days not even anything with which to make a salad. Nothing is getting through. We're eating pasta again!! It's a reprisal for the three German soldiers killed on the rue de Courcelles a few days ago. Dilys brought me 6 eggs. I wonder what she wants?

\section{Sunday 30 May}

Mass. C. Mother's day. Villeparisis with Aunt, Yo, Marcel. Bathed in the River Ourcq. First time since 1938? 1936?

\section{Monday 31 May}

Office. Lesson with Chabert.

\section{Tuesday 1 June}

Office all day. Lesson with Dick, Delplanque. A new arrival at the office, a Madame Félice. Ugly. Says that she is a teacher but she sings at the cabaret.

\section{Wednesday 2 June}

Dilys brought 6 eggs! No kidding!! What does she want from me? Lesson with Chabert. Brought back pulses to cook. Looked after Danielle La Berrie 2.30 til 6.30. She is still strapped into her cot!! Got a carton of eggs: 7 cracked, 3 missing and 2 alright!!

\section{Thursday 3 June}

Ascension Day. Mass Cooked beans. Had lunch at Madame Laberrie's with Chabert. Tired. Illish. ${ }^{411}$

${ }^{410}$ Both painters' surnames misspelt by Madeleine. Etchevarry should be Hubert Denis Etcheverry (1867-1950) and Clossade should be Pierre de Clausade (1910-1978).

411 'Illish' written in English in the manuscript. 


\section{Friday 4 June}

Welsh. Last lesson with Vendryès. Sweet adorable. ${ }^{412}$ Told me to go and see Monsieur Humbert (his son in law). Office. I really do not like Marcelle Félice. Brought up in Algeria. Has she got Algerian blood?? No lesson with Dick today. He's going away on business.

\section{Saturday 5 June}

Office. Lesson with Chabert ( $3 / 4$ hour). Got wine for Mad. Fortan. Went to do the tickets for the 6th and the last "Musique et Jeunesse" concert (Ecole Normale Supérieure de Musique). Brémaud came. He was furious that Mademoiselle Péchegut had not told me that he had gone away - hardly worth a lie. Came home early.

\section{Sunday 6 June}

Mass. C. Depressed. Cried. Slept. Darned. I am not living. I just sleep and dream.

\section{Monday 7 June}

Got copy of birth certificate - backdated a month. Lesson with Chabert. Marie Blot telephoned. Dédé has hurt his foot. Voirin has written about the money he sent me for the burial? I am furious. Why not write to me about it? Went to Dilys to get the books (stayed there $1 / 2$ an hour). Darned. Dilys came over. Stayed 3 hours!!!! Depressed. Office.

\section{Tuesday 8 June}

Office. St Médard. Rain. Dressed up smart because depressed (white flannel blouse with a brooch in rose gold) and made myself up. Went to the Coop on the rue de Richlieu with Mademoiselle Kerjean for work. Got some cherries. Lesson with Dick, Delplanque.

I'm so depressed, tis true

I'm leaving then, but where to?

I won't write a word more

Still alive in August or dead before? ${ }^{413}$

412 'Sweet adorable' written in English in the manuscript.

${ }^{413}$ Car puisque j’ai un cafard fou; Je vais partir je ne sais où; je nécrirai plus rien du tout; Vivrai-je encore au mois d'août? 
(Scribbled that on a bit of paper at $10.30 \mathrm{pm}$ with no light in bed). I have eaten too many cherries (1 pound). My stomach hurts a bit. Office all day.

\section{Wednesday 9 June}

Office. Welsh. Bachellery. Wrote to Aunt. Brought back gainko. ${ }^{414}$ Walk with Maggy Desportes.

\section{Thursday 10 June}

Office all day. "Testament of Friendship" (Vera Britten) "Picture of Dorian Grey" (Oscar Wilde). Homesick. I adore Winifred Holtby. Went to the Red Cross. "This long silence drags on. Asking for news right now, even if bad. Family, friends all well. Still working, studying very little. Hope for an improvement on the work front before too long. Hugs and kisses'.

Dilys is very depressed. She came to mine. We went to the "Closérie des Lilas". Orangeade. The hats aren't ready.

\section{Friday 11 June}

Went to the hairdressers. Saw Maggy Desportes. Office. Sent a pneu to Denise because no office tomorrow. Telephoned Denise. She'd left her exam after $1 / 2$ an hour. Got the hats. Very happy with my red one. Parcel from Monsieur Zéau, beans etc.

\section{Saturday 12 June +}

Got up late. Letter from Aunt. Lazy. Unhappy. 3 lessons Deirdre. I.

\section{Sunday 13 June +}

Pentecost. Mass. Villeparisis. I

\section{Monday 14 June +}

Lazy. Went to St Denis. Went to see the fortune teller but she wasn't there. I

\section{Tuesday 15 June +}

Lazy. Bought a thing for my legs - but didn't go to see Humbert because ill. Lesson with Dick. Delplanque.

${ }^{414}$ Possibly Ginkgo plant although spelt Gainko in the manuscript. 


\section{Wednesday 16 June +}

Office. Rain and as it was Chabert's lesson he lent me a raincoat. "Les Chemins de la Mer" (?). ${ }^{415}$ Went to see Dilys. Welsh with Bachellery. Went to St Denis. Pneu from Beaujean. Telephoned Beaujean. Went to the fortune teller. [Will be told of a pregnancy or a birth. Change on the work front which will be better from all points of view. Death of a young soldier from my family in an accident. I'll be told by letter. News and money from my father. In about a year, I will be travelling abroad or to the colonies where I will settle. Marriage with a civil servant who is very well off and older than me. My father will be there to meet us both during the night at the end of the journey. I must beware a jealous widow and someone in her entourage who will try to pinch my civil servant. Mum worried about an inheritance. I am too much of a mug.]

\section{Thursday 17 June}

Office all day. "Testament of Youth" (Vera Brittain). ${ }^{416}$ "The Edwardians" (V.Sackville-West). ${ }^{417} 3$ lessons with Dudu.

\section{Friday 18 June}

Met Beaujean. Café. Mlle Komatsu (Japanese woman). Saw Maggy Desportes and Humbert does not take visitors in the morning. Office. Humbert. Lesson with Dick.

\section{Saturday 19 June}

Office. Went to Dilys's (she's passed études pratiques and Philology). Went to the 'Great Exhibition of the French Family' in the Mairie in the 5th arrondissement. Gave the toilet a thorough clean. $10.45 \mathrm{pm}$. It isn't dark outside.

\section{Sunday 20 June}

Mass. Sewed 10th patch into sheet. Started to alter the clothes rail curtain. 2-3.30 pm. Air raid warning.

415 By François Mauriac (1885-1970). The novel was first published by Grasset in 1939.

416 Published in 1933. Elizabeth Day's 2013 feature in The Guardian is a useful introduction to Brittain and the background to the writing of Testament of Youth:

https://www.theguardian.com/books/2013/mar/24/vera-brittain-testamentof-youth

417 Vita Sackville-West (1892-1962). 


\section{Monday 21 June}

Office. First lesson with Beaujean. Charming. Sent off packing for the parcel. Pneu from Mme Faure.

\section{Tuesday 22 June}

Office all day. "Mandoa, Mandoa" (W.Holtby). ${ }^{418}$ Lunch. Went to the Parc Monceau. ${ }^{419}$ Lesson with Dick and Delplanque. Shelled the peas. Had dinner at $10 \mathrm{pm}$. Alert from 1-2 am.

\section{Wednesday 23 June}

Office. Had lunch at the Parc Monceau. 100 gr of bread. Made up the hour I had taken to see Humbert - there was no need but Kort didn't say anything - the pig!! Last lesson with Bachellery. He is clingy. Saw student arrests - horrified. Went to Madame Faure's for the language records. Had dinner at Madame Faure's listened to Georges Thill, Yvonne Printemps, Ninon Vallin, Sacha Guitry ${ }^{420}$ and "Chant du Désert". Spoke a lot about my family.

\section{Thursday 24 June}

Office. Lunched on 100 grams of dry bread. Office all day. Lesson Dudu. Went to Dilys to tell her about the arrangements for Bachellery. Had dinner. Got back at 12.30 pm!! "Week-end Book". Good. Had photo done for work permit.

${ }^{418}$ First published in 1933. See Lisa Regan's entry in the Literary Encyclopaedia: https://www.litencyc.com/php/sworks.php?rec=true\&UID=3752

${ }^{419}$ Paris park in the 8th arrondissement just off the Boulevard de Courcelles.

${ }^{420}$ Georges Thill (1897-1984) was a French opera singer and tenor. Read John Rockwell's obituary in The New York Times:

http://www.nytimes.com/1984/10/18/obituaries/georges-thill-is-dead-at86-was-famous-french-tenor.html.

Yvonne Printemps (1894-1977).

See page 218 of Richard Traubner's Operetta: A Theatrical History (2004) for more about Printemps' career in opera and music hall. Ninon Vallin (1886-1961) was a French soprano. There is little background available in English about her other than Andrea Suhm-Binder's fan site:

http://www.cantabile-subito.de/Sopranos/Vallin__Ninon/hauptteil_ vallin_ninon.html.

Sacha Guitry (1885-1957) was a French playwright, actor and director. See here for more about his life and career:

https://www.britannica.com/biography/Sacha-Guitry 


\section{Friday 25 June}

No lesson with Komatsu. Lesson with Beaujean. I'll know all there is to know about judo! He is sweet. Set ball rolling for papers etc. Dick didn’t come but will charge for his lesson. Read until $1 \mathrm{am}$ !

\section{Saturday 26 June}

Office. Bought shoes, buttons etc. Since Tuesday students have not been allowed in the Luxembourg gardens. Had tea at Maggy Desportes' place. She and her children were good cover in the Luxembourg. Went to give a bedpan to Mrs Evans but was forced to stay so stayed ${ }^{421}$ from 6-12.15 pm. Didn't have dinner. Wasn't offered anything. Sewed on the buttons and ribbons. Charming pneu from Aunt.

\section{Sunday 27 June}

Mass. Tired out. Just about cleared the kitchen. Almost passable. I just have to clean it from top to bottom. Wrote a long letter to Aunt.

\section{Monday 28 June}

Office. Lesson Beaujean. Pneu from Aunt inviting me to dinner Tuesday evening. Dinner with Dilys. Wanted to see "Volpone" 422 but didn't go. Ended up going to "Chateau des 4 obèses". ${ }^{23}$ Daft. Got a parcel from Portugal (2 packs of almond figs). Great. Went to the Red Cross "Very pleased to get the parcel. Huge thanks. Don't worry. I am in excellent health despite not being able to study. I still haven't had any news from you. I think constantly about you. Hugs and kisses".

\section{Tuesday 29 June}

Office all day. Telephoned Aunt. She is coming tomorrow!! Lesson with Dick. Delplanque. Housework til $3 \mathrm{am}$. Cleaned kitchen from top to bottom. "Truth is not Sober" (W. Holtby), "England their England" (A.G Macdonell). ${ }^{424}$

\footnotetext{
${ }^{421}$ 'so stayed' in English in the manuscript.

4221941 French film adaptation of Ben Jonson's seventeenth-century play directed by Maurice Tourneur and starring Harry Baur: http://www.telerama.fr/cinema/films/le-chateau-des-quatre-obeses,471020.php

${ }^{423} 1939$ French murder mystery film directed by Yvan Noé. For information about plot and casting (in French) see: http://www.telerama.fr/cinema/films/le-chateau-des-quatre-obeses,471020.php ${ }^{424}$ A. G. Macdonell (1895-1941). The novel, a social satire on the English way of life in the inter-war years was published in 1933.
} 


\section{Wednesday 30 June}

Got up at $5 \mathrm{am}$. Washed the floor and the floorboards. Office. Went to the Portuguese Consulate for parcel. Went to the Red Cross to acknowledge ${ }^{425}$ parcel. Aunt came. 7-8.10. Liked everything. Went to Chabert's for nothing. Gave me mouldy butter.

\section{Thursday 1 July}

Office all day. Lesson with Dudu for 3 hours (waited 11/2 hours). Foot hurts.

\section{Friday 2 July}

Lesson Mlle Komatsu. Beaujean. Doctor's appointment St Antoine. Air raid alert 4.45 to 5.15. Casier Judiciaire. ${ }^{426}$ Lesson with Dick. "The White Hare" (Francis Stuart). ${ }^{427}$

\section{Saturday 3 July}

Office. Paid electricity. Bought "Mabinogi" (Loth). Slept. Typed.

\section{Sunday 4 July}

Mass. Went to see Dilys who asked whether going out today could be put off until tomorrow evening. Typed. It is hot. "Sortilèges exotiques" - nice scenery but that was it. In the Rue Soufflot I heard a German soldier say "What is that house" - "Le Panthéon".

\section{Monday 5 July}

Pneu putting Marguerite Delplanque off until later. Office. Telephone call from Beaujean who can't come for his lesson. Denise is very close to becoming Guy's mistress. Got a very kind letter from André. Lesson with Madame Endeville.

${ }^{425}$ The word 'acknowledge' is written in English in the original manuscript.

${ }^{426}$ Casier judiciaire is evidence of a criminal record - or absence of one.

${ }^{427}$ Novel published in 1936. Francis Stuart (1902-2000) was an Irish novelist. He lived and worked in Nazi Germany during the war, was arrested by the Allies but later released. Accusations of Nazi sympathies surrounded Stuart both before and after his death. Colm Tóibín's 2001 feature on Stuart in The London Review of Books (a review of Stuart's wartime broadcasts from Germany) is balanced and well-informed:

https://www.lrb.co.uk/v23/n01/colm-toibin/issues-of-truth-and-invention 
Dilys not at all well. Making no sense. Pneu from Delplanque who can't come because she is tired. Our pneus must have crossed.

\section{Tuesday 6 July}

Office all day. Lesson with Dick, Delplanque. Message of 10 May for Mummy: "Don't lose faith or heart despite the lack of news. Everything is fine. Health is excellent. Happy that everyone is doing well. Much sadness about uncle's death. Tender thoughts. Hugs. Mummy" "Old Wives Tale" (Bennett). ${ }^{428}$ Very good. "Mon Repos" (Nicholas Bevel). Daft.

\section{Wednesday 7 July}

Office. Lesson with Madame Endeville. Two hours done inadvertently. "Forgot" to go to the office to cover on Friday afternoon (had a doctor's appointment).

\section{Thursday 8 July}

Office all day. Lesson with Dudu. Cécile Péchegut came over. Tired out. ${ }^{429}$ "Family History" (V. Sackville West). "Androcles and the Lion" (+"Overruled" + "Pygmalion") (Bernard Shaw). ${ }^{430}$ Met up with Roland. Yo has passed.

\section{Friday 9 July}

Lesson with Komatsu. Beaujean. Office. Lesson with Dick who was with his friend Mark who was in the BEF. ${ }^{431}$ Dilys is depressed and came to get me to go to the cinema for "Chasse à l'Homme" (German film). ${ }^{432}$ So so. It was raining when we came out and my ersatz jacket has shrunk!!! Radioscopie in the office.

${ }^{428}$ Arnold Bennett (1867-1931). The novel was published in 1908. See Charlotte Jones's 2016 feature on the author and novel in The Guardian:

https://www.theguardian.com/books/booksblog/2016/jan/01/the-oldwives-tale-by-arnold-bennett-an-extraordinary-story-of-ordinary-life

429 'Tired out' written in English in the manuscript.

${ }^{430}$ George Bernard Shaw (1856 -1950). Irish playwright and Nobel Prize in Literature winner for 1925 . See the Nobel entry here:

https://www.nobelprize.org/nobel_prizes/literature/laureates/1925/shawbio.html

${ }^{431}$ BEF is the acronym for the British Expeditionary Force.

${ }^{432}$ It would seem unlikely that this 'Chasse à l'homme' is Fritz Lang's 1941 antiNazi film about a thwarted attempt to assassinate Hitler. However, there appears to be no other film by that title in France's cinemas at the time. Is Madeleine's reference to 'German film' a reference to Lang? 
Full of awful bodies!!! Wrote to Aunt. Michael annoyed me with his romantic trials and tribulations.

\section{Saturday 10 July}

7.45-8.50 am air raid warning. The English have landed in Sicily. Tired out and down. Letter from Cyla but not a pleasure to read.

\section{Sunday 11 July}

Mass. Tired out. Illish. ${ }^{433}$ Slept from 2.30 til 5.30 pm. Copied up diary. Sieved flour.

\section{Monday 12 July +}

Office. Fine weather, close in the morning. Rain. Lesson with Mme d'Eudeville and afternoon tea (buttered toast and jam, peaches, fresh figs). Went over to Françoise Boësse's. Had dinner there. Came back at 10.30 pm. At 11.15, loud doorbell ringing. It's Dilys. She has lost her key and can't get in. In the end, at 11.30, Madame Bergen's key worked. Marcel is leaving for Carenton. I

\section{Tuesday 13 July +}

0.15-0.45. Air raid alert. Stupid, because the bombing had more or less finished by the time the first sirens were screaming out. Butter had gone very off. So, it seems we will have a month's holiday!!! Lesson with Dick. New moon.

\section{Wednesday 14 July +}

7.45-8.50 air raid warning. Renaud ${ }^{434}$ got hit. 80 bombers were visible but stood on the rubbish chute I was mistaking flak smoke for planes when they were going in front of my window. Read, rested up. Holidayed. "Bring 'em Back Alive (Frank Buck) ${ }^{435}$ “The Eternal Moment" (E.M.Forster) ${ }^{436}$ Went to meet Beaujean at Louis-le-Grand ${ }^{437}$ but it was all closed up. Came back via the rue

${ }^{433}$ 'Illish' in English in the manuscript.

${ }^{434}$ Means Renault factories in the suburbs.

${ }^{435}$ Frank Buck (1884-1950). Bring 'em back alive, a book about the author's game-hunting experiences, was published in 1930.

${ }^{436}$ E.M. Forster (1879-1970). Short stories published in 1928.

${ }^{437}$ Louis-le-Grand, famous sixteenth-century lycée (secondary school) on the rue St Jacques. 
Sommerard ${ }^{438}$ but he wasn't there. Thought that would be the case. Feel a bit sluggish and have a headache. But that is how I am all the time. When will I no longer have to drag this $100 \mathrm{~kg}$ weight of mine around? When will my head feel clear and alert? Very hot. My cockscomb destroyed by the heat. I.

\section{Thursday 15 July +}

Wrote to Aunt but forgot to put the letter in the post. Office but so dreadfully poorly. I. This is the fourth day in pain. Nico, + nauseous. Left eye is running and vision blurred and everything is spinning. Came back to the house (it took me $1 \frac{1}{4}$ hours instead of the usual $3 / 4$ of an hour). Went to bed. Slept. Too hot. When I wanted to get up my heart started to beat like a piston or a water pump. Big waves of red before my eyes, I've never had that before. It eased off later. Roast veal from Bléneau. No lesson today (Denise sent pneus). I hope I can manage to replace them so as not to lose money. 4.50-5.10. Alert. Got up in order to get food in. Everything is spinning. And still this silly wanting to cry which has hounded me all day. Letter from Aunt. Overjoyed because Yolande passed the exam and will be getting a permanent job. Amazing, she's going to be able to have a pension. Feel catty - but I am counting my blessings. ${ }^{439}$ She has set herself up before me - but I don't want to be a civil servant and I don't want to settle in France. So, what I'm feeling isn't logical particularly given that amazing job that awaits me when (when!) I get my doctorate. If only my head wasn't so empty and not up to studying. If only I didn't feel so terribly poorly. Cheer up duckie. ${ }^{440}$ Tomorrow, you will feel better. I.

\section{Friday 16 July +}

Lesson with Beaujean. Went to the Sorbonne for copy of certificates. Office. Still wonky ${ }^{441}$ so straight home. Had to give a lesson at Ranelagh at $9 \mathrm{pm}$ but air raid alert from 7.50-8.55. Mad. F talked for a long time then Cécile Péchegut came. Decided to go out to Montfort l'Amaury. What a pain. I hate going out so much. Sent pneu to Aunt. Went to the Comtesse d'Eudeville's but no lesson. Very hot. I

\section{Saturday 17 July}

Office. Still wonky. ${ }^{42}$ Since Thursday my left eye has been streaming. Went to Dudu's. Saw M. Pietraru - a senile old boy!! He is at least 40 years older than

\footnotetext{
438 Rue de Sommerard.

439 'Feel catty' and 'blessings' written in English in the manuscript.

440 'Cheer up duckie' written in English in the manuscript.

441 'Still wonky' written in English in the manuscript.

442 'Still wonky' again written in English.
} 
Mme Pietraru. Shattered, Very hot. Mad. F insists on talking. Mme Tiffernan is expecting a baby!!

\section{Sunday 18th July}

Didn't go to mass. [...] Went to get potatoes but couldn't. Bought some peaches for granny's birthday. Villeparisis. Aunt, Yo, Aimée, Huguette, Nicole. Nicole is pretty with brown curly hair but she does not shut up. Huguette sat on lap in the front. Nicole is still sucking her thumb - at 5 and a half years old!! Hot. Astonished at myself because not at all jealous of Yo. She is earning 1,900, the same as Aunt, and with her qualifications could go up to 2,500. Pension too. At last she's got a job. Praise the Lord!! Impossible to find food - brought back a pound of green beans. Hot, hot, hot.

\section{Monday 19th July}

Office. Marcelle Félice fainted and Kort caught her in his arms!! Lesson with D'Eudeville and Beaujean. Queued for $3 / 4$ of an hour to get the train times for Montfort l'Amaury on Sunday. Sent card to granny. Pneu to Mademoiselle Barland. Went to Dilys's to tell her that I could not go to dinner. Marcelle from St Denis visited Madeleine F. We get on very well. Washed blouse. Paid for the meat from Frey thought I had 50 francs worth - but 90 francs including delivery!! Never again!!

\section{Tuesday 20th July}

Office all day. No lesson with Dick. "Five Red Herrings" (Dorothy L. Sayers) ) $^{443}$ Lesson with Mademoiselle Barland. She's been to America. Sweet. ${ }^{444}$ Sent a birthday card to granny. St Marguerite

\section{Wednesday 21 July}

Office. Lesson with d'Eudeville. Invited Françoise Boësse for a cup of tea and she stayed from 4.35 until 9.45!!!! She never knows when to go but she is nice. Cécile Péchegut came over. Denise brought peaches for my birthday!! "My Life" (Isadora Duncan). She was such a Zazoue!!

${ }^{443}$ Dorothy L. Sayers (1893-1957). A British writer of crime and mystery novels and like a number of Madeleine's preferred inter-war women novelists, a university arts graduate. Sayers studied French at Oxford. See her biography on the Somerville College web pages.

https://www.some.ox.ac.uk/about-somerville/somerville-stories/dorothy1-sayers/

444 'Sweet' in English in the manuscript. 


\section{Thursday 22 July}

St Madeleine. Got a card off Aunt and Madame Faure. Office all day. Dudu lesson but left 5.30. Flappée dead. Pneu from Barland telling me not to come tomorrow. Cyla came!! and brought roses for my birthday. Was very surprised but didn't show it. She has put on a lot of weight and has filled out a lot. She is very much the matronly figure. I didn't know what to say to her. I think that I would have preferred not to see her because she is no longer her. No two people ever grow in the same direction. I forgot to invite her to dinner because I was so stunned by the surprise of seeing her. She invited me round on Thursday. I hope that she cancels. "Fin Isadora Duncan" (Mary Desti) ${ }^{445}$ Isadora more zazoue than ever.

\section{Friday 23 July}

Lesson with Beaujean. Office. I have never been so bored - nearly cried out of boredom and sadness. Never, NEVER, NEVERRRRRRRR, do I want to stay in this office. I won't be here in October - tutoring or no tutoring. Unhappy, sick. Down, no desire to work. "The du Mauriers" (Daphne du Maurier) ${ }^{446}$ Not bad. Humanity disgusts me. At the moment what I need is:

1. An iron fist to make me work and to which I can stand up to.

2. Someone with whom I can argue whilst remaining a good friend.

3. A very romantic love affair.

\section{Saturday 24 July}

0.10 - ? Air raid alert. Office. Cécile Péchegut came. We decided not to go to Montfort-l'Amaury tomorrow because of the unsettled weather. Had lunch at $2.30 \mathrm{pm}$. Copied up diary. Went to Cécile Péchegut's and decided not to go to Marly tomorrow. Met up with Renée Desprès who will be taking an exam on aesthetics on Monday. Talked with Mad. Fortan. I must sort myself out. I spend too much time talking to Mad. F, sometimes 3 hours. It's mad. But, we are unhappy both of us and so we talk. She is a great girl, very full of herself but very simple in her ways and direct. She'd tell me to go to Hell if she felt like it. We're comfortable with each other because of this - there's just the

${ }^{445}$ Mary Desti (1871-1931) was a close friend of dancer Isadora Duncan. Her biography of Duncan was published in 1929.

446 Daphne Du Maurier (1907-1989). A useful introduction to the life and work of Du Maurier is The Daphne Du Maurier Companion, a collection of short essays and anecdotes about the author published in 2007 and edited by Helen Taylor. 
conversation problem I am stuck with. 9 pm. Françoise Boësse came over with butter and stayed until 11.10. She is nice. So many visits and visitors!! And still this inertia - heaviness in the legs, incessant pain in the eyes and head. Not hungry but I need to eat all the same, but I am off food. I would like to learn:

1. Red Cross. First Aid

2. French and English shorthand

3. How to drive a car.

4. Learn German

5. Learn how to spin thread.

It would be fun to do this in August but what about my exam?

\section{Sunday 25 July}

Mass, housework, copied up diary. Did several bits of mending. Did ironing. An autumn day today, grey sky, misty, cold. It's like September. Lots of energy for once, how did that happen? Made some delicious crêpes with the sieved flour, 1 egg, rum, powdered milk.

\section{Monday 26 July}

Mussolini resigned!! Yaow yaow, yaow. The Italians are buggered!!! The Germans have put wire mesh over the Speiselokale ${ }^{447}$ on the Boul'Mich and doubled the watch. Lesson with Mlle Barland. No lesson with d'Eudeville. Lesson with Beaujean.

\section{Tuesday 27 July}

Office all day. "This was my World" (Lady Rhondda). ${ }^{48}$ Very good. "The Volume of Ghost Stories" (?)

\section{Wednesday 28 July}

Office. Went to get paid at $2.30 \mathrm{pm}$. Lesson with d'Eudeville in her husband's parlour. So many pretty ornaments. Lesson with Barland. Very hot. Went to the hairdresser.

${ }^{447}$ Café/restaurant for the German military.

${ }^{448}$ Margaret Haig Thomas Mackworth (1883-1958) was a suffragette and feminist campaigner. This was my World was published in 1933. 


\section{Thursday 29 July}

Office all day. Had lunch in the Parc Monceau - in the shade and with the sprinklers in front of me. Wrote to Aunt. Dudu was not there. Dropped in at Dilys's who lent me "Murder off Miami" (Dennis Wheatley). ${ }^{449}$ Nicely presented. Went to Colette's and had dinner with Cyla. All talked rubbish - awful! Cyla has changed a lot. Giselle du Mesnil came to the office. Went to the station to find out time of train to Montfort l'Amaury.

\section{Friday 30 July}

Went to see Mademoiselle Péchegut who wasn't there - ill. So, we won't be going out on Saturday. Hooray!! ${ }^{450}$ Bought potatoes. Lesson with Beaujean. Ate grapes - exquisite. Last afternoon in the office - then it is the holidays! Hooray, hooray. Mlle Haillon is 40! I didn't think that she was so old. Note from Denise - poor kid. Lesson with Barland, late. Telephoned Madame Pietratu (Marion Dorianne) twice. Paris $51^{\circ} \mathrm{C}\left(124^{\circ} \mathrm{F}\right.$ ?) Hot.

\section{Saturday 31 July}

Slept very well - amazing given how hot it is. Am wearing swimming costume, because I am baking hot. 11.30-12.5 air raid alert. Copied up diary. 2.30-5 slept a bit. Heat is oppressive. Letter from Aunt. Went to Dilys's. Confession. "The Little Man Murders (?) Ruth Camp came to borrow the typewriter. She annoys me. Couldn't sleep. Sent card to Godfather.

\section{Sunday 1 August}

Impossible to sleep. 1-2 am. Put the concert on the radio. Got off at $4 \mathrm{am}$. Woke up at 7 am Mass. C. Villeparisis. Knitted. Hot. Fight in the train coming back. Aunt was called a nutcase. I don't think she's could believe it.

\section{Monday 2 August}

Housework. Ruth came to give the typewriter back. Went to Dilys's. Rain. Pneu from Giselle. St Alphonse. Housework. Went to Denise Pedron's for dinner. She was charm itself. Her mother is a vixen. ${ }^{451}$

${ }^{449}$ Dennis Wheatley (1897-1977). Murder off Miami, a crime mystery, was published in 1936.

450 'Hooray' written in English in the manuscript.

451 'vixen' written in English in the manuscript. 


\section{Tuesday 3 August}

Clothes washing ( + a sheet ${ }^{452}$ ). Went to Dilys's place for my first ever manicure. Not bad. I have pretty nails now. Did some ironing. Lesson with Barland. Huge storm.

\section{Wednesday 4 August}

Pneu to Giselle. Peeled the beans I'd been soaking to make bean soup. Housework and very worried ${ }^{453}$ about the cooking for dinner this evening. Denise came at $6 \mathrm{pm}$. Admired my view. Introduced her to Mad. F as well as to Giselle when she came. Alert between 6.15 and $6.40 \mathrm{pm}$. Made dinner. Bean soup (exquisite - though I says it as shouldn't) ${ }^{454}$ fried potatoes but Denise's pan sticks and so, as Denise said "from time to time one comes across them nicely cooked". Jam and rum omelette, grapes. The dinner was a huge success. Giselle and Denise loved my room. Denise was tearful when I had to throw her out at $9.30 \mathrm{pm}$ but the time it'd take her to get to L'Odéon would mean she'd never be home by 10.30 !! Giselle came back up. Talked at the window as the sun set and then went with her to Denfert for her last métro. It was a very successful evening. Spoke to Mad Fortan until $1 \mathrm{am}$.

\section{Thursday 5 August}

Mad F went on holiday. I went to the market. I love markets. Cyla came to have lunch at $1.30 \mathrm{pm}$ because she thought that the testing of the sirens was a real alert!!! Sausage (brought by Cyla) fried potatoes (exquisite today) and beefsteak, tomato salad, grapes, tea with rum. At last I have found my Cyla, a really wonderful girl. Stayed until $4.30 \mathrm{pm}$ because I had a lesson with Dudu. Cyla is annoyed and disappointed with Ruth Camp. That doesn't surprise me. Cyla admires the huge changes in me and thinks I am the perfect housewife. I am pleased about that. Françoise Boësse flying visit ${ }^{455}$ to give me back "South Riding" and to invite me to lunch on Saturday, annoying but I accepted anyway. Lesson with Dudu - not him, his brother Riquet who is a splendid man and very courteous. He learns English with dizzying speed. Weather very unsettled, rain.

\footnotetext{
${ }^{452}+$ is usually a reference to menstrual cycle in the manuscript. This may mean soiled sheets.

453 'worried' in English in the manuscript.

${ }^{454}$ 'though I says it as shouldn't' in English in the manuscript.

${ }_{455}$ 'flying visit' in English in the manuscript.
} 


\section{Friday 6 August}

Housework. Remembered with horror that I had a lesson with Mlle Komatsu at $10.30 \mathrm{am}$. Flew out. Lesson Mlle Komatsu - very tiring because her Japanese brain does not get things in the same way as we do and it is necessary to explain even the simplest thing using examples and details. Finished - at last! - copying up diary. Rain. Tired. Battling tiredness. All I want to do is sleep. I should be studying, darning or knitting. These things are more pressing. I am cold. Amusing letter from Maggy Desportes. At 8 pm I saw a marvellous rainbow, right in front of my window right over the Val-de-Grâce. The right side went right down in front of the trees at the Val-de-Grâce and gave the leaves an extraordinary tint and ended in a little outhouse. The other leg stretched over the Chapel. It kept its splendour for several minutes, a double arc encircling it timidly, and then it paled and it retreated into the distance, into the sky where I'd never be able to reach it. I have never seen one so close. If the Val-de-Grâce was accessible to mere mortals I would have climbed down into the rainbow and bathed in its colours, I would have become a fairy. Continual rain. It is cold. Lesson with Barland. It is a long way out to Ranelagh. On the way back I was falling to sleep in the métro. It is annoying, it is $11 \mathrm{pm}$ before I get back. The nights are not that dark yet.

\section{Saturday 7 August}

Woke up late after an extraordinary dream about a man who was dying in a chapel and he knew that he was dying because his likeness was already engraved on the family tomb. The priest gave him the communion wafer but he returned it in the form of a white stone. The tomb opened slightly and the dead from his family in both Hell and Heaven each demanded his soul. He had committed a crime, a young girl of 25 years of age, all white, in a white dress. She came out of the shadows and he took her in his arms once again as he had done on the fateful day but when they got to the ravine, he didn't let her fall but held her tightly. Thus he was saved and while they all went to get the priest (where had he gone?) the man was buried alone by invisible hands underneath the bronze plaque which was still bearing his picture. Dahlias and gladioli were thrown and I put gypsophila everywhere. Then the scene changed to a moorland ${ }^{456}$ village where there was a girl who was going to get married.

The meter reader for the electricity came. I've gone over by 3. Rain. Went for lunch to Françoise Boësse's. She is very nice but I really have to rack my brain to find something to talk about with her. Left to her own devices she is practically dumb. Having silences does not scare me with people I am close to but with her I worry that it is impolite. We went to the Jardin des Plantes, a pretty

456 'village des moorlands' in the manuscript. 
garden but very poorly maintained. We went to the Musée d'Histoire naturelle. Bones, bones everywhere. I think that I was the most impressed by the whale carcass. It is enormous. It gave me the shivers. It is strange that a mass of bones could make me feel like that. Afterwards, the Diplodocus, the Mastodon, the Mammoth left me cold. It the first time I had seen them but I couldn't believe that they were real. They looked too plaster-like to me, strange. The Diplodocus has an absolutely huge tail and the last vertebrae in its tail is miniscule (about $5 \mathrm{~cm}$ ) set against the big bones of the animal. I liked the fossils a lot and I was pleased when I recognised a specimen from afar. There should be someone there to explain all these things. Downstairs there was an extraordinary collection of tongues - although the moulds or preserved specimens are as horrible and unrealistic as the real insides are adorable, delicate. I didn't like looking at the monkey parts. They had a suffering in their expression which made me feel bad. I must go back to the Jardin des Plantes. There's not a lot of people and the flowers are nice - but it is a long way away, too far for me to drag myself and I don't feel like going out at the moment, Tea at Françoise's place. She lent me "Mr Proback (Arnold Bennett), ${ }^{457}$ "Les Eaux Printanières" (Tourgénieff?) ${ }^{458}$ and "Le Journal de Marie Bashkirtseff". 459 So, naturally I read "Mr Proback" until 2 in the morning whilst eating a kilo of grapes without even thinking about it. This vice I have is terrible, because a vice it is. When I don't read I really get through a lot of work, be it intellectual work or practical work. When there is something to read, the house could fall down around me and I wouldn't be able to stop. It is worse than opium (I would guess) If the book is there, I won't do anything else until it is finished and the housework and everything else falls by the wayside. That and my "procrastination"... I don't have many other faults. I can control them, overcome them but these two vices will ruin my life for me I fear. What can I do to sort myself out?

${ }^{457}$ Arnold Bennett (1867-1931). Mr Proback was published in 1922. For more on English writer Bennett and another of his famous novels, The Old Wives' Tale, read Charlotte Jones's 2016 feature in The Guardian:

https://www.theguardian.com/books/booksblog/2016/jan/01/the-oldwives-tale-by-arnold-bennett-an-extraordinary-story-of-ordinary-life

${ }^{458}$ Russian novelist Ivan Tourgueniev (1818-1883). Eaux printanières was published in 1871. The English translation, Torrents of Spring, was published in 1872.

${ }^{459}$ Marie Bashkirtseff (1858-1884) was a Ukrainian writer and painter who settled in Paris at the end of the nineteenth century. Her diary was well known in student circles and much admired by Madeleine. Bashkirtseff's diary is available via the digital collections of the Bibliothèque nationale at: http://gallica.bnf.fr/ark:/12148/bpt6k1131377 


\section{Sunday 8 August}

9.55-10.35 am Air Raid sirens so mass at 11 am. Made a grape tart. Very good it is but not having any yeast, it was a bit heavy. Started to read 'Le Journal de Marie Bashkirtseff'. What an honesty about her. I blush when I compare my diary to hers - but there is a difference between the two in that Marie intended that her journal be read by the general public and I am just wanting mine to help me remember everything later on. When I am writing, I have a constant fear that someone will open it - at customs, I don't know, which stops me putting down everything I think and feel. I hope that I will remember when I read things which appear to be insignificant. Memory is a powerful thing. I want it to follow the traces I am leaving, prompted by the vaguest hints that no one else will be able to see. But, at the moment, I don't really feel an awful lot. I am less numb, certainly, than I was in August 1940 for example, but I feel that I am waiting. My life now is no more than a pause, a stop between two stations. The more I read about the period after the last war, the more I am shamefully pleased that things got back to normal so quickly. I can't listen to the radio announcements urging me to serve or help recruit. I feel 'out of it'. ${ }^{460} \mathrm{I}$ haven't done anything to speed up the end of the war. I've only fought a battle to survive, to not die of hunger and mental exhaustion. I have not fought for others. I have had to fight alone to survive. Those who love me are too far away. I don't even have the comfort of fighting shoulder to shoulder for something better against an enemy. For me, the enemy is hunger, cold, the lack of money. If I were to die one evening no one would notice except my mother and father. The few words of regret uttered after news of my death would be swept from the memory in quarter of an hour, at most, by a social gathering or else hand-outs of pasta. Prisoners are able to say: 'I fought. I was beaten but, all the same, I paid my dues to the country'. I can't say any of that. Nothing. 'What did you do during the war?' 'I tried not to die of hunger.' What a brave and heroic response. Enough now. I have, nevertheless, learnt how to live a bit and I have not built my life on the misery of others.

Until the age of 20: "Don't get too close, you might get burnt."

Now: "A big [...] $]^{461}$ and true love" But, alas! Neither one nor the other seem to be on the horizon. I need to find some willpower-! I don't have any. What can I do to get some. It is such a beautiful day outside but no willpower to make me go out. Slept from 4 til $7 \mathrm{pm}$. It was a mistake because tonight I will be 'as wide awake as a mouse" as Mad. F says but I still feel this need to sleep which makes me wonder how I stayed wide awake when I was young. More than anything I am plagued by Nicodème which doesn't come and which makes me ill, which causes me to have funny turns. I may well go out this evening for a walk?

460 'out of it' written in English in the manuscript.

461 Unclear but could be 'tache' which means task. 
10-11.15 pm. Went for a walk - my old shoes from England. God how good they feel, I could have walked the night through. Went to the Bd de Port-Royal, Bd. St Marcel, Bd. de l'Hôpital, along the banks by the Jardin des Plantes and the Halle aux Vins. The moon was out, lighting up Notre Dame. I crossed the Seine to walk in front of its gate - its 3 doors which are like three mouths wanting to eat up the square in front. It made me think of an old print of a mystery play where Hell had a huge devouring mouth the same 3 doors of ND, but a holy place - although those doors do not look very holy to me at night. Went along the banks on the other side of the water to see the moon behind the Temple (?) (the prison that runs alongside the Seine). Its many pointy roofs - the arrow of the St Chapelle, all of it black against the moon and a river of diamonds in front. Oh, it's so beautiful, particularly when seen from the side. Face on it seems flat, like a theatre decor. Maybe I am terribly romantic. I don't care. I have always loved the great dark cathedrals sparkling in places under stained glass, the alter a lake of golden light from the candles, the arches invisible and [. . . $]^{462}$ in the incense smoke and the little white chapels where sand crackles in the wind which smells of kelp and tar and where, perhaps there is a little dusty model boat given in thanksgiving moving slightly from side to side with a creaking sound like that of the red lamp, the only animate shape against the white and the brown. I fell asleep and had an awful dream. I hadn't finished my studies and father didn't want to lend me the money to finish my degree and to do my thesis. Mum was weeping and I went to see about financial support from the government and was promised a grant of $£ 40$ a year on condition that I lived at the Franco-British College. This only covered the rent and I said that I would have to give language lessons but that would mean that I could not finish in a year. It really upsets me to have a thesis which is barely started and these classical literature studies which are like a slow-acting and painful poison. I flinch from them just as I would in front of a chasm I have to jump into. At the same time, it is just hard, boring graft. I need to get down to it. If only I had someone here to encourage me, meaning mum or if I felt that I was competing, that'd be better. I am dying to do my thesis but I want to finish my degree first. There is no point having 36 things on the go especially given that I am so interested in my thesis that in comparison Etudes Litt seems all the more insipid and even someone standing over me with a whip wouldn't make me get down to it.

\section{Monday 9 August}

I wanted to be a saint and work from 9 am-12 am this morning but I had to do some urgent repairs to my bed sheet and that took me absolutely ages to do. Anyway, I decided that morally the holidays were over for me and that I would work (study) 8 hours a day. I hope I have the energy to do that!! I still

${ }^{462}$ possibly 'bleues', blue in the incense smoke. 
feel very sluggish and peaky because of Nico which is late. Drizzling. Knitted. Worked myself silly with 6 hours at one go on Tacite. Gave myself $1 / 2$ an hour to translate 10 lines of the Annales but remembered that it was les Histoires that needed doing. I set about reading the translation of the Annales to give myself a start. Feel sicky. ${ }^{463}$ Cécile Péchegut came with some tomatoes to borrow some potatoes but I don't have any more. I may even have to buy some on the black market if I don't get a ticket from somewhere soon. Read Marie Bashkirtseff's diary. Françoise Boësse thinks that it is crackers. I don't. It's a girl who knew that she didn't have long to live and knew that she had a role to fulfil. Aren't we all the same? I felt very strongly that I had a mission between 18 and 19 . Even if now I do not feel that as strongly it is because I feel that the walls of my prison are too high for now - I believe that it will take another one or two years before I can show what I'm capable of. I know so little about anything. I am so abysmally ignorant - and my writing style!! How can I write with such an awful style?? I have to rid myself of some staid ideas.

A moment ago the sky above me was beautiful, grey then blue, white clouds with grey undersides, pink with light grey clouds like smoke, edged with fawn and then mauve. Then it became like a pigeon plumage but in pastel, now it is grey, grey-blue and white. And the dome of the Val-de-Grâce stands out with its flesh-tinted stone and roof of greenish-blue metal. Gosh, it is so pretty. In the evening when the sun lights up the buildings in the distance the shadow of this building hastens nightfall over half of Paris. So many people must curse the building which deprives them so quickly of the setting sun. I am perched so high that nothing takes the sun away from me in the morning and in the evening I get it a little round the back. So there is a teaching conference at York? I had a pang when I heard that and shed silly tears. Where is the conference? I can think of three or four halls but perhaps it is in none of them. Will there be people I know there? This could well make me very depressed indeed. When it comes down to it I get attached to people or things far too much and being separated from them makes me suffer terribly. And I joke around and laugh so that no one suspects anything. Lots of my acquaintances are duped by that.

I stayed sitting on the window sill with my feet in the window box, I was looking up at the sky and suddenly a star shot through a gap in the clouds like a tiny spark from a blazing hearth to fall amongst a rich mass of velvet. I waited for more stars. It was fun because there was only the sky and clouds and then suddenly, without knowing why, a star would appear. They seemed to be shooting so very quickly above my head. Later on, we were back to having just clouds again.

463 'Feel sicky' written in English in the original manuscript. 


\section{Tuesday 10 August}

Went to the market. Huge queue for tomatoes and I was out of tickets. Other than tomatoes there was nothing except some beans "which rabbits would break their teeth on" said someone behind me. Bought nothing. I had to register for fruit and vegetables with number 13 coupon from the half-year ration card. Poor us. It is horrifying now. But it is silly to sign up now, everyone is on holiday. I am being increasingly forced to use the black market but I would rather do that than go to a restaurant. It is still less dear and I have nothing to eat. I also know what I am eating.

Very pleased with myself. Worked for 3 hours on Latin; 4 hours on French and later I'll be giving some private lessons. That will make up my 8 hours. I don't know whether it is the climate or what but I think that I have got back the person I was four years ago - what optimism, what enthusiasm, what confidence in myself. But, physically, I am not good. Went to have a manicure round at Dilys's - who is jealous of my pretty nails. I must be careful. She has set out the bedroom nicely. But the kitchen - Good Lord - what a disgusting mess - It has never got as bad as that at my place.

This afternoon a fellow at the Val-de-Grâce started to scream and to cry. It was terrible, so terrible. It lasted 5 minutes. They must have given him something; - but to think that someone can suffer so much!! It was barely human. It was heart wrenching. Poor fellow.

Lesson with Mlle Barland. She knows one of Vendryès's sons. Drizzle. 11.2512.20 air raid siren.

\section{Wednesday 11 August}

Awoke still very sleepy. Hardly surprising because the flak guns hammered away all night non-stop!!!! What I like is when they sound an air raid alert there is absolute silence but when there isn't one that's when all Hell breaks loose!! It started at 2.30 am with the sky all lit up with flashes. At 4 am the house began to tremble, my bed shook me around like a rag doll. You could hear the shrapnel falling on the roof. At $5.30 \mathrm{am}$ I got up to have a look because the noise was so loud and didn't stop. It was like 20 storms all at once with thunderclaps coming one after another without stopping. I could only see flashes from my bedroom window. From the kitchen it was like daylight because the explosions lit everything up and came so quickly one after the other. There must be an anti-aircraft gun nearby. It wasn't the one at St Michel. Wrong direction. I've never felt the building shake like that before. The weather is closing in menacingly, as if the flood is on the way (I dreamt that I was in a submarine).

Studied my Latin for 4 hours - I can't do more than 4 hours at one go because It tires me out. So, knitted a bit before leaving for the lesson with Dudu. Went to the Red Cross. "Was absolutely delighted to receive message. Yol. got into the Civil Service. I am on holiday. How are Aunt Marguerite, Joan, Margaret, Nibs, 
Sammy? Do send me news, especially yours. Health is excellent. Love". Got soaked in the rain. Went to Dudu's but got the day wrong. It must have been Friday. Françoise B coming to lunch! I sent her a pneu to put her off. Letter from Mad. F and Giselle who have put me off until Saturday instead of tomorrow. That suits me better. Today, my 8 hours of work plan went well, because I did four but what about the other four? It is $18 \mathrm{~h} 30$ and I want to listen to "Pygmalion" in French on the radio this evening. I would rather ${ }^{464}$ do it tomorrow. I've had two heels ripped off my little red shoes. Goodness, I am so tired!!! And I have spent so much money unfortunately. I must go carefully now but I haven't spent unnecessarily so what can I do? Listened to "Pygmalion". Well translated - but I didn't really like the adaptation.

\section{Thursday 12 August +}

Slept like a log until $9 \mathrm{am}$. It is 9.30 and I am already starting to feel extremely poorly. I'm wrapped up, in the sun, trying to see off the poorliness without having to go to bed. I want to work. Pity, I think I can only manage one more hour. Stayed in sun and felt sick but wasn't. Did some French. Between 11 and 11.20 there was an alert. Afterwards I made myself do a past paper for 2 hours . It was pretty demanding and I am wiped out I have to say. So can I not do this studying anymore? - I have done 6 hours of intensive study. Montaigne this afternoon, but that's ok. I am [. . .]. After a rest (?) I did the crossword whilst eating grapes, am still as tired. It is 7.15 and I still have two hours study to do probably a little exercise or something because my brain is no longer working. Is 8 hours too long? I've just got to organise myself, Didn't have to go to bed because I kept myself extremely warm. Good thing to know. Finished the back of my ribbed cardigan. It looks elegant. 11.15-11. 50 alert. I think that the Piatiers are back - just as well that I went to pick up their linen. I

\section{Friday 13 August}

Was woken up again last night at around 3.30 because of the flak. But I was so tired that I fell back to sleep immediately and don't know whether it carried on. Oh, I am so tired!!! Wrote to Aunt Violette, André. Had lesson with Komatsu. Lesson with Dudu. 5.30-5.40 alert. Mme P says that things are just pitiful in Berlin. They have told them to stand tall just like the English did when they were in danger of being invaded. Haven't been paid yet for the month of July. I need to ask. Letter from Aunt Violette and a word from Françoise B. Such a nice letter from Aunt that I had a few regrets about having said I would not be there for the 15th August because of Nicodème. She will never understand

464 'rather' written in English in the manuscript. 
what a joy it is to be alone. She is going to be angry but never mind. If Nico had come the day after I still wouldn't have gone, it is true. I read something very good about the love of solitude in the literary reviews section of "Panorama". It's Roman Fernandez speaking about "A la recherche de Marie" (Madeleine Bourdouxhe). ${ }^{465}$ "Marie, Jean's wife" he says "is, in fact, a presence first and foremost, a silent presence. . . . she is both a woman of the home and a wanderer, loving her husband but with routine intimacy (a tamed existence) a solitary woman penned in. The truth is that it is Marie who is searching for Marie ... happy when no one watches her, when no one bothers with her, "wonderfully alone" and infused with a sense of self! . . " Further on he continues - "She is dangerous because she is living by the destiny she has chosen for herself which does not fit with what is expected. And her silence, which also makes her dangerous, she wears like the halo of her solitude ..." Too often the power of silence and of solitude have not been appreciated in my view. It is only here that one can find what one is about. The outside comes in, shouting, it forces you to acknowledge it, stamping around, like a crowd at a garden party flattens the grass and crushes the flowers. Left alone with its gardener, the space becomes perfect, grows harmoniously and beautifully. If the gardener passes by only now and again weeds will grow and what will become of the beautiful garden?

Solitude? Noise dies away and in the silence of the soul one can see so many things which spring back like trodden-down grass which stands up again little by little with a light rustle. One finds one's sense of self alright but it is dangerous too - for others. They are restless, speak, empty themselves out while, in front of them, silence rises; a torrent which, when it breaks the dam walls, will sweep away these empty vessels. Flaubert's image of a gutter overflowing suddenly is very accurate. One can polish oneself by using others but one must watch not to wear oneself away. One must not polish oneself so much that that the image of the other becomes engraved in us. I am getting carried away this evening but it is something I hold very dear and I will fight for that and my freedom all my life.

I met up with Cécile Péchegut. All she thinks about is eating. She leapt on my coffee ration coupon like there was no tomorrow. ${ }^{466}$ Did my 8 hours (counting in 4 hours of lessons). I only did Irish which I enjoy, interpreting old grimoires. Studying Etudes Litt. Classiques bores me to tears in comparison. To think I have to numb my brain over that when there is my thesis, Celtic - which I adore as Mme. $\mathrm{P}$ would say. I had a detailed commentary to do. My thoughts are flying so ahead of my pen that I struggle to keep hold of them [1p, 2 p?? So

${ }^{465}$ Madeleine Bourdouxhe (1906-1996) was a Belgian writer. She was a feminist and friend of Simone de Beauvoir who referenced Bourdouxhe's 1937 novel La Femme de Gilles in The Second Sex.

${ }^{466}$ Possibly to barter it for food. 
many spelling and grammar mistakes in French]. ${ }^{467}$ It is on Táin bó Fróech. I love the ring episode. The learned scholar recounts the tale dryly but the scenes leap like flames in the mind's eye. If only I could paint. "I swear on my life that I haven't seen anything as beautiful," says Findabair, "as the whiteness of Fróech in the black water with the red berries". Oh, the pointed chin and the grey eyes, the black hair which streams out and which tangles with the berries. Glistening arms, heavily laden, white, in the swirl of the greeny-black water. Findabair, completely white, with a large green hooded cape like a newly peeled flower stalk. In front there is Ailill, drunk among his warriors and his treasure gleaming under the light of the torches. Behind, but not clearly, is the milky whiteness of the 50 girls and the blue black sky. What poor taste, my dear - but I do love the colours, all the shades of red, garnet, scarlet, cock-of-the-rock, flame, tangerine, all the blues. I tried to look at the view out of my window pretending to be deaf. It was terrible. Everything seems flat. Good God, hope that I don't go deaf or blind.

\section{Saturday 14 August}

Did some Irish. Had lunch with Giselle and Denise. Denise came to mine. She is lovely. She thinks I am marvellous which gives me a curious sense of power. Poured down.

\section{Sunday 15 August}

Mass. Knitted. Will I have enough wool? Broke a needle. Listened to the news on P.S. "An Average Father speaks of his Average Son". He is frightened about what will happen after the war when his son comes back. How will they get along? Who wouldn't be worried about that? I am terrified about what the post-war will hold for me. With all my heart I want the war to be over but then what? Where will I live? What will I do? What will become of me? Where will I be able to live? Perhaps I will be able to find some work at home? Perhaps these questions will find answers more easily than I think. Anyway, I think that I have shown by not dying during this stagnant Occupation that with determination one can always find a way through. Sure enough, these are big questions which may not be resolved by a marriage and they worry me from time to time. But the really big problem, and one that really sends chills down my spine, is how I relate to my parents. There it is. I have said it now. I bet my life that in their hearts they hope that nothing has changed and that life will just take up where it left off in the cosy little threesome - foursome with the dog. But, well, everything has changed. I adore my parents, even more than before

467 'rattraper' is the verb Madeleine struggled to spell, crossing out two ' $\mathrm{t}$ ' and adding a second ' $\mathrm{p}$ '. 
perhaps, in that the separation from them has enabled me to be able to see just how good they are. I have been able to compare them to other parents - what a huge difference - I am so lucky to have parents who are just about perfect but, but, they love me too much. I am their sole reason for living - and . . . and ... Why didn't I have brothers and sisters - Oh, I know that they did want some. Nature didn't want it - but what a burden it is to be an only child. When I come back they will think that everything will be as it was before - but no it won't be. I have changed. I have lived for four years on my own. I am no longer a child. I even think that I have gone straight from childhood to adulthood and I miss the adolescence that I never had. I have made some amazing discoveries - that everyone [...] at the same age even if the body changes - that faced with authority, whatever that authority is, everyone grovels and follows and lots more besides - I have been too close to misery and to death to be how I was before and I do not share the same opinions as my parents. And what about my freedom?? Of course, they wouldn't complain. They would say 'Darling, just do as you see fit. It is your life not ours, ours is finished'. But their eyes, their eyes full of sadness - I'd never be able to cope with that. It is their life or mine. Why should I have this dilemma? A girl stays at home - well, yes, perhaps but not when she has had to earn her crust all alone for three years dictated to by necessity and with only herself to keep her going. I hope that I will return with a better understanding of my parents' love for me and forgive the wrongs they have done. Daddy - I misjudged him for a long time. I couldn't see his good heart under the rough exterior. What a dreadful life he has had. 14 hours a day stuck underground sweating over ovens or frozen amid refrigerators so that his daughter, who only loved her mother really and showed it so obviously, could have her heart's desire. I hope that it is not too late. It is four years since I left, 4 years and they are no longer young - and the bombing - let's hope that I don't go back to a deserted home. Oh, God. I hope they live for many years yet. When I think about all this I think that everything will just be the same as before but, then, I know what I am like. Since the age of 16 family life weighed me down. The only thing keeping me at home was the look in my mother's eyes. If I stay, I will be dead as a woman and will work; the housework, the gardening, I'll embroider beautiful tapestries and I'll take the dog out with mum and dad. I will have to get married. I'll live just nearby, say about $1 / 2$ an hour from home (on foot of course) But, who will I find to marry? Who would want me? I am not beautiful but I'm not ugly either - but I am fat - and then, of course, the education I have had - ! Oh Good Lord!! Maybe I will find a job which will mean I can live away - in my own house - but my parents will move, Oh God!! What can I do about it. I won't be able to live the way I want with them. It won't work. Dad will go on about the electricity that I use late into the evening. Mum will get irritated if I stay up late and neither will be able to sleep before I come up to bed. Oh what's the point worrying. I will go back. I will fall in love with a chemist or an engineer at university and him with me. We will get married and we will have ourselves a lovely house just next to the main road he'll go by 
car to work every morning and in the afternoon my parents will come straight over with Sammy - oh, no, Sammy will be dead by then. Oh God, why is it that the things we love have to die. Oh I don't want to cry again this evening. One sobbing fit is enough for this evening. Oh Hell, what a life this is. What did my grandparents do for my parents to have had such a wretched life. Mum loses her mother at 14 and has to live with a stepmother and a father who doesn't care about her. The 14-18 war ruins my parents' youth. Then poverty in a country they don't know. ${ }^{468}$ Dad works 14 hours a day, 13 days out of $14 .{ }^{469}$ Mum lives in a house that she hates. Then it's the Great Strike and the threat of the sack. Then it is the house in Nancy and the frightening totting up of the cost. I had nearly forgotten. Mum thrown out by her second stepmother and then mum gets TB!! They move house and everything seems to be going well except for the perpetual threat to Dad's job. He's old and can't see it. Then there's the war. I leave. Then it's the exode ${ }^{470}$ and four months of agony not knowing whether the only thing that they care about is alive or dead - no news and the separation goes on and on. The daughter who is so far away. The frightening telegrams. When will it all end? When will it all end? When I think about all that I feel that I will always stay with them. But, could I cope with so much love? I mustn't think about it. I mustn't ever think about it or else I would spend my life crying. - I need to go to bed. The radio has been on a lot today and it is half past 11. And what about my electricity ration? Phew! I have already eaten up the whole of next week's ration. It's the same with money - I've only got 50 francs left. I've done too much inviting over of friends - and the extra money from the cigarettes, Dilys doesn't want any and I promised 200 francs to Godfather - they have got so little money that I daren't give backword on that. I gave a packet to Cyla and I'll manage by selling the other even at a loss to be able to make up something of the 200 francs. And Mme P hasn't paid me for the month of July - 500 francs less makes a difference. Oh, I really shouldn't get so worked up - if I can get it everything will be fine again and life will be leisurelyand that goes for my parents' life too. I've never yet had reason to complain about [...]. Touch wood. ${ }^{471}$

\section{Monday 16 August}

Yesterday night I nearly got up again to say that I would support the entire family. I will stay proud. 10.20-11.50 alert. Le Bourget is in flames. 2.15-2.45 alert.

468 The Blaess family moved to York, England, sometime after the end of the Great War.

${ }^{469}$ Madeleine's father worked as a chef in a hotel in York, England.

${ }^{470}$ The flight of French civilians from Paris and the north of the country ahead of the German army advance in June 1940.

471 'Touch wood' written in English in the manuscript. 
Splendidly sunny. Darned. My, how my back hurts. I didn't see the moon come up and I was worried when a frightening orange claw gradually appeared. Then a huge orange moon appeared which, as it rose, paled - and it really did rise quickly. I was too hot last night.

\section{Tuesday 17 August}

Market. There was nothing to be had other than a few sticks of celery and a few radishes (and what queues!!) and grapes, grapes everywhere, (between 7.25 and 7.50 a pound). Washed the double sheet (it killed me - over a basin measuring $75 \mathrm{~cm}$ by $75 \mathrm{~cm}$ and without a boil-pot ${ }^{472}$ or a washboard, I could hardly manage it. Wrote to Aunts. Went to fortune teller at Dilys's and learnt that because I was born in the month of August I am very proud and good under a surly exterior; that I can get on well with everyone but being a high achiever I like honours and recognition and all that; that I'll struggle to get married and then only late on and then there will be an immediate divorce; that I am extremely independent; that I will be very comfortably off later on in life; that I would be better placed to succeed and that my worth will be recognised abroad rather than at home; that I get on very well with Mum or those born under my star sign or under Taurus who are all very intelligent (!); but never with my Aunt (why?) nor with my cousin (dilettante). The things one finds out!! I am being watched over by my grandfather because I dreamed about him and he spoke to me in the dream (He said to me: "You did know that your Uncle Julien died?" I said "No". He said "What do you mean? But he didn't tell you??). Did some ironing. I think that there is going to be a storm (what is wrong with my nib, since yesterday it's been all funny). The wind is getting up. 5.20-5.30 alert. They are Zazous!! Sicily has fallen. Saw a shooting star and had time to make a wish!! Hot. Flappée. Fed up.

\section{Wednesday 18th August}

I'm 25 years old - Good Lord, A quarter of a century already, nearly half of my life, at best a third. And what have I done with it? Let's not get into philosophy or we'll never get out. Darned - decided to study, but thought better of it and decided that I'd prefer things clean and I did some darning. I only have to keep the student bit up for half an hour each evening and that'll do the trick. Increasingly I don't want to take the exam in October. I don't know anything, I don't

${ }^{472}$ The 'lessiveuse' was a French invention; a metal container seemingly not dissimilar to the coffee pot principle of water shooting up and round the container when boiled and, in the case of the 'lessiveuse' cleaning and sterilising the fabric. 
study. It is also much too hot to make the effort. Supplies are so marvellous that I was forced to open a tin of beans for lunch being so tired of eating pasta and one can't just eat grapes. Great!! And what about this winter if I'm already starting on my stocks.

It was so heavy and humid at my place that it was airless at home. Went to join the Bibliothèque Municipale. The Librarian, just like the other woman who had given me information, couldn't believe that I don't live at home with my parents. Do I look so young then? Deep down, I am pleased about that. "Grandeur et décadence de césar Birotteau" (Balzac) ${ }^{473}$ "Le 18e sc" (Faguet). ${ }^{474}$ Then I went to the Luxembourg. Was dripping with sweat just sitting down. Wrote to Mad. Fortan - Maggy Desportes. Knitted. It is colder this evening. It is nice to be at the window in the breeze - but less good to be sat - after nearly 4 hours sat on an iron chair in the park. They should hire out little cushions.

\section{Thursday 19th August}

Went to the market. Nothing. Darned. Dreamed of "Rennard Heights! 7 rooms, large garden, chickens, secretary and job at Univ. Today (Friday) it has grown by a few rooms, a chemist husband and a car. My dear child. ${ }^{475}$ But this solitude is doing me a lot of good. Birthday card from Aunt. Lesson with Barland. What a sticky heat.

\section{Friday 20th August}

Darned. Heat even stickier. Card from Mad. Fortan who is back on Monday. Lesson from Komatsu, Barland. François comes for lunch tomorrow and I can only offer him pasta!!! Terrible. No potatoes opposite. What on earth can I give him? Terribly hot.

\section{Saturday 21 August}

Got some potatoes without having to pay because they had to get them from a cupboard where there were mice. Lunch of pork rillettes. ${ }^{476} \mathrm{Had}$ a veal escalope

${ }^{473}$ Honoré de Balzac (1799-1850). The novel was published in 1837, one of the Comédie humaine series.

${ }^{474}$ Emile Faguet (1847-1916). French Literary critic. Madeleine may be referring to his study of eighteenth-century French literature published in 1901. See the Edinburgh Review for more on Faguet and his works: https://archive.org/stream/edinburghreview196londuoft\#page/506/mode/2up 475 'My dear child' written in English in the manuscript.

${ }^{476}$ A kind of paté. 
and fried potatoes, brie, cake (brought by Françoise), grapes, pears, coffee. Not so bad. Great success, Lesson with Dudu. They've gone on holiday. Will they telephone me again? Went to Dilys to sell cigarettes. Gaël is adorable, a beautiful little thing but they are going to have a hard time with her - 'oh damn it all', Gaël was saying!!!

\section{Sunday 22 August}

Daddy's birthday - 55 years old? Poor, dear, Daddy. Went to mass at the Val-de-Grâce. The scene of a military burial in wartime could not be more moving. Radio Paris is not working - (alert?) Went to Villeparisis. Aunt and Yo were very happy to see me. They are going on holiday to the Cotentin ${ }^{477}$ peninsula - for good food. That will do them a lot of good. Yolande's organs haven't been affected but she is very anaemic. She's not hardy says Aunt. She's terrified about TB, it's awful. Sat at the end of the table with the family all squeezed tightly together - they forget sometimes to serve me. Only Godfather remembers - but I couldn't care less. I realised a long time ago that I am not a part of this family. In the evening Aunt gave me 100 francs for my birthday. They think that I didn't see Yo look over quickly and say "What are you giving her now?". Yo runs the house. She listens carefully to what I say so that she can reuse it later - more than once I have heard my own words reused cf that evening in the train about camping. Aunt said to me "Yo doesn't like camping, she doesn't like earwigs". My own words except I say [. . . ] $]^{478}$ and earwigs Yo scowled away because she knew I had said it. Strange expression from Aunt. At 8 o'clock she arrived "to consign me to the station . ..." Shouldn't it be relay? - Looked in the Larousse and what I thought was right. Went to see the plane, or, at least where the plane, a German fighter had come down behind Godfather's place, a 100 metres away. Hit in the electrics, it went all the way into the ground and was buried. I brought back two little pieces of it. Afterwards I pruned the climbing roses. Granny would like me to go and do the garden. Godfather doesn't like that sort of thing. Feel so wonderfully happy.

\section{Monday 23 August}

Cold. I still think I am in September. Still drying out that crushed salt - it is using an enormous amount of gas and takes ages. Waited in vain for Mad. F. Was starting to get into a bit of a state when she hadn't got here by 6 . I'd never have thought that I would feel as worried or feel anything in fact about her. Finally, at 7.55 a telegram was brought up telling me that she is coming back on Thursday; and a pneu (which should have arrived at $2 \mathrm{pm}-$ and which the

477 Spelt 'Cottentin' in the manuscript.

${ }^{478}$ Looks like 'veches' in the manuscript. 
concierge swears that she brought up) from Mlle Barland asking me to go to her friend's, 21 rue Fontaine, which is where she has gone with her stomach upset. It's strange, acting like this. She doesn't want to be on her own when she is ill and lands herself on friends. I'm the exact opposite; I don't even want visits. Very opulent at her friend's. lots of little fitted bookshelves - I've seen the same thing at Count Eudeville's but I hadn't seen shelves (above the bed) with the shelf just the size of the book. It's very good. I've taken note.

\section{Tuesday 24 August}

Darned - but finally finished the white knickers. Phew! Manicure at Dilys. I found out that I am psychic because I have two selves. But that goes back some way - I have gone back to being 'ordinary'. That gave me a start. I had always thought that I had lived my childhood over the other side. But still!!! Maybe I am scoffing too much potato. I'm as jumpy as a bowl of noodles. 'Nuff said!?."79 Around 6.55 am there was an air raid alert. Lots of excitement amongst the civilian population. We watched the planes come over. There were two squadrons one with 18 (or maybe 16 which I got when I recounted). The other was larger, around 25. Counting was difficult as the formation was very close together and there was lots of anti-aircraft fire which I'd taken for planes or parachutists or tracts first of all before it dispersed into smoke. 8.15 am and the end of the alert sounded when everyone had ceased taking notice.

\section{Wednesday 25 August}

St Louis. I must go to lay flowers on my grandfather's grave. It's a way away at St Denis. Goodness but it was cold this morning around 7 am. My cockscomb has been leaning over to one side as if she wants to fall over for a few days now. I think (damn this pen) that her end is nigh. But, she has lasted a while. Fifteen days ago I walked in front of the shop window and all the flower heads were dead and been stuffed under the display. And the [.. .] is still splendid (sorry, sorry pen you had just run out of ink). I think that I am going to trim it. It won't live as long but I want to replace it with a chrysanthemum or something. Wrote to Denise P to invite her to lunch on Saturday. I'm not keen but the poor kid is expecting to come. Wanted to write to Vendryès but put it off again. My French isn't good enough. Siel came back. I'll go see him. I'll get more out of him if I speak to him even though a reference is hardly asking much. Bought some beautiful bronze coloured chrysanthemums for grandfather at the market. Went to St Denis to take them. The grave is covered over with white stones surrounded by a curved silver railing. Someone had brought some bashed up flowers with China Aster and a geranium. I am pleased that I went - but goodness

479 'Nuff said' written in English in the manuscript. 
me, it is a long way. It's an entire afternoon gone!! Took the net bag ${ }^{480}$ to Giselle. Went to Aunt's to drop off the striped satchel. Had dinner there. Between 7.45 and $8.10 \mathrm{pm}$ there was an air raid alert but I didn't hear anything. Went with them all to the cinema to watch Tino Rossi in "Chant de l'Exile'". 481 He's a good singer, little Marie is beautiful. Pas Béni is funny but as for the rest - daft!!

Here we go! Here we go! I could have bet on it!! They are going to have a manicure. Ha, it worked. On Sunday I told them that I have them. I would have bet my life that they would. I wasn't wrong!! It's flattering to be copied and all that.

\section{Thursday 26 August}

Wrote to Vendryès and to Bachellery. It took me one and a half hours because I was so frightened that I would write badly. All for a simple reference!! Got eggs off Gilberte Frey - one missing, one cracked and possibly off and the rest just empty shells!!! I don't know what they do to wrap them up. Other people get theirs' intact. I'm sickened. 60 francs up the spout and no eggs.

My word, I regret being patriotic sometimes. Of course, I wouldn't look at a German even if it meant ending up dead in a dustbin. But, now and again - !! Went to get Panorama downstairs. The shopkeeper wasn't there but there was an adorable Hun. Tall, tanned, blue eyes, very pleasant. And goodness me, if he didn't address me "My Lady" ${ }^{482}$ and all so very nicely. I was sorry. He would have liked to know my name, to strike up conversation - but, well, he's the enemy isn't he? It is a shame that we are not at peace. Half an hour later and I am still thinking about him- that's bad. (ps: I'm sorry that he is not French). Did washing. The rain is pouring down and so it is not drying. Lesson with Barland. Mad. F didn't come at $15 \mathrm{~h}$ and came at 8.30 am having spent 6 hours at Dreux!! Sabotage on the line.

\section{Friday 27 August}

It looks as if it wants to be fine. My washing is still damp - and the sheet? Well - ! Only 2 days of holiday left. Woe, woe! I so hate the office! Lesson with Komatsu. I am always exhausted by this lesson. She doesn't understand the slightest figurative language and I have to explain as if I am explaining to a little child but it is worse because a child retains and applies it. Queues for food

${ }^{480}$ Unclear whether 'filet' is fillet here or net bag, its other meaning. Given the reference to dropping off a satchel in the following line, it may mean bag. Perhaps Madeleine borrowed them for shopping.

${ }^{481}$ Le Chant de l'exilé, directed by André Hugon, was released in April 1943. For more details see: http://en.unifrance.org/movie/37505/le-chant-de-l-exile\#techniques

482 'My Lady' written in English in the manuscript. 
cards. Ironed. Daily alert between 9.40 and 10.05 am. It is so cold. Darned. Lesson with Barland.

\section{Saturday 28th August}

Housework. Denise came for lunch (tomato salad, beef steak, fried potatoes (in lard given to me by Mad. F.). Salad, rice cake, grapes, apples. Pretty good! Mad. F. came to help bake the cake. Very anxious to do it well. It was perfect. Went to see "Goupi Mains-Rouges". ${ }^{483}$ Perfect, brilliant film. I was thrilled. It shows farming life so well! A brilliant film. It's a real documentary with some of the detail on rural life. Fernand Ledoux made a very good Goupi Mains-Rouges. I was struck by Goupi Tonkin's (acted by Robert Le Vignan) end - a remarkable acting-out of utter insanity. When he climbs up the tree, it is stunning. I would never have let myself be done over like Goupi; a strange little scaredy cat. The photography - brilliant!! Some magnificent shots. Jean was there in a light coloured hat. Jean looked like an awkward lump not knowing what to do with himself. Came back home and ate what was left of the feast. I have very bad stomach pain. I am not used to eating so much. I had to do the washing up too. I don't know what it is, whether I am getting old or what but it's amazing how tidy-minded I am becoming. I put everything back straight away and I don't leave the washing up hanging around, the housework is always done. This is not a recent thing. It's been going on for a few months and the longer it goes on the worse (or rather better) it is. Where do all these housekeeping qualities come from? If only I could cure myself of the impulse to put off everything to the next day.

Letter from Maggy Desportes. She is very sweet (my nib is awful and I can't change it. There aren't any). Today Aunt and Yo should be setting off on holiday. Curiously enough, ${ }^{484}$ I don't feel even slightly envious.

\section{Sunday 29 August}

Woken up at $6.30 \mathrm{am}$ by the buzzing of wasps round the grapes on the table. Mass. Adjusted white trousers. Baked. Made grape jelly but nervously and with some reservations because I was doing it a bit according to how I thought it should be and from very vague guidance. First of all, I over-filled my stewing pot. Then, wanting to press the skins I finished up tipping half of it on the blue dress and gave myself a boiling foot bath. I think I might have tried to press the skins too early. For $4 \mathrm{kgs}$ (a bit over) of grapes I got barely a pot. It reduces down

${ }^{483}$ Goupi mains rouges directed by Jacques Becker (1906-1960) was released in 1943. For further details about the film see the British Film Institute website: http://www.bfi.org.uk/films-tv-people/4ce2b6ab67b86

484 'curiously enough' written in English in the manuscript. 
a lot and I did spill a lot of it. Washed hair. Tired out. While I sampled (bread and jam) drying my hair in front of the open window I watched the wasps around the jam. When they eat, their back ends vibrate without stopping. They look as if they go about in twos. First two came, then a third which they chased away but which quickly came back with another. In the end there were 6. One fell on his back in the jam. When he got out I watched him clean himself up. He did his face first and then his body before having a taste. I took the jam away and they couldn't believe it stubbornly flying around the place where it had been as if it was going to come back. I'll be glad when the jelly is in a pot. I am tired out. I am worried about one thing. For some time now the merest mouthful of food gives me stomach-ache. It is quite worrying. Gosh, I am writing so badly - but it is not entirely my fault. My nib is all over the place.

$6 \mathrm{pm}$. Done it. The jam jar is now filled. It's really good - even over-sugared. I wish I hadn't put in the 5 sugar cubes now. It takes a good 6 hours to do it all from stemming the grapes to potting it all. What an awful lot of work for one pot of jam (which weighs, I reckon, 500 grams) which cost about 50 francs including the gas. But it is not as dear as the black market and I know what there is in it. All I have to do is wait for it to cool down - if the wasps let me at it. I wish Cyla could send me a block thing for juicing grapes I could make good cheap jam. I'd make it a little more runny than this because it would solidify a lot when it cooled down. I feel strangely tired. My pen is annoying me but it will have to last until the end of the war because there aren't any more to be found. Couldn't resist going to look at the grape jelly. It is as hard as rubber. I should have made it more watery - I could have made one big pot and one small pot. It would keep better. I was worried about the pan but it is fine. Nothing stuck. I like cooking.

\section{Monday 30 August}

Started back to work this morning. It feels like the holidays never happened. Most people stayed in Paris but everyone has a splendid tan. Mine is fabulous. And I have put on weight - I daren't weigh myself. Started exercises again this morning. Gilberte Frey is getting engaged in October. She's marrying a man just like that having hardly seen him \& barely knowing him. I couldn't do it. She made me pay for all the broken eggs. I think she's pushing it. Just a little more bran in the packing and it wouldn't have happened. Mme Felice has a great tan. She was only at the hospital for 6 days - thank the Lord that I couldn't motivate myself to go. I would have looked intelligent. Kort spent his holidays cycling around Calvados and the Manche. He spent one and a half hours telling us all about it which shortened the morning nicely. For some reason he comes out with: 'Don't get married, stay free as long as you can. That's the only piece of advice I can give you mademoiselle". That's great coming from a young man who has been married for barely six months!! Denise was even more chatty 
than usual. When she was at mine on Saturday she barely said a word. I studied for an hour this afternoon but made the mistake of going for a lie down for a rest for 5 minutes, because I was so exhausted I slept for 2 hours - and all the while my washing was boiling away. It didn't do any harm but my gas - ! Did washing and now at $6.30 \mathrm{pm}$ I am going to do some studying. The nap has put me behind with everything. It is odd how I fall asleep so easily in the afternoon. Beautiful day, very windy. I hope that everything will be dry by tomorrow so that I can iron it before leaving for the office - if Madeleine gives me back my iron. I washed my slippers which had had the grape jelly over them. No staining on the dress, thank God. I was scared about that because it went down the front but the petticoat is all red. I think that it'll go in a few washes. Mad. F. came to chat which meant that I lost an hour. Read Faguet's critique of Lamartine and Chateaubriand and it makes me want to read them. It is strange how I am now captivated by the classics. When I was younger I turned my nose up at them.

My misfortune continues. Wanted to stretch out my sheet to dry in the toilet but, I did something I never do, I didn't take off the other washing. Catastrophe; worse than a region laid waste. The wardrobe collapsed. I was worried about the glass bowls on top but they didn't break. I pulled free my jacket and a skirt. The rest will have to stay there until Wednesday which will be the first chance I'll have to clear it away. Went to bed and was all cosy when - horrible thought the feather in my hat!! I leapt up but all was OK. The hat was perched happily, feather in the air, on top of a pile of coats.

\section{Tuesday 31 August}

Got up at $6.30 \mathrm{am}$. Did ironing. Did the housework. Office all day. I am so fed up. Went to the carpenter's about putting the wardrobe back together. Bought $5 \mathrm{~kg}$ of grapes to make a jelly. It costs a lot but I will be glad of it this winter. Was paid. Air raid alert between 6.25 and 7.35. Annoying day. 11 pm got back from lesson with Barland. Shattered.

\section{Wednesday 1 September}

Around 3 am the anti-aircraft guns were banging away like mad. Office. Cleared up the bathroom. Made grape jelly. Studied badly because constantly distracted by the jelly and melancholic thoughts. Got letter from Aunt. Yo "is a child of nature"!! Letter from Bachellery inviting me for the weekend but I am doing something else on Saturday. Anyway, I don't want to. Go there a week on Sunday. Denise was unbearable at the office this morning. She talked without stopping with her arms folded. I felt as if I had my head under a waterfall, numbed by the water falling on my head and unable to catch my breath. I didn't put the radio on when I got home so as to have a bit of quiet. Mad. F. came to chat for an hour. 


\section{Thursday 2 September}

Was at the office all day. Went to St Lazare to get the train times for going to the Bachellerys. Wrote to Bachellery. Chose a present for Denise's 21st - quite pretty white dangly earrings. Got the flapjack for Yo which I will pay for next month. Went to Dilys in the evening. Did some radiesthesia ${ }^{485}$ So, I'll be marrying Teddy Baker in 1947 and I'll have 5 children by him!!! My dog will die. The English will land in France in October, the Germans will be out of France by February 1944 and I will be back with my parents in April. As soon as I got back I couldn't wait, obviously, to do the same with my ring even though the stone impedes the message coming through. I am going to buy a thing for radiesthesia and I shall see for myself. I am a good doctor apparently. Hardly!

\section{Friday 3 September}

9 am lesson with Barland. 9.30-11.20 alert. Stayed at Barland's until 11 am and then went to Dupleix on foot. As I was going over the Pont de Grenelle, lots of black and white smoke to the right and to the left. Renaud ${ }^{486}$ and ? A crippled plane dropped its bombs all over. The destruction is terrible. Lesson with Komatsu didn't happen. No water at midday. Office in the afternoon. Went to Mlle Komatsu's but didn't have a lesson. Drank coffee and chatted. Tired out. Melancholic.

\section{Saturday 4 September}

Office. Air raid alert 10.15-10.45 am. Had a good lunch to make up for yesterday. Manicure. Had tea at Françoise Boësse's. I do so like her apartment!! I'd be glad to have it were she to give it up. Looked after Mrs Evans and Gaël so that Dilys could go to the cinema with Georges. Knitted and talked. Mrs Evans said a very sad thing. "It's like Gaël is my daughter and not Dilys's. Dilys is like a stranger to me". She doesn't like Georges one bit. I think that she feels that he has stolen her daughter from her.

\section{Sunday 5 September}

Went to mass. Coming out I saw a man, quite an old man, who had fainted or else had died in the church. That would be a good death, just like that, suddenly at the end of mass. I certainly wouldn't want to be surrounded, be injected,

${ }^{485}$ Foretelling the future using pendulum dowsing, sometimes over Tarot cards.

${ }^{486}$ Madeleine probably means the Renault factories here. 
everyone wailing and saying 'She hasn't got long now' 'Shush, not so loud!' 'Oh, she can't hear anything now!' All that was dreadful for grandfather, all like ravens around the bed. I'd like to die suddenly or if I feel that the end is coming, I'd like to go alone in a little corner of the countryside. I wouldn't want there to be witnesses to my dying. I wouldn't want anyone to watch over me.

It's cold. There's a warm sun but the air is brrr! Wrote to Aunt Violette. I don't know what to say to her. We are so distant from one another. Once again she said: "I really regret now not having brought you but I didn't want the responsibility”. Heavens!! Does she think I am still 3 years old. I didn't know that she was still responsible for me. I think it is for me to decide what I want to do. Knitted. Nearly finished the front but because it wasn't right I undid it all. What a job!! Listened to "Le Renaud Bleu" on the radio. Well performed but all the characters are zazous. Lord they are complex - and what for? I'm sleepy but I am not tired. I'm not sure how to explain that. The mere thought of having to go back to work tomorrow - uh! I'd like to be ill, something, let there be an air raid alert, it annoys me so much!!

\section{Monday 6 September}

Between 2 am and 4 am there was a pounding of guns - a huge din. Left for the office; in the métro at St Michel, air raid alert!! (8.35 am). Got out sharpish and came back here by the side streets because the police were out in force. Getting across the Rue Soufflot was a bit scary but I managed it. Got back at 9 am and just as I did so, the alert ended. But, I'm not bothered. I have a nice half hour here. The métro is supposed to get going again in $3 / 4$ hour but I am in no hurry! Arrived at the office at $10.20 \mathrm{am}$. I'm doomed as far as St Michel station goes. No sooner had the métro arrived then there was another alert. $12.30 \mathrm{am}$. Got my skates on to get back. A mad race. Five cops on the rue Gay-Lussac, St Jacques were stopping everyone - and I got through!! Thinking about it afterwards I reckon that it was because they recognised me because I live in the quartier. 12 am. End of the alert. Paid the electricity. Worked like a saint on my Irish. Bought some [. . . ] for my circulation which is atrocious. Drank two bowls, one at $4 \mathrm{pm}$ and the other now $(11 \mathrm{pm})$. God I am so hot. I think that I'll be drinking a lot of it this winter. Cooked once again the 6th batch of grape jelly that won't 'jel'. My two pieces of sugar were what was needed I think. Didn't have the time to knit because Mad. F came to talk. I gave her the ladle to lick. She loved it.

\section{Tuesday 7 September}

+ Office all day. Filled out questionnaire for the office and when I got home I found another one!! I don't like all that. Letter from Bachellery. Lesson with Barland. I. Ill “Anderby Wold” (W. Holtby). 


\section{Wednesday 8 September}

+ Office. Ill. Couldn't work this afternoon, a ton on legs. Dilys is drugging herself up on coffee!! Italy has surrendered!! "Voyage égoïste" (Colette). She is such a good writer. "Les Celtes et la Civilisation celtique" ${ }^{\text {"87 }}$ (Hubert). Gosh I feel sick and my legs are so heavy. Worn out. I

\section{Thursday 9 September}

+ Office all day 9.15-10.45 air-raid alert. Saw 75 planes. It seems that a plane and a parachutist came down. Went to the Red Cross: "Still haven't had your news. Holidays over. In excellent health. Family and friends send kind thoughts. Happy birthday to Daddy. How is Barbier, Nibs, Sammy and everyone? Much love, kisses and hugs." Was supposed to be going to Dilys's to look after her mother but she didn't go out. Didn't work because I read "The Crowded Street" ${ }^{\$ 88}$ (W. Holtby). It is terrible how this reading demon can get a hold of me. I drop everything to do it. Didn't feel too bright. Raining. I.

\section{Friday 10 September}

+ Wrote to Bachellery. Picked up one book on Celts (Hubert). Phoned Sabine Vialla. I [. . . ] by her voice. Went to Komatsu's who has to go some to finish her translation of "La Moisson de "40" (Benoiste Méchin) ${ }^{489}$ before the end of the month when the Nippon envoy returns to Japan. Lessons have been put off until next month (not good for my finances!). Office. Went to Sabine Vialla's. She is charming, delightful, adorable. We talked about everything, about the office, intellectual things, about getting food, about "Samson" which she is writing, about archaeology, about Celtic studies - and no fee! Met her mother. Sabine gave me half a bar of chocolate (stayed 2 hours!!) Lesson with Barland. If it is true, the arrest of Mussolini on the 25th July was ridiculous. Tied to a stretcher and carried into an ambulance. What a knock to his pride. So shaming. How can the Germans publish all the facts? I'd die of shame. I'd rather commit suicide.

${ }^{487}$ Henri Hubert (1872-1927). The text Madeleine refers to is most likely to be Les Celtes et l'expansion celtique jusqu'à l'époque de La Tène, published in 1932:

http://gallica.bnf.fr/ark:/12148/bpt6k921326

${ }^{488}$ First published in 1924.

${ }^{489}$ Jacques Benoiste Méchin (1901-81 ). A diary of life as a POW after France’s defeat in 1940. 


\section{Saturday 11 September}

+ Pretty sunrise. I love my apartment. Office. No meat this week! Glad that I didn't get my tickets last Sunday - had the mutton. News from Mummy: "patience, news will get through, Andrée is working with Nibs, Colette, medicine. Germaine got messages from Lecler. Gilberte died after an operation. Everyone is fine. Us, Toutou \& friends all send much love. Mummy - 9 July". Was very shocked about the news of Gilberte's death - how old was she - 28? Poor, poor Germaine. Raoul leaves her and now the terrible death of her child. Poor woman. Did I say that when I was at the Red Cross, I had seen two machine gun posts on the Av. de la Grande Armée? The buses used by German troops as well as the hotels and the bars are protected with mesh. They say that the trains going North aren't running - that'd explain why I haven't heard from Aunt. She must be going mad if she is stuck over there in that tiny place. Manicure.

Confession. Brought back the extension cables. I'm going to be fine for working in the evening now without using too much electricity. 6.45 air raid warning, 7.25 end of the warning without anything happening. Went to look after Mrs Evans. Miss Beach came over. Very pleased to see her. Françoise Bernheim has been deported. It is terrible. HB . . e escaped by sheer chance. Listened to "Russian Commentary" where everything was "cheerful" 490 - Russians who had nearly died, trains, villas they had strewn with flowers standing amongst the ruins - [. . ] the Alamani ${ }^{491}$ My room is looking very sweet with the indirect lighting ${ }^{492}$ and I will use less. I need some biscuits and some mineral water in case of accidents. I. It's a year since Godmother Berthe died.

\section{Sunday 12 Sept}

Mass. C. Heard a huge row on the landing, it was the young woman from Martinique and her husband; they had killed a rat as big as a 4 month old cat. My legs were trembling. Wrote to Maggy Desportes, to Godfather and to Granny. I'll need a lot of money to dress smartly - alas. I'll have to do some work on my cherry-red dress for going to Sabine's on Saturday and I'll have to go to the hairdressers beforehand!! Sylvia said that I dress "so meekly". ${ }^{493}$ I will not be meek. Oh God, I don't want to be forever the doormat. I need more self-confidence hard to put back what 13 years of school tried to take from me. I didn't know that Sabine Vialla was - at least her pseudonym is - Maria Le Hardouin, the one

\footnotetext{
490 'cheerful' and 'Russian Commentary' in English in the manuscript.

${ }^{491}$ Possible reference to the Alemmani (Alamanni) tribes?

492 'Lighting provided by reflection usually from wall or ceiling surfaces'. This is taken from Schorsch.com.

493 "so meekly" and 'meek' written in English in the manuscript.
} 
who wrote "La Voile Noire". ${ }^{494}$ Detourne or Letourne ${ }^{495}$ was the name she was born with, she used to live in Troyes. I adjusted my red dress, pulled it in under the sleeves, covered over the buckle and shortened the dress. I am shattered. There is a dramatic chivalric moon behind the tragic black clouds.

\section{Monday 13 September}

Slept in (7.10 am). Mussolini kidnapped (taken away) by parachutists!!! Never a dull moment. Office. Rain. Slept for an hour without meaning to. I want to get married. I think that I am going to get a boil on my behind. I should take a purgative. Marvellous sky this evening - a luminous lemon blue sea with grey mist in the distance. Two arms of a rainbow - the other arm very [. . . ] to the left of the Val-de-Grâce. Then orange and flame coloured. Above it grey clouds against a blue sky. Very strong wind. I go back to my Celts.

\section{Tuesday 14 September}

Office all day. Record - 10 hours work $-6^{1 / 2}$ at the office $2 \frac{1}{2}$ studying, 1 lesson. Mlle Barland was half asleep. Full moon. Bad ovulation pain. Odd experience in the lift. Was going down with the fair headed boy from the 7th floor who lives next door to the Zazous. I hate it when silence weighs as heavy as lead. He had a very big bunch of keys in his hand; looking for something to say. I said "Good God, I thought it was a revolver!" "No, I don't have it on me at the moment" (he's the police officer then). "Was it the clinking that made you think that?" "No, it was your hand being closed around something" "You are on edge Mademoiselle". Of course, I protested but without being able to say to him that it was just to say something having only thought of the revolver after having seen the bunch of keys and making the comparison. "No you are edgy - it was the 'Good God' that gave you away". Interesting that Good God = fear. Thought about it afterwards: Am I fearful? Instinctively I would say no but . . . ? I don't deliberately go against the rules, I don't like hurting be it physically or emotionally. I am sensitive to the opinions of others, an unexpected ring of a doorbell or telephone makes me freeze, meeting someone unexpectedly rattles me; and in a sweat my body just acts automatically. But no one notices. My mind is stronger. Bought fabric for Gilberte.

\section{Wednesday 15 September}

Still got pain in the lower abdomen; it's all hard and swollen. What a day!! $2 \mathrm{pm}$ went to the hairdresser, $4 \mathrm{pm}$ was starting the washing up when the doorbell

${ }^{494}$ Marie Le Hardouin (1912-1967). Awarded the Prix fémina in 1943 for the novel La Voile noire.

${ }^{495}$ In fact, she was born Sabine Outhoorn. 
went - Aunt Violette!!! I was flabbergasted!!! She had brought me back my suitcase and gave me a little bit of veal, a camembert and a few apples!! She stayed for 2 and a 1/4 hours. Charming and chatty and very lively!! Thought that my garden was sweet. Gosh, I could have fainted. OK now. I have the feeling that they are going to carry out raids now and again. Madeleine Fortan came over. We were talking when at 7.30-9.00 there was an air raid warning but for real this time!!! First of all 7 flying fortresses then 4 (they said 6) squadrons of 28 planes. I saw 2 planes shot down, one was in flames and was like a star. The other rolled over and over as it fell. It was like being at the cinema. I was more perturbed by the horrified faces all around me. Huge smoke clouds. The little woman from Martinique ran away screaming we all rushed to her place. We could see huge smoke clouds over the Porte de Versailles masking the Eiffel Tower rising in the air for kilometres. I wasn't frightened at all. The flak was pounding so much that everything was shaking and large star bursts could be seen within and above the squadrons but apart from 3 which were smoking a bit there was nothing else. I saw two parachutists from crashed planes but the sky was so blue that it hurt to look. When the first was brought down the concierge came up her eyes popping out of her head and screaming 'He's falling on our building. 'Poupette', the policeman's wife as white as a sheet was following her husband around holding runner beans in her apron. . saying nothing, understanding nothing, sticking to her husband like a shadow. Dilys said that when the plane started to fall everyone in the street watching the planes started to scream and run towards the Val-de-Grace covering their heads with hats, papers, helmets and frying pans. After the air raid I felt very, very cold and tired. No tap water. I had to drink some mineral water. Cards from Bach. ${ }^{496}$ and from Jacqueline Prévost (Piatier).

\section{Thursday 16 Sept}

It is 3 years today that I left Aunt's to go to 4 rue Rollin. ${ }^{497}$ No train is running out of St Lazare. Kort gave me a real dressing down for 'innumerable cataloguing mistakes' that I've been making and I will have to move departments if I don't stop being all over the place or, at the very least, that I no longer do any cataloguing if I'm going to make so many bad and repeated mistakes - there were THREE documents which had been wrongly catalogued out of all the hundreds which I have done this month. One on poppyseed oil put in oleaginous plants, one on weed identification put in insecticides, one on aeronautical engines put in plane engines. What a funny man. I was thinking that I had wrongly catalogued a good forty!! He made himself scarce before I could say

\footnotetext{
${ }^{496}$ Bachéllery.

${ }^{497}$ First mention of the date Madeleine moved out of her lodgings with her aunt to move into rue Rollin with Ruth Camp.
} 
"is that all?" but afterwards he was as nice as nice could be. What an idiot!! Was at the office all day. "Return to Yesterday" (Ford Madox Ford). It was pounding away around $1.30 \mathrm{am}$, women were running for the shelters, German officers were walking like crabs looking at the sky. Wished Denise a Happy Birthday. She is as pleased as Punch with her ear-rings. Gilberte gave her roses out of her garden, I will give her flowers Saturday morning. Went to look after Mrs Evans and Gaël. Letter from Barland. Dilys is jealous that I am Sabine Vialla's "secretary" or near enough. Had lunch in the Parc Monceau.

\section{Friday 17 Sept}

Wrote to the Service des Délégations and Bachellery. Ironed dress. I am sure that it is too short. Wrote diary. I've got a real cold - rain. Office. Lesson with Barland.

\section{Saturday 18 Sept}

Denise Pedron 21 years old. Gave her 2 roses as a present. Office. So nervous about tea that couldn't digest the cabbage. Had to lie down. Manicure. When I was getting ready to leave, Dick arrived to start up lessons again. He thought I looked nice. Tea with Sabine Vialla. Charming. Air raid warnings - 12-12.20 and 7.05-7.25. After tea, went by Dilys's with Madeleine to make her jealous. It worked completely. Letter from a Madeleine Rochette for lessons. Godmother Berthe was buried a year ago today.

\section{Sunday 19 September}

Mass. Went to Montalet. Very pretty. The Bachellerys live in an old abbey. A baby has brought out the human side of this intellectual couple who were really charming. Met a Mme Jacob, lovely woman, very worn down by what it happening to her and horribly thin. ${ }^{498}$ Picnic in the afternoon on the Issou heights near to Vexin. Went and came back on a double-decker bus. A lot of houses destroyed near to Asnières and Courbevoie. William was very kind. Escorted Mme Jacob back to rue Monge. Brought back tomatoes and apples. Cold has gone.

\section{Monday 20 September}

Office. Dead tired. Slept an hour in the afternoon. Lesson with Dick. Went to look after Mrs Evans. Gaël made a horrid scene about going to bed which really upset me. Spoke with Mme Baron, very nice. Letter from André.

498 This is very likely to be a reference to anti-Semitic persecution. 


\section{Tuesday 21 September}

Office all day. "She" (Rider Haggard). 499 "The Importance of being Earnest" and "Lady Windermere's Fan" (Oscar Wilde). 10.35-11.25 alert. Invited Denise to dinner. Lesson with Barland.

\section{Wednesday 22 Sept}

Office. Slept in the afternoon because I couldn't stay awake. I should have written job application but too exhausted. Have been going to bed at midnight since Wednesday without a minute's rest nor time to do the housework. Second letter from Rochette. Letter from Granny. Has Jacqueline Piatier come back? Wrote to Rochette, Bachellery, Aunt, André. Alert 5.15-5.35 pm. Lesson with Dick. Went to bed at midnight again!!

\section{Thursday 23 September}

Office all day. "Thirty Clocks strike the hour" (V.Sackville-West). She describes the characters admirably. "Experiment in Autobiography". Had lunch in the Parc Monceau as I did last Tuesday. It is splendid out in the sun. Went to bed early (7 pm) but read H G Wells (Exp. in Autobiog.) He says some very just things. I admire this man a lot. 7.10-7.25 alert. Bought "Panorama" for the last time I think. It is no longer worth $3 \mathrm{fr} .^{500}$ Intrigued by the short story that got first place ex aequo in the under 30 section of the competition: Procal Renoux ("Le Gire"). Ideas, images, vocabulary but unintelligible and incoherent. Am I out of touch or just stupid? Around about $11 \mathrm{pm}$ there was a violent burst of anti-aircraft fire, the worst yet. Got up to fill a basin with water. Was worried but not frightened.

\section{Friday 24 Sept}

Around 2 am it started up again with even more violence. Everything was lit up by the continual flashing of the anti-aircraft fire. Whistling of bombs and zooming of a shot down plane. So close!! Huge glare. Went to the rubbish chute to take a look but so much shrapnel was falling that I had to beat a hasty retreat. On the way back, I was pleased that there was a roof or otherwise there would be no more Madeleine. I am sure it was happening right where I was. I was frightened. Not very but the sort of fear that makes you say I'd prefer to be

${ }^{499}$ H. Rider-Haggard (1880-1925). For more on She see: https://www.britannica.com/topic/She-novel-by-Haggard.

${ }^{500}$ Panorama was a weekly magazine covering literature, fine art, cinema, theatre and current affairs. It appeared between 1943 and 1944. 
standing up, less to hit than there would be if I was lying down and to wonder whether I needed to put a pillow over my head. Fell asleep and dreamt that a German officer wanted to marry me despite my resistance and the fact that I was engaged to a Frenchman. Read Wells instead of doing the housework. I have two major vices - putting off what I could do today to tomorrow and READING. But this latter vice is terrible. Wells also went against marriage. Every man seems to do so unless they are absolutely conventional. When I think about it, I would have been Jean's mistress if I had loved him because he didn't want marriage, offering the prospect only so as not to upset me and all the time thinking that I didn't love him. If I had loved him I would have slept with him marriage or no marriage. But, whilst I don't object to marrying a man I don't love, - so long as I respect him and we get on well, I will not be someone's mistress on the same terms - particularly if respect does not exist. The marriage sacrament is like a business arrangement in order to build society where there are rules. Sex outside of marriage is only there for the pleasure of two people and it bears no fruit. The ideal would be to have love in marriage but it never lasts. It is much better to go into an arrangement with one's head screwed on than to go from disappointment to disappointment. Went to 15 rue Soufflot for job. Took laundry back to Jacqueline Prévost (née Piatier). 12.40-1.05 alert. Alerts always relax me, when there's nothing, because at least I don't have to think about going to the office. I should have left from here at 12.45. As it is I'll go without rushing around $1.30 \mathrm{pm}$. Broke a glass but it was already badly cracked.

Office. Alert 5-5.30. Waited for Dick who didn't turn up but met up with him afterwards. Met with Madeleine Rochette about lessons. She is very nice but too reserved. Flew back here to eat but Mad. Fortan had her talking head on so swallowed $100 \mathrm{gr}$ of bread and ran to the lesson with Barland. Was late but she was even later. Her father made me welcome. He works for Bon Marché! 11 pm. Too sick to eat. ${ }^{501}$

\section{Saturday 25 Sept}

Office. Rain. Letter from Aunt. No Villeparisis but walk with Aimée and Huguette in Paris "given the nice weather". It's looking as if it'll be a great Sunday. No meat this week - and what about my tickets? Manicure.

\section{Sunday 26 Sept}

Mass. Cold. Went to see Aunt - Yo has got tonsillitis. They could have warned me!! I managed to entertain the invalid. Aunt, Yo were so charming. Slept over. 7-7.25 am alert. Rained.

501 Alongside the entry of 24th September, Madeleine writes, 'the plane fell on the big shops on the rue du Louvre'. 


\section{Monday 27 Sept}

Arrived at the office $1 / 4$ hour early!! 11.20-12.15 alert. Bored because nothing to read. Cleaned from top to bottom and in the middle of doing it Mme Beaugrand came to book a lesson, she's so chic and I am so grubby!! Anyway, she's charming. I start tomorrow. Lesson with Dick 6.25-6.50 alert. Dick is getting "fresh". ${ }^{502}$ I don't think that his intentions are strictly honourable. Lesson with Madeleine Rochette. Lesson Mad. F. 10.20 the anti-aircraft guns started firing. Tired out. Because I have a bit more money I am going to adopt a prisoner. It is a little late in the day but I couldn't afford it before. I could write loads but I am going to hurry \& get down some [...] to warm me up and go to bed. It is so cold. Office and Kort is sulking with me. Right now I can't do anything right for him. Denise not there this morning - registering for exams.

\section{Tuesday 28 Sept}

Office all day. 5.15 lesson with Mme Beaugrand. Tiring because she is so stubborn. Raced back to have dinner. Sent pneu to Aunt about dinner tomorrow. Lesson with Barland.

\section{Wednesday 29 Sept}

Office. Went to collect godson. First went to the Prisoners' Parcels Office (closed) then to the Prisoners' Family Offices (Mme Atmans), got sent to the Prisoners' Chaplaincy. Lesson with Dick. Dinner with Aunt, Brought vegetables back from the Villeparisis plot - a big courgette, a little pumpkin, a little cabbage, 10 tomatoes.

\section{Thursday 30 Sept}

Office all day. Went to the Chaplaincy. Quite badly organised. Finally got a label for a Camille Cavé and a card to request a prisoner from Stalag 1A. Could I take 2 prisoners? Or just one? 1, I could manage, 2, I would have to go without (I am talking about money because I will send parcels through the Town Hall). I am going to sleep on it. Lesson with Mlle Rochette. Went to Chabert. Card from Maggy Desportes. Rain. Went to bed early thank God.

\section{Friday 1 October}

Got up late. Still undecided about the prisoners. Of course, I'll send a parcel to Camille Cavé even though I have to [...] the first packet. But will I have to write

502 'Fresh' is written in English. 
to get another one? And another thing. What other subject am I going to take? Went to the Sorbonne on Wednesday and found out that my BA does not count as a licence libre because I am French!! So many things I cannot have because I am French!! I will have to have another qualification alongside the Etudes littéraires classiques in case I fail it. I'd like to do Psychology . . . .

Why not have 2 prisoners? It would not be a big sacrifice for me and it would mean so much for "them". Wrote to the Chaplain of 1A, Pierre Dubois [25519FZ]. It was difficult. Now, all I have to do is wait.

Office. Mme Felix wasn't there. Roche, Bayard suspicious ${ }^{503}$ so sent [....] ___ ${ }^{504}$ and she wasn't there. Richter, Zaukel's right hand man was assassinated a few days ago and since then there have been 6 murders. We'll surely be punished Sunday and perhaps Saturday. That'll give me time to get on with things. Lesson with Barland. I am exhausted and feel anxious. I hate it. I look as if I am in fantastic health but there are only about 3 days a month without illness or some woe. Homesick. ${ }^{505}$ Depressed and tired most of all. And to say I have to get up early tomorrow morning to see Mme Felix before the office. What a stupid little idiot.

\section{Saturday 2 October}

Went to Mme Felix's. Not there. The things I have heard said about her!! She was at the office. Didn't telephone Dick so no lesson. Didn't have a manicure. Tired, ill, went to concert. Jean de Rohonzinski ${ }^{506}$ was in a very bad mood. But the concert was fabulous. Really enjoyed Bach for the first time.

\section{Sunday 3 Oct}

Mass but didn't go to Villeparisis because I was tired and fed up. It is the only day when I can get some rest and if I have to go chasing around again!! We were expecting there to be a curfew but there wasn't. 3-4.30 pm, alert. A plane fell Pont de Tolbiac. 7-7.30 alert. Darned and knitted - and had a good rest.

\section{Monday 4 October}

Clocks went back. Nice to stay an extra hour in bed but as strange as anything in the streets; and this evening I was shattered because it was $11 \mathrm{pm}$ (midnight really). Office. Denise talked, talked and talked. I could have killed her. What's more I'm in a very bad mood. 12.35-1.10 alert. Washed blouses etc. Scrubbed

\footnotetext{
503 'suspicious' written in English.

${ }^{504}$ Illegible word then a gap left in text.

505 'Homesick' written in English.

506 Jean de Rohozinski.
} 
around with the wire wool, did the housework. 4.45. Lesson with Chabert. 5.50 lesson with Dick. 7.15 lesson Rochette. No lesson with Madeleine. I was sure that she would pack in. Wrote to Aunt, Villeparisis, prisoners. So many things!! Saw the new quartier en plein air - good sign. I'm very thirsty which is a rarity. Sleepy byes because I'm very tired. Cold but things are drying quickly.

\section{Tuesday 5 October}

Office all day. Lesson with Beaugrand. She is so, so stubborn!! Lesson with Barland.

\section{Wednesday 6 October}

Office. "James Joyce" (Gorman). ${ }^{507}$ I didn't know that Joyce had taught English abroad. By mistake got "My American" which I had already read. Sickly and tired. No desire to go out. Blue sandals broken. Went to see Maggy Desportes. Very happy to see her and she me. Katy looks like a little boy, a little too thin. I think that I am going to do Celtic archaeology. Brilliant. Lesson Dédé. Went to bed. early. Maggy gave me 1 egg and a camembert.

\section{Thursday 7 October}

Office all day. Lots of upset. Mme Broussard and Mme Marguerite were threatened with the sack. What's more, it looks like the Centre will be closed in December. I will have to look for something else. "Walter de la Mare" (R.L. Mégroz). ${ }^{508}$ "The Years" (Virginia Woolf). ${ }^{509}$ Not bad, read it already. Went to the Red Cross. "Got message from July. Sympathy and sadness death Gilberte. News André, health good. Congratulations Andrée, Colette. Happy birthday Daddy. Send your news. Hugs and kisses, thinking of you". Lesson $1 / 2$ hour Chabert, lesson with Rochette. Read til 2 am. 1.30 anti-aircraft fire. I

${ }^{507}$ Herman Sherman Gorman (1893-1954). His biography of Joyce was reviewed by Horace Reynolds in The New York Times in February 1940: http://www.nytimes.com/books/00/01/09/specials/joyce-gorman.html

${ }^{508}$ Rodolpe Mégroz (1891-1968). English novelist and art critic. The University of Reading holds his personal archive comprising letters, photographs, notebooks and journal articles:

https://www.reading.ac.uk/special-collections/collections/sc-megroz.aspx

${ }^{509}$ Virginia Woolf (1882-1941). A contemporaneous review of The Years, 'Virginia Woolf's richest novel', was published in The New York Times in 1937: http://www.nytimes.com/books/97/06/08/reviews/woolf-years.html 


\section{Friday 8 October}

Bought shoes. Lesson half an hour with Chabert. Went to Komatsu's. Not there. Corrected application for teaching. Office. Lesson with Dick. No Barland. I.

\section{Saturday 9 October}

Office. Pneu to Aunt saying that I am not going tomorrow; pneu from her saying that Marcel is there. Pneu to her saying that I would come. Note from Dilys for me to go at $2 \mathrm{pm}$. Urgent - and she leaves in no haste at $2.45 \mathrm{pm}$. Manicurist arrives at 3.30. Afternoon ruined. Gaël is becoming objectionable - she was anything but pleasant with me as her mother looked on smiling tenderly. For a 2 and a $1 / 2$ year old she has a fantastic vocabulary. And she speaks so clearly!! You'd think she was 6 or 7 years of age. I think that Dilys spoils her too much and it's a shame. Her hair is wonderful, adorably fine. I must have one of those colds coming. The butcher had some meat - the only butcher in the whole of Paris. They say that it'll be three weeks before our ration tickets will be honoured. 1-2 (90gr). In September we had 217 gr of meat - but since Wednesday we have had 25 gr more bread a day. That makes 300 gr a day. But there isn't much getting through. For two days I ate just pumpkin. It's going down. Tuesday: Lunchtime $200 \mathrm{gr}$ of bread and butter, 3 pears, evening $100 \mathrm{gr}$ bread, plate of pumpkin. It isn't enough. I feel ill constantly too. Since having eaten I feel a bit better. It is very cold. You could imagine it snowing.

Denise disgusts me - together, she and her brother bring in 3,300 fr a month (between 3, they have $1000 \mathrm{fr}$ rent a quarter). The medicine for her mother costs $400 \mathrm{fr}$ (or thereabouts). They owe in the region of 4 to 5,000 $\mathrm{fr}$ and have only $300 \mathrm{fr}$ left to get through the month (it's the 9th). They are going to have to sell something and there's the little matter of the 100 to 200 frs commission on shopping which she blows on getting her hair done. Ok, the 50 frs she gets from her mother each month is not enough - but she can't do much more. She could at least have the good manners not to go out and get her hair straightened when her parents are having to sell the crockery. I do like Denise - but she has an unpleasant side and is not easy to be around, always flying off the handle. Her mother is the same of course but even then ... !! Some faults I just don't mind but disloyalty to one's family - no! At the same time, God knows, I do like the family - at a distance. The family unit, parents and children, should never be divided. Sisters and brothers are different, they are in different units.

Denise doesn't reflect on much. I spoke to her of the cost (moral) that one pays for everything - "Take what you want" said God, "take it - and pay for it". ${ }^{10}$ She got really irritated and decreed that I spend too much time thinking!!

510 “"Take what you want" said God, "take it - and pay for it". Sentence written entirely in English. 
At the office - the parents of M. Delbot (collaborators) and their daughter (17 years old, a collaborator too) received little coffins on which was written "Sentenced to death". I find all that pretty puerile. I

\section{Sunday 10 October}

Woke up, voice gone and bad stomach ache. Thick fog. The thought of having to go to Aunt's. What annoys me is that it is my only free day and next Sunday I will have to go to Villeparisis because I have been away for too long. But I will go even if my body doesn't want to because I have two selves. There is one that loves me and thinks only about me being happy and the other, it is the opposite. The first nearly always obeys when the second self shows up - in fact, I could say that it always obeys.

Sometimes I feel that I am not free and that I have to obey - if I don't, I feel I have done something wrong and worry about being punished - something bad will happen. These two selves are increasingly in evidence just lately. I suppose that one might call that having a Catholic conscience. That 'self' never loses her head and is as hard as nails. In a crisis when I am frightened or emotional or dreaming, it is this self who speaks, who acts outside of me. I only seem to realise what is happening to me or what has been said to me some time after it has happened. Have I a 'double'? I don't think so, I think it is the 'me' I have been trying to become since my youth. I've let this go since I have been in France, other than now and again - because I don't feel that I have a purpose, no, that can't be right - I feel that I am waiting before getting back my "drive" 511 to go for my goal.

Yesterday the manicurist told me that at 25 (ie: this year) I will be in danger of death if not dead. That doesn't scare me. I do not think that I am going to die but I do think that I am going to have a very serious illness. What is written is written. My poor parents if I die. But, as I said, I don't think that I will. I do sometimes think that I might have an illness back home in 18 months time. After applying for jobs at universities (I am not sure whether I will get one) I will get married to a lecturer probably a chemist. Then I will get a big house in the countryside with chickens, large gardens, an orchard etc. I can't decide between two plans. Neither are brilliant. The halls of each are too big, the stairs are difficult to fit in. I've done it approximately and it is not quite in proportion. I'd like an aquarium but set back in a wall like a window and lit up at night. Why not? And I'd like a bathroom for each bedroom. An office for my husband and an office for me and a lot of bedrooms because I'd like four children at least, please God. ${ }^{512}$ The Brown's house is alright but I prefer the main door at the front. There needs to be a wash basin on the ground floor with cupboards so that the children can hang up their coats and wash their hands before coming

511 'drive written' in English in the manuscript.

512 'please God' written in English in the manuscript. 
in. There will be central heating everywhere but fireplaces too. There'll be an oven and a fridge. A big window over the sink etc. Gosh so many dreams! Linen cupboards, sink, sewing machine, table, bed because that room will be a sick room as well. I'll need that if I have lots of children! Mass went to Aunt's. Put on an act and it worked. I was ill but not as much as I seemed to be. Anyway [. . .] is amazing painkiller. Went to see "Grande Marnière" with Fernand Ledoux, Jean Chevrin and Robert Le Vigan. They acted well in a run-of-the-mill film, although the last scene in the courtroom was pretty gripping - it's a classic device which rarely fails. Very misty. I.

\section{Monday 11 October}

Office. Robert Guillou came by to see Mme Roche-Bayard about Denise and now she works from home. The poor little woman bemoaned the fact that the measure didn't apply to me. It was touching. But although it would be good for me to work at home instead of coming in to the office Kort suggested that I work the whole day for - hed try to get it - 2,200. It is not worth it. I said that I need my Friday morning and that I would think about it. I have thought about it. I am going to try to see the Teaching Appointments Officer tomorrow. Got letter from Mme Beaugrand putting her lesson off until Thursday. Dilys came to get me because M. Dougall can't give a lesson this evening and Dilys is not allowed to go out. ${ }^{513}$ I agreed. I'll see. I will try it to see whether it suits me. Housework. Did washing. Cleaned kitchen. Humid and misty day. Marguerite Delplanque came with a friend. She wants to start back with her English lessons. Lesson with Dick. I waited for him for $3 / 4$ hour. He is never on time. Came back at $7.10 \mathrm{pm}$. 7.15-8.15 lesson with Rochette. 8.15 left for a lesson with Barland. Got back shattered. Put on pretty little shoes as I'd taken my sandals to be re-covered - but oh my heels. Three blisters and skin pulled off on the left. All bloodied on the right. I

\section{Tuesday 12 October}

What's this on the radio? All men between the ages of 18 and 40 and all single women between 18 and 40 have to report to the Commissariat de Police me (B) tomorrow. Good God. Looks like I am as good as gone to Germany despite my work permit given that I'll be unemployed by December, unless I find a teaching post. ${ }^{514}$ I'll go Saturday to see the Director. It is pointless going today because I don't want to push the idea with Kort although I will hint that

${ }^{513}$ Dilys Le Colleter (née Evans) was a British citizen married to a French policeman. Not interned, she was, however, subject to a curfew.

514 This is a reference to compulsory work service (Service de travail obligatoire, STO). Demands for more French workers increased in the summer and autumn of 1943 but by this time, civilian non-compliance was rife. 
I will be looking for something else. I'm not too keen on going to get bombed in Germany. I was wrong. It's just Italians. What a weight lifted off me. But I am not happy that Denise is leaving today. Cried. Sad. Lesson with Barland "Autobiography" (A. A. Milne). Three Fevers (Leo Walmsley). ${ }^{515}$ Good. Office all day.

\section{Wednesday 13 October}

Office. Went to Maggy Desportes place. She lent me "L'Oiseau bleu" (Maeterlinck). ${ }^{516}$ So-so. Inspected her skull (not her skull but that of the skeleton she owns). It's a brachycephalic variety (I think the dolicocephalic sort have a head a quarter longer than their width). Arrived very later for lesson with Chabert. No lesson with Dick. Bought chestnuts. Fog.

\section{Thursday 14 October}

Office all day. Went to Denise's at midday for the Saint-Loup goat's cheese to go with the potatoes. Had lunch again at her place. Lesson Beaugrand (was given pears). Chabert ( $1 / 2$ an hour) and Rochette. "Self-Portrait" ([. . .] Frankan). Showy Jew boy. ${ }^{517}$ "The Bat flies Low" (Sax Rohmer). ${ }^{518}$ For a detective novel it isn't bad. Fog.

\section{Friday 15 October}

Rent. Lesson with Delplanque. Office. Waited in vain for Denise to bring the bag for the potatoes, came at the back end of the afternoon. Lesson with Barland. Read until 2 am.

\section{Saturday 16 October}

Office. 1 and a half lessons with Chabert and Mme (Simone) Laberrie. Not fair. I only ask for 25 frs an hour. They'll probably get married. Sun. 4.40-5.10

515 Leo Walmsley (1892-1966 ). Like Winifred Holtby - another of Madeleine's favourite writers - Walmsley was Yorkshire born and based and his writing featured the moors and coast of North Yorkshire. For more on the Shipleyborn writer, see the Walmsley Society website:

http://www.walmsleysoc.org/Leo.html

516 Maurice Maeterlinck (1862-1949) was a Belgian playwright. Oiseau bleu was published in 1908.

517 'Showy Jew boy' written in English in the manuscript.

518 Sax Rohmer (1883-1959), otherwise known as Henry Ward, was a British crime writer. Some of his Fu Manchu series are available at:

http://www.gutenberg.org/ebooks/author/110 
alert. It feels like Autumn is here. It is really cold. If this evening is colder than yesterday evening. I'm bringing my cactus in. They say that Jacqueline Prévost (Piatier) is pregnant. They're saying that it is early.

\section{Sunday 17 October}

Didn't go to mass because got up too late. Villeparisis. What a bore. Granny is annoyed because I have not been for so long but damn it if I have to always be stuck with the family now. I know that Aunt is expecting me to go each Sunday now and she is not happy that I will be going to have lunch at the Delplanque's place next week. "Oh, I wanted to go to Fontainebleau". "Alright, go on then" But, oh no, that isn't satisfactory. Marcel is around at the moment and Yo has taken 15 days sick leave (???) (PS: she earns 2,500, which is good but that gives her 2,100 a month. She would go green if she knew what I was making. I started working 3 years after she did and it wouldn't surprise me if I had caught up with her). But when Marcel leaves there's only going to be me around to amuse Missy. Oh well, they can go whistle for it. I have my own life. The Roches have suggested cutting down the 4 oak trees and the silver birch and replacing them with fruit trees which will be ours and mine to take from. I would like to say yes but Godfather is furious; he has made little allotments in there, a strip for Mme Henri, a little bit for Charles - I suggested that the Roches may be able to buy after the war? Aunt was furious. In the end, the Roches seemed to be saying that they felt sorry for me because life must be miserable with a family like that. (Politics or something else?) Anyway!! Roche gave me a cabbage, a potato, a carrot, beetroot, 3 apples, 3 tomatoes. Aunt gave me a few apples and green beans. M. Laberr came with his little fox terrier Mascotte (4 months old). Came back early $(9.30 \mathrm{pm})$ and got the meal ready for today.

\section{Monday 18 October}

Office. Started back to classes - and alert!! 9.20-9.50 am. Mme Félix came back to the office, Went to Dick's lesson at 2 pm but he didn't come and so went back there at $5.45 \mathrm{pm}$. Misunderstanding but he didn't pay for the afternoon, the beast. He told me why lino is cooler than wool. Very clever. 4 pm lesson with Rochette. She is lovely. At midday had some whiting - took out nearly everything there was inside to clean them. The fattest one had three little half-digested fish inside him - but I didn't eat them. I do want to eat a fish but not one that it has eaten. Bought butter. Did my 8 hours work!! Beautiful day like yesterday but cold. Rain this evening. I heard drops running down the window panes.

\section{Tuesday 19 October}

Office all day. Denise turned up at midday - brought me some pears, the poor dear. "The fountain" (Ch. Morgan). "Psychology (Judd). Lesson Mme 
Beaugrand who gave me some butter and a ration card for the potatoes!! Lesson with Barland. Mme Kerteux has a 'girlfriend' - at her age. At any age it's a disgrace.

\section{Wednesday 20 October}

Office. I found out from Mme Broussard and Marcelle Felice how women make love to one another. Well now!! I was in tears laughing I was so shocked. I was laughing although shocked to the core. How terrible. I would have never believed such things existed even though I struggle to picture it. Marcel and Yolande came. Marcel thought the apartment was delightful and Yo, the wretch, utterly jealous. "Oh, you're always so deep in your studies" she muttered to me. It must be the 'family joke"519 - if I didn't have to work for a living I would have produced something by now but when I can only manage three or four hours a week - what to do ${ }^{520}$ As Chabert would say. Lesson with Chabert.

\section{Thursday 21 October}

Office all day. Rain. Lesson with Rochette. Autumn is coming quickly. The trees at the Val-de-Grâce are all golden and their leaves are falling, falling. Russet, crackling cloaks cover the lawns of the Parc Monceau. But again it is quite mild. $8.45 \mathrm{pm}$ and I finished my 8 hour work stint and I had dinner. I am going to be able to do some darning. I was thinking fondly today about my 'prisoner'. Is that a sign that I have one?

\section{Friday 22 October}

Did the washing. 10.30-11 am. Air raid alert. 11.15-12. Lesson with Dick. Saw Dilys. Office. Lesson with Barland at least I went, no lesson but got paid. Denise has a law exam. Rain. Letter Yvonne Disnar who is expecting a baby in April. Félix has been back for 7 months already!! Letter from Marguerite Delplanque.

\section{Saturday 23 October}

Confession. Office. Lesson Chabert. Manicure. I had intended not giving a present to Dilys - after all, she doesn't give me anything for my birthday and she is the ultimate in self-centeredness. She cornered me and was so obviously waiting for something with her little face all tensed up that I relented. ${ }^{521}$ Afterwards, she heard me whispering with her mother and she insisted that I come to

\footnotetext{
519 'family joke' written in English in the manuscript.

520 'what to do' written in English in the manuscript.

521 'relented' written in English in the manuscript.
} 
dinner on Wednesday evening when I go to look after her mother and Gaël (that's a rarity, dinner). Sent her a card with 5 cigarettes. Rested up. Sometimes, one can spend a lot of time doing one thing without getting better at it and suddenly, one day, that changes. I am pretty slow at ironing but in one hour I did 2 skirts, 2 pairs of pants, 2 tablecloths, 3 bath towels, 6 flannels, 1 pillow case, 1 dress ([. . . blue), 1 net bodice, 6 handkerchiefs and I "pressed"522 the wool jacket and the skirt I had let down!! Still raining. Knitted a little bit. Had dinner with Denise who had failed her exam.

\section{Sunday 24 October}

Mass. Went for lunch at the Delplanque's. 12.40-1.15 air raid alert. Lunch. Thick vegetable soup. Roast pork and sautéed potatoes; ham and salad in a dressing, camembert; gâteau de Savoie with jam. apple and pear tart, apéritif, red and white wine, Cointreau, coffee and before leaving, buttered pain d'épices and tart!! I couldn't manage any more. Very on edge. Met up with Denise in the morning. Poor love. Danced here this evening and then bedtime.

\section{Monday 25 October}

Office. (Heating on). Rain. Went to Dick's but he wasn't there. It is not funny now. I really must make him pay for the lessons he makes me come to do. Telephoned Felix and Jacqueline. Food ration card. Housework. Lesson Delplanque (6-7) and Rochette (7-8). Rochette stays on afterwards for at least a $1 / 2$ hour to speak to me but she is very nice. Madeleine $\mathrm{F}$ is being funny with me because she offered me butter yesterday which I refused (I had just bought $1 / 2$ a pound). She is furious and told me that she didn't know how I could eat the butter that I had because when she got some off me, it was rancid and mouldy which is not true. It was strong, I know, but I didn't make her have it and she was very short at the time. I have often noticed that she always runs down the purchases I make and has wanted me to buy from her alone which doesn't suit me because it is often dearer from her. Her butter is always fresh, but I have only had to complain once about the butter I've had from the little concierge woman. Very sleepy.

\section{Tuesday 26 October}

Office all day. Lesson Beaugrand - she gave me a packet of coffee which was very nice of her - the nice old lady. Lesson with Barland. Rain. There are, it would seem 32 ways to make love and Mme Felix and Broussard have taught

522 "pressed" written in English in the manuscript. 
me 12 of them!! It makes me blush. I am sure that I know more than Mum now. Darned with Madeleine F. Met up with Mlle Komatsu.

\section{Wednesday 27 October}

Office. Lesson with Chabert. Lesson with Dick who gave me vegetables and pasta. Went to Maggy Desportes place, she had some friends there but she was glad to see me. She lent me "Suzanne et le Pacifique' (Jean Giradoux). ${ }^{523}$ Went to Dilys's for dinner and to look after Mrs Evans and Gaël - but had dinner before. Did the right thing because a very small dish, 4 potato 'croquettes'. Potatoes the size of the palm of my hand and [.. .]) and an apple. Poor Mme Evans doesn't like George. It isn't going well. She herself says that Dilys should never have got married - well now!! Met up with Mlle Kamska.

\section{Thursday 28 October}

Office all day. Denise came by. Went to Grandfather's grave at St Denis. Train 15.30. Cemetery closes at 17.30 until 15 Nov and after then at 5 pm. Lesson with Rochette who wouldn't leave - and given that I had only eaten 400 grams of bread and butter, 1 hard boiled egg, 1 piece (small) of chestnut cake (given to me by Denise) and drunk 1 bowl of ersatz coffee, I was, by 8.30 starving, and Madeleine Rochette just wouldn't go. In the end, she did go. Lessons with Barland have stopped for the moment - shame because that means $400 \mathrm{fr}$ less a month!!

\section{Friday 29 October}

8.50 at Porte d'Orléans. Went on foot to the cemetery at Bagneux because the bus left right in front of me and I had a lesson with Dick at $10.30 \mathrm{am}$ - arrived 9.30 at the cemetery. Looked forever for the little door and then completely lost my bearings for the grave. Finally, I arrived at the information point (10.20 am!!) Was wanting Berthe Requin when it is Sidonie Delgorge!! Came back on foot to the Porte d'Orléans, $11 \mathrm{am}$. Shattered, dead tired. I couldn't pray on her grave or on that of Grandfather. The body doesn't mean anything to me at all. Might as well put flowers on an old pullover they used to wear. Because I love the soul of the person first and the body second because the body belongs to the soul. The human body is not so beautiful that it can be loved just for its beauty. An animal, maybe, but I'd rather a living animal than its hide. I like fur

${ }^{523}$ Jean Giradoux (1882-1944). Suzanne et le Pacifique was first published in 1921. The 1925 edition published by Éditions Émile-Paul Frères is available via the digital collection at the Bibliothèque nationale:

http://gallica.bnf.fr/ark:/12148/bpt6k80734v 
gloves, soft and warm - that's flesh - but standing over a square of earth saying "underneath there, in a box, are grandfather, godmother" - they are not as I knew them. Perhaps there are only bones but I doubt it. They have died too recently. It would take 10 to 20 years for that to happen. So, strips of green or blue flesh liquefied and evil smelling. A shapeless mush which would be disgusting to see eaten through by fat white maggots which shimmer with a yellowy sheen they are so fat and squidgy. Yes, indeed, I prefer their souls. I loathe cemeteries. I wanted to go to see Uncle Henri and Cousin Giselle but because I didn't know the date of their death will give the money to Aunt. Office. Denise came to get paid. Went to Felix Disnar's to get potatoes. I had put a hat on and made myself up. I think I made quite an impression on him. I must have been 15 when I saw him the last time - an awkward little girl with two pig tails down to the waist. I had an eye on those $15 \mathrm{kgs}$ of potatoes (but don't say a word to Yvonne) And if ever I need something ... !! (apparently Mme Zéau is very [...] and very pessimistic). Tired out with $5 \mathrm{~kg}$ of potatoes one side and $10 \mathrm{~kg}$ the other. I must be looking pretty lovely ("aggressive" Kort says) because I was followed in the métro. He lost me at Odéon. ${ }^{524}$

\section{Saturday 30 October}

Holidays, holidays. Got up at $9.30 \mathrm{am}$. Dreamt that I was married with a baby and my husband didn't want me to go out or to study. He burnt all my books. One day I decided that I had had enough. I left home with the baby under my arm. I didn't know that my husband was a sentry on the road to the town where I needed to go to get to the station. He saw me and he jumped into a car. He caught me up and knocked me out and when I came round he told me that I was ill and had fainted. He hurriedly tried to make another baby so that I couldn't leave and I was begging my mother to get a midwife so I wouldn't have to give birth on my own when I woke up. That one was even better than Thursday's dream. Dilys, an Englishman and I were on Scarborough Bridge. There were Germans on the end of it near Leeman Road. I went ahead to give Dilys and her companion time to escape but we were surrounded. I don't remember the rest of it very clearly except that Dilys, in trying to escape, threw herself in the Ouse, then got into the lift at 322 rue St Jacques. I was denying everything. There was also something about biscuits and meeting Ruth in the métro which had taken flight and was going to the most amazing places. Gaël was also mixed up in it all. I should recount my dreams straightaway.

${ }^{524}$ Written alongside the entry of 29th October, 'Grave of Godmother Sidonie Delgorge 18 September 1942. 65th section, 14th row. Number 4. Cemetery Bagneux. Métro: Porte d’Orléans. Bus. Number 128.' 
Lesson with Chabert, but I am losing my mind. I went at 12.45 instead of 1.45 !! Then, as he was 40 minutes late I waited - 14.40. The hotel cat is hilarious. He opens the office window by pressing his paw on the latch - and he carries his tail in a curl like a Pomeranian dog. Cleaned from top to bottom and in a hurry because Jacqueline Eichhorn came to lunch. When it comes to it, her job doesn't pay much. OK, she earns 2,400 fr but she works 5 days a week from 7.45 to 15.15 non-stop because she is in charge of the canteen. Thursdays off, at least 4 Thursdays out of 5 . Not so good. ${ }^{525}$ The office is still better than that. She is very nice - and she certainly enjoyed my tea!! At the moment things are not going too well with Dilys. She thinks that Gaël is a little devil and told Dilys so. So that means she won't be able to cross the threshold for a long time. Mad F came round to chat for 2 hours. Letter from Aunt telling me to bring a jacket because we will go to the cemeteries at St Denis and Bagneux. Phew. Am I glad that I have already been. And given that I have 3 lessons on Monday ... . !! Cold.

\section{Sunday 31 October}

C. Mass. Villeparisis. Oh, not good. They are very nice but I feel like a fish out of water. Went to see Jacqueline Charles (who is bored stiff) and went to see M and Mme Henry to get back the bits of land that Godfather lent them. Gave the document to Roche about chopping down the trees to have fruit trees. I hope that I haven't acted against our interests. I hope that my parents will approve. Knitted. Aunt is furious that I have already visited the cemeteries. M. Laberr came over. His dog Mascotte is a little treasure. I noticed that Yolande was trying to cut me off with insidious questions. Why do they think that I am always lying? She's the one lying with her 400 warrants to do a day!!! Got some supplies from Roche ( 1 cabbage, 1 pumpkin, a few apples, leeks, potatoes et some dahlias). Villeparisis is a filthy godforsaken place, everyone stabs their neighbour in the back and runs them down. Godfather is pro-German. Can't believe it. I've rarely witnessed it to such an extent. As I left, broke the news that I would stay 2 Sundays and then have the $3 \mathrm{rd}$ at home (not quite true - hope to have all 3 at mine). Aunt half-smiled, half-grimaced. They are hoping to get me over there now that Marcel has gone so that Yolande is not on her ownsome. Beautiful sunny day, but cold. Saw new crescent moon. Party at Villeparisis.

\section{Monday 1 November}

C. Mass. Peaceful and content today. 10.30 lesson with Dick. Afternoon, stuck down photos done and knitted. Delplanque didn't come. Rochette stayed over half an hour after her hour. She is terribly talkative but very nice. Read a bit

'Not so good' written in English in the manuscript. 
of "The Fountain" by Charles Morgan. ${ }^{526}$ It will take a lot of time to read it. It rained a little. The book is alright but you have to read a few lines and then mull over them. It is cold but I only have a wool top and a thin blouse on. Obviously, because I am sat still all day I need to be wearing a dressing gown or a cardigan. Quiet and lazy just as I like my days. Listened to a lot of concerts including Haydn's number 104. It's not my favourite but it took me back to University. What does one really need in life? Time (ie: not to have to go out to work), a garden, music and a pet. And lovely Mummy. I'm going to go to bed early because I have much dreaming to do. It has been such a long time since I allowed myself a day's holiday. Tomorrow afternoon I'll be forced to go out oh dear. ${ }^{527}$ But I've bathed in silence and solitude and am refreshed. What an oasis!!

\section{Tuesday 2 November}

Stayed in. Was getting ready to go and give a lesson to Chabert when he came to cancel. Darned. Lesson with Beaugrand who gave me a slice of meat and a little bit of butter which turned out to be margarine. Potatoes from Delplanque arrived.

\section{Wednesday 3 November}

Office. 1.45 lesson with Chabert. Perm. It's great, good cut.

\section{Thursday 4 November}

Office all day. Rochette didn't come for lesson. Went to the Red Cross. "Still no news despite sending monthly messages. Félix on POW leave. ${ }^{528}$ Yvonne is expecting a baby. The Zéau family send warm wishes. Christmas greetings, Happy New Year. Am in excellent health. Hugs". Jacques brought the potatoes

${ }^{526}$ Charles Langbridge Morgan (1894-1958). English playwright and novelist. The Fountain was published in 1932. His 1936 novel Sparkenbroke is probably his most famous and most successful novel. Hélène Berr mentions it in Journal (and one of her friends carries the title as a nickname). For more on Morgan see:

http://www.charleslmorgan.org/index.html

527 'oh dear' written in English in the manuscript.

${ }^{528}$ Some French POWs - those with young families and those with skills needed in France - were allowed to return to France to work. The scheme was called 'Congé de captivité. An interesting resumé of this arrangement and other fascinating facts about the Occupation outside Paris can be read at: http://www.memorial-quineville.com/index.asp 
up for me $(50 \mathrm{~kg})$. I smoked 2 cigarettes to help me to concentrate on studying but nothing doing.

\section{Friday 5 November}

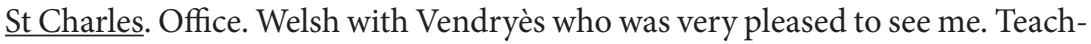
ing job flop. ${ }^{529}$ Pity. I love J.V. He is adorable. It is a shame that he is so old. I

\section{Saturday 6 November}

+ Office. Kort invited me to his place on Sunday!! Denise is going to have a perm done. She talked to me a lot about Guy. Met up with Giselle du Mesnil who is very nice but who is dropping us. Met Kokinakis in the métro. Mme Berasalus (from the Annonciade convent) is expecting a baby. Have I already said that Mme Roussel is expecting a baby at the end of June. And that Mme Caillat has a little boy François? Got back at 13.05. 13.30 lesson with Chabert. $3 \mathrm{pm}$ manicure. Mrs Evans is very ill - abscess on the lung. Went for tea and spent the evening at Dilys's to keep her mother company. 10.10 to 10.42 air raid alert.

\section{Sunday 7 November}

Mass. 9.45-10.50 alert. Went to Dick's but no lesson. Darned stockings. Went for tea to Kort's who was charming. Mme Kort was too. They have a daughter who is 25 . He's never seen her!! Very cold. I

\section{Monday 8 November}

Office. 1.30. Lesson Chabert. Registered at the Sorbonne. 5.30 lesson with Delplanque. Sent Pneu to Rochette asking to give the lesson at her place as I have a carbuncle on my behind. The fees at the Sorbonne - phew!! - 540 francs to register. I

\section{Tuesday 9 November}

Office all day. Had lunch at the foyer féminin - very so-so. ${ }^{530}$ Wrote to Yvonne Disnar, Hélène Barland, Aunt V. 5.45 lesson with Dick who, as he was leaving, shook me by the shoulders. Why? Went to the Dougall's place to get the address for the school. Dropped in at Dilys's. Her mother is much better. Lent

\footnotetext{
529 'Teaching job flop' written in English in the manuscript.

530 'very so-so' written in English in the manuscript.
} 
her "Om" (Talbot Munday) 531 "Hans Christian Anderson. by himself". Wrote to Charles-Gaby. Lesson American civilisation (Le Breton).

\section{Wednesday 10 November}

Office. "Visite aux Américains" (Jules Romains). ${ }^{532}$ "Fermentation" (Steinberg). Paid fees. Breton. Welsh. Bachellery. Two new arrivals. Mlle Le Hir and M. ${ }^{533}$ Maggy Desportes was very peeved because Bach. interrupted our conversation to introduce Mlle Hir to me but not to Maggy. 3.10-3.25 air raid alert. Bach. went with me to Gay-Lussac. 5.30 lesson with Delplanque. In the morning left without having eaten breakfast and at midday scoffed 3 sautéed potatoes but sick this evening after 2 sautéed potatoes so went to bed early (10 pm) to make up for the other days when I stayed up until 1-2 am.

\section{Thursday 11 November}

Office all day. Went to the community canteen. Aunt Marie phoned. No news from André for a month. 5.15 lesson with Beaugrand. Denise came this morning. Evening 7 pm lesson with Rochette. Had coffee at Madeleine F's. Her bit of rough was there and paid me lots of compliments - that I didn't look 25 but more like 22 because I didn't have wrinkles etc. I've already found an admirer in Resco. . . .! Letter from Hélène Barland. Wrote back. Wanted to study but it is already $11.15 \mathrm{pm}$ and I have to get up tomorrow - I am tired. I haven't written my diary and I don't know if I am on my head or my heels chasing to the office, to lessons, to the Sorbonne - sleeping in raggedy sheets and eating snacks as and when. It will settle down. Tomorrow and Saturday to get through and I will, I think, be able to get some balance back. It is cold!

\section{Friday 12 November}

Went to see Aunt Marie. René has bought a restaurant 4 rue du Cherche-Midi. It's St René day today. Didn't notice. Bit of a slip. Never mind. André injured in 3 places:- foot, cut on the face, knocked over by a dustcart. Welsh with Talandier. Vendryès. Office. Had brolly nicked. Really annoyed. Telephoned the Academy but can't come. Brought back potatoes. Lesson with Dick. Lots to say, but no time.

${ }_{531}$ Talbot Munday (1879-1940).

${ }^{532}$ More on Jules Romains (1885-1972) and Visite aux Américains can be found in Dominique Viart's 1996 study Jules Romains et les Ecritures de la simultanéité: Galsworthy, Musil, Döblin, Dos Passos, Valéry, Simon, Butor, Peeters, Plissart.

${ }^{533}$ Left blank in the manuscript. 


\section{Saturday 13 November}

Office. Had a 10 minute lunch. (beef 90 g, 2 raw carrots, $200 \mathrm{~g}$ of bread, 2 sugar cubes). Lesson with Chabert $1.30 \mathrm{pm}$ (lesson half an hour). Went in the pouring rain and without a brolly looking for the "Ambassades" language school. Found it but there was no one there. Came back with a migraine. Had tea with Sabine Vialla. Did some studying. Rain. Quite cold. Migraine.

\section{Sunday 14 November}

Mass. Housework. Did some darning, Worked very hard but tired out. And I still have this migraine. Beautiful weather and windy this morning. Rain in the evening. The electrician no longer wants to exchange eggs for wine. That's a pity. I'll drink it or I'll find another swap. Rheumatism in my right hand.

\section{Monday 15 November}

Office. After lunch with Resco, walked to the Louvre. 2 pm. Lecture by Lantier on Celtic archaeology. Registered. Saw Maggy Desportes. Went with her to the Magasin du Louvre. Came back on foot via the Latin quarter. 5.30 lesson with Dick but didn't give it. 5.30 lesson with Margaret Delplancq. Paid for the potatoes - broke now. 7 pm lesson with Rochette. 9 pm lesson with Nicole Capon - I got lost it was so dark but everyone was very nice about it. Got back at $11 \mathrm{pm}$. Darned stockings until $1 \mathrm{am}$. Rain.

\section{Tuesday 16 November}

Office all day. Went to Le Breton's seminar. 5.15-6.45. Lesson with Dick. $8.30 \mathrm{pm}$ lesson with Chabert with Mme Laberrie. I don't think that this is fair, doing both of them for 25 francs. He surprised me by telling me what I was doing at the Hautes-Etudes - but he had bought the directory where it says that I do literary analysis. I have to confess that I was quite proud and flattered by that. Letter from Cyla which pleased me enormously. Talked with Mad. F. and decided that I would not go for tea at Dilys's. I don't have the strength to refuse to do what she is going to ask me to do. I am sure of it now (I have been for several days). Oh. I am so feeble and cowardly and so weak even though I am stubborn. I've a real pride although not always about the right things. Good that the mention in the directory and the letter from Cyla have bucked me up. Cold.

\section{Wednesday 17 November}

Office. Eager to buy the directory. 1.30 pm Half an hour lesson with Chabert. 3-5 lesson with Bachellery. Hibernating in silence at home so that Dilys won't get an answer if she comes to try again. It is very cold; bought draught excluder 
but impossible to find any tacks. If I still can't find any I'll have to go flirt with the cobbler. If that fails, then I'll ask Mad. F. I can't put the electric radiator on because I will put it on tomorrow for a lesson and I've already gone over 3. It really gobbles up a lot this little radiator. When it comes to it, I am tough enough to deal with shortages, physical and mental collapse, air raids etc but not with the danger of being picked up. I am not a very good liar either (other than lying to be polite). Cold but I am going to study.

\section{Thursday 18 November}

Office all day. Lesson with Beaugrand. Lesson with Rochette. Very cold but going to study.

\section{Friday 19 November}

Welsh with Vendryès. Went to Dilys's to get books on American literature but not enough time to take them away. Office. Lesson with Dick (didn't come). Letter from Cyla which I was very pleased about.

\section{Saturday 20 November}

Office. Am. Lit. not open. Lesson with Chabert. Manicure. Pneu from Aunt. Letter from Rochette. Card from Resco. Very cold. Put down the draught excluder. Had tea at Dilys's.

\section{Sunday 21 November}

Mass. Darned. Wrote to Cyla but can't find her address. Cold. Put the electric radiator on. Ill, sick. Weekend already over more is the pity!!

\section{Monday 22 November}

Office. Lesson Lantier. Telephoned Mlle Capon. Lesson with Capon at mine. Went to Rochette's for lesson and stayed for dinner (pork, beefsteak, roast beef, chips). Her father sorts out the stamps. ${ }^{534}$

\section{Tuesday 23 November}

Office all day. Lesson with Dick. Had some rabbit (1/4).

${ }^{534}$ Unclear what this means. 'soccupe des timbres'. Looks after, collects, sorts out. It may be a reference to Resistance activity or possibly to stamps given to Madeleine in payment for lessons. 


\section{Wednesday 24 November}

Office. Lesson with Chabert. Lesson with Bachellery. Lesson with Marguerite Delplancq who brought handkerchief and sent a card for St Catherine's day!! Had dinner at Dilys's who gave me 3 eggs and some lard. Looked after Mrs Evans.

\section{Thursday 25 November}

I am a Catherinette!!! At the office they gave me a brooch, orange blossom perfume spray and a carnation. Mlle Kerjean gave me an apple. I was very touched by all this kindness. They are really great at the office. Phoned Aunt Marie. Lesson with Beaugrand. Lesson with Rochette who brought me a bouquet of orange tree blossom (imitation wax ones!). Dashed off 8.30 pm to Renés. André was there, back from Germany. The poor love. As thin as a lat. You could count his teeth through his skin, trembling all over and silent. René seems older than he is and he knows how to order people about.

\section{Friday 26 November}

Lesson with Vendryès. Nearly arrived late because woke up at 9.15 am (didn't hear the 5 am anti-aircraft fire which shook the house!!) 10.20-11.45 alert but didn't go down. Met up with Madeleine Lavelle who has cut her own hair. Office. Alert. $1.30 \mathrm{pm}-2 \mathrm{pm}$ lesson with Dick - was wanting to give him the sack $^{535}$ but he was so charming and paid in advance and so I didn't.

\section{Saturday 27 November}

Office. Lesson with Chabert. Dropped by at Dilys's. Wanted to do my washing which had just boiled but Mad. F. came to chat for 2 hours!!! That buggered that up. So studied instead.

\section{Sunday 28 November}

Didn't go to mass because got up too late. Went Villeparisis with bad grace. Gave flapjack to Yolande which she was very pleased about I could see and everyone charming as a result. Poor Granny poured out her memories. What a sad childhood she had. Her brother committed suicide (he didn't have nerves of steel like Granny). But there must be some hereditary blight. The father of Granny's Grandmother abandons his children but comes back to be kept by his daughter (Granny's granny was a baker). Granny's father leaves too. And if one looks at the wreck Henry is (her son) and the obsessive that is Aunt Violette only Granny and Yolande are spared. Poor Godfather and Granny trying to sell

535 'sack' written in English in the manuscript. 
things to get some money. I brought three books back to get them valued. Poor Granny. What sort of life has she missed out on?

\section{Monday 29 November}

Office. Lecture with Lantier. Bought birthday and Xmas present for Gaël. Rain. Wind. Feet hurting. Manicure. Bought butter. Lesson Rochette.

\section{Tuesday 30 November}

Office all day. Bad day because felt angry. Everyone has got a pay rise except me. Said to Mme RB. "Why?", "Student" "Why can't I be like Denise?" "If you can find someone with as much influence as Denise did then I wouldn't say no but I can't do anything myself". Told Denise who will ask Robert Guillou as soon as she sees him. I will take the law into my own hands and I will go to see Moignard. If that doesn't work I'll turn my guns on Guillou. I don't see why I don't get perks too. I'm not a penny pincher like Dilys but Christ I've had enough of being taken for a ride. Nearly cried but sang a song to myself. Lesson with LeBreton. I started to feel a little better. Lesson with Dick. On the way there I saw the crescent of the new moon so all is well. I love it that the view is so pretty in the morning when I get up - the roof slates all silver and grey, the grey of the sky, the grey mist - all of it is alive and in harmony with the warm rain which has been falling against the window panes. I feel as if I have melted with tenderness looking at this composition. Did the washing this evening. Did it slapdash but didn't want to finish it at midnight. Made a list for Christmas presents - 800 frs!! Decided - and my salary confirms it - no presents for those who are older than 7 years old - but I would like to give one to Cyla. Oh well, I am going to go to bed!!!!

\section{Wednesday 1 December}

Office. Mme Félix got on my nerves by asking where to catalogue every single item. I said to her, "Well, read it and see! How will you get on when I am not here?" Kort heard all this and since then he has been thrashing around trying to get me a pay rise. Before, he didn't bother in the slightest even though he knew that I was still on 1400. He told me not to do anything - I said: I am going to see M. Moignard this afternoon." "Don't do that", "Yes, I am going". Alert 10-10.20 am. They are messing us around. Lesson with Chabert. "La Civilisation du Renne" (Leroi-Gourhan). ${ }^{536}$ "Manuel de recherches Préhistoriques"

${ }^{536}$ André Leroi-Gourhan (1911-1986) was a French archaeologist. See Vincent Albert's 1938 review of La Civilisation du renne (1936) in Revue des Sciences Religieuses, tome 18, fascicule 1, 1938. pp. 143-144.

www.persee.fr/doc/rscir_0035-2217_1938_num_18_1_1753_t1_0143_ 0000_2. 
(Soc Préhist). Went to Moignard's - of course, my suspender breaks just before seeing him, that made me think of my first kiss. Saw Moignard, he is not against me working from home, Mme RB doesn't have the final say. Obviously, Kort is going to be furious but given that it will be great for my studies I will stick it out as long as possible. ${ }^{537}$ If not, I will get something else. I have been so comfortable doing that in the cosy cocoon of a little routine. Why shouldn't I have money? Why can't I study as I like to study? I am two years behind with my studies. But, I've been ill. I've been more ill than I wanted to admit. When I think that not a day has gone by that I haven't had dizzy spells, felt sick, pains in the side, problems with my vision etc. And, now - touch wood - a glowing complexion and good health. Well, beddy-byes ${ }^{538}$, if I don't, I won't be able to get up tomorrow morning; it is hard when it is dark. When it is light, I can easily get up at 6 am (German time 4 am in the sun). Lesson Delplancq. Letter from Capon about the time of the lesson on Friday. Mme Le Beyré wants me to use my influence with Vendryès to help her; but she has a good case. She doesn't need me. All the same, I promised that I would put a word in for her. Meeting with Moignard. Didn't go to Bachellery's lesson. He must be furious. He counts us in like the Hotel accountant used to count the number of pigs - but on Friday I will spin him a yarn even if it means him getting worked up. I think that he is "strongly attracted". 539

\section{Thursday 2 December}

Oh dear! ${ }^{540}$ What a day. I tell Kort that I am going to work from home and he flew into a rage. "I forbid you to leave my department Mademoiselle. I categorically forbid you to work at home". Then he pulled on the heart strings wringing his handkerchief "How could you do that me. I've trained you up for two and a half years, etc, etc". At one point I thought that he was going to cry, his face went all wobbly and he started to blow his nose violently'. It went on for about two hours until I went down to see Mme RB who said "that's absolutely fine, marvellous. You've done right there etc". At 2.30 pm, another carry-on. Kort and I went to see RB - "Who told you that you could involve me?" "But I didn't involve you!", "Yes, you did. Moignard telephoned me. You're just a rotten little wretch who is jealous of Denise Pedron" and he went on and on. I just stared at him wide eyed and open mouthed. In the end, it is agreed that I will work two mornings and won't be able to leave before finishing the file run - which will take at least 15 days Kort says. I leave and cry my eyes out. He comes back up and talks to me as if I am some kind of dangerous animal then, having forced me to look up to take some document from him, he sees my red eyes and then

\footnotetext{
${ }^{537}$ Writes 'Je vais sticking it out le plus possible' in the manuscript.

538 'beddy-byes' written in English in the manuscript.

539 'strongly attracted' written in English in the manuscript.

540 'Oh dear' written in English in the manuscript.
} 
drama. He rushes to the window, blows his nose loudly and he says very gently that I have worked enough, that I can read "Toute la Vie", "La Semaine" - and so I do. What a carry on!!!

Went to the Red Cross. "Still no news. Uncle André has come back from Germany. Health is good. Sending lots of love. How are Nils, Aunt Marguerite, Jeanne, Marguerite? Birthday wishes to mummy. Hugs and kisses”. Lesson with Mme Beaugrand. When I got in, going over and over the day in my head, I found a parcel for me from Portugal!!' I was ecstatic!! 5 tins of sardines - I opened one of them straight away. Yum yum. They are so, so good. Gave 3 to the concierge 2 and a half to Mad. F and given that it was Rochette's lesson, have given one to her too. I had one and a half left. They are absolutely delicious. That cheered me up. I don't mind having days as horrid as that so long as I have a parcel waiting for me in the evening. "Nightingale Wood" (Stella Gibbons) ${ }^{541}$, "The Dolliver Romance" (Hawthorne). ${ }^{542}$

\section{Friday 3 December}

Welsh with Vendryès. Office. Kort." I want you to get parcels from your parents, of course I do, indeed, I hope that you do, from the bottom of my heart but let's get back to business, have you decided which days you are going to come in?"Righty-ho!! Lesson with Mlle Capon. Letter from Jean-Claude Poussif asking for a lesson. Most importantly, got a message from the Red Cross written by Mummy on the 23 August: "Gilberte died. Aunt Germaine is staying with us for the moment. We are all well. Be patient. Our thoughts are with you. If we have bad news we will send it via the Red Cross. Kisses. Mummy" - this was a response to my message of the 10 June.

\section{Saturday 4 December}

Office. Started to copy the index. I rushed so much I felt sick. Lesson with Chabert. Read "Nightingale Wood" curled up against the radiator after ironing. Good evening. Peeled some mushrooms then went to bed. OK.

${ }^{541}$ For more on Stella Gibbons (1902-1989) and her writing, including her most famous novel, Cold Comfort Farm, and Nightingale Wood, referred to by Madeleine, read Sam Jordison's Guardian 2013 feature:

https://www.theguardian.com/books/2013/dec/27/cold-comfort-farmstella-gibbons-novels-reading-group

${ }^{542}$ Nathanial Hawthorne (1804-1864). Dolliver Romance is available at: http://www.gutenberg.org/ebooks/7119 


\section{Sunday 5 December}

Mass at the Val-de-Grâce. Got up late. Air raid alert 12-12.15. Spent a nice day at the Delplancqs'.

\section{Monday 6 December}

Letter from Aunt inviting me to go with her to Chatêlet on Wednesday. Letter from Gaston Boyelle asking what the terms are for lessons. Office. Kort is making it as difficult as he can for me to finish the index - asking me one thing and then another, interrupting - the pig. Lesson with Lantier. Did a bit of cleaning. Wrote to Poussif. Lessons with Delplancq and Rochette.

\section{Tuesday 7 December}

Office all day - copied up the index all day and even through the lunch hour. I don't want to spend 15 days doing it. Lesson with Dick.

\section{Wednesday 8 December}

Office. Lesson Chabert. Welsh Bachellery. Mme Desportes wasn't there. Mlle Le Hir is in love with Bachellery. She walked part of the way with me to talk to me about HIM. She's also very curious about me. The girl is childish and stupid. Maggy Desportes says - "Vendryès's sense of humour goes right through them like an X Ray". That is very accurate. Maggy has a heavy cold. Katy has recovered well and Izou is a sweetheart. Went to Chatêlet earlier, got Aunt's pneu in the evening. "Valses de la France". Fairly pretty but very silly. The fellow who puts a settee cover over himself and pretends to be a settee was quite funny. They've not been to take the electricity reading. Will I get cut off? Furious.

\section{Thursday 9 December}

Office - or at least, on with the index all day!! Finally finished it. Ner ner finished! Took a week. Crowing about it! "Sally Lunn" (Leo Walmsley), "Abraham Lincoln (Morgan). Didn't have a lesson with Beaugrand, not there. Lesson with Rochette. Saw Denise.

\section{Friday 10 December}

Welsh with Vendryès. Rather, Irish for 2 hours. Housework. Did it very well - dropped everything, broke (cracked) the little Delft pot and broke cactus planter. Lesson with Capon, Dick, Poussif. Wrote to Boyelle. 


\section{Saturday 11 December}

Office. Travelled with Mlle Roussel. How stupid she is about loving Claude. She turned down a librarian job - 3000, was promised 5000 at l'Odéon. $9^{1 / 2}-12,2-6$ - because wouldn't be able to see Claude at lunchtime!!! Lesson with Chabert. Snow and ice. Saw 2 horses lying on the ground. It made my stomach turn over. For a week I have felt continually sick. I have found out what it is. Quite simply, it is the cold because we do not have any heating. Confession with a very passionate young priest. Made crêpes with jam and tidied up papers. Very, very cold. I am going to put the radiator on because I would like to do the work for the office which I have to take back on Tuesday. Letter "Aide Social aux Emigrants" ${ }^{\prime 43}$ with a message from Granny dated 9.11.43. "We are still in good health and sending hugs. Would like recent news. From all the family Gabrielle Blaess". So I'm not the only one not to receive any news. The typed message from the bureau declares that it would like to know whether I am still in good health, if things are relatively problem-free at the moment and, in general terms, what personal information I would like to be sent. All that is very nice but I could have been dead and buried in the three and a half years I have been alone here. But, I am going to go if only to complain that I haven't had any news.

\section{Sunday 12 December}

C. Mass. Villeparisis. Very cold. Had to wear a little cloth hood - looked like a baby in a bonnet. Was awake from $3 \mathrm{am}$. My last wisdom tooth is hurting. Took the tin of sardines to Villep. ${ }^{544}$ God I am bored there!! It's awful - and the worst of it is that I am starting to despise them! Godfather has taken against the English - before he was as Communist as they come, then the Germans were terrible and the English were darlings. Now the English are bastards etc etc. One side only has to shout long and loud enough and he falls for it and is even more extreme than before. It doesn't matter whether one is pro-German or pro-English I've got friends with both opinions, even three opinions but Good Lord don't change colours according to who yells the most. Marcel really puts his foot in it - or perhaps he does it deliberately? Very sweet towards me. I take my hat off and he says "what a beautiful head of hair she has, so much of it and so soft, my goodness" - Yolande glares. She'd done herself up to look "beautiful" today but looked as hard faced as anything. With a bit more work, shed look splendid. Aunt pulled a face when I announced that I would only come for one day over Christmas - I wouldn't be able to stand the atmosphere. It isn't their fault but it bores me. In the train we chatted about outfits and Aunt said to me miserably - because I had gone on about how wonderful the Delplancqs were

\footnotetext{
${ }^{543}$ Association supporting emigrants.

${ }^{544}$ Villeparisis.
} 
etc - "Yolande needs to go out more. Other than you and Marcel there is no one she can have fun with." I have been alone for three years and I have turned down invitations (turned down 4 invitations for Christmas - Dilys, Delplancq, Rochette, Bachellery) and Yo, for 20 years, hasn't had any friends. Mum always said that she has found it strange that Yo didn't have any friends - I did too. But I am not going to introduce her to my friends. They wouldn't find anything to talk about. Now, having been nice and catty ${ }^{545} \mathrm{I}$ am going to take myself off to bed. Aunt wants to make a white rabbit fur jacket for Yolande. Et nunc, dixit Pepys, alias Magdalene - "and so to bed". PS. Marcel is leaving tomorrow for Chef du Pont. He is barely earning 1800 a month every second month. Not so good. ${ }^{546}$

\section{Monday 13 December}

First day of the new routine!! Bad start getting up at 7.45 am instead of 7.15. Because I did the housework I started to work at 9.30 instead of 9 am. Very cold. Went an hour without putting on heating but couldn't stick it out and so put it on. Lesson with Lantier. Last one in the 3 month block. He will start again on the 3rd of January - it is a shame that he is stopping so early. He reminds me of Noble. Went to 391 rue de Vaugirard to the "Aide sociale aux Emigrants". It is in a big building for foreign workers. I was able to write a lot. I wrote the following by and large: "Madeleine Blaess sends a message to her family every month and is worried that she only receives an answer every six or eight months. She is well. She's arranged her hours at the office so that she can start up her studies again. Her Uncle Joseph is very pleased with her about this. Her Uncle André is back from Germany. He has been injured three times but not seriously and is now well. Yolande has got her permanent post. Félix has been released. Yvonne is expecting a baby. All the family is well and sends warm wishes. Most of all I would like to have more regular news. Kisses and hugs". Well, it was something like that. They say that they will send it. I hope to God that they will and that my request for more news will come to something. I also put that I received a parcel from Portugal with 5 tins of sardines. Waited pointlessly for Marguerite Delplancq. Her pneu arrived at 8 o'clock it was probably [...] like that sent by Mme Beaugrand which arrived yesterday and which was given to me today by the concierge who saw me coming down. Washed a few smalls. Denise came to ask me to come on Sunday perhaps. She also asked whether I could give her and Guy the keys to my room on Wednesday and Friday afternoon. I asked her whether she wanted clean sheets. I probably shouldn't have done but it happened without me being able to say no. All he has to do is take her to a hotel. I am not a brothel keeper - or whatever the word

545 'nice and catty' written in English in the manuscript.

546 'Not so good' written in English in the manuscript. 
is for someone who runs a place where people come on dates. And if the deed hasn't already been done, I would rather that it wasn't done at my place. I don't say anything to her about it because that would be pointless. In the end, she's going into it with her eyes wide open. And, as for him, what a little boor. She's clearly a mistress on the cheap. Lesson with Rochette but she started to cry and she stayed for 2 hours crying away because at home her parents don't care about her faith which upsets her. It's probably heroic to angrily defend one's faith but I find that shutting up and just doing what one wants is more effective because that doesn't make people angry and because what's done is done and they can't do anything about it. Well, what a carry on. I am hot and cold. I really should have a big wash for the medical tomorrow but I will do it tomorrow morning. It is already quarter to 11 and I don't know when I will get to bed. The days are over when I studied until 2 or 3 oclock in the morning and got up at 7.00. If I am not in bed before 11.30 then it's a disaster because I can't get up before 7.30 and it's the office tomorrow. I did my chores this morning. That'll give me more time obviously.

\section{Tuesday 14 December}

Office. Marcelle Felix has got a new rich lover. What a whore!!! It is cold, cold, cold and still no heating!! Came back to work here for an hour before leaving for the medical examination and froze to death. I really must buy myself a thermometer. Went to look at the electricity meter. I can't see whether or not a reading has been taken but in any case they won't cut me off. Medical examination. Weight is stable. But had a bit of a shock with the $\mathrm{X}$ ray. There's some sort of calcification in the right lung. I didn't really understand I was so shocked. Is it serious - serious enough to have the right to a card for extra rations? ${ }^{547}$ Anyway, it's a great excuse not to have to go very often to Aunt's. In July there was no trace of anything. But I have always known that there was something there because when I twist my chest area without moving the lower part of my body (from the waist downwards) it gives a sort of "rasp, rasp", like there is a sort of rubbing and it takes me a few minutes to get my breath back. Well, anyway, I'd be amazed to have anything serious. Other than when I am cold, I have never felt so well - if only I didn't put on so much blubber. I'm going to start up the gymnastics again to see whether that makes a difference. Lesson with Dick and Poussif. Red Cross membership.

${ }^{547}$ Calcification was a sign of TB, which was endemic during the Occupation. Yolande, Madeleine's cousin, contracted it, as did Georges, Dilys's husband. This appears to have been a false alarm. It is interesting that Madeleine's first thought was whether she would qualify for extra sickness rations as a result. 


\section{Wednesday 15 December}

Very cold. Worked on the cataloguing. Frozen stiff. Welsh with Bachellery. Felt strange to be in the warm. Letter from Cyla. So, it seems that Curlylocks ${ }^{548}$ will be in Paris. I haven't see her yet. Cyla is really fantastic. I would do anything for her. She is really charismatic. After a simple dinner - a helping of soup and vegetables, I felt really poorly, felt nauseous, head bursting. Fell into bed at 8.30 $\mathrm{pm}$ and despite trying to work, I fell asleep straightaway. Woke up at $11.30 \mathrm{pm}$. The radio was still on. Switched everything off, opened curtains and went back to bed. Ice on the panes.

\section{Thursday 16 December}

Stayed in bed until midday but studied between 9 and 12. Pneu from Boyelle. Took wine to Mme Felix. Lesson with Beaugrand, Rochette.

\section{Friday 17 December}

Welsh with Vendryès. Bachellery has invited me over for the day after Boxing Day. What a bore that is. Lesson with Capon, Boyelle (what a disappointment. Thought it was a 19 year old kid and it's a middle-aged man). Dick (he is impossible, he plays around all the time). Poussif, Marcelle St Denis over at Mad. F's. Poor kid has got to go back to the mountains. She is thin. She hasn't got long left! ${ }^{449}$

\section{Saturday 18 December}

Office. Denise came to confirm that it is dinner at her place tomorrow. My word but she is a chatterbox so didn't have lunch until $2 \mathrm{pm}$. Did some cataloguing. Went to Mlle de Fricourt's to see whether I can get more rations because of my lung. I feel very depressed. It's the cold. My back and lungs are hurting. The cold must have got into them. I am very, very anxious about Mum and Dad. Are they ill? So many deaths, 1400 last week. Dad is susceptible to 'flu and Mum isn't that robust. I am horribly worried. When I think about it, I tremble and get a lump in my throat. No more sugar nor butter. I will have to find some on the Black Market but I have no money. I don't care about what happens so long as Mum and Dad are not ill. My feet are like blocks of ice - as soon as I have some money I will buy myself a hot water bottle.

\footnotetext{
${ }^{548}$ It is unclear who Madeleine means here.

${ }_{549}$ Possibly a reference to TB.
} 


\section{Sunday 19 December}

Mass. Spent the day at Denise's - drying dishes!! Guy came for afternoon tea. Torrential rain. Bored out of my mind.

\section{Monday 20 December}

Woke up at $9.20 \mathrm{am} ! !$ Ashamed about being so bored with everything. Darned girdle. Started the housework. Splendid weather. Window open 'til $2.30 \mathrm{pm}$. 10.10-10.25 air raid alert. 3.30-4.15 pm another alert. Cleaned the copper pans. Lesson with Boyelle and Rochette. Chilly evening.

\section{Tuesday 21 December}

Shortest day of the year. Office. Mme Felix is a really nasty woman. She says the nastiest things about Denise - why? Kort is charming. "The Joyful Delaneys" (Hugh Walpole) "The Film of Memory" (Shane Leslie). Lecture LeBreton. Waited for Dick for a whole hour. This time, that's it. He's getting ditched. He'll say that I get my 30 frs but I really hate having pupils like him - they won't work, plays around during his lesson and turns on the charm when I get cross. Lesson with Poussif. That kid soaks up English like blotting paper. Read until $1.30 \mathrm{am}$.

\section{Wednesday 22 December}

Woke up at $9.10 \mathrm{am}$. Worked. Lesson with Chabert who was very excited by any reference to sex - what's wrong with them all that they have to wriggle around and fidget like little puppies? "Anthologie nègre" (Blaise Cendrars) ${ }^{550}$ "La Bretagne" (Lébillot). Welsh. Bachellery. The little Raude is letting his beard grow along his jaw line. He looks like a satyr.

\section{Thursday 23 December}

Woke up at $10.15 \mathrm{am}$ !! Oh it's awful. It is so cold. I stay in bed reading until midday. Depressed, depressed, so depressed. Should go see about Godfather's books but can hardly drag one foot in front of the other I feel so depressed. Sadness.

${ }^{550}$ Blaise Cendrars, whose real name was Frédéric-Louis Sauser (1887-1961). Read Lee Rourke's Guardian article for more on the life and work of this French writer:

https://www.theguardian.com/books/booksblog/2007/jul/23/thehazyworldofblaisecendr.

Download novel here:

https://archive.org/details/anthologiengre00cenduoft 
I go to take presents for Maggy Desportes' children - what a great girl. She is ingenious when it comes to her kids. She has made a Father Christmas and because she couldn't find any cotton wool she used "Camelia". What ingenuity! She has to keep everyone on very little money. Izou is an absolute angel. Didn't see Katy because she was asleep. Bought a beautiful little elephant for Will B. He is just so adorable (the elephant that is) that I didn't want to give it away. I want to buy myself one after Christmas. But I also want a flower and "Nuit Enchantée de Merlin". 3 things costing $50 \mathrm{fr}$ a piece. Oh dear. I do so need money. Went to see whether there was any butter or sugar. Still absolutely nothing. That makes 15 days without butter or sugar. Fortunately I still have a little bit of oil. Went mad shopping - because I'm depressed. Got some black rust paint for the gas and two thermometers. One for the outside and one for inside. I am absolutely delighted! A thermometer furnishes a room straight away. Outside (at $6 \mathrm{pm}$ ) $0^{\circ}$. Inside $\underline{1}^{\circ}$. This is why on Wednesday a week ago I was freezing to death. Outside it was (so they say) $-8^{\circ}$ to $-10^{\circ}$. Inside, it was $-7^{\circ}$ to $-9^{\circ}$ at the most. I have a stoic side. Indeed, I have become so stoic that I don't find it cold when it is $-4^{\circ}$ !!! Waiting for Poussif to come for his lesson. I put the radiator on for half an hour and it is $9^{\circ}$. Not bad going!!! Maggy gave me a branch of holly. I decorated Mum's photo with it. I am happy about buying two thermometers. I love this little elephant. I forget to say that Marguerite Delplancq came yesterday to insist that I come on Sunday. Gosh!! Saturday - Sunday - Monday!! Maggy asking me for Thursday!! Lesson with Poussif $\left(10^{\circ}\right)$

\section{Friday 24 December}

Went for a shampoo and set - it took 2 hours to get it done. So that was the morning over. Lesson with Capon. But at $2 \mathrm{pm}$ there was an alert and I was in the métro!! The lighting was switched off and the métro train was going some to get into the station but it was no good - stopped just before Barbès. Wanted to get out but it is quite high and rocky gravel. A lot of women were falling around. In the end I jumped - like a flower. It looked worse than it was. It's always like that. Walked through the dark tunnel to the station and then to my lesson. There was a Christmas tree there and they were making a meal for 20 people and she was sewing little moons, stars and comets and hearts etc all sparkling onto a long black velvet bow for her hair. It will look very pretty I think. Went to the BN for Godfather but because of the alert I arrived there at $4 \mathrm{pm}$ and it was closing. Tried to sell his books. The [. . . librarian didn't want to know - two fakes and the romantic one was too damaged. On the quais they asked me in all seriousness if I had my parents' permission (they thought that I was younger than 21). They offered me 20 frs per volume. At this, went home. I ran about a fair bit for Godfather. Poor old fellow. He set huge store by these three old books thinking that they were worth an amazing amount of money this isn't going to improve my popularity with them but I don't care. They will have to manage. Basically they are treating me like a domestic servant. It is up to them to do what is needed to sell. I hope that he is able to sell them, him 
or someone else at not too low a price. I ordered some Cartes de visite from a fairground stall. I probably should have gone to a real printers but it would have taken time when I'll get them from there on Tuesday. I wanted to buy a bunch of violets but at 20 and 40 francs for 3 sprigs I can't. Miserable looking Christmas without flowers. "La Génie Romain" (A Grenier) 551 "Les Grains de la Grenade" (Tharaud). ${ }^{552}$ Outside $3^{\circ}$. Inside $7^{\circ}$. I'm going to become a proper meteorologist. Annoyed. Didn't get mushrooms opposite for Aunt's tomorrow. Never mind. Will take coffee and a litre of wine and that's it. Anyway, I haven't got any money at all. Rochette doesn't look as if she is going to come for her lesson. That's 40 francs less. I was stupid not to say the last time she missed that it'd still count if I wasn't told before. I will tell her this time and insist that I will have to be at midnight mass (which takes place at $5 \mathrm{pm}$ )

Lesson with Rochette. She brought me 2 pencils ( 1 black, 1 red and blue) and a Christmas card, some blotting paper for my table and a pair of stockings!! Very kind. Madeleine Fortan gave me a croissant - I had given her a cigarette. I have been spoiled this year - lots of presents. Got a note from Cécile Péchegut under the door. She annoys me. The crayons are great! There are loads of [...] reds, blues, blacks!! I'm just a big kid! I'll have to darn a pair of stockings for tomorrow and keep my new ones for a something important. The concert on Radio Nationale is quite good. I don't feel sad this Christmas Eve. I hope that Daddy and lovely Mummy are happy over there at home. Read the Christmas service (Midnight Mass)

\section{Saturday 25 December}

C. Mass. Went to Villeparisis where Aunt was all charm etc, etc. She gave me 100 frs for Christmas. Got fed up. Came home early. Went to Dilys's. Sylvia and Eileen Baron were there. Mrs Evans is very ill. She can't move and speaks like a broken record. Dilys gave me a pair of stockings, 3 eggs, $50 \mathrm{~g}$ of butter. Christmas card from her and from Ruth.

\section{Sunday 26 December}

Mass. Lunch. Dinner. Delplanque gave me a handkerchief in a little clog. They do so love their dead daughter Henriette. That is difficult for the poor little Marguerite. One can fight a living person but not a dead one. [ate chips] 9.30-10 alert.

551 Albert Grenier (1878-1961). French theologian.

552 Jérôme Tharaud (1874-1953). French novelist. Member of the Académie française.

http://data.bnf.fr/11926314/jerome_tharaud/ 


\section{Monday 27 December}

Went to Bachellery's. Fine weather. Met Roberta Owens (60 years old) who is a descendent of the great Robert Owens. She was the one who was released from the camp after breaking both her ankles and having her shoulder and her wrist dislocated falling into the ditch (where she remained until the morning) going to the WC during the night when she wasn't allowed to. She's a giant of a woman, very nice what's more but so snobbish (phew!! 553 ) If she had known that I was a cook's daughter I am sure that she would not have found me as nice. Little William is adorable. He's a fat baby, a little pudgy but friendly. His father only speaks Welsh to him and his mother only French!! If it was the opposite it would be worse! But what is he going to learn and with what accent!! A day at the Bachellerys' is awful. All she talks about is William and school and Gisèle (the maid). He only speaks Welsh and about getting revenge. Fortunately Roberta took the brunt of it. I got back feeling sick and dropped by at Dilys's to return the books that she had lent to Bachellery.

\section{Tuesday 28 December}

Ill all night. Bloating, bloating. At 7 am I took down some peppermint oil. Why didn't I do that before? Mad F did a big clean. I'll shake the rugs, and I'll whistle along to it and I'll have the radio blaring out and bang goes the door, slam goes the door! I could have screamed, the slightest thing got on my nerves. Tried to get up for Chabert's lesson. Impossible. Couldn't for Dick either. Pneu from Poussif who couldn't come because of babysitting. Mad F was kind enough to drop by to ask me whether I needed anything. Got up. Lesson with Rochette. Letter from Jourdain asking for a lesson.

\section{Wednesday 29 December}

9-11 Lesson Delplancq. Shops. 1.30-3 pm lesson with Chabert. Went to get Cartes de Visite. Not very happy. Thought that it would be the others. Chatted with Mad. F. Lesson with Poussif.

\section{Thursday 30 December}

Terrible insomnia. It has been impossible to sleep since 4 am (hungry. In 2 days I think that I have eaten 4 apples, 2 carrots, 3 little eggs like pigeon eggs, 100 gr of noodles) listened to German music which is the only music on at $5 \mathrm{am}$. Housework, scrubbed the floorboards with wire wool. Moved books and food from round the radiator because we have heating today!! Very nice. Lovely sun.

553 'phew' written in English in the manuscript. 
11.30-1 pm alert. Lesson with Chabert. 1.30-2.10 alert. Got paid at the office. Saw Denise. "The Wind Blows West" (B.M. Bower) ${ }^{554}$, "The Life of Katherine Mansfield” (Mantz and Murray). Went to Maggy's for tea. Izou is beautiful. Kitty looks like a little urchin. "She's got the complexion of one of those children painted by Rembrandt" said Maggy. If she was plumper that would be accurate. She snuggled down against me and didn't want to go. Maggy had made a beautiful chocolate log. Met Mlle George there. Maggy gave me a handkerchief. Lesson with Rochette.

\section{Friday 31 December}

Yesterday I was woken up at $4 \mathrm{am}$, this morning, I woke up bright as a button at $10 \mathrm{am}$ !! It is lovely and warm. $11.10-12.50$ and $12.51-1.20$ pm alert. Saw squadron. Lots in the sky but too high and the sky was too blue to see well. The suburbs were bombed. Lesson Capon. Bought a key to bleed the radiator. Now, I don't have to ask the concierge. My tulips and my crocus are coming through as well as the hyacinth!! They are too early. Very moving seeing the first green sproutings. Bought calendar. I don't like it. Too long. Ended the evening and the year doing my bookkeeping. Happiness spoilt a little by having to sleep over at Villeparisis tomorrow. If I had the courage I would find an excuse. I am so bored at their place. On the whole not a bad year. ${ }^{555}$

${ }^{554}$ Bertha Muzzy Sinclair (1871-1940) an American writer specialising in narratives of the American West. She was known under the pseudonym of B.

M. Bower. https://www.fantasticfiction.com/b/b-m-bower/

555 'On the whole not a bad year' written in English in the manuscript. 


\section{Introduction 1944}

\section{The Liberation}

The D-Day landings of June 61944 marked the beginning of the protracted and bloody land campaign to liberate France that ravaged swathes of northern France throughout the summer of 1944. The intensive aerial bombardment over the preceding spring months had already exacted a huge toll in civilian lives. Now with the two modes of assault mobilised in the Allied push through the German lines, civilian deaths mounted. The military campaign to liberate France took the best part of three months to reach Paris. When the Allies did arrive, the newsreels and newspapers recorded the Liberation as a historic moment where triumph of victory met with civilian outpourings of relief and gratitude. In reality, the Liberation in Paris, like the Liberation elsewhere in France, was a much more complex experience for the civilian population. It was, in fact, a liberation which had been awaited for months, during which time living conditions had deteriorated markedly and the news of bloody combat and large numbers of civilian deaths made the Parisians extremely anxious. It was an anxiety exacerbated by the fact that there was, unsurprisingly, a dearth of reliable information about how this second Battle of France was progressing for the Allies. If the Parisians danced in the streets, paraded with and serenaded the liberators, then it may well have been because they were relieved to have survived. Relief, was certainly a dominant emotion.

In recent years, historians have challenged the popular, broadly accepted historical account of the event with narratives and testimonies which cannot be easily contained within the memory of the Liberation as an event which generated an unprecedented collective outpouring of joy. ${ }^{566}$ These 'official' narratives ignored the misery of families who had lost loved ones to the death camps, to forced labour, to illness and disease, to suicide, to a martyrdom in

${ }_{556}$ See Azéma, J-P (1994) 'Les Libérations de la France: prologue', French Cultural Studies, 15.5, 223-226. 
the Resistance and, in the provinces and coastal areas in northern France in particular, to Allied bombing and ground battles. ${ }^{57}$

In the spring and summer of 1944, Madeleine began to write about the war for the first time since the arrest of her flatmate Ruth Camp in December 1940. Then, she had resolved not to write further about 'political matters' fearful that she might be compromised if the diary was ever discovered by the authorities. Now, confident that Liberation was near, Madeleine cast caution aside and addressed the Liberation directly and exhaustively in an hour-by-hour account of the Resistance-led civilian insurrection, the arrival of Allies into Paris, street skirmishes and the first retributions of the 'épuration'. Madeleine's observations of what was happening in the streets interwoven with the rest of her everyday life have produced a unique testimony recording how the Liberation was lived and experienced as it was awaited as well as when it finally arrived. The detailed daily backdrop to the historic event, of the kind provided by Madeleine, has not had a great deal of exposure in narratives of the Liberation. The 'victory' narratives have tended to foreground the civilian insurgency and street combat led by Resistance forces and the Allies. The acute deterioration in living conditions of the population of Paris and greater widespread suffering as a result from the June D-Day landings onwards is less known about. The landings had been met with a flurry of German military activity and generalised civilian excitement and some panic as Parisians fearing an immediate military onslaught fled for Versailles and other outlying suburbs. Madeleine's diary registered the thrill of the landings and the expectant, nervous activity, but by the following day, there was a return to normal routine. People carried on as best they could with their lives even into the tumult of the final Liberation week and the Allied battle through northern France was barely mentioned until the liberators were at the gates of Paris.

Madeleine's record shows that the anxieties and difficulties experienced over the course of the Occupation intensified rather than lessened as the Liberation approached. People were frightened. The prospect of being in the front line of an assault by land and by air was terrifying. They had seen newsreels of bombing destruction in France, across Europe and in Russia. Many civilians had already had direct experience of the bombs. The Paris suburbs had been heavily bombed, resulting in high civilian casualties from 1943 through 1944, and the destruction of Caen in the summer of 1944 had made people very afraid of what would happen if the Germans were to put up fierce resistance in Paris. On August 2 1944, Madeleine herself was caught in the blast and bloody

${ }^{557}$ For an account and analysis of Madeleine's experience of the Liberation, refer to the chapter by Michallat, W., An emotional history of a long liberation in the Occupation diary of Madeleine Blaess' in Vichy France \& Everyday Life: Confronting the Challenges of Wartime 1939-1945 ed. by Lindsey Dodd and David. 
aftermath of a raid on the Paris suburb of Montreuil, which she described from start to finish in her diary.

The wait was made more anxious by the news of battlefield horrors carried to Paris by refugees from Normandy, and throughout the summer there was very little positive news to reassure that there would be a victorious outcome. Pro-Nazi propaganda dominated on the radio and in the newspapers. Worsening living conditions meant that attention quickly switched away from thoughts of freedom. Food and fuel shortages became more acute. A severely damaged transport infrastructure was being bombed continuously, and the risks of moving freight by road or rail were great. Parisians had restrictions placed on their movements, on mail deliveries and phone calls, which meant it was all the more difficult to find food and to maintain the strategies for obtaining food through networks of friends and acquaintances that had been so crucial to surviving the Occupation for so many.

Once it became clear in June that the Liberation was not imminent, Madeleine's diary reverted very quickly to the day-to-day struggle to survive. Any hope and excitement there had been on June 6th quickly dissipated. She was frightened and anxious and at times convinced that she would not survive to return home. Food shortages worsened to such a degree over the summer that in the final days before Liberation there was practically no food or water to be had. The arrival of the Allies thus followed months of civilian anxiety and paranoia. The patriotic and joyful crowds greeting the allies were relieved survivors. Madeleine's account of the Liberation is full of tales of the street fighting and word-of-mouth rumour about what had happened and was about to happen. When the tanks finally arrive, the diary described her ebullient celebrations with the liberators, but the exhilaration did not last much beyond the first day.

Civilian distrust of the Resistance has been well documented by historians. Vichy and Nazi propaganda painted them as criminals and terrorists of course but they were also perceived as thuggish and lawless by many French civilians. Earlier in the Occupation Madeleine, intolerant of violence of any kind, had described as puerile Resistance threats to harm colleagues it had accused of collaboration. Her account during the Liberation shows that this uneasiness did not abate when the Resistance began to appear openly on the streets. She was intolerant of brutality both towards the Germans and towards women suspected of collaboration who were brutalised by being stripped, daubed with swastikas and having their heads shaved. Some historians who have written about the Epuration and about the so-called 'tontes' where women were publicly shamed in this way tend to suggest that the public was broadly supportive of it. But Corran Laurens cites numerous testimonies of horrified and disgusted civilians. Georgette Elgey, then a teenager and later a historian wrote: 'I am horrified. The priest intervenes. I draw back. At the end of an hour the woman is taken away. I hated this scene. It spoilt my happiness for a long time.' (Laurens, 1995: 157). In Madeleine's account there is a sense that she does not realise at first that the women she sees being dragged 
through the streets are not in fact German military personnel but French civilian women. There is no ambiguity about her reaction, however. She found the spectacle repulsive, remarking on the terrible shame and suffering they must have been enduring.

The Liberation events soon disappeared from Madeleine's diary when she resumed her normal work and university routines within days of the Allies arriving in Paris. One month later, on September 18, the diary entries ceased completely and six months later she left for Britain. 


\section{4}

\section{Saturday 1 January}

Woke up early but didn't go to mass or to Communion because I didn't yet know whether I would be able to avoid staying at Aunt's tomorrow with the result that I got up late and had a mad dash for the train. In my haste I gave the New Year's gift to the Concierge saying 'Happy Birthday'(!!!) Decided to plead illness so that I could get home. I readied myself for it, looking mournful and not saying a word all evening. Nico is on the way, made me feel cold and gave me rings around the eyes. It was perfect. Jacques and Gerard Deschamps and Mme Dumont were there. The 4 Faure kids came. Stayed on a chair all afternoon like a misery while the others went for walks. I wasn't too fed up (got up from the lunch table at $4 \mathrm{pm}$ and had dinner at $6 \mathrm{pm}$ ) and because of that Aunt wasn't difficult about me going. I don't feel at all ashamed of this deceit. She is so clingy the poor woman. She knows that Yo is fed up and she wants to avoid that by me being there but damn it! I am not her governess. Aunt gave me a beautiful pair of stockings and for tomorrow a tiny piece of meat, 3 apples, 4 cooked beetroot. I brought the wine ration for the week and a big cauliflower that I got with the November tickets. When I got home I ate 1 apple, 2 beetroot, 50 gr of bread because I was quite hungry. I had said no to meat which was pretty much the main thing in the meals and didn't have much of the rest of it. The country air makes me hungry. Tonight the searchlights were lighting up the sky and made it seem like day.

\section{My New Year Resolutions?}

1/ 8 hours work or studies a day

2/ 1 hour cleaning and 1 hour darning a day

3/ 1/4 hour exercise each morning

4/ Do today what can be done today (ie: reply immediately to letters, mend little holes as soon as I see them, etc)

5/ Put myself first (for my free time etc)

6/ Buy myself at least two outings a month

7/ Be good. .58

558 'good' written in English in the manuscript. 
What a bunch there! Will I keep to them all? I hope so, yes, if God gives me the strength. I think that I am right to want to put myself first because if I don't all my free time is taken up and the housework, studies go by the wayside. I need to be knitting or something when Mad. F comes to pay me one of her [. . .] visits. ${ }^{559}$ Also, this buying myself two outings. I don't ever go out. It's all work and sleep, housework and lessons. I am going to become stale. ${ }^{560}$ The most important thing is not to waste a minute. It's the odd minutes here and there which will be so difficult to get back. I had waited to see in the New Year at the open window. I do so love to hear all the bells ring in midnight. Someone fired 6 rifle shots and a strange beam shone on and off on the Ivry hill. It was a clear and cold night .... Mad. F came in and laughed heartily at my ruses to feign illness today and thought that I looked tired. She gave me the love and happiness chain letter which I am going to continue just for laughs. It only costs 4 stamps and a little bit of time typing at the machine because I don't want my writing to be recognised. Everyone knows that I am not superstitious and so they don't burden me with things like that. . . but if they were to see that I'm doing it for once. . .!!

\section{Sunday 2 January}

C. Mass. Mrs Evans died peacefully in her sleep. They had gone to bed early. Mrs Evans said to Dilys "let's sleep in tomorrow". Dilys got up at 3 am and her mother was sleeping. She woke back up at 11.15, got dressed and went to kiss her mother who she thought was still asleep and she was cold. Poor kid. What a shock. She had expected it before Christmas but Mrs Evans had been so much better. The shock has made it all the more harder. She has been extremely brave. She has lots to do. Letters and pneus to send and telephone calls to make. There are no stamps to be had anywhere. Everyone is being very kind. They came straight away and everything. It's funny but when I am in pain I prefer to be alone, - and Dilys wants lots of people around her. Shared a bed with her. I could hear her breathing heavily and calling out. It made my blood freeze. Spoke until 4 am then slept until 8 am. Made dinner.

\section{Monday 3 January}

Spent the morning sending letters, telegrams etc. Made dinner and ran out for cigarettes for Dil. By 3 pm I was hating her profoundly. She enjoys ${ }^{561}$ all the attention and the buzzing round her and she is relying on the money. She must be making around 1500 a week in lessons, that is why she can dress so chic. Was

\footnotetext{
${ }_{559}$ Possibly 'ennuyeuses' - annoying/boring.

560 'stale' written in English in the manuscript.

561 'enjoys' written in English in the manuscript and underlined twice.
} 
with her all day yesterday and up against me all yesterday night (I think that she finds my body a comfort) and to have messed around ${ }^{562}$ doing all the errands made me feel sick of her. But once I had an hour on my own in my room I felt much better. I must spend too much time on my own. Too many folk exasperate me. Yesterday I sent New Year wishes on a calling card and wrote to Granny and Aunt. Today Denise Pedron came with Guy to ask me about work we had been set. What is annoying is that I have barely been to the courses myself and who do I ask about what to do for Lantier? Not much to eat at Dilys's (in the evening 2 jacket potatoes, 1 baby slice of roast beef ( 3 centimetres [...] $]^{563}$ at $10.30 \mathrm{pm}-$ this morning had 2 baby slices of meat, 3 spoonfuls ${ }^{564}$ of fried potatoes) Ate when I got back here. Dilys is surviving on cigarettes and endless cups of tea. Waited for Rochette's lesson. Went back to Dilys's to sleep. Didn't sleep. Card from Hélène Berr offering lesson.

\section{Tuesday 4 January}

Office - no heating so worked 10-12 and 2-4. Knitted for an hour in the post room and chatted with Gilberte Frey who is going to get married at the end of April. 1.30-2.30 Lesson with Beaugrand but the poor woman's heart is heavy because she has gone 3 years (on 18 May) with no news of her son. I stayed listening to her until 3.30. Warning of imminent alert. So tired so I stayed at home to eat without going to LeBreton's course (because at Dilys's I'm conking out with hunger). Lesson with Poussif who arrived 40 minutes late. His watch was half an hour slow and he didn't want to admit it. Mad. Fortan insisted that I go to have dinner at her place before going to Dilys's. She's great. Had a bit of a scare with a German patrol turning off just ahead of me before going to ring at 320 probably about the hall light they could see from outside. There must be something going on. I saw an armed bicycle patrol this afternoon. Jacqueline Eichhorn and Eileen Baron were at Dilys's. Jacqueline stayed in bed because she is very insensitive. I was wanting to go back to mine to sleep but Dilys didn't want that. That would have done me some good though. I felt as if I was drunk. It is the first time that this has happened to me. It must be tiredness. Slept better.

\section{Wednesday 5 January}

Dilys is really a poor hostess. She didn't even look to see whether Jacqueline had something to cover herself with for sleeping (she didn't and froze under her fur coat, my coat and her sleeping bag ). It could be that Dilys's head is a bit all over at such a difficult time but given that she never wants to show it she shouldn't

\footnotetext{
562 'messed around' in English in the manuscript.

563 possibly 'eaten'. Unclear in the manuscript.

564 'spoonfuls' written in English in the manuscript.
} 
have slipped up over the blankets. Went to Père Lachaise by métro with Eileen Baron and Jacques Henri. The cemetery there is just so ugly. Arrived at the same time as the coffin. There were two male witnesses for the cremation, all of us were in the [...] chapel for the sermon where Miss Watson read the English funeral service. "I am the Resurrection and the Life". It is very beautiful, I'd like to have that. The room wasn't heated. It was like ice. People dispersed after the service and Mme Roussel (Tappy), Mme Beech, ${ }^{565}$ Miss Watson, Mme Busy, the concierge from 322, Dr Duheim and I waited the 1 hour 15 minutes until the end of the cremation. The little duck ponds were frozen. Sylvia's mother was cremated here. Loie Fuller too. Went to see Epstein's tomb for Oscar Wilde. You'd think it was an advertisement for an aviation company. It was good that Dilys didn't come. What would she have done? Afterwards, we went down into the crypt of the columbarium where Mrs Evans is starting a whole new row with the number 13,645 . Two men brought down a stretcher with the casket draped in black. The casket was made out of clay and a lot bigger than I had thought it would be. It was put in the hole and plastered in front of us. Poor Bessie - since her death I have been thinking of her as Bessie; when she was alive it was always Mrs Evans for me. She was virtually a saint. She died like one, in her sleep possibly. Her purgatory was on earth the poor woman.

At the end of the ceremony, there was an alert. We came back on foot. I went ahead with the concierge. We were stopped on the Place Voltaire. We had to do a huge detour. After $3 / 4$ of an hour (at 12.30) the alert ended. Took the bus to Bastille. Light lunch then lesson with Chabert who was upset because hed had 2 suits, an overcoat and all his food supplies stolen. Didn't go to Bachellery's class because I was too tired. Bought a little seat. Lesson with Delplancq and afterwards read “The Wind Blows West”. Liked it. I

\section{Thursday 6 January}

Woke up at 12 am!! (slept 11 hours. It's done me good). I need to go and get my nightshirt back from Dilys. She said that if she came back she would give me a knock but she hasn't come. But I had a visit from Jacqueline Martin who would love to try out her medical knowledge on me. We are going to go to see "Le Soulier de Satin" 566 a week tomorrow. She had come to get her Latin books which reminds me that I should get my notes back from Monique Vignet. Jacqueline $\mathrm{M}$ has filled out in the face a lot. Today I worked hard despite the lie-in. I made myself a carrot cake for Twelfth Night but it wasn't cooked through. Didn't go out. Rochette thinks I have a dreadful complexion. It is very

${ }^{565}$ Misspells Beach (Sylvia Beach) in the manuscript.

566 A play by Paul Claudel (1868-1955). First performed on 27 November 1943 by the Comédie française. Produced by Jean-Louis Barrault (1910-1994). See entry in data.bnf.fr via the Bibliothèque nationale. 
cold and I have a pain in the chest. I am very pleased with myself. I repaired the electric lamp all on my own.

\section{Friday 7 January}

During the night I was thinking it must be very cold. I wanted to look. This morning at 9 am (I am still having trouble getting up and feel like I have a knot in the middle of my chest) it was $-4^{\circ}$ outside and ice on the windows. $7^{\circ}$ in here. Outside, it is white over with frost and there's ice wherever there is water. I'm going to have to hurry now for Vendryès. Lesson with Vendryès. 1 pm-1.30 alert. Arrived late for the lesson with Capon where it was horribly cold and so I felt horribly ill. On the way back I took the watch to be repaired. It needs a clean - 1 month and 110 frs!!! Dropped by at Dilys's to pick up my nightshirt alas, ${ }^{567}$ Dilys wants me to sleep at her place. Margaret Lavenu came to see Dil. With Rémi Puissant who is terribly shy. Talked - at least, she talked. Slept badly. In her sleep, she mistook me for Georges and wrapped her arms around me and made a kissing sound. Alert.

\section{Saturday 8 January}

Got up late because they phoned yesterday to tell me not to go in to the office. Quite groggy ${ }^{568}$ with tiredness. Dilys had lunch here. Lesson with Chabert. Alert 1.45-2.20 pm. 2 parcels from Portugal (28 tins of sardines). Mme Brun is offering to sell them for me to get butter, etc. I'm not sure because they are talking about Allied invasion more and more. I've got plenty of beans and some flour, a small amount of pasta, 3 tins of vegetables - and my sardines, but no crackers, no sugar, no butter. And if the water, gas and electricity are cut off I think we'll need biscuits, crackers etc, things that we can eat without having to cook and that is why I am not sure about letting the sardines go. Poor Daddy and Mummy. They must be worrying so much about me. I would like to send waves of moral support but at the moment I am so tired that I can hardly stand upright. I am very cold and very hot. Gosh, I am so tired I've almost gone silly. ${ }^{569}$ The food poisoning - the dashing about for Dilys, not sleeping in my own bed and almost no sleep and Nico, ${ }^{570}$ which is very painful this time. I've had to take pills nearly every day and again yesterday I thought that I was cracking up at Capon's. Dilys wants me to sleep over again tomorrow evening. I hope that that is going to be the last evening because in truth it is becoming a habit and she is talking about coming for lunch here Monday etc, etc. I hope that she will be able

\footnotetext{
567 'alas' written in English in the manuscript.

568 'quite groggy' written in English in the manuscript.

569 'silly' written in English in the manuscript.

570 'Nicodème', Madeleine's term for menstrual cycle.
} 
to go to Poitiers and that when she gets back I won't have to sleep over there. Oh, she does annoy me. It really suits her. I do the washing up etc, etc. Poor Dilys. I've been doing it gladly but now it is a week since her mother died. She has got to get her life back on track. Of course, it will be hard at the beginning but if she gets too used to living with me then it will be hard when I stop - so what!! Hell, my writing is abysmal. ${ }^{571} \mathrm{I}$ am so tired. I am going to go to bed early. I. Ground some flour and knitted. That calmed me down a lot. I'm not shaking any more. It is the usual time, $11 \mathrm{pm}$. I have decided that I need at least $3 \mathrm{~kg}$ of crackers and $2 \mathrm{~kg}$ of sugar stocked up. But where can I buy it and where can I put it? (I'll be able to find a spot once I have it). I am going to make bread with the flour from 1942 to save on ration tickets. I'd also like to have a pound of salted butter, but that is unlikely!! Midnight - I gave my hair a good brush and comb. It is beautifully soft and I plucked my eyebrows - I overdid it. Luckily, they will grow back. This was good for someone who wanted to go to bed early!! Jacques hasn't been over to put up my clothes rail yet. He said that he would see about it pulling a funny expression I thought or perhaps I am imagining that? He's been coming to put it up for 5 months. I am going to do it myself even though I can't say that I am keen. It is so hard putting holes in the wall.

\section{Sunday 9 January}

Mass. Made some bread rolls. Not a great success because I put the bran I had left in the dough but they are filling and not too bad. Bought 1 pound of crackers but they use up 900 frs worth of tickets. It's staggering. Mad. F talked for a long time. She is starting with a lousy 'flu. The poor thing looks like she's been dug up. I won't be going to sleep over at Dilys's this evening. I am going to stay here to see whether Madeleine needs anything. Wrote New Year greetings letters to: Uncle Julien, Roger, Jeanne Semaille, Mme Blom, Zéau, Voirin (first letter was very catty ${ }^{572}$ and I tore it up and sent a very nice but distant one), Mme Faure, Hélène Berr, Malot, Jourdan, and Aunt Violette. Should have liked to write to Cyla too but after this huge job felt like I'd been squeezed out like a lemon. I prefer sending calling cards (sent 20 and just oral responses from Kort and from Vendryès - card from Rochette, Simone Le Hartel, Zinzer). Today, it is mild and raining. So, it went dark at $5.30 \mathrm{pm}$ instead of $6.15 \mathrm{pm}$ as it did yesterday. The days are getting noticeably longer. I like my view when it rains. It is all grey and silver. But, when do I not like the view in truth? I want to finish my second sleeve today but I feel tired out after these letters. Damn. I will have to drop a line to Dick. No, I will phone tomorrow morning before my 9 am lesson. Didn't knit but wrote to Cyla. It was a sad letter but I sent it anyway. I've done something very bad. Dilys came to get me to sleep over but I said that I didn't want to leave Mad F. Miss Beach suggested that Dilys sleeps here. I said yes, yes straight away

571 'so what!! And 'Hell!' written in English in the manuscript.

572 'catty' written in English in the manuscript. 
knowing full well that Dilys would not be keen on the too-small bed. She is going to go to Eileen Baron's but has announced that she is going to come here tomorrow evening. In my opinion, it is a week since her mother's death and she should be starting to manage on her own again. I am being hard perhaps but spending six nights with her has made me so sick of the human body that even shaking a hand makes me feel nauseous. I am afraid that I do not think that I could stand married life - only solution, twin beds. I don't think that Brussel sprouts get on with me that well either. Only solution - bed. ${ }^{573}$ And what bliss to be alone in a bed. And I don't want Dilys to come to live here. I have my life, my work, my lessons, my studies and because she has nothing to do for 10 days she thinks that everybody should be the same. I'm mean when it comes down to it.

\section{Monday 10 January}

Woke up with a start at $8 \mathrm{am}$ !! Bad head. Made myself up. It suits me. Dashed off to Barrin's lecture. Phew. He's strict. Everyone files in like little lambs. Went to see him afterwards. I saw admiration in his eyes and I played up to it. On the way back I looked at myself in all the shop windows. I am indeed pretty with wavy chestnut hair around a pale oval face (sometimes with a rose tint in the wind or when feeling emotional about something). Two lines (my eyebrows are quite good after all) above two chestnut pools ${ }^{574}$ and a peony. It is a shame that I am so fat. Was feeling so, so, so joyful. Drizzle. Lesson with Le Breton, Levaillant, ${ }^{575}$ LeBègue ${ }^{576}$ (nearly fell asleep for the latter two). Lesson Rochette. Very tired. Not at all beautiful now. Waited for Dilys who invited herself to dinner. I made some mushroom pasta shells. Worked on the catalogue for the office. Waited until 10.15 but she didn't arrive and so ate. I think that she didn't come because she is madly jealous that I want to stay here for Madeleine Fortan. Tomorrow I will take her meat and eggs with an affectionate little letter hoping that she is OK. I don't think I will be seeing her until the next time she has need of me. Read "Mon Oncle et Mon Curé" (Jean de la Brète). ${ }^{577}$ It is wonderfully fresh. Obviously at 12 years old I couldn't appreciate its honesty

573 'Only solution' is written in English twice in the manuscript.

574 'pools' written in English in the manuscript.

575 Probably Maurice Levaillant (1884-1961), lecturer in literature at the Sorbonne. See: https://www.idref.fr/

576 Raymond Lèbegue (1895-1984). Lecturer in French literature at the Sorbonne from 1941 to 1965 . See https://www.idref.fr/

577 Jean de la Brète, pseudonym for Alice Cherbonnel (1858-1945). Winner of the Académie française's Prix Montyon. Full text available via the Bibliothèque nationale:

http://gallica.bnf.fr/ark:/12148/bpt6k5786117c 
and natural egotism, all the adorable coquettishness of a child of 16 . I really am terribly tired.

\section{Tuesday 11 January}

Kort telephoned because I should have been at the office yesterday. Returned the food to Dilys. Went to see Kort who was very nice. Lesson Beaugrand. Went to Red Cross to get the messages for Portugal. Lesson with LeBreton. Lesson with Boyelle, Poussif. Lesson Beaugrand who gave me one egg, $100 \mathrm{~g}$ of butter.

\section{Wednesday 12 January}

Office. "Washington Irving" (Wurmer), "The Scarlet Letter" (Hawthorn) "Mari, une ville perdue" (Parrot). ${ }^{578}$ Very good. "Irlande et cavernes anglaises" (Martel). ${ }^{579}$ Went to see the gas company because got notice that I was going to be cut off and have been sending payment since the beginning of the year. Waited in vain for Delplancq, her pneu arrived afterwards. Letters to Aunt, Mme Roche, card Odette. Rain. Lesson with Bachellery. Fed up.

\section{Thursday 13 January}

Office. Moved the archives. Tired out. Lesson with Chabert. Malot came before his letter did. I didn't know who it was but gave a lesson anyway. Lesson Rochette, Poussif. Letter from Malot.

\section{Friday 14 January}

Irish, Welsh with Vendryès. He is sweet. Very happy. Lesson with Capon. His mother is an artist. She painted all the pictures (which are not very easy to understand). 2.50-4.20 alert. Came back on foot too late for the lesson with Boyelle. Had a note from Jacqueline Martin moving "Soulier de Satin" to Monday. I would like to go but I have a lesson with Rochette? Charming letter from Georges Le C. I am dizzy with tiredness. I wanted to go to bed at $9 \mathrm{pm}$ but Mad. F. came and then curlylocks and Ruth Camp came. It is 11.15 and I am still shattered. Read "Mari, Une ville perdue" in one go. Very interesting. I want to buy it. Another alert from 7.05 to $8.30 \mathrm{pm}$.

${ }^{578}$ André Parrot (1901-1980). See contemporaneous review of the archaeologist Parrot's account of the excavation of Mari here:

http://www.persee.fr/doc/rscir_0035-2217_1937_num_17_2_1728_ t1_0243_0000_3

${ }^{579}$ Edouard-Alfred Martel (1859-1958). Published in 1897, a reference listing of caves and caverns in Ireland and Derbyshire, England. 


\section{Saturday 15 January}

Woke up at $10 \mathrm{am}$. What a disgrace although when one is tired out yet hears it striking midnight before falling asleep, it is pretty understandable. I feel so lazy which means I don't want to wash, iron, do the housework, etc. But on Monday I really must get down to work intellectually and physically. What a nuisance that I have to go to Villeparisis tomorrow. But I hope that it is going to be the last time for a long time. Catalogued and filed. Everything is finished for today but I am absolutely shattered. I am cataloguing in the stacks at the rate of 116 an hour. It's great but it is killing me. Letter from Yvonne (who sends ration tickets for bread) and from Jourdain who is of course having a lesson on Monday and Thursday. I am going to have to telephone. Went for tea at Françoise Boësse's. She is nice but I really am stuck for words. In 15 days I have spent nearly 2000 fr!! It's crazy. But January with the rent, the present buying etc, is a tough month. All the more because I bought a pound of butter on the black market. All the same, I am going to have to go carefully. It is 11.30 again and I am still not in bed. I have one of those stomach aches. For 2, 3 days now even the thought of eating makes me feel sick. I force myself. It must be tiredness and this constant headache, Anyway, time for sleepy byes because tomorrow at Villeparisis there won't be an opportunity to lie in. The family really does get on my nerves.

\section{Sunday 16 January}

Went to mass of course. Villeparisis. It is cold. Marcel flirting a lot. Everybody is very indulgent because at the back of their minds they are thinking about marriage. If M. larks around with me he gets a frown but with Yo he gets docile smiles. Enjoyed myself a bit and then got fed up. Marcel got melancholic suddenly around evening time. To think that this kid will be 21 on 1st March!! I can't get over it. I remember him being tiny as if it was yesterday - a real pest and a half but cuddlesome. It was St Marcel's day and Yo gave him a tie. I didn't give him anything. I'm going to have to for his 21 st. Wrote a Red Cross message. OCA, 10 rue de Lorete, ${ }^{580}$ Lisbonne sending thanks for the parcel. Wrote to Mummy too. "Got message from August. One little and two big parcels. Huge thanks. Uncle Julien was operated on for a hernia. Dilys's mother died. Send me news about how you are health wise straightaway. Hugs". If I tell them about Bessie dying even though they don't know her it's because the message will go quicker. Wrote to Marguerite Delplancq, Washed salmon pink pullover and gloves. Feel pretty fed up. I always do after a day at Villeparisis.

${ }^{580}$ No such street name in Paris. Possibly a street in Lisbon or a misspelling in the manuscript. 


\section{Monday 17 January}

Telephoned Jourdain and Rochette to put off the lessons. Office. Very cold. Kort has a bad cold. Lesson with Lantier. Dropped in at Dilys's. Changed and went to the Comédie française where I waited for a quarter of an hour and then eventually saw Jacqueline Martin and her friends Mlle Bras, Seneque and Henri. "Soulier du Satin" (Claudel) music by Honegger. Fantastic. Didn’t understand all of it but it was really wonderful, scenery, lighting. J. Louis Barrault was marvellous. Madeleine Renaud was too. Marie Bell was a bit stiff but loosened up. I was very taken with Don Camillo, especially at Mogador in the first part with his sombrero off his shoulder.

\section{Tuesday 18 January}

Lesson with Jourdain, Beaugrand, Boyelle, Poussif, Rochette. Lesson with LeBreton. Didn't have the time to have lunch or to have dinner. Worked on the catalogue. Sent a message Portugal.

\section{Wednesday 19 January}

Gave the bedroom a thorough clean and did half of the kitchen. Copied up notes to pass on to Mlle Le Hir. Welsh with Bachellery was such a terrible drag. Lesson with Delplancq. Had dinner with Marcel (Titi) and Mad. F. Good scoff at mine but Titi had brought everything (except the mackerel in oil and the beans which I put in). Letters from Voirin and Blum. Card from Giselle de Mesnil. Catalogued until 3.30 am.

\section{Thursday 20 January}

Tired out. Have a tooth abscess which hurts. Office. Kort has Mlle Gueler and Mme Fouché to relieve us. Booked place for Saturday's concert. Took coat to be turned up. Had tea at Maggy's but we don't have anything to talk about. Lesson with Poussif. It is pouring down. Gave some money for flowers for Mrs Evans. Sylvia gave me the change back. Note from Vendryès saying that he has flu and not to come tomorrow. He sends me his regards!!! Sent a message to Giselle du Mesnil turning down dinner this evening. I am dead tired. Returned the linen to Dilys. Have not written my diary since Sunday evening but I have too much to do. Writing is impossible. Too tired.

\section{Friday 21 January}

9.10 Lesson with Malot. Saw Chabert. Dropped in at Cécile Pêchegut's. She died last Friday and she was buried on Monday!! Her brother died the Tuesday before. She found out Thursday, collapsed, took to her bed and died the following evening. Poor Cécile. The end of a wretched life. What happiness did this poor girl have 
other than eating. She must have adored her brother. I do feel a little sorry that I wasn't always as kind to her as I could have been. Françoise Boësse came by. I've decided. I am going to take Egyptology. The sun is fabulous today. There'll be an alert for sure. 1-2.30 alert. 2.10. Lesson with Capon in his father's garret. I don't like the way he paints particularly - it is too "earthy" but the garret is really nice. Signed up to the Egyptology group. 5.15 lesson with Boyelle who is on the list to be interned when the landings happen. 7 am lesson with Rochette who has lent me an inept Protestant book about marriage. I prefer the Catholic view a 1000 times over.

\section{Saturday 22 January}

Woke up late. I can't shake off my tiredness. 11 am had a lesson with Jourdain. "Edfu", great paper by ${ }^{581}$ on the architecture of old Egyptian towns. Beautiful photographs. Went with Françoise Boësse. 5.30 concert. Jean de Rohozinski. I don't like Schumann at all but the "Nuits dans les Jardins d'Espagne" by de Falla ${ }^{582}$ is magnificent. The "Fêtes" by Debussy are beautiful too. But why do they play so little of the harp? I would like to learn the harp. Got to go to bed. I am just so exhausted again. I nearly don't want to go out at all tomorrow so not go to mass though I already have a missed service on my conscience. Mad. F. says to me: 'You have got your miserable face on, the one you have when you are tired'. Three times in 2 days I've been told that I am miserable.

\section{Sunday 23 January}

Got up at $10 \mathrm{am}$. Didn't go to mass. Did a bit of washing. Worked on the catalogue. Ironed brown coat. Darned. Very restful. ${ }^{583}$ Rain coming with the gusts, very windy. Woke up several times in the night thinking that the wind had wrenched off my window box.

\section{Monday 24 January}

9-12 at the office. Kort poured out all his woes. His wife has water on the lung. Mme Félix is a rich woman now as a result of not having trodden the virtuous path. She no longer has to come to work etc, etc. Lesson with Lantier. Then, I catalogued and copied up notes here. Lesson with Rochette who came out with a grand speech about religion. It poured down with rain this afternoon and I was very pleased because this morning I'd seen a red sky - a morning sky rare

${ }^{581}$ Gap left by Madeleine in the text.

${ }^{582}$ Manuel de Falla (1876-1946) was a Spanish composer. For more on the piece referred to by Madeleine and on his life and other works see: https://www.britannica.com/biography/Manuel-de-Falla

583 'restful' in English in the manuscript. 
in its beauty. Rows of little angel wings all close together, greyish white first of all and then shades of green, mauve, pink like the neck of a pigeon or the underside of a wonderful fish before burning up in the crimson sun. And it disappears so, so quickly!

The Paris I see from my window is always grey - the grey of the dull sky, the shiny grey of the roofs of the Val-de-Grâce. Is there anything more beautiful than a brief shower and a pale sun that makes these grey roofs twinkle silver? I do so love my view and in the distance the grey sky draped over the grey of trees far away. I worked a lot today. I'm not finding much time to write my diary. Slightly depressed all day. I'm dreaming of getting back there, a thousand arrival scenarios, what is said, what isn't said, the looks, the expressions. I hug these dreams so, so close. God - let it happen soon!! As I was going to bed I noticed that I had forgotten to copy down something important and I did it. Got to bed at $1.30 \mathrm{am}$.

\section{Tuesday 25 January}

Woke up at $9 \mathrm{am}$ !! I am so exhausted. I really must try to get to bed earlier. I can't find the notes I borrowed on American Civilisation. Very worried about it. Lesson with Beaugrand. Kept me back half an hour to talk to me about the immorality of the English whilst staring at me lasciviously. God, all this sex stuff really irritates me. Lesson with LeBreton. Lesson with Boyelle. Lesson with Poussif. Very cold wind. No Philosophy lesson, already 11 am. I'm still building my house. I've just abandoned a 9 room house with outbuildings for a cottage with 4 rooms. Still depressed. I can't find crackers anywhere in Paris because people fear the invasion is coming. I really must get at least a kilo to have at home.

\section{Wednesday 26 January}

Slept in again and haven't done anything. 10.30 had lesson with Jourdain. 1.30 Lesson with Chabert. 3-5 lesson with Bachellery (he bores me to death). Took the black shopping bag to be repaired. Went to the seamstress to try on the brown coat she has turned up. Mad. F. talked a lot. I feel depressed. Finally finished a plan for the cottage which I am pleased with (just about, except for the kitchenette which has two badly sited doors one opposite the other . ..!).

\section{Thursday 27 January}

9-12 Office. "Death comes for the Archbishop" (Cather). ${ }^{584}$ "A Short History of the United States" (Bassett). Telephoned Capon. Read "Death etc". Missionary

${ }^{584}$ See Mary Duenwald's 2007 New York Times article 'Entering the World of Willa Cather's Archbishop' for more on Cather and the background to the novel: http://www.nytimes.com/2007/08/26/travel/26Footsteps.html?mcubz=1 
story. Not bad, boring at times. 5-7 lesson with Delplancq. 7-8 lesson with Poussif. Spoke with Mad F for a long time. Letter from Aunt Violette who has had a parcel from Portugal. Saw Denise Pedron who told me that Dédé had been over.

\section{Friday 28 January}

8.45-9.45 lesson with Malot. I am always cold on the "sit-upons"585 on the terrasse of the Ecole de médecine but she is so frightened about being overheard. 10-12.15 lesson with Vendryès. 11-11.20 alert. 1.15 to 2.15 lesson with Capon (was not paid). 2.45-3.15 paid. Went to see Dédé who was very pleased to see me. Marie gave me butter, coffee and a sandwich. Colette talks too much. She has a vivid imagination - a little too much so. What an odd life Dédé must have. 5.15-6.15. Lesson with Boyelle. 7-8.15. Lesson with Rochette. Georges came over. We talked for a long time (Dilys must be green with jealousy). I promised that I would go there tomorrow to look after Gaël - and I have just remembered that I was supposed to be going to Giselle's for dinner tomorrow!! I will have to pop round quickly to Dilys's tomorrow. Georges is a nice fellow. Wrote Aunt a little letter saying that I was poorly and that I won't be going on Sunday. She is going to be furious. As if I care!! I really must get up early tomorrow to do my washing. Did the cataloguing. Can't get any matches again!!

\section{Saturday 29 January}

Did the washing between 4 am and 9 am. Housework. Didn't go to lesson with Chabert. 1.45 to 2.45 "Dendvrala"586 [Mlle Labouette] 3.15 - 7.30!!! Françoise came over for tea. I talked for most of the time and it didn't seem to bore her because it seemed that she would never go even when I offered her a second round of tea at $6 \mathrm{pm}$. She accepted and stayed!! When she left, I went to Giselle du Mesnil's who had nearly given up waiting for me. Had a nice evening. Again, I talked for most of the time but Mme Le Dreux finds that I am cheerful and that I have a calming presence. In the morning, I went to the market and dropped in at Dilys's to tell her that I had made a mistake and that I couldn't come that evening.

\section{Sunday 30 January}

Mass. Cleaned the gas stove and blacked it - got it on my hands too unfortunately and can't get them clean. Luckily, I had done the ironing in the morning. Looked after Gaël who is very spoilt. First, she was furious that I had not

585 'Sit-upons' is written in English in the manuscript. 'Sit-upons' are simple waterproof cushions - a popular craft in the Girl Guides and Brownies. Madeleine refers here to the type of seats they sit on in the café.

586 Spelling unclear in manuscript. 
come yesterday - "not nice". Her parents were very embarrassed. They went out. I had dinner. Gaël calls me. I tell her that Daddy had gone to get tickets for champagne - oh! Then, the afterthought ${ }^{587}$ "And Dilys?" Darned. I think that Dilys thinks, as does Aunt, that I am here for her personal use and that what she wants should come before my arrangements. Slight error! $!^{588}$

\section{Monday 31 January}

9-12 at the office. 2-3 lesson with Lantier. Cold. Very cold. Housework. Met up with Dilys who was terrified by a telephone call telling her that they were going to arrest her tomorrow? [. . . . ${ }^{589}$ Lesson with Rochette. Went to see Ruth.

\section{Tuesday 1 February}

André came - when I kissed him I tried to forget that he was my uncle so that I could remember that he shares the same blood with my mother, the closest to my mother that it is possible to kiss here. It was mother by proxy I kissed. Feel so depressed. Poor Dédé didn’t understand. I felt that in him. He was saying 'Poor Madeleine, poor Madeleine" without understanding. That made me feel terribly depressed. Went for lunch at his place. Lesson with Beaugrand who gave me butter and cheese. Lesson with LeBreton. Lesson with Boyelle. Saw Ruth. Copied up notes in a hurry to lend out. Returned "Lost Lady" (Cather), “The Irrepressible Conflict" (B.O. Flower). ${ }^{590}$

\section{Wednesday 2 February}

Hairdressers but went out in the rain before hair was dry and cooled down with disastrous results. Lesson with Jourdain. Lesson with Chabert. Bought

587 'afterthought' written in English in the manuscript.

588 'Slight error' written in English in the manuscript.

589 Several words scribbled over in the manuscript.

${ }^{590}$ B. O. Flower (1858-1918). American reformer, populist and anti-Catholic. More on his life and work can be read in Jean-Louis Marin-Lamellet's article 'What's the matter with Benjamin O. Flower', published in the Spring 2013 number of the European Journal of American Studies:

http://ejas.revues.org/10086.

The book Madeleine was reading was published by the Free Press Defence League in 1915. Full title: 'The patriot's manual, dealing with the irrepressible conflict between two mutually exclusive world theories of government: a compendium of facts, historical data, reasons and present-day chronicles, showing why every friend of fundamental democracy must oppose politico-ecclesiastical Romanism in its un-American campaign to make America "dominantly Catholic." 
snowdrops and violets at last. Went to confession finally. I hadn't managed it for 10 days. Sobbed in the Confessional. So, so, so depressed. I've been fighting it for 36 hours. Went to try on the coat but it wasn't ready. Cried again. The dressmaker was lovely all the more so because my fit of despair reminded her of her beloved daughter who is now in a convent. Horribly unhappy. And what can I do about it? What can I do? What can I do? Skived off Bachellery's lesson. He'd have driven me mad. Ate something to feel better. That helps a bit. ${ }^{591}$ Wrote to Aunt and told her, two months late, that I have calcification in the right lung. Invited her and Yolande for Sunday. I hope that they go to Verrières. Not nice of me but that is the way it is. The family makes my depression worse at the moment especially because they do not understand anything about this dreadful despair I feel after 5 years of separation. They don't understand that the wound is still raw and one only has to brush against it - "Good grief. Your nose is cold! said André when I kissed him. Which is what sweet mummy would have said. There's an intonation in the voice, I don't know, a gesture. It was her and not her. And so on and on it bleeds and bleeds. It is frightening that I can no longer hide my tears in front of people - in front of Mad. F, the priest, the dressmaker. Tiredness must be causing it. I am still holding up but between the knee and the thigh something feels like it is flexing. There is always this horrible sensation that it is going to bend or break. And I still feel sick and cold, so cold although today there is no excuse. The temperature has climbed back up from $2^{\circ}$ to $15^{\circ}$. I need to go to bed earlier and do less thinking. 1.50-2.25 alert, I mustn't forget to go to collect Mad. F. at Vavin métro station at 21.20. She is frightened of coming back alone at night. Went to get Mad. F.

\section{Thursday 3 February}

9-12 at the office. Had lunch with Françoise Boësse. Her parents are very nice but very snobby and they are proud of it. Raced off to Maggy's to get "Mari" back to be able to swap it at the library. She wasn't there at first. I waited for her and then we chatted for a long time. It was like it was before (lately we have grown apart a little). Got back terrified that Marguerite Delplancq would be standing outside the door but got a pneu from her saying that she was going out or something like that. Great. Lesson with Poussif. Worked until 3 am translating Welsh. C. Mass. (St Blaise). Wrote to Aunt.

\section{Friday 4 February}

8.45-9.45 lesson with Malot. But given that she insists on sitting on the terrasse in the open air I freeze to death. Her oral is poor. 10-12 Vendryès - and didn't do Welsh. It was well worth me killing myself to get to. 2-3 lesson with

${ }^{591}$ Not clear but looks like 'soigné par nourriture' in the manuscript. 
Capon. Went to change a book at the Bibliothèque municipale. "Initiation à la Préhistoire" (S.Blanc), "Au temps du Pharaon". Beautiful photos but the writing wasn't good. 5-6 lesson with Boyelle. He doesn't work and makes no progress. 7-8 lesson with Rochette. Went to get the bacon I had ordered but it was a cold joint of pork??!! Nice letter from Aunt.

\section{Saturday 5 February}

Took the pork back for $1 \mathrm{~kg}$ of salted pork - very thin and expensive. M.Bxxx confides in me that his family is useless in business. Was late for lesson with Chabert. Didn't give it. Went for a lesson with Jourdain who was in bed. She has a beautiful bedroom. 10.45 to 12.40 alert. I came back in spite of the alert, bombs and flak. Saw a lot of planes. It is irritating walking during an alert. You are pushed from one shelter to another and you never know who is going to stop you. Was back in half an hour from Chabert. Lecture on "Saggarah". Interesting but the lecturer, an architect, very "dumb" and quite painful. ${ }^{522} 2.15-2.50$ alert. Went down into a shelter in the Sorbonne. It was like going into a pyramid. Huge walls and very hot. Bought crackers. Worked on the catalogue.

\section{Sunday 6 February}

Got up late. 9.45 to $10.30-11.55$ alert. Went to the butcher's and didn't go to Mass. Saw Dilys who insisted that I have changed a lot, look unwell etc and that I will have to go to stay at her place so that she can look after me etc, etc. And that I should go there for lunch. I didn't want to but we were speaking English and she was raising her voice and I didn't want to create a scene but it made me want to cry. Dilys doesn't care about my health but she feels lonely. Georges left yesterday. 12.25-2 alert. Had lunch at Dilys's. Ruth came. She had gone by mine to leave me a little pot of honey to thank me for yesterday. Got back 3.30. Catalogued. 4 until 4.30, third alert. Went to bed at 5 pm. Slept until 7 pm. Had dinner. Read until 9 pm. Tossed and turned ${ }^{593}$ until 2 am.

\section{Monday 7 February}

9-12 at the office. Lesson with Lantier (boring). Came back. Catalogued. Lesson with Rochette and I kept him until 9 pm. Dilys went mad. She had insisted that I go there for dinner at 8.30, she who has me waiting around so often, was furious that I. . . . ${ }^{594}$ I can't directly stand up to her but I trust in my "Passive Resistance" to succeed. I didn't do anything at her place (no washing up, no

\footnotetext{
592 "dumb" and 'painful' written in English in the manuscript.

593 'Tossed and turned' written in English in manuscript.

${ }^{594}$ Left blank in the manuscript.
} 
nothing unlike the usual). Moaned. She was being very mystical at the beginning. Slept over and she wanted to "put me to sleep", fingers over eyes, over forehead etc. After a few minutes, she fell on her side and fell fast asleep, I was wide awake - and very amused.

\section{Tuesday 8 February}

Had breakfast in bed. Dilys "rather disgusted". 595 From "living together" she now thinks that "we could have dinner together a few times a week". Meanwhile, she is going to come here to eat this evening. Waited for Dédé who didn't come but finished the cataloguing. Lesson with LeBreton. Lesson with Boyelle. Poussif. Dilys came to eat here, very excited, talked a lot about herself, insisted that I go to sleep over. I took some notes to copy up. Dilys was writing and I was mindful not to ask what. Annoyed, after a while, she closed her book and "talked at" ${ }^{596}$ me a lot - about the friends who are hurt because their friend doesn't go see them etc etc. She really doesn't know me well.

\section{Wednesday 9 February}

I made breakfast and Dilys said "Goodbye. Come to see me now and again". In other words, I've won through the power of passivity. Lesson with Jourdain. Lesson with Chabert. Went to the doctor then office. So, I am very tired. I need to sleep a lot and eat a lot etc, etc. I have some phials to take and some injections for Nico which I don't want - and this evening when I got home Nico arrived. You'd think he was frightened of Dr Duret. Went to the dressmaker and went to collect the watch. Bought myself a pretty navy blue leather box calf strap. Lesson with Rochette. Ruth came for a catch up. Very nice. 9.30-10 am. Alert. Wrote to Aunt. I. ${ }^{597}$

\section{Thursday 10 February +}

8-12 office. Denise came. Lesson with Beaugrand. Lent the night light. Catalogued. Lessons with Delplancq and Poussif. Snowed in the evening.

\section{Friday 11 February}

Lesson with Malot. Went to Vendryès lesson but he was ill. Found letter from him when I got back. 10.15-10.50 alert. 2 pm lesson Capon and lesson Boyelle.

\footnotetext{
595 "rather disgusted" written in English in the manuscript.

596 'talked at' written in inverted commas and English in the manuscript.

${ }^{597}$ Inserted over the first line of this entry is a reference to an air raid alert: '10.45-11.30 alert'.
} 
Went to a Beethoven concert with Françoise B. Alfred Cortot was conducting. He conducts very abruptly and they say that he drinks. Better looking from the back than from the front. Roland Charnay violinist was good. In the evening I went down to métro Vavin to collect Mad. F who is frightened to come home alone. Mad F. was so horrid when I first met her, so snobbish, so stony - she is so lovely and understanding on a one-to-one.

\section{Saturday 12 February}

10.25-11.10 alert. So, no lesson with Jourdain. Furious because I need the money. "Abydos". Not bad. The paper giver was very young. Came back straight away because felt poorly. Went to bed. Went to "Eaux basses". Very topical but good too. Some of it was fair and well said but it is a play which won't succeed because it picks out the sore spots and attacks the weak. Got a letter from Aunt which enraged me. I shouldn't be enraged though because number 1 it is a given that I am not allowed to be ill and number 2 each time I go to the doctor's, I go to the most useless one in Paris.

\section{Sunday 13 February}

Mass. C. I prayed for patience with my Aunt and got it. Cold day. Fed up. Darned Yolande's tights. Helped to patch Marcel's trousers. Such trivia! And Aunt is surprised that I run away from her (she has been pretty charming apart from a few barbs). She has promised to take me to the cinema for a big outing on Sunday. I couldn't give a fig ${ }^{598}$ about her cinema! Poor Granny. She said as I was leaving "It's not the body but the mind that'll go. My Violette doesn't want me here. I can't get it out of my head and the thought will finish me off". Poor woman. Heating is off.

\section{Monday 14 February}

Was late to the office because wasn't able to get out of bed $-3^{\circ}$ in my bedroom and ice on the inside of the windows. Kort was angry. Gilberte Frey is getting married on 22 April. She is as pleased as punch. I can understand that. Renewed "The Irrepressible Conflict" by Byron ${ }^{599}$ and took out "Tales without Women". There are some stories about the other war. What child's play that other war was. I know that there was death and, worse, dismemberment but when compared to the technical advances of the modern age - and what is in store 50 years from now - but to read that they thought flying over enemy

${ }^{598}$ Underlined twice in the manuscript.

${ }^{599}$ In fact, Irrepressible Conflict is by Chandler Tedholm. The lead character is called Byron Giles. 
lines at $50 \mathrm{~km}$ an hour was amazing!! Denise came for a few minutes. Lesson with Rochette. Dilys came to get me. She is bored. It's the first time that she has experienced solitude and dearie me, she doesn't like it at all and so she does everything she can to escape it. She is horribly selfish. She mustn't suffer at any cost so she doesn't mind at all about bothering others. I didn't feel right and I wanted to go to bed early but she was so insistent that I went and for a moment she looked as if she was going to cry if I didn't. Rochette came late. Dilys stayed until she arrived sure that there wouldn't be a lesson. She had come on Sunday even though I had told her that I was going to Aunt's. Ruth dropped off the honey. Had a conversation with the concierge. She wants to ban the lessons!!

\section{Tuesday 15 February}

Did the cataloguing. 4 degrees in my bedroom. To keep out the cold I put on 2 cardigans, one long sleeved jumper, a nightgown, a blanket wrapped around my legs, a coat and a blanket over my feet, gloves. It's not funny being unable to move in such low temperatures, especially when I haven't slept well. I never sleep well at Dilys's place. Sunshine. Now it is $7^{\circ}$ in the bedroom. Passable. Went to the Red Cross. Sent a telegram to my parents. Lesson with LeBreton. Lesson with Poussif. Went for dinner and to sleep over at Dilys's. Copied out notes again. Jean Boyelle. Went to give the sardines to Vendryès.

\section{Wednesday 16 February}

Lesson with Jourdain. Lesson with Chabert. Lesson Bachellery who was very flirtatious. Went to bed early because very cold.

\section{Thursday 17 February}

Office. Lesson with Beaugrand. "The Tomb of Tut-ankh-armon" (Carter). Splendid. "La Lorraine" (Bertrand). ${ }^{600}$ "Des Peintres Maudits" (Coquiot). ${ }^{601}$ Pneu from Françoise B saying that she isn't coming for afternoon tea. It is too cold. Got the medicine I need. Wrote to Godfather and Aunt.

${ }^{600}$ Possibly Bertrand Auerbach (1856-1942), specialist in the geography of Lorraine where Madeleine was born in 1918. For more on Auerbach and his work see the 1974 article by Numa Broc in Revue Géographique de l'Est (3): http://www.persee.fr/doc/rgest_0035-3213_1974_num_14_3_1299

${ }^{601}$ Gustave Coquiot (1865-1926). French art critic. Certain of his works, including Des Peintres maudits have been digitised by the Bibliothèque nationale:

http://data.bnf.fr/12391219/gustave_coquiot/ 
Saw Hélène Berr yesterday. She looks very well but she is a bit disorganised with her work, a bit like everyone I would guess. Collected the brown coat which I had taken to be turned up and it suits me well but I have lost a lot of weight even since the last time I went to try it on. I'll have to move the button. +2 In my room in the morning $(-2$ outside $)+5^{\circ}$ in the evening after 2 hours with the heating on for lessons with Poussif and Delplanq. Filled with enthusiasm about Tut-ankh-amen. He is so handsome, like a young God. The statue of him at 12 is fantastic. I want to cuddle ${ }^{602}$ it. I have fallen straight in love with him I think. Wildly excited by more photos coming out showing the discoveries. And 2 showing his real death mask made my heart jump. I'm mad about it all.

\section{Friday 18 January $^{603}$}

Mummy's 52nd birthday. Went to the Sorbonne. Vendryès is still ill. Worked. ${ }^{604}$ showed us his book and his fine quality white wool fishing coat $[\ldots]^{605}$ - it's quite like an Arab cape. Lessons with Malot, Capon, Boyelle, Rochette. Telephoned Aunt Marie and the office. Jacques Texier died this morning - at 18 !! His poor father. Admired the photos of Tutankamen ${ }^{606}$ again.

\section{Saturday 19 January}

Snow. How awful: $-4^{\circ}$ outside and +1 here. It is pretty though, all white, but I don't like it. From time to time, there's a 'flip-flop' sound - it is someone falling over. Lesson with Jourdain. Oh what it is to be in love. I feel full of vitality and all electric. I feel very attractive. Lesson on Deir el-Medina . Good, some nice slides but nothing as beautiful as when he went back to my little Egyptian king. He only told us about the village. Interesting - but oh - the lamp with the three lotus flowers. Françoise went on too much about me having tea at her place. I showed her my handsome little king. I read "Prayer for my Son" (Walpole) ${ }^{607}$ Not bad. Went to sleep. My foot was shaking. The hot water bottle had completely gone cold after having been in the bed for 3 hours!! I got up at midnight

\footnotetext{
${ }^{602}$ Madeleine makes 'cuddle' into a French 'verb': 'cuddler'.

${ }^{603}$ From the 18 th to the 20 th of the month Madeleine mistakenly writes January instead of February.

${ }^{604}$ Gap left in manuscript.

${ }^{605}$ Looks like 'c'hap gwen' in the manuscript which may be an incorrectly spelt Breton fishing/seafaring garment.

${ }^{606}$ Tutankhamen spelt incorrectly in the manuscript.

${ }^{607}$ Hugh Walpole (1884-1941). A Prayer for my Son was first published in 1936.
} 
to put 2 coats on the bed and do re-do the hot water bottle. Letter from Aunt wanting me to go tomorrow.

\section{Sunday 20 January}

Mass. Didn't go to Aunt's. I said that I wouldn't be going. Her skin is thicker than rhinoceros hide. Darned whilst reading Tutankhamen. Finished the 1st volume. It is fascinating beyond and despite the narrator if I can say that. Temperature is about $15^{\circ}$. Had the heat on a bit but well wrapped up and with a hot water bottle at my feet it is very manageable. The doorbell goes. There's a gentleman looking for a teacher for his son. I must have looked like a Zulu with a cardigan wrapped around my waist, a hood on my head but I wasn't at all bothered and I knew that he thought I looked charming. Oh my sweet, dear little Egyptian God. I am blushing with excitement about the discovery of his tomb - and here I am off on an archaeological expedition - !! What a fruitcake I am but he is adorable with his long mannered hands - and the four goddesses watching over his sarcophagus. What delicacy, what style, what crazy charm. And now, dear child, beddy byes. Sent a card to Godfather.

\section{Monday 21 February ${ }^{608}$}

Office. Very cold. $0^{\circ}$ in my bedroom. $-6^{\circ}$ outside. Kort was talking about mussels being "bissextiles". Lantier. Studied. Lesson with Rochette. Wrote a little note to Dilys about being depressed and that I will not be coming. Not true, but she irritates me. I was sent a slice of beef and 4 eggs. It was nice. I wonder how much I owe her for the eggs. Mme Beaugrand made me take some beef to the office. Met up with Maggy Desportes. Talked about her [... .], Egyptian Gods and Georges.

\section{Tuesday 22 February}

Catalogued. Waited for Marguerite Delplancq. Le Breton. Lesson with Boyelle who suggested letter. Great. Lesson with Poussif. Ice on all the panes. Shrove Tuesday.

\section{Wednesday 23 February}

Ash. And I'm in half-light. It is still 0 in the mornings. Lesson with Delplancq, Jourdain, Chabert. Lesson with Bachellery. He has acquired the habit of escorting me onto the rue Gay Lussac every Wednesday. Went to bed at $8 \mathrm{pm} .4^{\circ}$ in the bedroom. It is impossible to study. Ruth dropped a line to thank me for

${ }^{608}$ Madeleine returns to correct date order. 
the birthday presents. It is a new moon tomorrow. Let's hope that it brings an improvement in temperature.

\section{Thursday 24 February}

Went to the office but it was closed. Went to the post office and wrote to Yvonne, Aunt, Cyla. Sent card to Granny. Lesson with Beaugrand who gave me some pork paté, jam and 1 egg. She is so lovely. Saw Denise. DCA. Nice weather. $-5^{\circ}$ in the morning $(8 \mathrm{am})+4^{\circ} 6 \mathrm{pm}$. Beautiful sunshine. I think that we've survived. And, what's more, it is $22 \mathrm{~h} 15$ and I am still working. Telegram from Mlle Kerjean telling me not to come - a little late!! Lesson with Poussif. Waited pointlessly for Dick. It's a bit much he never comes when he promises he will. I always have to be chasing after him and it annoys me. Worked for 9 hours - and worked well.

\section{Friday 25 February}

Lesson with Malot. Lesson with Vendryès. Poor thing. His pleasure at the present I bought him is so touching. I think that he was very happy to have it. 11.40-12.20 alert. Lessons Capon, Rochette. Gave the crockery back to Dilys and the flowers to make up for the breakages. Wrote to Dad and Mum. Worked. What beautiful weather. I think that Spring is here. Beautiful blue sky and beautiful sun. The nights are very cold.

\section{Saturday 26 February}

Got up late. Lesson with Jourdain. Looked for the food ration card. Saw Ruth. Went to lecture on Byblos by Mortet who was like a Cockney. Worked. Had a turn and I fell down the entire flight of stairs at the Hautes Études. I'm all bashed up. It's going to look quite something tomorrow. Lesson with Boyelle who has just buried his father-in-law. Mad F is in a bad mood. Very cold. Damp. Saw the new moon looking like a fingernail in the sky. Homesick. Now, we have a power-cut two hours a day. What fun.

\section{Sunday 27 February}

C. Mass. Went to Villeparisis. Aunt missed her train. All Granny lives for is her daughter's visits. She is bored to death. But she never wants to come back to Paris probably because she has realised that it is completely impossible to live with Aunt who, if one doesn't do exactly what she wants, sulks and gets nasty. Three birthday celebrations. M. Labère came. I played with his dog, just like with Sammy. Cold. Snow. Got back irritated and annoyed after a day around Aunt Violette. 


\section{Monday 28 February}

Office. No heating. Cold. "Herman Melville" (Lewis Mumford). ${ }^{609}$ Lesson Lantier. Cleaning. Lesson with Rochette. Full of cold. Paid the electricity. I've already gone over my February and March allowance but they are going too far with their cuts $-15 \mathrm{kw}$ for February. $12 \mathrm{kw}$ for March and 6 for the other months. I can manage at a temperature of $8^{\circ}$. I can work in $3^{\circ}$ but lower than that I am very sorry but no. Didn't go to Dilys's. Sent a message to Mum and a card to Marcel.

\section{Tuesday 29 February}

Got up late. Dilys came to bring the eggs and wants me to sleep over on Friday (what a pain). Missed hairdresser. Got paid and exchanged book for Rochette. Lesson with LeBreton. Lesson with Boyelle and Poussif. Darned sheet. Alert $8.50-9.20 \mathrm{pm}$. Snow.

\section{Wednesday 1 March}

Lesson with Jourdain. I want to get up early. I've woken up but it so cold that I'll wait another 5 minutes. ... If what Granny said is true and if Roche has only put in 2 fruit trees and not the 4 then that is annoying because I don't want to go back there for a month by which time it will be too late for planting. If I have made a mess of this land then it's my fault for having been so well brought up and for having given way to family pressure when I should have said to them: "Hang on, I want to cultivate this land myself. I am keeping it". When there were still trees there they swore blind that we'd have to pay someone to take up the tree and give them the tree as well. Now, they are coming out with astronomical figures for each tree sold (and which the purchaser has had to chop down). There was no peace until I lent or gave up land to Roche - (for Yolande's marriage which never happened). I've let myself be done. I wouldn't care but for:

a/ It is my parents' land - and what would they have to say about it.

b/ They think I am a little baby who shouldn't be holding such things. Take them off her quick so that we can make use them to our advantage. But I know that if I had objected, the trees would have been chopped to bits (nobody would have noticed anything) or if I had planted the land, everything would have been stolen (nobody ditto). Strangely, I am not angry with the two old men but Aunt gets my back up and makes me hopping mad.

${ }^{609}$ Lewis Mumford (1895-1990). Biographer of Melville. 
Everything about her is staid. I can see that Marcel gets annoyed when he's around her and every day I praise the Lord that I left. If I hadn't been so stupid as to listen to her in 1940 and go back to her place I could have been with my parents now. At home, they taught me to respect and to obey my Aunt too much - and, oh but I could kick myself now - but all of that is over and done with now. Does Aunt sense it? She couldn't be kinder to me etc, etc. Sometimes I think that I love her but in truth I think that I hate her. I am as distant and as indifferent to Yolande as I would be with a passer-by in the street. It is 3 o'clock. Enough of this ranting and off to Bachellery's lesson. I am going to be late but I don't care. Let's hope I don't sleep through it. Cold, cold, cold. The thick snow which fell yesterday is still around and is now frozen hard. Reading back over other years on the same date: warm sun, daffodils nearly out etc. Gave a hollow laugh. . . . Mind you it is the 5th arrondissement and the wind has changed direction from $\mathrm{N}$ to SW. It is very mild outside. Felt gay ${ }^{610}$ Lesson with Bachellery - 3.30 and he went at $4 \mathrm{pm}$. Was sat next to ${ }^{611}$ - an economist. Uncouth. Vendryès called me to give me two tickets for the Prisoners' Gala, in the stalls my dear!! Overwhelmed. ${ }^{612} \mathrm{He}$ is so kind. Ran off to Maggy's to give her the other tickets but she has bronchopneumonia. Lesson with Chabert. There was another fellow there who wanted a lesson. Feel grand. ${ }^{613}$ The only thing that is missing is a letter from my parents. If I get this new lesson I will buy the thing made out of birch second-hand for 500 francs. It is ugly but it is better than nothing. I'll invite Mad. F to the concert and if she can't go I will ask Françoise. If she can't go - then Dilys? It'll have to be someone who will make the effort. Mad. F. would be best. Madeleine Fortan can't come. I will invite Dilys. The lake in the Luxembourg is frozen.

\section{Thursday 2 March}

Office. Lesson Beaugrand. Ordered "Aero". Bought and wore perfume for Colette's birthday who came over. She wants to live with me, for me to guide her etc, etc. I would supervise her studies!! "Teach me everything you know" Very touching, but - ! That doesn't fit with the café to be shared by Aunt and René etc. I could see that coming. Lesson with Poussif. Dilys does want to come to the concert. Telephoned Capon to put the lesson off until Saturday. Pneu from Delplancq.

\footnotetext{
610 'felt gay' written in English in the manuscript.

${ }^{611}$ Gap left in manuscript.

612 'overwhelmed' written in English in the manuscript.

613 'grand' written in English and underlined in the manuscript.
} 


\section{Friday 3 March}

Lesson Malot. 9.40-10.30. Alert. Lesson with Vendryès. Bachellery is trying to flirt with me. He's very jealous that the tickets were given to me and not to him. Lesson with Boyelle. Rochette. Slept over at Dilys's (irritating).

\section{Saturday 4 March}

Lesson with Jourdain. Egyptology lesson. Gala de Paris. The orchestra had a very young conductor. The cellist was so-so. "Les 4 Compagnons de route" very good. Lola Bobesco ${ }^{614}$ amazing. Left at the interval because of Capon's lesson. I'd worn my hat. I looked very attractive. Dilys was convinced that I had a date. Lesson Capon. Saw Françoise coming back in the métro.

\section{Sunday 5 March}

Got up very late. Didn't go to mass. Pottered about. ${ }^{615}$ Concert [...] at the Palais de Chaillot with Françoise, Anne and their mother. "Ouverture d'Euryanthe" (Weber). ${ }^{616}$ "Concerto en [. . .]" (Beethoven). Pianist Jean Hubeau - a young composer. ${ }^{617}$ He plays well. "Symphonie du Nouveau-Monde" (Dvorak). ${ }^{618}$ Very good. Very fresh. Thrilled to bits with it. Cold.

\section{Monday 6 March}

9-12 office. Housework. Lesson Poublan. Delplancq. Rochette.

\section{Tuesday 7 March}

Lesson with the Rumanian. Very shy. I don't know his name. Lesson with LeBreton. Lesson with Boyelle. Poussif. Because I ate 2 crackers and honey last Tuesday I'm not being given any tea this week. Will that be it from now on? Bought furniture unit and cleaned.

\footnotetext{
${ }^{614}$ Lola Bobesco (1921-2013) was a Belgian violinist.

615 'Pottered about' written in English in the manuscript.

${ }^{616}$ German opera by Carl Maria Von Weber (1786-1826).

${ }^{617}$ Jean Hubeau (1917-1992). French composer and pianist.

${ }^{618}$ Antonín Dvořák (1841-1904). Czech composer. Informative entry on Dvořák and his work at: https://www.britannica.com/biography/Antonin-Dvorak
} 


\section{Wednesday 8 March}

Lesson Jourdain. It's the penultimate one. She is going to the mountains. Annoyed. It's my best lesson. Lesson Chabert. Lesson Bachellery [ . . .]. "Lart anglais" ( ). ${ }^{619}$ "Carnets intimes" (Sarmain). ${ }^{620}$ Painted furniture.

\section{Thursday 9 March}

9-12 Office. "Mystères du Thibet". Good. A very traditional Thibet but good all the same. The film was also great on dragonflies. Queued for an hour! Went to see Maggy Desportes. I went on Tuesday but couldn't get her to hear me. Found Denise and Guy at the door. I didn't let them in because the housework hadn't been done. Lesson with Poussif. Wrote to Aunt.

\section{Friday 10 March}

Lesson with Malot. Lesson with Vendryès. Lesson Capon. Boyelle (who made tea and I made sure that I only had one cracker). Rochette. She started talking to me about her love life. It was a bit like me and Jean but she was more gullible and the poor woman has suffered more. Stayed 2 and a half hours!! Message from Dilys insisting that I go. I didn't want to and then I did. I am pleased that I did. She was upset by the death of the fellow below. It reminded her of her mother. She had nightmares. What a night. Between her nightmares and falling back to sleep I had to go chasing the sheets. Bought daffodils and violets.

\section{Saturday 11 March}

Went to Jourdain. Didn't give a lesson but got paid. My violets overflowed onto the furniture. I had to redo the walnut stain. Waxed it. Egyptology lesson with M. Robichon who is Egyptian despite the French name. He showed a film natives and more natives. Interesting but not archaeology. Confession. Pneu from Valeix.

\section{Sunday 12 March}

C. Mass. Beautiful crisp weather. Sun. There are buds everywhere. Up top the trees are lighter, redder. Went to lunch at Andrés who completely forgot. The poor little love isn't happy there. He has applied for the SNCF. Played the

${ }^{619}$ Left blank in manuscript.

${ }^{620}$ Albert Samain (1858-1900). French Symbolist poet. See the on-line entry at French National Archives:

https://francearchives.fr/commemo/recueil-2008/39248 
barmaid etc. 'Got off' ${ }^{\prime 21}$ with a customer. 3 pm. Lunch. Went with Colette to the Lutetia swimming pool to look at the legs. I prefer to swim than watch people swim. Colette has such a pleasant disposition!! She is furious that I am not taking an interest in her career outlook. The relationship is on the rocks on the rue du Cherche-Midi. Got back with a nasty cold. An awful pain in my chest.

\section{Monday 13 March}

Lost voice completely!! That's handy for lessons! 9-12 office. 10-10.25 alert. Mlle Poublan has invited me to [...]. It is tempting for the horses and the boating but I haven't got the clothes for it. Lesson Delplancq, Rochette. Constantly using inhaler. "Katherine Mansfield, Journal" "My Antonia" Willa Cather. ${ }^{622}$ I

\section{Tuesday 14 March}

+ Got up late. Lesson with Roumain. Pottered about. ${ }^{623}$ Read. Lesson with LeBreton. Lesson with Boyelle. Poussif. Pneu from Valeix. I

\section{Wednesday 15 March}

+ Got up late. Lesson with Chabert. Didn't go to Bachellery's lesson because I was still feeling too poorly. André came to put the clothes rail back together. He got in at the SNCF near Orléans. He looks a lot better since the poor love. I do love him. It's mad. He doesn't look like my mother though. It's about 12 years since he last saw her!! Françoise Boësse came in the evening to bring me a slice of pork, a little cream and butter. She is very nice. I think that she is extremely fond of me. She opens up like a flower and confides silly but touching little things in me. Letter from Cyla who is very down about being so far from Paris. I think it is less about Paris itself than it is about the place where she was happy. This area is always loved. Paris means nothing to me but I would miss my view, always so silvery grey. 3.30-4.10 alert. In the evening there was lots of artillery fire. Mended my net stockings. I

621 'Barmaid' and 'got off' written in English in the original manuscript. Uncertain what is meant by this incongruous phrase. Perhaps Madeleine cleared a drink or brought one to a table and flirted with a customer?

${ }^{622}$ Willa Cather (1873-1947). American novelist. For more on Cather and her work, see The Willa Cather Foundation:

https://www.willacather.org/

623 'Pottered about' in English in the manuscript. 


\section{Thursday 16 March}

9-12. Office. 10.25. 11. Alert. Denise came to the office. She is really sweet. Poor Gilberte Frey doesn't have any luck. Three weeks before her marriage her father is paralysed, her grand-mother is crippled and her fiancé Jean's parents haven't sent any news since the bombing of St Etienne!! Everyone in Paris is talking about the crimes of Dr Petiot, ${ }^{624}$ the new Landru. ${ }^{625}$ Folk are like vultures around this. The 15th March came and went and no landings. Jean-Hérold Paquis is very happy about that. I am too. At all costs I don't want the landings to happen in France. We have suffered enough. You have to have a pass to walk in front of the Sénat on the rue de Vaugirard between the post office and the rue Guynemer. There's loads of works going on in front of the Sénat. They say that they are installing grills to block access to the sewers. I haven't written my diary since the 3rd of March. I really mustn't leave it so long. Lesson with Beaugrand - he gave me an egg. Lesson with Valeix a little 17 year old kid - he thought he'd be coming to see an old lady!! 4.40-5. Alert. Lesson with Poussif. Got a parcel from my parents. Very happy. Sardines!! Mid lent. Made myself some pancakes. Saw Dilys who was so, so charming - hope not to have to sleep over at her place tomorrow - thanks to my cold. Looked for my rent receipts to enable me to get a coal card on Monday. I need to go to bed early. We only get $6 \mathrm{kw}$ a month and it is already the 15th - I've gone over by 4 !! Surely they will cut me off. Where is it all heading!! 50 gr of butter a month!! Not a single vegetable left in Paris. Oh well. Spring is on the way.

\section{Friday 17 March}

8.45-9.45. Lesson Malot. 10-12.15 Vendryès. Jolivet was there. During the lesson we could hear the medical students making a row "In a lecture theatre..." with a "Oh, we're sick of being here" - Vendryès lifts his head "Isn't that the Germans singing?" 2-3 Lesson with Capon. 2.30-3.30 alert. Came back on foot to Montmartre with Mlle Capon. Shattered. Bought daffodils and primroses. The daffodils were wrapped any old how. The bulbs were at the bottom and the shoots were all bent over etc. It's a disgrace making flowers suffer so horribly. 5.15 lesson with Boyelle. 7 pm lesson with Rochette. 9 pm. Went to bed because dead tired. There are new electricity restrictions.

${ }^{624}$ Marcel Pétiot (1897-1946). In March 1944, human remains were found at 21 rue de Sueur, Paris home of Dr Marcel Pétiot. Pétiot escaped, joined the Resistance and was captured at the Liberation. He was charged with multiple murders and executed in 1946. For more on Pétiot and the case, read: https://www.herodote.net/18_mars_1946-evenement-19460318.php

${ }^{625}$ Henri Landru (1869-1922). French serial killer. 
25 underground stations are shut including Notre Dame des champs. I had to run all the way to Voirin and I wasn't early - What's more, the trains start half an hour later in the morning (6 instead of 5.30) and the last one leaves at 10.45 in the evening. The cafés are closed 2 days a week. The cinemas have had to reduce their showings by $40 \%$, they have 2 a day now instead of 3 except on Sunday when they have 3 instead of 4 . Word has it that they are putting security grills in the sewers. There are no vegetables in the whole of Paris. To make up for it we've had a pound of pasta and $250 \mathrm{~g}$ of jam. Happily I have some potatoes and I bought some Brussels sprouts opposite - gone up - 30 francs a kilo!! And I still haven't had my egg for December. Creil has been bombed. Getting news is going to become more and more of a rarity.

\section{Saturday 18 March}

Went to market. They only had parsley, flowers and haberdashery. Saw Dilys wearing her smartest togs on the way to see the Dean of Sciences for something for Georges. She wants me to come over this evening. I won't be going even for half a dozen eggs. This desire of hers for physical closeness annoys me. 12.5-12.40 alert. 3.40-4.40 alert. Catalogued. Worked hard. Didn't go to the Egyptology seminar because had a very bad headache. Françoise came to see what was up. She is very kind. Washed stockings etc. I've only got 6 matches left and I can't get any. Pneu from Aunt telling me not to come tomorrow because there's lots of bother - but health wise all ok. It's bad but my joy about not to have to lie about tomorrow (because going to a concert) outweighs any anxiety about her worries. Mad. F pointed out that I am not nice when I attribute mean motives to people who haven't got them. I was pretty annoyed but she's right. I think that Aunt has damaged me. I'll have to keep that in check. Got a note from Ruth with the photograph of her portrait - which looks like her, with a very gentle expression which I don't associate with her at all. Even not being mean minded I find all that very American - very new money. I would like to see her portrait. Worked. Spoke a lot with Mad. F. I don't think that she's easy to live with which doesn't mean that she isn't a great girl. Went to bed at $10 \mathrm{pm}$ because of the electricity ration. Resolved to go to bed early and to get up early. But, I only work well after 9 pm. In the morning it is so cold. Splendid sunset, red flame - mauve on blue burning fiercer and fiercer.

\section{Sunday 19 March}

C. Mass. At the moment I can barely pray. I am very much a morning person. Got up at 6.30. Went to 7 am mass. Put out the [...] for the birds. Today they are happily eating it as soon as I put it out. Yesterday they hardly touched it - why? Perhaps the new flowers were scaring them or perhaps it's because it's market day or just spring. Or perhaps they didn't know what it was. It's well and truly spring since the day before yesterday. But although it has been cold the buds are 
puffing out. The __ ${ }^{626}$ is in flower. How stupid not being able to remember its name. The Ouse next to St Mary's Abbey gardens was lined with them and in the evening coming back, especially Saturdays back then, Mummy and I would spend ages looking at the colourless little flowers which looked like buds from a distance. Darned tights. Went to a Beethoven and Wagner concert at the Palais de Chaillot. Leonore's overture de "Leonore" (Beethoven), "Concerto in [. . .] (Beethoven). Monique de la Bruchollerie ${ }^{627}$ was playing - a bit hammed up but what exquisite playing. She has an incredible Pianissimo. Her white dress, very full, big sleeves turned up at the wrist was extremely pretty. The juniper is flowering at Denfert Rochereau but shyly. Raining. Françoise is always very happy to see me. I like to see, at the Palais de Chaillot, the human torrent flowing down and winding round the columns. It's even more striking when it climbs; the river running backwards.

\section{Monday 20 March}

Beautiful day but struggled to get out of bed at 6.30. By 7 am I was up but didn't have the time to do the housework and everything else before having to leave. Went shopping 9-10.15 there was an air raid warning. 10.20-11 there was another alert and then again at 12.20 but thankfully I was in the underground at Châtelet. I didn't get out quickly enough to cross the Seine, police cordon, forced to go behind N. Dame by the side streets. I love the huge and heavy oak doors studded with nails. The willow tree at the tip of the Ile-de-Paris looked as if it was draped in a green veil, thin and light. By the time the alert ended I had done a huge detour to avoid the Panthéon where one usually gets fined for something. Waited half an hour for a ration card for coal. Got some for Mad. $\mathrm{F}$ - forgot to declare that she had an electric cooker. I will have to go back and get that changed. Finished letter to Cyla. Letter from Poublan - couldn't come. His sister is ill. Wrote to Poublan. Sent a card to Marguerite. Marguerite came for her lesson. Brought all her presents to show me. Hugged me with great affection for the earrings (I'd only worn them once). It isn't good to give them as a gift but I have no money. Dilys came because I didn't go there. I don't care. Her face is becoming more "coarse". ${ }^{628}$ Found a little box of matches. Thank the Lord for that. Saw Jews being moved off. The Germans were organising the whole thing. These seizures are happening a lot. There are also lots of arrests. Mrs Ravelliotti was sent to the Kommandantur this morning and she hasn't returned. Letter from Rochette. Still nothing from my parents. I don't want to worry. I've heard that there is a cold snap in York. Will we get it? Hope not. I am sure that I am losing weight.

\footnotetext{
${ }^{626}$ Gap left in manuscript.

${ }^{627}$ Monique de la Bruchollerie (1915-1972) was a French classical pianist.

628 "coarse" written in English in the manuscript.
} 


\section{Tuesday 21 March}

Spring. Marguerite Delplancq 18 years old. Furious. I only got up at $8.30 \mathrm{am}-$ and had woken up at 6.30. I should be ashamed of myself. It is raining. The little Malot girl came over for me to lend her the book on English painting. Lesson with the Rumanian. I get the feeling that he is looking for anything to show that I am wrong. Did some good work. Rumania has been invaded. Lesson with LeBreton. Lesson with Boyelle to whom I gave a litre of wine. The boulangeries are going to be closed 2 days a week. Until now, food shops were exempt from this measure. It's starting. Lesson with Poussif. It is raining and it is colder.

\section{Wednesday 22 March}

Got up at 8.30 am again instead of 6.30. But I feel so tired. I had a really nice dream. I had, quickly and painlessly, a pretty baby which I called Elizabeth. The following morning I had got up and I was going on at the office to tell my mother. I woke up when they told me that the line was down. Daddy was with me. Worked. Did the cataloguing for the office. Looked for the income tax sheet. Lesson with Bachellery. He went over time by $15-20$ minutes as per usual - and his wife was waiting for him without him knowing!!! He was asking me very nicely whether he could go to the rue Gay-Lussac with me when he saw her - what a face he pulled!! They took the métro to Odéon. Letter from Aunt who is making mountains out of molehills ${ }^{629}$ over Marcel. She thinks that all I am waiting for is her invite to go over on Sunday. If she knew that I have a ticket for a concert she'd be hopping mad. I sent her a reply straight away - a new resolution. Had December's egg. Better late than never. I am waiting for Mad. F and her friend Marcel. Cooked some beans. All students have been registered for the STO. I think that it could be lecturers too - Bache looks very worried. It's Bache's son's birthday on the 27th or 28th of March. Mustn't forget to send a card. Have I already said that on Monday I saw this year's first buds opening - a privet. The willow tree in the garden of the Institut Curie is all green, much further on than the one next to Notre-Dame. Very cloudy. Everything is dry. We need some rain. The days are getting longer. $7.10 \mathrm{pm}$ and not put the light on.

629 'molehills' written in English in the manuscript. 


\section{Wednesday 23 March $^{630}$}

Went to the Town Hall to change the coal ration card for Mad. F. Couldn't. Lesson with Bachellery. His wife was waiting for him on the way out - should've seen his face.

\section{Thursday 23 March}

Office. Lesson with Beaugrand. Valeix. Poussif.

\section{Friday 24 March}

Lesson with Malot. Lesson Vendryès. Lesson Capon. Bought red striped material for gloves. Didn't have lesson with Boyelle. The concierge didn't pass on the message. Lesson Rochette.

\section{Saturday 25 March}

$10 \mathrm{am}$. Chabert. Lesson on Egyptology. Went over to see Dilys who sold me 4 eggs. Had tea with her. I gave her a tin of sardines.

\section{Sunday 26 March}

Mass. Communion. Went to Villeparisis. The first fine day. Stayed outside all day in the sun. Roger was there. Yo and Marcel came over Saturday afternoon. Marcel chopped a tree down. Yo is very possessive about him. She wants to be the only one to darn his socks etc. In the afternoon collected pussy-willows with Roger and Aunt. Yo and Marcel were sat together on the bank - !! Yo has a new hairdo combed back off her forehead which makes her look hard-faced. I told her and told the others too. A few minutes afterwards "You really have put on weight Madeleine. Another illness like the last and we won't be able to see your eyes". And that is all Yo and I said to one another this Sunday. I feel as if I am in a frigidaire - and then they are surprised that I don't rush over there every Sunday!! Went to see René Roche's twins who were born on Friday. They are terribly tiny - called Bobby and Sammy but they have very long hands and big feet and are not "chubby". They are ugly. They weigh 3 pounds together. Spring is marching on. There aren't a lot of pussy willows but the flowers on the fruit bushes all came out within

${ }^{630}$ Madeleine muddles the dates of her entries from 22nd March to the 26th. Both Wednesday and Thursday are marked as the 23rd and Friday, Saturday, Sunday follow on with corrected dates. 
a day. There are some anemones in the wood. We got the train in the evening because a lot of trains were cancelled. On the way, while Yo was sleeping on Marcel's shoulder, Aunt said to me, "Do you know what? I am very angry. If I had known I would not have invited such misbehaviour home, Marcel wants to marry Yolande". After having done all she could to get them together (they have breakfast together in the same bed), she is "taken aback". Marcel hasn't got a good job but he is elegant. Yolande has turned down so many chances to get away - the years are passing by. Marcel was smiling awkward smiles. To my mind, she is making a mistake. Yo is 4 and a half years older than Marcel. He doesn't have the same level of education. But on the other hand, I'd love to see her married off. I'd give a sigh of relief when she is "Madame". 'Nuff said. ${ }^{631} \mathrm{I}$ am all excited about it. "Why don't you get married?" Roger asks me. "I can't find a handsome boy!" "You are too fussy" (Aunt pulls a face). Gosh I will be so very happy if Yolande gets married quick, quick, quickly.

\section{Monday 27 March}

Office. It's the Move. Poublan didn't come. Lesson with Delplancq. Rochette.

\section{Tuesday 28 March}

Waited for Rumanian for nothing. Then the Concierge brought the note up. Given what is going on he can't come. Lesson with LeBreton. Lesson Boyelle. Poussif.

\section{Wednesday 29 March}

André is 39 years old. I haven't wished him Happy Birthday yet - don't have a packet of cigarettes yet. Lesson with Bachellery. Went to Mme Bourgeois to arrange a lesson.

\section{Thursday 30 March}

Office. Got paid. Saw Denise. Lesson Beaugrand, Vaieix, Poussif. Sent a pneu to Aunt.

631 'Nuff said' written in English in the manuscript. 


\section{Friday $31 \operatorname{March}^{632}$}

Lesson with Malot. Lesson with Vendryès who is very worried about what happened yesterday - 5 young people arrived at the Secretariat at around $4.30 \mathrm{pm}$ with revolvers and took away all the registration files. He is frightened that the Sorbonne will be closed or he will be arrested. Poor blighter. A. handed round his notes on the book. "I am sorry to have little more of interest to offer but you have arrived late in my life". Fleetingly, during the lecture, caught his eye, shining and blue like a stream in the sunlight. My heart flipped. I love JV. I hope that nothing happens to him. Aunt is furious with me. Got a pneu from her yesterday evening inviting me to the theatre Gaité-Lyrique this evening for 6.30. But I couldn't care less about the G.L and I don't particularly want to see Aunt. So, I telephoned this morning apologising that a dinner arrangement this evening was stopping me. She was furious. Her voice sounded as if she was fatally wounded. It doesn't occur to her that I might have a private life and she is furious that I don't rush over to see her when she clicks her fingers. Lesson Capon, Boyelle. Rochette. Bought Fernand Aubry lipstick. Drank orange juice cocktail at "Oldo". Bought some sheets of franked paper for the exam. Went to sleep over at Dilys's. Lost my second and most recent umbrella.

\section{April Saturday}

Bought an Easter egg for Izou and some [. . .] to make some pants because I'd never be able to buy all the linen. Lesson with Chabert. No Egyptology lesson.

\section{April Sunday}

Palm Sunday. Mass at the Val-de-Grâce. I found the handing out of the palms by the chaplain very moving. English Double Summer Time. ${ }^{63}$ Darned. Worked at office.

\section{Monday 3 April}

Office. The weather is summery. Métro and bus prices have gone up to 15 francs. This morning the Luxembourg gardens looked as if it was in the middle of a green snowfall. The snowflakes fixed in the air momentarily. Near

${ }^{632}$ Written in the margin against the entry of 31st March: 'Wrote Red Cross: A thousand thanks for the parcel. Urge you to send news. André is working for the SNCF. Aunt Violette's marriage plans are succeeding. Cousin Marcel has asked Yolande to marry him!!! Family is in good health. Love'. Nb: Cousin in the original French may mean cousin in English or a more distant relation.

${ }_{633}$ 'English Double Summer Time' written in English in the manuscript. 
Invalides there is an almond tree which is completely pink - gorgeous. "Teeftallow" (Stribling). ${ }^{634}$ It filled me with rage about human stupidity. America looks modern but it is living in the middle ages. Lesson with Bourgeois. She is very proud about having L'infant de l'Espagne, Prince de Bourbon in her clinic. Lesson with Rochette. Lesson Delplancq. Heavy rain storms.

\section{Tuesday 4 April}

Copied notes. Lesson Lebreton. Haven't yet signed up for the exam because at $2.10 \mathrm{pm}$ there was a queue right the way into the courtyard. Didn't have a lesson with Boyelle. Lesson with Poussif who could stop staring at me. Stomach ache.

\section{Wednesday 5 April}

8.50 am was at the Sorbonne. There was a queue of 60 people. Signed in at 10.30. Vendryès has been sacked. The poor love. Since Saturday only two doors at the Sorbonne have been open and are heavily guarded by the Police. No lesson from Bachellery (Praise be God ${ }^{635}$ ). Lesson Chabert who wanted to kiss me. He is mad. Lesson with Bourgeois. Luxembourg; a blizzard of green. Dilys brought [...].

\section{Thursday 6 April}

Office. Still moving things out. Even though Kort is on holiday he was there. He invited me and Denise to have a hot chocolate with him. So, I sent a pneu to Denise. Lesson with Beaugrand, Valeix. Beaugrand gave me some jam and $90 \mathrm{~g}$ of meat. I gave him a tin of sardines. All the leaves are out in the Luxembourg. Resolution: write a diary entry every night.

The latest:

$\begin{array}{lll}\text { Meat for the month of March }-120 \mathrm{~g} \\ \text { Fat “ } & \text { “ } & -50 \mathrm{~g} \\ \text { Pasta “ } & \text { “ } & -500 \mathrm{~g} \\ \text { Jam “ } & \text { “ } & 200 \mathrm{~g} \text { And that's all. }\end{array}$

Electricity is cut between 9-11-and 2-6 (but it's only the lift that doesn't work) Round ups all the time (especially in cafés)

${ }^{634}$ T. S. Stribling (1881-1965). See a 1926 review snippet from the archive of The Spectator:

http://archive.spectator.co.uk/article/3rd-july-1926/28/teeftallow-by-t-sstribling-nisbet-7s-tkl-netreade

635 'Praise be God' written in English in the manuscript. 
Sorbonne heavily guarded - as is the Quartier Latin.

Underground and bus travel prices have increased.

Nearly no milk for children.

No matches.

Electricity $6 \mathrm{kw}$ a month.

29 metro stations shut down. Factories working part-time as no electricity.

Radios confiscated in the North.

Tall stories (or maybe not?).

All dogs measuring more than $40 \mathrm{~cm}$ have been requisitioned by the Germans: $\mathrm{a} /$ to be made into sausages b/ to carry explosives to the Russian lines.

Métro closed a/ 9-11, 2-5

b/ Saturdays and Sundays

All girls have to go on compulsory work service to Germany.

Railway strike imminent.

Freed POWs in Seine \& Oise made to register for compulsory work service.

That is all I can remember for now. Shall I wear the hairnet that Dilys gave me to go to Aunt's tomorrow? I'm going to go to bed early $(9.30 \mathrm{pm})$. I am putting on weight again. I hate it. It's because I have been eating potatoes non-stop for two weeks. I'm fed up with it.

\section{Friday 7 April}

Good Friday. Had lesson with Malot here. Lesson Capon. On the way back I bought some lovely red earrings, dangly ones. Bought [.. . ] for Aunt's birthday. Went to Maggy's to take Easter presents for the little ones. She wasn't there so left them with the concierge. Had an ice cream. Lesson with Boyelle. Mad. F. doesn't like my earrings at all, at all. I do though they make a sound when I turn my head. She thinks they make me look cheap.

\section{Saturday 8 April}

Got shopping. Showed the earrings to Dilys who doesn't like them either. Damn. They are so cute though.

\section{Sunday 9 April}

Easter Day. Woke early but didn't go to mass because I was tired. Arrived at the train station at 10 . Got sat down but five minutes later there were people standing all the way out to the steps up. When the train left it was mad. Crowds 
of people pushing against the doors. I had a lovely little girl sitting on my lap. At Villeparisis Aunt flew into a rage when she saw me all dressed up with my hair up in the hairnet. She was so angry that I knew that I looked great (despite "the hard face and looking old" etc). Marcel told me that I looked good. Did a bit of hoeing and then darned some socks. Went to see Roche's twin girls who are getting prettier and prettier. Left - the official reason being that I was going to Bachellery's. Forgive the lie but it's "self-defence". Brought back some stocks.

\section{Monday 10 April}

Darned. Blissful, quiet and good day. Showed Mad. F how to darn her stockings. Gorgeous sun. Is it the calm before the storm? Happy nonetheless. I forget to say that after coming back from Villeparisis I pottered around until midnight when - air raid alert. It looked fabulous from my window (the first time). Fires. Red and green flares, explosions, flames which were red against the pale velvet night with its full moon. Once huge flames leapt kilometres high. And to think how something so beautiful could bring about death and destruction!! It was at Villeneuve St Georges. Another alert at 10 am. Inevitable.

\section{Tuesday 11 April}

So many letters: Denise, Mme Korbelecky, Margaret Lavenu, Maggie. Telephoned Boyelle. Pneus Mme. K. Maggie. Bought 1 kilo of jam and 1 pound of butter. Got shouted at by Mad F because I had said to B that she could have some and she hasn't got any money. Later, she came to make peace with a sweet. Lesson with Boyelle, Poussif. Lesson with LeBreton. Aunt's birthday. Air raid alert in the night. Wrote to Bachellery.

\section{Wednesday 12 April}

Sent Aunt a card. Lesson with Chabert who asked me to marry him indirectly little runt (my hairdo must indeed be pretty). Tea with Françoise. We talked about lots of things. We were in agreement on a lot - marriage in particular etc. I also realised that I can no longer take things in easily. Sad. Chabert lent me “The Mystery Book". Read it until 3 am. That's bad. Went to Dilys's who was tired out. I

\section{Thursday 13 April}

Lesson with Bourgeois. He ran after me as I was leaving to introduce me to Dr Class who wants lessons. I am scared stiff. He looks like an animal. Lesson Valeix who didn't come. Lesson Delplancq and Poussif. Went (pouring with sweat) to Dil. Not there. Was paid and came back. Read until 1 am. I 


\section{Friday 14 April}

Lesson with Malot. Lesson with Vendryès. He didn't say anything and we didn't either but we shook his hand and squeezed it as hard as we could. He kept his fingers closed tightly around his thumb. Love!! Went to see Capon - not there. $\mathrm{He}$ is at Dreux and there is only one train a week. Went for afternoon tea at Maggy's who is extremely annoyed with Camille who has inoculated himself with a monkey larva and is very poorly. A hero for science - but with a wife and two children....!! She sent a painting to the Salon. It's very original. Maggy insists that she wants to paint me with my hair up in two buns with hairnet, from $3 / 4$ on with the light on the hair and just my big dark eyes. I'd be pretty happy to do that. I could give it to Mummy. Izou and Katy are adorable. Telephoned Boyelle. He really has missed so many lessons. I

\section{Saturday 15 April}

Chabert ( $1 / 2$ an hour) Bourgeois who told me a lot about C. His mother is Greek. His father's mother is Rumanian and his paternal grandfather's mother comes from Central Europe. As far as 'pure breed' goes, there's better. He came himself to apologise, all pale and pink and embarrassed. I'm not scared any more. Denise came to have lunch. She was very late, as usual. The poor little flower had one of her colds. Mad. F came for coffee and I couldn't get rid of her. Got to Kort's at 5.15. Drank some real hot chocolate. It was a very pleasant afternoon. His wife was lovely. Went to sleep over at Denise's parents who were annoyed with us because we arrived at 8.15 but things improved later. Poured down. Denise thinks that Mad. F has gone terribly old looking and vice-versa. There's only me who ....? I'm told that I look very young! What [. . .]. Very nice day. I. Card from Dick!!

\section{Sunday 16 April}

Still haven't been to mass. Are you not ashamed of yourself? But at the moment I don't feel at all religious. I don't pray. But I am very happy. Very peaceful. It feels like the calm before the storm - and I am making the most of it. Did the washing up and the cleaning before going to Aunt's who was lovely. I don't understand her. When we're alone just the two of us she makes out she is horrified about this marriage. She doesn't know what she can do to prevent it - but she encourages Marcel and Yolande as much as she can. She pays for everything. I'm not going to get involved. I'd write 50 pages on it. She does her best to make sure I go every Sunday. I can't do anything about that. Went to watch 'Un Seul Amour' ${ }^{\text {'636 }}$ at the cinema (Pierre Blanchar ${ }^{637}$ and Micheline

${ }^{636}$ Un Seul amour (1943) directed by Pierre Blanchar.

${ }^{637}$ Pierre Blanchar (1892-1963), French film actor and director. For more on Blanchar's life and career, see:

http://www.imdb.com/name/nm0087018/ 
Presle $\left.{ }^{638}\right)$. Was OK. Marcel is angry with me because I'm insisting that my husband will earn enough to enable me not to work. "You read too much" he moans at me. What he means is that I have compared life here with life over there and made my choice. Got off the métro at Châtelet and walked home. I love the night. The clouds hanging heavily over the blackness of the Seine. I

\section{Monday 17th April}

Darned. Studied. Lesson with Rochette. Pneu from Delplancq. Got up at $10 \mathrm{am}$ - terrible. Washed tights. Madeleine Rochette is very nice but she has religion on the "brain" 639 - 3/4 hour after the end of the lesson she was still talking to me. She must be insecure in herself? Jacqueline Piatier had a little boy called Jacques just over a month ago. I saw her husband on Saturday. The huge red moon rising behind the Panthéon 10 days ago. . . . The coolness of the so very green trees. When I am happy I never write my diary. Nothing when I have just 'done' 10 days. Do writers write because they are happy? They say: 'A happy people does not have a history'. 10.50-11.15 air raid alert sounded. The night is so black that when I looked outside I near enough had a fit of panic thinking I had suddenly gone blind. Marcel has good taste. Aunt told me that he doesn't want to go out with them because he thinks that they don't dress well. I need to write down the M.a.Y thing. I am fat. How can I lose weight? I have spent so much this month.

\section{Tuesday 18th April}

Dreamt that a man from the Beaux-arts - I don't know his name - who has been on the ticket kiosk with me was at the Brotherton and gave me one of his books on Greek sculpture. I left him and whilst going across the Hall I thought that I'd look in at the French Bay. Margaret Bennett was there and Teddy Baker; I was very surprised to see him. He wasn't. I thought that it had been arranged in advance. I thought 'I mustn't show him that I love him' then I said to him 'Can I talk to you for a little bit'. He had a very delicate nose with very prominent nostrils and I thought; Goodness, I didn't know that he was Jewish. We left together, went along a dark "cobbled" 640 street which went upwards and I found myself at the top of a house in a little cold bedroom in the eaves. I got into the bed and Cyla was there with a lot of people she had invited. There was an ethanol lamp and a sinister woman arrived and murmured to Cyla 'It's for ___ and everyone looked at me. I went very cold. Went to Bourgeois. C let me in with

${ }^{638}$ Micheline Presle (1922-). French film actress. For more on Presle's life and career see:

http://www.imdb.com/name/nm0696163/

639 'brain' written in English in the manuscript.

640 'cobbled' written in English in the manuscript. 
Madeleine. I was making lunch when Dilys came to suggest we ate together. I took my potatoes over to hers and we had lunch together, She is very restless and on edge. Wrote to Margaret Lavenu, Marguerite Delplancq. It is very cold. $9^{\circ}$ outside. The latest rumours: the invasion will take place in two days. There will be an uprising on the 25 April. Paris will be bombed. ps: If Teddy B really did have a dainty nose instead of the red blob he has then we would have never fallen out. Lesson with LeBreton. Afterwards I asked him for a reading list for Willa Cather. He didn't say anything special to me - but when I said to him "I can't come Tuesday morning you know", he said slightly awkwardly "yes, yes, I know'. I am so happy. Lesson with Boyelle. Poussif. So, they are saying that the landings are a certainty. I will need to get some food supplies together but with what, good God (I don't want to touch the 2000 francs I've put to one side - Goodness knows when I'll need it. I need another delivery of sardines quick! (I'm so ungrateful).

I am so, so, so happy. I could explode with joy. Why though? It is surely a good sign (perhaps seeing Daddy and Mummy again soon?) I could sing and dance all day long (to tell the honest truth, I feel very admired at the moment especially with my hair like this. I have always been playing catch up to my feelings. That's why I think I will live to see old age). My God, let's hope this joyfulness lasts.

Went to bed at 10.30. Round about 11 o'clock there was an air raid alert. Very bright light in my room. I got up in a hurry. To the South, it was as bright as day with hundreds of flares slowly falling, Shells exploding with blinding flashes. Saw a plane flying straight across like a beautiful shooting star then it made a graceful arc - and a terrible explosion when it hit the ground and burst into flames. Almost immediately afterwards, dark again except for a huge cone of beams pointing and criss-crossing the sky up through to the stars. Then, over to the N.E. Flares and red and green "showers" 641 like fireworks. Vast tracts of reddening earth quickly masked by smoke. Explosions. 3 spheres of light coming down slowly - then falling rapidly - 4 planes brought down tonight. At one point noise was coming from everywhere all at once. Explosions and fire to the south and straight ahead a huge green explosion. Everywhere shells bursting bright like air bubbles in mineral water. Everything was thundering, humming away, juddering, flak falling like hail. Very cold but only noticed it later. Finished around 12.25.

\section{Wednesday 19th April}

They are saying that it is Pantin Châtenay?? Had a terrible dream. Was stood in a strange kitchen with Dad and Maurice Baud. We were waiting and watching the stairway. Then I rushed into my bedroom with them and the Val-de-Grâce

641 'showers' written in English in the manuscript. 
was on fire and against the windows we could see silhouettes of men hung up by the feet in two rows and they were shooting men in the courtyard. Then iron bars went up in front of the windows 'to protect me.' It was night but in the morning we could see sick people laid out on mattresses placed on the ground in the blackened ruins. Food was being prepared for their lunch.

Sunny. Got a new blanket for my bed. It's disgraceful. I have one to turn and 3 to darn and they have been sat there for months. Mad. F is landing me in it. She gave me the money to pay her electricity which is in Andrés name. The collector asks me to tot up the charges on the back of the bill. I say to him "No, here is the paper you need. We're not paying together". "Oh really?" It's hilarious. They think I am the mistress of a boy I have never met - and he has probably never even heard of me!

\section{Thursday 20 April}

Office. Lesson with Beaugrand. Valeix. Delplancq. Poussif. We are very cold. Around midnight there was heavy bombing in the north of Paris, Porte de la Chapelle, St Ouen. All the sky was lit up. It was a dreadful noise. Just for a moment, out there on the landing I was a bit frightened. I saw a parachutist who had jumped just above my head. Horrifying. A Hellish vision. Such intense light, noise and so much smoke.

\section{Friday 21 April}

Went to Barbès to see Aunt. The crowd was very dense. Impossible to get by. In the end, managed to get round through the side streets. They were passing me with hand carts full of bundles of clothes and frightened kids. Aunt was beside herself. Levitan opposite had been transformed into a chapel of rest and there was a queue worse than at the cinema to identify the dead. I saw coffin number 71 being taken away. Sacré-Coeur was hit as well apparently. Several streets in Montmartre. The Flea Market no longer exists. St Ouen doesn't either. The barracks have been obliterated. All the goods yards to the north have been battered. It will take 5 years just to level it they are saying.

\section{Saturday 22 April}

Lesson with Bourgeois. Chabert. Went to Maggy's. Mlle Boué and Cioran came for lessons.

\section{Sunday 23 April}

Mass. C. Telephoned Peggy David to agree to type her dissertation. Spent the day at Françoise's place. Very nice. Dug over her garden. Came back with an enormous bundle of mauve lilac. Gave some to Madeleine F. 


\section{Monday 24 April}

Office. Got a pneu from Delplancq. Not coming. Lesson with Rochette.

\section{Tuesday 25 April}

Went to market. Bought some pinks. Lesson with LeBreton. Lesson with Boué. Boyelle. Poussif.

\section{Wednesday 26 April}

Lesson with Bourgeois, Ciorann, Chabert. Lesson with Bachellery. Note from Yvonne Disnar inviting me to dinner.

\section{Thursday 27 April}

Office. Lesson Beaugrand. Valeix-Class (very friendly). Went to Yvonne's to tell her that I couldn't come. Elizabeth is a beautiful baby. She looks so much like Pierre side-on it's unbelievable. Nicole is very pretty. Italian look.

\section{Friday 28 April}

Lesson with Malot. Capon. Boyelle. Lesson with Vendryès. Cancelled Rochette. Had dinner with Yvonne.

\section{Saturday 29 April}

Telephoned office to find out whether Monday is a holiday day. Sent a message to my parents. Lesson with Bourgeois. Chabert. Egyptology lesson. Went to Mme Faure's (what an old fossil she is!). She speculates horribly on how Gilberte died. I really don't want to see this silly old trout again. Alert (there is one every day). Joly brought his diploma to type up.

\section{Sunday 30 April}

Mass. Went to Andrés. Went to "Tragédie de l'amour" at the Vieux-Colombie. ${ }^{642}$ So-so.

${ }^{642}$ Written by Gunnar Heiberg (1857-1929) and performed for the first time at the Théâtre du Vieux-Colombier on 22 December 1943. See: http://data.bnf.fr/39459357/la_tragedie_de_1_amour_spectacle_1943/ 


\section{Monday 1 May}

Holiday. Typed the diploma. Lesson with Rochette.

\section{Tuesday 2 May}

Lesson with Bourgeois. Poussif. Lesson with LeBreton. Pneu from Boyelle cancelling.

\section{Wednesday 3 May}

Lesson with Boué. Chabert. Lesson with Bachellery. Typed the diploma.

\section{Thursday 4 May}

Office. Lesson Beaugrand. Valeix-Class. Poussif. Pneu from Delplancq saying she's not coming.

\section{Friday 5 May}

Lesson with Vendryès. Lesson Malot. Capon. Boyelle. Rochette. Pneu from Bourgeois who is cancelling his lessons.

\section{Saturday 6 May}

Lesson with Chabert. Finished diploma for Joly. Still got a few pages left of Peggy David's but she's not brought it. Went to Dilys's.

\section{Sunday 7 May}

Mass but air raid alert after the gospel readings. Went to see Marguerite Delplancq. Alert at midday. Went to Croix de Berny to see the cyclists. Fun but a biting wind. Another alert.

\section{Monday 8 May}

Office. Lesson with Delplancq. Rochette. Finished David’s diploma.

\section{Tuesday 9 May}

Lesson with Boyelle. Poussif didn't come. Let's hope that he hasn't got himself arrested. Wrote to the Red Cross. "Yvonne has a little girl called Elizabeth. Friends and family are all in excellent health and are thinking of you. Don't go worrying about me but do send food supplies if you can. Thinking of you all. With love" 


\section{Wednesday 10 May}

Went to have fortune read at Mrs Brun's. She told Madeleine F: "You are very honest. If you want to say 'Go to Hell' then you will say it. You have had 2 men in your life, one with blond hair, one with brown. The one who loves you is far away and you will have a letter from him by Sunday. You work in an office and you don't like it there. You will leave it after the war to start a business. You will spend the rest of your life abroad. You will have two children. Your husband will marry you for your personality. You won't have any money." To me she says: "You aren't from here, you. Your parents are across the sea and you will see them soon. You have a man in your life. He's a worthless cheat. Be careful. He'll be coming to see you before the end of the month. You don't like the men here. You won't marry a Parisian. You will marry a brown-haired man and you will have 3 children, 1 boy and 2 girls who you will love with all your heart. You are a good little girl, very honest but too good (translation: a mug). You'll go through a lot of changes before the month is out and you will have news from your parents. You'll be married for you and not for your money because you haven't got any. Someone in your family has been ill for a while and you are going to be poorly soon unless you have been ill recently that is. There is a woman in your family who means you ill." Well, well! All I have to do is wait for the letter, the changes and for the young man with brown hair!!

\section{Thursday 11 May}

Office. Alert at $10 \mathrm{am} .1 .30$ exam. American Civilisation. "The Definition of [...] in both Hawthorn and Poe". Think I did alright. LeBreton was charming. (I love him). Went to Valeix-Class's place. Not there. Wrote to Aunt.

\section{Friday 12 May}

Letter from Poussif's sister. Lesson with Malot, Capon. Rochette, Boué. Didn't get back in time for Valeix. Boyelle cancelled. Denise came over to get potatoes.

\section{Saturday 13 May}

Bought a Billy can for soup kitchens because according to rumours:

1/ Invasion by sea before 15 May

2/ Soup kitchens

3 Electricity off between 7 in the morning and 11 in the evening

4/ Gas only on for an hour a day

5/ No underground trains (25 stations have shut)

6/ No bread

7/ No wine

8/ All men sent to Germany and all women sent to work in factories. 


\section{Sunday 14 May}

Mass. Was supposed to go to Aunt's but she's at Villeparisis and I just don't have the energy to take the métro to Porte de la Chapelle, wait hours for a bus to Bourget and then get a train - and at what time? Did some darning.

\section{Monday 15 May +}

The gas is only on between 5 and 8 , from 11 to 12 , from 19 to $20 \mathrm{~h}$. This means that there'll be a supply of gas between these hours but the meter spins like crazy!! Did washing. Washed sheets. Very cold. Worried that I might have stopped Nicodème. Office. Lesson with Rochette. The laundry is shut. They're no longer taking in washing. The electricity is cut off here between $13 \mathrm{~h}$ and $18 \mathrm{~h}$. Elsewhere, though, it's off between 8 and 12 and $13 \mathrm{~h}$ and $20 \mathrm{~h}$. Luckily the Val-de-Grâce protects us from these draconian measures. I

\section{Tuesday 16 May}

Sent pneus Beaugrand. Class-Veleix. Lesson with Boyelle. I

\section{Wednesday 17 May}

Lesson with Chabert. Malot. Bachellery cancelled. His house in S. and O has been invaded by refugees. I wrote to Aunt to invite her over.

\section{Thursday 18 May}

Ascension. Mass. Darned. I

\section{Friday 19 May}

Lesson with Vendryès. Lesson Capon. Boyelle. Rochette. Boué. Went to Beaugrand's but he didn't answer. Went to the American Library. "My Mortal Enemy" (W.Cather). "The Sketch Book" (Irving). I. Letter from Aunt inviting me over.

\section{Saturday 20 May}

Lesson with Chabert. Valeix. Telephoned Aunt to find out who is coming. I am going. Julien Goussin invited me to cover for him at a school.

\section{Sunday 21 May}

Mass. C. Alert, so didn't go to see Julien Goussin (alert at 11.30 and the meet up was at 11.30 but, as is always the case when I am in a hurry, Mad. F held me 
up for hours. Mother's Day. Bought Lily of the Valley for Mum and two roses for Aunt. Everybody had a good time. Nearly no cattiness. Went to the Flea Market and then "Vautrin" (with Michel Simon and Madeleine Sologne). Utter rubbish. Got a pneu from Mlle Gommès.

\section{Monday 22 May}

Office. Boyelle cancelled. Last lesson with Delplancq. Lesson with Rochette. Pneu from Mme G.

\section{Tuesday 23 May}

Telegram from Mlle Gommès. Went to her place. Not there. Went to the watercolour salon. Better quality than usual. Maggy's picture was badly positioned in the gloom. Her colours are luscious. Her shapes are not so luscious. Went to urbanism. They are rebuilding full of mistakes. Furious. Tired out. Migraine. Pneu from Beaugrand.

\section{Wednesday 24 May}

Lesson with Chabert. Malot, Lesson with Bachellery. Pneu from Beaugrand. Went to Mlle Gommès.

\section{Thursday 25 May}

Office. Got parcel from Portugal. Denise came with potatoes. Lesson with Beaugrand. 2 hours with Valeix.

\section{Saturday 27 May}

Went to St Joseph. Taught English to a class of second years. Very nervous but went OK. Alert. Came back on foot. Lesson with Chabert until 2.30 pm. Had lunch at $3 \mathrm{pm}$. Maisons Lafitte bombed. Dilys is allowed to leave.

\section{Sunday $28 \mathrm{May}^{643}$}

Mass. Went to Villeparisis. Métro to Porte de la Chapelle. Walked [.. .] to Plaine St Denis. 2 hour wait for the train. Everybody charming but I was a little catty having put on my best blue silk dress which suits me so well. Came back via the Gare du Nord. The damage is worse than any war photographs I have seen; rails winding round carriages thrown up into the air and on top of one another,

${ }^{643}$ 'Pentecost hot' written in the margins opposite the entry of 28th May. 
wrapping round mangled engines. Huge craters, everything so, so horrible. What must it be like the morning after a bombing? 6 alerts.

\section{Monday $29 \mathrm{May}^{644}$}

Went to Andrés. Young, blond haired man very taken with me. His family and mine had been to see "Vautrin" (again!!). Very bourgeois matrimonial overtures. Ye Gods! He’s blond and an artist. Dilys left.

\section{Tuesday 30 May}

Lesson with Boyelle. Studied. Hot. $40^{\circ}$ at midday. Mme Leberry and Cismaresco came.

\section{Wednesday 31 May}

Lesson with Chabert. Malot. Got results of the written exam. Got a 'bien'. Passed with a 14 .

\section{Thursday 1 June}

Office. Lesson Beaugrand. Paid. Saw Denise. Have the feeling that Denise is distancing herself from me. Swotted. I want to make a good impression on LeBreton (who I am madly in love with. I think about him all day but don't dream of him at night. I think that this is a sign). "O Pioneers" (W Cather) "A History of USA" (Hart). I know everything even all the presidents and their dates. I'm very frightened.

\section{Friday 2 June}

Oral exam for American Civilisation. "Art in 'Lost Lady' by W. Cather" and “Transport in the United States before 1850". Was so intimidated that my French was worse than terrible. The words just wouldn't come. Spoke in pidgin French. Wanted to cry out of fright and wounded pride. He made fun of me but at the same time was nice. I love him. Lesson with Vendryès who was very sweet. Lesson with Capon Boyelle, Rochette. Alert so Boué didn't come. Saw a shot down plane.

\section{Saturday 3 June}

St Joseph to teach the second year class. They are lovely. 11-11.10 alert. Lesson with Chabert. 1.30-1.45-2.15-3.30. 8-8.50 alerts. Got a 'mention assez bien'

${ }_{644}$ ' $38^{\circ}$ here $8 \mathrm{pm}$ ' written in the margins opposite the entry of 29 th May. 
and am furious about it because the person who I was joint first with on the written got a "bien". That wretched panic at the oral. I'd like me and LeBreton to be stuck behind a wall for five hours during an air raid alert and then I would speak French to him like I normally do without breaking off. Grr!!! Tired and very down. Pneu to and from Aunt who is expecting me tomorrow. I won't be going. “Tom Brown's Schooldays" (Hughes). ${ }^{645}$ "La Discorde” (A. Hermant). ${ }^{646}$ Got "Paradise for Sale and other Novels" (Philip Gibbs). ${ }^{647}$

\section{Sunday 4 June}

Mass. C. Worked at the Office. Have written up diary from the 20 April. I mustn't let the days go by like that especially given that so much is happening at the moment. But, what with the exam, the two dissertations to type up and all the rest there is hardly the time. 11.40-12.15, 1.30-1.50. Alert. Beautiful sun. Tired of writing. Don't want to work. Going to read a little. 7.15-7.35; 7.458.40. Alerts. This time it's the big [...] in the south which is getting it. Loads of smoke like cumulus clouds. Jacqueline came over for a bit. She bores me. Plane shot down over towards Villeneuve St Georges. What a day!! Alert was over by 8.40. Saw an 8 plane formation in the sky this morning. That'll probably mean 8 alerts today (we're on the 5 th). 9.02 end of the alert.

\section{Monday 5 June}

9.12. Office. 11.45-12.20 alert. “The Techniques of Marriage” (Mary Borden) "Our Village" (Miss Mitford) Read "Holy Dreadlock" (E.P Herbert). Sociological study on the inept divorce legislation in England. Lesson with Rochette. Various alerts (5 in total I think).

\section{Tuesday 6 June}

'They' have landed!!!!!!! A $1.30 \mathrm{am}$. They are at Carenton (near Cherbourg). They are at the mouth of the Rivers Orne and Vire and at the Seine, Le Havre. Parachutists landing in Caen. $10-11$ St Joseph $\left(3^{\circ}\right)$. Sweet. $11-12\left(2^{\circ}\right){ }^{648}$ Fair bit of noise. Went to see Madame Gommès at the hospital. Jacqueline is sticking to me like

${ }^{645}$ Thomas Hughes (1822-1896). Tom Brown's Schooldays was published in 1857.

${ }^{646}$ Abel Hermant (1862-1950). French novelist. See Bibliothèque nationale entry for more information about his life and works:

http://data.bnf.fr/12090487/abel_hermant/

${ }^{647}$ Philip Gibbs (1877-1962). British novelist.

648 'St Joseph' and 'sweet' are references to English lessons Madeleine is giving at a school in Paris. 
glue to listen to the radio and getting on my nerves. Went to Dilys's. Waited for a student to arrive. Read on and off. 7.10-8.20; 10-10.15; 11-11.10; 12.30-12.45; $12.50-1.10 ; 4.20-5.10 ; 6-6.25 ; 8.25-8.45$. Air raid alerts (complete silence during the alerts and as soon as the all clear signal sounds bombs start to fall).

\section{Wednesday 7 June}

2.10-2.50 am alert. 9-10 St Joseph $\left(3^{\circ}\right)$ 10-11 $\left(2^{\circ}\right)$. Hellish but almost funny too. Lesson with Chabert who is frightened about reprisals because he worked at the German Institute. 1.40-2.45 alert. Telephoned Aunt about Colette but given what is happening!!Lesson with Bachellery who was nearly bombed out (at Versailles one landed 100 metres from his house). They're saying that the Secret Police were asking for papers from all the men. At the Sorbonne they were appealing for students to help distribute food by pulling carts. There's a mass exodus towards Versailles. Paris remains calm - but lots of furniture for sale. 5.20-6.10 air raid alert. There's no bread anywhere. I am dead tired, going to go to bed early. Wrote Red Cross. 'A thousand thanks for the parcel. I got my degree. Family, friends are in good health and send you tender thoughts. Whatever happens try not to worry about me. I am in excellent health. With love'. Wrote to Aunt and Poussif. Pneu from Beaugrand cancelling tomorrow. Cold and raining.

\section{Thursday 8 June}

Bayeux has fallen. Radio P says that Bayeux is in ruins, Caen is in flames, more landings etc. The situation remains confused. Apparently lots of planes went over last night. Fighting around Falaise (and around Jacqueline Piatier). 7.50-8.25 $10-10.20 ; 12.05-12.35$. Sirens. 9-12 office. On the way back along the Albert 1 quay I could see lots of 'Tiger' tanks (the gun turrets are khaki with green and blue markings). The tanks run on gas but are impressive. Lorries and tanks covered in twigs and leaves. Heard on Radio Paris: "The Germans are carrying out a stalling offensive which the Allies haven't been able to stop". "At Falaise, the German troops are pushing the English troops towards the South" (??!!). Letter from Aunt (curt, untrue and vulgar. She disgusts me). Darned tights. Mended blanket. Did I say that they have called out the Milice ${ }^{349}$ No bread, not a single vegetable in Paris. No lettuce, nothing. My cactus are growing amazingly well. Finished 'Discorde' by Abel Hermant. ${ }^{650}$ Horrid - and boring. And to say he is an academic - yeah, it's true!

${ }^{649}$ French Paramilitary force which was set up in 1943 to combat the Resistance.

${ }^{650}$ Abel Hermant (1862-1950). Writer and playwright. For more on Hermant's life and work:

http://www.abelhermant.com/Association.html 


\section{Friday 9 June}

10-12 Vendryès. Bye bye diploma with LeBreton then! V. was charming but determined that I do the diploma with him and that I present it as a second thesis for the doctorat ès lettres (that annoys me a bit because I want the doctorat de l'université and have done with it). 12.10-40 alert. Went to Capon for lesson. Boyelle. Rochette (who brought me 6 roses for my degree results - really nice). Boué. Went to see Mad. F for her birthday. 11 pm Jacqueline Eichhorn came over and stayed until $1 \mathrm{am}$. She never knows when to leave. $12 \mathrm{pm}-1.30 \mathrm{am}$. Alert. Bombing raid over Paliseau. Jacqueline had one of her panic attacks!! But nothing was really blasting away over this side.

\section{Saturday 10 June $^{651}$}

8.45-9.25; 9.45-10.30. Alerts. Arrived at St Joseph at $11 \mathrm{am}$. Essay work so no classes. On the way back went to the market at Auteuil. There was absolutely nothing other than parsley and flowers. That's it. There's been no vegetables, nothing in Paris for a fair while. There's a ban on sending telegrams or making telephone calls (both local and long distance). There's talk of water being rationed. Darned stockings. Françoise came at 5.30 until 9 pm. She's very nice but if only she knew when to go too. Numerous alerts, 5 in all I think. There was one during the night which I didn't hear.

\section{Sunday 11 June}

6.50-8.20; alert. Went to mass at 8.30. Sign of the times that at Communion I only had half a wafer. 9.05-9.35 alert, mass continued regardless. 10.20-11 alert. Got up. Darned stockings again. Turned the blanket but still got a patch to put on. ${ }^{652} \mathrm{Had}$ a nice dream about the house I'll have after the war. $8-10.30 \mathrm{Mad}$ $\mathrm{F}$ is [...] What is the matter with all these people that they have to be like that?

\section{Monday 12 June}

Alert. Heavy bombing at Palaiseau. 1.40 end of the alert. 8.45-9.15; 9.20-9.50; 12.10-12.40 alert. Office. Walked from Palais-Royal. The Tuileries are lovely early in the morning, the sky, the trees, the smell of the grass. American Library shut between 12 and 1.30. What a pain. Sat in the Parc Montsouris with the

${ }^{651}$ Written alongside entry of 10 June: '2pm. Lesson Chesnier du Chesne think that I give better lessons than Dilys'.

${ }_{652}$ Turning the blanket ('retourner' le drap) meant cutting a worn blanket in half and sewing it back together turning it so that the outer, less worn sides were in the middle and the worn sides were on the outer edges. 
smell of freshly cut grass. Fine weather. June, but with the scent of summer. Roses everywhere. "Brave New World" (A. Huxley) ${ }^{653}$ left me feeling a bit uneasy. But, well, I feel that anyway. Ill. More alerts; several.

\section{Tuesday 13 June}

8.10-9. Alert. St Joseph. Slept $1 / 2 \mathrm{hr}$. Lesson in the 3rd. Waited for exam scripts. 12.30 alert. Went on foot to Motte Piquet Grenelle. Tired out. My foot is hurting a lot. Went to Maggy's. Lovely afternoon. Forgot the time and only gave a half hour to Boyelle. Mlle Poussif came. Letter from Dilys. She left with Mad. F. Alerts. I

\section{Wednesday 14 June}

7.30-9.15. Alert. Assessed students and put down comments (on pupils I hardly know) 12.30-1. Alert. Bought plants for my garden. Lesson with Chabert. Read Mary Williamson's thesis - very limited and without any zip and Vendryès wanted me to do one like that. I wouldn't be able to. At the moment, my brain shuns any effort. It's like it's a house brick. Lesson with Bachellery - who is very charming. It would seem that I got a parcel of sardines when no one else did and that it is shameful etc that some people (ie, me) get parcels from home when everyone is dying of hunger etc, etc. I didn't even see a parcel and I am going to make enquiries about it. I am pretty "ruffled" - I hate bother. I've had enough. I must have anaemia to feel so rotten. I thought that writing it down might help it pass but no. Oh, for God's sake. I am going to do the office work and turn my 2 nd blanket and tomorrow make enquiries. If I find it then I've thought wrong. Told Mad. F about it and feel better. ${ }^{654} \mathrm{I}$

\section{Thursday 15 June}

Office. Had lunch with Denise. Went to the customs depot at Bercy where after looking numerous times I discovered that the last packet was delivered on the 25 May. Was it stolen? Looked back at the diary proves that no it wasn't. Joy. Two hour queue for cherries half of which were rotten but when they are washed the remaining half are just about presentable. There is nothing to eat. I

${ }^{653}$ Huxley (1894-1963). Science-fiction dystopia Brave New World was published in 1932.

${ }^{654}$ 'Feel better' written in English in the manuscript. 


\section{Friday 16 June}

+ Vendryès. Lesson with Capon. Went with her to the American Library for her to register. "Dark Island" (Vita Sackville-West ). ${ }^{655}$ "Heroes and Hero-Worship" (Carlyle). Terribly thirsty because it is so hot. Lesson with Boyelle. Bought 'How to Play Tarot' and spent the whole evening doing it. Fun. Lesson with Rochette.

\section{Saturday 17 June}

Feel so very poorly. Read “The Dark Island”. ${ }^{65}$ Really fabulous. I really need to buy it. It's good. I really do like V. Sackville-West a lot. Went to Françoise's place where we moaned and groaned together. Not a great success. Got a pneu from Aunt. Letter from Aunt. Ill, ill, ill. ${ }^{67}+$ Lesson Chesnier du Chesne.

\section{Sunday 18 June}

Mass. Communion. Have I already said that we only get half a wafer? Finished turning the 2nd blanket. Started patch for the third one now. Mad. F settled in at mine for a long conversation. Ill.

\section{Monday 19 June}

Office. Lesson with Capon. Rochette. "There hasn't been an alert for a few days now. That's the lot" Madeleine F tells me and ten minutes later, alert $11 \mathrm{pm}$. Jacqueline came. What a pain. I wasn't very welcoming. Wrote to Aunt.

\section{Tuesday 20 June}

Got the tobacco which finishes off Dilys's card. Finished the patch for the blanket. Washed silk underwear and stockings. Lesson with Poussif. Boyelle. Poussif's little boy is brittle ${ }^{658}$, as fragile as glass and very edgy. He's frightened of being hurt.

\section{Wednesday 21 June}

Wrote to Dilys. Letter from Cyla. Letter from Aunt who is very anxious about me - but I just see all that as a facade. It may well be sincere but she and the

\footnotetext{
${ }^{655}$ Vita Sackville-West (1892-1962). Novelist, poet, gardener. Lover of Violet Trefusis and Virginia Woolf. Husband of diplomat Harold Nicolson. Creator of Sissinghurst's famous gardens.

${ }^{656}$ The Dark Island was first published in 1934.

${ }_{657}$ 'Ill, ill, ill' written in English here and in entry of 18 June.

658 'brittle' written in English in the manuscript.
} 
family no longer exist for me. Washed woollens. Lesson with Chabert. Bachellery. Mme Bachellery came over. He doesn't even look at her. I think that she annoys him intensely - And, her, the poor woman, I knew that she was unhappy and now she looks it [.. .] ? "L'Inde contre les Anglais" (A. Viollis). ${ }^{659}$ "Dessins à 3 Crayons"

\section{Thursday 22 June}

Office. 'Time was' (W. Graham. Robertson) ${ }^{660}$ 'Strong Prison' ${ }^{661}$ Dorothy Sayers. Took back the Carlyle without having read it. Went to Mrs Boissin; I am as sure as she is that I have appendicitis, but we didn't speak about it. Operations at the moment are totally impossible. There are no more bandages, no anaesthetic, no medicine. On the way back I saw a lovely pitcher - 225 frs. I didn't have enough on me and came out with a little rustic jug, plain and very sweet which Mad. F doesn't like. She treats this apartment as her own so much because she will have it when I leave and she gets annoyed whenever I spend money which does not improve it. She gave me some climbing roses ${ }^{662}$ probably to thank me for the gas she uses when she is here. She can't manage the electricity restrictions. She doesn't adapt very easily. Today she is all shaken up and with good reason. Air raid alert this evening and Gennevilliers is well alight, the smoke is blocking out the sun. It's all pounding away. Yesterday she went up the Boulevard Montparnasse almost right up to the Closerie de Lilas. She got frightened and took shelter under an archway and almost right next to her a flak shell fell, exploded and killed two people and injured others. Madeleine $\mathrm{F}$ was very shaken up by all the screaming and the blood. Françoise has just brought me some butter and some meat because her father was in Normandy. He's had a nightmare journey back. The Germans are going to battle in everything they can find, even French cars and so the English are machine gunning everything. The milk lorry behind [...] was machine gunned. The teeth of a person in it were found incrusted in

659 Andrée Viollis (1870-1950). French writer, journalist and feminist. See Anne Renoult's 2004 biography published by the Presses universitaires de Rennes for more on her life and career. L'inde contre les Anglais was published in 1930.

${ }^{660}$ Walford Graham Robertson (1866-1948) was a British writer, painter and illustrator. See Avis Berman's 2001 article about him at:

http://www.nytimes.com/2001/09/23/arts/art-architecture-not-justanother-pale-victorian-aesthete.html.

John Singer Sargent's 1894 portrait of Roberson hangs in the Tate in London: http://www.tate.org.uk/art/artworks/sargent-w-graham-robertson-n05066

661 Strong Poison, one of the Lord Peter Wimsey series of crime novels, was published in 1930.

662 'climbing roses' written in English in the manuscript. 
the dashboard. It was impossible to get them out. They had a white flag and a look-out on top of the lorry but it is sometimes impossible to avoid accidents.

\section{Friday 23 June}

Wrote to Aunt. Letter from Dilys. Last confession. Vendryès. Lesson Capon. Rochette. Pneu from Boyelle cancelling the lesson. Walked to St Denis to see Dr Duheim and to get the tobacco for Dilys. Went to visit Grandfather's grave. Exhausted. It is cold. $14^{\circ}$. At the Gare Montparnasse I saw a woman who had come from Normandy with her dog and two little suitcases. There was a huge crowd around her and she was answering questions. She was hard, fiery and tough, lots of bravado. One could feel her quivering and sense her tension from the struggle to get out. $10.30 \mathrm{pm}$ Jacqueline came. Was welcoming because I had been so awful the last time. But she has a skin as thick as that of a rhinoceros. She is a real [. . . $]^{663}-$ no soul. What a difference to Françoise who is so sickly fragile and who closes up like a sea anemone at the slightest thing. We have one of these dark blue night skies again. I love this colour. It's like living in an underwater city. The city of Is. When I was going by the Seine on Thursday the sun was making 'stars' in the arc of the ripples. Water always holds mystery. I'm going to have trouble with Nicole Capon. She doesn't work - hates making any effort. Mad. F. when she noticed this diary (she had never read it) said that she was disappointed that I only seemed to write about domestic trivia. I told her that I didn't dare write about how I feel. At the start - in 1940-41 - that was true. Now, it isn't but I don't find myself interesting. Why write what I am feeling when it bores me - it's like saying it all twice. I want to write things down about others - and about things. My character is changing. I am stronger and stand by my decisions - people rely more on me. I say 'oh you need to do this or that', they sigh with relief and go off and obey. It is so much easier to let other people make decisions - and what delight in disobeying!!! Shrapnel bombs don't leave many traces just one smashed cobble on the road, slight cracks in the kerb, a few broken panes of glass. Another one fell on Buffon. I saw the smoke from my window. Mad. F ranted about working Saturday morning. Vitriolic she was about it. I don't have any sympathy for her. If she doesn't like it she only has to go find something else. And she always treats you like an idiot if you don't agree with everything she says. Afterwards, she was sorry and came to heat some water off the gas and smoke a cigarette. I never sulk with her. I'd rather she explodes from time to time rather than being a lifeless blob. She's much more bearable afterwards. Several alerts today.

${ }^{663}$ Looks like 'ordure' in the text which would mean 'bitch', 'wretch', but the script is unclear and it is out of character for Madeleine to use abusive terms. 


\section{Saturday 24 June}

Got up at $9.30 \mathrm{am}$. Cold $\left(11^{\circ}\right)$. Ill. The market yesterday tired me out. Lesson with Chesnier du Chesne ${ }^{664}$ who like me adores Colette. Worked at the office. From the 1st July I'll seriously start working hard, until then I'll let the time drift by. I am going to play at cards a bit. Really fed up. Mad. F can't stand my little pitcher. As soon as I buy something like flowers she is always saying "You don't half buy a lot of useless stuff. You'd be better off going to get your hair styled or buying a piece of furniture..... or getting the locksmith to come out.... 8 or 9 alerts.

\section{Sunday 25 June}

Woke up at 3 am with an aching wisdom tooth. It was a grey dawn. 7.30-8.25 air raid alert. Mass at 8 am and communion at the Val de G. 11-11.30 air raid alert. Jacqueline Eichorn came to take me to Sceaux but I didn't want to go out. Washed hair and darned underwear, 5 pairs of tights and washed coloureds. Very pleased with myself. 7.20-9 pm. Air raid alert. A really big alert. Saw 3 planes come down in flames near Orly and now (8.30) smoke is sweeping over us from the South-West. It has got to be Gennevilliers where 20.000 litres of petrol and stocks of rubber have been set alight. Still got pain in my wisdom tooth in my lower right jaw but better than yesterday.

\section{Monday 26 June}

Office. Denise came over because she got her exam with a 'mention bien'. She is going on real odysseys to get food. 6 am she was at St Germain where they refused to sell anything to Parisians. She got back on the train and went to Chatou. She walked across fields and queued for 2 hours for $10 \mathrm{~kg}$ of carrots (100 frs). Went to Montesson on foot, nothing, and got back to Paris at $2 \mathrm{pm}$. I think that's all a bit mad. Once the tops are taken off there's only $5 \mathrm{~kg}$ left for $100 \mathrm{frs}$. And she got back ravenous. I'm not being critical but she would pay less buying on the black market and she wouldn't waste time like that. Lesson with Capon, Rochette. André and Aunt Marie came to see me. They admired the apartment. They took me for dinner to the "Nègre de Toulouse" soup, braised beef with lettuce and cucumber, a peach (30 frs), biscuit, wine, coffee - 300 frs!!! Was wide awake until 1 am and because I have decided not to do any work until July 1st I was a bit bored. I'm fed up with falling asleep at 1 am only to wake up at 6 am - and if I fall asleep again I have unsettling dreams.

${ }^{664}$ More likely to be Chesnier Duchesne. 


\section{Tuesday 27 June}

Went to the Gare de Lyon to get information about Poitiers. Impossible. Went to the manicurist. Worked at the office. Lesson Poussif and Boyelle. Wrote to Bachellery. Mad. F very depressed. She's always having depressions and she does not try to control them. I sometimes feel like getting cross with her but I perk her up. She was singing by the time I left. I've given in. I have started to work. Copied out notes until $1.30 \mathrm{am}$. I feel better for it. Several alerts but no danger. The news-reels are worth watching apparently with the English flotilla arriving on the 6th June. Cherbourg has fallen.

\section{Wednesday 28 June}

Alert 7.30-9 am. Wrote to Cyla and to Aunt Violette. Dilys. My tooth is still hurting. I think that I could write something about Aunt Violette which I would called 'Mrs Stain" or "Mrs Task", depending on whether I put a circumflex accent. ${ }^{665}$ Lesson Chabert. Went to do some studying at the Hautes Etudes. Saw Maggy, In the evening I went for dinner at Jacqueline's. We went to Dilys's apartment to tinkle on the piano and to sing. She plays the piano very badly. She annoys me.

\section{June Thursday}

Office. Got paid. Saw Denise. Went to the cinema with Jacqueline Eichorn. "Croisières (ou Trafic?) au Large".666 German film. Smugglers v Customs Officers. Custom Officer killed, his brother swears that he will avenge him, leaves the police under a cloud, joins the rebels but uncovers their game, dramatic chase, vindicated and restored in the end (health and job) and finishes up in the arms of a blonde fiancée. Very KKK. Banal but alright enough. Want to watch a film on the landings saw the Japanese - and also very pretty (but alas very old of the type "rain" and "darkness") documentary about Japan. I think that I horrify Jacq. with what I say. She thinks I'm St Anne material. ${ }^{667}$ If only she knew that it is only for selfprotection saying such things and especially things that are empty of meaning.

\section{Friday 30 June}

Lesson Capon. Boyelle. Rochette. I don't remember anything about this day.

${ }^{665}$ tâche means task or chore whereas tache, without the circumflex accent, means stain or mark.

${ }^{666}$ Trafic au large was a 1939 German film directed by Ernst H. Albrecht (1906-1982).

${ }^{667}$ Reference to Sainte-Anne psychiatric hospital in the 14th arrondissement of Paris. 


\section{Saturday 1 July}

Bought the syllabus for the Licence ${ }^{668}$. I know 3. Poésie française (René Lalou). Littérature anglaise (same) and Vie au moyen âge ( )]. Read 'Life'. Good. Lesson with Chesnier du Chesne. Françoise came over. I'm going to take a course at the Red Cross.

\section{Sunday 2 July}

Went to St Denis with Dédé and Marie. They bought me a horrible bra. Had a good lunch, Went to Villeneuve-La-Garennne to see the English fellow. He was in a camp for 13 months. He is very nice but not in the slightest bit "intellectual" like they had said he was. He adores novelettes. His wife made a disgusting cake (didn't thin out her saccharine) and it practically took the surface of our tongues off. She did the cards. ${ }^{669}$ "A great success. Big journey soon. Illness. News of a pregnancy. News about someone by letter. Everything will come right. There will be a few problems. A few job changes. Beware a brunette friend and a widow. A young man with fair hair is thinking about me. I'll get married a little earlier than I think, in 7 weeks or else 7 months. I have someone watching over me who only wants good things for me." She read the lines in my hand. "2 loves and probably more likely 2 marriages than just the one. Very ill but I hang on in there. I think too much. I would be much happier if I did less thinking. Long life. From 70 years of age there will be a few little ailments. Will never be rich but will be well off and will never want for anything. 2 children, son and daughter and one which will miscarry. Look after eyesight!" Well indeed! Let's hope that my lovers coincide with my marriages.

\section{Monday 3 July}

Powerful storm which lasted until $4 \mathrm{am}$. Hail. Never seen a storm so near and so long lasting (but in the Vosges it was even more terrifying). Read 'The Wind in the Willows (Kenneth Graham) ) $^{670}$ and "100 familles gouvernent l'Empire". The English fellow lent me "PSmith Journalist" and "Leave it to PSmith" (Wodehouse). ${ }^{671} \mathrm{I}$ don't find them funny ha ha except perhaps 3 episodes in

\footnotetext{
${ }^{668}$ Undergraduate degree.

669 Tarot cards.

${ }^{670}$ Kenneth Grahame (1859-1932 ). Rosemary Hill describes the social context for Grahame's 1908 children's novel Wind in the Willows in her 2009 Guardian article:

https://www.theguardian.com/books/2009/jun/13/wind-in-the-willows-review

${ }^{671}$ Pelham Grenville Wodehouse (1881-1975). British comic author. For more on Wodehouse, bibliography and reference materials, see:

http://www.pgwodehousesociety.org.uk/

and

http://www.wodehouse.org/
} 
"Leave it to PSmith". Office. Lesson Capon. Waited in vain for Rochette. Jacqueline rang the bell at $11 \mathrm{pm}$ but I didn't answer.

\section{Tuesday 4 July}

2 am alert. Went to the Red Cross to sign up for courses. I've already missed 3. Put down that I was French. Pneu from Rochette. Telephoned Boyelle about the prisoner who is not coming. Went to the First Aid course. Very funny.

\section{Wednesday 5 July}

Went to the Parc des Sceaux with Jacqueline and one of her friends. I could have ripped off both their heads they were so showy, pretentious and 'noticebox' ${ }^{672}$ Really enjoyed rowing although only did it until 11 am thanks to two alerts. Came back to Paris. Lesson with Chabert and hadn't had lunch. Witnessed a scurrilous deed Simone Laberrie $\rightarrow$ Schneider. Headache. Had lunch (S.L gave me an egg) Went to the First Aid course. The young intern is a sweetie. Saw Madeleine Lavelle and her sister.

\section{Thursday 6 July}

Office. (Alert 7.30-9.10. 11.10-11.30). Other than Kort, was the only one in the Department. He was furious. Saw Denise and went out looking for bread for an hour but unsuccessfully. There's a bread panic again and the bakers are under siege. They are saying that they might make people go on a list for it. Since the métro cuts (Tuesday) I've gone on it 10 times. Auteuil - Austerlitz is off. Railway station stops are off and Nation, Place de l'Italie are off. You can't imagine the number of people. Took a book back to the American Library. Went on foot to rue Bonaparte to get a book on first aid. Pajès ${ }^{673}$ is a religious bookshop!!! Telephoned Boyelle. Went over to Françoise's to practice bandaging etc, etc for 5 hours. "Les Cosaques" (Tolstoi). Got some butter ( $1 / 2$ a pound for 200 francs), some rolls and some lettuce, peaches - but at astronomical cost!! Tired. Read "Cold Comfort Farm," (Stella Gibbon). ${ }^{674}$ It is hilarious - and there's Jacqueline saying that she "didn't think that it was a satire" (Ye gods!! ${ }^{675}$ Where is this child's sense of humour?).

672 'notice-box' is written in English in the manuscript.

${ }^{673}$ Pajès or Pagès. Unclear.

${ }^{674}$ Stella Gibbons (1902-1989). Cold Comfort Farm was published in 1932. For more on the novel and Stella Gibbons, see Robert McCrum's review in The Guardian's best novel series:

https://www.theguardian.com/books/2014/oct/20/100-best-novels-coldcomfort-farm-stella-gibbons

675 'Ye Gods' written in English in the manuscript. 


\section{Friday 7 July}

Rain battering down all morning. Lesson Capon. Telephoned Rochette. Lesson Rochette. First Aid. Bought "La Gerbe" for Philippe Henriot's poem. ${ }^{676}$ Read "La Porte Etroite" which is very good. Went to the Gare du Nord to find out the times of the trains. In the week there is nothing between 9.15 and $5 \mathrm{pm}$.

\section{Saturday 8 July}

Telephoned Aunt. Alert 2 am (very loud but hardly heard anything) and again 6-9.30. Bought the sugar for July/August. Next week they will be giving us the ration for September/October. There aren't any cubes. Wrote Bachellery (I went to see Madame Jacob on Tuesday). Lesson with Chesnier. First Aid particularly the practical side. They did a "Bombing". Hilarious. The victims looked healthy enough sat on chairs, tables and stools. The boys took off a door to make a stretcher. I love these First Aid courses. Jacqueline came over and stayed 2 hours. Made good progress on the glove. Read "Impossible People" (Mrs George Wemyss). ${ }^{677}$ It is a terribly sad book despite seeming jolly on the surface. And, read "The Lady of Ascot" (Edgar Wallace) ${ }^{678}$ Read in the evening. The [...] took 1 hour to read. I looked at the time 12.50. I didn't think I would be able to finish it by $2 \mathrm{am}$. When I finished it I put out the light and opened the window. It was daybreak in the East. Nights [...]. A pale green like a dull emerald and the rising sun behind the Val, a dark blue, the full moon on the wane and a star towards the south. I wanted to run in the wet grass. Everywhere 5 am was ringing out and my clock was silent....

\section{Sunday 9 July}

.... struggled to get back to sleep. Mass. Communion. Queued afterwards. Just after Communion was thinking that an alert was due and lo and behold but there was an alert. Started "Une ténébreuse affaire" by Balzac. ${ }^{679}$ Slept. Got a pneu from Aunt which had been sent again (when will our concierges turn up?) I got a letter yesterday evening. There are no deliveries on a Sunday.

${ }^{676}$ Philippe Henriot (1889-1944). Vichy politician and poet, anti-Semite and fascist sympathiser, assassinated by the Resistance in June 1944. La Gerbe was a weekly newspaper of the extreme-right.

677 Published 1918.

${ }^{678}$ Edgar Wallace was a British writer of thrillers and crime novels. The Lady of Ascot was published in 1933.

${ }^{679}$ Honoré Balzac (1799-1850). Une ténébreuse affaire, published in 1841, was one of the volumes of La Comédie humaine. 
Notes: Write this diary every day (I did it fine before. Why this sudden laziness). Avoid seeing Mad. F. She is starting to take me for granted. When I brought back some peas she said bitterly that I could have brought some back for her to spare her the queue. She would have done it for me. (I know from experience that this is not true. Also, when I buy for her without asking she doesn't want what I buy). When I say something she always makes caustic remarks wrongly contradicting me. When I come back at her sharply, she softens a little. I'd prefer it if we didn't bite off our noses to spite our faces even if we are friends. Avoid Jacqueline. She is conceited. I disconcert her I think. Let's hope so. I've been wanting to work from 3 July. I have done nothing. I should get down to it. The little Lakener woman got married at Malzéville. She used to live on the rue de l'Orme!!!

Enormous queues for bread. No vegetables except on the Black Market. $50 \mathrm{gr}$ of butter this month. No trains - not on a Sunday. In the week not between 9 am and 5 pm. Rumours: Only 4 métro lines running and those are off at the end of the month (trains only run every 15 minutes already). No gas or electricity next week. The Gestapo has moved to Nancy. Slept because I didn't sleep last night. Washed dress, blouse, apron and girdle. Ground 3 coffee grinders worth of wheat. That is a job and a half and I finished up out of breath. Finished the index finger on the glove. This evening, the sky was black. A wave of rainclouds coming over and brief snaps of yellow sun. I love the evening. The yellow sun comes from the back, illuminating everything. The trees are green-yellow. The dome of the Val goes a faded red or flesh colour. One can see for a long, long way and even the air seems golden, Mad F came back early because [...], Andrée's cousin has an abscess in her breast. Mad F is going into a depression. She feels really alone but it is nothing like the solitude that I've experienced. I know well enough that one is alone from birth for the whole of one's life and that other than one's mother no one gives a damn other than the pets one has. I am not alone. I have the feeling that I have something in me. What though? A plan, a house, a garden, a book, the children I will have? I don't know. But I hold them gently and secretly close to my heart. And I don't know what they are quite. Let's hope that the fruit and the flower are as beautiful and as satisfying as this unknown soft bud.

\section{Monday 10 July}

6-7.30 alert. Couldn't they do it 2 hours later maybe!! Did some ironing. Office. Kort is annoying me. He creates work. And there is nothing I hate more than work which is pointless. Mlle Kerjean has invited herself for afternoon tea on Thursday. That means a thorough clean-up. About time too. Wrote to Mlle Nicolas and Aunt. I need to see Ruth this evening. I'm feeling very "book-keeperish". I have calculated that with the pound at 200 frs I am making about $£ 4$ per week. Not bad. And I have $£ 25$ put to one side. I feel as proud as Artaban. I have determined that I shall go back with $£ 100$ in savings - that's if the $£ 25$ 
I have to pay back is taken out. I shall have, when all's said and done, $£ 15$ in the bank. If they give me the grant for the two years that will make $£ 150+£ 15=$ $£ 165$. And if I bring in $£ 100$ that will make $£ 265$. So, I could, if I have to, live for 2 years without working, which is not what I want, because I have to go back after the war, perhaps buy a little house. I can see it clearly, near Knapton, a little garden out the front (flowers, trees). A lawn round the back, a vegetable garden, an orchard. I will have to get married. That could be trickier. My husband might not want to live right in the countryside. So many plans I have - and these when I might not even get out of the storm alive. ( $£ 100=20,000$ frs even if I put 1000 to one side I won't have it until next August. Who knows, maybe I will manage to get it before?). Work and save. . . . lesson with Capon (2 pm) who had just started his lunch!!My first First Aid case. A woman slipped when going up to Pigalle and cut her leg open. I leapt in to help and insisted that I bandage her up but faced with her tears and refusal I forced myself not to knock her out so that I could dress her knee. I took her to a chemists. Went to swap food card at the school on Monge. The children are terribly pale with rings around their eyes. On the way back I saw a German truck. The Germans were selling butter. Lesson with Rochette. Mad. F came over and we chatted the three of us together. $\mathrm{Mad}$. F is cold and hungry. I gave her some peas. Went to Ruth's. Her portrait is very good and very well painted. She hasn't changed much and she feels very lonely I think. She got me to read two stories that she had written. Very immature but her style is simple. She writes by way of images. I stayed until 12.30. She made me a hot chocolate.

\section{Tuesday 11 July}

A grey day. Drizzle. Waited for Françoise at the Gare du Luxembourg to go boating at Sceaux. Either she thought the weather was too bad or else she had gone to wait for me at Denfert. So, went to collect Mlle Kerjean's hat from a dreadful building. There really are people who live in such hovels, filthy, damp, airless. I didn't find it at first and went up to the garrets on the 2 nd floor. I would have liked to have seen one although if the toilets, the corridors and the beams I saw are anything to go by! (the beams were fascinating, like the inside of a flour mill). Saw the hat workshop which is no longer open because there is not enough gas for the shaping machines. Got bread without having to queue. Cleaned the toilets. Threw away old shoes (the leather came away when I pulled my finger across it). Tomorrow I will do the cooking and the washing. Last lesson with Poussif who is going to Chantilly. Lesson with Boyelle. Got the pound of potatoes for June and Mme Braun gave me a full account of what Mad. F had said about the potatoes. (She had seen the sacks arrive on Friday evening and on Saturday she had kicked up a stink accusing Mme B. of keeping the potatoes for the black market. I believe what Mme B says, that they were peas. She already kept back some of what was handed out for the black market but there were too many sacks and the potatoes arrived today). This evening Mad. F. said that 
no one has said anything to her. I'd be surprised by that. She looked oddly pale when she came out of there tonight. She doesn't know that I saw her. What a gossip monger I am but I really find that she lacks self-control. She yells and rages without even caring whether she is right or not. She likes to say exactly what she is thinking which is good, obviously, but it is better to have ones facts straight and rage then. Mlle Nicolas came to get the notes. It was her I had seen before on the rue de l'Ecole de Médecine with a white fleck in one eye and the iris floating around in the other. She has a very beautiful longhand, delicate and small which is something for someone who can't see much. She seems very nice. Copied out the Red Cross course. It is very chilly but I feel full of energy. (I think a healthy mind dictates everything. Healthy mind, lots of energy). I think that my geranium cuttings are going to take. A little sun wouldn't do them any harm. The cactus bit which had fallen has perked up and grown. It looks like a snail because it fell on its side. (My drawing looks a bit like a chicken floating on water).

\section{Wednesday 12 July}

Wanted to get up early but exhausted. Got up at $8 \mathrm{am}$. Cleaned the kitchen from top to bottom and did the washing. Tired out. Lesson with Chabert. He offered me lamp ethanol for $100 \mathrm{fr}$ a litre. Impossible. Got a box of matches even though it is not distribution Wednesday today. It is going to be fine. The linen I washed at $5 \mathrm{pm}$ was dry by $7 \mathrm{pm}$. Ruth invited herself to dinner - when I had finished - ate with Mad. Read Tarot. She is very lonely and Mad. F was very sympathetic. Alerts. 8-8.37; 2-2.20; 6.50-7; 7.50-8.10. I am exhausted. 11 pm. Ironed.

\section{Thursday 14 July}

It's the day of national celebration. Lesson with Boyelle who had decorated everything with flags and rosettes. Half an hour before I arrived a huge procession went up to Place Maubert with flags and placards. 'Vive la Libération' and distributed badges and flags. The Milice was at Louis-le-Grand. They were seen at $2.30 \mathrm{am}$. A group of people went by as drunk as skunks yelling out the Marseillaise. They couldn't have been more out of tune. Two coaches pulled up. 'Get in the back men' 'to La Santé. Who are they going to arrest? No, it's the Milice going as reinforcements to quell a riot by civilian prisoners who have been bribed by Francistes to get Bucard out who is in there for theft. They've set light to the place and rioted. There are 50 dead.

\section{Saturday 15 July}

Letter from Aunt which starts off nicely and then finishes "You seem as if you are relying on us coming; I am sorry if my refusing will upset you but it is not do-able!" etc etc. In other words, you put us out but we will come anyway, as 
you insist, what a chore. I got hold of some paper (with the help of Mad. F) and I sent a pneu to tell her not to come and that I would phone in a few days "for a catch up". Covered my books - not a small job. There are sixty of them. Lesson with Chesnier du Chesne. Someone knocked but I didn't open the door. Got a parcel from Yvonne Disnar. "Evening at the Grove."

\section{Sunday 16 July}

Mass. C. Opened the door to no one (no one came). Made two pairs of shorts out of a nice quality sheet that I had. They are sweet though a bit of a boarding house look to them.

\section{Monday 17 July}

9-12. Office. Lesson with Capon. Didn't find any bread but got a few [. . . ]. Got a pound of vegetables for the week - peas. Rochette didn't come. Visit from Delplancq. Jacqueline Eichhorn. Visited Françoise. Not there. Barricades. Françoise came over.

\section{Tuesday 18 July}

Bought some blue rayon to do my dress. Lesson with Boyelle.

\section{Wednesday 19 July}

Pneu from Rochette 30 hours late. Telephoned Blanc. Went to Blanc's to arrange a lesson. Went to Villeparisis to wish happy birthday to Granny who gave me a potatoes and rhubarb compote. Arrived at $3 \mathrm{pm}$ at the Gare du Nord. 4.25 for the train. 5.30 arrived Villys. 7 arrived station. 8.15 train. 10 pm arrived Paris because there were two air raid warnings. Waited for the métro until 10.40. Took Pantin Place d'Italie. No connection. Walked back from Austerlitz at 11.30. Had dinner at 12.30!!! Lesson with Delplancq, Chabert.

\section{Thursday 20 July}

St Marguerite. 9-12 Office. Went to Françoise's to revise the Red Cross stuff. Got carrots and salad from the kiosk. Barricades still up at La Santé. Lesson Capon. Blanc. [Attack on Hitler - or yesterday?]

\section{Friday 21 July}

Got up late - and Maggy came over early. Bought flowers for her birthday as well as for Mad. F and Rochette. Written exam for the Red Cross. Telephoned Rochette. 


\section{Saturday 22 July}

St Madeleine. Letter from Granny. Lesson Ch. de Ch. Bought sugar. Françoise came. Revised bandages. 17 h. Written exam Red Cross. Practical 33/40. Oral 18/20 (you've got to get $50 \%$ to get through, I'll get a merit). Went to dinner at Marie and Andrés who gave me a something to wear for the party. (Dédé came yesterday with the meat). Telegram from mummy. "Parents well. Ask for news". 680 7.6 .44

\section{Sunday 23 July}

No mass. Message to Marie about lunch. Don't come because of the milice yesterday evening. Marie and André had a fall out. Aunt Violette had also told her that I had also said that I had left her house for a lover!! (and before her marriage told her that she didn't know what she was doing marrying André, that she had been very unhappy with Henri). [. . . ]. Went to bed.

\section{Monday 24 July}

There are only a few métro lines working. Vincennes - Neuilly, Porte d'Orléans Clignancourt, St Lazare - La Fourche; Maire D'Ivry - Montparnasse; Lilas Levallois, Pantin - Place d'Italie; Pont de Sèvres - Havre Caumartin; Balard - Opéra; Charenton - Reuilly; Sceaux; these are big cuts!!! Left $1 / 2$ an hour earlier. 8 h 20 was on the platform at Clignancourt - Châtelet. 9 am on the platform Marboeuf ${ }^{681}$ to Châtelet. I've never been crushed like that ever and that is saying something. My coat was soaked through. I'll have to send it to the dry cleaner. Didn't have a lesson with Capon. Got flowers from Denise, Mad. F and Maggy for birthday. Mlle Kerjean gave me a box of sweets and Ruth gave me "LAnnonce faite à Marie" by Paul Claudel. ${ }^{682}$ Paid Maggy a visit. She is great. Lesson with Blanc. Rochette. Letter Mlle Faure.

\section{Tuesday 25 July}

Did the housework. Wrote to Ruth and Mme Faure, Yvonne, Granny. Wrote diary. I really must write it every day. The days are too long. I only put in the 'husk' ${ }^{683}$ of days. Yesterday I went to the Public Library. "Ce Quatre Voix"

\footnotetext{
${ }^{680}$ Telegram written in English.

${ }^{681}$ Marbeuf.

${ }^{682}$ Paul Claudel (1868-1955). During the Occupation, Louis Jouvet took the play on tour to Brazil where it was performed in June 1942.

683 'husk' written in English in the manuscript.
} 
(Tagore). ${ }^{684}$ Lesson Chabert. Telephoned René. Went to get the outfit. Lesson Delplancq. Boyelle. Rested [. . .] because I had come back from the office on foot at midday and from Blanc in the evening. Electricity was off between $5 \mathrm{am}$ and $11 \mathrm{pm}$ - except us.

\section{Wednesday 26 July $^{685}$}

Suzanne was lovely. Had dinner at René and Suzanne’s.

\section{Thursday 27 July}

9.12 at the office. Left on foot with Mad. F. Beautiful fresh morning. She annoys me when she speaks so loudly. Showers. Didn't have an umbrella, and had my new jacket on. Lesson with Capon - at least I waited for him for $1 / 2$ an hour and then left. Got paid. Had a permanent wave. Lesson with Blanc.

\section{Friday 28 July}

Went to have my hair done. Bought perfume and a comb [. . . . Sleepiness hit me like a blow from a club. Slept in the afternoon. Bought a book for Madeleine Rochette - and "Patrick" for me. What a disgrace Spent 400 frs today 350 yesterday. I don't dare do my accounts this evening. Read "Claude" until 1 am. I like these tales of the countryside even if they are a bit sentimental. But they have everything I want. Marie phoned the concierge with the message that Dédé is in hospital - nothing serious. I have to telephone. I have the feeling that this peace I have been enjoying is coming to an end. Lately, I've been full of the joys, of burgeoning energy, of memories making me so happy. I have the feeling that there will now be a price to pay and I fear unhappiness. But, I had two beautiful days. Did nothing, but pleased with myself. Am going to put perfume on before I go to bed - It is 2 o'clock in the morning and in 4 and a half hours I'll be going into battle. The month of August is going to be a month of miserliness.

\section{Saturday 29 July}

Telephoned Marie. André is going to have to have an operation this morning. "Stomach pains" Appendicitis? Duodenitis? I'll know by this afternoon. Went to fetch my skirt - 50 frs for the dry cleaning!!! Full of aches and pains.

${ }^{684}$ Rabindranath Tagore (1861-1941). The novel won the Nobel prize for Literature in 1913. See Ezra Pound's 1913 review of Tagore's poetry in The Fortnightly Review:

http://fortnightlyreview.co.uk/2013/04/rabindranath-tagore/

${ }^{685}$ Madeleine arrows this entry to the previous day. 
Have I already said that the Métro lines are back on from yesterday? Maire d'Issy. Porte Chapelle. Porte d'Ivry - St Genn-Villette. Nation-Etoile. Pont de Sèvres-St Cloud. Went to the clinic on the rue de [. . .] to see Dédé who was operated on this morning for appendicitis. They took out some adhesions and shortened his intestine which was badly infected and then sewed it up. He has got TB in the gut and stomach. Awful to see him in such pain when the student was tapping his stomach, it wrenches my insides out and makes me feel like fainting. It is the first time that I have seen someone I love suffering (I was too young to see my father's lumbago and my mother's migraines). Goodness, I will suffer when my children are ill. The poor mother of the little boy next to André who was groaning "Mummy, I am thirsty", "I know you're thirsty my darling" "Mummy give me something to drink" "I'm not allowed to my precious" "That doesn't matter" "Mummy I am thirsty" etc etc. I have loved André since the age of 12 . Went to Confession. There was only Abbé des Graviers there who I don't like because of his "Do you think troubling thoughts about chastity?" Obviously I do. Still a virgin at 26 it would be surprising if I didn't have inappropriate dreams. I was fine before my gland started to work OK. I said that I said nasty things about Aunt $\mathrm{V}$ because I had argued with her. He wanted to know more about it which annoyed me. I flew off the handle. In the end, after having showered me with compliments and nice words, he absolved me, whining "Make an effort to control your pride and above all be a little clearer when you confess". Then he set about reading his Bible where I would find guidance about how to atone for having become the "beautiful sinner" that I am (all made-up and perfumed, the blue scarf that suits me so well draped across me like that of the Madonna - I had dressed up because I was going to see André). This evening there was a beautiful sky, grey-blue, a big frothy cloud lit up by the sun and the green, green trees above the roof near the Val glistening in the rain shower.

A few nights ago I had a dream. I was in a port swimming in a stormy sea, I arrived in "Normandie", shaped like a boat, bigger under the sea like an iceberg. Because of this I could walk on it (in the sea) leaning up against the side of it. A porthole was open and I went inside. They wanted to catch me, I ran through corridors and up stairs chased by negroes and officers. Then I went down some fire escapes, down, down and ended up with sailors. One of them said I was his sweetheart to hide me. After this the "Normandie" left for the high seas through a canal. I watched grey stone houses covered with roses pass by and I leaned out of the porthole and could see the back end of the "Normandie" which was winding round a bend just like the back of a train. Yesterday I had a dream but I can't remember the end of it. There were some fish in water tanks in the purest water and I was catching them and putting them in other tanks. I also went to see George Washington's widow who had barricaded herself in against the maquis. I dream every night but some dreams stay with me for a long time. It has been a week since I had the "Normandie" dream. Went to bed early at 9.30 . 


\section{Sunday 30 July}

Mass. C. Fed up. Tired. Weather unsettled. Did I say that I had been spoilt for my birthday. News from my parents. Roses from Mad. F, Denise, Maggy. Box of sweets from Mlle Kerjean, a little decorative glass beehive from Marguerite Delplancq, an outfit from André? My leg hurts. Will I be sleeping or working this afternoon? I am dead tired (and very worried about André). Opened a box of sardines. Went to bed at 12.30 and slept like a $\log$ until $5 \mathrm{am}$. I really needed it I think. I have a pain in my side. I hope that I don't have another attack of appendicitis (6th or 7th). I'll wait until the end of the war for the operation. Alert.

\section{Monday 31 July}

Did myself up nicely and everyone complimented me. 9.12 Office. 12.30 Capon. Went to see André. He has lost so much weight (but not as much as he had when he came back from Germany). Stayed 1/4 hour with one hour to get there and one hour back ( $1 / 2$ hour on foot each time). I've got staying-power. 4 to $6 \mathrm{pm}$ lesson with Blanc. Very nice. Gave me 40 frs extra. Lesson with Rochette. The little Nicholas girl dropped by to return the American Civilisation book. She is very sweet the poor thing with her bowing and curtseying. But how awful not to be able to look beyond that. She brought me 3 beautiful peaches. I am bursting with energy. Has the moon gone full? Worked at the office. Evening, went to bed at 11.30 but waited until midnight for the news. I should avoid this waiting in the dark because my head fills with everything; my argument with Aunt. The longer it goes on the more difficult it is going to be to repair it. Am I right to get frustrated? She treats me like a doormat too much. I've had enough of her hints and her digs. An open argument is what is needed or nothing at all. Anyway, I have been polite and well-behaved that's all I care about when there has been a big row. Thought about André a lot - his weeping foot has taken a whole month to heal over ... analogy ... I get a knot in my stomach when I think about it. I shouldn't think about it. Letter from Mlle Troublon about the lesson.

\section{Tuesday 1 August}

Did the lesson. 10. Lesson with Delplancq. I will have to leave early at around 12.30 to see André, stay $1 / 2$ an hour and then go again. A trip of $1 \frac{1}{2}$ hours for lesson. I really do have staying power. It is cold $\left(15^{\circ}\right)$ and grey. It is real September weather. Put some perfume on. Bingo. Saw André who was no longer in pain (thanks to two injections) and who was jolly. I am worried. He is all swollen and his wound is weeping a lot and he is speaking very badly as if he doesn't have teeth. I am exhausted. 40 minutes to get to Porte de Clignancourt and the same back. I really am walking a lot. And at 3.10 there was an alert. Good that the 
métro carries on regardless now unless there's firing. ${ }^{686}$ Lesson. Boyelle. Bought potatoes on the black market. 40 frs a kilo. Got myself some carrots on the street from a peddler. Went to try outfit on. Mlle des Allées is a bit of a slouch and she doesn't half talk. Mad. F. introduced me to Elie Rabourdin. Washed socks etc and ironed. Tired out, especially because the weather is very close.

\section{Wednesday 2 August}

Lesson with Chabert. Bought a building blocks game for little Rémi. Put it in my room or Andrés? André is better. They put him a drain in. He is still a bit swollen. They X-rayed him. There's nothing on the lung. Round about 5 oclock I was planning on leaving. The anti-aircraft guns were firing. Aunt told me to stay. Then, there was a terrible crash, like thunder and crashing planes at the same time. Impossible to describe. Everything black. A huge flame. The window jumped out of its frame and went back in again letting the smoke and dust in etc, terrible noise, glass falling, everything shaking. Then our thoughts turned to André who was next to the window but all he was bothered about was protecting Renés head and telling him not to be frightened. We pulled the beds to the end of the room and pulled down the blind. We heard other bombs but they were in the distance. The electricity went off and we could hear screaming. After a bit we pulled up the blind and all around seemed to be in flames. Aunt said that it was the surgery. Several houses had been hit, some were burning, a school had been flattened. They took away the injured from the street and those injured in the courtyard of the surgery which was in flames. André was remarkably calm. I treated a woman who was in a state of shock (her lips were burnt) Then they sent me to the convent. It was difficult to walk in the road, glass, telephone lines down, shutters, bricks etc. Lots of dust and rubble. Lots of houses on fire. The emergency services were trying to rescue as many people as possible. There was no water. The policeman didn't let me through because I didn't have an armband. Helped to evacuate a burning house but a tile fell on my head and I didn't have a helmet on. I had to get out. Very hot. Dazed people stared. A little girl was stumbling around holding her doll 'I want to go Mummy, I want to go. I am frightened, I want to go' No one knew who she was or where her mummy was. There was a tall man. Blood running down from his nose and ears his right arm limp, didn't want to be helped. He wanted to see his wife. His friend was killed right next to him. Went back to the stretcher bearers. Piles of rubble in the road. Difficult to walk in wooden shoes. My heel got caught in a shutter. We requisitioned a coal truck, whistles were blowing, detour because the road was flooded. No water. Carrefour Pleyal. No more injured. A lot of ambulances. We have something to drink, requisition an empty coal lorry and off we go again.

${ }^{686}$ Presumably the firing is the firing of flak during air-raids. 
The young male stretcher bearer gave me his arm band. We went to the convent. The policeman wanted to stop me. He recognized me but I had an arm band. They didn't want to let us in but we break down the door. Luckily our team leader is brilliant. It is 6 o'clock. 40 little girls and 5 nuns have been killed in the trench shelter. The firemen were super but they had to come up every 5 minutes. They brought out the corpses or limbs in sheets putting them down on stretchers to be identified. There were 2 bundles of flesh pieces or two bodies per stretcher. They take away a man from the DP who has just identified his little girl. It took time to clear a way through, to get back up putting in beams for support at the same time. Finally, at 7.30 I was in front of the hole with my stretcher. There had been three women on the site not including the nuns. Now there was only me. The men sent us away. They took my arm band off me but I kept hold of my stretcher. I wanted to do something. In the end, I had two little girls on the stretcher. Took them to the ambulance. Came home. Very tired. Madeleine F was lovely, she made dinner etc. I don't think I shall ever cry again.

\section{Thursday 3 August}

9-12 Office. Lesson with Capon. Blanc. Dinner at Delplancq's and wore my skirt. Deaf in right ear.

\section{Friday 4 August}

Lesson Boyelle. Rochette. Off today. Telephoned Aunt Marie. Mlle Taron.

\section{Saturday 5 August}

Lesson Chesnier du Chesne. Tired out. I haven't slept since Wednesday but caught up. Slept after the lesson and through the night.

\section{Sunday 6 August}

Mass. C. Slept all afternoon. All night. My right ear still hurts. A lot of alerts at the moment. Tired out. Mad. Lavelle and Jacqueline E.

\section{Monday 7 August}

Métros - 6-11; 15-22 h. Went to the office to reimburse "Mlle Rivière" for the jam. Stayed for an hour. Went to Capon for lesson. Had telephoned for me not to come. Waited. Gave lesson from 2 til 3. Alert. Bombing at St Ouen? Worried about André. Went to the Rescue Office to offer my services with Françoise. Lesson with Rochette who gave me a cactus and gingerbread for birthday. She is going on holiday. 


\section{Tuesday 8 August}

Lesson with Delplancq. [. . .]. Boyelle. Went to get identity card photo done. It is hot. Only have one hour's worth of gas (one evening in the week and lunchtime on Sunday). Read "Les attitudes face à la vie" (Saisset). ${ }^{677}$ Not bad. Chapter on courage the best. "The Scarlet Sin" (Mrs Victor Pickard) [. . .] stupid. "Le mystère du train bleu" (Agatha Christie) ${ }^{688}$ So-so. $33^{\circ}$ in the shade. André was operated on without an anaesthetic. First time.

\section{Wednesday 9 August}

Went to St Denis in mauve dress. Went to see André. Went to see the tarot reader. "Dad is poorly and needs looking after. André is ill and is going to die. $\mathrm{Me}, \mathrm{I}$ am in great peril in a bombing raid but I get out. Work ends. In $1 \frac{1 / 2}{2}$ to 2 months I'll be changing job - good money wise. An old woman dies. My parents move house. Mum will go out to work. A young foreign man with brown hair will come end November, beginning of December. In a hurry to get married. I'll meet another young man with a good job at work who also wants to get married. I will be very hesitant about getting married. I will get married at the beginning (or the end?) of next year. I'll have a little boy straight away, a little girl some years later. Will succeed with my studies. Fun. Outings with friends". Bought a red belt.

\section{Thursday 10 August}

Lesson with Capon. Telephoned Tenon. Had tea with Mlle Faure. Went to First Aid meeting.

\section{Friday 11 August}

+ Went to the photo booth. I am as bonny as anything. Very pleased with these photos. Tired out and ill with Nico. Letter from Jacqueline Malot, Yvonne Zéau. Chesnier du Chesne (who doesn't want a lesson Saturday - great). No métro tomorrow from Saturday $13 \mathrm{~h}$ until Tuesday 15 August $18 \mathrm{~h}$. Then working between 18 and $22 \mathrm{~h}$. Next weekend working 6-10;16-22. What a carry on. The English are making headway. Lesson with Courtelier. Boyelle. "They" ${ }^{8} 9$

${ }^{687}$ Frédéric Saisset (1873-1953). See bibliography of works: http://data.bnf.fr/12749484/frederic_saisset/

${ }^{688}$ Agatha Christie (1890-1976). The Mystery of the Blue Train was published in 1928.

689 "They" being the Allies. 
are at Rambouillet apparently. Go to Chabert's who wants to bathe with me. Cioran came for a lesson. Put him off until Wednesday. Read "Hatter's Castle" (Cronin) ${ }^{690}$ until $4 \mathrm{am}$. I. Very hot. Changed my 1000 fr notes.

\section{Saturday 12 August}

+ Watched shooting stars. Slept 5-9 am. I think that we can hear the guns. Didn't have a lesson with Chesnier du Chesne. Didn't go out. Exhausted +

\section{Sunday 13 August}

+ Mass. C. Yesterday evening I signed up for the night time rescue crew, from $21 \mathrm{~h}$ to $8 \mathrm{~h}$ in the morning. They didn't give me a pass for the combat zone. Went to see "our" godson with Françoise (who brought me potatoes). He is called Ben Hassar and is really young and as handsome as a prince (apart from his lips which are a bit thin). He's got TB. He was very frightened of us at first and then it was better. He can hardly speak French. Françoise was very good but I hardly opened my mouth. Read "Le Rideux d'arbres" (Elie Rabourdin). ${ }^{691}$ Very soppy. "A Long Time Ago" (Margaret Kennedy) ${ }^{692}$ So-So. "Twelve Men (Theodore Dreisner) ${ }^{693}$ I don't like American men. I can hear the guns firing. German planes are flying over Paris very, very low. I.

\section{Monday 14 August}

+ Birthday Marie Blot and Mad F (39 years old). Lesson Taron. Luxembourg Gardens have been shut for a few days now. They are building barricades on the Boulevard St Michel. The métro which should have been back on is suspended until further notice. Electricity is only on between $22 \mathrm{~h} 30$ and $24 \mathrm{~h}$. The gas is going to be cut off.

${ }^{690}$ A. J. Cronin (1896-1981). Hatter's Castle was published in 1931.

${ }^{691}$ Information on Rabourdin scarce. She published several novels with Gallimard. Le Rideau d'arbres was published in 1941. She forged a career as a fashion writer in the post-war.

${ }^{692}$ Margaret Kennedy (1896-1967). Somerville graduate of History and prolific and commercially successful novelist. See the Penguin books biographical entry for more on Kennedy and her career:

https://www.penguin.co.uk/authors/margaret-kennedy/1018961/

${ }^{693}$ Theodore Dreiser (1871-1945). American novelist. Twelve Men was published in 1919. 


\section{Tuesday 15 August}

Mass. St Marie. (Blot) Sent a card. The German general in overall charge of Paris said that food supplies would come through if terrorist attacks stop. Tickets for bread aren't being accepted. We're going to have a shortage. For several days now I have been filling what I can with water. I can't be short of it. It isn't as hot. Thank God. I am so tired. I have no appetite. I feel sick all of a sudden and if I walk any way my legs start to tremble. I don't think we have enough to eat. The post offices are only open in the afternoon from $1 \mathrm{pm}$. I heard about troop landings in the south of France which happened at 7 am this morning which explains the planes that are prowling around here. Oh let it be over soon! $3.30 \mathrm{pm}$. Oh no! No water!! I hope that we get it back. All the police are on strike. The GMR ${ }^{694}$ are stationed in the primary school on the rue des Feuillantines. Chabert came to change the day. It is raining. Storm. Midnight. Water still isn't back on. And I want to do the washing tomorrow while there is still some gas. The pillbox on the Boulevard St Michel has been finished.

\section{Wednesday 16 August}

9 hrs. Dziuta Pavilanaïté-Padalskis. Still no water. Post offices shut. De Gaulle’s call to arms posted up everywhere. Queued one and a half hours for bread. No lorries or anything else safe to carry bread now (so we won't have any more). They are moving everything from the Senate building (there was a cow there. They killed it and sold it off at $100 \mathrm{fr}$ a kg). They have dug trenches on the rue de Chartres. The gas will be going off, tomorrow probably, at the latest on Sunday. I had got it into my head to do some washing. It is soaped but how am I going to rinse it!! I have already brought a pail of water up to the 8th floor. Mad. F is driving me mad..!!! I don't like this, I can't eat that. She asks me to buy her something and then it isn't right. It may well be feminine but one of these days I am going to lose my temper. Basically, she's a nice girl but she has a tendency to speak in such an unpleasant hectoring way so "I am right, you idiot, always putting your two penneth in". I do have some self-control ${ }^{695}$ but I am pretty annoyed and my head and my eyes ache. Rain. 3.30. Water came back on. Did the washing despite having cold sweats, headache etc. I think that it's just being shattered rather than TB. Felix came to bring me potatoes. Nice. Didn't give me to [...] I have to telephone. Made a rice cake. Tomorrow I will sign up for the kitchen-on-wheels (registration starts tomorrow). The undertakers are on strike. Fine time for it! Let's see where we are with the dead in a few days. Didn't sleep. Nice has been captured. The Germans have announced that there

${ }^{694}$ GMR - groupe mobile de réserve. Paramilitary units working for the Vichy government.

695 'self-control' written in English in the manuscript. 
is fighting on the road between Dreux and Chartres. Guns firing all night. At South-South-East there was a continuous glow in the sky and a very intense glow all night. I dreamt that I returned home but it was strange. A night terror I won't ever see my parents again etc. Packed suitcase and wrote a goodbye letter etc. Fell asleep at dawn.

\section{Thursday 17 August}

I still have a little gas left but it takes $1 / 2$ an hour to boil $1 / 2$ a litre of water. I think I shall pack a suitcase anyway. 19 degrees. The weather is cold. No water. Went to get food coupons for the food wagons. They are cutting off the gas everywhere. Started to tidy bedroom. Madame Beyer said that Paris is an open city and that the Germans will have to leave by midnight at the latest. There are lots of Germans in the rue St Jacques. There are two tanks on the Boul'Mich. Went to Françoise's. No police on the barricades. Just paramilitaries in front of the prison. Went to see Ben Nassar. I find him less attractive than I did the time before. Very tired. Took him some honey. The Americans have encircled Rambouillet apparently. The explosion I heard wasn't guns but Villacoublay which the Germans had blown up. Explosions all afternoon [. . .] in front (Ormesson?) then Orly and Ivry. Explosion after explosion this evening. The sky is flame red, at Versailles too (seen from Mlle Jullian's). Lots of explosions and gunshots 9 pm. 'They' are at Dreux, Chartres, Orléans and have gone further than Chartres. $10 \mathrm{pm}$. They are on the outskirts of Paris. Mademoiselle Julian swears blind that they advancing on Versailles. We can hear gun shots. It is worrying. Everybody is restless and anxious. They are saying that the Germans have blown up the power stations, the bridges, the hotels where they have been staying, the Senate building. Meanwhile, the suburbs are well alight. The water came back on this evening. There is a little gas but it takes $1 \frac{1 / 2}{2}$ hours to sauté potatoes. Explosions, one after the other and one which set the building rocking but I don't know where that one was. Fires near Villeneuve St George.

\section{Friday 18 August}

I am 26 today. Couldn't get off to sleep yesterday even though I was tired because with all these explosions I thought that my rescue unit might come to get me. I was all set at $6 \mathrm{am}$. Woken by a doorbell. Rushed up but it was an alarm clock. Wide awake. Still nothing new on the radio. Explosions still. Have they gone? Very excited. ${ }^{696}$ I would like to be 'liberated' for my 26 th birthday. 6. $30 \mathrm{am}$ and already a queue of 20 or so in front of the bread shop which opens at $8 \mathrm{am}$. It is cold. Going to finish cleaning. There are still Germans around. Lorries and other vehicles are going past very quickly. We can hear them. We

696 'excited' written in English in the diary. 
rush to the windows but they are already gone. 8 am. Nearly finished cleaning. Just some dusting left to do. Vichy isn't giving out any more news. Radio Paris and Information Permanente ${ }^{697}$ have been off-air since yesterday. There is fighting at St Arnoult, that is $42 \mathrm{~km}$ from Paris. They must be closer. Lesson Coutelier. They say that the English are at Corbeil. C. very pessimistic. Fears trouble ahead. On the way saw Nasar ${ }^{698}$ and Bilgassion. They were very nice and asked lots of questions. Lesson with Chabert and I translated the manifesto for the Democratic Party of Rumania. Lesson with Taron. Ciorann. Boyelle. Saw Cismaresco who was injured in the leg yesterday in the uprisings on the Boul'Mich - one lasted 15 minutes and then another 20 minutes. The summer displays in the stores on the Boul'Mich and especially the cinema 'Le Latin' were riddled with bullets. They are moving all the [. . . $]^{699}$ next to the American hostel. Rue Auguste Comte, some '75, the Germans scrutinising all the lorries. Saw Ruth. Mad. F is constantly complaining. Curfew from 21 h to $6 \mathrm{am}$. I think that the Germans will be out by this evening. Gott sei dank!! But won't Paris be strange without them. They were part of the scenery. Explosions still, now also to the north of Paris. People are behaving in a dignified way. It's only the rabble who went out to laugh at the Germans moving out of the "Trianon". During the curfew, everyone was standing at the doors and at the windows. Alert and we raced inside and closed the door, shutters, window - and a harmless lorry went by. Explosions all night. Mad. F. gave me some roses for my 26th birthday.

\section{Saturday 19th August ${ }^{700}$}

What a day!!! No lesson with LeBreton because she has not slept for two nights. She's been helping her friends get out of Paris. Went up to the Rue Marbeuf on foot to get to work. Saw a number of cars, lorries and injured people as well. At Alexandre III bridge they were loading lorries on to barges - a tank too. Gunshots and machine gun fire near to the Grand-Palais. Very anxious. Could hear bullets whizz by [... ] It's a battleground rue Royale, Place de la Concorde, Chambre des Députés. Went to work - had a bar of chocolate. Drank some dry Dubonnet. Came back but Alex. III now guarded by the Germans. Still some isolated bursts of gunfire. Germans sat on the front bumpers of cars ready to shoot and to machine gun. A large gathering on the rue St Jacques - Le Val-deGrâce has fallen to the Liberators. They hoisted the flag in the main courtyard to the strains of 'Aux couleurs' and the 'Marseillaise'. It was very moving. A van full of Resistance passed and told us to go home. All afternoon I was dashing

${ }^{697}$ German propaganda station broadcasting from the Eiffel Tower.

${ }^{698}$ Usually spelt 'Nassar' but 'Nasar' here.

${ }^{699}$ Looks like 'telephones' in the manuscript but unclear.

700 The date for this entry is underlined in red crayon and a cross marked beneath. It is unclear when this addition was made. 
between the bed and the window. They are fighting at the Hôtel de Ville which has changed hands 2 or 3 times. Machine guns, gunshots, grenades everywhere. Lots and lots of injured being brought to Cochin and to the Val-de-Grâce. Went to Mlle Desallés. M Lexenaire came. The Préfecture is surrounded. 500 men inside. Nearly out of ammunition. They fear being bombed. Huge fires, the Hotel de Ville and the Préfecture we think. Later, the Gare de l'Est and Nord. And these God-forsaken allies who don't come. Flags being hung everywhere then taken down because the Germans are shooting at decorated windows. They are evacuating their injured, piled up in open wagons in the full glare of the sun without bothering. Jacqueline came. She is so tense. Good Lord, if only we knew something, were able to know. No lesson with Corneau. Too dangerous outside just here in this district. Stormy weather. Listened to the radio. Not a single word about Paris. The Resistance uprising has been premature. And these fellows who are walking around without a care with machine guns tucked under their arms or grenades in their hands as if they were holding an umbrella or a walking stick. They are still killing. Good Lord, when will it end. I was frightened of the bullets this morning. We don't know where they come from. Lexenaire was horrified looking at the fire, thinking that it was the Préfecture. There are 500 people inside and friends. I'm very worked up. Mesdames Brun and Desgroux, Desallées and her sister Madame Charrère climbed up to see what they could see and Madame Jullian needed reassurance. We can hear tanks - German? American? What a day.

\section{Sunday 20 August}

Went to mass. Saw some Free French Resistance members with revolvers in their hands going to execute people. They went, apparently, to $72 \mathrm{Bd}$ PortRoyal. Went to LeBreton's lesson but not there. Came back. The shoot-outs are still going on. They are attacking the Colonial on the Boulevard Port-Royal. It wasn't the Prefecture that was on fire yesterday. All sorts of rumours are going round about huge lorries full of petrol on the square in front of N. Dame or on the Bd' Mich. Went to the Val to see Ben Nassar. He is calming down, I think that he is happy to see us. There are still a lot of injured in the Val (from the street fighting). Saw German cars with huge letters F.F.I stuck on them. Everyone was clapping. Saw a prisoner who they were bringing in with his left hand behind his neck, his right wrist was being held behind his back and there was a revolver stuck into his waist. He looked wretched. Françoise jumping for joy at the window because she can't see anything from her place. The little injured German (16-17 years old) that they brought to the Val yesterday was holding a grenade in each hand and didn't want to let go. The FFI arrested a hairdresser opposite Mancion and interrogated him. There are still shoot-outs. Phoned Aunt at St Denis. André is doing fine - as well as can be expected. The fighting at St Denis has stopped. The Germans have requested an Armistice in order to retreat. The Americans are at Porte de Vanves she says. There was a 
rumour going around, and they've since said it is true that it is true, that the SS don't want to surrender and they are cornered in the Bois de Boulogne. RadioNationale is appealing to the population to stop attacking public buildings and to let the Germans leave. This was at 20.00. At 22.00 the 'General' commanding the German forces in Paris announced that the Parisians' uprising will be crushed and, if needs be, crushed mercilessly and issued the decree:

1. Curfew from $9 \mathrm{pm}$ to $7 \mathrm{am}$.

2. All windows to be closed. No one to stand at the windows.

3. All main and side doors to buildings have to be kept open even during the night.

4. All cinemas, theatres, cafes and other going out places are to be closed (a bit late there).

5. Gatherings of more than 3 people are banned.

6. Certain zones are off-limits to civilians who will be shot on sight.

7. Anyone giving information to the enemy will be treated as a spy.

Mad. F and I can only think that it is the SS laying down the law. Spoke for a while with Mme Julien, Mad. F sulked and then got over it. We went for a walk together along the rue de Val and Boulevard St Michel, Boulevard Port Royal, rue St Jacques. We saw a lorry full of Germans with machine guns on the top. Perhaps these are the last Germans we will see. It feels strange thinking about it. They are bringing injured or those who look dead to the Val, sometimes on a stretcher with a Red Cross flag at the top. Around 9 in the evening there was lots of shooting near the Closerie de Lilas. One hour later Jacques arrived in a complete state. He and two friends were the ones being fired at and they had managed to hide in an apartment block where they stayed for $3 / 4$ of an hour. Jacques swears he is going to get the Germans. Hed had such a fright. Started work for Doré Ogrizek. ${ }^{701}$ It is painstaking. Went to bed at 2 am. Large bursts of light in the distance towards Vincennes and lots of gunshots probably fired into lit up windows because almost no one is keeping to the curfew. Had a note from Mademoiselle Nicolas but I wasn't around.

\section{Monday 21 August}

There's a new "Nation Française" radio programme. The English are saying that there 'must be something happening in Paris'!!! Chabert came by to tell me to come only when he gives the word because it is much too dangerous where he is. There was an all-out battle on the corner of the Boulevard St Michel and the rue de l'École de Médecine between a German tank and Resistance fighters.

${ }^{701}$ Madeleine and Marguerite Bigot translated Doré Ogrizek's France: Paris and The Provinces published in 1944 by Clifford, London. 
I have been up since 7 am and it is now 11 am and I have done nothing, nothing, jumping up at the window every three minutes. The Free French ${ }^{702}$ must be using the building as a muster point, their vehicles (German painted with letters) are coming here to be repaired. The concierge is being very friendly and giving them information (well, well). Gosh it rained so heavily last night!! I haven't had any gas since yesterday. From today Madeleine F is cooking grub for the both of us. The undertakers are back at work. The windows are starting to rattle again. The big gun is banging away constantly. They signalled the end of an air raid alert (why?). Shots ring out from time to time. Madeleine F went out. She can't stay in one place very long. Apparently, the Germans have called up heavy reinforcements. It was the mills at Pantin that were burning and not the Préfecture. Got a Liberation newspaper. Worked well on my adaptation. Had lunch and supper with Madeleine F. She is making the grub. We are putting what we have together. Luckily she has electricity because the gas is off. This evening the Resistance came by blowing whistles. 'The water storage tanks have been blown up, stock up. There's a mad dash to get water. I had some already but brought up three bucketfuls and a Billy can. Fancy blowing up the water supply like they did at Florence - the bastards. English radio is saying that the Resistance is fighting in Paris - my parents must be so worried. Tomorrow it is Dad's birthday. No water, no gas, no food supplies, no transport - I only have electricity left. I'm wondering who the young man was saying 'bonjour, bonjour' after me in the street this morning. It wasn't Ben Nasar. I don't want him to come up here. Damn it. I haven't done my report for the Red Cross. It is half past midnight and I am not remotely tired.

\section{Tuesday 22 August}

Dad is 55 years of age. Went to see Coutelier who is part of the resistance at the Town Hall in the fifth arrondissement. It was attacked by two big guns. They fired but the doors held firm - and prisoners - including German soldiers and officers were evacuated out of the back. I haven't done much work at all. I am always looking out of the window. There are gunshots and bursts of machine gun fire etc. When I was queuing for bread I saw German lorries but no one fired. I took my report to the Red Cross this afternoon and volunteered but it is useless. They don't want women - they only want men for the barricades, to drive and to courier. I am furious. Made it through to the Panthéon where there was a battle this morning. It is impossible to get through onto the rue Soufflot.

${ }^{702}$ Resistance forces. The Forces françaises de l'intérieur (FFI).

Page 368: View of Val-de-Grâce from 320 rue St Jacques in summer. Copyright Delphine Biechler, licensed under CC BY-NC 4.0. 
They have stuck flags on the barricades. The Town Hall is knocked about and the houses around it have great chunks knocked out of the stonework. I wanted to go to the Place Maubert but I had to take shelter on the Rue Valette because there was an all-out battle on the Boulevard St Germain and there was non-stop firing. Read all of the tracts that had been posted up and the various proclamations. Jacqueline Eichhorn came over. I want to throttle her. She is such a scaredy-cat and feeble. When will the allies get here? They are making everyone wait. Very depressed, - then, just like that at 8.30 am on Radio de la Nation Française they called for the people of Paris to rise up and join the barricades. Then they played the Marseillaise. Madeleine F. and I were almost in tears. It was just magnificent. We went to fetch Mademoiselle Julien and we all toasted it. Saw some soldiers and right next to them a big gun and machine guns. The barricades are being lifted says Jacques, on the Boulevard Port-Royal, rue Claude Bernard etc. Seven Free French who were having problems dropped in here for shelter and to get their bearings. They are saying that tonight there will be one almighty fight, the German tanks are intending to attack the Resistance strongholds. There is a magnificent spirit. Volunteers are sawing wood for the boulangeries for bread for the FFI. They have been coming round from door to door collecting sheets, bandages, safety pins etc. There isn't enough to go round the wounded. I gave my towel and sponge and $3 / 4$ of an old sheet that I was keeping to cut up for rags. Tonight has been a magnificent evening despite

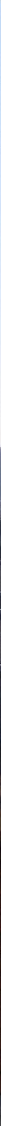


a few gun blasts that were a little too close for comfort. It is good to hear the radio talking about the Paris Resistance but poor mum and dad they must be beside themselves with worry. It is our arrondissement, the 5 th, that has fought the most fiercely. The Préfecture is also magnificent.

\section{Wednesday 23 August}

Round about 3 am, woke up with a start because everything was shaking and there was a muffled clanking noise of metal like a bomb falling but much fainter and going overhead. Huge flash bursts in the direction of the Porte d'Italie because the Americans are at Malesherbes. Dreamt of Mum but she looked like someone else because she had to camouflage herself. Mademoiselle Kerjean tried to hypnotise me. English radio has said not a single word about Paris. That really makes me cross. They are taking the City backwards - battle at Mantes, [...], Étampes. I went to have a walk around. I went to see Ruth who wasn't there. Then I went to the rue Soufflot where there are barricades and we saw barricades (three) that go all the way down to the Seine. In the afternoon, there was an alert in the street. 2 German caterpillar trucks were passing and they stopped in front of the building (they had seen Jacques running with a baguette and thought that it was a gun. Jacques nearly dropped dead with fright but doesn't want anyone to know that). Went out with Madeleine F up to the Gare Montparnasse. We saw 3 German tanks and 1 German car go past and then they turned round in front of the barricades on the Boulevard Port Royal. I wanted to take the rue Soufflot back but there was a sniper in the bell tower at St-Jacques-du-Haut-Pas making a target of passers-by. I had a huge salad. Telephoned the office, Mlle Kerjean, and Doré-Ogrizek twice. The garage opposite Mlle Kerjean's has been taken over and her windows have been knocked out. Jacqueline Eichhorn came by this morning, such a pathetic frightened weak mess. Mlle Julien is being better than I expected. Around 18.00 a huge volley was fired from two big tanks (guns are 72 calibre) and a small Renault tank. They tried to destroy the barricade. The noise is terrible because they are firing at the corner of the street. They advance and advance a bit more, alas, and then they turn round. Hooray. All of a sudden the street is full of people repairing the barricade. On the radio they are telling us that Paris is 'liberated'. That really makes us hopping mad because fighting is still going on. In the evening we hear 'Paris-Paris-Paris'. Rumania has signed an armistice with the Allies. Huge storm this evening. Slept well.

\section{Thursday 24 August}

Went round the barricades to see the damage. Beautiful barricade up at the Panthéon. On the rue d'Ulm I nearly got myself killed by one of the militia on the roof next to the École normale. I sheltered in a porch for 10 minutes. There are barricades on all the streets. Those on the rue Bertholet and the Boulevard Port-Royal are fantastic with overturned lorries and everything! Quite a lot of damage because of yesterday - no windows left, trees knocked down, cornices and stonework 
around doorways gone. There are bullet marks on the front of buildings. I'm very worked up and tense. Since Monday when we started to cook together Madeleine F has done nothing but complain and if I say anything she sulks and yells - result, I get cross which shocks her and gets her back up. I'm going to find myself a portable stove I can't cope any more with hearing her complaining about the 'filthy' quartier, the Communists, my personality, etc, etc, that she is not suited to this way of life etc, etc. At $10 \mathrm{pm}$ there was an alert, well the Resistance went by telling us to take shelter because the Sénat was going to go up. In a rush (10 minutes) I packed a case and went downstairs with my typewriter and my travel blanket. We stayed in the lobby. Then I got fed up of it and we came back up. There are fires everywhere. Huge strange flashes. Rockets and tracer bullets. Exhausted I get undressed without bothering to sort my hair out and I lie down until $2 \mathrm{am}$. I don't want to sleep.

\section{Friday 25 August}

Around 6 am I hear lots of noise. It's the Free French forces going south armed to the teeth. I fall back to sleep. Around 7 am there's shouting and clapping. It's Leclerc's tanks. I scream and wave out of the window then with Madeleine F and Mademoiselle Josephine we all go down in our dressing gowns. Leclerc's tank division, colonial soldiers, Americans, Canadians. We clap, yell and shake hands. We got fired on from the rooftops and the column returned machine gun fire. We took shelter momentarily and then surrounded the vehicles again. I talked to an American and then to a little Canadian from Ontario, Melville. I gave him a little note I've hurriedly written for my parents. I am on the newsreels - but properly dressed because earlier an American had shouted 'Half past eight and not dressed yet!!' Everyone laughed and I came back up and got dressed and made myself up. In the afternoon we went to up to the rue Denfert. There were some really nice chaps in the tank called 'Mesnil-la-Saulaie. They had been at York three months ago. The town hasn't had it bad. Saw a 'pressman' from Leeds who took down in shorthand a long message for my parents. The Sénat was fired on. On the way back, the Sénat fired back with its heavy gun causing the branches of the trees above us to break off. There were two blasts. We went in. Madeleine F was scared stiff. She had to bandage herself because she threw herself down on the ground too quickly scraping her knee and her arm. To be fair to her, today she hasn't gone on too much. Tried to telephone from everywhere. There is no reply from St Denis. Tried phoning from one of the Leclerc tanks but no response either. Mme Galle is very chic. Tea. She lent me some espadrilles because my wooden shoes have had it and I can't wear the other shoes in the summer. Went to see Ben Nasar with Madeleine F. He wasn't there.

\section{Saturday 26 August}

Telephoned St Denis. Lots of damage and plenty of dead. Went to Boulevard [...]. Much destruction and a lot of barricades have been taken down now. 
There are a lot of tanks. A colonial soldier comes up to me and says 'I hope that you are happy now' and kisses me noisily on both cheeks. In front of the Lycée Montaigne a German lorry full of paper is still burning. Five women go by, their heads have been completely shaved and a swastika stuck on them. They are wearing a Nazi flag around their necks and are making the Nazi salute holding a Nazi flag. They are ashen with hatred and with rage. The crowd just goes 'ha ha' but doesn't do anything else. They have put the soldiers from the Sénat building into the colonial barracks. I saw a lorry come by with prisoners in it. The crowd was whistling and yelling. The buildings at the corner of the avenue de l'Observatoire, rue Auguste Comte are badly damaged. The École des mines is too. In the afternoon I went out with Madeleine F. On the corner we saw another woman, bare feet, hair shaved off, a red cross on her head, left to make her way through a crowd of people heckling her. She looked to be suffering terribly with the shame of it all. People who seemed as if they knew her said that she deserved it. I worry that she will be so terribly poorly after that. I saw a portrait of Hitler hung from a lamppost. Buildings everywhere are damaged. They are still firing from the rooftops. Me and Madeleine F [.. .] ${ }^{703}$ All the quartier has been on the Champs Elysées to see De Gaulle. There was shooting. They even fired at him in Notre Dame. How shameful. I can understand hunting, if that's the right word, outside but not in a church. They arrested two in the rue Pierre-Nicole. It's mostly militia. There is a rumour that lots of Japanese are doing it. Went to bed. Around midnight was woken by a bright light - it's always an unusual light that wakes me and not noise. Huge fires at Villeneuve, St Georges, Vincennes etc and on rue Monge. And then came the blast and I could hear windows breaking. I raced to Madeleine F's to tell her to go down but her bed was empty and cold. I was very frightened and went down. There was a heck of a noise going on. Madeleine F says that I am too stubborn and don't want to go down. Quite simply, she was too scared to give a thought to me and she had forgotten to take her key. Went to give first aid but they only need stretcher bearers. They're only bringing out the dead - rue Monge was hit, [.. . $]^{704}$ Jardin des Plantes, Vincennes, St Denis etc, etc.

\section{Sunday 27 August}

$1 \mathrm{am}$. Alert. I go down. But there's nothing. Mass. The bell tower of St-Jacquesdu-Haut-Pas is badly damaged. They fired into it because they said that there was a sniper inside. Very close weather. Went to the Val to see Ben Nasar. Not there but visited Mme Charrier's office. There's an Englishman there in a bad way. He only understands "thirsty". Nothing else gets through. He has an abscess on the brain. During the whole time, the German next to him, lying on his

${ }^{703}$ Illegible. Possibly snap at one another.

704 Possibly les Halles. 
stomach, was watching with his single blue eye boring into me. He didn't blink once. I found that very unpleasant. Slept. Did the housework. The weather is very close.

\section{Monday 28 August}

Wanted to get up at 6 am to go to the office but woke up at 8.30. Telephoned office. I'll go tomorrow. There is no answer from St Denis. I am very worried. It has been heavily bombed. Telephoned the BNCI. Aunt is on holiday. I am going to write a letter. That is a pain. Finished housework. Dzinta came for exchange of English and German lessons. Mad. F lent me her electric hob. Thank God for that. I know that I annoy her. She criticises my vanity [...]. That's not to say that she isn't a really lovely girl. I don't know how to write lying on my front on the bed like this, looking at what I am writing with one eye it looks like the lines on the page are stretching away like telephone wires. I really want to sleep, to catch up. Wrote to Aunt Violette. Don't know what sort of reply she will send. Looked for bread and vegetables but didn't find any. Soldier threw me a cigarette. Was accosted in the street. Bought wooden shoes. They are ugly but I won't have to wear Mme Galliot's espadrilles. What's more, everything is shut on Monday and tomorrow I leave at 7.30. Colette came to get Andrés certificate. Saw Jacqueline Eichhorn who seemed furious with me (because of the little Canadian. I find it amusing). Very tired. I hope that there won't be alerts or snipers. To think that these bastards are firing on firemen and the Red Cross. Alert round about midnight. Went down in all the kit. People always think that I look as if I am going to go on a cruise liner with my travelling rugs. If we go down it's because we think that we won't be going up again and so it is best to take as much as possible. Nothing. Went down the Catacombes. ${ }^{705}$ Impressive but horribly cold and damp, a yellowish mud on the ground and gooey drip-drops falling from the ceiling. Afterwards, went into the cellar of 320 but not easy being stood up like that. Slept like a log afterwards. The gun fired through the night apparently.

\section{Tuesday 29 August}

Was up at 6 am. 7.30 I was on my way to work in the drizzle and in new shoes. They don't hurt me as much I had feared they would but they hurt enough. Furious with Kort. There is nothing to do at the office but he makes me come in on purpose and I will have to come in tomorrow afternoon for my pay and Thursday as usual. It is clear that he does not have to make the journey in. He bought a second-hand bicycle [...]. He wants to leave the office and work with me. I told him that I would prefer to return home and he said that he will do

705 Ossuaries under the city of Paris. http://www.catacombes.paris.fr/ 
all he can for that to happen. Telephoned Courtelier. Doré Ogrizek, Boyelle. The Allies are just about everywhere and have set up little tents on the lawns and sleep - it's a funny sight. The Ministry of the Interior is badly fire damaged. Worked on the ODE. Mad. F queuing for food tickets and moaned on that my shoes made a lot of noise this morning. I know but she should realise that I go past as quietly as possible. I replied in the same tone and shut the door in her face. She is still horrified I think. She has gone to sleep over at her Aunt's this evening. I hope that it'll put her in a better mood because for 15 days or more (but particularly for 15 days) every time she has opened her mouth she has complained. I've had enough of it now. Lesson Boyelle. He lived through 10 days of terror with the gun in front of his house getting it wrong from time to time and firing on them. His balustrade has been destroyed and there are 6 bullets in the wall. The Concierge told me that [C..] came for a lesson. The gun has been firing away from $7 \mathrm{pm}$ (it is now $11 \mathrm{pm}$ ). I'm afraid that the night will not be a peaceful one. Today I am not going to go down (unless something serious happens in which case it will be too late to go down). The thing which bothers me the most is the lack of water. Usually it comes back a little in the night but I have now gone 48 hours "without". Washed my feet in a litre of water!!! Happily this evening a bit came back. There's been no bread for a few days now - or queues of 200 to 300 people. The Germans burned down the mills at Pantin. But I saw flour sacks arriving - in the 8th and there is some white bread. Very, very tired. "Les Héros du Sahara" (Howe) ${ }^{706}$ "La Ville Perdue" (Jouglet). ${ }^{707}$ I got myself a ticket for shoes without having to queue. -18 months since my last one. Let's hope nothing goes on this evening. Since the bombing of St Ouen my heart gives a little twinge when I hear something - but God willing. As Mme Desgroux says I am in a state of grace and I would fly up to heaven (but surely not in a straight line given my foul mood).

\section{Wednesday 30 August}

Got up late. Went to the Office for pay but didn't get it. Furious. Tired and it is a long way. "As Much as I Dare" (Faith Compton Mackenzie). Ordinary autobiography. "The Mystery of Dr Fu Manchu (Sax Rohmer). These 'horrors' don't impress me one bit but they are relaxing. When I got back I found a note from Dick!!! Doré Ogrizek and Chesnier du Chesne.

706 Sonia E. Howe. Les Héros du Sahara was published in 1931. See persée.fr \& Revue de l'histoire des colonies françaises for a contemporaneous review of the work:

http://www.persee.fr/doc/outre_0399-1377_1931_num_19_84_1080_ t1_0657_0000_2

707 René Jouglet (1884-1961). 


\section{Thursday 31 August}

I don't remember what I did. I read and worked. Telephoned Doré-Ogrizek. Went to have tea with Françoise Boësse. Everyone is very happy about the Americans.

\section{Friday 1 September}

Started up English/German lessons again. Dzinta. Office, got pay. Tired. Telephoned Boyelle. There is no answer from St Denis. Went to Kort's this evening. Nice get-together. Saw roof snipers arrested. On the way back gave directions to 3 Americans. Very nice. They don't like England or the English because too snooty. The girls are awkward lumps who don't know how to dress or make themselves up and they don't paint their legs etc, etc. They really like French girls and Paris is beyond their wildest dreams. They brought me back in a car and Ken (from Illinois) kissed me. Date at the Lion on Sunday at $7 \mathrm{pm}$ if they haven't gone by then. Lovely moonlight. Went to Dorés and he gave me an advance of 2000!!

\section{Saturday 2 September}

Registration. Went to the Val to see Williams the Englishman. In a bad way. Left with Mme Charrisse - her Michel is only 26!! Worked.

\section{Sunday 3 September}

Mass. Went to see another patient. Didn't go to see Ben Nassar - he asked where Madeleine was (!!) Quite flattered. Worked. Got all dressed up to go to the Lion with Mad F (who was extra dressed up). No Ken. They must have had their 'marching orders. ${ }^{\text {'08 }}$ At quarter past I wanted to go but Mad. F. insisted that we stay until half past. I saw several and asked them whether they were Ken (they all said that they were) and none of them like the 'Limeys'. Mad. F went into one of her sulks with me. It's hardly my fault if they aren't there. I saw her in a new light. She is like a bitch on heat. She was counting on it obviously. It embarrassed me.

\section{Monday 4 September}

Office. Took the work over to Doré, Waited at Parc Monceau for the American Library to open. Weather fine.

\section{Tuesday 5 September}

Lesson with Dzinta. Ciorann, Boyelle

708 'Marching orders' written in English. 

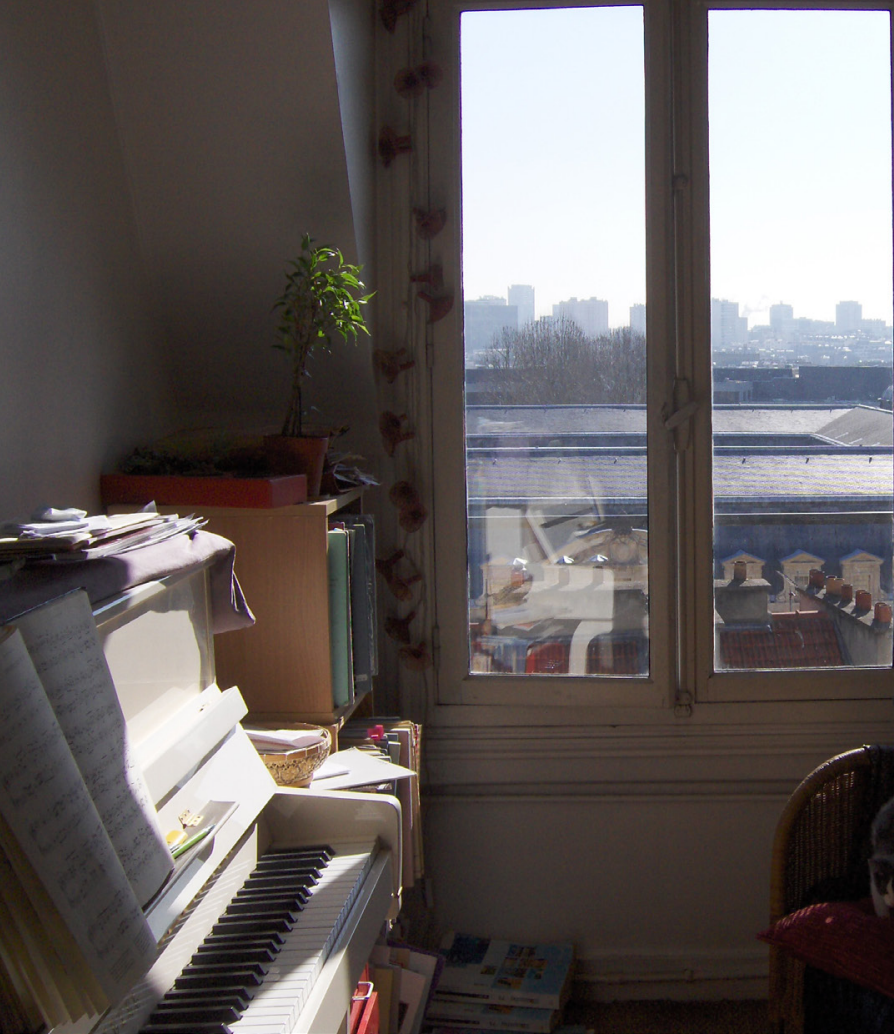

Inside 320 rue St Jacques (present day). Copyright Delphine Biechler, licensed under CC BY-NC 4.0.

\section{Wednesday 6 Sept}

Worked ODE. Val-de-Grâce

\section{Thursday 7 Sept}

Office.

\section{Friday 8 Sept}

Lesson with Boyelle

\section{Saturday 9 Sept}

Lesson Chesnier

\section{Sunday 10 Sept}

Mass. Telephoned Aunt Marie. Worked ODE. M and Mme Faure came over. 


\section{Monday 11 Sept}

Office. Worked ODE.

\section{Tuesday 12 Sept}

Lesson Ciorann. Lesson Boyelle. Travail ODE.

\section{Wednesday 13 Sept}

Worked ODE.

\section{Thursday 14 Sept}

Office.

\section{Friday 15 Sept}

Took the ODE work. Got 10,000 fr. Went to the hairdressers. Had a shampoo and set. Lesson with Boyelle.

\section{Saturday 16 Sept}

Went to hairdressers. Bought powder compact for Denise's birthday. Val de G.

\section{Sunday 17 Sept}

Mass. Bought red dahlias. Saw Françoise.

\section{Monday 18 Sept}

[Madeleine's diary is blank on this day. Her entries ceased and within six months she had returned to Britain.] 


\section{References}

Azéma, J-P. 1994. Les Libérations de la France: Prologue. French Cultural Studies, 15.5: 223-226.

Berr, Hélène. 2008. Journal. Paris: Éditions Tallandier.

Brossat, Alain. 1994. Libération, fête folle, 6 juin 1944 - 8 mai 45: Mythes et rites ou le grand théâtre des passions populaires. Paris: Éditions autrement.

Chaperon, Sylvie. 2001. Une génération d'intellectuelles dans le sillage de Simone de Beauvoir. Clio. Histoire, femmes et sociétés 13: 99-116.

Dodd, Lindsey and Lees, David, eds. 2018. Vichy France \& Everyday Life: Confronting the Challenges of Wartime 1939-1945. London: Bloomsbury.

Dodd, Lindsey and Michallat, Wendy, eds. 2017. Hidden words, hidden worlds: Everyday life and narrative sources (France 1939-1945). Special issue, Essays in French Literature and Culture 54, November 2017.

Diamond, Hanna. 1995. Women's Aspirations, 1943-47: An Oral Enquiry in Toulouse. In The Liberation of France: Image and Event, ed. H. R. Kedward and Nancy Wood. 91-101. Oxford: Berg.

Diamond, Hanna. 1999. Women and the Second World War in France 1939-1948: Choices and Constraints. Harlow: Pearson Education Limited.

Gennari, Geneviève. 1961. J’avais vingt ans: Journal 1940-1945. Paris: Éditions Bernard Grasset.

Gildea, Robert. 2003. Marianne in Chains: Daily Life in the Heart of France during the German Occupation. London: Pan Books. 
Gildea, Robert. 2006. Surviving Hitler and Mussolini: Daily Life in Occupied Europe. Oxford: Berg.

Guéhenno, Jean. 1947. Journal des années noires, 1940-1944. Paris: Gallimard. Humble, Nicola. 2001. The Feminine Middlebrow Novel 1920s to 1950s: Class, Domesticity and Bohemianism. Oxford: Oxford University Press.

Jackson, Julian. 2001. France: The Dark Years, 1940-1944. Oxford: OUP.

Laborie, Pierre. 1990. L’Opinion française sous Vichy: Les Français et la crise d'identité nationale 1936-1944. Paris: Éditions de Seuil.

Laborie, Pierre. 2001. Les Français des années troubles. Paris: Desclée de Brouwer. Lamberton, L. Jill. 2007. Claiming an Education: The Transatlantic Performance and Circulation of Intellectual Identities in College Women's Writing 1870-1900. DPhil diss., University of Michigan.

Laurens, Corran. 1995. La Femme au Turban: les Femmes tondues. In The Liberation of France: Image and Event, ed. H. R. Kedward and Nancy Wood. 155-179. Oxford: Berg.

Lécuyer, Carole. 1996. 'Un thé chez les étudiantes parisiennes' par Marguerite d'Escola (1926). CLIO: Histoire, femmes et sociétés 4: 1-9. http://clio.revues. org/443. DOI : 10.4000/clio.443 (accessed 1 April 2016).

Lejeune, Philippe. 2010. Le Journal d'Hélène Berr. http://www.autopacte.org/ Berr.pdf (accessed 1 April 2016).

Lefébure, Antoine. 1993. Les Conversations secrètes des Français sous l'Occupation. Paris: Librairie Plon.

Maack, Mary Niles. 2005. Exporting American Print Culture: The Role of Bookwomen in Paris during the 1920s. https://pages.gseis.ucla.edu/faculty/ maack/Documents/BookWomenWeb.doc (accessed 24 November 2017).

Michallat, Wendy. 2012. Mon cher Papa, ma chère Maman: The drôle de guerre of Madeleine Blaess, Essays in French Literature and Culture 49: 135-153.

Michallat, Wendy. 2017. Mental Distress under Occupation: The Journal of Madeleine Blaess. French Cultural Studies 28, 2: 173-185.

Michallat, Wendy. 2017. Writing a Scholarly Occupation: Student women diarists (1940-1944). Essays in French Literature \& Culture, 54: 39-58.

Michallat, Wendy. 2018. Madeleine Blaess: An Emotional History of a Long Liberation, In Vichy France \& Everyday Life: Confronting the Challenges of Wartime 1939-1945 ed. Lindsey Dodd and David Lees. 179-196. London: Bloomsbury.

Moran, Joe. 2015. Private Lives, Public Histories: The Diary in Twentieth Century Britain. Journal of British Studies 54, 1: 138-162.

Muel-Dreyfus, Francine. 2001. Vichy and the Eternal Feminine: A Contribution to a Political Sociology of Gender. Durham: Duke University Press.

Pollard, Miranda. 1998. Reign of virtue: Mobilizing gender in Vichy France. Chicago: University of Chicago Press.

Roberts, Mary-Louise. 2013. What Soldiers do: Sex and the American GI in World War II France. Chicago: University of Chicago Press. 
Singer, Claude. 1993. Léchec du cours antisémite d'Henri Labroue à la Sorbonne (1942-1944). Vingtième siècle, revue d'histoire 39: 3-9.

Sturdee, Jill, 1995. War and Victimisation through Children's Eyes: Caen Occupation and Liberation. In The Liberation of France: Image and Event, ed. H. R. Kedward and Nancy Wood. 297-308. Oxford: Berg.

Thomas, Gregory M. 2009. Treating Trauma of the Great War, Soldiers, Civilians and Psychiatry in France 1914-1940. Baton Rouge: Louisiana State University Press.

Vinen, Richard. 2006. The Unfree French: Life under the Occupation. London: Allen Lane.

\section{Library Collections}

Sylvia Beach Papers, 1872-1999 Department of Rare Books and Special Collections, Firestone Library, Princeton University.

Madeleine Blaess Documents, MS296. Special Collections and Archives, University of Sheffield Library, United Kingdom.

\section{On-line Archive}

Turma Vengeance : Réseau de renseignement - évasion - action de la Résistance http://chantran.vengeance.free.fr/ [accessed 4 January 2011].

\section{The Madeleine Blaess Collection}

The manuscript of Madeleine Blaess's diary is held in the Special Collections Department of the Western Bank Library at the University of Sheffield, in Yorkshire, United Kingdom. Madeleine Blaess (1918-2003) left her books and papers to the University of Sheffield and the diary constitutes one item in a voluminous archive of materials. When Madeleine died in 2003, Jacky Hodgson, Head of Special Collections, was asked to help gather and curate Madeleine's papers. Jacky found the diary under Madeleine's bed in her house in Fulwood, Sheffield. The collection comprises correspondence from friends and family, photographs, newspaper articles and cuttings. There are a number of documents dating back to the Phoney War and to the Occupation, including letters sent by Madeleine to her parents in York between November 1939 and June 1940, shortly before the German invasion of France.

More information about the Madeleine Blaess collection can be found at this link: https://www.sheffield.ac.uk/library/special/blaess 
The catalogue can be downloaded directly at: https://www.sheffield.ac.uk/ polopoly_fs/1.517412!/file/BlaessDocuments.pdf

For further information about the Collection, please contact Special Collections at: Email: lib-special@sheffield.ac.uk

By Post: Special Collections, Western Bank Library, University of Sheffield, Western Bank Sheffield, S10 2TN 


\section{Principal Personalities}

\section{Georges Auclair (1920-2004)}

Georges Auclair was a student of Philosophy and Economics at the Sorbonne during the Occupation. He was also the leader of a Resistance cell in Paris. There are two mentions of him in Madeleine's diary, each of which suggest that he was approaching her to ascertain her willingness to engage in acts of Resistance. After the war, Auclair wrote a number of novels and essays, the first of which, 'Un amour allemand', won him the Prix interallié in 1950. After the war he became a literature teacher and journalist.

\section{Hélène Barland}

Hélène Barland (Resistance name Hélène Dutreuil) was an art student at the école du Louvre and was working in conservation at the musée des Arts décoratifs and musées des monuments historiques in Paris during the Occupation. ${ }^{709}$ Madeleine first meets Barland in October 1942 to arrange English

${ }^{709}$ Limore Yagil (2015) Au nom de l’art, 1933-1945: Exils, solidarités et engagements (Paris : Fayard). See also François Wetterwald (1911-1993) Vengeance: Histoire d'un corps franc first published in 1947 and transcribed and placed on line on 2 February 2010. There is a reference to Barland's 
lessons, which continue into 1943. Although Madeleine does not make any specific mention of Barland's Resistance activities, her tutee was active in the network Turma Vengeance from the early years of the war. She was responsible for forging documents and identity papers, for finding safe houses for Resistance fighters, airmen and for meetings of the network. Whilst there is no proof that Madeleine knew of Barland's activities, it would be surprising if she didn't, and one might suppose that the English tuition she gave had a pragmatic purpose.

\section{Sylvia Beach (1887-1962)}

Sylvia Beach was a book publisher and owner of bookshop and lending library Shakespeare \& Co. Born in Baltimore in the United States, she came to study literature in Paris during the Great War. She became involved in feminist politics and was a friend and supporter of radical socialist feminist Hélène Brion and contributor to the journal La Lutte féministe. She published James Joyce's Ulysses and the bookshop and lending library became a meeting place and literary forum for the leading writers, both French and American in Paris during the inter-war years. Madeleine first meets Beach on March 1st 1940, during the Phoney War and four months before the Occupation begins. Beach advises her to borrow books 'to keep you from the dangers of life my dear.710 During the Occupation, Beach helped Madeleine financially by lending her money and employed her part-time for a while in her bookshop. The bookshop and lending library was central to Madeleine's social life. Most of her friends had a connection to it, and Beach's influence on Madeleine is perceptible in the latter's fascination with contemporary British and American literature of the inter-war. Indeed, reading becomes Madeleine's main leisure activity throughout the Occupation.

\section{Françoise Bernheim (1912-1943)}

Françoise Bernheim was a Jewish doctoral student of Sanskrit and Comparative Linguistics at the Sorbonne and she worked part-time at Sylvia Beach's bookshop and lending library Shakespeare \& Co. It is likely that Madeleine met her through the bookshop. References to Bernheim are few in Madeleine's diary but the women were in close contact until Bernheim's arrest in July 1943. When Madeleine finally returns to Britain in February 1945, she writes to Beach to find out what had become of Françoise. It was only in the summer of 1945

activities in Marc Chantran's excellent on-line archive about the Resistance network Turma Vengeance. See bibliography.

710 Blaess, 1 March 1940. 
that Françoise's father accepted that his daughter would not be returning from Auschwitz. In a letter dated July 3rd, 1945, he writes to Sylvia Beach, in reply to a letter she had sent him: 'I was right in thinking given the length of time that I would not be one of those to receive good news but, nevertheless, the reality is so terrible. Sadly, there is nothing that can be done.711

\section{Cyla (Cécilia) Babicka (1914-1995)}

Cyla Babicka was a young Russian and Jewish medical doctor who Madeleine met through her Canadian friend Ruth Camp. There are numerous references to Cyla and Madeleine's friendship with her in the diary. However, it is through Ruth Camp's post-war testimony that we discover that Cyla was Jewish and on the run from the Vichy authorities and the Gestapo for much of the war. According to Ruth, Cyla Babicka managed to leave Paris and join the armed resistance where her medical skills were in demand. It is interesting that Madeleine was in touch with Cyla by letter throughout the latter stages of the war and, on occasion, met up with her when Cyla returned to Paris. Madeleine's close relationship with Cyla and knowledge of her whereabouts implies a complicity which undoubtedly put her at risk. Indeed, Ruth Camp was interviewed by the Gestapo about Cyla's disappearance and asked to explain why she was paying the rent on her room. In an obituary in Le Monde of the typographer Ladislas Mandel (1921-2006), Cécilia Babicka is mentioned. According to the obituary, she was indeed in the Resistance and was working as a doctor when she met Mandel, a Resistance fighter in the FTP-MOI network, in Lyon. ${ }^{712}$

\section{Hélène Berr (1921-1945)}

Hélène Berr was a Jewish student of English and mutual friend of Françoise Benheim and Madeleine. In all likelihood, Madeleine met Hélène through the English speaking lessons she was giving at the Sorbonne, or else through Sylvia Beach's bookshop and Françoise Bernheim. Madeleine makes frequent reference to her friendship with Hélène throughout her diary until Hélène's arrest in the spring of 1944. From what Madeleine writes in the diary and the frequency

711 Blaess, M. Letter to Sylvia Beach, February 1945, and Bernheim, André, Letter to Sylvia Beach. General Correspondence and Related Material. Sylvia Beach Papers, Box 190, Series 6; Department of Rare Books and Special Collections, Princeton University Library.

712 Obituary of Ladislas Mandel: http://www.lemonde.fr/disparitions/article/2006/11/03/ladislas-mandel_ 830506_3382.html [accessed 24 April 2017]. 
of the letters she sent to Berr throughout 1942 in particular when Berr's father was imprisoned, it is clear that Madeleine is actively supporting Hélène and her family. Poignantly and movingly, after spending an evening with the Berrs on 29 September 1942, she wrote that he was knitting yellow socks and gloves to wear in solidarity with her friends who from June 1942 had been forced to wear the yellow star. Hélène Berr was deported to Auschwitz in March 1944 and died in Bergen-Belsen in April 1945.

\section{Ruth Camp (1918-2012)}

Ruth Camp was born in Calgary and, like Madeleine, went to Paris during the Phoney War to study. Like Bernheim, Camp worked at Sylvia Beach's bookshop and may have made Madeleine's acquaintance there. The two women shared an apartment for several months in the late summer and autumn of 1940 until Ruth was arrested and interned. Ruth endured six months' detention in Vittel camp and was able to return to resume her studies. The often stormy friendship between Ruth and Madeleine endured throughout the Occupation. After the war, Ruth returned to Canada where she taught French and History in schools and at the University of Lethbridge. She gave a number of press and radio interviews in which she mentions Madeleine and illuminating information about life in the social entourage of Sylvia Beach and the Paris literati. ${ }^{713}$

\section{Dilys Evans (LeColleter) (1914-?)}

Dilys Evans was born in Birkenhead and did her undergraduate degree at Liverpool University. She taught at Cheltenham Boys School before leaving for Paris where she married French policeman Georges LeColleter. It would seem that Madeleine met Dilys, like many of her friends, through Sylvia Beach, and it was through Dilys that Madeleine found the apartment at 320 rue St Jacques. Dilys lived at number 322, next door, with her ill husband (he contracted tuberculosis) and her invalid mother, and from December 1940, with a new baby, Gaëlle. Much of Madeleine's everyday life centres around Dilys. They shared shopping and cooking chores and meals, and Madeleine regularly looked after Dilys's mother and child. Dilys's friendship with Sylvia Beach was particularly strong and when Dilys and her family moved to the provinces it continued by way of letters until Beach's death in 1962.

${ }^{713}$ Thanks are due to Errol Nadeau and his family for giving me sight of the transcripts of Ruth's radio interviews and wartime reminiscences. 


\section{Marie Le Hardouin (1914-1967)}

Born Sabine d'Outhoorn in Geneva, Marie Le Hardouin was a writer who, by the time Madeleine met her in 1943, had published three novels. Entries referring to Hardouin are concentrated in the summer of 1943 and largely focus on enjoyable afternoon teas and stimulating conversations. These entries are sparse and soon peter out. Hardouin continued her successful career as a writer and won Le Prix fémina in 1949 with La Dame de Coeur.

\section{Joseph Vendryès (1875-1960)}

Joseph Vendryès was Dean of the Arts Faculty at the Sorbonne during the Occupation and a specialist of Medieval Celtic Studies and Welsh. Madeleine registered for a doctorate with Vendryès on 'The Role of Merlin in the Courtly Novel of the Twelfth and Thirteenth Centuries'. Vendryès was a key source of moral and academic support for Madeleine throughout the Occupation and a man she much admired. She maintained contact with him until his death in 1960.

\section{Yolande \& Aunt Violette}

Madeleine's aunt Violette and cousin Yolande lived in Villeparisis on the outskirts of Paris. When Madeleine returned from the exode in July 1940, she went to live with her aunt before moving out into shared accommodation with Ruth Camp. Both Yolande and Violette feature regularly in the diary largely in the context of family gossip, and Madeleine goes to see them most Sundays. However, there was very little they could provide in terms of material support. They, like most other Parisians, suffered the same material deprivation and hardships. 



\section{Places}

Madeleine details most of her daily movements and itinerary in her diary meaning that hundreds of people and places are noted down. Certain of these are fleeting encounters or single visits. However, there are many places which feature time and again and acquire a practical or a sentimental importance in Madeleine's life in wartime Paris.

\section{La Bibliothèque nationale, 58 rue de Richelieu, 75002, Paris}

As a student Madeleine went regularly to the French national library, the Bibliothèque nationale to study even though she found the atmosphere staid and unfriendly and was not allowed to borrow books for her research. She tended to supplement the limited reading material she had access to with books borrowed or purchased from private bookshops and libraries like the American Library and Sylvia Beach's Shakespeare \& Co. She found part-time work in the archives whereupon entries about her working day become very frequent. She worked at the Bibliothèque nationale until the end of the war.

\section{Le Jardin du Luxembourg, 75006, Paris}

When Madeleine arrived in Paris in November 1939, she lodged opposite the Luxembourg Gardens in the Pension Les Marronniers, 78 rue d'Assas. Her love of the gardens endured for the whole of the time she spent in Paris, and she fills 
her diary with descriptions of them through the seasons. Madeleine missed the lush pastoral landscapes of North Yorkshire, and the gardens offered some relief from the grey urban environment of Paris which became progressively more oppressive as the Occupation wore on.

\section{0 rue St Jacques, 75005, Paris}

In December 1940, Madeleine found an apartment next door to her friend Dilys on the rue St Jacques. The arrest of Ruth in the flat they shared at 4 rue Rollin so frightened Madeleine that she started to look in earnest for new lodgings. It was also a necessity because the rue Rollin flat belonged to a British expatriate, Miss Longhurst, and it risked being confiscated by the Vichy authorities. Madeleine's new apartment was on the 8th floor of 320 rue St Jacques and comprised a small living space, only big enough for a double bed and a small table and a small kitchen and toilet cubicle. Small though it was, for Madeleine, a first home of her own and represented freedom and independence, even though she knew that she would struggle to afford to pay the rent on it. All the diary entries are written in the apartment and many comprise descriptions of its interior, the views across Paris and, on occasion, accounts of bombing raids and fire-fights she can see in the distant suburbs. She remained in the apartment for the duration of the Occupation and even returned to it in 1946 on a brief, three month, return to Paris.

\section{Les Marronniers, 78 rue d'Assas, 75006, Paris}

Madeleine first arrived in Paris in November 1939 and rented a room at the lodging house Les Marronniers, where she remained until the Germans occupied Paris in June 1940. Her letters home describe a lively and convivial living space shared with soldiers on leave, refugees from Eastern Europe and other students from France, other European countries and America. Madeleine's letters home from Les Marronniers give insight into how a crosssection of the community, young and old, civilian and military, French and foreign, citizens and refugees lived and experienced the Phoney War and the weeks before the German invasion. Les Marronniers does not feature in the diary but it is relevant to Madeleine's life under Occupation because it was there that she began to build the social networks she had during the war.

\section{4 rue Rollin, 75005}

Madeleine moved to rue Rollin in the summer of 1940 and shared the apartment with Ruth Camp. It was here, at this address, that she began her 
diary on October 1 1940. When Canadian national Camp was arrested in December 1940, Madeleine, herself vulnerable to arrest because of her British links, decided to find a new apartment. She moved into 320 rue St Jacques on the 28th December 1940.

\section{La Sorbonne, Place de la Sorbonne, 75005, Paris}

The Sorbonne features regularly in both Madeleine's Phoney War letters and in her Occupation diary. Throughout both periods, she notes down interesting details about how the war disrupts her scholarly routine and impacts on the learning environment. Lectures are often over-crowded and frequently cancelled, sometimes due to staff absence through illness or shortages of personnel. The Sorbonne and its teaching staff are routinely the target of sanctions in response to student protests against the Vichy regime and its policy of collaboration with the Germans. After the demonstration at Etoile in Paris on Armistice Day 1940, which resulted in the beating and imprisonment of many students, the Sorbonne was forced to close temporarily. Madeleine describes these events in detail and the sanctions which ensued. Even though the expatriate postgraduate community which had been a focus for Madeleine's social life during the Phoney War had, for the most part, broken up by June 1940 as many students fled for the ports and escape to Britain, Madeleine did still orientate much of her life around the Sorbonne and its students and lecturers. Françoise Bernheim, Hèlène Berr, Dilys Evans and Ruth Camp, all key figures in the diary, were all students who were studying at the Sorbonne during the Occupation.

\section{Shakespeare \& Co, 12 rue de l'Odéon}

Madeleine met Sylvia Beach at Shakespeare and Co in early 1940 before the German invasion. The meeting proves to be fortuitous because the relationship with Beach and the connection with the bookshop introduced Madeleine to a new scholarly social circle to replace the one of mainly postgraduate overseas students which had broken up in 1940. Madeleine worked part-time for a brief period at the bookshop. One can see from the library lending records that she relied on Shakespeare \& Co for research material and, over the first years of the war, developed a keen interest in contemporary fiction. When Sylvia Beach closed her bookshop in December 1941, because, it is said, she was under threat of arrest by the Germans, many of the books were 'sold' to La Maison des amis du livre, the bookshop opposite which was run by Beach's partner Adrienne Monnier. Madeleine continued to borrow books from Monnier and continued to log her reading choices in the diary as she had done from the first months of the Occupation. Madeleine's links with Beach, Monnier and the student 
circle connected with the bookshops enabled her to develop a rich social and cultural life. Little known about is the support, both moral and financial, Beach offered to this circle of young women students. Madeleine recorded a number of instances where Beach helped her out with accommodation and money.

\section{Villeparisis, Seine-et-Marne, Île de France}

Madeleine had extended family in France. Aunt Violette was Madeleine's mother's sister and Yolande, Violette's daughter, was Madeleine's first cousin. The family lived in the Paris suburbs and Madeleine lived with Aunt Violette during the summer of 1940 after her return from the exode. At some point between July and October she left Villeparisis to share the rue Rollin apartment with her student friend Ruth. In the first entry in the diary on October 1st 1940, Madeleine explained that she had left because her Aunt regarded domestic responsibilities as more urgent and important than her studies. Nevertheless, Madeleine kept in close contact with her Aunt and cousin and frequently went to Villeparisis at the weekend, albeit often with a lack of enthusiasm. There is much tittle-tattle, venting of petty frustrations and jealousies about Aunt Violette and Yolande. In amongst it, one can discern a recurring tension between Madeleine's intellectual vocation and career ambitions and the impatience and lack of understanding this met with on the part of the family. 


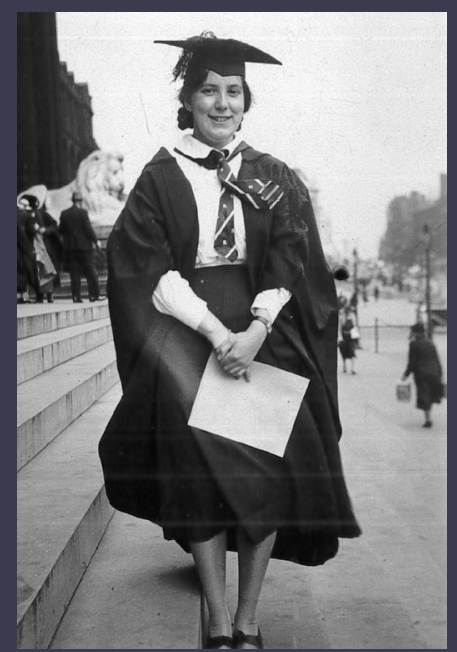

In November 1939 Madeleine Blaess, a French-born, British-raised student, set off for Paris to study for a doctorate in Medieval French literature at the Sorbonne. In June 1940, the German invasion cut off her escape route to the ports, preventing her return to Britain. She was forced to remain in France for the duration of the Occupation and in October 1940 began to write a diary. Intended initially as a replacement letter to her parents in York, she wrote it in French and barely missed an entry for almost four years.

Madeleine's diary is unique as she wrote it to record as much as she could about everyday life, people and events so she could use these written traces to rekindle memories later for the family from whom she had been parted. Many diaries of that era focus on the political situation. Madeleine's diary does reflect and engage with military and political events. It also provides an unprecedented day-by-day account of the struggle to manage material deprivation, physical hardship, mental exhaustion and depression during the Occupation. The diary is also a record of Madeleine's determination to achieve her ambition to become a university academic at a time when there was little encouragement for women to prioritise education and career over marriage and motherhood. Her diary is edited and translated here for the first time.

Dr Wendy Michallat was born in West Yorkshire. She studied at the Universities of Warwick and Nottingham and lectures in the School of Languages and Cultures at the University of Sheffield. She researches and teaches French cultural history, life-writing and popular culture and has published on diverse subjects including cartoon art, women's football and first-wave French feminism.

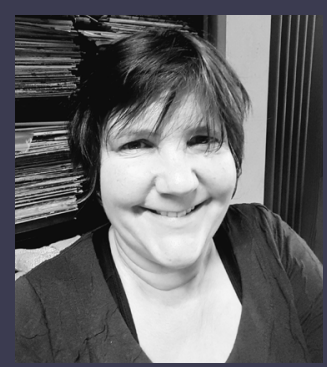

\section{WHITE ROSE \\ UNIVERSITY PRESS}

Universities of Leeds, Sheffield \& York

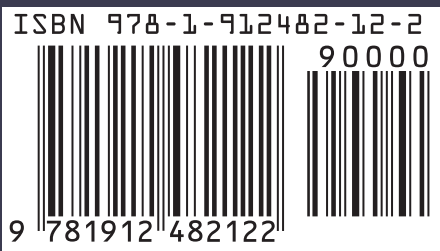

